Федеральное

государственное

бюджетное

учреждение

науки

Институт

Российской

том 3 \#3

мировой

академии наук

2018

литературы

имени

А.М. Горького

Москва

Studia Litterarum

Литературные исследования

Научный журнал

Издается с 2016 года 
Studia Litterarum:

Науч. журн. - 2018.

-T. 3, № 3. - M.:

ИМЛИ РАН, 2018.

-368 c.

Academic journal. - 2018 .

- Vol. 3, no 3. - Moscow,

IWL RAS Publ., 2018.

$-368 \mathrm{p}$.
Журнал

зарегистрирован

в Федеральной службе

по надзору

в сфере связи и массовых

коммуникаций

Свидетельство

о регистрации

ПИ № ФС $77-66625$

от 27 июля 2016 г.

Подписной индекс

по каталогу «Роспечать»

80538

ISSN 2500-4247 (Print)

ISSN 254I-8564 (Online)

Адрес редакиии:

І2І069 г. Москва,

ул. Поварская, д. 25 а

Телефон:

+7 (495) 690-50-30

E-mail: stud-lit@mail.ru

www.studlit.ru
The journal

is registered

at the Federal Service

for Supervision

of Media and

Mass Communications

Registration Certificate

PE № FS $77-66625$,

July 27, 2016

Subscription index in the catalogue "Rospechat" 80538

ISSN 2500-4247 (Print)

ISSN 254I-8564 (Online)

Address of the Editorial

Department:

Povarskaya 25 a,

I2I069 Moscow

Phone:

+7 (495) 690-50-30

E-mail: stud-lit@mail.ru

www.studlit.ru 
Federal State

Budget

Institution

of Science

A.M. Gorky

of the Russian

vol 3 \#3

Institute

Academy 2018

of World

of Sciences

Literature

Moscow

Studia Litterarum

Literary Studies

Academic journal

Published since 2016 
Главный редактор

А.Б. Куделин (ИМЛИ РАН, Москва, Россия)

Заместитель главного редактора

О.А. Туфанова (ИМЛИ РАН, Москва, Россия)

Ответственный секретарь

Редакторы

М.В. Каплун (ИМЛИ РАН, Москва, Россия)

А.В. Голубков, А.П. Уракова (ИМЛИ РАН, Москва, Россия)

\section{МЕЖДУНАРОДНЫЙ РЕДАКЦИОННЫЙ СОВЕТ}

Д.П. Бак (Государственный литературный музей, Москва, Россия), Т.М. Горяева (Российский государственный архив литературы и искусства, Москва, Россия), Р. Джулиани (Университет Ла Сапиенца, Рим, Италия), Л.И. Ливак (Торонтский Университет, Торонто, Канада), Э. Лэрд (Университет Браун, Провиденс, США), Д. Ота (Кумамото Гакуэн Университет, Куматото, Япония), Ф.Б. Поляков (Институт славистики Венского университета, Вена, Австрия), Р.М. Распопович (Исторический институт Университета Черногории, Подгорица, Черногория), Д.Рицци (Университет Ка Фоскари, Венеция, Италия), И.В. Силантьев (Институт филологии СО РАН, Новосибирск, Россия), Г. Тиханов (Лондонский университет королевы Марии, Лондон, Великобритания), Л.С. Флейшман (Стэнфордский университет, Стэнфорд, США), М. Цимборска-Лебода (Университет Марии Кюри-Склодовской в Люблине, Люблин, Польша)

\section{РЕДАКЦИОННАЯ КОЛЛЕГИЯ}

М.Л. Андреев (ИМЛИ РАН, Москва, Россия), С. Гардзонио (Пизанский университет, Пиза, Италия), Б.Ф. Егоров (Санкт-Петербургский институт истории РАН, Санкт-Петербург, Россия), Ж.-Ф. Жаккар (Женевский университет, Женева, Швейцария), Н.В. Корниенко (ИМЛИ РАН, Москва, Россия), О.А. Коростелев (ИМЛИ РАН, Москва, Россия), А.Ф. Кофман (ИМЛИ РАН, Москва, Россия), А.В. Лавров (Институт русской литературы (Пушкинский Дом), РАН, Санкт-Петербург, Россия), Д.С. Московская (ИМЛИ РАН, Москва, Россия), В.В. Полонский (ИМЛИ РАН, Москва, Россия), А.Ф. Строев (Университет Новая Сорбонна - Париж 3, Париж, Франция), А.Л. Топорков (ИМЛИ РАН, Москва, Россия), М. Шруба (Рурский университет, Бохум, Германия)

Адрес редакции: г21069 г. Москва, ул. Поварская, д. 25 а

Телефон: +7 (495) 690-50-30

E-mail: stud-lit@mail.ru

Сайт: www.studlit.ru 
Editor-in-Chief

Alexander B. Kudelin (A.M. Gorky Institute of World Literature of the Russian

Academy of Sciences, Moscow, Russia)

Deputy Editor-in-Chief

Olga A.Tufanova (A.M. Gorky Institute of World Literature of the Russian Academy

of Sciences, Moscow, Russia)

Managing Editor

Marianna V. Kaplun (A.M. Gorky Institute of World Literature of the Russian Academy of Sciences, Moscow, Russia)

Editors Andrei V. Golubkov (A.M. Gorky Institute of World Literature of the Russian Academy of Sciences, Moscow, Russia), Alexandra P. Urakova (A.M. Gorky Institute of World Literature of the Russian Academy of Sciences, Moscow, Russia)

\section{INTERNATIONAL EDITORIAL COUNCIL}

Dmitry P. Bak (State Literary Museum, Moscow, Russia), Tatiana M. Goryaeva (Russian State Archive of Literature and Art, Moscow, Russia), Rita Giuliani (Sapienza University, Rome, Italy), Leonid I. Livak (University of Toronto, Toronto, Canada), Andrew Laird (Brown University, Providence, USA), Jotaro Ohta (Kumamoto Gakuen University, Kumamoto, Japan), Fedor B. Poljakov (Institute for Slavistics, University of Vienna, Vienna, Austria), Radoslav M. Raspopovic (University of Montenegro, Historical Institute of the University of Montenegro, Podgorica, Montenegro), Daniela Rizzi (Ca' Foscari University, Venice, Italy), Igor V. Silantiev (Institute of Philology of Siberian Branch of the Russian Academy of Sciences, Novosibirsk, Russia), Galin Tihanov (Queen Mary University of London, London, Great Britain), Lazar S. Fleishman (Stanford University, Stanford, USA), Maria Cymborska-Leboda (Maria Curie-Skłodowska Universtity in Lublin, Lublin, Poland)

\section{EDITORIAL BOARD}

Mikhail L. Andreev (A.M. Gorky Institute of World Literature of the Russian Academy of Sciences, Moscow, Russia), Stefano Garzonio (University of Pisa, Pisa, Italy), Boris F. Egorov (Saint Petersburg Institute of History of the Russian Academy of Sciences, Saint Petersburg, Russia), Jean-Philippe Jaccard (University of Geneva, Geneva, Switzerland), Natalya V. Kornienko (A.M. Gorky Institute of World Literature of the Russian Academy of Sciences, Moscow, Russia), Oleg A. Korostelev (A.M. Gorky Institute of World Literature of the Russian Academy of Sciences, Moscow, Russia), Andrey F. Kofman (A.M. Gorky Institute of World Literature of the Russian Academy of Sciences, Moscow, Russia), Alexander V. Lavrov (Institute of Russian Literature (Pushkinsky Dom) of the Russian Academy of Sciences, Saint Petersburg, Russia), Darya S. Moskovskaya (A.M. Gorky Institute of World Literature of the Russian Academy of Sciences, Moscow, Russia), Vadim V. Polonsky (A.M. Gorky Institute of World Literature of the Russian Academy of Sciences, Moscow, Russia), Alexander F. Stroev (New Sorbonne University - Paris 3, Paris, France), Andrey L. Toporkov (A.M. Gorky Institute of World Literature of the Russian Academy of Sciences, Moscow, Russia), Manfred Schruba (Ruhr University, Bochum, Germany) 
Содержание

Теория литературы

Iо Юдин А.А. Понятие эстетического долженствования в эстетике раннего Бахтина

Мировая литература

26 Зыкова Е.П. Эволюция классицизма в XVIII в. и английский роман

46 Зотова Т.А. Сборник «Стихотворения» Л. Тика: от фрагмента к энциклопедии

64 Останина М.А., Шастина Т.П. Английская леди в «wild space» Сибири (по книге Mrs. L. Atkinson «Recollections of Tartar steppes and their inhabitants»)

82 Копча H.A. «Sibirische Möglichkeiten»: zur deutschen Dostoevskij-Rezeption (О непознанных возможностях Сибири: к вопросу о немецкой рецепции Достоевского)

94 Харитонова Н.Ю. El misterio chino у mistificación literaria: poemas enigmáticos en la revista «Prisma»

IO4 Елисеева А.В. Дети-мученики в пантеоне тоталитарной культуры (фильм «Юный гитлеровец Квекс»» Х. Штайнхофа)

Русская литература

II6 Дмитриева Е.Е. Миф о Беловодье, Опоньское царство староверов-бегунов и загадка второго тома Гоголя

I44 Акимова М.С. Часовня в романе И.С. Тургенева «Накануне»: история, литература, миф (К 2оо-летнему юбилею Ивана Сергеевича Тургенева) 
I62 Комия М. Автобиографический миф в романе Ю.К. Олеши «Зависть»

I76 Дужина Н.И. «Ювенильное дело»: история одной повести А. Платонова

I98 Садуов Р.T. «Я - слон»: развернутая метафора в современном российском комиксе

Литература народов России и Ближнего зарубежья 208 Жулева А.С. Мифопоэтика пространства в романах Юрия Рытхеу

Фольклористика

232 Эспань М. Германия эпохи Просвещения и изучение Сибири

254 Сорокина С.П. Петрушка в детском театре первого послереволюционного десятилетия (две пьесы С.Я. Маршака)

278 Доронин Д.Ю. Огонь, потоп и война с Востока: культурный трансфер в современных эсхатологических представлениях на Алтае

Текстология. Источниковедение. Публикации 304 Рейнгольд Н.И. Lumières английской критики («Жизнеописание Свифта» из книги «Жизнеописания наиболее выдающихся английских поэтов» (I78I) Сэмюэла Джонсона) 
Contents

Literary Theory

Io Alexander A. Yudin. The Notion of Aesthetic Imperative in the Early Bakhtin

World Literature

26 Ekaterina P. Zykova. Evolution of Classicism in the $18^{\text {th }}$ century and the English novel

46 Tatyana A. Zotova. Ludwig Tieck's Collection "Gedichte": From a Fragment to an Encyclopedia

64 Maria A. Ostanina, Tatyana P. Shastina. An English Lady in the "Wild Space" of Siberia (based on Mrs. L. Atkinson's Recollections of Tartar Steppes and Their Inhabitants)

82 Natalya A. Kopcha. "Siberian Possibilities": German Reception of Dostoevsky

94 Natalia Yu. Kharitonova. Mysterious China as a Source for Literary Hoaxes: Poetry in the Spanish Literary Magazine Prisma

IO4 Aleksandra V. Eliseeva. Child Martyrs in the Pantheon of Totalitarian Cultures (H. Steinhoff's Film Hitlerjunge Quex)

Russian Literature

II6 Ekaterina E. Dmitrieva. The Myth of Belovodie, Oponskoe [Japan] Kingdom of the Old Believers, and the Mystery of the Second Volume of Gogol's Dead Souls

I44 Maria S. Akimova. The Chapel in Turgenev's Novel On the Eve: History, Literature, Mythology

I62 Michiko Komiya. The Autobiographical Myth in Ju. K. Olesha's Novel Envy 
I76 Natalya I. Duzhina. "A Juvenile Case" The History of a Story by Andrey Platonov

I98 Ruslan T. Saduov. "I am an Elephant": The Use of Metaphor in Contemporary Russian Comics

Literature of the Peoples of Russia and Neighboring Countries 208 Albina S. Zhuleva. Mythopoetics of Space in the Novels by Yuri Rytkheu

Folklore Studies

232 Michel Espagne. Enlightenment Germany and the Invention of Siberia

254 Svetlana P. Sorokina. Petrushka in the Theatre for Children in the First Ten Years After the October Revolution (Two Plays by S.I. Marshak)

278 Dmitry Yu. Doronin. Fire, Flood and War from the East: Cultural Transfer in Altaic Modern Eschatology

Textology. Materials

304 Natalya I. Reinhold. Lumières of the English Criticism (Introductory Article). Samuel Johnson. Swift (From The Lives of the Most Eminent English Poets). Translated into Russian, with Notes 
УДК 821.0

ББК $83+87.8$

\section{ПОНЯТИЕ ЭСТЕТИЧЕСКОГО ДОЛЖЕНСТВОВАНИЯ В ЭСТЕТИКЕ РАННЕГО БАХТИНА}

\author{
(C) 2018 г. А.А. Юдин \\ Национальный педагогический \\ университет им. М.П. Драгоманова \\ Киев, Украина \\ Дата поступления статьи: І6 января 2018 г. \\ Дата публикации: 25 сентября 2018 г. \\ DOI: I0.22455/2500-4247-20I8-3-3-10-25
}

Аннотация: В статье рассматривается эстетика раннего Бахтина, как она представлена в работе «Автор и герой в эстетической деятельности». Отмечается методологическое несоответствие между первой философией Бахтина как феноменологией события бытия и его эстетикой феноменологией эстетического события, поскольку в одном случае речь идет о непосредственном описании, а во втором - об опосредованном, ибо оно опирается на текст, но пренебрегает различием между автором и субъектом описания как разными центрами ответственности. Эстетическая деятельность предстает как аналог религиозного спасения и как выражение эстетического долженствования. Но понятие долженствования относится к событию бытия, недоступному теоретическому схватыванию, а только участному мышлению. Поэтому бахтинское понятие автора-творца предстает как недифференцированное соединение автора как трансцендентальной субъективности и собственной деятельности завершения исследователя, руководствующейся религиозно-эстетическим идеалом и описанной в тонах эстетического долженствования. Делается вывод о переходном характере эстетики (и философии) раннего Бахтина как частично успешном преодолении философского трансцендентализма, а также о плодотворности понятия эстетического долженствования, переосмысливаемого как герменевтическое долженствование.

Ключевые слова: автор-творец, трансцендентальная философия, трансцендентальный автор, феноменологический метод, участное мышление, эстетическое завершение, избыток видения, эстетическая любовь, эстетическое долженствование, герменевтическое долженствование.

Информация об авторе: Александр Анатольевич Юдин - доктор филологических наук, доцент, Национальный педагогический университет им. М.П. Драгоманова, ул. Тургеневская, д. 8/І4, ого54 г. Киев, Украина.

E-mail: alexayu@mail.ru

Для цитирования: Юдин А.А. Понятие эстетического долженствования в эстетике раннего Бахтина // Studia Litterarum. 2018. T. 3, № 3. С. Iо-25. DOI: I0.22455/2500-4247-20I8-3-3-IO-25 


\title{
THE NOTION OF AESTHETIC IMPERATIVE IN THE EARLY BAKHTIN
}

This is an open access article distributed under the Creative Commons Attribution 4.0 International (CC BY 4.0)
(C) 20I8. A.A. Yudin

\author{
National Pedagogical \\ Dragomanov University, \\ Kiev, Ukraine \\ Received: January I6, 2018 \\ Date of publication: September 25, 2018
}

\begin{abstract}
The article deals with the aesthetics of the early Bakhtin as manifested in the work Author and Hero in Aesthetic Activity. The essay primarily points out a methodological discrepancy between Bakhtin's early philosophy and his aesthetics as variations of phenomenology. The former implies unmediated description while the latter is always mediated by the text albeit ignoring the difference between the author and the subject of description as two different centers of responsibility. The key notions of Bakhtin's aesthetics such as "consummation" and "aesthetic love" are borrowed from Hermann Cohen yet reconsidered from a different metaphysical standpoint. Aesthetic activity appears as analogous to religious salvation and as expression of the aesthetic ought. But the notion of the ought, according to Bakhtin's early philosophy, relates to the event of being which cannot be grasped theoretically but can be achieved only through participative thinking. This means reattribution of the reader's activity of consummation to the author. Consequently, the notion of the author-creator appears as the undifferentiated combination of the author as transcendental subjectivity and the researcher's own activity of consummation guided by religious-aesthetic ideal and described in the tones of aesthetic ought. The essay argues that early Bakhtin's aesthetics (and philosophy) had transitional character as partially successful surpassing of philosophical transcendentalism. It also proposes reconsidering the notion of the aesthetic ought as the hermeneutical ought.
\end{abstract}

Keywords: author-creator, transcendental philosophy, transcendental author, phenomenological method, aesthetic consummation, surplus of vision, aesthetic love, aesthetic ought, hermeneutical ought.

Information about author: Alexander A. Yudin, DSc in Philology, Associate Professor, National Pedagogical Dragomanov University, Turgenevskaya 8/I4, OIO54 Kiev, Ukraine.

E-mail: alexayu@mail.ru

For citation: Yudin A.A. The Notion of Aesthetic Imperative in the Early Bakhtin. Studia Litterarum, 2018, vol. 3, no 3, pp. I0-25. (In Russ.)

DOI: IO.22455/2500-4247-20I8-3-3-IO-25 
Эстетика М.М. Бахтина, изложенная в его ранней работе «Автор и герой в эстетической деятельности», опирается в свою очередь на понятийный фундамент разработанной им нравственной философии (или первой философии). Она представляет собой феноменологическое описание Книга эстетической деятельности автора-творца по завершению героя. И хотя в самой работе такого положения нет, но, используя понятие, введенное в тексте «К философии поступка», можно сказать, что, по Бахтину, авторство - это форма реализации своего не-алиби в бытии.

Вместе с тем в самом тексте «Автора и героя» понятие автора в значительной степени предстает как предельное для эстетики, т. е. как последний, самый глубокий фундамент эстетической деятельности, фундамент литературы и творчества вообщег

Однако здесь обнаруживается некое методологическое несоответствие, расхождение между первой философией и эстетикой, коль скоро в обоих случаях Бахтин использует феноменологический метод и, соответственно, они являют собой в одном случае феноменологию события бытия

I B частности, то, что публикация текста «Автор и герой в эстетической деятельности» (I979) на семь лет опередила публикацию текста «К философии поступка» (I986), способствовало восприятию первого как вполне самодостаточного, а понятия автора-творца как своего рода беспредпосылочного понятия, т. е. как понятия, которое однозначно в своем содержании и выступает точкой отсчета в анализе и истолковании произведения, а не изменчиво и зависимо от других понятий (и, соответственно, их изменчивости).

Вообще хронология публикации работ Бахтина, далекая от хронологии их написания, обусловила и усложнила рецепцию его текстов для мирового бахтиноведения. «Это сделало задачу рассмотрения творчества Бахтина как развивающегося целого крайне проблематичной. Ранние работы были прочитаны через призму более поздних, создав впечатление, что его идеи фундаментально не менялись» [II, p. 3]. 
и в другом - феноменологию эстетического события. Ведь существенная черта феноменологического метода состоит в непосредственности описания данного. Но, в отличие от феноменологии поступка, феноменологическое описание эстетической деятельности как авторской активности уже не является всещело непосредственным. Оно опосредовано текстом, созданным автором, хотя ставит перед собой задачу описания деятельности сознания этого автора. Иными словами, в отличие от феноменологии события бытия, где описание мира поступка с позиции субъекта поступка действительно исходило от этого субъекта, т. е. «я» как категория архитектоники события бытия совпадала с самоидентификацией субъекта описания - и, следовательно, можно говорить об определенной непосредственности (по крайней мере с точки зрения феноменологии в ее бахтинском варианте как архитектоники события бытия), - в эстетике феноменологическое описание означает рефлексию исследователя-читателя над собственным сознанием, а не непосредственно над сознанием автора.

Это различие нейтрализуется тем, что Бахтин вводит синтетические понятия, в которых объединяются автор и читатель: автор-читатель [I, с. 223], автор-зритель [I, с. I47, I49, I5I], автор-созерцатель, созерцатель-автор [I, с. I46, I50], автор-режиссер-зритель, а также общее понятие эстетического субъекта [I, c. 72]. Но, таким образом, описание деятельности эстетического субъекта в принципе происходит на уровне, где можно пренебречь различием между автором и читателем как разными индивидуальными центрами ответственности (в терминах самого Бахтина). И тем самым (уже в терминах Канта) автор-творец предстает как своего рода конкретизация понятия трансцендентального субъекта в эстетике ${ }^{2}$.

Трансценденталистская составляющая обнаруживает себя в ключевом понятии эстетики Бахтина - «завершение», которое определяет суть эстетического события как такового. Понятие завершения выводится Бахтиным из архитектоники события бытия: эстетическое отношение автора и героя есть конкретизация этического отношения между «я» и «другим»3. Авторство выступает как обогащение избытка видения, которым

\footnotetext{
2 Эту мысль о понятии автора-творца как соответствии понятия трансцендентального субъекта в общем виде высказывал также А.В. Домащенко [3, с. 360].

3 «Это отношение изъемлет героя из единого и единственного объемлющего его и автора-человека открытого события бытия, где он - как человек - был бы рядом с автором как товарищ по событию жизни, или против - как враг или наконец в нем самом - как он
} 
располагает «я» в отношении «другого» ${ }^{4}$ и восполнение его до позиции вненаходимости. Наконец, категория завершения уже фиксирует сугубо эстетический феномен, который не имеет соответствия в открытом событии бытия: «Цельный человек есть продукт эстетической творческой точки зрения, только ее одной...» [I, с. I55]. Нетрудно видеть, что в этой последовательности и конфигурации понятий, переходе от события бытия к эстетическому событию, сохраняется трансцендентально-феноменологическая позиция. Эстетический процесс целиком выводится из сознания и ограничивается сознанием, ибо сам он заключается в том, что второе сознание, сознание героя, здесь объемлется сознанием автора. При этом область эстетического конституируется исключительно сменой установки сознания. Избыток видения определяется как необходимое и достаточное условие последующего эстетического завершения: «Как пространственная форма внешнего человека, так и временная эстетически значимая форма его внутренней жизни развертывается из избытка временного видения другой души, избытка, заключающего в себе все моменты трансгредиентного завершения внутреннего целого душевной жизни» [I, с. I78; курсив мой. - А.Ю.].

Однако с понятием завершения дело обстоит сложнее. Строго говоря, оно не выведено из феноменологии события бытия в том смысле, что в действительности избыток видения как чистая бытийная характеристика не является достаточным условием для завершения образа другого человека5. Не является оно и эмпирическим обобщением, хотя и обнаруживает большое поле соответствия в приложении к литературному материалу.

Сам термин заимствован из эстетики Германа Когена - Vollendung. При этом Бахтин переосмысливает его, исходя из метафизических основа-

сам...» [I, с. 97]. Однако стоит отметить, что именно непосредственность этого перехода, этой трансформации лежит за пределами феноменологического наблюдения как такового. Ведь оно недоступно самому живому автору, поскольку он не рефлектирует это свое отношение, а видит его в культурном продукте [г, с. 95].

4 «...в этом моя архитектоническая привилегия» [г, с. ІІ8].

5 Здесь не место подробно аргументировать это соображение. Ограничиваясь коротким пояснением, напомним, что в «Авторе и герое» описаны три формы завершения героя: пространственная, временная и смысловая. Понятие избытка видения как феноменологическое понятие, фиксирующее характеристику я по отношению к другому, относится, пожалуй, лишь к пространственной форме. А вот «избыток» во временном аспекте и тем более смысловом уже не является непосредственным свойством конкретного я в открытом событии бытия, но социальным продуктом, т. е. они опосредованы социальным общением. 
ний собственной первой философии, так что завершение предстает у него как определенный эстетический императив, своего рода идеал эстетической деятельности. Кроме того, у обоих мыслителей понятие завершения включено в одну и ту же понятийную конфигурацию, но у Бахтина ее смысл также существенно иной.

В эстетике Когена понятие завершения подчинено понятию эстетической любви. Завершение предстает как продукт, коррелят и в то же время критерий эстетической любви, эстетического чувства [I3, S. I84-I85] В эстетику Бахтина переходят оба эти понятия, но акцент смещается на понятие завершения, тогда как понятие эстетической любви несколько отступает на второй план. Точнее, русский мыслитель активно использует понятие любви (подразумевая именно эстетическую любовь), но, в отличие от Когена, который прямо ставит его во главу угла и дает ему логическое определение, Бахтин словно бы избегает дефиниций. Любовь выступает практически тождественной понятию завершения, коль скоро она объединяет оба этапа эстетической деятельности (вживание и завершение извне) и оба кругозора (героя и автора) в единое целое («эстетическое явление»). Однако такого рода косвенные определения встречаются в движении текста, в ходе развертывания, уточнения мысли, но не в отправных или итоговых формулировках.

Кроме того, в концепциях обоих мыслителей эти понятия выступают в связке с вопросом об отношении между эстетикой и религией. Коген однозначно отрицает значение религии для искусства7. Такое понимание в определенном смысле противоположно бахтинскому. Уже в тексте «К философии поступка» явно и неявно присутствуют христианские мотивы (в частности, важное указание на жизнь и смерть Христа как модель ответственного поступка вообще). В эстетике же эта связь не менее существенна. Из множества косвенных формулировок отчетливо видно, что

6 Напомню, что главный эстетический труд Когена называется «Эстетика чистого чувства». Эстетическое чувство и эстетическая любовь - тождественные понятия. Можно сказать, хоть это звучит тавтологически, что эстетика Когена - это эстетика эстетической любви.

7 «В корне неверной является методика... которая руководствуется взглядом: искусство питается религией. Верно ровно противоположное: религия питается в полной мере искусством в том, что касается всех ее содержаний и людей, с помощью которых она так или иначе приводит в действие культ...» [13, S. I84]. 
бахтинское понятие как раз в значительной мере питаемо христианской идеей любви ${ }^{8}$.

Прежде всего, понятие эстетической любви у Бахтина является двусторонним: моей эстетической любви к другому соответствует в нем потребность в этой любви 9 . Эстетическая деятельность предстает в определенной мере аналогом эстетического спасения: «Эстетически творческое отношение к герою и его миру есть отношение к нему - как к имеющему умереть (moriturus), противопоставление его смысловому напряжению спасительного завершения» [I, с. 248]. Лексика, связанная с христианством, в частности, с темой спасения, можно сказать, пронизывает характеристику эстетической деятельности, сообщая ей проникновенную теплоту и без преувеличения мистическую глубину. Эстетическая активность со стороны героя в некоторых местах бахтинского текста истолковывается как «эстетическая благодать», «милость» и, в конце концов, прямо как «эстетическое спасение» [I, с. I46]. Позиция автора моделируется по позиции Бога в отношении человека: «Божественность художника - в его причастности к вненаходимости высшей» [1, с. 248 $]^{\text {10. }}$.

Ориентация на эстетический идеал отношения между Богом и человеком придает этому понятию и эстетике завершения в целом почти априорный характер и черты нормативизма, поскольку идеал авторской деятельности получает вневременное, внеисторическое значение.

8 Христианский подтекст в эстетике Бахтина уже многократно отмечался исследователями, см., например: [2, с. 487-488; 4; 5, с. 33-35; 6, с. 144, 238, 443; 7, с. 57; Іо, с. 56-57]; а наиболее основательное изучение темы: [12]. В данном случае мы лишь обращаем внимание на принципиальное различие и смену знака в методологии между Когеном и Бахтиным.

9 «..я испытываю абсолютную нужду в любви, которую только другой со своего единственного места вне меня может осуществить внутренне; эта нужда, правда, разбивает мою самодостаточность изнутри, но еще не оформляет меня утверждающе - извне» [I, с. I29]. Нужно добавить, что в эстетике Когена отсутствует понятие второго сознания.

IO Примечательно, что, несмотря на несомненное присутствие христианских мотивов в эстетике Бахтина, у него, в отличие от Когена, отсутствуют прямые обращения к вопросу о связи между религией и искусством. Таким образом, у Бахтина, как и у Когена, обнаруживается присутствие и, пожалуй, соотнесенность трех концептов: эстетической любви, завершения и момента связи искусства с религией. Причем первые два Бахтиным заимствованы у Когена и переосмыслены, а в третьем случае эта связь у Когена предстает под знаком отрицания, а у Бахтина - скорее под знаком утверждения, однако косвенно, без прямой постановки вопроса в общем виде. На фоне Когена этот отказ выглядит сознательным решением. 
В то же время именно благодаря этой двусторонности понятия эстетической любви эстетическая деятельность получает привязку к событию бытия и, соответственно, к нравственной философии Бахтина. Поскольку эстетическая любовь является бытийным ответом на абсолютную потребность другого во мне, она предстает как выражение долженствования эстетического долженствования.

В описании эстетической деятельности автора Бахтин настойчиво употребляет модальный глагол «должен». Стилистика долженствования норма бахтинского описания и анализа авторской активности, окутанной атмосферой нравственной императивности: автор должен занять определенную позицию по отношению к герою; автор должен стать вне себя; автор не должен обращаться к себе; автор должен найти точку опоры вне героя; автор должен вжиться в другого человека; тело героя должно быть пережито мною изнутри; автор должен активно создать внешнее тело другого человека; я должен быть для другого человека тем, чем Бог является для меня; я должен ценностно стать вне своей жизни; я должен ценностно вжиться в каждого из участников картины; я должен создать произведение, которое завершает героя [I, с. I22, I29, I33, I35, I4O, I4I], и т. п.

В такого рода нормативизме можно выделить два аспекта. Во-первых, он обусловлен эстетическим идеалом полной завершенности героя. Постулируется «прямое отношение автора к герою», а уже на его основе выявляются и анализируются различные виды «отклонений» от этой нормы [I, c. 97-IO2]. С другой стороны, в большинстве случаев употребление модального глагола имеет значение именно модальности долженствования, а не является стилистическим вариантом обозначения нормы. В частности, в тех случаях, где Бахтин описывает авторскую деятельность уже от первого лица. Наконец, единожды появляется прямое понятие «эстетического долженствования», а именно в контексте утверждения о том, что герой является не объектом, а субъектом: «...только по отношению к нему возможно эстетическое долженствование, возможна эстетическая любовь и дар любви» [І, с. I65].

Однако - если вернуться к исходным положениям первой философии - бахтинское понятие (нравственного) долженствования относится к измерению открытого события бытия. По Бахтину, «долженствование» как установка, состояние живого сознания не поддается теоретическому схва- 
тыванию, превращению в теоретический концепт ${ }^{\mathrm{II}}$ Стало быть, тот факт, что Бахтин, описывая эстетическую деятельность автора, постоянно прибегает к модальному глаголу и нередко переходит от третьего лица к первому, означает, что его описание относится именно к измерению события бытия, т. е. к измерению, принципиально недоступному для теоретического познания. Событие бытия открывается только участному мышлению ${ }^{\text {I2 }}$.

Но это означает, что эстетическая феноменология в отношении события бытия может быть только феноменологией деятельности читателя, тогда как деятельность автора непосредственно недоступна феноменологическому видению, во всяком случае в том, что касается эстетического долженствования и эстетической любви. Поскольку же оно пренебрегает этим различием, феноменологическое описание тут выходит на «структурноэйдетический» уровень ${ }^{13}$, или уровень автора как трансцендентального субъекта, т. е. в той мере, в какой автор тождествен читателю. Иными словами, сочетая участное мышление и структурно-эйдетическое описание, эстетика Бахтина не дифференцирует (возможно, принципиально) между феноменологией события бытия и трансцендентально-феноменологическим рассмотрением деятельности автора. Однако в отношении долженствования можно сказать, что Бахтин фактически описывает свое читательское долженствование, переприсваивая его автору. Долженствование может быть описано (констатировано, засвидетельствовано) только как «мое» долженствование. Впрочем, ничто не мешает выдвинуть тезис об эстетическом долженствовании также читателя.

В самом деле, живое сознание всегда остается за скобками, коль скоро всегда существует лишь в категории «я». И в этом смысле терминологический перевод первого лица в третье дает повод к недоразумению. Ведь автор-творец как живое сознание с его долженствованием в принципе не может быть объективирован, транскрибирован и т. п. Он недостижим для

\footnotetext{
II «Вообще ни одно теоретическое определение и положение не может заключать в себе момент долженствования, и он не выводим из него» [г, с. го].

I2 «Только внутри моей участности может быть понято бытие, как событие..» [I, с. 2I]. «Участное мышление» - оригинальное бахтинское понятие. Вот его наиболее развернутое определение: «Участное мышление и есть эмоционально-волевое понимание бытия как события в конкретной единственности - на основе не-алиби в бытии - т. е. поступающее мышление, т. е. отнесенное к себе как к единственному ответственно-поступающему мышление» [1, с. 42].

I3 Термин, предложенный применительно к поэтике Бахтина С.Г. Бочаровым [2, с. 475].
} 
теоретического познания. У Бахтина это различие снято за счет, так сказать, стилистики.

Ясно, что только в событии бытия, т. е. в моем свободном акте, моим свободным волевым решением возможно прощение всех долгов и отказ от всех надежд ${ }^{\mathrm{I}}$, и это имеет значение только тут и теперь и до тех пор, пока я удерживаю ответственность за это решение ${ }^{15}$. Следовательно, другой не менее важный вывод заключается в том, что эстетическое завершение, коль скоро оно коррелирует с эстетическим долженствованием, также, в соответствии с логикой бахтинских понятий, в конечном счете осуществляется в измерении открытого события бытия.

Таким образом, бахтинское понятие автора-творца не различает между трансцендентальным автором и автором как живым сознанием, как субъектом (специфического) поступка в измерении события бытия. В этом смысле, на наш взгляд, эстетика и теория автора Бахтина, как она представлена в тексте «Автор и герой в эстетической деятельности», является переходной в методологическом отношении, поскольку отчасти это эстетика трансцендентальной субъективности, отчасти же - в той мере, в какой она тяготеет к участному мышлению, - она выходит за рамки трансценденталистского подхода.

Понятие автора-творца (с его характеристиками «вненаходимости», «деятельности завершения», «избытка видения») метафизично в силу своего происхождения и в части своего содержания. Метафизика у Бахтина предстает в форме феноменологии. Благодаря феноменологическому методу Бахтин лучше других мыслителей Серебряного века и в целом начала ХХ в. сумел соединить философские поиски и философскую эстетику с разработкой конкретного эмпирического материала, использовать метафизические поиски спасения как эвристический потенциал для разрешения позитивных научных проблем литературоведения. Феноменология послужила мостом и одновременно фильтром, который соединил метафизику, эстетику и теорию литературы. Метафизический заряд был отчасти редуцирован, однако не полностью. В итоге присущее бахтинским поня-

I4 «Только в мире других возможно эстетическое, сюжетное, самоценное движение движение в прошлом, которое ценно помимо будущего, в котором прощены все обязательства и долги и все надежды оставлены» [1, с. 185].

I5 Очевидно, что в данном случае мы прибегаем к языку участного мышления и описания. 
тиям метафизическое содержание, обеспечивающее единство понятий как «идеальных типов», форм мысли, создает определенное напряжение между ними и исследуемым эмпирическим материалом. Область фактов и область понятий соответствуют друг другу частично ${ }^{\mathrm{I6}}$.

Таким образом, понятие автора-творца в изложении Бахтина предстает недифференцированным сочетанием автора как трансцендентальной субъективности и собственной деятельности завершения исследователя, руководствующейся религиозно-эстетическим идеалом и описанной в тонах эстетического долженствования (что и проявляется в колебании между третьим и первым лицом в изложении).

Стало быть, наиболее глубоким фундаментом бахтинской эстетики выступает понятие эстетического долженствования, которое выводится непосредственно из события бытия (описания события бытия). Упрощая, можно сказать, что эстетическое событие, или авторство (что одно и то же), зачинается в тот момент, когда некое «я» вменяет себе в долг спасти некоего «другого» от забвения, создав его цельный, завершенный образ.

Однако бытие как событие - культурно обусловленное, культурно нагруженное понятие, оно вовсе не получено в результате чистого описания (т. е. беспредпосылочного в гуссерлевском смысле). С одной стороны, оно означает непосредственное самопереживание индивида, предельное достижение феноменологии (подобно понятию бытия у Хайдеггера). С другой стороны, в это самопереживание уже встроено исторически линейное восприятие времени, т. е. в нем уже присутствует «теория». Но, для того чтобы это стало очевидным для индивида, он должен выйти за рамки непосредственного переживания.

Категории «я» и «другого», опирающиеся на философски обоснованный идеал эстетического завершения, недостаточны для объяснения художественного произведения. Иначе говоря, для того чтобы осуществить завершение героя, автор заимствует ресурсы у культуры и общества. В этом смысле автор-творец - если вынести за скобки момент самопереживания, принадлежащий измерению события бытия, т. е. живое сознание читателя,

I6 В этом смысле о понятии автора-творца, как и некоторых других понятиях Бахтина, можно говорить скорее как об идее, т. е. это некая научно плодотворная метафора, имеющая неопределенный эвристический потенциал, но не описывающая четко ограниченное множество явлений. 
пронизанное эстетическим долженствованием, - предстает, по сути, как социокультурное отношение.

Если вернуться к бахтинской формуле о единственности места человека в едином и единственном событии бытия, то эту единственность невозможно схватить, определить через нее самое, т. е. через самосоотнесенность, а только через сопоставление с другими точками в этом бытии-событии, причем здесь недостаточно одной точки - другого, поскольку такое сопоставление превращается в простое обращение разных полюсов одной оппозиции, снование между ними. Вместо этого необходима множественность точек для сопоставления, причем точек, выстроенных в определенную конфигурацию - историческую структуру. Понятие истории уже лежит в основе понятия события бытия. Поэтому и автора как «принцип видения» можно понять только через сопоставление с другими пунктами в определенной исторической конфигурации - в истории культуры и истории в целом.

Эта социокультурная и историческая подоплека эстетики Бахтина становится очевидной в заключительном разделе «Автора и героя». Здесь вводится концепция кризиса авторства, которая обнаруживает историчность понятия автора-творца и вместе с этим отчетливо выявляет исторически ограниченный характер категории завершения (и намечает формирование незавершенности как самостоятельной категории). Кризис автора, по Бахтину, обусловлен культурными условиями утраты авторитетности и невозможности завоевания позиции вненаходимости. Таким образом, автор-творец не является онтологическим, сущностным или, проще говоря, всеобщим понятием, но предстает как исторический тип литературных форм, состояния литературного общения и культуры в целом. Также и в еще большей мере культурно обусловленным является понятие эстетического долженствования (как и эстетического завершения). Эстетическое долженствование не есть нечто безусловно бытийное, оно связано с культурной установкой, которая, как было показано выше, имеет христианские корни.

Впрочем, отказ от понимания эстетического долженствования как безусловной онтологической категории не означает отрицания его плодотворности как понятия исторически обусловленной читательской установки. Более того, на наш взгляд, именно такую установку стоит развивать, воспитывать, в особенности в уходящую эпоху доминирования научных методов 
познания, в частности, методов правильного понимания текста в гуманитарных науках. Понятие эстетического долженствования дает импульс к включению ценностной сферы читателя в поле внимания самой герменевтики, к рефлексии над ней и ее формированием. В этом контексте изображение Бахтиным эстетической деятельности завершения в рамках «сознания автора» также сохраняет мощный эвристический потенциал именно как модель живого прочтения и восприятия произведения. Ведь, пожалуй, ни один другой эстетический подход не позволяет с такой полнотой и внутренней убедительностью переживать произведение как ценностный процесс творчества, так сказать, за автора. Речь идет лишь о том, что процесс познания произведения не может ограничиваться рамками переживания и тем более постулировать его исчерпывающий характер.

Уместно вспомнить дискуссию вокруг проблемы автора, тезис о «возвращении автора» и обеспокоенность его сторонников в отношении безответственности интерпретатора в связи с исчезновением фигуры автора или возможным отрицанием авторской интенции как главного предмета и критерия интерпретации (см.: [8, раздел «Автор», в частности, с. 62, III; I3]). Одним из них было высказано то соображение, что спасением от произвола интерпретатора должна стать идея ответственности и автора как ответственного центра, как она представлена в раннем тексте Бахтина (см.: [9, с. 32]). Однако, как мы указывали, из положений первой философии Бахтина следует, что ответственность автора находится за пределами теоретического схватывания. Более того, эта идея ответственности в применении к области эстетического является объективацией и обобщением ответственности читателя, личной ответственности М.М. Бахтина ${ }^{17}$. Однако есть смысл расширить ее значение. Бахтинское «эстетическое долженствование», по нашему мнению, можно истолковать применительно к деятельности читателя и интерпретатора. В этом случае стоит говорить о герменевтическом долженствовании, или герменевтической ответственноcmu. О долженствовании и ответственности автора - коль скоро, согласно Бахтину, она принадлежит событию бытия и находится вне сферы теоре-

I7 Разумеется, речь не идет о субъективизме, а только о том, что долженствование и ответственность, опять-таки в соответствии с философией Бахтина, могут быть зафиксированы только как факт живого события бытия. По нашему же мнению, он может интерпретироваться как культурная установка, возможно, как некое культурное априори. Но эта тема требует отдельного рассмотрения. 
тического познания - исследователь может судить только на основании собственных авторских высказываний, а это уже является интерпретацией. Внутренняя, не высказываемая прямо ответственность автора и вовсе сфера догадок. Но себе исследователь вполне может вменить некие императивы. Интерпретация не является нейтральным в отношении ее субъекта познавательным актом. Сам Бахтин дает выразительную формулу личной бытийной вовлеченности интерпретатора как необходимого условия понимания: «Понять предмет значит понять мое долженствование по отношению к нему (мою должную установку), понять его в его отношении ко мне в единственном бытии-событии, что предполагает не отвлечение от себя, а мою ответственную участность» [I, с. 20-2I]. Иными словами, акт понимания и интерпретации, по Бахтину, имеет этическое измерение как неотъемлемую предпосылку.

В современных гуманитарных науках в области интерпретации фактически господствует методологический анархизм, и призывы вернуться здесь к авторитаризму, к тезису о единственной верной интерпретации тщетны. По этой причине (и также учитывая невозможность отказа от идеи смысловой незавершимости) мы полагаем, что выход следует искать именно в направлении разработки идеи ответственности читателя и интерпретатора. И понятие герменевтического долженствования могло бы стать отправным пунктом для размышлений. 


\section{Список литературы}

I Бахтин M.M. Собр. соч.: в 7 т. М.: Изд-во русские словари; Языки славянской культуры, 2003. Т. г: Философская эстетика г920-х годов. 960 с.

2 Бочаров С.Г. Сюжеты русской литературы. М.: Языки русской культуры, І999. $632 \mathrm{c}$.

3 Домащенко А.В. Порождающее лоно поэзии // Литературоведческий сборник. Донецк: ДонНУ, 2006. Вып. 25: Проблема автора: онтология, типология, диалог. С. $32-48$.

4 Исупов К.Г. Апофатика М.М. Бахтина // Диалог, карнавал, хронотоп. І997. № 3. C. $19-3$ I.

5 Исупов К.Г. О философской антропологии М.М. Бахтина // Бахтинский сборник. М.: Прометей, г990. Вып. І: Сб. ст. С. 30-46.

6 Исупов К.Г. Судьбы классического наследия и философско-эстетическая культура Серебряного века. СПб.: Русская христианская гуманитарная академия, 20 оо. $592 \mathrm{c.}$

7 Кларк К., Холквист М. Архитектоника ответственности // М.М. Бахтин: pro и contra. Творчество и наследие М.М. Бахтина в контексте мировой культуры / сост. и коммент. К.Г. Исупова. СПб.: РХГИ, 2002. Т. II. С. 32-7І.

8 Компаньон А. Демон теории. Литература и здравый смысл. М.: Изд-во им. Сабашниковых, 200I. 336 с.

9 Фрайзе М. После изгнания автора: Литературоведение в тупике? // Автор и текст: сб. ст. / под ред. В.М. Марковича и В. Шмида. СПб.: Изд-во С.-Петербургского ун-та, г996. С. 25-32.

Іо Фридман И.Н. Незавершенная судьба эстетики завершения // М.М. Бахтин как философ. М.: Наука, г992. С. 5I-67.

II Brandist C. The Bakhtin Circle: Philosophy, Culture and Politics / Craig Brandist. London: Pluto Press, 2002. 22I p.

I2 Coates R. Christianity in Bakhtin: God and the Exiled Author (Cambridge Studies in Russian Literature). Cambridge University Press, I999. xiv, 204 p.

I3 Cohen H. System der Philosophie. Berlin: Cassirer, I9I2. T. 3: Ästhetik des reinen Gefühls. Bd. I. XIV, 402 S.

I4 Intention and Interpretation / edited by Gary Iseminger. Philadelphia: Temple University Press, I995. 272 p.

\section{References}

I Bakhtin M. M. Sobranie sochinenii: $v$ t. [Collected works: in 7 vols.] Moscow, Izdatel'stvo russkie slovari; Iazyki slavianskoi kul'tury Publ., 2003. Vol. I: Filosofskaia estetika I920-kh godov [Philosophic aesthetics of the I920s]. 960 p. (In Russ.) 
Bocharov S.G. Siuzhety russkoi literatury [Plots of Russian literature]. Moscow, Iazyki russkoi kul'tury Publ., I999. 632 p. (In Russ.)

3 Domashchenko A.V. Porozhdaiushchee lono poezii [The begetting womb of poetry]. Literaturovedcheskii sbornik [Collection of literary criticism]. Donetsk, DonNU Publ., 2006. Issue 25: Problema avtora: ontologiia, tipologiia, dialog [The problem of the author: onthology, typology, dialogue], pp. 32-48. (In Russ.)

4 Isupov K.G. Apofatika M.M. Bakhtina [M.M. Bakhtin's apophatics]. Dialog, karnaval, khronotop [Dialogue, carnival, chronotope], I997, no 3, pp. I9-3I. (In Russ.)

5 Isupov K.G. O filosofskoi antropologii M.M. Bakhtina [On M.M. Bakhtin’s philosophical anthropology]. Bakhtinskii sbornik [Bakhtin's collection]. Moscow, Prometei Publ., I990. Issue I: Collection of articles, pp. 30-46. (In Russ.) Isupov K.G. Sud'by klassicheskogo naslediia i filosofsko-esteticheskaia kul'tura Serebrianogo veka [The fates of classical legacy and philosophic and aesthetic culture of Silver age]. St. Petersburg, Russkaia khristianskaia gumanitarnaia akademiia Publ., 20IO. 592 p. (In Russ.) Clark K., Holquist M. Arkhitektonika otvetstvennosti [Architectonics of answerability]. M.M. Bakhtin: pro i contra. Tvorchestvo i naslediie M.M. Bakhtina v kontekste mirovoi kultury [M.M. Bakhtin: pro and contra. M.M. Bakhtin's work and heritage in the context of world culture]. St. Petersburg, Russkaia khristianskaia gumanitarnaia akademiia Publ., 2002, vol. II, pp. 32-7I. (In Russ.)

8 Compagnon A. Demon teorii. Literatura $i$ zdravyi smysl [The demon of theory. Literature and common sense]. Moscow, Izdatel'stvo im. Sabashnikovykh Publ., 200I. 336 p. (In Russ.)

9 Fraize M. Posle izgnaniia avtora: Literaturovedenie v tupike? [After the expulsion of the author: Literary criticism in a dead end?] Avtor i tekst [Author and text]. Collection of articles. Edited by V.M. Markovich and V. Shmid. St. Petersburg, Izdatel'stvo S.-Peterburgskogo universiteta Publ., I996, pp. 25-32. (In Russ.) Fridman I.N. Nezavershennaia sud'ba estetiki zaversheniia [Incomplete fate of the aesthetics of consummation]. M.M. Bakhtin kak filosof [M.M. Bakhtin as a philosopher]. Moscow, Nauka Publ., I992, pp. 5I-67. (In Russ.) Brandist C. The Bakhtin Circle: Philosophy, Culture and Politics. London, Pluto Press, 2002. 22I p. (In English) Coates R. Christianity in Bakhtin: God and the Exiled Author (Cambridge Studies in Russian Literature). Cambridge University Press, I999. XIV, 204 p. (In English) Cohen H. System der Philosophie. Berlin, Cassirer, I9I2. T. 3: Ästhetik des reinen Gefühls. Bd. I. XIV, 402 S. (In German) Intention and Interpretation, edited by Gary Iseminger. Philadelphia, Temple University Press, I995. 272 p. (In English) 
УДК 82I.ІІІ.о

ББК 83.3(4Вел)5

\section{ЭВОЛЮЦИЯ КЛАССИЦИЗМА В XVIII В. И АНГЛИЙСКИЙ РОМАН}

\author{
(C) 2018 г. Е.П. Зыкова \\ Институт мировой литературы \\ им. А.М. Горького Российской академии наук, \\ Москва, Россия \\ Дата поступления статьи: о6 декабря 2017 г. \\ Дата публикации: 25 сентября 2018 г.
}

DOI: I0.22455/2500-4247-20I8-3-3-26-45

Аннотация: В статье рассматриваются те изменения, которые происходят в классицистической концепции личности в начале XVIII в. под влиянием новых социальных обстоятельств (появлением на сцене среднего класса с его культурными интересами, сменой идеала воина идеалом частного человека, просвещенного джентльмена). Мотивы борьбы долга и страсти в душе героя преобразуются в мотивы взаимодействия разума и страстей, при котором страсти не подавляются, a «воспитываются» под руководством разума, что помогает развитию творческих способностей личности, достойному исполнению ею своих социальных ролей и достижению счастья. Подчеркивается связь этой концепции личности с гуманистической традицией и осмысление ее творческого потенциала в понятии «искусство жизни». Далее черты этой новой концепции личности прослеживаются в творчестве Ричардсона и Филдинга. Автор полагает непродуктивным связывать творчество Ричардсона с сентиментализмом. Романы «Памела» и «Кларисса» представляют своеобразную параллель классицистической концепции XVII в., с ее конфликтом долга и чувства и тонким психологическим анализом, а в «Истории сэра Чарльза Грандисона» можно увидеть воплощение нового классицистического понимания личности в XVIII в. Филдинг гораздо снисходительнее Ричардсона относится к людским слабостям и недостаткам, что свойственно мировосприятию рококо. Однако его положительный герой (Том Джонс, капитан Бут), человек «доброго сердца», проходя через испытания и искушения, осознает важность благоразумия, приучается отвечать за свои поступки, его путь к совершенству ведет к той же гармонизации разума и чувства.

Ключевые слова: классицизм, рококо, разум и чувства, «искусство жизни», Поуп, Ричардсон, Филдинг.

Информация об авторе: Екатерина Павловна Зыкова - доктор филологических наук, ведущий научный сотрудник, Институт мировой литературы им. А.М. Горького Российской академии наук, ул. Поварская, д. 25 а, І2Іо69 г. Москва, Россия.

E-mail: epzykova@yandex.ru

Для цитирования: Зыкова Е.П. Эволюция классицизма в XVIII в. и английский роман // Studia Litterarum. 20I8. T. 3, № 3. C. 26-45. DOI: IO.22455/2500-4247-20I8-3-3-26-45 


\section{EVOLUTION OF CLASSICISM IN THE $18^{\text {th }}$ CENTURY AND THE ENGLISH NOVEL}

This is an open access article distributed under the Creative Commons Attribution 4.0 International (CC BY 4.0)
(C) 20I8. E.P. Zykova

\author{
A.M. Gorky Institute of World Literature
}

of the Russian Academy of Sciences, Moscow, Russia

Received: December 06, 2017

Date of publication: September 25, 2018

Annotation: The article discusses changes that took place in the classicist concept of personality at the beginning of the $18^{\text {th }}$ century, due to the new social environment (the rise of the middle class and its cultural requirements, change of the martial ideals by private life values and codes of genteel behavior). It mainly focuses on A. Pope's “Essay on Man.” The essay argues that the motifs of struggle between reason and passion become transformed into the motifs of interaction between them, passions being not thwarted but disciplined under the guidance of reason. This inner harmony leads to the flowering of various skills, enables a person to fulfil social roles and to reach happiness. The author stresses connection of this concept with the humanist tradition and comments on its creative nature as manifested in the idea of the "art of life." In what follows, the essay analyzes how Richardson's and Fielding's novels draw from the concept of personality explicitly expressed in the "Essay on Man." The author argues that it is not productive to view Richardson as a sentimentalist. His Pamela and Clarissa known for their psychological subtlety present a curious parallel to the $\mathrm{I}^{\text {th }}$ century classicist concept since both novels center on the conflict between duty and passions whereas The History of Sir Charles Grandison embodies the new classicist concept of personality. The art of Fielding combines two styles - classicist and rococo. Unlike Richardson, Fielding condescendingly treats many human frailties, which is a trait of the rococo style. Yet, his positive character, a good-natured man (such as Tom Jones or captain Booth), passes through various trials and temptations, educates himself in the "school of life," comes to realize the value of prudence, and learns to take responsibility for his actions. This means that he also harmonizes his reason and his passions in order to come closer to human perfection.

Keywords: classicism, rococo, reason and passions, "art of life," Pope, Richardson, Fielding.

Information about the author: Ekaterina P. Zykova, DSc in Philology, Leading Researcher, A.M. Gorky Institute of World Literature of the Russian Academy of Sciences, Povarskaya 25 a, I21069 Moscow, Russia.

E-mail: epzykova@yandex.ru

For citation: Zykova E.P. Evolution of Classicism in the $18^{\text {th }}$ century and the English novel. Studia Litterarum, 20I8, vol. 3, no 3, pp. 26-45. (In Russ.)

DOI: I0.22455/2500-4247-20I8-3-3-26-45 
Классицизм, как литературное направление и как явление европейской культуры, определенная модель поведения, переживает в XVIII в. заметную эволюцию. Она связана с происшедшим на рубеже XVII-XVIII вв. переломом, утвердившим светский характер государства и культуры, что привело к изменению идеального образа личности, представлений о достойных ее побуждениях и мотивациях, новому пониманию отношений долга и страстей.

Однако, говоря о классицизме XVIII в., мы, как правило, имеем в виду поэзию и драматургию, что же касается прозы, особенно романа, то с ним этот стиль никак не связывается. Англоязычные исследователи также предпочитают говорить об «августинской эпохе», «августинском гуманизме» [І2], имея в виду эпоху конца XVII - начала XVIII вв., когда многие деятели английской культуры любили сопоставлять свое время с веком римского императора Августа (само название эпохи говорит о классицистическом стиле мышления). Между тем с тех пор, как суждения о реализме романа этой эпохи оказались поколеблены, выбор остается между стилями рококо, сентиментализма и предромантизма, не охватывающими всей сложности и многообразия материала. Думается, было бы небезынтересно попытаться обнаружить черты новой классицистической концепции личности в романе XVIII в., что существенно дополнило бы стилевую картину эпохи. При этом следует иметь в виду, что классицизм в это время редко встречается в чистом виде, но почти всегда в сочетании с другими стилями, чаще всего рококо.

Попробуем обратиться к авторитету Гете и Шиллера. Ведь романы Гете о Вильгельме Мейстере создавались именно в период «веймарского классицизма» и обсуждались в переписке Гете и Шиллера, в основном с 
точки зрения чистоты романа как жанра - точки зрения вполне классицистической. Шиллер пытался на примере «Вильгельма Мейстера» выявить и определить своеобразие романа как жанра и, включая его в иерархию классических жанров, уточнить его границы. Он находил в романе Гете элементы эпического, но считал их оправданными замыслом и сюжетом, однако излишнюю «театральность» романа он уже называл «ошибкой» [I, с. 437]. Обсуждались и проблемы становления личности главного героя, в частности, роль эстетического начала в его «воспитании», и Гете во всем соглашался с Шиллером. Но так ли уж своеобразен классицизм великих веймарцев, что он не имеет сходства с другими классицистическими явлениями эпохи?

Вероятно, мы недостаточно учитываем те изменения, которые происходят в классицистических представлениях в новую эпоху. Важным моментом в формировании новой классицистической концепции личности было то, что на рубеже XVII-XVIII вв. идеал воинской доблести, до сих пор одушевлявший высший класс общества, постепенно уступает место сугубо мирному идеалу частного человека, который, разумеется, готов служить государству, если в том будет необходимость, но осознает устроение своей частной жизни как культурную цель. Это делает актуальной идею достижения счастья частного человека.

На арену культурной жизни выходит средний класс, желающий, с одной стороны, усвоить себе ценности, признанные предшествующей культурой, с другой стороны, привнести в культурное пространство свои собственные интересы и предпочтения. В связи с этим человек среднего (в исключительных случаях - даже низшего) сословия приобретает статус положительного героя, мыслится способным воплотить по-новому осмысленный классицистический идеал, но воплотить в более конкретных бытовых условиях жизни.

Новая классицистическая концепция личности наиболее отчетливо выражена в философской поэме Александра Поупа «Опыт о человеке» (I733-I734). Классицизм, как художественный стиль раннего Нового времени, ориентированный на создание светского идеала личности, противопоставлял страсти, как элемент природный, и нравственный долг, определяемый разумом и возвышающий человека над царством природы. Долг воспринимался в классицизме XVII в. как понятие надличное, требующее от человека морального действия во благо общества или государства, и в 
случае конфликта долга и страстей безусловного подчинения последних высшему, разумному началу. Этому не противоречит мастерское изображение страстей в драме классицизма: чем сильнее страсть, тем нравственно возвышеннее победа над нею.

В эту концепцию Поуп вносит существенные коррективы: он вновь «реабилитирует» страсти, без которых счастье человека невозможно, и полагает, что задача разума - не подавлять их, но сосуществовать в гармонии с ними:

Куда верней идти путем Природы;

Здесь Разум наш не метит в воеводы,

А Страсти - не враги, скорей - друзья.

(Здесь и далее пер. В. Кутика [4])

По-новому оценивая роль страстей в жизни человека, Поуп вступает в полемику с моралистами XVII в., в первую очередь с Ларошфуко, на которого ссылается в комментариях к своей поэме. Поуп ратует за такой компромисс между страстями и разумом, при котором разум теряет абсолютное господство, но все же остается руководителем и «воспитателем» страстей, способным их облагородить. Страсти для него не неуправляемая природная стихия, но необходимый «двигатель» человеческой воли, источник, из которого растут добродетели:

Как черенок, привитый садоводом

К дичку лесному радует приплодом,

Так из Страстей рождается на свет

Всех наших Добродетелей букет.

Поуп придает новое, просветительское звучание традиционному христианскому сопоставлению человеческой души с возделанным садом: у него речь идет не о выпалывании сорняков-страстей, а о «прививке» черенка разума к природному дичку страсти и превращении его в культурное растение добродетели. Чтобы страсть превратилась в добродетель, она должна не только подчиниться контролю разума, но и обрести достойную цель, иначе она становится пороком: 
Так, честолюбье, мыслями владея,

Творит и патриота, и злодея.

Поуп стремится к восстановлению ренессансной гармонии между низшей частью природы человека и высшей, разумной ее частью, доказывая, что именно в таком гармоническом единстве и воплощается во всей полноте Божественный замысел о нем.

Поуп уверен также, что каждому человеку на его жизненном пути приходится играть множество ролей в обществе - сына, мужа, отца семейства, друга, гражданина, представителя своего класса и своей профессии и т. д. и все их необходимо сыграть в совершенстве, чтобы в полной мере осуществить свою личность и свое предназначение. В этой новой формулировке идеала универсализма сказывается интерес просветительской эпохи к социальному устройству жизни и одновременно стремление подчеркнуть значение частной сферы (роли сына, отца семейства, друга и т. д.) наряду со сферой общественной (роли дворянина, купца, художника, гражданина и т. п.).

По-новому осмысленный идеал универсальной личности требует конкретных условий для своего воплощения, поэтому особую актуальность приобретает способность человека организовать свою жизнь и свой быт так, чтобы в них гармонически сочетались труд и отдых, польза и развлечение, дружеское общение и любовь к природе, любознательный интерес к научным достижениям и развитие эстетических способностей. В связи с этим английская классицистическая поэзия проявляет повышенный интерес к обустройству быта, организованного для соответствия определенному жизненному идеалу. Большой интерес вызывает поэма Джона Помфрета «Выбор» (г690), автор которой выражает пожелание содержать сельский дом вблизи города, «жить благородно, но не роскошно», иметь возможность общаться с друзьями и предаваться тем культурным занятиям, которые облагораживают досуг. Джонатан Свифт, выражая сходные пожелания в «Подражании части шестой сатиры второй книги Горация», прибегает к горацианскому идеалу «золотой середины», который становится популярен в культурных кругах Англии этого времени и освящает своим авторитетом новые ценности (что немаловажно для творческого сознания классициста). По-новому осмысленный идеал универсальной личности может быть воплощен в жизни только творческими усилиями личности, уверен 
Поуп, создающий новую концепцию жизнетворчества. При этом для него важно, что творческая деятельность человека не противоречит Природе, но находится в гармонии с нею. Завершая первую часть «Опыта о человеке» утверждением о мудром устройстве вселенной, Поуп говорит (эти слова не нашли отражения в переводе И. Кутика): All Nature is but Art, unknown to thee (Вся Природа - это Искусство, которое ты не постигаешь). Природный мир сотворен Богом-Творцом, напоминает Поуп, т. е. то, что человек уже привык считать «естественным», на самом деле создано высшим Искусством. Так и человек, в меру сил подражая своему Творцу, должен гармонизировать свой разум и страсти, стремясь к совершенству, к развитию своих способностей и достойному исполнению всех своих жизненных ролей, а тем самым и к достижению счастья. Стремление к идеалу, по мнению Поупа-классициста, и позволяет человеку пребывать в гармонии с Природой, как произведением Божественного творчества.

Для Поупа и его друга Свифта особую актуальность приобретает проблема цивилизации (учитывая, что разделения понятий цивилизации и культуры еще не произошло, ее можно сформулировать и как проблему культуры). Цивилизация у Поупа не противостоит природе, а, напротив, строится по ее образцу, воспроизводит ее гармонию, ее принципы единства в многообразии, сопряжения противоположностей. Цивилизация это колосящиеся нивы, богатеющие города, мощный флот, гражданская свобода, охраняемая законом, и процветающее искусство, но прежде всего это творческое самовоспитание и внутренняя самодисциплина личности. Цивилизации в художественной системе Поупа противостоит варварство, состояние, когда разрушительные инстинкты в людском сообществе берут верх и воцаряется хаос, война и разорение. Такова концепция его поэмы «Виндзорский лес» (г7Із).

У Поупа, как и у Свифта, речь не идет о непременном прогрессе: движение между варварством и цивилизацией возможно в обе стороны. Так, в одном из писем Свифт замечает «Истинная религиозность сравнима, на мой взгляд, с ученостью и благонравием (Civility), которые существовали всегда, однако часто меняли местоположение: бывало, они покидали те страны, в которых раньше процветали, и перебирались в земли, прежде населенные варварами» [5, с. 31]. Мысль о хрупкости цивилизации, легкости ее утраты и возвращения к варварству подхватит в четвертой книге поэмы 
«Дунсиада» (I74I) Поуп, проникнувшийся к концу жизни пессимизмом Свифта. Поэт заканчивает эту книгу, а с ней и всю поэму картиной возвращающегося хаоса и тьмы, внушая читателю, что цивилизация поддерживается усилиями человеческого разума и отсутствие таковых усилий способно повергнуть ее снова в состояние варварства.

Концепция личности, сложившаяся в кружке Поупа - Свифта, продолжает оставаться классицистической, поскольку этих авторов, как и классицистов XVII в., волнует воплощение идеала человеческой личности, а также поскольку в дихотомии разума/страстей разуму оставляется ведущая роль. Однако и внесенное изменение принципиально значимо: страсти и разум не противостоят друг другу, но вступают в творческий союз, в котором разум становится «чувствительным», а чувство - «разумным». Это важный шаг, сближающий классицизм XVIII в. с гуманистической концепцией культивирования всех способностей, заложенных в человеческой природе.

Классицизм XVIII в. противостоит стилю рококо, который отвергает стремление к идеалу как ложное и не соответствующее человеческой природе. Он противостоит и сентиментализму, который не доверяет более понятию нормативного разума (right reason, т. е. заложенного Богом в человеческую природу) и представляет заблуждения разума, который лишь тешит себя иллюзией, будто он руководит страстями, хотя на самом деле все происходит ровно наоборот (Стерн), и выдвигает на первый план особую ценность непосредственного впечатления и переживания жизни в противовес «скучному разуму» (Вертер). Поскольку классицизм продолжает стремиться к идеалу, индивидуальность интересует его меньше, чем сентиментализм и рококо. Классицизм XVIII в. теснее связан с прошлым, в то время как сентиментализм и рококо тяготеют к будущему.

Для кружка Поупа-Свифта классицизм является не только литературным стилем, но и стилем поведения, что можно продемонстрировать на материале сохранившихся писем молодого Свифта I696 и г70о гг. к Джейн Уоринг, кузине братьев Уоринг, с которыми Свифт учился в Тринити-колледже в Дублине. В г695 г. Свифт был рукоположен в Дублине и получил провинциальный приход Килрут, где его соседкой и оказалась Джейн Уоринг. 29 апреля г696 г. датировано длинное письмо Свифта к ней. 
Сударыня, - пишет Свифт, - нетерпение - неотъемлемое качество влюбленного, оно свойственно каждому, кто преследует цель, от коей зависит все его дальнейшее благополучие. Происходит это и на войне, и при дворе, и в делах самых заурядных. Всякий, кто ищет удовольствий, славы или богатства, пребывает, покуда не добьется своего, в постоянной тревоге и беспокойстве - и это не только вполне естественно, но и, пожалуй, логично, ведь сильное желание под стать недугу, а потому нет ничего зазорного в том, что человек ищет возможности от своего недуга излечиться. Болезнью этой заразился и я - тешу, однако ж, себя надеждой, что у меня есть больше оснований рассчитывать на прощение, чем у других, ибо драгоценный объект, от коего всецело зависит будущее мое счастье, подвергается постоянной опасности (перевод наш. - E.3.) [І7, p. I7].

Свифт извиняется за свое нетерпение и старается объяснить его разумным образом, признается в пламенной страсти и рассматривает эту страсть как болезнь, в одном ряду с погоней за удовольствием, славой или состоянием. Вместе с тем он видит страсть как потребность естественную и достойную разумного удовлетворения. Рассуждая далее об отношениях страсти и разума, Свифт утверждает, что естественную страсть не всегда надо держать в узде: «Сопротивление нашим естественным желаниям есть самоотречение, которое может претендовать на добродетель, однако, когда желания эти обоснованы, когда они пустили глубокие корни, дали богатые всходы, сопротивляться их диктату - безумие, безумие и несправедливость, ибо они имеют то отличительное свойство, что похвальны в своих крайностях - избыток благочестия может ведь быть ничуть не менее греховным, чем избыток любви» [I7, p. І9]. Любовь нуждается в контроле со стороны разума, но только на первых стадиях отношений, когда же разум уже одобрил ее, сдерживание в тисках благоразумия становится глупо и недостойно.

Второе сохранившееся письмо Свифта Джейн Уоринг написано четыре года спустя, 4 мая І7оо г., в нем Свифт вновь предлагает пожениться и задает ряд вопросов, положительный ответ на которые считает непременным условием счастливой семейной жизни: «В состоянии ли Вы управлять домашним хозяйством при доходе (быть может) меньшем, чем три сотни фунтов в год? Приятны ли Вам моя личность и мой темперамент настолько, 
чтобы идти навстречу моим желаниям, принимать мой образ жизни и стараться сделать нас как можно более счастливыми? Согласны ли Вы употребить те методы, которые я предложу, для совершенствования Вашего ума, чтобы мы стали приятным обществом друг для друга и не чувствовали себя несчастными, когда у нас нет гостей и когда мы не едем в гости? ...Буду ли я иметь такую власть над Вашим сердцем или Вы такую власть над своими страстями, чтобы при моем появлении Вы приходили в хорошее настроение, даже если Вас провоцируют?» [I7, p. 35-36]. Свифта волнуют проблемы личных взаимоотношений, которые будут важны для романа и в XVIII, и в XIX в., причем он придает своим вопросам именно классицистическое звучание: для него важны и умение властвовать над своими страстями, и готовность к самосовершенствованию в сочетании с вниманием к бытовой сфере, способностью справиться с бытовыми проблемами.

Следует иметь в виду, что в «августинскую эпоху» классицистическому идеалу в Англии приходится конкурировать с иными тенденциями в понимании личности, поэтому некоторые современные исследователи отвергают термин «августинский» как не соответствующий всей сложности картины эпохи. Научный стиль мысли эпохи (наиболее весомо в «Опыте о человеческом разумении» Локка) вырабатывает понятие дискурсивного разума, которое отвергает нормативный разум (right reason), заложенный Богом в человеческой природе. Дискурсивный разум, по мысли философа, способен вывести законы человеческого поведения столь же неотменимые, как и законы естественных наук, т. е. полагается возможным редуцировать моральное поведение личности до «естественных реакций» на ту или иную ситуацию, основанных на интуитивном чувстве удовольствия или страдания [13]. Б. Паркер настоятельно подчеркивает разрыв между «возвышенным» классицизмом и «низменной» сатирой (речь идет не о «низком» стиле классицизма, а именно о сатире, иначе видящей человеческую личность) [I5].

Классический английский роман бытового типа рождается в Англии в среде среднего класса, исповедующего протестантизм, не признающий государственного англиканства. С этой средой связано творчество Дефо и Ричардсона. Дефо чужд классицистической культуре, он опирается на противостоящие ей философские тенденции, сводящие мораль к «естественному чувству» самосохранения. П. Бэкшайдер справедливо характеризует его как наиболее «современного» из всех романистов XVIII в. [9, р. 8]. 
Ричардсон происходит из той же социальной среды, что и Дефо, но его творчество приходится на середину века, и проблематика его иная. Действие «Памелы» и «Клариссы» происходит в тщательно выписанной бытовой обстановке, героини - представительницы низшего и среднего класса, стремящиеся исполнить как можно лучше внушенный религией закон социального поведения. Конфликты и структура личности героинь этих романов составляют своеобразную параллель классицистической схеме характера XVII в.: подвергая испытанию добродетель своих героинь в ярко драматических ситуациях, автор изображает борьбу страстей и разума или долга. Тонкий психологический анализ внутреннего мира героинь также сближает поэтику Ричардсона с классицизмом. Однако внутренняя борьба героинь имеет пуританские корни, изощренный психологизм обусловлен пуританской дневниковой традицией религиозного самоанализа [І8]. Проблематика же «Памелы» и «Клариссы» по сравнению с классицизмом предшествующего столетия предельно сужена: действие многотомных романов сосредоточено вокруг соблазнения невинной девушки и ее отпора соблазнителю. Комедийный и трагедийный варианты конфликта обусловлены характерами героев - более легкомысленного и покладистого героя «Памелы» и сильного, гордого и циничного героя «Клариссы».

Ричардсон слишком акцентирует стремление своих героинь (особенно Клариссы) к идеалу и совершенству, слишком строго настаивает на подавлении страсти, если есть опасность, что она помешает исполнению долга, чтобы можно было отнести его романы к сентиментализму. Их психологизм обусловлен именно внутренней борьбой в душах героев, а вовсе не наблюдением за тонкими душевными движениями и любованием мимолетностями, как это свойственно сентиментализму или рококо.

Между тем в третьем романе «История сэра Чарльза Грандисона» Ричардсон, создавая образцовый мужской образ, выходит за пределы пуританского менталитета и ориентируется на общенациональную моралистическую традицию. В главном герое должен был воплотиться новый общественный идеал джентльмена, и, создавая его, романист ориентировался на воззрения современных ему философов и теологов с их установками на социальную эффективность норм морали [I4]. В последнем романе Ричардсона увлекает процесс совершенствования героев под влиянием нравственного начала, как процесс жизнетворческий, предложенный новым класси- 
цистическим пониманием личности. Теперь Ричардсон уверен, что именно такой путь согласуется с требованиями религии и морали и одновременно обеспечивает человеку максимальные возможности найти счастье в земной жизни и заслужить счастье в жизни вечной.

Последний роман Ричардсона, в отличие от «Памелы» и «Клариссы», построен не на остродраматическом конфликте между двумя центральными героями, а как изображение жизни целой социальной среды, достаточно большого круга персонажей, чьи жизненные проблемы и судьбы в равной степени интересны для читателя. Конфликты, теряя в своей драматической остроте, становятся более разнообразными и более неоднозначными с нравственно-психологической точки зрения.

Сэр Чарльз Грандисон представлен читателю как идеальный герой, который, работая в юности над своим характером, стремился во всем руководствоваться доводами разума и понятием справедливости, что совершенствовало его ум и облагораживало чувства, пока он не привык спонтанно поступать именно так, как велит долг. Это создает ощущение восхитительной легкости всех побед сэра Чарльза, дает ему возможность полного контроля над любой драматической ситуацией, но совершенно исключает для него возможность душевной жизни. Сэр Чарльз, несомненно, воплощает собой модель совершенной личности, но с некоторым смущением романист и его читатель обнаруживают, что, насколько увлекателен сам процесс культивирования своих способностей и гармонизации духовного мира, в разных вариантах представленный в образах персонажей, окружающих сэра Чарльза, настолько же сух и маловыразителен конечный результат этого процесса, воплощенный в моральном совершенстве главного героя.

Привлекательность и обаяние других героев романа обусловлены именно несовпадением, разрывом между естественным темпераментом, спонтанными, бессознательными движениями души и тем идеалом совершенного личностного развития, к которому они стремятся. Этот разрыв и дает возможность динамического изображения душевной жизни, создает объемность и психологическую неоднозначность образа. Очаровательная и жизнерадостная Гарриет Байрон, влюбившаяся в сэра Чарльза и узнающая, что во время путешествия по Европе он чуть было не женился на благородной итальянке, сестре своего друга, и до сих пор считает себя связанным определенными обязательствами; сестры сэра Чарльза - спокойная 
Каролина, кротко переносящая тиранию отца, который, пока Чарльз путешествовал, проматывал семейное состояние, держал дочерей взаперти и отказал жениху Каролины от дома, не желая платить приданое; младшая своевольная и взбалмошная Шарлотта, которая, видя обращение отца с сестрой, завела тайную переписку с неким капитаном Андерсоном, а дав ему обещание не выходить замуж без его согласия, вдруг обнаружила, что письма за капитана писал какой-то другой, гораздо более образованный и благородный человек; дядюшка сэра Чарльза лорд М., который каждый день бранится со своей любовницей и не может с ней расстаться, потому что в этом случае обязался платить ей содержание и жалеет денег; благородная Клементина делла Поррета, которая борется со своей несчастной любовью к человеку иного вероисповедания и почти что теряет рассудок в этой борьбе, - эти и многие другие колоритные лица романа попеременно занимают внимание читателя то комическими, то почти трагическими проблемами, которые в конечном счете разрешаются благополучно при помощи титульного героя.

Обратим внимание на характерную для классицизма XVIII в. метафору души человека как возделываемого сада, которая присутствует уже в поэзии Поупа, используется и Ричардсоном. Если французский регулярный парк, в котором весь естественный ландшафт выровнен, деревья посажены в геометрически правильном порядке и подстрижены, удачно символизирует собою полное подчинение природных страстей воле и долгу классицистического героя XVII в., то приемы создания пейзажного парка - бережное сохранение естественного ландшафта и кропотливое, остающееся незаметным для глаза гуляющего украшение природы - аналогичны приемам самосовершенствования, культивирования задатков и способностей своей души, которые предлагает классицистическая культура XVIII в. Поуп не случайно воплотил новые принципы создания пейзажного парка в своем имении в Твикнеме и стал признанным авторитетом в парковом искусстве [I5]. В конце «Истории сэра Чарльза Грандисона», описывая свадьбу героя и его возвращение в родовое имение Грандисон-холл, Ричардсон создает образ ландшафтного парка, окружающего поместье, изображает восхищение гостей искусством хозяина, его тактом и изобретательностью в украшении естественного пейзажа. Здесь ландшафтный парк становится символом души классицистического героя. 
Если романы Ричардсона мне представляется уместнее всего сближать и связывать именно с классицизмом, то творчество Генри Филдинга не укладывается в рамки одного стиля и обнаруживает как черты классицизма XVIII в., так и черты рококо. В ту пору, когда Ричардсон со своим пуританским максимализмом отстаивал добродетель своих героинь, Филдинг, проявлявший большой интерес к спорам моралистов, вырабатывал в своей эссеистике идеи нового классицизма, озабоченного поисками счастья в гармонии разума и страстей (см. подробнее: [2]). «Мудрые люди справедливо предпочитают победу над собой победам над армиями и королевствами, - утверждал он. - Это то мужество, которое настоятельно рекомендуется нашей религией и которое, как бы пассивно оно ни было по отношению к другим, чрезвычайно активно по отношению к самим себе. Всякий, кто тщательно исследует свое собственное сознание, найдет достаточно врагов, с которыми надо бороться; целое полчище упрямых страстей, которые держат его в плену, часто заставляют его разум отступать, и если будут по истечении длительного времени побеждены, то не без большого труда и упорства» [І2, т. I5, p. I77]. Кажется, Филдинг идет на уступки Ричардсону, когда предлагает бороться с «полчищем страстей», однако это не совсем так. Он сравнивает внутренний мир личности с государственным устройством: только «справедливый баланс власти может стать основой известной степени свободы в политическом устройстве, так же как точный баланс страстей сохраняет порядок и равновесие внутренней жизни. Поэтому задача каждого человека тщательно исследовать, не склоняется ли баланс в какую-нибудь сторону, иначе он может оказаться в беде раньше, чем заметит опасность...» [І2, т. I5, p. I79].

В этой связи Филдинга волнует проблема «господствующей страсти». Если комедиографы XVII-XVIII вв., да и сам Филдинг в своих комедиях, рассматривали ее в эстетическом плане, используя ее как способ создания характера, то в своих эссе Филдинг подходит к «господствующей страсти» как моралист. Он утверждает, что, если какая-либо страсть становится господствующей, она подчиняет себе разум и волю человека, лишает личность свободы. Поэтому с каждой страстью, которая грозит нарушить равновесие внутреннего мира, следует вести борьбу, постоянно наблюдая за своей внутренней жизнью. Подобную работу над собой в начальной главе «Амелии» Филдинг назовет «искусством жизни». 
В своей эссеистике Филдинг выдвигает понятие «доброго сердца», которое, однако, он понимает не в сентиментальном, а в классицистическом духе: «доброе сердце» (good nature) - это не только свойство темперамента, но и «устроение ума», побуждающее человека сочувствовать ближнему и помогать ему, причем так, чтобы это шло ему на пользу. Семена добра, как и семена зла, заложены в человеческой природе, но сознательная задача человека - пестовать одни и подавлять другие: «В самых достойных человеческих умах существуют мелкие прирожденные семена Злобности, которые в наших силах или удушить и подавить, или пестовать и возрастить, пока они не расцветут и не принесут свои отравленные плоды» [І2, т. I4, p. Іоо].

Подобные идеи Филдинг воплощает в своем центральном романе «История Тома Джонса, найденыша». Начиная с эпизода с куропаткой, подстреленной во владениях сквайра Вестерна, импульсивный характер Тома постоянно увлекает его за пределы добропорядочности, и его опекун мистер Олверти, напутствуя его во время своей тяжелой болезни, говорит: «Я убежден, друг мой, что ты добр, великодушен, благороден; если к этим качествам ты присоединишь еще благоразумие и благочестие, ты будешь счастлив. Первые три качества, я признаю, делают человека достойным счастья, но только последние два сделают действительно счастливым» [7, V, VII]. Том должен научиться обуздывать свою импульсивную натуру и осознавать свою ответственность за совершаемые им поступки. Научиться этому он сможет только на собственном жизненном опыте. Не раз согрешая, Том всегда чувствует, что поступает дурно, и пытается тем или иным способом загладить свой проступок. Филдинг организует сюжет романа так, что ни один такой проступок не сходит Тому с рук: о каждом становится известно Олверти и/или любимой им Софье, тем людям, чьим мнением он дорожит и от кого зависит его счастье. Пережив жгучий стыд, герой постепенно учится управлять своими страстями.

В знаменитой главе «О любви», открывающей шестую книгу романа, Филдинг протестует против «новейших» философов, «открывших», что такой страсти не существует в человеческом сердце. Каким бы соблазнам ни поддавался Том Джонс в своих странствиях, его любовь к Софье остается тем возвышенным чувством, которое ставит счастье своего кумира выше своих интересов, что Том демонстрирует, когда, будучи изгнанным Олверти из дома, решает отказаться от Софьи: «Мысль покинуть девушку 
раздирала его сердце; но сознание, что он будет причиной ее гибели и нищеты, было для него, пожалуй, еще большей пыткой. <...> Таким образом, чувство чести, подкрепленное отчаянием, благодарностью к благодетелю и подлинной любовью к Софье, в заключение одержало верх над пламенным желанием, и Джонс решил лучше покинуть возлюбленную, чем погубить ее своими домогательствами» [6, VI, XII]. Здесь можно увидеть классический конфликт разума и чувства, в котором разум одерживает верх. Однако Филдинг видит проблему немного по-иному. Он показывает, что подлинная, т. е. бескорыстная, любовь Джонса к Софье как раз подкрепляет его решение расстаться с ней, таким образом, долг и страсть не вступают в конфликт, но одинаково присутствуют в принятии морального решения.

Вместе с тем Филдинг снисходительно, в духе рококо, относится к любовным эскападам своего молодого героя, неспособного устоять перед искушением (однако никогда не помышляющего о том, чтобы самому искушать невинность), за что на него обрушивается праведный гнев Ричардсона.

Если в «Томе Джонсе» Филдинг достигает полноты оптимистического видения мира и ясности разрешения моральных проблем, то в написанной двумя годами позже «Амелии» оптимизма убавляется, а путь героя к совершенству становится более тяжелым. Роман начинается, а не заканчивается свадьбой капитана Бута и Амелии, его герои взрослее и обязаны быть ответственнее, и заблуждения обходятся им дороже. В сложносплетенном сюжете романа проявляется та же черта, что и в «Томе Джонсе»: ни один недостойный поступок героя, как ни стремится он скрыть его от своей жены, не остается ей неведомым, за каждый ему приходится расплачиваться стыдом и раскаянием.

Камнем преткновения становится для капитана Бута идея господствующей страсти. Вместо того, чтобы бороться со своей страстью, сохраняя внутреннюю свободу, Бут убеждает себя, что если существует господствующая страсть, которая определяет поступки человека, то эти поступки не могут быть ни нравственны, ни безнравственны, ибо страсть не оставляет ему возможности поступить иначе. Добросердечие он понимает как черту темперамента, утверждая, что «все люди - самые лучшие, точно так же, как и самые худшие, - руководствуются в своих поступках себялюбием». Вооружившись этой детерминистской идеей, он потакает своим страстям, греша и неверностью Амелии, и мотовством, и пристрастием к азартным 
играм, при этом обвиняя в своих несчастьях судьбу. Бут попадает под влияние «научных» концепций морали, которые не приемлет Филдинг.

Окончательно запутавшись и попав в тюрьму во второй раз, Бут читает там проповеди Исаака Бэрроу, уважаемого Филдингом, и переживает обращение. Он сообщает об этом своему другу доктору Гаррисону как о свершившемся факте: «..эти проповеди оказали на меня столь благотворное влияние, что теперь, мне кажется, я буду более достойным человеком до конца своих дней» [6, XII, V]. Попав в безвыходное положение и пережив отчаяние, герой наконец оказывается доступен доводам разума и - одновременно - религии. Вряд ли такой поворот был возможен в ранний период творчества писателя. Создается впечатление, что в последнем романе Филдинг движется навстречу Ричардсону в религиозно обоснованном понимании долга.

Не только герой романа с большим трудом постигает «искусство жизни», но и мир вокруг героев становится более опасным и мрачным. Амелия, убедившись в предательстве друга, готова поверить, что «едва ли не все люди в душе своей негодяи и подлецы» [6, с. Іоо]. Друг семьи, доктор Гаррисон, увещевает ее, утверждая, что «человеческая природа по сути своей далека от порочности, она с избытком наделена отзывчивостью, милосердием и состраданием, она жаждет одобрения и почестей и остерегается позора и бесчестья. Однако дурное воспитание, дурные привычки и обычаи развращают нашу природу, а безрассудство влечет ее к пороку. Мирские правители, а также, боюсь, и духовенство повинны в падении нравов» [6, c. гоо]. На фоне падения нравов, обрисованного Филдингом в этом последнем романе, и классицистический идеал поисков счастья на путях самосовершенствования все более выглядит как наивная утопия.

Более в эксплицированном виде мы его в английской литературе не находим. Смоллет, Голдсмит, Стерн идут каждый иным путем, констатируя падение нравов и противопоставляя ему непосредственное сердечное переживание сентиментального героя. В редуцированном виде мы найдем его в творчестве женщин-романисток - Фрэнсис Берни и Джейн Остен. Однако он еще раз и очень ярко обнаружит себя у Гете и Шиллера периода «веймарского классицизма». Гете в «Вильгельме Мейстере», как и Филдинг в «Томе Джонсе», представит классицистический идеал в романе воспитания как процесс, а не как достигнутый результат. Шиллер осмыслил этот идеал 
в «Письмах об эстетическом воспитании», назвав человека, осуществившего подобный идеал, «прекрасной душой». «Невысоко мое мнение о человеке, - писал он, - раз он так мало может доверять голосу внутреннего побуждения, что вынужден всякий раз сопоставлять его с требованиями морали; напротив, он внушает уважение, когда, без опасения оказаться на ложном пути, с известной уверенностью следует своей склонности. Ибо это доказывает, что оба начала в нем возвысились уже до того согласия, которое есть печать совершенной человеческой природы и называется прекрасной душой» [8, с. I45].

Если у Филдинга процесс воспитания героя охватывал исключительно моральную проблематику, то Гете показал героя, ориентирующегося в пространстве культуры, осмысляющего свое место в ней. Этим он оказался особенно созвучен образу мысли романтиков. Так Гете в «Вильгельме Мейстере» завершил гуманистический этап развития европейской культуры и открыл путь романтической мысли.

\section{Список литературы}

I Гете И.-В., Шиллер Ф. Переписка: в 2 т. / пер. и комм. И.Е. Бабанова. М.: Искусство, І988. Т. І. 539 с.

2 Зыкова Е.П. Генри Филдинг как моралист // Известия РАН (серия литературы и языка). М., 20Іі. Т. 70, № 5. С. 3-17. Пахсарьян Н.T. Искусство жить рокайльно // XVIII век: искусство жить и жизнь искусства / отв. ред. Н.Т. Пахсарьян. М.: Экон-информ, 2004. С. 205-216. Поуn А. Опыт о человеке / пер. И. Кутика // Англия в памфлете. Английская публицистическая проза начала XVIII века. М.: Прогресс, I987. С. 423-460.

5 Свифт Дж. Письма / пер. А. Ливерганта. М.: Текст, 2000. 204 с.

6 Филдинг Г. Амелия / пер. А.Г. Ингера. М.: Наука, І996. 544 с.

7 Фильдинг Г. Избранные сочинения. М.: Худож. лит., г989. 685 с.

8 Шиллер Ф. Собр. соч.: в 7 т. М.: ГИХЛ, І957. Т. 6: Статьи по эстетике. 79I с.

9 Backscheider P.R. Daniel Defoe: Ambition and Innovation. Lexingyon: Kentucky, 2015 (f.p.I986). 3I2 p.

Io Battestin M. The Providence of Wit. Aspects of Form in Augustan Literature and the Arts. University Press of Virginia, 2012 (f.p. 1974). 33I p. Doody M.A. A Natural Passion. A study of the Novels of Samuel Richardson. Clarendon Press, I974. 4IO p. Fielding H. Complete Works: in I6 vols. London: Cass, I967. Vol. I4, vol. I5. 33I p. + 366 p. 
I3 Fussell P. The Rhetorical World of Augustan Humanism: Ethics and Imagery from Swift to Burke. Oxford: Oxford U.P., I965. 3I4 p.

I4 Gordon I.R.F. A Preface to Pope. Routledge, 20I7. 296 p.

I5 Parker B. The Triumph of Augustan Poetics: English Literary Culture from Butler to Johnson. Cambridge: Cambridge University Press, I998. 262 p.

I6 Sacks Sh. Fiction and the Shape of Belief. A Study of Henry Fielding with Glances at Swift, Johnson, and Richardson. Chicago and London: University of Chicago Press, I980. $277 \mathrm{p}$.

I7 Swift J. The Correspondence of Jonathan Swift: in 5 vols. / ed. by Harold Williams. London, Oxford: Clarendon Press, I963. Vol. I. 427 p.

I8 Wolff C.G. Samuel Richardson and Eighteenth-century Puritan character. Hamden: Conn., I972. $259 \mathrm{p}$.

\section{References}

I Gete I.-V., Shiller F. Perepiska: $v 2 t$. [Letters]. Moscow, Iskusstvo Publ., I988. Vol. I. 539 p. (In Russ.)

2 Zykova E.P. Genri Filding kak moralist [Henry Fielding as a Moralist]. Izvestiya RAN (Literature and Language series), Moscow, 20II, vol. 70, no 5, pp. 3-I7. (In Russ.) Pakhsar'ian N.T. Iskusstvo zhit' rokail'no [The art of rococo life style]. XVIII vek:

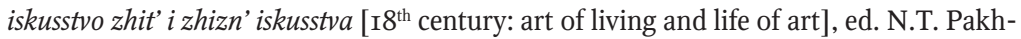
sar'ian. Moscow, Ekon-inform Publ., 2004, pp. 205-216. (In Russ.)

4 Poup A. Opyt o cheloveke [The essay on man], trans. I. Kutika. Angliia v pamflete. Angliiskaia publitsisticheskaia proza nachala XVIII veka [England in the pamphlet. English essayist prose of the beginning of the ${ }^{8^{\text {th }}}$ century]. Moscow, Progress Publ., I987, pp. 423-46o. (In Russ.)

$5 \quad$ Svift Dzh. Pis'ma [Letters], trans. A. Liverganta. Moscow, Tekst Publ., 2000. 204 p. (In Russ.)

6 Filding G. Ameliia [Amelya], trans. A.G. Inger. Moscow, Nauka Publ., I996. 544 p. (In Russ.)

7 Fil'ding G. Izbrannye sochineniia [Selected works]. Moscow, Khudozh. lit. Publ., I989. 685 p. (In Russ.)

8 Shiller F. Sobranie sochinenii: $v 7$ t. [Works: in 7 vols.]. Moscow, GIKhL Publ., I957. Vol. 6: Stat'i po estetike [Essays on aesthetics]. 79I p. (In Russ.)

9 Backscheider P.R. Daniel Defoe: Ambition and Innovation. Lexingyon, Kentucky, 2015 (f.p.I986). 3I2 p. (In English)

Battestin M. The Providence of Wit. Aspects of Form in Augustan Literature and the Arts. University Press of Virginia, 2012 (f.p. 1974).33I p. (In English) Doody M.A. A Natural Passion. A study of the Novels of Samuel Richardson. Clarendon Press, I974. 4IO p. (In English) 
I2 Fielding H. Complete Works: in I6 vol. London, Cass, I967. Vol. I4. 33I p. Vol. I5. 366 p. (In English)

I3 Fussell P. The Rhetorical World of Augustan Humanism: Ethics and Imagery from Swift to Burke. Oxford, Oxford U.P., I965. 3I4 p. (In English)

I4 Gordon I.R.F. A Preface to Pope. Routledge, 20I7. 296 p. (chapter 3, section landscape gardening). (In English)

I5 Parker B. The Triumph of Augustan Poetics: English Literary Culture from Butler to Johnson. Cambridge, Cambridge University Press, 1998. 262 p. (In English)

I6 Sacks Sh. Fiction and the Shape of Belief. A Study of Henry Fielding with Glances at Swift, Johnson, and Richardson. Chicago and London, University of Chicago Press, I980. 277 p. (In English)

I7 Swift J. The Correspondence of Jonathan Swift: in 5 vols., ed. by Harold Williams. London, Oxford, Clarendon Press, I963. Vol. I. 427 p. (In English)

I8 Wolff C.G. Samuel Richardson and Eighteenth-century Puritan character. Hamden, Conn., I972. 259 p. (In English) 
УДК 82I.II2.2.0

ББК $83.3(4$ Гем $) 52$

\section{СБОРНИК «СТИХОТВОРЕНИЯ» Л.ТИКА: ОТ ФРАГМЕНТА К ЭНЦИКЛОПЕДИИ}

\author{
(C) 2018 г. Т.А. Зотова \\ Национальный исследовательский \\ университет Высшая школа экономики, \\ Москва, Россия \\ Дата поступления статьи: І2 января 2018 г. \\ Дата публикации: 25 сентября 2018 г.
}

DOI: I0.22455/2500-4247-2018-3-3-46-63

Аннотация: Первый поэтический сборник Л. Тика, «Gedichte» («Стихотворения»), выходит в I82I г., через несколько лет после шеститомного сборника «Фантазус», собравшего все хоть сколько-нибудь значимые произведения автора, в период творческого кризиса Тика. Интерес представляет первая часть «Стихотворений», состоящая как из фрагментов уже изданных текстов, так и новых произведений. Особенность сборника заключается в нетипичном для Тика подходе к обработке собственных текстов: все фрагменты публикуются без указания источника. Сам же текст при фрагментации изменяется и корректируется. Фрагменты получают собственное название, краткое и суммирующее. Названия стихотворений указывают на основные романтические топосы, а редакция текстов производится в согласии с указанной в названии темой. Автор организует сборник тематически, переходя от одной группы близких другу другу тем к другой, вырывая фрагменты из привычного контекста и давая им новый. Этот нетипичный для Л. Тика сборник можно интерпретировать как способ создания автором своеобразной «энциклопедии» раннего романтизма. В отличие от универсализма сборника «Фантазус», где тексты Тика, относящиеся к разным родам и жанрам, обрамлены повествовательной рамкой, раскрывающей основные эстетические воззрения автора, энциклопедичность «Стихотворений» предполагает новый, максимально отстраненный взгляд на собственное творчество. Сборник принципиально отличается от всех прочих сборников Тика и, по-видимому, представляет собой попытку автора переосмыслить собственную роль в развитии романтического движения и маркирует начало размежевания с ним.

Ключевые слова: немецкая литература, романтизм, Тик, лирика, фрагмент, сборник.

Информация об авторе: Татьяна Алексеевна Зотова - кандидат филологических наук, старший преподаватель, Национальный исследовательский университет, Высшая школа экономики, ул. Мясницкая, д. 2о, Іогооо г. Москва, Россия.

E-mail: nur_ostwind@inbox.ru

Для цитирования: Зотова Т.А. Сборник «Стихотворения» Л. Тика: от фрагмента к энциклопедии // Studia Litterarum. 2018. Т. 3, № 3. С. 46-63.

DOI: $10.22455 / 2500-4247-2018-3-3-46-63$ 


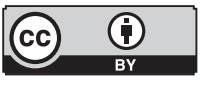

This is an open access article distributed under the Creative Commons Attribution 4.0 International (CC BY 4.0)

\section{LUDWIG TIECK'S COLLECTION "GEDICHTE": FROM A FRAGMENT TO AN ENCYCLOPEDIA}

\author{
(C) 20I8. T.A. Zotova \\ National Research University Higher \\ School of Economics, \\ Moscow, Russia \\ Received: January I2, 2018 \\ Date of publication: September 25, 2018
}

Abstract: The first poetic collection of Ludwig Tieck, Gedichte (Poems) came out in I82I, a few years after the publication of the six-volume Fantasus, a collection of all the most significant works of the author. Gedichte thus saw light during the period of Tieck's creative crisis, when no new collection was needed. The first part of the Poems consists of both the fragments of already published texts and of some new works. The peculiarity of this collection lies in the peculiar approach to the processing of Tieck's own texts: all the fragments are published without indicating the origin. Being fragmented, the original text is changed and revised, and this makes it difficult to determine its origin. Fragments always get their own name that is short and summative. The titles of the poems feature the main romantic topoi, and the editing of the texts is fulfilled in accordance with the title of the topic. The author organizes the collection thematically, moving from one group of closely related topics to another, cutting out fragments from their original context and giving them a new one. Tieck's peculiar collection may be interpreted as a kind of "encyclopedia" of early Romanticism. Unlike the universalism of the Fantasus collection where the texts of Tieck, relating to different genres, are framed by a narrative framework that reveals the author's main aesthetic views, the encyclopedic nature of the Poems implies a new, maximally detached view of one's own creativity. The collection is fundamentally different from all the other collections by Tieck and, apparently, represents an attempt of the author to rethink his own role in the development of the Romantic movement and also marks the beginning of his disengagement with the movement.

Keywords: German literature, Romanticism, Tieck, lyric, fragment, poetic collection.

Information about the author: Tatiana $\mathrm{A}$. Zotova, $\mathrm{PhD}$ in Philology, Senior Lecturer, National Research University Higher School of Economics, Myasnitskaya 20, IOIOOO Moscow, Russia.

E-mail: nur_ostwind@inbox.ru

For citation: Zotova T.A. Ludwig Tieck's Collection "Gedichte": From a Fragment to an Encyclopedia. Studia Litterarum, 20I8, vol. 3, no 3, pp. 46-63. (In Russ.) DOI: $10.22455 / 2500-4247-2018-3-3-46-63$ 
Лирика Л. Тика (I773-І853) - одна из самых малоисследованных сторон творчества писателя. Ее исследование затрудняется тем более, что Тик, согласно эстетическим воззрениям немецких романтиков, целенаправленно разрушает все границы между жанрами и родами литературы. Один и тот же текст может функционировать у него как часть крупного драматического или даже прозаического произведения или, будучи обособленным, как в рассматриваемом в этой статье сборнике, становится образцом лирического жанра. Наша задача состоит, однако, не только в том, чтобы понять, как именно происходит этот специфический «переход» из одного «состояния» в другое, но и в том, чтобы выяснить, какие цели преследует автор, снова и снова аргументирующий, изменяющий и актуализирующий свои тексты.

Настоящая статья посвящена сборнику «Gedichte» («Стихотворения»), изданному Тиком в I82I-I823 гг. Это внушительное трехтомное издание включает в себя как старые стихотворения Тика, издававшиеся в составе ранних сборников и журналов, так и фрагменты его драм и романов - однако в довольно измененном виде. Тексты в сборнике относятся к I795-18г6 гг., охватывая, таким образом, период творческого расцвета писателя. Именно на это время приходится создание его наиболее знаменитых и влиятельных текстов в разных жанрах.

Прежде всего, следует сказать, что очевидной необходимости в выпуске очередного переиздания своих трудов у Тика на тот момент не было: буквально за пять лет до выпуска «Стихотворений» был выпущен последний том огромного шеститомного сборника «Phantasus» («Фантазус», I8I6), в который вошли практически все сколько-нибудь значимые произ- 
ведения автора, начиная от ранних проб пера и заканчивая поздними зрелыми работами.

Структура «Фантазуса» была рамочной и состояла из повествовательной рамки и окружаемых ею произведений Тика, которые, подобно новеллам в «Декамероне» Боккаччо, целиком встраивались туда в качестве «рассказов» персонажей повествовательной рамки. Эти тексты обязательно снабжались названиями, совпадавшими или почти совпадавшими с названиями текстов в предыдущих изданиях. Отметим, что этот момент очень важен для исследования творчества Тика, поскольку для этого автора характерна игра с названиями и несколькими вариантами редакции текста, как, например, в случае его интерпретации сюжета о Синей Бороде, где жанровые изменения всегда тесно связаны с изменениями заглавий.

Итак, на начало 20-х гг. все основные тексты тексты Тика уже были собраны воедино в «Фантазусе», хорошо принятом читательской аудиторией. Кроме того, на этот же период приходится писательский кризис Тика. Этот кризис совпадает по времени с началом работы автора в Дрезденском театре в должности заведующего репертуарной частью.

Он впервые сталкивается с реальной театральной практикой и вообще впервые так глубоко погружается в мир театра, столь ярко описанный им в его «театральных» комедиях І790-х гг. - «Кот в сапогах», «Мир наизнанку», «Принц Цербино» и «Пролог». Этот мир увлекает его, и мысль Тика в это время движется в основном в русле театральной теории и практики: автор работает над эссе по истории немецкого театра, сборником заметок «Драматургические листки» и многим другим.

Таким образом, в начале I820-х гг. Тик пишет только критические статьи, возвращаясь к художественным жанрам в середине I820-х гг. А.В. Михайлов отмечает, что в это время в творчестве писателя наблюдаются очевидные сдвиги, обозначающие его отход от традиций литературы романтизма к литературе бидермейера [4, с. 3I-57]. Тик обращается к жанру новеллы, «в которых порывает со всяким романтизмом» [5, с. 75].

В уста персонажей повествовательной рамки «Фантазуса» вложены высказывания, манифестирующие эстетическую программу автора. Напротив, состоящие из причудливо отредактированных и скомпонованных отрывков тех же самых художественных текстов «Стихотворения» представляют собой скорее квинтэссенцию, сумму теории и практики. Следовательно, 
последний сборник можно интерпретировать как завершающий аккорд, попытку переосмыслить пройденный романтиком путь, вехи которого собраны в «Фантазусе». С большой вероятностью можно утверждать, что самим Тиком сборник также воспринимался как попытка подведения итогов.

Заметим также, что это его последняя работа с драматическими и лирическими жанрами: чуть позднее, в I826 г., он обратится к новелле и в I840 г. к роману. До конца жизни Тик продолжит работать в театре и даже получит место режиссера-постановщика и позднее художественного директора в берлинском театре, куда его уже на закате его жизни пригласит лично прусский король, однако драма будет интересовать Тика исключительно в прикладном аспекте. Стоит упомянуть такие значительные критические труды автора, как «Отношение Шекспира к чудесному» (Shakespeare's Behandlung der Wunderbaren, I793), «Начала немецкого театра» (Die Anfänge des deutschen Theaters, I8I7), а также «Драматургические записки» (Dramaturgische Blätter), «Письма о староанглийском театре» (Briefe über altes englischen Theater) и «Критические труды» (Kritische Schriften, I828).

Известно, что творчество в драматических жанрах тесно связано для романтиков с ощущением театральности, двойственности бытия, и поэтому драма является ключевым родом романтической литературы. Об этом говорят и А. Карельский [2], и Л. Пикулик [6], и Ш. Шерер [7]. Таким образом, можно предположить, что отход от драматических жанров и создание сборника «Стихотворения» действительно связаны с окончанием романтического периода в творчестве Тика.

Лирическое творчество Тика исследовано мало: об этом говорит, в частности, Ш. Шерер в новейшей библиографии Тика [2, с. 478]. Отдельные работы на эту тему принадлежат В. Мисснеру (1902), М. Грейнеру (1930), Р. Кинцерле (I946), некоторые аспекты лирики Тика затрагивают Х. Боссе и X. Ниемейер в работе г995 г., а также Р. Виммер (г995), Г. Клюге (1976) и М. Франк (1972). В отечественной исследовательской традиции лирика Тика остается практически незамеченной, однако давно и талантливо переводится, в частности, В.Б. Микушевичем.

Немецкие ученые предлагают рассматривать поэзию Тика как Stimmungslyrik, «лирику настроения», и полагают, что история этого явления начинается в немецкой литературе как раз с Тика [7, S. 476]. Такое понимание его лирического творчества основывается на происходящем, по 
мнению Ш. Шульца, «решительнейшим разрывом с классическими формами и классической мифологией» и обращением к «звукам безвременной потерянности во времени и тоски» [7, S. 476]. Другие исследователи говорят об «отсутствии формы и содержания» и вместе с тем «легкости», «спонтанности» тиковской поэзии [7, S. 476], об ее ориентации на музыкальность, на уподобление музыке [7, S. 477].

Таким образом, исследователи переосмысливают вслед за самим Тиком его трактовку сборника «Стихотворения». В предисловии к нему поэт сообщает, что целью нового переиздания своих произведений было как будто «представление его текстов в музыкальном виде», а также небольшая услуга друзьям, «пожелавшим иметь отдельное собрание его стихотворений» [8, S. I].

Действительно, факт музыкальности и поэзии вообще, и отдельного поэтического сборника в частности очень важен для поэта-романтика. Известно, что у ранних романтиков, к которым относится Тик, часто встречается мысль о том, что музыка лежит в основе мироздания: она «понимается как нечто общее, лежащее в основе бытия, его пронизывающее, связывающее в единое целое» [3, с. 320]. Понять язык музыки означает понять мир: так, Ф. Шлегель пишет, что «не искусство, но музыкальный энтузиазм создает художника», поскольку искусство вторично по сравнению с музыкой мира. Создание «музыкального» сборника, таким образом, подобно созданию универсума, гармонии мировых частиц. И именно эта ориентация на формирование смысла целого, часто в обход смысла отдельных частиц, приводит к тому, что, по мнению немецких исследователей, эти отдельные частицы-стихотворения становятся малопонятны [7, S. 477].

Мы склонны согласиться с тем, что для сборника «Стихотворения» действительно характерна скорее ориентация на смысл целого, а не отдельных фрагментов, однако это типично для сборников. Невыясненным остается скорее вопрос, что же именно является лейтмотивом, главным принципом, по которому построен сборник.

Наше предположение заключается в том, что для Тика наиболее важна не «музыкальность» «Стихотворений», а уподобление всего сборника компендиуму, специфическому набору ключей, в котором фрагмент играет роль энциклопедической статьи, содержащей в себе как краткое изложение сути предмета, так и указания на контекст, в котором его необходимо рассматривать. 
Итак, как же организован сборник «Стихотворения»?

Если рассматривать его как сумму текстов, то он состоит из более чем двухсот стихотворений, которые частично объединены в обозначенные или не обозначенные в оглавлении циклы. Назовем озаглавленные циклы, их несколько: это «Сонеты» из ненапечатанного романа «Альма, или Книга любви» в первом томе, «Стихотворения о музыке», «Любовь юноши» и «Листки воспоминаний» во втором и «Стихотворения из путешествия больного» и «Возвращение выздоравливающего» в третьем. Стихотворения из последних двух циклов мы не будем рассматривать здесь, поскольку они по сути не являются фрагментами уже изданных Тиком ранее текстов и находятся за пределами нашей темы.

Но и все остальные стихотворения, кроме входящих в эти последние два цикла, не обязательно являются фрагментами ранних текстов. Такие фрагменты окружены в сборнике относительно новыми, не издававшимися ранее или даже специально написанными для сборника стихотворениями. Таким образом, сборник «Стихотворения» состоит частично из цельных, частично из фрагментированных, отредактированных и по-новому именованных текстов.

Они организованы, очевидно, тематически, блоками-циклами, с узнаваемыми ассоциативными принципами внутри них, хотя и в целом нестрого и несколько хаотично.

Например, блок «Стихотворения о музыке» делится на две части. Он начинается с текста «Освящение», открывающего блок, посвященный музыке в ее историческом аспекте, преимущественно церковной. Сюда входят микроблоки «Музыка говорит», «Святая Цецилия», «Марчелло», «Перголези», «Stabat mater», «Музыка прекращает говорить», «Палестрина. Марчелло. Перголези», включающие в себя по нескольку безымянных стихотворений, чаще всего сонетов. Можно заметить, что в организации этого блока присутствует элемент повтора, как и во многих музыкальных произведениях. За пределами «музыкальной» темы располагаются тексты «Напев», «Сад», «Ночь», «Время», «Звуки», «Узнавание», «Любовь», «Утешение», а завершает блок программная «Глосса», для жанра которой тоже характерно повторение элементов структуры - строк первой строфы в последующих строфах.

Типичный ассоциативный блок сборника «Стихотворения» (на примере первого тома) включает в себя несколько любовных стихотворений, 
следующий за ними образец патриотической лирики, далее длинный ряд любовных собственно сонетов-посланий, единственные в сборнике тексты без заглавия, потом хрестоматийные «Звуки шалмея», «Звуки почтового рожка», «Мелодия лесного рожка» из «Франца Штернбальда», затем появляется тема поэтического творчества как мучительного, но жизненно необходимого процесса в тексте «Поэт и голос», и потом неожиданно «Romanze» «Юность Зигфрида» и в том же жанре «Зигфрид - убийца дракона» и «Веланд», а затем тематически почти никак не связанные с ними и друг с другом «Охотничья песня» и «Цветы». Таким образом, здесь представлены почти все ключевые романтические темы.

Кроме тематического, другие способы организации, по-видимому, не представлены - ни хронологический, ни порядковый, ни алфавитный и ни какой-либо еще. Таким образом, становится очевидно, что «Стихотворения» были запланированы Тиком как совершенно новый, отдельный сборник, управляемый своими внутренними законами.

Темы составляющих сборник стихотворений восходят либо к общим для европейской культуры топосам, либо к топосам романтическим (конечно, они в известной степени пересекаются). Так, сборник открывается текстом, заглавие которого отражает центральный для романтизма топос «томления», «Sehnsucht». В «Стихотворениях» представлены все ключевые для романтизма темы, сгруппированные ассоциативными блоками: кроме «томления» еще «странствие», «одиночество» и изобретенное Тиком «лесное одиночество», «искусство», «Средневековье», «сказка»; неоднократно появляется национальная тема.

Не тронутыми в плане фрагментации остаются те тексты, которые изначально были относительно обособлены - были самостоятельными произведениями или находились в составе крупной прозаической формы. Преобладают в сборнике фрагменты драм, зачастую значительно измененные. Для большинства текстов-фрагментов в сборнике характерно утрачивание связей с исходным текстом.

Как же происходит такое нарушение связи между исходным и новым текстами?

Во-первых, Тик как автор сборника редактирует составляющие его тексты таким образом, чтобы пресечь в них малейшие смысловые связи с содержанием исходного (чаще всего драматического) произведения: уда- 
ляются упоминания имен персонажей, элементов сюжетных линий. Так, в стихотворении «Вдохновение. Romanze», являющемся крупным фрагментом драмы «Император Октавиан», вырезано более десяти строк, в которых передается содержание этого участка пьесы.

В некоторых текстах частью заглавия становится ремарка, так же как в случае с этим отрывком - «Romanze». Согласно раннеромантическому пониманию термина, «романтическое» означает одновременно и историческую форму средневековой поэзии, романцо, и романтическую поэзию в прямом смысле слова. В наполненной аллегорическими персонажами мистериальной драме «Император Октавиан» Romanze, т. е. Поэзия, появляется как персонаж, озвучивающий интерлюдии и осеняющий своим присутствием «земную» жизнь персонажей. С ремарки «Romanze», естественно, начинаются все его реплики и монологи. Однако в стихотворении-фрагменте, образованном усечением драматического текста, слово «Romanze» означает уже указание на литературную форму. Этот эффект только усиливается тем, что из стихотворения, как уже было сказано, удалено всякое напоминание о сюжете драмы, и «Romanze» перестает пониматься как аллегория.

Однако Тик разрушает не только смысловые связи между исходным драматическим и конечным лирическим текстами. Единственное, что остается в этих текстах от драматической формы, - это редкие оставшиеся элементы свойственной драме диалогической структуры.

Так, стихотворение «Лес, сад и гора» целиком состоит из нескольких собранных воедино сцен из комедии «Принц Цербино, или Путешествие за хорошим вкусом», которые представляют собой диалог пародийных, но и не только, персонажей с персонажами аллегорическими: с Цветами, Лесом, Кустами и т. д. В новом тексте реплики всех персонажей, кроме олицетворений природы, вырезаны.

Во-вторых, абсолютно каждому такому отрывку Тик дает новое название, в обобщенном виде отражающее его тематическое содержание. Нигде не указывается источник фрагмента, т. е. название драмы. Как мы знаем, в кратком (что не совсем типично для Тика) вступлении автор сообщает, что настоящий сборник - переиздание уже известных текстов, дополненное некоторым количеством новых. Таким образом, он не скрывает, что представленные стихотворения не новы, но и не указывает прямо на то, откуда они взяты. Здесь явно читается некий код, неявное послание внимательному читателю. 
Немецкие исследователи также замечают тематический аспект названий, однако склонны интерпретировать их в контексте музыкальности, уподобления сборника музыкальному произведению и говорят о «слиянии поэтического текста и звуков природы в мимолётном мгновении» [7, S. 479]. Так, например, Кремер называет их «аллегорическими шифрами». Ш. Шерер, напротив, вполне логично указывает на то, что такой подход не объясняет наличие в сборнике твердых форм - это, прежде всего, стансы, терцины и сонеты.

Он предлагает интерпретировать стихотворения Тика как связанные или не связанные с контекстом [7, S. 479], понимая наличие или отсутствие контекста как наличие или отсутствие исходного фрагментируемого текста. Однако мы убеждены в том, что для Тика контекст чрезвычайно важен, и его произведения всегда находятся в тесной связи друг с другом. Так, все драматургическое наследие Тика можно представить как единый интертекст с ясными и логичными взаимосвязями и обилием внутренних цитат и ссылок (ссылка на себя). Таким образом, даже если стихотворение в сборнике не является фрагментом, оно тем не менее должно рассматриваться в контексте остальных текстов, а не обособленно.

Наше предположение заключается в том, что сборник «Стихотворения» создавался как своеобразная энциклопедия романтической поэзии. Здесь важно, что в йенском романтизме концепт поэзии включает в себя всю сферу искусства, будь то искусство лирическое, прозаическое, драматическое или даже вовсе не относящееся к литературе. Лирический род произведений, составляющий сборник, выступает здесь в роли наиболее подходящего инструмента: так, поэзия говорит о поэзии естественным для нее языком.

Как же строится этот компендиум? Его механизм опирается, во-первых, на самоцитирование, во-вторых, на топосы как на важную форму передачи культурной памяти, и запускается этот механизм при помощи особенностей жанра фрагмента.

$\mathrm{B}$ «Стихотворениях» топос работает как ключ к прочтению сборника как единого текста. На материале исследуемого сборника очевидны две стратегии работы с топосами, отражаемыми в текстах сборника: во-первых, это актуализация традиционных топосов в романтическом искусстве и, во-вторых, внесение романтических топосов в мировой фонд. 
Топосы обоих типов фигурируют в располагаемых бок о бок текстах (например, «Фантазия», «Поэтическое искусство», «Romanzen» «Роза» и «Лилия»). Форма отрывка, тематическая оборванность всех линий, очевидным образом на поверхности связывающих частное с целым, концентрирует внимание на предмете отрывка.

Как уже было замечено, этот механизм запускается благодаря жанру. Вряд ли здесь можно говорить именно о памяти жанра, поскольку о твердых лирических жанрах речи в романтическую эпоху уже не идет, и жанровые границы сильно размыты. Для Тика характерны в основном послания и песни, чуть увереннее можно говорить о формах, например, сонетах, рондо и уже упоминавшейся глоссе, которые автор использует преимущественно в целях стилизации в духе романской поэзии.

О памяти фрагмента тоже говорить вряд ли возможно, поскольку романтический фрагмент - жанр слишком новый, хотя, конечно, и генетически родственный более древним сентенции, афоризму, максиме и т. д. Однако, по-видимому, можно говорить о сходстве смысловой структуры фрагмента, например, философского, и исследуемого лирического.

Как известно, фрагмент отражает ход мысли, концентрируясь не на результате, выводе, а на процессе. Фрагмент «рожден фрагментарной действительностью и поэтому показывает само движение, раскрывает процесс осмысления мира» [I, с. I2]. Если романтическая трансцендентальная поэзия иронически изображает себя саму, то мысль фрагмента мыслит сама себя. Автор фрагмента всегда вступает в своеобразный диалог с читателем. Так, например, философский фрагмент демонстрирует последовательный ход рассуждения автора, призывающего читателя наблюдать за ходом размышлений. Однако в случае лирического фрагмента цель несколько иная.

Если предположить, что сборник «Стихотворения» создавался как компендиум, т. е. определенное средство припоминания пути, пройденного романтизмом, и передачи его наработок в обобщенном, сжатом виде для дальнейшего запоминания, укоренения его в культурной памяти, тогда фрагментарная форма становится базовым принципом сборника. Диалогическая форма фрагмента из «Стихотворений» предполагает воспроизведение процесса запоминания. Сохраняя свою афористичную форму высказывания, фрагменты, как известно, обладают прочной связью с системой. 
Структура фрагмента включает в себя не только названное, но и подразумеваемое смысловое поле, которое достраивается вокруг краткого отрывка. Таким образом, фрагмент из сборника «Стихотворения» немедленно актуализирует то произведение, из которого он взят.

В данном случае включается припоминание цитируемых художественных произведений. Форма фрагмента предполагает и ссылку на исходный текст, и указание на внесенную правку. По характеру этой правки можно понять, как функционировали эти тексты в прошлом и как их следует воспринимать сейчас. Цитируемые произведения создают необходимый контекст для этой новой правки, высвечивают ее. Особенно важную роль играет, если речь идет о драме, тематика цитируемого монолога и действующее лицо, которое его озвучивает.

Заметим, что значительной правке подвергаются только фрагменты, бывшие когда-то частью драмы. Драма в целом очень важный, если не центральный, род для Тика. Жанр драматического фрагмента, который окончательно оформляется у него к I805-I807 гг., и вовсе жанр особый, поскольку обладает ауторефлексивной функцией. Драматические фрагменты у Тика, особенно поздние, всегда суммируют его наработки в этой области. Так, его мифологические фрагменты изящно сочетают элементы универсальной драмы, комедии, пародии, сказки и «страшных» жанров, т. е. основных драматических жанров для Тика. Драматический фрагмент для него - это жанр для самоцитирования и переосмысления. Здесь автор снова прибегает к нему, превращая свои драмы в вещь сложной жанровой и родовой природы, одновременно драматической и лирической.

Итак, что же автор считает нужным вспомнить в массиве работ за двадцать лет? Во-первых, бросается в глаза попытка, если так можно выразиться, идеализации романтического искусства. Например, при фрагментации драм Тик игнорирует все локальные иронические в смысле скептические и пародийные контексты. В приведенном выше примере, стихотворении «Лес, сад и гора», фрагменте комедии «Принц Цербино» вырезаны все монологи пародийного персонажа Нестора, который в этой пьесе олицетворяет филистерство, а Цветы, Лес и др. - напротив, голос одухотворенной природы. Эта правка фактически снимает или, лучше сказать, замалчивает существующий в пьесе типично романтический конфликт между близким к природе, тонко чувствующим Цербино и толпой. 
Фрагментов комедий в сборнике «Стихотворения» много, однако использованы в основном минорные части пьес, которые изначально в комедиях имели функцию иронической вставки, параллельного действия, оттеняющего основное. В качестве примера можно привести линию с участием Отшельника и влюбленных пар в «Принце Цербино». Ее сюжет основан на поисках друг друга влюбленными, заблудившимися в лесу, и изобилует комическими сценами. Так, например, один из влюбленных, Клеон, постоянно проходит буквально в двух шагах от хижины, где его ждет невеста. Эта линия пародирует основные штампы «слезливых драм» рубежа XVIII-XIX вв.

Игнорируются и образцы самоиронии и самопародии: так, в сборнике нет известных сонетов-монологов Геновевы из одноименной драмы, в частности, ее письма супругу из темницы. Причиной, как можно предположить, является тот факт, что драма «Жизнь и смерть святой Геновевы» спародирована его же «Жизнью и смертью маленькой Красной Шапочки», где центральное место занимает как раз травестирующий сонет Геновевы сонет маленькой героини.

Другой пример - это сильная правка другого отрывка из «Цербино». Он называется «Dichtung», т. е. «Поэзия», и представляет собой фрагмент из Эпилога драмы. Из Эпилога, в свою очередь, удалено почти все, что касается рефлексии над судьбой поэзии в реальном мире и над самой жизнью. Отрывок, который короче Эпилога в три раза, заканчивается на попытке отстраненного примирения, решения уже упомянутого конфликта между толпой и поэтом. Внешний мир обозначается неким «они»:

Aber sie vernehmen dich nicht,

Sie wenden sich hinweg vom Licht,

Sie leben weiter

Immer trüber, wen'ger heiter,

Merken nicht daß alles Trübe

Durch der Künste Göttermacht

In der heitern Milde lacht,

Selbst der Haß wird lichte Liebe [9, S. 2II].

(«Но они не слышат тебя, / Они отворачиваются от света, / Они продолжают жить / Все печальнее, не так весело, / Не замечая, что всякая печаль 
/ Смеется благодаря божественной силе искусства / Весело и нежно, / И сама ненависть становится светлой любовью».)

Внешний мир, таким образом, понимается уже не как враждебная художнику толпа, а отношение к ней связано скорее с симпатией.

Оставаясь фрагментом Эпилога, этот текст апеллирует к нему и к прологу, которые у Тика всегда образуют комплекс. Пролог «Принца Цербино» сконцентрирован на идее Поэзии как путеводной звезды, которая направляет в жизненном странствии, а Эпилог, напротив, уже содержит некоторое разочарование в этой идее. В отрывке из сборника конфликт снова снимается или, скорее, воспринимается не таким необходимым и обязательным для упоминания. Таким образом, перед нами попытка воспринимать поэзию как законченный образ, не являющийся больше предметом полемики, что, опять же, напоминает о статье в компендиуме, где полемика обычно просто намечается.

В числе основных моментов правки стоит также упомянуть попытку удаления всех элементов текста, которые каким-либо образом связаны с осознаваемыми как художественный ориентир авторами.

Рассмотрим этот момент на примере редакции, внесенной Тиком во фрагмент комедии «Принц Цербино», стихотворения «Лес, сад и гора». Весь этот отрывок собран из сцен в «Цербино», включающих в себя, кроме эпизода с филистером, также и эпизод с Садом Поэтов. В «Цербино» Сад Поэтов - это такое реконструированное «пространство для запоминания», где размещаются тиковские небожители, кроме самого главного, Шекспира: Данте, Петрарка, Сервантес. Кроме того, там эпизодически появляются Ганс Сакс и Гоцци, а также дается намек на то, что скоро в пантеоне появится и Гете, который на момент написания драмы был еще жив.

В стихотворении сборника все эти имена отсутствуют. Можно предположить, что, фрагментируя и редактируя текст драмы таким образом, Тик делает попытку если не канонизации романтизма, то трактовки его как важной вехи литературного процесса. Знаменитые имена отсутствуют в этом тексте, поскольку отсутствует прямая необходимость их причащаться. Романтизм в интерпретации Тика манифестирует себя как сложившееся искусство, которому больше не нужно постоянно вписывать себя в ряды классиков, поскольку оно уже достаточно давно и полно существует и заслуживает внимания само по себе. 
В этом контексте становится любопытным, что в сборнике единственный раз все же упоминается другой поэт - Хольберг, но Хольберг воспринимается Тиком скорее как лично близкий автор, чем небожитель и представитель пантеона. В Саду Поэтов для Хольберга места, напротив, нет.

Стоит назвать еще один принцип правки, близкий первому. В сборнике «Стихотворения» заметна высокая концентрация тем, которые связаны с романтически идеализированным Средневековьем: рыцари, миннезингеры, пилигримы, куртуазное поклонение даме. Таких стихотворений в сборнике довольно много, более двадцати пяти. При этом в тех случаях, когда фрагмент взят из драмы, для которой тема Средневековья изначально является основной, например, «Жизнь и смерть святой Геновевы», он практически не редактируется. Фрагменты из универсальной драмы «Император Октавиан», которую сам Тик считал вершиной своего драматического творчества, тоже передаются без изменений, если они достаточно обособлены сами по себе и не нуждаются в удалении видимых связей с остальным текстом.

Итак, как можно заметить, редакция стихотворений, составляющих сборник, всегда обобщающая, тематически определенная, оставляющая все полемические, скептические, иронические контексты в подразумеваемом и легко читающемся смысловом поле фрагмента, в тени. В «Стихотворениях» отредактированные тексты организованы явно тематически, но, по-видимому, и по звуковому сходству названий тоже: «Liebe», «Lust», «Qual», «Tal», «Tränen», «Sehnen», «Freud`» (с апострофом, сокращающим немецкое «Freude», «радость», ради рифмы с «Leid», «горе»), «Leid» и т. д., что отмечено, как мы говорили выше, немецкими исследователями [7, S. 478]. «Музыкальность» сборника, о которой говорилось во вступлении к нему, достигается этими созвучиями и повторами основных тем.

Сходство с компендиумом проявляется, с одной стороны, как в тематической организации по обобщенным до топоса названиям, с другой благодаря тому, что этот сборник, как и компендиум, дополняет краткое изложение основных тем теоретическими положениями и методическими указаниями. Благодаря свойствам фрагмента как жанра темы «смысловых блоков» остаются на поверхности, а считываемая теория - в тени, как часть цитируемых произведений. Таким образом, сборник «Стихотворения» является таким своеобразным ключом ко всему наработанному - для самого Тика, для его современников и последующих поколений. 
Сборником «Стихотворения» Л. Тик завершает наиболее значительный этап своего творческого пути. В этом финальном издании можно отметить следующие аспекты: во-первых, организация сборника происходит все еще по романтическим канонам. Это в целом свойственно для критической и редакторской деятельности Тика даже в тот период, когда в его художественном творчестве наступает период обращения к литературе бидермейера и реализма.

Романтический метод заметен как в уподоблении сборника музыкальному произведению и, благодаря этому, универсуму в целом, так и в наполнении этого «универсума» романтическими топосами, среди которых «томление», «лесное одиночество» и другие. Поэт-романтик выстраивает сборник текстов как карту созданного им мира, используя фрагменты актуализированных текстов как своеобразную легенду этой карты.

Можно утверждать, что в этом случае Тик использует романтическую иронию, для которой, как известно, характерно отстранение, рефлексия «извне». Возможно, важную роль в формировании такого подхода к сборнику сыграла дружба Тика с известным философом Зольгером (I780-I8I9), который создал свою теорию иронии, дополняющую романтические представления о ней.

«Карта», получившаяся у Тика, удивительным образом напоминает книгу отшельника из «Генриха фон Офтердингена» Новалиса, в которой юный Генрих видит самого себя, свою грядущую встречу с Клингзором и т. д. Сборник «Стихотворения», как и книга, предоставляет символическое изображение: в то время как книга изображала основные вехи жизни человека, сборник посвящен основным вехам жизни литературной эпохи. Безусловно, важную роль здесь играет и романтическое представление о мире как книге, потенциально бесконечной и содержащей в себе информацию обо всех феноменах.

Если попытаться описать романтический универсум, увиденный глазами Тика, окажется, что с высоты прожитых лет романтизм воспринимается им скорее идеализированно. В романтическом искусстве, каким оно показано в сборнике «Стихотворения», постепенно снимаются все конфликты, сглаживаются острые углы противоречий, утихают злободневные споры. Не только прошедшие двадцать лет, но и смена перспективы разделяют «литературные войны» представителей различных художественных 
направлений начала I80o-х гг. и «Жалобу Талии в Германии», впервые напечатанную в «Литературном Меркурии» в Дрездене в І82I г. и изданную через два года без изменений в «Стихотворениях».

В йенский период теоретики романтизма пытались горячо отстаивать свою позицию, противостоя тому, что казалось им ложным, издавая журналы, печатая статьи и манифесты. К началу же І820-х гг. романтизм воспринимается как вполне оформившаяся эпоха, породившая множество эпигонов и начинающая постепенно отходить на второй план.

Тик оставляет в своей «энциклопедии романтического искусства» только тематические элементы, напрямую связанные с искусством как таковым, и фиксирует преимущественно то, что было изобретено и привнесено романтизмом в европейскую литературу. Именно поэтому в сборнике нет ни ссылок на авторитетные имена поэтов прошлого, ни споров с деятелями настоящего. Самым ценным, по мнению Тика, оказывается для романтического искусства его полнота и разнообразие, его близость к природе, национальной истории и культуре, способность творить собственный волшебный мир.

\section{Список литературы}

I Грешных В.И. Художественная проза немецких романтиков: Формы выражения духа: автореф. дис. ... д-ра филол. наук. М., 200I. 23 с.

2 Карельский А.В. Драма немецкого романтизма. М.: Медиум, I992. 336 с.

3 Михайлов А.В. О Людвиге Тике, авторе «Франца Штернбальда» // Странствования Франца Штернбальда. М.: Наука, І987. 360 с.

4 Михайлов А.В. Проблемы анализа перехода к реализму в литературе XIX века // Методология анализа литературного процесса. М.: Наука, І989. 236 с.

5 Михайлов А.В. Языки культуры. М.: Языки русской культуры, І997. 9І2 с.

6 Pikulik L. Erzähltes Welttheater. Paderborn: Mentis Verlag GmbH, 20Io. I96 S.

7 Scherer S. Lyrik // Ludwig Tieck. Leben - Werk - Wirkung. Berlin/ Boston: de Gruyter Lexikon, 20II. VIII, $652 \mathrm{~S}$.

8 Tieck L. Gedichte. In 3 Bde. Dresden: Hilscher, I82I. Bd. I. 280 S.

9 Tieck L. Gedichte. In 3 Bde. Dresden: Hilscher, I82I. Bd. 2. 275 S. 


\section{References}

I Greshnykh V.I. Khudozhestvennaia proza nemetskikh romantikov: Formy vyrazheniia dukha: avtoreferat diss. doktora filologicheskikh nauk [Fiction prose of German Romanticists: Forms of expression the spirit's: PhD thesis, abstract]. Moscow, $200 \mathrm{I}$. 23 p. (In Russ.)

2 Karelski A.B. Drama nemetskogo romantizma [The drama of German Romanticism]. Moscow, Medium Publ., I992. 336 p. (In Russ.)

3 Mikhailov A.V. O Liudvige Tike, avtore "Frantsa Shternbal'da". Stranstvovaniia Frantsa Shternbal'da [On Ludwig Tieck, the author of Franz Sternbald. The wanderings of Franz Sternbald]. Moscow, Nauka Publ., I987. 236 p. (In Russ.)

4 Mikhailov A.V. Problemy analiza perekhoda $k$ realizmu v literature XIX veka. Metodologiia analiza literaturnogo protsessa [How to analyze transition to realism in the $\mathrm{I}^{\text {th }}$ century literature. Methodology of the analysis of the literary process]. Moscow, Nauka Publ., I989. 236 p. (In Russ.)

5 Mikhailov A.V. Iazyki kul'tury [Languages of culture]. Moscow, Iazyki russkoi kul'tury Publ., I997. 912 p. (In Russ.)

6 Pikulik L. Erzähltes Welttheater. Paderborn, Mentis Verlag GmbH, 20IO. I96 p. (In German)

7 Scherer S. Lyrik // Ludwig Tieck. Leben - Werk - Wirkung. Berlin/ Boston, de Gruyter Lexikon, 2OII. VIII, 652 S. (In German)

8 Tieck L. Gedichte. In 3 Bde. Dresden, Hilscher, I82I. Bd. I. 28o S. (In German)

9 Tieck L. Gedichte. In 3 Bde. Dresden, Hilscher, I82I. Bd. 2. 275 S. (In German) 
УДК 82І.ІІІ.о

ББК 83.3(4Вел) 52

\section{АНГЛИЙСКАЯ ЛЕДИ В «WILD SPAСЕ» СИБИРИ (ПО КНИГЕ MRS. L. ATKINSON «RECOLLECTIONS OF TARTAR STEPPES AND THEIR INHABITANTS»)}

\author{
(C) 2018 г. М.А. Останина, Т.П. Шастина \\ Горно-Алтайский \\ государственный университет, \\ 2. Горно-Алтайск, Россия \\ Дата поступления статьи: І8 марта 2018 г. \\ Дата публикации: 25 сентября 2018 г.
}

DOI: I0.22455/2500-4247-20I8-3-3-64-8I

Аннотация: В статье рассматривается влияние горных образов Южной Сибири на воображение английских путешественников середины XIX в. Томаса и Люси Аткинсонов (Atkinson) в ракурсе ориентальной направленности текста и закрепленных за Сибирью образов terra incognita и wild space. В травелогах Аткинсонов вычленяется имагологическая доминанта. Контексты исследования составляют английская литература путешествий (эго-документы и художественные произведения) и землеописательные работы о Сибири второй половины XIX в. Письма Люси Аткинсон лондонского издания I863 г. анализируются в гендерном аспекте истории английского культурного трансфера. В основу интерпретации писем положена идея пионерства, соотнесенная с отчаянной страстью англичан к путешествиям. Свой вояж Люси описывает в духе приключенческой литературы, создавая образ смелой, выносливой, отчаянной путешественницы. В письмах она показывает превосходство истинной английской леди над дамами сибирской провинции и женщинами коренного населения алтайского высокогорья.

Ключевые слова: Люси Аткинсон, Томас Аткинсон, Сибирь, Алтай, травелог, дикое пространство, калмыки.

\section{Информация об авторах:}

Мария Александровна Останина - кандидат филологических наук, доцент, ФГБОу «Горно-Алтайский государственный университет», ул. Ленина, д. 9/І, к. 316, 649000 г. Горно-Алтайск, Россия.

E-mail: maria-ostanina@yandex.ru

Татьяна Петровна Шастина - кандидат филологических наук, доцент, ФГБОУ «ГорноАлтайский государственный университет», ул. Ленина, д. 9/I, к. 4I5, 649000 г. Горно-Алтайск, Россия.

E-mail: tshliteratura@mail.ru

Для цитирования: Останина М.А., Шастина Т.П. Английская леди в «wild space» Сибири (по книге Mrs. L. Atkinson «Recollections of Tartar steppes and their inhabitants») // Studia Litterarum. 2018. T. 3, № 3. C. 64-8I.

DOI: I0.22455/2500-4247-20I8-3-3-64-8I 


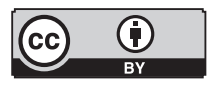

This is an open access article distributed under the Creative Commons Attribution 4.0 International (CC BY 4.0)

\section{AN ENGLISH LADY IN THE "WILD SPACE" OF SIBERIA (BASED ON MRS. L. ATKINSON'S RECOLLECTIONS OF TARTAR STEPPES AND THEIR INHABITANTS)}

\author{
(C) 20I8. M.A. Ostanina, T.P. Shastina \\ Gorno-Altaisk State University, \\ Gorno-Altaisk, Russia \\ Received: March I8, 2018 \\ Date of publication: September 25, 2018
}

Acknowledgements: «The research has been prepared with the support from RFBR (grant № I8-4I2-040004)».

Abstract: The research has an objective to study the influence of images of mountains of South Siberia on the perception of Siberia by Thomas and Lucy Atkinson, the English travelers, in the middle of the I9th century with regard to an idea of orientalism of the texts of the travellers about Siberia and its images of terra incognita and a wild space. The work singles out an imagiologic dominant in the travelogues, published by the Atkinsons in London. The English travelling literature (ego-documents and imaginary literary works) and land-describing works about Siberia of the second half of the ${ }^{\text {I }} 9^{\text {th }}$ century have made up the contexts of the research. Lucy Atkinson's London edition of I863 is analyzed with the help of a gender approach to the history of the English cultural transfer. An idea of pioneering that corresponds with the desperate passion of the English for traveling is placed in the bases of how L. Atkinson's letters are interpreted. Her journey is described in the spirit of adventurous literature, which forms her own image of a brave, enduring and reckless traveler. The letters reveal the dominance of a real English lady over women of the Siberian province and women of the indigenous population of the Altai mountainous area.

Keywords: Lucy Atkinson, Thomas Atkinson, Siberia, Altai, travelogue, wild space, Kalmyk. Information about the authors:

Maria A. Ostanina, PhD in Philology, Associate Professor, Senior Lecturer, Gorno-Altaisk State University, 9/I Lenin Str., office 3I6, 64900o Gorno-Altaisk, Russia.

E-mail: maria-ostanina@yandex.ru

Tatyana P. Shastina, PhD in Philology, Associate Professor, Senior Lecturer, Gorno-Altaisk State University, 9/I Lenin Str., office 4I5, 649000 Gorno-Altaisk, Russia.

E-mail: tshliteratura@mail.ru

For citation: Ostanina M.A., Shastina T.P. An English Lady in the "Wild Space" of Siberia (based on Mrs. L. Atkinson's Recollections of Tartar Steppes and Their Inhabitants). Studia Litterarum, 20I8, vol. 3, no 3, pp. 64-8I. (In Russ.)

DOI: Io.22455/2500-4247-20I8-3-3-64-8I 
Еще в середине XIX в. (и значительно позже) общим местом российских публикаций о Сибири оставалось представление как о земле незнаемой. «Сибирь неизвестна Европе и мало известна России. Отдаленность этого края, превратные о нем понятия, отсутствие популярных описаний, доступных большинству читающих, были всегда этому причиной» $[7$, с. I]. В зарубежных же публикациях Сибирь оставалась экзотической Тартарией (Тартария, как и Беловодье, в географической ономастике рассматривается как страна, никогда не существовавшая [Іо, с. 56]). В первом выпуске «Encyclopedia Britannica» Тартария - географическое понятие [26, с. 887], в последующих изданиях - этнологическое (Тартары / Татары); Сибирь в указанном справочнике - это территория от Урала до Тихого океана, от берегов Северного ледовитого океана до границ с Монголией и Китаем [28, с. 776].

В таких пространственных пределах локализуется образ экзотической Сибири в книгах совершивших совместную поездку из Петербурга за Урал в І848-г853 гг. англичан Томаса и Люси Аткинсон (Thomas Witlam Atkinson, I799-I86I; Lucy Atkinson, I8I8-I893) [2I; I9]. У британцев в XVIII-XIX вв. было модно путешествовать по миру и сообщать о своих впечатлениях в письмах, дневниках, рассказах; книги Аткинсонов вошли в основной корпус трудов европейских путешественников, посетивших Российскую империю с XVI в. по I9I7 г., составленный Энтони Кроссом [24]. Путешествующими по России руководили разные мотивы, в том числе желание описать образ страны, который, как отметила Е. Кулакова, так или

I При написании статьи все переводы с английского языка на русский выполнены М. Останиной. The English texts that have been used in the research are translated into Russian by M. Ostanina. 
иначе создавался через призму «своего» британского восприятия и был связан со сложившимися уже к тому времени в европейском сознании стереотипами о «варварской» России [8].

В подобном ключе ныне книги Аткинсонов спорадически рассматриваются в работах по сибирской регионалистике [4]. В Алтайском крае популяризатором творчества Аткинсонов стала Наталья Волкова, ею выполнены первые переводы фрагментов писем Т. Аткинсона [4, с. I3I-I37] и его спутницы [I]. Английский журналист Ник Филдинг издал в Лондоне книгу об Аткинсонах [27], предварительно пройдя часть их степного маршрута по Казахстану (о казахской части маршрута Аткинсонов см.: [13]).

Первые упоминания о художнике Т. Аткинсоне встречаются в словаре Брокгауза и Ефрона, где, в частности, отмечалось, что художник Аткинсон «...по дорогам, которых до сих пор не касалось еще ноги европейца, <...> проник в самую внутренность Монголии» [І8, с. 424]. Содержащаяся в данной справочной статье идея пионерства соответствует бытовавшим среди русских современников Аткинсона представлениям об англичанах (о путях формирования таковых см.: [6, с. 304-3Іо]). Одно из них звучит во вступлении к самой первой публикации фрагментов книги Т. Аткинсона в Иркутске в I858 г.: «Англичане - классические, отчаянные туристы: многие из них готовы подвергнуться всевозможным лишениям и всяким опасностям, чтобы только побывать там, где никто еще не был, и это - без всякой цели исследования, без всякой пользы для науки и других - а просто, чтобы написать о своем путешествии журнал: был и видел, или своим англинским почерком нацарапать свое британское имя на какой-нибудь скале» [2, с. 8]. Другое представление корреспондирует с ним: англичане - чудаки и эксцентрики [II, с. 67-74], «люди с причудой» [5, с. 36-67]. Последнее, безусловно, формировалось на основе чисто английской рефлексии: «...наши глупости и нахальная оригинальность сделали нас, может статься, столько же заметными в Европе, как высокий тон, которого мы считаем себя обладателями. Очень может быть, что европейское общество смеется над нами и ненавидит нас, когда мы бродим с надменным чванством по Европе, однако кто из нас захочет отречься от своей национальности? Кто захочет быть не Англичанином?» [I7, с. I27].

Вторая попытка познакомить русского читателя с травелогами Аткинсонов являет собою любопытный тип компиляции текстов иностран- 
цев о Сибири. Ею стала подготовленная и переведенная немцами (в отличие от англичан-туристов известными в Сибири как исследователи) на русский язык книга І865 г., на обложке которой значится «Путешествие по степям и горам Сибири и соседним землям Средней Азии» [I4]. В этом издании заметки и наблюдения художника-англичанина были дополнены извлечениями из трудов ученых (так своеобразно оказался компенсирован недостаток научности текста Аткинсона, на который сетовали иркутяне). Практически третью часть книги составляет Введение, раскрывающее иностранную точку зрения на Россию: «Глаза всей Европы с любопытством устремлены на Россию - на этот колосс, который является одним в виде страшилища-великана, готового поглотить ничтожных карликов западной Европы, а другим представляется каким-то непонятным Эльдорадо...» [I4, с. I].

Образ английского художника-путешественника немцами был романтизирован и героизирован: «Аткинсон нередко набрасывал на бумагу виды местностей, которых до него никто не пытался исследовать, <...> он нередко, однако же, подвергался такому стечению опасностей, что его погибель казалась неминуемою; смерть угрожала ему почти на каждом шагу, то со стороны орд диких номадов, то со стороны осужденных на каторгу беглецов <...>, то при карабкании по скалистым утесам...» [I4, c. 4-5]. Как видим, переводчики оперировали константами колониального образа Сибири, по ходу изложения книги Т. Аткинсона прибавив к ним и самую распространенную - «медвежий угол».

Дотошные немцы отыскали книгу Люси Аткинсон и воздали должное смелости англичанки, пустившейся вместе с мужем в опасное путешествие (из русских путешественниц по Алтаю и казахским степям с нею можно сравнить только Л.К. Полторацкую, дочь популярного исторического романиста К.П. Масальского, оставившую яркое описание своего путешествия [І2]). Люси «с детства привыкла применяться ко всяким обстоятельствам жизни, обладая притом редкою способностью замечать хорошие стороны вещей, даже когда ей приходилось быть в неловком или неприятном положении. Здоровье ее было до такой степени закалено, и она была такая почитательница холодной воды, что не боялась даже вскалывать лед, чтобы освежиться. Ездила она верхом как на коне, так и на верблюде...» [I4, c. I53] и «с одинаковым искусством умела заботиться о кухне и столе и собственноручно приводить в порядок свой гардероб» [14, c. I54]. Эта характе- 
ристика точно передает детали поездки и эмоциональную составляющую эпистолярной книги Люси Аткинсон, гордящейся своим статусом первой женщины-англичанки в Сибири.

Письма Люси - ценный источник для изучения гендерного аспекта в истории английского культурного трансфера. В предисловии к изданию I972 г. [20] профессор Э. Кросс указывает, что это были реальные письма Л. Аткинсон своим друзьям (в данной статье мы остановимся только на описании английской путешественницей впечатлений от дикого пространства Горного Алтая). Жанровая контаминация этого эго-документа (письма/ воспоминания) свидетельствует об акцентировании пространственно-временной дистанции, разделяющей адресата и адресанта, с одной стороны, событие и его письменную фиксацию - с другой.

При публикации все имена адресатов убраны, тем самым потенциал воздействия был перенаправлен искушенному читателю-европейцу, хорошо знакомому с жизнью цивилизованной Европы и с культурной жизнью Петербурга и Москвы, но абсолютно незнакомому с жизнью народов Средней Азии и Сибири. Об этом свидетельствуют довольно частые вкрапления в английскую лексику текстов французских слов - дань моде образованного общества. В тексте французские слова чаще всего выделены курсивом и могут рассматриваться как знак светскости:

"my little protégé was taken for the sacred animal” (мою маленькую протеже (о детеныше марала) приняли за священное животное) [I9, с. I5I], "the perquisite of the femme de chambre" (гонорар горничной) [I9, с. 2I7], "You would doubtless be surprised to hear that my son has made his début in the great world. He has been to a bal costumé dressed á la Kirghis" (Без всяких сомнений, вы были бы удивлены, услышав, что у моего сына был дебют в большом мире. Он побывал на костюмированном балу, наряженный á la киргиз) [І9, с. 2І3].

Включения же в текст отдельных русских (shube, somervar, sucarees, zavod) и тюркских слов (aoul, yourt, taboon) или транслитерированных реплик на русском языке ('Rarely has a Cossack the slightest idea of anything of the kind, for when the question is put to one of them as to what weather we shall have, the answer invariably is, 'Bogh Yevo znai!' (God knows) [ı9, с. 66] - («Очень редко когда казак имеет хоть малейшее представление, если его спросить, 
например, какая будет погода; он скажет ‘Бог его знает!', и другого ответа вы не услышите») - своеобразный знак экзотичности предмета описания. Люси, в отличие от своего мужа, русским языком владела хорошо, поскольку восемь лет служила гувернанткой в Петербурге в семье генерала Муравьева (сведения о ее биографии см.: [16, с. 374]). Книга снабжена списком из 59 «русских и татарских терминов» (подобный гипертекстовый элемент характерен для книг, описывающих коренных обитателей Сибири, см.: [9]).

Во введении Люси Аткинсон указывает, что целью ее записей являлось осмысление именно женского цивилизованного восприятия дикой природы Сибири и ее экзотических насельников (досл: передать, как женщина-англичанка (an Englishwoman) побывала в Сибири и Тартарии «странах столь отдаленных и столь неприветливых для тех, кто привык в жизни лишь к роскоши» ('countries so remote and so uninviting to those attached merely to the luxuries of life') [г9, c. V]). Отдавая должное опубликованным к тому времени трудам своего покойного мужа (заметим, оказавшегося многоженцем - вот почему он ни разу в своих книгах не упоминает о Люси как о верной спутнице), она пишет, что мужской взгляд на жизнь людей в Сибири изложил мистер Аткинсон и как ученый, и как художник, но в его книгах мало упоминаний о приключениях, которые они пережили на своем пути, и совсем не упоминаются необычные случаи, которые произошли с нею самой.

Проанализировав названия британских книг о путешествиях (реальных или вымышленных), выпущенных в Лондоне в период I750-I880 гг., можно утверждать, что слова recollections (воспоминания), explorations (исследования) и adventures (приключения), выбранные Люси и Томасом Аткинсонами для жанрового обозначения своих книг, достаточно частотны. При этом обнаруживается тенденция обозначать путешествия по изведанным, хорошо изученным местам или «цивилизованным» землям словом tour - это, как правило, поездки по территории самой Британской империи - Уэльс, Шотландия, Ирландия, остров Света; части и страны Европы (Северная Европа, Франция, Германия, Италия, пролив Гибралтар, Турция), земли Западной России (Крым, Кубань). Слово travel в значении 'поездка', 'путешествие' преимущественно используется для называния странствий по территориям, мало известным британскому читателю, а потому представляющим значительный интерес своей экзотикой. 
При описании путешествий в далекие и неизвестные края чаще используется слово adventure (приключение). B XVIII и XIX вв. в Лондоне издаются книги, повествующие о приключениях на маршрутах по Лапландии, Аляске, Альпам, Крыму, Сибири, Камчатке, Востоку, Северной Азии, Африке и вокруг света.

В названиях книг слово travel (поездка) часто стоит в одном ряду со словом adventure - travel and adventure (по Аляске, Востоку, Турции, Персии, Крыму, Кавказу). В книгах о посещении Сибири (и России) чаще используются слова life (жизнь), exploration (исследование), journey (поездка), recollections (воспоминания), discovery (открытие), narrative (рассказ), record (запись), anecdotes (анекдоты). Реже встречаются слова view (взгляд), route (маршрут): view of the Russian empire (взгляд на Российскую империю), the Siberian overland route (Сибирский наземный маршрут). Сочетание слов «исследования» и «приключения» (explorations and adventures) в названии книги Т. Аткинсона можно считать исключительным.

Итак, путешествие первой англичанки в Сибирь началось в середине февраля I848 г. на санях, которые должны были доставить небольшую группу (Томас Аткинсон, Люси, сопровождающий их некто Николай, ямщики) до Барнаула. Перед дорогой в Сибирь она как будто прощается с хорошо знакомым ей миром и ступает на путь ей совершенно неизвестный, ведущий в «дикую Сибирь» ('the wilds of Siberia'), «страну льда и снега» ('land of ice and snow') - мотив, характерный и для русских описаний путешествий в Сибирь. «Когда мы выехали, мне казалось, что я прощаюсь с миром...» ('As we passed through, I seemed to be bidding farewell to the world') [ı9, с. 5]. Выезд из Москвы представляется ей «дверью в Сибирь» ('portal on their way to Siberia'), через которую в первую очередь прошло множество ссыльных преступников.

На «великой Сибирской дороге» ('the great Siberian road') англичанка отмечает для себя много нового и дикого ('novel and wild'): в русском лесу раскидистые сосны, бросающие тени, ей мерещатся волки и медведи, готовые на них напасть. В начале пути Люси огорчают и пугают холод, тряска в дороге, пьянство ямщиков, попытки обмануть иностранцев (продать дорого карты местности, забрать их лошадей); обветренное лицо и губы, отсутствие приличной постели на протяжении нескольких недель. Но по мере продвижения в глубь Сибири реакции на обстановку меняются и возникает новый образ путешественницы-англичанки - женщины смелой, 
боевой, ничуть не капризной, любопытной, ищущей приключений и даже авантюрной.

Она пойдет туда, куда пойдет ее муж, но не потому, что должна ему помочь, а потому, что это единственная возможность побывать там, где она еще не была, испытать свою смелость, пойти на риск, продемонстрировать всем (мужчинам в первую очередь), какая она сильная и ловкая. Но в то же время все, что она хочет доказать, не соответствует образу «английской леди» (этот образ, по наблюдениям О. Солодянкиной, формировался под воздействием романов С. Ричардсона, Д. Остен и сестер Бронте [г6]). Люси часто называет себя леди, подчеркивая цивилизованность. «Дикий» мир сибирской страны формирует у нее новые черты женщины-борца. Постепенно в письмах начинают сочетаться «истинные» черты леди и «приобретенные» - и те, и другие, она уверена, должны ее отличать от всех прочих женщин, ей важно быть исключительной.

Настоящей леди требуется чистая постель, ей необходимо красиво выглядеть, получать цветы от мужчин, у нее свое седло, она ловкая наездница. Чувствуя свою отличительность (часто упоминается, что женщины обсуждают ее, сверлят ее взглядом), она все более хочет быть другой и хочет быть лучше других женщин. Женщины - ее соперницы. Победить их - значит выглядеть лучше в глазах мужчин. Она достигает этого не броской красотой, а своей ловкостью, неутомимостью. Например, Люси обрадовалась, узнав, что на маршруте к Телецкому озеру она будет единственной женщиной, никто из местного общества не будет сопровождать ее в поездке по горным территориям, местам обитания диких номадов.

Описывая длительные горные переходы, переправы через реки, проходы на лошадях узкими тропами по прибрежным обрывам, Люси подчеркивает, что все опасности она выносила стоически и благодаря своей ловкости осталась живой и невредимой. Она гордится умением хорошо управлять лошадью: «..я должна была заставить калмыков мной восхищаться, потому что они прекрасные наездники, а это большое удовлетворение, когда тебя хвалит тот, кто может судить» ('I was to have gained the admiration of the Kalmuks, because they are splendid riders, and it is satisfactory to be praised by those who are capable of judging') [19, с. 56].

Физические тяготы пути нисколько не отвлекают внимание путешественницы от романтических пейзажей. Ее восхищает вкусная речная рыба 
(такой она никогда не пробовала), аромат ягод, яркие цветы. Восторг вызывает возможность купания в реке по три раза в день, ночевки на берегу реки Бии, под звездами, когда стелют войлок, сверху две медвежьи шкуры, чтобы не было сырости. «Конечно, я ложусь не раздеваясь. Чувство странное; спишь в лесу, вода у ног журчит, и вокруг только мужчины» ('I lay down, of course without undressing. The feeling was a strange one; sleeping in a forest, the water rippling at my feet, and surrounded by men alone') [19, c. 55].

В какой-то «калмыцкой» деревне, когда Люси Аткинсон купается, приходят девушки, «больше всего ими движет желание пощупать каждый предмет одежды, который им попадается» ('but one of their principal objects is to handle every article of clothing they can come near') [19, с. 56]. «В этих тихих калмыцких деревушках, далеко от распрей суетного мира, в котором мы живем, происходят такие же сцены, только они имеют более грубую форму, чем то, что мы у нас наблюдаем: ревность, любовь и самоубийства знакомы этим некультурным детям природы» (uncultivated daughters of nature) [19, с. 56]. Заметим, что Т. Аткинсон в своих книгах порой использовал более резкие выражения, чтобы подчеркнуть свое смущение цивилизованного европейца при виде обрядов кочевых народов Сибири, являющих, по его мнению, «нечеловеческие традиции варварской эпохи» ('the inhuman customs of a barbaric age'), «это сцена из азиатской жизни, для которой в Европе параллели не найдется» ('a scene in Asiatic life which finds no parallel in Europe') [22, c. 8I-82].

Горное озеро Алтын-Кёль (досл. Золотое озеро, географическое название - Телецкое озеро) поразило Люси. Путешественники подошли к нему вечером, когда «вода была спокойной и блестела как растопленное золото, в котором скалы, лес, горы отражались как в зеркале, преумножая красоту пейзажа» [19, с. 62]. На маленькой лодке группа добралась до «калмыцкой» деревушки. Несколько домов было построено из дерева и покрыто берестой. Они зашли в некоторые из них и увидели только кухонную утварь и один или два сундука для хранения ценностей (treasures) жильцов, которые наверняка были очень бедны. Огонь разводился в центре помещения, отверстие в крыше позволяло выходить дыму. «Калмыки» подарили Люси большую связку дикого лука, который потребляется в больших количествах казаками и местными «дикими племенами» (wild tribes).

Созерцание озера вызвало у английских путешественников приступ романтизма: даже сдержанный мистер Аткинсон на берегу исполнил 
мелодию на флейте, звуки которой поразили местных обитателей - «новых друзей» путешественников; позднее бушующее озеро заставило Люси вспомнить четыре строки лорда Байрона (см. цит.: [19, с. 65], в книге не указан источник - «Паломничество Чайльда Гарольда»), смысл которых, по ее признанию, она поняла, только когда увидела бурю на Алтын-Кёле.

\section{Гром летучий}

Наполнил все: теснины, бездны, кручи.

Горам, как небу, дан живой язык,

Разноречивый, бурный и могучий...

Люси поняла горную топику Байрона, только оказавшись в одном из самых красивых мест Горного Алтая, традиционно в литературе путешествий сравниваемого с Альпами, но она не продолжила цитату:

...Ликуют Альпы в этот грозный миг,

И Юра в ночь, в туман им шлет ответный клик,

Какая ночь! (Пер. В. Левика) [3, с. І32].

Жителей прителецкой тайги Люси называет «простосердечными» (simple-hearted people), «очень бедными» (so very poor), так как должны платить подать двум императорам - китайскому и российскому; полностью зависящими от охоты, «исключительно добродушными» (extremely goodnatured), мужчины выглядят «дико», «полуголые» ('wild-looking fellows, half naked') [19, с. 63], тело «сальное» (greasy), «мускулистое» (muscular), «мощное» (brawny), «почти черное, поскольку открыто для ветра и солнца» ('nearly black from exposure to the air and sun'), на голове волосы прибраны в хвосты (pigtails), как у китайцев, выражение лица «суровое» (fierce), оно становилось еще суровее при споре. Когда Л. Аткинсон подстрелила белку (это был первый случай в ее жизни), ее похлопал по плечу один «калмык» в знак похвалы и попросил разрешения съесть эту белку, на что она согласилась при условии, что шкура достанется ей. Люси отметила, что «этим людям, кажется, без разницы, что есть; когда бы Мистер Аткинсон ни подстрелил рысь, они всегда ее съедали» ('These people seem not to care what they eat; whenever Mr. Atkinson shot a lynx, they always consumed it') [I9, c. 67]. 
В поездке по Алтаю были дни, когда голод заставлял есть даже ворон. В деревнях, которые встречались на пути, была возможность поесть козлятины: козы - единственное животное, которое здесь разводят, сообщает путешественница [I9, с. 65].

Появляется в письмах и традиционная для алтайского травелога XVIII-XXI вв. тема шаманизма. В одной деревне в высокогорной степи происходил обряд жертвоприношения, все было готово к началу «пира» и «веселья», которым мистер Аткинсон положил конец, взявшись за эскиз шамана (priest). Об испуге шамана Люси пишет: «Перед нашим отъездом старик поднял бубен и, громко по нему стуча, произнес молитву, которая, по его словам, должна позволить нам вернуться невредимыми в родные края... Бедняга не на шутку испугался, когда его рисовали, думая, что М-р Аткинсон теперь навсегда будет иметь над ним власть» [І9, с. 80].

Вторая поездка в горы из Барнаула предполагала посещение горы Белухи - самой высокой точки Русского Алтая. Люси и ее спутники только издали любуются красотой горы, но близко к ней подойти не удалось - мистер Аткинсон принял решение не рисковать. Но отважная путешественница пишет, что пошла бы и на эту гору, решись ее муж на восхождение.

Встречи в предгорьях Белухи оказались весьма интересны путешественнице благодаря отмеченному ею контрасту в уровне развития местного населения и населения прителецкой тайги. Уточним: и те, и другие имели статус российских инородцев, но долины реки Коксы и верхней Катуни с XVIII в. были местами компактного проживания староверов-кержаков, этнических русских. Люси, по ее утверждениям, вызвала большой интерес у здешних девушек и женщин: «Их никогда не посещали женщины из их-то краев, а уж понятия об англичанке у них и подавно нет» ('they had never had a visit from one of their own countrywomen, but an Englishwoman was an object they had no conception of') [19, с. 77]. Ее буквально засыпали вопросами, которые могут составить собрание в нескольких томах. Более всего поразил интерес к персоне российского императора.

Звучали вопросы о царской семье, о княжнах. Люси делает вывод: этот «бесхитростный, но добродушный народ» ('simple-minded but kindhearted people') представляет семью императора как «что-то божественное» ('something divine') [ı9, с. 77]. Стремление понять образ жизни насельников высокогорного пространства (в котором традиционно локализуется миф о 
Беловодье) приводит к восприятию этой местности как страны в стране это сказочные Уймония и Катуния.

Анализируя письма Люси Аткинсон, мы приходим к мысли о том, что она ставила перед собой задачу представить читателю свое путешествие как уникальное, практически неповторимое. Заметим, Джон Кохрэн тридцатью годами ранее пересек Российскую империю из Санкт-Петербурга до Камчатки и, вернувшись обратно в Петербург, уповал на то, что его книга может служить «полезным, а для путешественников нужным уроком» (useful, and to travellers, necessary lesson) [23, c. 409].

Представив свое путешествие поразительным, уникальным и неповторимым опытом пребывания в красивом, но диком пространстве, Л. Аткинсон говорит, что лишь женщина с особым мужеством может предпринять подобный поход, - она должна быть готова справляться с ежедневными неудобствами в нецивилизованном мире, где существование человека похоже больше на жизнь «животного» ('living more like a beast than a man') [19, с. I53].

Изложение супругами-англичанами культурных и этнографических, деталей и личных эмоций, полученных во время путешествия по Сибири и прилегающим к ней землям, безусловно, подкрепило устоявшиеся к тому времени представления о Сибири как территории вечного льда, ссыльной интеллигенции и диких кочевников. Сформировавшийся в умах европейцев, по словам Э. Кросса, «неизбежный треугольник» (unavoidable triangle) Сибирь - вечные снега - ссыльные [24, с. 46] был заложен в фундамент географического и культурного осмысления сибирского пространства путешественниками, исследовательское любопытство которых взяло верх над возможными опасностями движения в wild space. Женский взгляд миссис Аткинсон на «неокультуренное» пространство значительно отличается от травелогов путешественников-мужчин: чувственное восприятие природного компонента превалирует в ее письмах.

В отличие от мужа-живописца, Люси Аткинсон выступила в роли литературного художника и наполнила свою книгу яркими красками и сказочным блеском. Миссис Аткинсон предстает в своей книге героиней полного опасностей и трудностей приключения, порою ее жизнь висит на волоске, и только чудо и ее недюжинные способности помогают избежать опасного финала и продолжить путь по невиданной доселе для женщины-англичанки дикой до экзотичности Сибири. 


\section{Список литературы}

I Аткинсон Л. Воспоминания о Татарских степях: письма из Барнаула / пер. с англ. Н.С. Волковой. Барнаул: Алтайский дом литераторов, 20I3. І6о с. Аткинсона путешествие по Восточной Сибири // Иркутские губернские ведомости. І858. № І8. г мая. С. 7-го.

3 Байрон Д.Г. Паломничество Чайльд Гарольда / пер. с англ. В. Левика. М.: Эксмо, 20I4. 220 c.

4 Ведерников В. В седле и на балу // Алтай. 20І2. № 2. С. І24-І37.

5 Дионео (Шкловский И.В.) Английские силуэты. СПб.: Ред. журн. «Русское богатство», I905. 5 ОІ с.

6 Ерофеев Н.А. Туманный Альбион. Англия и англичане глазами русских. І825-г853. М.: Наука, І982. 322 с.

7 Завалишин И. Описание Западной Сибири. М.: Общество распространения полезных книг, I862. 4I9 с.

8 Кулакова Е.А. Сочинения британцев о путешествиях в Россию второй четверти XIX века // Диалог со временем. 20I2. Вып. 39. С. 79-93.

9 Макарова-Мирская А.И. Алтайские рассказы. Харьков: Мирный труд. I9І2. 2Ііс.

Iо Малолетко А.М. Географическая ономастика. 2-е изд. Томск: Изд-во ТГУ, 200 . I85 c.

II Орлов А.А. «Теперь вижу англичан вблизи...»: Британия и британцы в представлениях россиян о мире и о себе (вторая половина XVIII - первая половина XIX вв.): Очерки. М.: «Гиперборея», «Кучково поле», 2008. 360 с. Полторацкая Л. Поездка по китайской границе от Алтая до Тарбагатая // Русский Вестник. г87І. Т. 93. С. 580-66I.

I3 Проскурин В. Томас Аткинсон в Казахстане // Простор. 20I4. № I. URL: http:// www.centrasia.ru/newsA.php?st=I392758280 (дата обращения: 20.09.2017).

I по описаниям Т.У. Аткинсона, А.Т. Фон-Миддендорфа, Г. Радде и др. / сост. А. Фон-Этцель и Г. Вагнер, пер. с нем. Н. Деппиша. СПб.: М.О. Вольф, І865. 518 с. Солодянкина О.Ю. Иностранные гувернантки и их роль в формировании усадебной культуры URL: https://www.booksite.ru/usadba_new/world/ı6_3_or.htm (дата обращения: 20.09.20I7).

I6 Солодянкина О.Ю. Иностранные наставники в дворянском домашнем воспитании в России (вторая половина XVIII - первая половина XIX в.): дис. ... д-ра ист. наук. М., 2008. 843 c.

I7 Теккерей В. Английские туристы / пер. А. Бутаков // Отечественные записки. СПб., І85г. Т. 76, № 6. Отд. VIII. С. І06-І44.

I8 Энциклопедический словарь. СПб.: Ф.А. Брокгауз, И.А. Ефрон. І89о. Т. 2: Араго-Аутка. 478 с. 
I9 Atkinson L. Recollections of the Tartar Steppes and Their Inhabitants. London: J. Murray, I863. 356 p.

20 Atkinson L. Recollections of the Tartar Steppes and Their Inhabitants. London: Taylor \& Francis, 1972. 35I p.

2I Atkinson T.W. Oriental and Western Siberia. A narrative of seven years' explorations and adventures in Siberia, Mongolia, the Kirgiz Steppes, Chinese Tartary and Part of the Central Asia, with a map and numerous illustrations. London: Hurst and Blackett, I858. 6II p.

22 Atkinson T.W. Travels in the regions of the upper and lower Amoor, and the Russian acquisitions on the confines of India and China: with adventures among the mountain Kirghis, and the Manjours, Manyargs, Tougouz, Tousemtz, Goldi, and Gelyaks: the hunting and pastoral tribes; with a map and numerous illustrations. London: Hurst and Blackett, I860. $570 \mathrm{p}$.

23 Cochrane J.D. Narrative of a pedestrian journey through Russian and Siberian Tartary: from the frontiers of China to the frozen sea and Kamchatka: performed during the years I820, I82I, I822, and I823. Philadelphia: H.C. Carey, \& I. Lea, and A. Small, New York: Collins \& Hannay, I824. 4I5 p.

24 Cross A. In the Land of the Romanovs: An Annotated Bibliography of First-hand English-language Accounts of the Russian Empire (I6I3-I9I7). Cambridge, UK: Open Book Publishers, 20I4. URL: http://dx.doi.org/IO.II647/OBP.0042 (Accessed 26 November 20I7).

25 Cross A. Russia through the Eyes of Foreigners. URL: http://www.brill.com/sites/ default/files/ftp/downloads/320II_Titlelist.pdf. (Accessed 26 November 20I7).

26 Encyclopedia Britannica: in 3 vols. Edinburgh: Printed for A. Bell and C. Macfarquhar, I77I. Vol. 3, M-Z (iii). 953, (i) p.

27 Fielding $N$. South to the Great Steppe: the travels of Thomas and Lucy Atkinson in Eastern Kazakhstan, I847-I852. London: First, 2015. I60 p.

28 The new encyclopaedia Britannica: in 32 vols. I5th ed. Chicago: Encyclopaedia Britannica, I997. Vol. I0. 952 p. 


\section{References}

I Atkinson L. Vospominaniia o Tatarskikh stepiakh: pis'ma iz Barnaula [Recollections about Tartar steppes: letters from Barnaul], trans. N.S. Volkova. Barnaul, Altajskij dom literatorov Publ., 20I3. I6o p. (In Russ.) Atkinsona puteshestvie po Vostochnoi Sibiri [Travels of Atkinson in Eastern Siberia]. Irkutskie gubernskie vedomosti, I858, no I8, I may, pp. 7-IO. (In Russ.)

3 Bairon D.G. Sobr. soch.: $v 4$ t. [Collected works: in 4 vols.]. Moscow, Pravda Publ., I98I. Vol. 2. 3I9 p. (In Russ.)

4 Vedernikov V. V sedle i na balu [In the saddle and in the ballroom]. Altai, 20I2, no 2, pp. I24-I37. (In Russ.)

5 Dioneo (Shklovskii I.V.) Angliiskie siluety [English silhouettes]. St. Petersburg, ed. zhurn. "Russkoe bogatstvo" Publ., I905. 50 I p. (In Russ.)

6 Erofeev N.A. Tumannyi Al'bion. Angliia i anglichane glazami russkikh. I825-I853 [Foggy Albion. England and the English as seen by the Russians. I825-1853]. Moscow, Nauka Publ., I982. 322 p. (In Russ.) Zavalishin I. Opisanie Zapadnoi Sibiri [Description of Western Siberia]. Moscow, Obshchestvo rasprostraneniia poleznykh knig Publ., I862. 4I9 p. (In Russ.) Kulakova E.A. Sochineniia britantsev o puteshestviiakh v Rossiiu vtoroi chetverti XIX veka [Written works of the British about travels in Russia in the second quarter of the $1^{\text {th }}$ century]. Dialog so vremenem, 20I2, issue 39, pp. 79-93. (In Russ.)

9 Makarova-Mirskaia A.I. Altaiskie rasskazy [The Altai stories]. Khar'kov, Mirnyi trud Publ., I9I2. 2II p. (In Russ.)

Io Maloletko A.M. Geograficheskaia onomastika [Geographical onomatology]. 2-e izd. Tomsk, Izd-vo TGU Publ., 200I. I85 p. (In Russ.)

II Orlov A.A. “Teper' vizhu anglichan vblizi...”: Britaniia i britantsy v predstavleniiakh rossiian o mire i o sebe (vtoraia polovina XVIII - pervaia polovina XIX vv.): Ocherki ["Now I see the English people close to me." Britain and the British through the Russian worldview and self-image (second half of the $18^{\text {th }}-$ the beginning of the $19^{\text {th }}$ centuries: Sketches]. Moscow, "Giperboreia", "Kuchkovo pole" Publ., 2008. 360 p. (In Russ.) Poltoratskaia L. Poezdka po kitaiskoi granitse ot Altaia do Tarbagataia [The journey along the Chinese border from Altai to Tarbagatai]. Russkii Vestnik, I87I, vol. 93, pp. 580-66r. (In Russ.) Proskurin V. Tomas Atkinson v Kazakhstane [Thomas Atkinson in Kazakhstan]. Prostor, 20I4, no I. Available at: http://www.centrasia.ru/newsA.php?st=I392758280 (Accessed 20 September 20I7). (In Russ.)

I4 Puteshestvie po Sibiri i prilegaiushchim k nei stranam Tsentral'noi Azii [Traveling in Siberia and neighboring countries of the Central Asia]: based on the descriptions by T.U. Atkinson, A.T. Fon-Middendorf, G. Radde and others; compiled by A. Fon-Ettsel' i G. Vagner, trans. from German N. Deppish. St. Petersburg, M.O. Vol'f Publ., I865. 5 I8 p. (In Russ.) 

[Foreign governesses and their role in the development of the estate culture]. Available at: https://www.booksite.ru/usadba_new/world/I6_3_or.htm (Accessed 20 September 20I7). (In Russ.) (vtoraia polovina XVIII - pervaia polovina XIX v.): PhD thesis [Foreign instructors in the home education of the Russian nobility (second half of the $18^{\text {th }}-$ first half of the I9 ${ }^{\text {th }}$ centuries]. Moscow, 2008. 843 p. (In Russ.)

I7 Tekkerei V. Angliiskie turisty [Thackerey W. English tourists], trans. A. Butakov. Otechestvennye zapiski. St. Petersburg, I85I, vol. 76, no 6, Otd. VIII, pp. IO6-I44. (In Russ.)

I8 Entsiklopedicheskii slovar' [Encyclopedia]. St. Petersburg, F.A. Brokgauz, I.A. Efron Publ., I89o. Vol. 2: Arago-Autka. 478 p. (In Russ.) Atkinson L. Recollections of the Tartar Steppes and Their Inhabitants. London, J. Murray, I863. 356 p. (In English) Atkinson L. Recollection of the Tartar Steppes and Their Inhabitants. Lucy Atkinson. London, Taylor \& Francis, 1972. 35I p. (In English) Atkinson T.W. Oriental and Western Siberia. A narrative of seven years' explorations and adventures in Siberia, Mongolia, the Kirgiz Steppes, Chinese Tartary and Part of the Central Asia, with a map and numerous illustrations. London, Hurst and Blackett, I858. 6II p. (In English) Atkinson T.W. Travels in the regions of the upper and lower Amoor, and the Russian acquisitions on the confines of India and China: with adventures among the mountain Kirghis, and the Manjours, Manyargs, Tougouz, Tousemtz, Goldi, and Gelyaks: the hunting and pastoral tribes; with a map and numerous illustrations. London, Hurst and Blackett, I860. 570 p. (In English)

23 Cochrane J.D. Narrative of a pedestrian journey through Russian and Siberian Tartary: from the frontiers of China to the frozen sea and Kamchatka: performed during the years I820, I82I, I822, and I823. Philadelphia, H.C. Carey, \& I. Lea, and A. Small, New York, Collins \& Hannay, I824. 4I5 p. (In English)

24 Cross A. In the Land of the Romanovs: An Annotated Bibliography of First-hand English-language Accounts of the Russian Empire (I6I3-I9I7). Cambridge, UK: Open Book Publishers, 20I4. Available at: http://dx.doi.org/Io.II647/OBP.o042. (Accessed 26 November 20I7). (In English)

25 Cross A. Russia through the Eyes of Foreigners. Available at: http://www.brill.com/sites/ default/files/ftp/downloads/320II_Titlelist.pdf. (Accessed 26 November 20I7). (In English)

26 Encyclopedia Britannica: in 3 vols. Edinburgh, Printed for A. Bell and C. Macfarquhar, I77I, vol. 3, M-Z (iii), 953, (i) p. (In English) 
Мировая литература / М.А. Останина, Т.П. Шастина

27 Fielding N. South to the Great Steppe: the travels of Thomas and Lucy Atkinson in Eastern Kazakhstan, I847-I852. London, First, 2015. I60 p. (In English)

28 The new encyclopaedia Britannica: in 32 vols. I5th ed. Chicago, Encyclopaedia Britannica, I997. Vol. IO. 952 p. (In English) 


\section{„SIBIRISCHE MÖGLICHKEITEN“: ZUR DEUTSCHEN DOSTOEVSKIJ-REZEPTION}

This is an open access article distributed under the Creative Commons Attribution 4.0 International (CC BY 4.0)
(C) 20I8. N. Kopcha

Russische Staatliche Universität für Geisteswissenschaften, Moskau, Russland

Eingangsdatum: 23.01.2018

Veröffentlichungsdatum: 25.09.2018

DOI: I0.22455/2500-4247-2018-3-3-82-93

Inhaltsangabe: Zu Beginn des 20. Jahrhunderts fanden Fedor Dostoevskij und seine Sicht auf das russische Volk, das Westlertum und die Revolution große Aufmerksamkeit in Deutschland. Mit erster deutschen Gesamtausgabe (1906-I9I9) wurde unter der Herausgeberschaft von Arthur Moeller van den Bruck ein neuer politisch orientierter Rezeptionsmodus etabliert. In der Forschung ist Moeller mit seinem Hauptwerk „Das Dritte Reich“ als Verkünder der Konservativen Revolution bekannt, aber bereits seine Einleitungen zu Dostoevskij können als erster Programmentwurf dieser Bewegung gelten. In den Einleitungen Moellers wird Dostoevskij zu einem Gewährsmann der neuen deutschen Rechten, deren Denkweise später als „Konservative Revolution“ definiert wurde. Im vorliegenden Artikel geht es darum, wie Sibirien von Moeller im neukonservativen Kontext wahrgenommen wurde. Die Autorin kommt zum Ergebnis, dass Sibirien in diesen Vorworten in verschiedenen Kategorien dargestellt wird: erstens als Ort, wo Dostoevskij seine Weltanschauung geändert und das „wahre“ russische Volk begriff; zweitens als Territorium, wo eine besondere Formation des russischen Volkes entstand, die durch die revolutionären nicht „aus Doktrin“, sondern „aus Instinkt“ kommenden Stimmungen bezeichnet wird, drittens als Raum, in dem es die Möglichkeiten für die gemeinsame deutsch-russische, dem westeuropäischen Rationalismus gegenüberstehende Zukunft gebe. So setzt Moeller van den Bruck den mehrseitigen politischen Mythos, der nicht nur das Wesen Sibiriens betrifft, sondern auch das Schicksal Deutschlands.

Schlüsselwörter: Sibirien, Dostoevskij, Konservative Revolution, Arthur Moeller van den Bruck, Volk, Nihilismus.

Information zum Autorin: Nataliya Kopcha ist Promovierende im Internationalen Graduiertenkolleg I956 „Kulturtransfer und ,kulturelle Identität“ - Deutsch-russische Kontakte im europäischen Kontext“ (RGGU Moskau, Albert-Ludwigs-Universität Freiburg), Sprachassistentin am Thomas Mann Lehrstuhl (RGGU Moskau), Miusskaja pl., 6, I25993 Moskau, Russische Föderation.

E-mail: nataliek645@yandex.ru

Zum Zitieren: Kopcha N. „Sibirische Möglichkeiten“: zur deutschen Dostoevskij-Rezeption. In: Studia Litterarum. 2018. Bd. 3, № 3. C. 82-93. DOI: IO.22455/2500-4247-20I8-3-3-82-93 


\section{"SIBERIAN POSSIBILITIES": GERMAN RECEPTION OF DOSTOEVSKY}

This is an open access article distributed under the Creative Commons Attribution 4.0 International (CC BY 4.0)
(C) 2018. N.A. Kopcha

Russian State University for the Humanities, Moscow, Russia Received: January 23, 2018 Date of publication: September 25, 2018

Abstract: At the beginning of the $20^{\text {th }}$ century, in Germany that was going through a period of cultural pessimism and crisis of conservative values, a new political dimension eloped in the German reception of Dostoyevsky. Arthur Moeller van den Bruck, essayist and future ideologist of Conservative revolution, the author of the book Third Reich developed such approach. From I906 through I9I9, he published the first complete works of the Russian writer in German that influenced further adaptation of Dostoyevsky. The aim of this article is to analyze the perception of Siberia in the prefaces written by Moeller with no other purpose but to declare new conservative views. The analyzed sources are devoted to a subject of Siberia which is considered by Moeller in different political and socio-philosophical categories. The author comes to a conclusion that Moeller sees Siberia (I) as a place where Dostoyevsky had changed his views and had discovered the "true" Russian people; (2) as a territory whose population had revolutionary moods coming not "from the doctrine" but "from the instinct”; (3) as a place with opportunities for German-Russian future union capable to overcome Western rationalism. Thus Moeller enters the multilateral political myth concerning not only the essence Siberia of but also the future of Germany.

Keywords: Siberia, Dostoevsky, Conservative revolution, Arthur Moeller van den Bruck, the people, nihilism.

Information about the author: Nataliya A. Kopcha, PhD student, Russian State University for the Humanities, Miusskaya 6, I25993 Moscow, Russia.

E-mail: nataliek645@yandex.ru

For citation: Kopcha N.A. "Siberian Possibilities": German Reception of Dostoevsky. Studia Litterarum, 20I8, vol. 3, no 3, pp. 82-93. (In German)

DOI: I0.22455/2500-4247-20I8-3-3-82-93 
УДК 821.I6І.І.о+

82I.II2.2.0

ББК $83.3(2 \mathrm{Poc}=\mathrm{Pyc}) 52+$ $83.3(4$ Гем $) 53$

\section{«SIBIRISCHE MÖGLICHKEITEN»: ZUR DEUTSCHEN DOSTOEVSKIJ-REZEPTION}

\author{
(C) 2018 г. Н.А. Копча \\ Российский государственный гуманитарный \\ университет, \\ Москва, Россия \\ Дата поступления статьи: 23 января 2018 г. \\ Дата публикации: 25 сентября 2018 г.
}

DOI: I0.22455/2500-4247-2018-3-3-82-93

Аннотация: В начале XX в. в Германии, переживающей период культурного пессимизма и кризиса консерватизма, в немецкой рецепции Ф.М. Достоевского развивается новый модус - политический. Такой подход осуществил публицист, будущий идеолог Консервативной революции и автор книги «Третий Рейх» Артур Меллер ван ден Брук. С г906 по г9г9 гг. он издает первое полное собрание сочинений русского писателя на немецком языке, повлиявшее на дальнейшую адаптацию Достоевского в Германии. В данной статье ставится проблема восприятия Сибири в предисловиях, написанных Меллером с целью заявить о неоконсервативных взглядах. Анализируемые источники посвящены теме Сибири, которая рассматривается Меллером в разных политических и социофилософских категориях. Автор приходит к выводу, что в этих предисловиях Сибирь, вопервых, представлена как место, где Достоевский поменял свои взгляды и познал «истинный» русский народ; во-вторых, как территория, где зародилась особая формация русского народа с революционными настроениями, идущими не «из доктрины», а «из инстинкта»; в-третьих, как пространство, где есть возможности для германо-русского будущего, способного преодолеть западный рационализм. Таким образом, Меллер вводит многосторонний политический миф, касающийся не только сущности Сибири, но и будущего Германии.

Ключевые слова: Сибирь, Достоевский, консервативная революция, Артур Меллер ван ден Брук, народ, нигилизм.

Информация об авторе: Наталия Александровна Копча - аспирант международной аспирантуры «Культурный трансфер и “культурная” идентичность -Немецкорусские контакты в европейском контексте» (РГГУ - Фрайбург), ассистент кафедры Германской филологии, Российский Государственный Гуманитарный Университет, Миусская пл., д. 6, І25993 г. Москва, Россия.

E-mail: nataliek645@yandex.ru

Для цитирования: Копча Н.A. «Sibirische Möglichkeiten»: zur deutschen DostoevskijRezeption (О непознанных возможностях Сибири: к вопросу о немецкой рецепции Достоевского) // Studia Litterarum. 2018. Т. 3, № 3. С. 82-93. DOI: I0.22455/2500-4247-20I8-3-3-82-93 
Was ist Sibirien für Deutschland? Man verbindet es vorerst mit dem Ausdruck „Sibiriendeutsche“, die sich im Gesicht der Handwerker, Händler oder Soldaten im I8. und I9. Jahrhundert dort freiwillig ansiedelten. Oder Sibirien ist auch als russischer Verbannungsort bekannt, wohin die Verbrecher und politisch Missliebige verschickt wurden. In diesem Zusammenhang erinnert man sich an Fedor Dostoevskij, der nach der Umwandlung der Strafe zum Militärdienst nach Sibirien eingezogen wurde und der dort seine Weltanschauung geändert hatte. Seine Erlebnisse beschrieb er in seinen wichtigsten Werken. Diese Themen werden in der geisteswissenschaftlichen Forschung gut untersucht, aber es gibt noch Fragen und Problemen, die wenig behandelt werden. Es geht zum Beispiel darum, wie Sibirien von deutschen Neukonservativen vor dem Ersten Weltkrieg und danach wahrgenommen wurde. Es war für sie ein Ort, der sich vom pragmatischen Westen stark unterschied und das bestimmte Potenzial hatte. Im Folgenden wird gezeigt, wie der deutsche Publizist Arthur Moeller van den Bruck Sibirien in Bezug auf Dostoevskij, das russische Volk und die deutsche Zukunft betrachtete.

Zwischen 1906 und I9I9 erschien die erste deutsche Gesamtausgabe der Werke Dostoevskijs im Piper-Verlag, die bereits mit dem ersten Band eine große Wirkung auf den deutschen Intellektuellen wie Thomas Mann, Otto Julius Bierbaum, Hermann Bahr und Stefan Zweig ausgeübt hatte. Der Herausgeber wurde der junge deutsche Publizist Arthur Moeller van den Bruck, der die Idee dieses Großprojekts einem neuen Verlag vorgeschlagen hatte. Der angehende Verleger Reinhard Piper betrachtete Moeller als einen aussichtsreichen, bereits auf dem Buchmarkt etablierten Autor, der Dostoevskij mit seinen eigenen begleitenden Einleitungen herausgeben könnte. Zum Projekt war auch Dmitrij Merežkovskij herangezogen, deren damals bereits bekannter Name zum größeren Erfolg beitragen konnte. 
Mit erster deutscher Gesamtausgabe unter Herausgeberschaft von Moeller wurde ein neuer politischer Rezeptionsmodus etabliert, der vorerst den Schriftsteller als politischen und kulturphilosophischen Denker in den Mittelpunkt des Dostoevskij-Bildes setzt. In von 1906 bis 1922 von Moeller verfassten Einleitungen wird Dostoevskij zu einem Gewährsmann der neuen deutschen Rechten, deren Denkweise später als Konservative Revolution [7] von Armin Mohler definiert wurde. Moeller transformiert in seinen Texten dostoevskisches Denken, um es für sein Eigenes nutzbar zu machen. In der Forschung ist Moeller für sein Hauptwerk „Das Dritte Reich“ [5] als Proklamation der deutschen Konservativen Revolution bekannt, aber bereits seine Einleitungen zu Dostoevskij können als erster Programmentwurf dieser Bewegung gelten.

Es ist über den Forschungsstand zu berichten. Zunächst sollte das Buch Christoph Garstkas „Arthur Moeller van den Bruck und die erste deutsche Gesamtausgabe der Werke Dostojewskijs im Piper-Verlag I906-I9I9. Eine Bestandsaufnahme sämtlicher Vorbemerkungen und Einführungen von Arthur Moeller van den Bruck und Dmitrij S. Mereschkowskij unter Nutzung unveröffentlichter Briefe der Übersetzerin E.K. Rahsin“ (I998) [I] genannt werden. Der Autor konzentriert sich auf das Editionsprinzip Moellers im Piper-Verlag und gibt einen faktisch-deskriptiven Überblick über die erste Dostoevskij-Gesamtausgabe mit vielen Hinweisen auf die chronologischen Aspekte, ohne konkrete Quellenanalyse zu geben.

20 Io hat Andrè Schlüter das Buch unter dem Titel „Moeller van den Bruck: Leben und Werk“ [8] veröffentlicht. Der Autor untersucht den Weg Moellers von dem Literaturkritiker bis zum geistigen Führer der Konservativen Revolution. Das Moeller-Thema in Bezug auf Dostoevskij wird in Kapiteln „Arbeit an Dostojewkij“ und „Dostojewskij als Politiker“ beleuchtet. Schlüter betrachtet die Frage nach Dostoevskij-Rezeption und gibt eine kurze Analyse zu allen von Moeller verfassten Einleitungen. In seinem Überblick ist das Thema des russischen „prinzipiell rückständigen“ [8, S. I80] Volkes, das in Texten Moellers zu finden sei, markant dargestellt. Der Autor analysiert die Quellen nach den konkreten Aspekten, dabei spielt die Frage des russischen Volkes als Gegensatz zum deutschen Volk eine zentrale Rolle. Da Sibirien keine Hauptfrage für Schlüter ist, steht es nicht im Mittelpunkt in Bezug auf die Vorworte. So erwähnt der Forscher zum Beispiel das Thema des Sibiriens nicht, wenn er über die erste zu „Dämonen“ aufgestellte Einleitung schreibt, weil Schlüter anderes Forschungsziel verfolgt. 
Für den vorliegenden Artikel werden nicht alle, sondern nur die Einleitungen ausgewählt, in denen Sibirien implizit oder explizit, direkt oder indirekt bei Moeller repräsentiert wird. Am Beispiel der chronologischen Quellendarstellung sollte gezeigt werden, dass Moeller Sibirien als Thema nie aus den Augen verliert, sondern es im Laufe der Zeit nur vertieft. Für Moeller ist es der Ort, der für Dostoevskij ein Wendepunkt und eine Entdeckung war. Aber noch wichtiger ist, dass Sibirien noch Möglichkeiten hatte, aus denen Moeller seinen eigenen politischen Mythos konstruieren konnte. Es geht beispielsweise um den echten in Sibirien geborenen russischen Nihilismus, was in der Forschung noch wenig untersucht und zum Beispiel bei Schlüter nicht zu finden ist.

Moeller schreibt nicht als Kulturkritiker und nicht als Historiker, sondern als Vordenker einer Bestätigungsgemeinschaft, die wegen innen- und außenpolitischer Ereignisse in Deutschland vor dem Krieg vorbereitet und nach dem Krieg etabliert wurde. Es geht ihm nicht um die Reflexion an historische Stimmigkeit und Konsequenz, sondern um die Formulierung eingängiger Narrative, die der Selbstvergewisserung einer ideologischen Zustimmungsgemeinschaft dienen können. Für die Vermittlung solcher besonderen Orientierung wird das sinnstiftende Narrativ mit politisch-mythologischem Charakter erheischt. Dieses Ursprungsnarrativ ermöglicht, die Konstruktion eines Volkes und Volkscharakters zu klären, die vermeintliche historische Mission eines Volkes oder einer Nation zu erläutern. Sibirien als besonderer Ort wurde ein der wichtigen Themen in diesen Einleitungen.

Sibirien wird von Moeller regelmäßig erwähnt. Es sind zwei Schwerpunkte auszuzeichnen. Erstens geht es um die konventionelle Vorstellung über die Wirkung, die Sibirien auf Dostoevskij und seinen weiteren Werdegang ausgeübt hat. Zweitens spielt Sibirien für Moeller die Rolle des Raums, wo sich ein großes Potenzial im geschichtlichen Kontinuum verwirklicht. Im Folgenden werden die beiden Aspekte am Beispiel der Quellenanalyse betrachtet.

Bereits in der ersten Einleitung „Bemerkungen über Dostojewski“ [2] (I906) zu „Dämonen“ schreibt Moeller über Bedeutung Sibiriens für Dostoevskij. Er möchte den Roman nicht aus einer literarischen Perspektive beleuchten, sondern er versucht die russische Dichtung, bzw. das Werk Dostoevskijs als neues Phänomen in der Weltkultur und das russische Wesen zu begreifen. „Die russische Dichtung ist die Dichtung eines jungen Volkes“ [2, S. VII], - so beginnt Moeller seine erste Einleitung zur Dostoevskij-Ausgabe. Diese These ist wichtig, 
weil sie drei Aspekte enthält, die später zur Grundbasis der Ideologie Moellers werden. Diese sind Russlandbild, Dichtung (damit ist immer Dostoevskij gemeint) und das ,junge“ Volk. Der letzte Aspekt wird nach dem Ersten Weltkrieg zum wichtigsten Teil der von Moeller proklamierten Konservativen Revolution. In den nächsten Einleitungen verwendet er dieser Topos für die Betrachtung des sibirischen Potenzials, was weiterhin zu beobachten ist. Im ersten Text handelt es sich noch um Sibirien als geistigen Perspektivewechsel bei Dostoevskij, nachdem „sein Leben das russischste aller russischen Leben, ein politisches Leben, gewesen“ war [2, S. XV]. Das Motiv des sibirischen Wendepunkts wiederholt sich in allen Einleitungen, in den Moeller über die Biographie Dostoevskijs schreibt. So ist das sibirische Thema hier ein Ausganspunkt, aus dem Moeller ein Dostoevskij-Bild und einen politischen Mythos über Zukunft konstruiert.

Der nächste Schwerpunkt ist Sibirien an sich. Das ist in den Einleitungen „Bemerkungen über sibirische Möglichkeiten“ [4] (1906) und „Bemerkungen über russische Mystik“ [3] (I907) zu beobachten. An dieser Stelle spielt der oben erwähnte Topos ,junges Volk“ die zentrale Rolle.

Das Hauptthema der „Bemerkungen über sibirische Möglichkeiten“ ist die Zukunft Sibirien, wo sich ein neues Volk und seine geschichtliche Sendung herausbilden:

Und gar in die Zukunft können wir schauen, in das Wachstum eines Volkes, von dem heute kaum mehr vorhanden ist, als die anthropologischen Bestandteile, wenn wir Dostojewskis „Aufzeichnungen“ aus seiner sibirischen Zeit unter dem Gesichtswinkel lesen, daß auch Sibirien einmal eine Kultur haben wird, und daß das Volk, das sie zu schaffen berufen ist, nicht nur die Russen sein werden, und erst recht nicht die Nachkommen der verschiedenen Turan-, Altai- und Mongoloidvölker, Sibiriens Urbevölkerung, von Tschuden, Tungusen und Jakuten, sondern auch hier wieder die sich entwicklungsgeschichtlich ergebende Rassenmischung, das dereinstige Volk der Sibiren [4, S. IX].

Sibirien wird hier als ein Ort „des Lebens und der Zukunft“ [4, S. XII] mit seiner eigenen Landschaft betrachtet, wo sich das neue Volk mit der Dominanz des slawischen Rassenhaften verkörpert, die „unzerstörbar im Völkerleben“ [4, S. X] seien.

Von den Gestalten „Aus einem Totenhaus“ ausgehend, vertritt Moeller die These, dass nur die starken und tätigeren Persönlichkeiten aller sozialen Schichte 
freiwillig nach Sibirien kommen, während die „gefügigeren“ und „untätigeren“ in Russland bleiben. Er richtet sich nach der Rassentheorie, wenn er über die „Gesetze der Auslese und die größere Erhaltung der stärkeren Rasse“ [4, S. XII] spricht, und Sibirien sei die allerbeste Landschaft dafür. In der Hinsicht, dass es „ja doch das allerbegabteste, allerstärkste Volk“ [4, S. XII] im russischen Volk sei, stimmt Moeller Dostoevskij zu, aber er möchte dostoevskische Verzweiflung, die im Titel des Werks gegeben wird, entgegenhalten, denn er sieht in Sibirien die Zukunft des ,jungen“, freien und schöpferischen Volks mit eigenen herausgearbeiteten Eigenschaften.

Der letzte Teil der Einleitung wird Dostevskij gewidmet. Moeller ist der Meinung, dass der russische Schriftsteller nicht richtig von der panslawischen Aussicht und in Bezug auf Sibirien über die Russen spricht, obwohl er bereits die "frischen seelischen Neuwerte“ [4, S. XV] dort beobachtet. Für Moeller sei Dostoevskij ein Prophet, der „ein erstes anthropologisches und psychologisches Dokument für Sibirien“ [Ebd.] geschaffen habe, aber noch „kein sibirisches Programmbuch“ [Ebd.] - Moeller van den Bruck scheint sich selbst für diese Rolle vorzusehen.

Es lässt sich noch die neue sibirische Bevölkerung verdeutlichen. Unter dem „neuen“ Volk versteht Moeller die Verknüpfung des „Besten“ Russlands und Sibiriens: Aus Russland werden die von Dostoevskij deklarierten Psychologismus und Religion genommen, Sibirien gebe „Pionierhaftigkeit“ [4, S. XIV], die aus Werk, Arbeit und Kultur summiert wird. Moeller ist hier kein Rezipient des Werks Dostoevskijs, sondern ein Schöpfer eines Mythos: Es wird ein neues, noch nicht existierendes Volksbild ausgearbeitet.

In diesem Zusammenhang wichtig die von Moeller untersuchten Typen des Russentums zu erwähnen, die in der Einleitung „Bemerkungen über russische Mystik“ zum Roman „Der Idiot“ dargestellt werden. Für ein „leidendens“ Russentum seien das Christliche, die Geduld und Demut charakteristisch; ein „tätiges“ Russentums schaffe „die eigentlich russischen Werte“ und wird das „Germanisch-Sibirische“ genannt [3, S. XVII]. Daraus ergibt sich, dass Moeller seine Aussicht entwickelt: Wenn früher hat er in Sibirien „eine große slawische Zukunft“ [4, S. XV] gesehen hatte, dann orientiert er sich nun an den „sibirischen Möglichkeiten“, an der germanisch-sibirischen Zukunft, die jedoch mit der russischen Religiosität verbunden wird. Das ist eine weitere Stufe in der Mythosbildung. 
In dieser Zuwendung Moellers an Sibirien und in seinem Versuch diesen Ort den Germanen, bzw. Deutschen anzupassen ist das Interesse des frühen 20. Jahrhunderts zu erkennen, die an dem Osten orientiert wurde. Im Osten fand man in dieser Zeit eine Opposition zum westlichen Rationalismus. Für Moeller wird Russland auch stark vom Westen beeinflusst, aber in Sibirien entdeckt er etwas Neues und noch Unbekanntes, Naturhaftes und Ursprüngliches. Moeller hat dieses kulturphilosophische Interesse in das geopolitische gerichtet.

Wenn die Einleitungen Moellers vor dem Ersten Weltkrieg mehr kulturphilosophisch waren, werden sie nach stark I9I8 politisiert, was den historischen Ereignissen entsprach. Moeller interessiert sich immer noch für Sibirien, aber aus einer neuen Perspektive. Er proklamiert keine germanisch-sibirische Zukunft mehr, sondern versucht er die Ursache der Russischen Revolution zu finden. Er untersucht in diesem Zusammenhang die Geschichte des russischen Nihilismus.

In der Einleitung „Der Nihilismus und die Revolution“ [6] (I922) unterscheidet Moeller zwei Typen des russischen Nihilismus. Der erste Typ ist der politische Nihilismus, der durch den westeuropäischen Frühsozialismus beeinflusst war. Die Vertreter solcher Denkweise waren laut Moeller die Petraschewzen und später Narodmiki, die die Revolutionäre „aus Doktrin“ [6, S. XV] waren.

Der zweite Typ des Nihilismus sei der „volksreligiöse“ Nihilismus. Moeller verknüpft diesen Nihilismus immer mit dem russischen Volk und „religiös“ versteht er als „rechtgläubig“. Es ist darauf hinzuweisen, dass das Volk für Moeller mit den sibirischen Bewohnern assoziiert wird, die Dostoevskij während seiner Verbannung erfassen hat. Einerseits spricht er darüber durch Dostoevskij-Rezeption, andererseits hat er seine eigene Meinung, als er über den Nihilismus spricht. Mit dem Thema des Raskols beginnt er seine Einleitung „Der Nihilismus und die Revolution“. Raskolniki werden als die ersten Nihilisten bezeichnet, weil sie die neuen Reformen der russischen Kirche verneint haben, um „rechtgläubig [zu] bleiben“ [6, S. VII]. Auf diesem religiös geprägten Eindruck aufbauend wartete das russische Volk seit dieser Zeit auf den Antichrist und die kommende Apokalypse. Laut Moeller war das die erste nihilistische Welle, die die ersten Nihilisten nach Sibirien gebracht hat, wo im Zuge der Zeit unterschiedliche religiöse sektiererische Gruppierungen, wie die Stundisten, die Molokanen und die Duchoborzen entstanden, die den „pietistisch-tugendhaften“ [6, S. X] Nihilismus entwickelt haben und womit "die nihilistische Zersetzung des russischen Volkes“ begonnen hat. Hierbei hebt Moeller hervor, dass die Grundlage des russischen 
Volksnihlismus immer religiös sei und dass der Name Raskolnikov nicht die Herkunft bedeute, sondern die Einstellung.

Die zweite nihilistische Welle, die das sibirische Volk herausgebildet hat, verbreitete sich, so Moeller, nach den Reformen Peters des Großen, in dem man den Antichrist sah. Das waren alle, die mit den auf dem Westen orientierten Reformen unzufrieden waren und dafür verbannt wurden. Gemeinsam mit den Altgläubigen, Barfüßern, Verbrechern, Mördern, Räubern und Dieben wurden sie in Sibirien „Brüder von Gesindel, doch Brüder in Freiheit“ [6, S. VII].

Moeller ist noch der Meinung, dass das russische Volk eine „schwere Ursprünglichkeit einer besonderen russischen Natur" [6, S. IX], eine Doppelnatur hat, die zweite Seite von derer Dostoevskij in Sibirien gesehen hat. An dieser Stelle wendet sich Moeller in Bezug auf das Wesen des russischen Volkes zu Dostoevskij wieder und zur Widersprüchlichkeit der Russen („Unberechenbarkeit in seinen Trieben“, „Widersprüche seiner Leidenschaften“, „Heftigkeit von Zuneigung oder Abneigung“) an. Auf einer Seite sind das die Menschen „voll von der eigenen Echtheit" und „der autochthoner Kraft", auf anderer Seite haben sie die Eigenschaften, sowie „Gier“, „Fleischlichkeit“, „Selbstbeschwörung“, „Maßlosigkeit“ [5, S. IX-X]. Das ist das von Moeller interpretierte Volksbild, das er angeblich bei Dostoevskij findet, aber das ist eine Neudeutung, denn man beobachtet bei Dostoevskij solches Bild nicht. Es handelt sich um die Umdeutung und Transformation, weil Moeller auf diese Weise den Widerspruch in Dostoevskij selbst und sein Verhältnis zum Volk darstellen will, um seinen „revolutionären Konservatismus“ zu bestimmen.

Zusammenfassend lässt sich sagen, dass Sibirien im ersten Viertel des 20. Jahrhundert für die deutsche neukonservative Bewegung eine bedeutsame Rolle spielte. Für Arthur Moeller van den Bruck, den Ideologen der Konservativen Revolution war Sibirien ein besonderer Ort mit dem vielsagenden Potenzial, das er vor allem im Werk Dostoevskijs gefunden hat. Auf einer Seite wurde in Sibirien laut Moeller eine kräftige besondere Volkbildung mit den revolutionären Trieben geboren und entwickelt, das dem westlichen Rationalismus wiederstehen konnte. Auf anderer Seite hat Sibirien wegen seiner Echtheit die Möglichkeit, um die germanisch-sibirische Zukunft zu schaffen. Es geht nur um einen gewissen der politischen Mythen über die Zukunft Deutschlands, die Moeller in seinen zahlreichen neukonservativen Aufsätzen konstruierte. 


\section{Список литературы}

I Garstka Ch. Arthur Moeller van den Bruck und die erste deutsche Gesamtausgabe der Werke Dostojewskijs im Piper-Verlag I906-I9I9: Eine Bestandsaufnahme sämtlicher Vorbemerkungen und Einführungen von Arthur Moeller van den Bruck und Dmitrij S. Mereschkowskij unter Nutzung unveröffentlichter Briefe der Übersetzerin E.K. Rahsin. Frankfurt am Main, Berlin, Bern I998. XIII, I68 S. Moeller van den Bruck A. Bemerkungen über Dostojewski // F.M. Dostojewski: Die Dämonen. Sämtliche Werke, Erste Abteilung : Fünfter Band. München und Leipzig: Piper, I906. S. VII-XV.

3 Moeller van den Bruck A. Bemerkungen über russische Mystik // F.M. Dostojewski: Der Idiot. Sämtliche Werke, Erste Abteilung: Dritter Band. München und Leipzig: Piper, I907. S. V-XVII.

4 Moeller van den Bruck A. Bemerkungen über sibirische Möglichkeiten // F.M. Dostojewski: Aus einem Totenhaus. Sämtliche Werke, Erste Abteilung: Achtzehnter Band. München und Leipzig: Piper, I906. S. VII-XV.

5 Moeller van den Bruck A. Das Dritte Reich. I. Auflage. Berlin: Der Ring Verlag, I923. 26I S.

6 Moeller van den Bruck A. Der Nihilismus und die Revolution // F.M. Dostojewski: Die Dämonen. Sämtliche Werke, Erste Abteilung : Fünfter Band. München und Leipzig: Piper, I922. S. VII-XXIV.

7 Mohler A. Die Konservative Revolution in Deutschland I9I8-I932. Darmstadt: Wiss. Buchges., I994. I3I S.

8 Schlüter A. Moeller van den Bruck: Leben und Werk. Köln: Böhlau Verlag, 2oıo. IX, 448 S. 


\section{References}

I Garstka Ch. Arthur Moeller van den Bruck und die erste deutsche Gesamtausgabe der Werke Dostojewskijs im Piper-Verlag I906-I9I9: Eine Bestandsaufnahme sämtlicher Vorbemerkungen und Einführungen von Arthur Moeller van den Bruck und Dmitrij S. Mereschkowskij unter Nutzung unveröffentlichter Briefe der Übersetzerin E.K. Rahsin. Frankfurt am Main, Berlin, Bern I998. XIII, I68 S. (In German)

2 Moeller van den Bruck A. Bemerkungen über Dostojewski. F.M. Dostojewski: Die Dämonen. Sämtliche Werke, Erste Abteilung: Fünfter Band. München und Leipzig, Piper, I906. S. VII-XV. (In German)

3 Moeller van den Bruck A. Bemerkungen über russische Mystik. F.M. Dostojewski: Der Idiot. Sämtliche Werke, Erste Abteilung: Dritter Band. München und Leipzig, Piper, I907. S. V-XVII. (In German)

4 Moeller van den Bruck A. Bemerkungen über sibirische Möglichkeiten. F.M. Dostojewski: Aus einem Totenhaus. Sämtliche Werke, Erste Abteilung: Achtzehnter Band. München und Leipzig, Piper, I906. S. VII-XV. (In German)

$5 \quad$ Moeller van den Bruck A. Das Dritte Reich. I. Auflage. Ring Verlag, I923. 26I S. (In German)

6 Moeller van den Bruck A. Der Nihilismus und die Revolution. F.M. Dostojewski: Die Dämonen. Sämtliche Werke, Erste Abteilung: Fünfter Band. München und Leipzig, Piper, I922. S. VII-XXIV. (In German)

7 Mohler A. Die Konservative Revolution in Deutschland I9I8-I932. Darmstadt: Wiss. Buchges., I994. I3I S. (In German)

8 Schlüter A. Moeller van den Bruck: Leben und Werk. Köln, Böhlau Verlag, 20Io. IX, 448 S. (In German) 


\title{
EL MISTERIO CHINO Y MISTIFICACIÓN LITERARIA: POEMAS ENIGMÁTICOS EN LA REVISTA «PRISMA»
}

This is an open access article distributed under the Creative Commons Attribution 4.0 International (CC BY 4.0)

\author{
(C) 20I8. N. Kharitonova \\ Instituto de Literatura Mundial A.M. Gorky \\ de la Academia de Ciencias Rusa, Moscú, Rusia \\ National Research University Higher \\ School of Economics, \\ Moscú, Rusia \\ Recibido: I6 de abril de 2018 \\ Fecha de publicación: 25 de septiembre de 2018 \\ DOI: IO.22455/2500-4247-20I8-3-3-94-IO3
}

Resumen: El artículo examina dos publicaciones de la poesía que han aparecido en las páginas de la revista literaria de los años veinte Prisma (Barcelona). En el primero de los casos se trata del poemario de un desconocido poeta chino ofrecido en español, mientras que en el segundo, de los versos notablemente influenciados por la poesía oriental de una joven y asimismo desconocida autora francesa. La investigación realizada permite aclarar que en realidad son mistificaciones literarias: el literato chino T'Zin-Pa-O no ha existido nunca, y todavía nos queda por descubrir el nombre del poeta que se esconde detrás del pseudónimo de Gisèle de Lorient. Ambos casos están condicionados por la transformación del motivo del misterio chino, muy persistente en la sociedad española, tal como se puede comprobar en las publicaciones españolas informativas de los finales del siglo XIX y principios del siglo XX que contribuían con sus interpretaciones a esa visión del Imperio Celeste. La imagen de la China misteriosa llevó hacia la mistificación literaria: la estilización modernista realizada con mucho esmero seguía jugando con el desconocimiento de China y generó a su vez nuevos misterios.

Palabras clave: España, China, poesía modernista, mistificación literaria.

Información del autor: Natalia Kharitonova, Doctora en Filología Hispánica, investigadora en el Departamento de Literaturas Contemporáneas de Europa y América del Instituto de Literatura Mundial A.M. Gorky de la Academia de Ciencias Rusa, c/ Povarskaya, 25 a, I21069 Moscú, Rusia.

E-mail: barrocorggu@mail.ru

For citation: Kharitonova N. El misterio Chino y mistificación literaria: poemas enigmáticos en la revista «Prisma». Studia Litterarum, 2018, vol. 3, no 3, pp. 94-I03. (In Spanish) DOI: I0.22455/2500-4247-2018-3-3-94-I03 


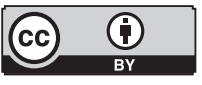

This is an open access article distributed under the Creative Commons Attribution 4.0 International (CC BY 4.0)

\section{MYSTERIOUS CHINA AS A SOURCE} FOR LITERARY HOAXES: POETRY IN THE SPANISH LITERARY MAGAZINE PRISMA

(C) 20I8. N.Yu. Kharitonova

A.M. Gorky Institute of World Literature

of the Russian Academy of Sciences, Moscow, Russia

Received: April I6, 2018

Date of publication: September 25, 2018

Abstract: The essay examines two blocks of poetry published in the pages of a Spanish literary magazine Prisma that came out in Barcelona in the I920s: one of them presents translations of the poetry by anonymous Chinese author; another one is formed by the poems belonging to the pen of aspiring French female poet with distinctive Oriental motifs. Both are literary hoaxes because the poet T'Zin-Pa-O never existed and the identity of Gisèle de Lorient has never been revealed. Both are the result of the mysterious China motif and its circulation in Spain. Spanish periodical press cultivated a peculiar image of Celestial Empire. The image of mysterious China led to literary hoaxing: elaborate modernist stylization appropriated of the general about China and invented new mysteries.

Keywords: Spain, China, modernist poetry, literary hoaxes.

Information about the author: Natalia Yu. Kharitonova, $\mathrm{PhD}$ in Hispanic Studies, Senior Researcher, A.M. Gorky Institute of World Literature of the Russian Academy of Sciences, Povarskaya 25 a, I2IO69 Moscow, Russia.

E-mail: barrocorggu@mail.ru

For citation: Kharitonova N.Yu. Mysterious China as a Source for Literary Hoaxes: Poetry in the Spanish Literary Magazine Prisma. Studia Litterarum, 2018, vol. 3, no 3, pp. 94-IO3. (In Spanish) DOI: I0.22455/2500-4247-20I8-3-3-94-IO3 
УДК 82I.I34.2.0

ББК 83.3(4Исп)

\section{ТАИНСТВЕННЫЙ КИТАЙ КАК ИСТОЧНИК ЛИТЕРАТУРНЫХ МИСТИФИКАЦИЙ: ПОЭЗИЯ В ИСПАНСКОМ ЛИТЕРАТУРНОМ ЖУРНАЛЕ «ПРИЗМА»}

\author{
(C) 2018 г. Н.Ю. Харитонова \\ Институт мировой литературы \\ им. А.М. Горького \\ Российской академии наук, Москва, Россия \\ Национальный исследовательский университет \\ Высшая школа экономики, \\ Москва, Россия \\ Дата поступления статьи: I6 апреля 2018 г. \\ Дата публикации: 25 сентября 2018 г.
}

DOI: IO.22455/2500-4247-2018-3-3-94-IO3

Аннотация: В статье рассматриваются две подборки поэзии, опубликованные на страницах испанского литературного журнала «Призма», выходившего в Барселоне в двадцатые годы XX в.: одна из них представляет собой публикацию переводов стихов неизвестного китайского автора, а вторая - сочинения начинающей французской поэтессы, в которых отчетливо звучат восточные мотивы. Речь идет о литературной мистификации, потому что поэта ЦыньБао никогда не существовало, точно так же как неизвестно, кто скрывается за псевдонимом Жизель Лорьен. Оба случая обусловлены трансформацией мотива таинственного Китая, устойчивого в испанском обществе, о чем свидетельствует даже испанская периодическая печать, культивировавшая этот образ Поднебесной. Образ таинственного Китая вел к литературной мистификации: искусная модернистская стилизация продолжала играть с незнанием Китая и порождала новые тайны.

Ключевые слова: Испания, Китай, поэзия модернизма, литературная мистификация.

Информация об авторе: Наталия Юрьевна Харитонова - doctora en Filología Hispánica, старший научный сотрудник, Институт мировой литературы им. А.М. Горького Российской академии наук, ул. Поварская, д. 25 а, І2Іо69 г. Москва, Россия.

E-mail: barrocorggu@mail.ru

Для цитирования: Харитонова Н.Ю. El misterio Chino y mistificación literaria: poemas enigmáticos en la revista «Prisma»// Studia Litterarum. 2018. T. 3, № 3. C. 94-I03. DOI: I0.22455/2500-4247-20I8-3-3-94-I03 
Para muchos investigadores el Oriente en la literatura española se asocia con el mundo árabe y, especialmente, con Magreb [véase Io; I2]. La proximidad geográfica y muchos siglos de la historia que compartieron la península Ibérica y África del Norte pusieron los cimientos para que el Oriente estuviera vinculado en España a un Oriente árabe. No obstante, a finales del siglo XIX la idea del Oriente se enriquece con un nuevo espacio geográfico e imaginario que es China. La visión española de China es especialmente interesante: por un lado, no ha merecido muchos estudios hasta ahora, y por otro, porque vuelve a confirmar que el conocimiento directo de un espacio geográfico no es necesario para realizar su representación cultural y literaria [I5, p. I6]. Dicho condicionamiento es capaz de provocar unas consecuencias absolutamente sorprendentes en el campo de las traducciones, lo que se comprobará a continuación en este artículo que tiene como objetivo analizar dos casos de la poesía china traducida al español y de los motivos chinos en los poemas publicados en las páginas de las revistas españolas de la Edad de Plata.

En general, a lo largo de varios siglos las noticias sobre China solían llegar a España a través de las traducciones. Siwen Ning en su reciente tesis estudió la historia de los textos en español dedicados a China [I6, p. 53-69]. Y eso que en la región asiática hasta I898 España poseía su colonia que era Filipinas, y ahí como resultado de los flujos migratorios incluso se había formado una comunidad china. El lugar privilegiado en las obras españolas dedicadas a China lo ocupan libros escritos por misioneros católicos, en especial dominicanos, agustinos o jesuitas. En la mayoría de los casos, en el siglo XIX las traducciones se realizaban con el fin de que los misioneros pudieran obtener todo tipo de conocimientos prácticos sobre el país cuya población iban a cristianizar. Por eso muchas veces al español se traducían tratados filosóficos y estudios históricos. A partir de la 
segunda mitad del siglo XIX empezaron a publicarse algunos libros de viaje de los viajeros españoles a China, por ejemplo, el libro de Raymundo Lozano y Megía titulado Viage a China con algunas observaciones útiles y provechosas para los que vayan aquel imperio publicado en I879, o unas novelas de inspiración verniana de Enrique Gaspar, El Anacronópete. Viaje a China. Metempsicosis (1887). A esos libros hay que sumar relatos de los diplomáticos españoles que estuvieron en China y luego compartieron su experiencia china con el público lector, como Adolfo de Mentaberry con sus Impresiones de un viaje a la China (I870), o Eduardo Toda, con su extensa narración La vida en el Celeste Imperio (1887).

En la vecina Francia la tradición de estudios chinos contaba con un historial mucho más prolongado. Al igual que en el caso de los jesuitas españoles, en China también funcionaban misiones de jesuitas francesas, y noticias sobre China que publicaban los frailes, se leían y se divulgaban en la literatura laica de los siglos XVII y XVIII por Pierre Bayle, François Fénelon, y luego Voltaire y Montesquieu. Todavía en I8I4 en el Collège de France fue fundado el departamento de estudios chinos, el primero de Europa [4, p. I44]. Precisamente en francés se publicaron varias antologías de la poesía china que a continuación se tradujeron a otras lenguas extranjeras, entre ellas, a español.

La investigadora Lucie Bernier que había estudiado la imagen de China en las literaturas francesa y alemana, señala que tras el Siglo de las Luces que privilegió China en sus narraciones, el interés hacia temas chinos experimentó un ocaso, no obstante, en la segunda mitad del siglo XIX, Théophile Gautier reactualizó la literatura china al descubrir el universo poético de la tradición oriental que señalaba entonces nuevos caminos para la renovación de la escritura occidental [I, p. 72-73]. En I866, en la primera entrega de la revista La Parnasse contemporain fue publicado el soneto de Gautier “La Marguerite” inspirado por la poesía del poeta clásico chino Li-Tai-Pe.

Uno de los rasgos más destacados del Modernismo hispano que sin duda alguna aprendió muchas lecciones del parnasianismo francés, fue el exotismo. En España el exotismo se manifestó prácticamente en todo tipo de artes: en la literatura, arquitectura y pintura. El arte chino se convirtió en una de las fuentes del exotismo al contestar a la idea de la belleza modernista [20, p. 6]. Es bien conocida la afición a los objetos chinos con los que se decoraban los interiores, y los museos españoles conservan muchas muestras de aquella moda finisecular. Aparte de esa manifestación puramente decorativa, el exotismo oriental, según la estudiosa Lily Litvak, ayudaba restablecer el vínculo con lo sobrenatural, “y de 
volver a calar en los estratos más secretos del alma humana” [II, p. I8]. El exotismo cultivó lo irracional, negó la historia, restituyó en sus derechos los mitos y las leyendas. En este sentido China fue un país que correspondía perfectamente bien a esos deseos. China se asociaba con la tradición de fumar el opio, se veía como un país de las antiguas tradiciones, mitos, creencias y cultos, de un estilo de vida peculiar y tradicional, muy diferente del estilo de vida europeo u occidental.

El interés en China que marcó la segunda mitad del siglo XIX, se inscribía en un contexto histórico de la penetración de las potencias occidentales en China que siguieron la Segunda Guerra del Opio. España no participó en las campañas militares, no obstante, en la prensa española con suficiente regularidad se publicaban noticias sobre la cuestión de China. La fuente principal de la información fueron publicaciones francesas y británicas, y junto a las noticias extraídas de los medios extranjeros, a la sociedad española se importaba la mirada orientalista hacia China. Por ejemplo, lo muestra uno de los ensayos políticos en Revista contemporánea (I878) cuyo autor subrayaba el beneficio de la intervención europea en la vida china que hasta entonces existía casi en el más absoluto aislamiento: «Japón y la China, esos dos potentes imperios de Asia que negaban a la civilización hasta el derecho de mejorar su suerte, que querían impedir el acceso a sus costas y cerrar a los europeos el curso de sus vías fluviales y terrestres. Los europeos han conquistado por la fuerza esos imperios para la civilización...» [5, p. 492].

En el ensayismo europeo y la literatura popular a finales de sigo XIX y principios del siglo XX se consolidaron dos tipos de la imagen de China, y junto a la poetización modernista del Imperio Celeste había otra, muy distinta. Algunos de los acontecimientos que marcaron la transformación de la imagen poetizada de China fue la revolución de los bóxers (I898-I90I) y los avances militares del ejército japonés en los años I895 y I905. Es lo que obliga a los europeos a hablar del 'peligro amarillo'. Y en ese contexto aparecen obras que justifican la expansión e intervención europeas en China. Entre los argumentos que sostienen esa versión está el carácter nacional chino, porque los chinos supuestamente son perezosos, supersticiosos, y además, son bárbaros, fieras crueles [I, p. 76-8I]. Por eso la permanencia de las potencias occidentales es necesaria en China. Es Europa la que lleva a cabo su misión civilizadora en ese país. El tema principal en las noticias sobre la revolución de los bóxers, dicho de otro modo, de la rebelión en contra de los europeos y la civilización, fueron la violencia contra los cristianos que correspondía a la tradición de la imagen de lo exótico como de la barbarie. 
La prensa española de finales del siglo XIX y principios del siglo XX ya tenía la posibilidad de hacer referencia a unas fuentes de información más profesionales que antes, los temas chinos en la prensa política que tienen poco que ver con la literatura, nos encontramos muy a menudo con unas expresiones que limitan los hechos concretos a los que aluden las noticias. Además, estas expresiones suelen destruir el carácter fidedigno de la noticia y le confieren un matiz de incertidumbre. Por eso son tan típicas las frases "según rumores" [3, p. I] o "Ha corrido el rumor de haber fallecido el príncipe de la corona” [9, p. 66I]. Y aunque sea una exageración afirmar que este tipo de filtro tiene el uso exclusivo en los artículos sobre China, en el caso de ese país adquiere un significado especial. Los comentaristas españoles no ocultaban su perplejidad ante la ausencia de la información fiable sobre los acontecimientos en China: "Las noticias sobre lo que pasa en China continúan siendo contradictorias. <...> El tiempo se encargará de ir descifrando estos enigmas" [8, p. 438]. Pese a su tarea de informar al lector sobre la actualidad china, los diarios confirmaban la visión de China como un país poco accesible para un europeo, un país impregnado de misterio. Con sus materiales, la prensa escrita española cultivaba esta imagen de la China misteriosa.

Sin duda, tanto China como su literatura fueron muy poco conocidas en la España finisecular. La literatura china podía interpretarse en el contexto de la superioridad del Occidente sobre el Oriente al convertirse en el objeto de la práctica orientalista. Es lo que muestra un artículo de I900: "Si [se trata] de literatura, la suya es abundante en cantidad, por más que en calidad no tenga gran valor, vista con ojos occidentales" [9, p. 66r]. Es muy difícil decir en qué basaba su juicio el autor de esta sentencia. Y solo una cosa está clara: el autor considera la literatura china como un fenómeno inferior comparado con la literatura europea. En aquel momento en España de hecho faltaban conocimientos de la historia de la literatura china, al igual que las obras críticas necesarias para interpretar la poesía china. Sin embargo, un lector español ya disponía de algunas traducciones españolas.

Las obras traducidas ayudaban a transferir a España conocimientos sobre las letras chinas. A principios del siglo XX fue publicada la traducción española de una breve antología de la poesía china compuesta en I886 por el vice-cónsul francés en China Camille Imbault-Huart [7]. Las lecturas en español podrían complementarse con las traducciones de la literatura china al francés y al inglés.

El proceso de conocimiento de la poesía china también es posible interpretarlo a la luz del concepto de orientalismo. Las revistas literarias de la Edad de 
Plata ofrecen un ejemplo de la transformación del tema del misterio que acompaña la imagen de China y de un juego literario que nace de este tópico. La revista Prisma empezó a publicarse en Barcelona en 1922, y en su primera entrega su director Rafael Lozano anunció que "Prisma es una revista internacional de poesía. Aparece con el objeto de provocar un renacimiento en la poesía castellana. <...> Prisma (estará) dando a conocer en castellano todas las tendencias mundiales de la poesía...” [I4, p. 3]. Entre otros textos, en el primer número de la revista el editor ofreció una selección de la poesía china, junto a los poemas de una poeta francesa cuyos versos también tienen cierto deje oriental.

La selección de la poesía china pertenece al poeta chino T’Zin-Pa-O [I9, p. 53-54], y la nota biográfica que acompaña la publicación en la revista reza: “T’Zin-Pa-O es uno de los mejores poetas chinos de la antigüedad. Desgraciadamente, no se tienen noticias suyas. En las últimas fechas, sus poemas han sido publicados en francés por Sébastien Congre, quien encontró el manuscrito original en la valiosa biblioteca del monasterio de los padres Jesuitas de Zi-Ka-Wei (situado a siete kilómetros al Suroeste de Chang-Hai)" [6, p. 56].

Sin embargo, tengo unas dudas serias de que el nombre de T'Zin-Pa-O dice algo a los expertos en la literatura china. Y lo que pasa es que en realidad el erudito y paleógrafo francés Jean-Sébastien Congre, el supuesto autor del descubrimiento de los antiguos manuscritos en un monasterio jesuita nunca había existido. Es nombre de una marioneta, un personaje teatral que había creado el actor teatral León Chancerel [véase I5]. Y el libro de la poesía de T’Zin-Pa-O es una mistificación literaria [2]. La pregunta es, si el director de la revista Prisma lo sabía o no.

La publicación de las traducciones de la poesía de influencia oriental en la segunda entrega de la revista nos puede ofrecer una solución a esta pregunta [I3, p. 9I-93]. De nuevo a nuestra disposición se ofrece una nota biográfica de la que sabemos que "Gisèle de Lorient es, quizás, la más joven de las poetisas francesas. Casi desconocida en su país, esta joven escritora comienza con un raro dominio de su forma” [6, p. 55]. Vamos a fijarnos en su nombre, Gisèle de Lorient. Por supuesto, los catálogos de las bibliotecas no dan ningún resultado de la búsqueda de sus obras. Es decir, es un seudónimo, no ha existido tal poeta. ¿Quién se oculta detrás de este nombre? De momento, es un misterio, quizás se trate del propio Fernando Maristany, falso o verdadero traductor de los poemas de Gisèle. Y si leemos el nombre de la poeta en francés, además del pretendido significado "Gisèle de Lorient", donde Lorient es una ciudad en Bretaña, también podemos 
descifrarlo como “Gisèle de l'Orient”, es decir, Gisèle del Oriente. Y es una mistificación literaria más de la revista Prisma. Sin duda alguna, es muy interesante este caso del juego literario relacionado con la poesía oriental y china. Y a juzgar por el manifiesto del director de la revista, con su objetivo de renovar la poesía española, los ejemplos de la poesía oriental y china podían sugerir vías del buscado renacimiento de la lírica española. El director de la revista perseguía una envergadura universal, mientras que en aquel entonces el conocimiento de la literatura china y, sobre todo, de la lengua china en España fue muy deficiente.

El autor español de la mistificación literaria ofrece elementos de la poética experimental como si de la poesía china tradicional se tratase. Por un lado, cuenta con un amplio repertorio de los elementos que están destinados a corresponder el sabor oriental a los poemas, es decir, es el verso libre, fragmentariedad, una sintaxis poco habitual. Pero es también la tradición del orientalismo, el imaginario oriental, que se traduce en una serie de tópicos como la caligrafía china, los inciensos orientales, y varios objetos decorativos como linternas, biombos o porcelanas chinas.

Sin embargo, este caso no se reduce tan sólo a la experimentación literaria. La mistificación nace en el terreno fecundo de la China misteriosa. Nadie puede desmentir a los mistificadores, porque la diferencia más profunda de la poesía china y sus imitaciones no radica en los elementos exóticos superficiales, sino en un sistema filosófico oriental y en otra mirada hacia el mundo que tiene muy poco que ver con la europea. No obstante, ¿quién poseía entonces esa sabiduría china? Casi nadie. No la poseen tampoco los mistificadores que reproducen la Otredad como un código orientalista que es bien conocido y es reconocible para todos los europeos de aquella época.

Según Edward Said, un escritor occidental podía dar forma y significado al gran misterio asiático [I8, p. 44]. El literato español construye una réplica del misterio chino y del exotismo de su poesía. El misterio conduce a la mistificación. Es un juego occidental en la poesía china que de momento tiene muy poco que ver con el verdadero conocimiento de Oriente.

Para intentar conocer China, era necesaria otra postura, otro punto de partida. Hacía falta comprender que hay una serie de conocimientos que los intelectuales occidentales han de adquirir. Los autores españoles ven el arte chino como un elemento de su estética, desean llevar la China exótica a la órbita de su cosmopolitismo. Tratan de apropiarse de China en un impulso de auto-identificación. Su arte y su creación también tenían que poseer un aura del estetismo y del misterio. Lo oriental estaba destinado a acentuar su excepcionalidad, su posesión 
de unos conocimientos raros y no accesibles para la mayoría.

\section{Referencias / References}

I Bernier L. La Chine littérarisée. Bern, Peter Lang, 200I. I8I p. (In French)

2 Chancerel L. Les Poèmes de T'sin Pao, traduits du chinois par M. Sébastien Congre, archiviste-paléographe. Illus. René Gabriel. Paris, Renaissance du Livre, I920. I04 p. (In French)

3 Correo extranjero. Francia. La Dinastia, I898, no 6406, January I, p. I. (In Spanish)

4 Detrie M. "Le myth de l'altérité chinoise et ses effets pervers sur le comparativisme français.” Orientalisme et Comparativisme. Eds. Yves Clavaron and Zoe Schweitzer. Paris, Publications de l’Univerisité de Saint-Étienne, 20I4, pp. I33-I44. (In French) F. Crónica de la quincena. Revista contemporánea, I878, no I5, May 30, pp. 487-500. (In Spanish)

6 Glosa. Prisma, I922, no I, vol. I, pp. 55-56. (In Spanish)

7 Imbault-Huart C. Antología de poetas chinos: siglos XIV al XX, con notas literarias, filológicas e históricas. Trans. Pedro Guirao. Vitoria, Ediciones Estudio, n.d. 69 p. (In Spanish)

8 La cuestión de China. Revista general internacional, I900, no 62, July 30, pp. 436-439. (In Spanish)

9 La cuestión de China. Revista general internacional, I900, no 76, November I5, pp. 66I-662. (In Spanish)

Litvak L. El jardín de aláh: temas del exotismo musulmán en España. Granada, Don Quijote, I985. I73 p. (In Spanish)

II Litvak L. El sendero del Tigre. Madrid, Taurus, I986. 293 p. (In Spanish)

I2 López-Calvo I., ed. One World Periphery Reads the Other: Knowing the 'Oriental' in the Americas and the Iberian Peninsula. Newcastle, Cambridge Scholars, 20I0. 405 p. (In English)

I3 Lorient G. de. Poemas. Prisma, I922, no 2, vol. 2, pp. 9I-93. (In Spanish)

I4 Lozano R. Propósito. Prisma, I922, no I, vol. I, p. 3. (In Spanish)

I5 Miquel A. and Léonor D. "Marionnettes et figurines du Fonds Léon Chancerel." Société d'histoire du théâtre: Available at: <http://sht.asso.fr/exposition-virtuelle/marionnettes-et-figurines-du-fonds-leon-chancerel/>. (Accessed Io April 20I8) (In French)

I6 Nagy-Zekmi S., ed. Moros en la costa. Orientalismo en Latinoamérica. Madrid, Iberoamericana Vervuert, 2008. 237 p. (In Spanish)

I7 Ning S. De la China legendaria al declive del Celeste Imperio: La representación de China y su imagen literaria en la España del siglo XIX. Diss. Universidad Autónoma de Barcelona, 20I5. 598 p. (In Spanish)

I8 Said E.W. Orientalism. New York, Pantheon Books, I978. 368 p. (In English)

I9 T'Zin-Pa-O. Poemas. Prisma, I922, no I, vol. I, pp. 53-54 (In Spanish)

20 Tinajero A. Orientalismo en el modernismo hispanoamericano. West Lafayette, Purdue UP, 2004. I73 p. (In Spanish) 
УДК 82I.II2.2.0

ББК $85 \cdot 373(4$ Гем $) 6$
ДЕТИ-МУЧЕНИКИ В ПАНТЕОНЕ ТОТАЛИТАРНОЙ КУЛЬТУРЫ (СЦЕНАРИЙ ФИЛЬМА «ЮНЫЙ ГИТЛЕРОВЕЦ КВЕКС» Х. ШТАЙНХОФА)

(C) 2018 г. А.В. Елисеева Балтийский государственный технический университет «Военмех», Санкт-Петербург, Россия Дата поступления статьи: 3г июля 2017 г. Дата публикации: 25 сентября 2018 г.

DOI: IO.22455/2500-4247-2018-3-3-IO4-II5

Аннотация: Основным предметом анализа является созданный К.А. Шенцингером и Б.Э. Лютге сценарий фильма «Юный гитлеровец Квекс» (“Hitlerjunge Quex”, I933) режиссера Ханса Штайнхоффа, относящегося к пропагандистскому кинематографу национал-социализма. На примере сценария этого фильма рассмотрены стратегии инструментализации фигуры ребенка в идеологических целях. Проведены параллели с советским искусством, в частности с кинематографом, в котором также присутствуют подобные модели пропаганды, например, культ пионеров-героев. Нарратив о подвиге и гибели юного нациста обнаруживает особенно много общего с популярной в советское время историей Павлика Морозова. В статье рассмотрены идеологемы, объединяющие конструкты «героического ребенка» в обеих тоталитарных культурах: миф о непредвзятости и «чистоте» детского восприятия мира, представление о приоритете той или иной концепции общественного блага над семейными взаимосвязями и др. Речь идет об истоках подобных идеологем, их связи с христианскими, просветительскими и прочими мировоззренческими системами.

Ключевые слова: немецкий кинематограф национал-социализма, фигура ребенка в культуре, идеология и кино, пропаганда в кинематографе, культура и политика, пионеры-герои.

Информация об авторе: Александра Владимировна Елисеева - кандидат филологических наук, доцент, Балтийский государственный технический университет «Военмех» им. Д.Ф. Устинова, ул. І-я Красноармейская, д. I, I90005 г. Санкт-Петербург, Россия.

E-mail: elisseeva_alexan@mail.ru

Для цитирования: Елисеева А.В. Дети-мученики в пантеоне тоталитарной культуры (фильм «Юный гитлеровец Квекс»» Х. Штайнхофа) // Studia Litterarum. 2018. T. 3, № 3. C. IO4-II5. DOI: IO.22455/2500-4247-20I8-3-3-IO4-II5 


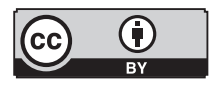

This is an open access article distributed under the Creative Commons Attribution 4.0 International (CC BY 4.0)

\section{CHILD MARTYRS IN THE PANTHEON OF TOTALITARIAN CULTURES (H.STEINHOFF'S FILM HITLERJUNGE QUEX)}

\author{
(C) 2018. A.V. Eliseeva \\ D.F. Ustinov Baltic State \\ Technical University "Voenmeh", \\ St. Petersburg, Russia \\ Received: July 3I, 2017 \\ Date of publication: September 25, 2018
}

\begin{abstract}
The article focuses on the film script for Hitlerjunge Quex (1933, director Hans Steinhoff) written by B.E. Lüthge and K.A. Schenzinger. This film is an example of the national socialist propaganda cinematograph at work. The case study discusses the strategies of the child figure instrumentalization for ideological purposes. It draws parallels between the Nazi art and the Soviet art, cinema in particular where similar propaganda models are present, such as the cult of heroic pioneers. The narrative about the heroic deed and martyrdom of the young Nazi has much in common the story about Pavlik Morozov, popular in the Soviet time. The paper deals with ideologemes that unite the "child heroes" constructs in both totalitarian cultures: the myth about the impartiality and "innocence" of the child's worldview, acclaimed superiority of the public welfare over family relations and others. It also studies the sources of such ideologemes, their connection with Christian, Enlightenment and other belief systems.

Keywords: German national socialist cinema, child figure in culture, ideology and cinema, propaganda in the cinema, culture and politics, heroic pioneers

Information about the author: Aleksandra V. Eliseeva, $\mathrm{PhD}$ in Philology, Associate Professor, D.F. Ustinov Baltic State Technical University “Voenmeh”, I $^{\text {st }}$ Krasnoarmeyskaya I, I90005 St. Petersburg, Russia.

E-mail: elisseeva_alexan@mail.ru

For citation: Eliseeva A.V. Child Martyrs in the Pantheon of Totalitarian Cultures (H. Steinhoff's film Hitlerjunge Quex). Studia Litterarum, 2018, vol. 3, no 3, pp. IO4-II5. (In Russ.) DOI: I0.22455/2500-4247-20I8-3-3-IO4-II5
\end{abstract}


Только в последнее время в отечественной германистике снимается негласное табу на исследование культуры так называемого Третьего рейха, особенно той, которая была официально принята и поощрялась нацистскими идеологами. Появились работы с несравненно более дифференцированным подходом к явлениям искусства нацистской Германии, нежели на предыдущем этапе развития науки, рассматриваются различные тенденции этой культуры, их истоки и т. п. [3]. Обращение к этому, ранее часто закрытому для изучения материалу представляется чрезвычайно плодотворным во многих аспектах; так, не может не представлять интереса сходство двух тоталитарных систем - нацистской и советской, которые для многих ученых еще неразрывно связаны с личным опытом. Существование в сегодняшнем мире тоталитарных режимов, постоянная угроза их установления делают чрезвычайно актуальной проблему изучения общности и различия данных систем, в том числе проблему исследования манипулятивных стратегий, реализующихся в искусстве. Занимаясь тоталитарными системами, трудно обойти вниманием кинематограф, ведь идеологи тоталитарных режимов, не упуская из виду ни один из видов искусства, огромное внимание уделяют кино как феномену, охватывающему значительные массы публики. Так, пожалуй, всем известна фраза Ленина: «Вы должны твердо помнить, что из всех искусств для нас важнейшим является кино» [5, с. 579].

В статье пойдет речь о сценарии фильма «Юный гитлеровец Квекс» («Hitlerjunge Quex») режиссера Ханса Штайнхофа (Hans Steinhoff, I882I945), премьера которого состоялась II сентября г933 г., т. е. в год прихода к власти НСРПГ. В центре исследования находятся линии пересечения 
между произведениями искусства двух тоталитарных систем - нацистской и советской.

В основу фильма «Юный гитлеровец Квекс» лег сюжет одноименного романа Карла Алоиса Шенцингера (Karl Aloys Schenzinger, I886I962), вдохновленного в свою очередь судьбой Герберта Норкуса (Herbert Norkus, I9I6-I932), погибшего в шестнадцатилетнем возрасте от рук коммунистов. К.А. Шенцингер выступил также как сценарист экранизации собственного романа в соавторстве с Бобби Э. Лютге (настоящее имя Роберт Эрвин Лютге (Robert Erwin Lüthge), I89I-I964). В дальнейшем речь пойдет о сценарии данного фильма, а именно заданной им нарративной структуре. Жанр киносценария, специфика его законов только относительно недавно стали предметом литературоведческого анализа [II; I2]. Следует отметить, что такие аспекты, как соотношение сценария и других структурных элементов фильма (визуального ряда, перспективы, величины кадра, музыки и пр.), почти не рассматриваются в данной статье либо упомянуты в связи с анализируемой проблематикой. Также за рамками статьи остается сопоставительный анализ романа и сценария, написанного на его основе (сценарий К.А. Шенцингера и Б.Э. Лютге не выходил отдельной публикацией). Методологически данное исследование исходит из общности нарративных структур в литературном произведении и в фильме, на которую указывает С. Чэтман [8], и соответственно присутствующих в кинематографическом сценарии как в своего рода «промежуточном» жанре. В дальнейшем речь пойдет в основном о таких элементах сценария, которые, по Чэтману, являются и «литературными», и «кинематографическими»: констелляции персонажей, сюжете, мотивах, времени, пространстве.

Фильм «Юный гитлеровец Квекс» получил безоговорочное одобрение руководства страны и был снабжен предикатом «особо ценный в художественном отношении». Его часто относят к разряду юношеских, поскольку многие его персонажи являются подростками и произведение во многом апеллирует к юношеской аудитории, предлагая ей идентификационные модели, идеалы и ценности, и прежде всего прославляет гитлерюгенд с его культом товарищества, строгими нравами, дисциплиной и т. п. Недаром подзаголовком «Юного гитлеровца» являются слова «Фильм о жертвенном духе немецкой молодежи» (“Ein Film vom Opfergeist 
der deutschen Jugend”). В фильме Штайнхофа впервые прозвучала песня на слова руководителя гитлерюгенда Бальдура фон Шираха «Вперед, вперед» (“Vorwärts, vorwärts”), ставшая впоследствии маршем юных гитлеровцев. При этом фильм невозможно причислить исключительно к категории юношеского кино, поскольку он отнюдь не исключает и взрослого адресата с его поисками выхода в сложной политической и экономической ситуации. Стоит отметить, что понятие детского и юношеского кино столь же расплывчато, как и понятие детской литературы: «...единой формулы $<\ldots>$, которая могла бы служить для определения кино для детей и устраивала бы всех, до сих пор нет» [I, с. II5].

Несомненным является пропагандистский характер фильма «Юный гитлеровец Квекс», Вернер Фаульштих называет его «одним из первых явно пропагандистских фильмов» нацистской Германии [9, S. 96] при том, что большую часть кинопродукции в то время составляли развлекательные фильмы, выполнявшие компенсаторную функцию, так из примерно г2оо фильмов, снятых в Германии с г933 по І945 гг., только І50-I80 «имели откровенно пропагандистский характер» [2, с. 7]. Заслуживает внимания тот факт, что юношеская проблематика сочетается в фильме о юном гитлеровце с относительно нечастой в кинематографе того времени пропагандистской направленностью, это позволяет предположить, что именно подростковая аудитория рассматривалась создателями фильма, в том числе его сценаристами, как благодарная целевая группа для идеологической обработки.

Действие сценария происходит незадолго до прихода Гитлера к власти, когда бедственное экономическое положение в стране доводит людей до отчаяния, фильм начинается с того, что голодная толпа громит магазин. Друг с другом сражаются политические силы: с одной стороны, коммунисты и социал-демократы, между которыми создатели фильма «Юный гитлеровец Квекс» в целях пропагандистского упрощения различия не делают, с другой стороны, сторонники Гитлера. Главный герой, ученик типографии Хайни Фёлкер, получивший впоследствии за свою прыткость и ловкость прозвище «Квекс» (от нем. Quecksilber - ртуть), происходит из бедной семьи - у него безработный отец и тяжелым трудом зарабатывающая пропитание для семьи мать. Близкий к коммунистам отец героя представлен при этом малосимпатичной фигурой, он тиранит несчаст- 
ную, забитую мать Хайни, отнимает у нее последние деньги, чтобы потратить их в пивной. Когда один из друзей отца приглашает мальчика на загородный сбор коммунистической молодежи, мероприятие вызывает инстинктивное отторжение главного героя - коммунистически настроенные молодые люди и девушки курят, пьют алкогольные напитки, в их среде царят свободные сексуальные отношения. Музыка, сопровождающая коммунистические мероприятия в фильме, - это «Интернационал» и джаз. Чувствуя себя неуютно в таком окружении, подросток уходит из лагеря коммунистической молодежи и случайно становится свидетелем сбора юных гитлеровцев, который показан на экране как противоположность мероприятию, оттолкнувшему Хайни, - в отличие от юных коммунистов, гитлеровцы предстают как опрятные, дисциплинированные, дружелюбные подростки, чинно и организованно проводящие время на лоне природы. С первого взгляда главный герой фильма оказывается очарованным организацией гитлерюгенда, а вступление в его ряды становится заветной мечтой мальчика, которой после ряда испытаний суждено сбыться. Юный гитлеровец участвует в различных акциях нацистов, используя информацию о замыслах коммунистов, которую получает из окружения отца. Коммунисты жестоко мстят подростку за предательство - фильм заканчивается убийством Хайни Фёлькера, в финале зритель видит его мертвое тело, лежащее на улице, этот кадр сменяется показом массового шествия под флагами со свастикой, убеждающего в победе нацизма.

Путь Хайни Фёлькера в гитлерюгенд, представленный в сценарии фильма, напоминает сюжет некоторых других произведений нацистской литературы, например, романа Георга Ламе «Путь к Гитлеру» (I933), где герой, потерявший работу, сначала попадает к коммунистам, но, разочаровавшись в их моральном облике (характерно, что, как и в фильме Х. Штайнхофа, коммунисты представлены гедонистами, лишенными моральных устоев, на их собраниях тоже присутствуют женщины легкого поведения, а участники танцуют танго) персонаж приходит к национал-социалистам, в организацию аскетических мужчин, где и находит свое место [4, c. 139].

При этом одна из манипулятивных стратегий фильма Штайнхофа состоит в активации распространенного литературного приема - вве- 
дения детской перспективы как непредвзятого взгляда на мир с целью остранения и критики тех или иных явлений. Об этой функции детской перспективы в литературе пишет, например, Моника Шпильманн [іо, S. 65, 22I]. Исследовательница также отмечает, что выбор детской перспективы иногда способствует лучшей рецепции книги у юных читателей, которые могут идентифицировать себя с героем [Iо, S. 59]. Детское сознание, не испорченное предрассудками, условностями, более непосредственно воспринимающее мир, используется во многих произведениях мировой литературы Нового времени, а впоследствии и кино, для раскрытия скрытых сторон жизни, критики лжи и т. п. К этому приему обращается и сценарий фильма «Юный гитлеровец Квекс», используя перспективу ребенка для пропаганды нацистской идеологии. Характерно, что в сценарии отсутствуют иные аргументы в пользу превосходства нацистских ценностей, кроме симпатии к ним подростка. Рациональных причин выбора нацизма как мировоззрения, его превосходства над идеями коммунистов текст не содержит. Тем самым потенциальному зрителю предложен путь некоей инфантилизации сознания - не сопоставление политических и экономических программ партий должно побудить его сделать выбор и принять решение, а исключительно эмоциональные импульсы, симпатии и антипатии. Стоит упомянуть, что аналогичные стратегии применял и советский кинематограф - в таких фильмах, как «Ванька - юный пионер» (режиссер П. Малахов, г924), «Как Петюнька ездил к Ильичу» (режиссер М. Доронин, г924), «Мишка Звонов» (режиссер П. Малахов, І925) и других, также представлен детский, «чистый, незамутненный взгляд» на события, легитимизирующий для зрителя советские ценности и культы.

Другим элементом, роднящим пропагандистские фильмы и книги советской культуры с «Юным гитлеровцем», является, несомненно, активация христианского культа мучеников. Хайни Фёлькер погибает за свои убеждения от рук беспощадных врагов, подобно тому как в Советской стране многочисленные пионеры-герои становились жертвами кулаков, белогвардейцев, фашистов и т. п. Пантеон пионеров-героев, предлагавшийся для почитания в каждой советской школе, заменил собой сонмы христианских мучеников, почитающихся православной (и католической) Церковью. Следует отметить, что среди христианских мучеников есть 
немало детей и подростков. Проблема агиографичности в биографиях героических пионеров уже не раз привлекала к себе внимание исследователей, став, например, предметом интересной диссертации С.Г. Леонтьевой «Литература пионерской организации: идеология и поэтика» [7]. $\mathrm{X}$. Гюнтер также пишет о популярности в соцреализме героя-жертвы, об использовании для жизнеописаний героев такого претекста, как житие святого мученика. Сходные наблюдения содержат и другие, ставшие уже каноническими, исследования советской культуры - Катарины Кларк, Евгения Добренко и т. д. Жертвенную смерть приветствовала и нацистская культура - нацистский кинематограф воспел не только безвременную гибель Хайни Фёлькера, но и обращался к другим мученикам за идею - в частности, к фигуре Хорста Весселя (1907-1930), предположительно убитого коммунистами и прославленного в романе Х.Х. Эверса, по которому впоследствии был снят фильм «Ханс Вестмар - один из многих» (“Hans Westmar - Einer von vielen”, режиссер Ф. Венцлер, І933).

В сценарной истории гитлеровца Квекса во многом просматривается парадигма жития христианского мученика - такие этапы, как принятие правильного учения, следование ему до самой смерти, нравственные черты персонажа - благонравие, серьезность, преданность, устойчивость к соблазнам, прежде всего плотским, которыми манит подростка коммунистическая среда (девушки «легкого поведения», спиртные напитки и т. п.), и, наконец, смерть от рук врагов правого дела. Можно отметить, что сцена в финале фильма, когда юные соратники приподнимают мертвое тело Хайни, обнаруживает визуальные параллели с иконографией Пьеты.

Очевидно, что неоднозначным, даже с точки зрения приверженцев нацистских ценностей, может предстать отношение персонажа к отцу: став членом гитлерюгенда, Хайни превращается в идеологического врага своего родителя, срывая планы его друзей-коммунистов и вызывая их злость. Организация юных гитлеровцев заменяет семью для Хайни, рвущего отношения с чуждым ему отцом. Интересно, что мотив отречения от собственных родителей и принесения родственного долга в жертву служению правому делу является довольно распространенным и в житиях советских пионеров-героев. Пожалуй, самым известным примером такого отречения от родственников является поступок Павлика Морозова, кано- 
низированного советской пропагандой, вызвавший бурные дискуссии, в том числе затрагивающие этическую составляющую его поведения, в годы перестройки. При этом Павлик Морозов был отнюдь не одинок в пренебрежении своим сыновним долгом, так, по сохранившимся документам, в I934 г. поездкой в Артек были награждены Оля Балыкина, «пионерка Татарии, разоблачившая своего отца и вместе с ним группу воров колхозного хлеба», Проня Колыбин, «пионер Северного края, разоблачивший свою мать, воровавшую колхозный хлеб», Любцев Митя, «разоблачивший своего отца конюха...» [6, с. го3].

Любопытно, что действия коммунистических и нацистских детей-героев, вызывающие нередко моральное негодование у адептов других культурных систем, на самом деле опять же восходят к христианскому претексту: «Если кто приходит ко Мне и не возненавидит отца своего и матери, и жены и детей, и братьев и сестер, а притом и самой жизни своей, тот не может быть Моим учеником», - говорит Христос (Лк. I4: 26). При всем многообразии возможных интерпретаций этого евангельского изречения одним из прочтений вполне может быть и то, которое реализовали нацистские и коммунистические герои, - отвержение родственников во имя дела, представлявшегося им правым.

Обнаруженные христианские элементы в сценарии фильма «Юный гитлеровец Квекс» соответствуют выводам, к которым пришел немецкий исследователь Хельмут Кизель, рассмотрев религиозные мотивы национал-социалистической и коммунистической литературы. Многочисленные христианские мотивы, метафоры, идеи характерны как для произведений так называемого соцреализма, так и для национал-социалистических опусов. Х. Кизель объясняет данный феномен двумя причинами: оба движения, будучи антирелигиозными и стремясь опровергнуть христианское мировоззрение, не могли не обращаться к его компонентам, что часто происходит, когда воинственно отвергают некую систему ценностей. Вторая причина заключается, по Х. Кизелю, в укорененности религиозных представлений в сознании и неспособности коммунистических и нацистских идеологов быстро найти им замену [4, с. I50-I5I].

Таким образом, сценарий фильма «Юный гитлеровец Квекс», с одной стороны, содержит немало элементов, роднящих его с произведениями советской культуры - прежде всего, использование детской перспек- 
тивы для легитимизации тех или иных ценностей, идеализации носителей определенной идеологии и т. д. В то же время культурные феномены, возникшие при обоих тоталитарных режимах, обнаруживают поразительную близость к христианской литературе, в том числе воспроизводя агиографические модели, прославляющие подвиг мученичества и провозглашая добродетелью отречение от родственных связей во имя ценностей, постулируемых как истинные. 


\section{Список литературы}

I Бим-Бад Б.М. Педагогический энциклопедический словарь. М.: Большая российская энциклопедия, 2002. 528 с.

2 Васильченко А.В. Прожектор доктора Геббельса. Кинематограф Третьего рейха. М.: Вече, 20іо. 320 с.

3 Зачевский Е.А. Очерки истории литературы времён Третьего рейха. СПб.: Изд-во Политехнического ун-та, 2013. 526 с.

4 Кизель Х. Политические религии в немецкоязычной литературе XX века / пер. с нем. А. Елисеевой // Литература в контексте культуры. Межвузовский сборник / ред. А.Г. Березина. СПб.: Изд-во Санкт-Петербургского ун-та, І998. С. І38-І5I.

5 Ленин В.И. Полн. собр. соч. Изд-е 5. М.: Изд-во полит. лит., І970. Т. 44. 725 с.

6 Леонтьева С.Г. Жизнеописание пионера-героя: текстовая традиция и ритуальный контекст // Современная российская мифология / сост. М.В. Ахметова.

М.: Изд-во РГГУ, 2005. С. 89-г23.

7 Леонтьева С.Г. Литература пионерской организации: идеология и поэтика: автореф. дис. ... канд. филол. наук. Тверь, 2006. 24 с.

8 Chatman S. Story and Discourse. Narrative Structure in Fiction and Film Story and Discourse. Narrative Structure in Fiction and Film. Ithaca, NY, London: Cornell UP, I978. $277 \mathrm{p}$.

$9 \quad$ Faulstich W. Filmgeschichte. Paderborn: W. Fink, 2005. 348 S.

Io Spielmann M. Aus den Augen des Kindes. Die Kinderperspektive in deutschsprachigen Romanen seit I945. Innsbruck: Universität Innsbruck, 2002. 242 S.

II Sternberg C. Written for the screen. Das amerikanische Spielfilmdrehbuch als Text. Diss. Köln, I996. 233 S.

I2 Tieber $\mathrm{Cl}$. Drehbuchforschung zwischen Narratologie und Produktionsästhetik // MEDIENwissenschaft. H. 3/I5. 20I5. S. 3II-324. 


\section{References}

I Bim-Bad B.M. Pedagogicheskij enciklopedicheskij slovar' [Pedagogical Encyclopedia]. Moscow, Bolshaja rossijskaja enciclopedia Publ., 2002. 528 p. (In Russ.)

2 Vasil'chenko A.V. Prozhektor doktora Gebbelsa. Kinematograf Tretjego Reikha [Doctor Goebbels' spot lamp. The Third Reich Cinema]. Moscow, Veche Publ., 20Io. 320 p. (In Russ.)

3 Zachevskij E.A. Ocherki istoriji literatury vremjon Tretjego Reikha [Literature history sketches of the Third Reich time]. St. Petersburg, Izdatel'stvo politekhnicheskogo universiteta Publ., 20I3. 526 p. (In Russ.)

4 Kiesel H. Politicheskije religii v nemeckojazychnoi literature XX veka [Political religions in the German-language literature of the $20^{\text {th }}$ century], transl. from German by A. Eliseeva. Literatura $v$ kontekste kultury [Literature in the cultural context.], ed. A.G. Berezina. St. Petersburg, Izdatel'stvo Sankt-Peterburgskogo universiteta Publ., I998, pp. I38-I5I. (In Russ).

5 Lenin V.I. Polnoje sobranije sochinenij [Complete works]. Izdanije 5. Moscow, Izdatel'stvo politicheskoj literatury Publ., I970. Vol. 44. 725 p. (In Russ.)

6 Leont'eva S.G. Zhizneopisanije pionera-geroja: tekstovaja tradicija I ritualnyj kontekst [Hagiography of heroic pioneers: textual tradition and ritual contexts]. Sovremennaja rossijskaja mifologija [Contemporary Russian mythology], ed. M.V. Akhmetova. Moscow, Izdatel'stvo RGGU Publ., 2005, pp. 89-I23. (In Russ.)

7 Leont'eva S.G. Literatura pionerskoj organizacii: ideologija I poetika: avtoreferat dissertacii na soiskanie uchjonoj stepeni kandidata filologicheskikh nauk [Pioneer organization literature: ideology and poetics: PhD thesis]. Tver', 2006. 24 p.( In Russ.) Chatman S. Story and Discourse. Narrative Structure in Fiction and Film Story and Discourse. Narrative Structure in Fiction and Film. Ithaca, NY, London, Cornell UP, I978. 277 p. (In English)

9 Faulstich W. Filmgeschichte. Paderborn, W. Fink, 2005. 348 S. (In German)

Io Spielmann M. Aus den Augen des Kindes. Die Kinderperspektive in deutschsprachigen Romanen seit 1945. Innsbruck, Universität Innsbruck, 2002. 242 S. (In German) Sternberg C. Written for the screen. Das amerikanische Spielfilmdrehbuch als Text. Diss. Köln, I996. 233 S. (In German) Tieber Cl. Drehbuchforschung zwischen Narratologie und Produktionsästhetik. MEDIENwissenschaft. H. 3/I5. 2015. S. 3II-324. (In German) 
УДК 821.І6г.І

ББК $83.3(2 \mathrm{Poc}=\mathrm{Pyc}) 52$

\section{МИФ О БЕЛОВОДЬЕ, ОПОНЬСКОЕ ЦАРСТВО СТАРОВЕРОВ-БЕГУНОВ И ЗАГАДКА ВТОРОГО ТОМА ГОГОЛЯ}

DOI: IO.22455/2500-4247-20I8-3-3-II6-I43

Аннотация: В статье анализируется внутренняя связь, что существует между намерением Гоголя перенести продолжение действия своей поэмы в Сибирь и намечающейся во втором томе темой раскольников. Тема эта у Гоголя появляется не случайно: именно в г840-е гг. в отношении государства к старообрядцам начинаются репрессии, а их деятельность становится объектом расследования различных комиссий. В одной из таких комиссий состоял Иван Аксаков, особо заинтересовавшийся в ходе работы комиссии сектой странников, или бегунов. В миросозерцании этого крайне левого ответвления старообрядчества, с которым связывается легенда о Беловодье, была одна особенность, которая дает возможность по-иному взглянуть на сам инцидент с покупкой «мертвых душ». Странники объявляли воплощением Антихриста не столько царя и никонианскую церковь, сколько первые всеобщие ревизии податных душ. Здесь замысел гоголевской поэмы и доктрина бегунов неожиданно смыкаются. Не случайно в первом томе поэмы Чичиков, скупающий «мертвые души», объявлен перепуганным обществом Антихристом. Но одновременно тема бегунов, бежавших в Сибирь в поисках своего рая на земле, «поддерживает» и известный нам по мемуарной литературе гоголевский план духовного преображения героев в продолжении поэмы.

Ключевые слова: Гоголь, «Мертвые души», второй том, староверы-бегуны, Сибирь, легенда о Беловодье.

Информация об авторе: Екатерина Евгеньевна Дмитриева - доктор филологических наук, ведущий научный сотрудник, Институт мировой литературы им. А.М. Горького Российской академии наук, ул. Поварская, д. 25 а, І2Іо69 г. Москва, Россия; профессор кафедры сравнительной истории литератур, Российский государственный гуманитарный университет, Миусская площадь, д. 6, І25993 г. Москва, Россия.

E-mail: katiadmitrieva@mail.ru

Для цитирования: Дмитриева Е.Е. Миф о Беловодье, Опоньское царство староверовбегунов и загадка второго тома Гоголя // Studia Litterarum. 2018. T. 3, № 3 . C. II6-I43. DOI: IO.22455/2500-4247-20I8-3-3-II6-I43 


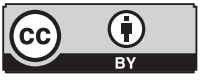

This is an open access article distributed under the Creative Commons Attribution 4.0 International (CC BY 4.0)

\section{THE MYTH OF BELOVODIE, OPONSKOE [JAPAN] KINGDOM OF THE OLD BELIEVERS, AND THE MYSTERY OF THE SECOND VOLUME OF GOGOL'S DEAD SOULS}

(C) 20I8. E.E. Dmitrieva

A.M. Gorky Institute of World Literature of the Russian Academy of Sciences,

Moscow, Russia,

Russian State University for the Humanities, Moscow, Russia

Received: November 28, 2017

Date of publication: September 25, 2018

Abstract: There is a hypothesis that Gogol was planning to move the setting of the second volume of Dead Souls to Siberia. The paper offers one more explanation of this design. Gogol seems to have left a clue in the last of the surviving chapters of the second volume where he outlines the theme of the Schismatics (Old Believers). This theme is not casual: it was in the I840s, when the state-afflicted repressions of the Old Believers began, and the activities of the latter became the object of investigation by various commissions. A member of one of these commissions was Ivan Aksakov who became particularly interested in one of the schismatics sects, namely the sect of wanderers or runners. The ideology of this extremely left branch of the Old Believers linked to the legend of Land of White Waters enables us to reconsider the purchase of the dead souls plot. The runners believed that not only the Niconian church incarnated Antichrist; they considered the audit of rustic population as demonic practice. Here we come to the point where the idea of Gogol's poem and the doctrine of the runners overlap. Let us recall that already in the first volume of the poem, Chichikov, the buyer of the dead souls, is called Antichrist. At the same time, the theme of the runners who fled to Siberia in search of their Belovodie, a kind of peasant paradise on earth, "supports" Gogol's plan for spiritual enlightenment and transformation of his characters in the second volume of Dead Souls.

Keywords: Gogol, Dead Souls, second volume, Old Believers, Siberia, the legend of Belovodie.

Information about the author: Ekaterina E. Dmitrieva, DSc in Philology, Leading Research Fellow, A.M. Gorky Institute of World Literature of the Russian Academy of Sciences, Povarskaya 25 a, I21069 Moscow, Russia; Professor, Russian State University for the Humanities, Miusskaya 6, I25993 Moscow, Russia.

E-mail: katiadmitrieva@mail.ru

For citation: Dmitrieva E.E. The Myth of Belovodie, Oponskoe [Japan] Kingdom of the Old Believers, and the Mystery of the Second Volume of Gogol's Dead Souls. Studia Litterarum, 20I8, vol. 3, no 3, pp. II6-I43. (In Russ.)

DOI: I0.22455/2500-4247-20I8-3-3-II6-I43 
В русской литературе есть роман, один из самых таинственных, ускользающий от какого-либо более-менее внятного толкования (сколько интерпретаций его было предложено, причем каждая из них словно полностью опровергала все другие!). Роман, который и романом не назывался, но поэмой. Имя ему, как легко можно догадаться, «Мертвые души».

Впрочем, надо признаться, что загадочность «Мертвых душ» есть не только следствие их поэтики, порождающей и сложнейшую герменевтику, но также и генезиса того текста, над которым Гоголь работал последние десять лет своей жизни, который три раза сжигал и который в результате так и остался незавершенным.

\section{Прозаик, в котором возобладал талант драматурга}

Позволю себе кратко напомнить эту историю. Первый том поэмы «Мертвые души», фабульно построенный на истории скупки предприимчивым героем Павлом Ивановичем Чичиковым умерших крестьянских душ, которые числились еще живыми в ревизских листах, был завершен и сразу же напечатан в I842 г., став одним из наиболее значительных и обсуждаемых явлений литературной жизни того времени. При этом, еще даже не закончив первый том, Гоголь замышляет его продолжение - второй том, а возможно, даже и третий, в которых, как он обещает, «явятся чудные образы и все повергнется в прах» [І2, с. I63].

Работа на самом деле шла сложно. Опуская многие детали, упомяну только, что, по некоторым версиям, уже в I843 г. Гоголь первый раз сжигает написанные им главы второго тома. Второй раз он сжигает их в I845 г. Виня в неудаче не только себя, но и потенциального читателя, он в это время 
считает необходимым подготовить его к восприятию своей поэмы другим произведением - публицистически-дидактического характера, а именно выдержками из писем к друзьям, которым он придает видимость книги и которые публикует в I847 г. соответственно под названием «Выбранные места из переписки с друзьями». Книга эта встретила резкую критику не только недругов, но и прежде всего друзей Гоголя, причем друзей, принадлежавших как к лагерю западников, так и славянофилов (уже в XX в. Дмитрий Чижевский увидит в «Выбранных местах...» русский аналог «Патриотических фантазий» (I765-I775) Юстуса Мезера [36, с. 755], ср.: [46]). Виссарион Белинский, с энтузиазмом приветствовавший более ранние произведения Гоголя, в том числе и первый том «Мертвых душ», и один из первых заговоривший о гоголевском периоде в истории русской литературы [5, т. 6, c. 259], написал Гоголю гневное письмо-отповедь, назвав «Выбранные места» ханжеством и мракобесием (знаменитое «зальцбрунское письмо» Белинского г847 г.). Потрясенный неприятием и непониманием книги, на которую он возлагал такие надежды, Гоголь вновь возвращается к работе над продолжением поэмы «Мертвые души», на этот раз настаивая уже на том, что живое изображение скажет читателю заведомо больше, чем абстрактное слово [2I, с. I93]. Так, в третий раз он приступает к работе над вторым томом в I847-I848 гг. и к концу I85I г. работу над ним завершает. Во всяком случае так он говорит об этом сам, обсуждает план печатания второго тома с друзьями, хотя рукопись в полном объеме никому не показывает. Максимальное же количество глав, которые в его чтении слушали некоторые его друзья, доходит до семи (публичные чтения глав второго тома Гоголь устраивал начиная с I849 г.).

Свою работу Гоголь вообще любил окутывать тайной. Но, пожалуй, ничто не сравнится с той таинственностью, которой была окружена работа над вторым томом «Мертвых душ». Обычно говорят, что современники несколько раз неправильно понимали Гоголя и принимали желаемое за действительное. Когда, например, Гоголь попросил своего друга и издателя Степана Шевырева (сам он в это время находился в Ницце) купить своим друзьям томик «Подражания Иисусу Христу...» Фомы Кемпийского в подарок от него на новый I844 г., а некоторые друзья, в частности С.Т. Аксаков, были убеждены, что получат рукопись второго тома [3, с. I28]. Или же когда матушка Гоголя приняла посланную Гоголем посылку с огородными семе- 
нами для сестер за только что вышедшую книгу «Мертвых душ», повторив тем самым историю с невольной мистификацией С.Т. Аксакова. Однако, по всей видимости, подобные мистификации входили в замысел того, кто умел быть великим драматургом не только в своих пьесах, но также и в жизни, талантливо режиссируя также и свой обман.

Развязка же драмы под названием «второй том 'Мертвых душ’» наступила в г852 г., когда Гоголь велел своему дворовому мальчику затопить камин и сжег рукопись поэмы, выход которой вся образованная публика России ожидала с великим нетерпением. Случилось это в ночь с II на I2 февраля. А 4 марта, т. е. менее чем месяц спустя, Гоголь умирает.

Как то и полагалось, комнату в доме графа А.П. Толстого, в которой последние месяцы своей жизни проживал Гоголь, после его смерти опечатывают, найдя в ней лишь немного «личных вещей покойного» и никаких бумаг [I9, т. I, с. 362]. Ничего сколь-либо значительного не было обнаружено и по ее вскрытии, 30 апреля I852 г. [І9, с. 366-369]. И лишь через несколько дней после того, как комната была распечатана, пронесся слух, что в ней был все же найден портфель с уцелевшими рукописями Гоголя, в частности, «Авторской исповедью» и вторым томом «Мертвых душ» [28, с. 486], ср. [4, с. І6г]. По другой версии, «Мертвых душ» в портфеле не было, но зато они были найденными завалившимися за книжный шкаф [22, с. 29I-292; см. также: І3, т. 2, с. 936]. Правда, это была рукопись незаконченного (или почти законченного) второго тома поэмы, некая ее промежуточная редакция. Именно эту редакцию, опубликованную три года спустя, т. е. в I855 г. стараниями С.П. Шевырева и племянника Гоголя Николая Трушковского мы и читаем и знаем как второй том поэмы «Мертвые души».

\section{Тайны второго тома «ертвых душ»}

Но что, в сущности, мы знаем о втором томе? Вопрос, при всей его очевидности, не из легких, поскольку даже самое главное знание о нем - о факте его сожжения - остается и по сей день загадкой, провоцирующей на разного рода домыслы: была ли то действительно рукопись продолжения поэмы, что погибла в огне в I852 г.? Или же, возможно, рукопись осталась спрятанной и тогда есть смысл ее искать [34, с. I37-I38; 35, с. I39; 4I, с. 455458]. Или же, наоборот: Гоголь, вопреки собственным утверждениям, второй том отнюдь не закончил и сжигал не столько рукопись, сколько соб- 
ственную фантазию. А ведь свидетелей сожжения было только двое: сам Гоголь и его дворовый мальчик, который быстро преисполнился сознанием важности своей персоны и со временем давал все более противоречивые показания [6, с. I66-186; 23, с. 42-47].

Далеко не все ясно и с найденными пятью главами второго тома, которые, как уже было сказано, представляют собой более раннюю редакцию, чем та, которая была сожжена. Точнее сказать, они представляют собой сразу две более ранние редакции, поскольку сохранившийся текст с очевидностью поддается расслоению: нижний слой рукописи представляет собой перебеленный (переписанный набело) текст, который уже затем (и скорее всего по прошествии некоторого времени) Гоголь правит. И правка эта образует более позднюю в сравнении с нижним слоем редакцию. Именно этот верхний слой переписал в г852 г. Шевырев, и его транскрипция появилась в издании I855 г. с пометой «Редакция в исправленном виде» [16, с. Іо3]. Однако уже начиная со следующего издания, подготовленного соплеменником Гоголя Пантелеймоном Кулишом [15, т. 4], издаваться второй том «Мертвых душ» стал в двух редакциях: по верхнему слою («в исправленном виде») и по нижнему («в первоначальном виде»). И традиция эта сохраняется по сей день.

При этом из материалов, относящихся ко второму тому поэмы, мы, помимо сохранившегося собственно гоголевского текста, имеем: І) воспоминания тех, кто слышал чтение Гоголем написанных им глав, дающие возможность реконструировать утраченное содержание второго тома'; 2) косвенные сведения о высказываниях самого Гоголя о возможном продолжении поэмы (например, свидетельство А.М. Бухарева, восходящее к их разговору с Гоголем по поводу продолжения «Мертвых душ» [7]); 3) а также предложения, исходившие от лиц, с которыми Гоголь беседовал и которые как-то могли повлиять на дальнейшее развитие замысла (например, о. Матфея Констаниновского [26]).

Сохранившиеся отзывы современников, присутствовавших на чтении Гоголем глав поэмы, показывают, что действие в ней продвинулось дальше, чем можно судить по опубликованным главам, что появлялись в

I Таковы воспоминания Л.И. Арнольди «Мое знакомство с Гоголем» и Д.А. Оболенского «О первом издании посмертных сочинений Гоголя. Воспоминания» [І2, с. 472-498, 544-556], а также свидетельства А.О. Смирновой-Россет [32]. 
нем и новые лица. И ожидало большинство героев «просветление», о котором написанный текст давал пока еще слабое представление. По свидетельству Бухарева, Гоголь «как будто с радостию подтвердил, что <...> первым вздохом Чичикова для истинной прочной жизни должна кончиться поэма» и что «прочие спутники Чичикова» «тоже воскреснут, если захотят», «потом стал говорить, как необходимо далее привести ему своих героев в столкновение с истинно хорошими людьми, и проч. и проч.» [7, с. I38-139].

Еще одно свидетельство, на этот раз непосредственно Гоголя, о том, что помимо Чичикова к «возрождению» Гоголь собирался привести еще одного персонажа первого тома - скопидомца Плюшкина, обнаруживается в письме «Предметы для лирического поэта в нынешнее время» (1844), обращенном к Н.М. Языкову и вошедшем впоследствии в «Выбранные места из переписки с друзьями». Призывая Языкова выставить читателю «ведьму старость $<. .>$, которая ни крохи чувства не отдает назад и обратно», он писал: «Воззови, в виде лирического сильного воззвания, к прекрасному, но дремлющему человеку <...> О, если б ты мог сказать ему то, что должен сказать мой Плюшкин, если доберусь до третьего тома “Мертвых душ”! По предположению Алексея Веселовского, поддержанному В.В. Гиппиусом, Плюшкин в продолжении поэмы «должен был превратиться в бессребреника, раздающего имущество нищим» [II, с. I83].

То, что этому просветлению и воскресению суждено было случиться даже и не во втором, а в третьем томе, породило впоследствии весьма устойчивую легенду о том, что Гоголь, задумывая «Мертвые души», собирался создать некий русский аналог «Божественной поэмы» Данте с ее трехчастным делением на «Ад», «Чистилище» и «Рай»². Для нашей же темы особый интерес представляют следующие два момента: свидетельства как самого

2 Легенда о том, что Гоголь в «Мертвых душах» ориентировался на трехчастную структуру именно «Божественной комедии» Данте, получила распространение, скорее всего, с легкой руки П.А. Вяземского, который, однако, использовал эту аналогию как раз в негативном плане: «О попытках его, оставленных нам в недоконченных посмертных главах романа, положительно судить нельзя; но едва ли успел бы он без крутого поворота и последовательно выдти на светлую дорогу и, подобно Данту, довершить свою Divina Comedia Чистилищем и Раем» [Іо, стб. Іо8I-IO82]. Впоследствии сравнение это уже в положительном смысле подхватили Д.Н. Овсянико-Куликовский, А.Н. Веселовский и С.К. Шамбинаго. При том что данная гипотеза уже в г920-е гг. была опровергнута почти одновременно В.В. Зеньковским [20, с. 230] и В.В. Гиппиусом [ІІ, с. I68], в последующей литературной критике она получила очень широкое распространение. 
Гоголя, так и его современников о том, что в продолжении поэмы герои должны воскреснуть для новой жизни, а также то, что местом действия этого «воскрешения» должна была стать Сибирь.

\section{Почему Сибирь?}

О том, что действие уже написанных Гоголем, но сожженных в феврале г852 г. глав второго тома «Мертвых душ» перемещалось частично в Сибирь, также имеются свидетельства первых слушателей второго тома поэмы (напомню, что действие первого тома поэмы разворачивалось в анонимном городе N, а действие сохранившихся от сожжения глав второго тома - в вымышленном Тьфуславле, имя которого есть уже само по себе оксюморон). Так, С.П. Шевырев, которому Гоголь прочитал в июле г85I г. семь глав, рассказывал Оболенскому о судьбе, ожидавшей персонажей именно второго тома: «...в то время когда Тентетников, пробужденный от своей апатии влиянием Уленьки, блаженствует, будучи ее женихом, его арестовывают и отправляют в Сибирь; этот арест имеет связь с тем сочинением, которое он готовил о России, и с дружбой с недоучившимся студентом с вредным либеральным направлением... Уленька следует за Тентетниковым в Сибирь, там они венчаются и проч.» [І2, с. 555-556].

Иван Аксаков (по свидетельству Данилевского) высказывал предположение, что в Сибирь (по-видимому, уже в третьем томе поэмы, где, собственно, и должно было произойти преображение и просветление главных героев поэмы) должен был попасть и Чичиков. Предположение это не было голословным, но основывалось на круге чтения Гоголя второй половины I840-х гг., когда он усиленно начинает работать над вторым томом и в связи с этим изучает книги о Сибири:

Надо думать, что Чичиков, в конце этой части, вероятно, попадет за новые проделки в ссылку в Сибирь, так как Гоголь у нас и у Шевырева взял много книг с атласами и чертежами Сибири. С весны он затевает большое путешествие по России; хочет на многое взглянуть самолично, собственными глазами, назвучаться русскими звуками, русскою речью и затем уже снова выступить на литературной сцене, с своими новыми образами ([І2, с. 44I], ср.: $[42$, c. $447-45 \mathrm{I}])$. 
И действительно, если судить по имеющимся у нас данным: переписке самого Гоголя, его друзей, воспоминаниям современников, - в это время на смену его интересу к среднеевропейской полосе России, которая и была местом действия его предыдущих произведений, включая первый и частично второй том поэмы, приходит ярко выраженный интерес к сибирскому материалу. Можно предположить, что геополитическое и этнографическое содержание утраченных частей второго тома и планировавшегося Гоголем третьего тома определялось, в частности, содержанием «Путешествия по Сибири в I733-I743 гг.» И.-Г. Гмелина и «Путешествий по разным провинциям Российского государства...» П.-С. Палласа (I773-1778) - книг, которые Гоголь брал в І85г г. для чтения у Аксаковых и Шевырева и которые (как, например, первые части «Путешествия» Палласа) он еще ранее конспектировал.

И все же возникает вопрос: почему Сибирь? Край, который Гоголь сам не знал, хотя и собирался туда отправиться. Казалось бы, ответ здесь может быть самый простой: в Сибирь должны попасть гоголевские герои за те или иные преступления. Тентетников - за преступление против государственных устоев (не случайно в его истории многими видится отраженная история петрашевцев). То, что за Тентетниковым едет невеста, ставшая его женой, также вписывается в известную литературную и историко-культурную мифологию, на этот раз декабристскую. За мошенничество попадает в Сибирь и Чичиков, что тоже вполне понятно. Хотя в его случае Сибирь могла иметь еще и дополнительную мотивировку: Сибирь как край открывающихся еще непознанных экономических возможностей могла оказаться весьма перспективным пространством для Чичикова, талантливого экономического предпринимателя³. Не случайно в последующих, довольно многочисленных попытках «дописать» «Мертвые души» уже в постгоголевские времена на первый план выступала именно это сторона Чичикова - хитроумного дельца, недооцененного в свое время, но пришедшегося «ко двору» в последующие времена. В одной из таких стилизаций г920-х гг. Чичиков и вовсе выступил как нэпман - деятель эпохи Новой экономической политики, имевшей целью развитие частного предпринимательства ${ }^{4}$.

3 О Сибири и Дальнем Востоке, ставших с начала XIX в. частью государственного проекта по «гомогенизации государства и порождению у подданных чувства общности» см.: [9, c. $245^{-345}$ ].

4 См. пьесу Сигизмунда Волка «Мертвые души, или Похождения Чичикова: Комедия в 3 д. 11 картинах» (ОРиРК СПбГТБ, шифр: І Лар). 
Однако если принять перечисленные здесь причины для объяснения того, почему Гоголь выбирает именно Сибирь местом продолжения своей поэмы, то открытым остается вопрос: как данные экспликации связаны с намерением Гоголя духовно (а вовсе не материально) преобразить своих героев и «воскресить их для истинной прочной жизни». Почему именно Сибирь должна стать местом этого духовного преображения?

\section{Неожиданно возникающая тема раскольников}

В дошедшем до нас тексте второй части, а именно в последней по счету главе, которую традиционно не совсем точно именуют заключительной, обращает на себя внимание эпизод, который долгое время интерпретировался скорее как гоголевский алогизм. Благородный откупщик Муразов, которому в этой же главе отведена роль спасителя Чичикова, пытается духовно спасти еще одного, казалось бы, периферийного, но весьма примечательного персонажа, Хлобуева (в поэме он впервые появляется в четвертой главе). В структуре сохранившихся глав второго тома персонаж этот занимает весьма загадочное место, будучи обрисован Гоголем как живущий не по средствам помещик-бездельник, способный за один вечер спустить огромные деньги и обрекающий тем самым свое семейство на существование в долг, но на которого постоянно «падает» откуда-то очередная сумма денег, позволяющая ему и далее существовать безбедно. И тем не менее он, как и Чичиков, оказывается тем, на кого возлагает надежду единственный абсолютно положительный герой второго тома откупщик Муразов. Именно ему, одному из самых легкомысленных гоголевских героев, благородный миллионер предлагает неожиданно покаяться, отправившись по России собирать пожертвования на церковь.

Возможный маршрут Хлобуева в сохранившихся главах не прочерчен, однако в разговоре с ним Муразова появляется одна реалия, которая все же позволяет предположить, куда мог отправиться Хлобуев. Предлагая ему «две службы» разом - сослужить «одну службу Богу, а другую мне», - Муразов призывает его тем самым, с одной стороны, собирать деньги на храм (служба Богу), а с другой - осведомляться о тех волнениях, которые происходят в крестьянской среде, и прежде всего в среде раскольников: 
- Призадумались? - сказал Муразов. - Вы здесь две службы сослужите. Одну службу Богу, а другую мне.

- Какую же вам?

- А вот какую. Так как вы отправитесь по тем местам, где я еще не был, так вы узнаете-с на месте все, как там живут мужички. Где побога<че,> где терпят нужду, и в каком состояньи все. <...> Раскольники там и всякие-с бродяги смущают их. Восстановляют против властей и порядков... [I4, т. 7 , c. 354].

На самом же деле тема раскольников у Гоголя появляется вовсе не случайно. Собственно, раскольниками Гоголь начинает интересоваться уже с начала I840-х гг. Н.М. Языкова он просит в письме от 23 сентября (5 октября) г843 г. из Дюссельдорфа прислать ему труд Дмитрия Ростовского «Розыск о раскольнической брынской вере». Записи о раскольниках мы находим в записной книжке Гоголя I84I-I844 гг., и они свидетельствуют о гораздо более толерантном отношении к ним самого Гоголя по сравнению с тем, какое он приписал Муразову. Но в особенности интерес его к раскольникам усиливается в I846 г., о чем свидетельствуют вопросы о раскольниках, которые Гоголь задавал Смирновой в письмах к ней от 27 января I846 г. и 20 февраля (4 марта) I846 г.

Что заставило Гоголя именно во второй половине І840-х гг. обратиться к теме раскольников? И как эта тема стала тем ключом, который проливает свет на замысел Гоголя перенести действие своей поэмы в Сибирь? На это были свои предпосылки, как сугубо биографические, так и социокультурные.

Вспомним, что именно в I840-е гг. в отношении государства к старообрядцам наступает резкий перелом: после почти столетия довольно терпимого к ним отношения начинаются репрессии, а их деятельность становится объектом расследования различных комиссий. В одной из таких комиссий состоял уже упомянутый выше Иван Аксаков, сын писателя-славянофила Степана Тимофеевича Аксакова, с семьей которого Гоголь особенно тесно общается в I840-е гг. К слову сказать, семейство Аксаковых принадлежало к числу тех особо чтимых Гоголем лиц, которым он прочитал наибольшее количество написанных им глав второго тома. И главное - это было семейство, которому Гоголь в особенности доверял. 


\section{Делопроизводство con amore}

Иван Аксаков занимал в том семействе особое место: литературно одаренный и высоко образованный, как и все Аксаковы, он, в отличие отца и своего младшего брата Константина, выбирает не литературный путь, но путь государственного чиновника и начинает свою деятельность в министерстве юстиции. Как вспоминали о нем люди, его знавшие, «это был новый, только еще начавший тогда развиваться тип чиновника-идеалиста, служившего “делу”, а не “лицам”, и требовавший одинаково как от своих коллег, так и от подчиненных, точного исполнения закона» [24, с. го6]. Характерно, что именно такого чиновника-идеалиста, своего рода белую ворону на фоне остального коррумпированного чиновничества, выводит во втором томе Гоголь в самом финале поэмы5 идеальном чиновнике угадывался именно Иван Аксаков, сам немало размышлявший о функциях чиновника в России и об уготовленной ему в России судьбе ${ }^{6}$.

А судьба этого «идеального чиновника» представала весьма драматичной. Отказавшись поставить свою подпись на подложном документе, он не избежал преследования властей, вынужден был оставить службу по министерству юстиции и перешел в министерство внутренних дел, которым управлял в те времена граф Л.А. Перовский. Именно Перовский предлагает в середине І840-х гг. опальному Аксакову заняться изучением раскола и посылает его в Бессарабию (нынешнюю Молдавию). Тщательно изучив раскол, Аксаков высказывается в его защиту в ряде статей, чем навлекает на себя новое гонение. На вопросы Третьего отделения он отвечает словами, в которых поразительным образом узнается гоголевская интонация («...цель моя на службе ездить по России с поручениями и изучать ее во всех отношениях, не только по одному предмету возлагаемого на меня поручения» [24, c. Io8]). Пережив арест и получив освобождение, Иван Аксаков хлопочет о командировке в Малороссию, но получает назначение в Ярославль - и тоже в связи с делом изучения раскола. В марте І849 г. Иван Аксаков от-

5 Ср.: «В это время вошел молодой чиновник и почтительно остановился с портфелем. Забота, труд выражались на его молодом и еще свежем лице. Видно было, что он недаром служил по особым порученьям. Это был один из числа тех немногих, который занимался делопроизводством con amore» [14, т. 7, с. І20].

6 См., в частности, статью И. Аксакова «О служебной деятельности в России (письмо к чиновнику)», так и оставшуюся не опубликованной при его жизни [1, с. 70-72]. 
правляется из Абрамцева в ярославскую командировку, заехав на пути в Москву к Гоголю. С этого времени обращенные к отцу и сестрам письма его полны сведениями о работе комиссии и полученными им впечатлениями о старообрядцах. Очевидно, что многие из этих писем читались и Гоголю, и в присутствии Гоголя. Вспомним, что І849 г. - начало особо интенсивной работы Гоголя над новой редакцией второго тома. Поразительные встречаются порой совпадения. «Отец... я сохраняю аккуратно твои письма, пишет Иван Аксаков отцу 29 сентября I849 г. - Вот так бы надобно было объездить всю Россию (разумеется, не одному человеку) и такого рода описания было бы полезно прочесть нашему Министру... Каково разнообразие нашей беспредельной Руси!» [2]. И Гоголь словно вторит ему в письме от Іо-І8 июля І850 г., предположительно обращенном к тому самому графу Л.А. Перовскому, под началом которого служил Иван Аксаков:

Нам нужно живое, а не мертвое изображенье России, - та существенная, говорящая ее география, начертанная сильным, живым слогом, которая поставила бы русского лицом к России <... >. Книга эта составляла давно предмет моих размышлений. Она зреет вместе с нынешним моим трудом и, может быть, в одно время с ним будет готова» [I4, т. I4, с. 280].

Но именно здесь возникает весьма примечательная «интрига», стягивающая в единый узел и гоголевский план духовного просветления и преображения своих героев в продолжении поэмы, и те географические границы, которые этому воскрешению оказываются предопределены (а именно Сибирь), и, наконец, тему раскольников.

За восемь месяцев работы в Ярославской губернии Иван Аксаков сумел в подробностях обследовать не только положение раскольников, но и экономическое положение края. Об этом свидетельствуют сохранившиеся по сей день его тетради, наполненные статистикой, песнями, преданиями, рисунками. Среди подготовленных им материалов - статья об одном из ответвлений старообрядцев - секте странников, или, как их в то время называли, бегунов, которую он вскоре публикует под названием «Краткая заметка о странниках и бегунах» [29, стб. 627].

А далее происходит неожиданное: правительство, проигнорировав совершенную И.А. Аксаковым работу, делает конфиденциальный запрос по 
поводу написанной и читанной на публике поэмы «Бродяга» (отрывки из нее были напечатаны в «Московском Сборнике» за г852 г.), и, хотя и не находит в ней ничего предосудительного [2], предлагает оставить ему литературное поприще как «отвлекающее от служебных занятий». Оскорбленный до глубины души Аксаков пишет отповедь министерству и в конце апреля г85 г г. подает и получает отставку.

Между тем, как бы ни относиться к реакции министерства, нельзя не признать, что была у министерства своя сермяжная правда. Поскольку повесть (точнее, поэма), носившая название «Бродяга», в которой ныне видится первый в России опыт народной русской эпопеи, предваряющий в этом смысле «Кому на Руси жить хорошо» Н.А. Некрасова [27, с. 3I], на этот раз художественными средствами преследовала ту цель, за которую Аксаков уже и прежде подвергался обструкции - а именно защиту интересов раскольников, и, более конкретно, по-видимому, наиболее заинтересовавшей его секты старообрядцев-странников, или бегунов, которых в народе называли еще и бродягами (так что название поэмы на деле было не столь уж и невинным). Достаточно сопоставить ее сюжет, где рассказывается о крестьянине, «отправляющемся бродить вследствие какого-то безотчетного влечения» [27, с. 3I], с размышлением Аксакова в статье о бегунах:

Независимо от идеи первоначального своего происхождения, секта странников обратилась в религиозное оправдание бродяжничества и бегства вообще. Бежал ли солдат из полку, крепостной мужик от барщины, молодая баба от мужа - все православные - они находили оправдание своему поступку в учении странническом, которое возводило бродяжничество в догмат, звание беглого в сан [29, стб. 627].

И хотя статья эта опубликована была лишь в I866 г., однако очень большая доля вероятности, что высказанные в ней соображения обсуждались в кругу Аксаковых в то самое время, когда у них часто гостил Гоголь.

Вся эта немного длинная предыстория важна мне была для того, чтобы показать возможный генезис не просто интереса Гоголя к староверам, который, собственно, очевиден, но и то, что этот интерес был подогрет деятельностью Ивана Аксакова, по-видимому, заставившей Гоголя присмотреться внимательнее также и к секте бегунов, о которых сам Гоголь, правда, 
конкретно не упоминает, но отголоски доктрины которых, как представляется, и являются во многом ключом для понимания так и не дописанного продолжения «Мертвых душ». Конечно, здесь мы вступаем уже в область некоторой умозрительной реконструкции, но тем важнее контекст, в которой эта реконструкция оказывается возможной.

\section{Бегуны и легенда о Беловодье}

Бегуны были одним из беспоповских направлений старообрядчества. Они считали, что невозможно сохранить «истинную церковь», сохраняя отношения с «антихристовым» миром, а потому призывали бежать и скрываться от «антихристовых» властей. В основе этого учения, изложенного основоположниками секты Евфимием и Никитой Киселевым, лежало общее старообрядческое представление, что со времени реформы Никона начался век антихристов. Однако существенное расхождение бегунов с другими старообрядцами заключалось в том, что бегуны, или странники, объявляли воплощением антихриста не только и не столько царя и никонианскую церковь, сколько государственные законы и установления. Был один, исключавший какие бы то ни было компромиссы выход: бежать, уклоняясь от всех гражданских повинностей - видимых знаков власти антихристовой, иными словами, «не имети ни града, ни села, ни дома», перейти к конспиративному существованию, меняя пристанища и не даваясь в руки начальства [37, с. 24I243]. Сам Евфимий обрел себе в пошехонских лесах первых последователей, скрывался затем в лесах галичских, а потом в окрестностях Ярославля, где и умер в I792 г. По смерти его в роли наставницы выступила его спутница Ирина Фёдорова, которая перешла в село Сопелки на правом берегу Волги, также недалеко от Ярославля. Это село с тех пор стало играть роль столицы бегунства; по его имени и секту стали называть «сопелковской». Именно сопелковское дело расследовал в конце І840-х гг. Иван Аксаков.

В фольклоре русских крестьян XVII-XVIII вв. существовала красивая легенда о Беловодье, стране с богатыми землями и природой, свободной от гнета бояр и «гонителей веры», где вдали от мира живут святые праведники, где главенствует добродетель и справедливость. Страна эта сначала помещалась на Крайнем Севере, в «северных землях в Поморье, от реки великой Обь до устья Беловодной реки, и эта вода бела как молоко...». Впоследствии представления о местонахождении Беловодья менялись: страну эту искали 
в Сибири, на Алтае, в Китае, Монголии, Тибете, наконец, в Японии, с чем связано появление другого ее наименования - «Опоньское царство». Так и не найденная земля блаженного Беловодья смещалась в представлении русских крестьян все дальше в неосвоенные территории.

С середины I820-х гг. Беловодье становится одной из наиболее обсуждаемых в обществе тем, что связано с сообщением приехавшего в Петербург из Томской губернии поселянина Бобылева, который донес министерству внутренних дел, что «на море», в Беловодье, живут старообрядцы числом до 500 ооо человек и дани никому не платят, что они осели на далеких островах Тихого океана, до которых можно было добраться, двигаясь от Бухтармы через Китай. Бобылев сообщил, что старообрядцы не прочь служить русскому царю. Министерство поверило страннику и выдало ему на посольские расходы І5о руб. Однако он не доехал даже до сибирского генерал-губернатора и бесследно исчез [37, с. 239-240].

Упомянутая в официальной переписке легенда о Беловодье не переставала будоражить умы почти до начала XX в. А основными распространителями этой легенды стали, по вполне понятным причинам, члены секты «бегунов», или «странников», которые на протяжении всего XIX в. отправлялись на поиски этого царства Божьего на земле.

Отправлявшиеся на поиски Беловодья бегуны тайно снабжались особым путеводителем - «Путешественником», в котором содержался прямой призыв бежать на «райские острова» и подробная инструкция о том, каким путем следует добираться до Беловодья: Казань, Екатеринбург, Тюмень, Алтайские горы, Уймон. Это были листки в одну-две странички, исписанные крестьянской рукой и восходившие к распространившемуся со второй половины XVIII в. в среде старообрядцев рукописному повествованию инока Марка из Топозерского монастыря Архангельской губернии, который в поисках «древнего благочестия» отправился на Восток. Добрался он до Китая, перешел Гоби и достиг Японии, где искомое благочестие обнаружил пребывающим в несказанном расцвете. А хранителями его он называл христиан «ассирскаго языка»7. Завершался рассказ описанием неземного благополу-

7 Существует также и научное объяснение, почему Беловодье с Севера, Сибири, Алтая, Китая оказалось в конечном счете вытесненным в японское пространство. Речь идет о так называемой несторианской «древней Церкви Востока». Беглые старообрядцы, столкнувшись в Азии с «ассирскими христианами», подхватили их рассказы о миссии в Японии, связав их с известной легендой о Беловодье, превратившейся теперь в опоньское царство [30, с. I8I-I86]. 
чия. «В тамошних местах... светского суда не имеют; управляют народы и всех людей духовные власти. Тамо древа равны с высочайшими древами» (ср.: [25, гл. II]).

\section{И снова «Мертвые души»}

Согласимся, что в доктрине именно странников-бегунов было немало того, что в особенности могло привлечь работающего над своими «Мертвыми душами» Гоголя. В миросозерцании и идеологии этого крайне левого ответвления старообрядчества, связанного с распространением ставшей весьма популярной с конца XVIII в. легенды о Беловодье (она же в расширительном толковании - Опоньское царство), была та особенность, которая вообще дает возможность по-иному вглянуть на сам инцидент с покупкой мертвых душ - и тем самым на генезис поэмы.

Казалось бы, в учении бегунов мы имеем дело с одним из проявлений анархического утопизма, отрицающего государство. Но - что для нас очень важно - бегуны связывали наступление царства антихристова даже не столько во временем Никона, сколько с первыми всеобщими ревизиями податных душ, переписью податного населения.

Здесь мы доходим до той точки, где замысел гоголевской поэмы и доктрина бегунов неожиданно смыкаются. Вспомним, что уже в первом томе поэмы Чичиков, скупающий мертвые души и в последних главах разоблаченный, объявлен перепуганным обществом антихристом. Во втором томе слух о народившемся антихристе, скупающем ревизские души, уже непосредственно приписывается раскольникам:

В другой части губерни<и> расшевелились раскольники. Кто-то пропустил между ним<и,> что народился антихрист, который и мертвым не дает покоя, скупая какие ${ }^{*}$ мертвые души. Каялись и грешили, и под видом изловить антихриста укокошили не антихристов [I4, т. 7, с. II8].

Но при этом многослойность и многосоставность поэмы позволяют взглянуть на проблему и несколько иначе. Это только по внешнему абрису Чичиков, скупающий мертвые души, - антихрист - роль, которая закрепляется за ним в массовом сознании и порожденной им легенде. А на самом деле Чичиков, скупая мертвые души, именно своим эпатирующим, анархи- 
ческим, глумливым над помещиками актом вскрывает абсурд ревизии как таковой. А закрепленная за ним роль бродяги-пикаро, который при всей своей обходительности нигде подолгу не находит пристанища, делает его дополнительно родственным сектантам-бегунам.

В этой перспективе смыкаются намеченные Гоголем для продолжения поэмы, казалось бы, гетерогенные ее моменты: Чичикова, мечтающего о жене с детишками в надежде создать свой маленький рай на земле - подобно тому как и бегуны-сектанты, в отличие о мистических сект духоборов и молокан, утверждавших царствие божие внутри нас, по-крестьянски жаждали царства Божьего на земле, а также путь Чичикова, как и других персонажей его поэмы, в Сибирь - событийно объяснимый теми или иными конкретными обстоятельствами, но бытийно ставший определенным аналогом пути в Беловодье.

В истории с Гоголем, мечтавшим о своем и своих соплеменников духовном перерождении, случилось так, что легенда о Беловодье и стала тем мыслимым «маршрутом», к которому устремился его творческий взор, заставивший его перенести окончание действия «Мертвых душ» в Сибирь. Произошло ли то сознательно или, выражаясь словами Пушкина, по странному сближению витающих в воздухе идей, судить трудно. Да и практически невозможно. Хотя в силу всего вышеизложенного исключить то, что Беловодье как страна, в которой живут по Божескому закону, как почти реализованная утопия, была в оптике Гоголя, тоже невозможно, тем более что второй и даже, скорее, третий том «Мертвых душ» и задумывался Гоголем во многом как дань утопическому мышлению [I7, с. 338-345].

Для нас же здесь не менее важно и другое: не только для Гоголя, но и для русской литературы в целом Беловодье (Сибирь) становится именно тем местом, с которым связывается возможность духовного преображения и где крестьянская материальная утопия встречается с поиском «древлего благочестия», антиохийского древнего восточного православия, жития согласного с мыслию Христовой (см.: [37, с. 286]). Так, М.Е. Салтыков-Щедрин в «Пошехонской старине» будет писать о ходивших в то время слухах о секте бегунов, которая «преходила от деревни к деревне, взыскуя вышнего града». Так и отлучение от церкви Льва Толстого немедленно порождает слух, что он побывал в Беловодье, и делегация уральских казаков немедленно посетит в этой связи Ясную Поляну, хотя и возвратится оттуда разочаро- 
ванной (Толстой этот слух не подтвердил). Беловодье описывает, как уже упоминалось выше, и Мельников-Печерский.

В последнее время Сибирь все более привлекает исследователей как пространство разных форм исторического и материального палимпсеста и культурного трансфера. Рискуя впасть в народную этимологию, укажу тем не менее на еще один возможный, на этот раз топонимический трансфер. Маршрут уже упомянутого выше «Путешественника» инока Марка проходил через Бийск, Горноалтайский округ, Бухтарминскую и Уймонскую долины. Далее, однако, начиналась легендарная часть маршрута - неведомыми горными проходами в Китайское государство и после 44 дней пути - в Беловодье. В этой дальнейшей части маршрута географические названия представляли одну загадку за другой: Губань (Гоби?), Буран (Бурат-река?), Кукания и проч. Что касается последнего топонима, то, конечно, можно вспомнить, что, как указывает К.В. Чистов, есть близкие ему модификации: село Кукан Улатавского района или же Куканский хребет [37, с. 26о]. Но не вправе ли мы услышать в топониме Кукания также и отголоски европейской страны Кокань (рауs de Cocagne ${ }^{8}$ ), аналога русской страны с молочными реками и кисельными берегами?

О стране Кокань Жак Ле Гофф говорил как о «единственной средневековой утопии - не только потому, что она получила особое распространение в Средних веках, но еще и потому, что в изображении Кокани отразились важные моменты жизни человека того времени: проживание и питание, религия, хозяйственная и социальная сферы. Тексты об этой стране содержат «радикальную критику феодального общества... и его главных ценностей, на которых оно держится: деньги и работа» [44, p. 276-277]. Так и в тексте старофранцузского «Фаблио про Кокань» герой-рассказчик идет к Папе за покаянием, а тот отправляет его в чудесную благословенную страну - Кокань, в которой «plus on y dort, plus on y gagne» («чем больше спишь, тем больше получаешь» (см.: [38; 39; 40; 45]).

8 Варианты слова «cocagne» можно найти во многих европейских языках, что свидетельствует о распространенности этого понятия: во французском "coquaigne", “quoquaigne”, "Cocaigne”, в итальянском “Cuccagna”, “Cucagna”, в испанском "Cucaña”, “Сосаña” и т. д. Характерно, что слово «Кокань» встречается и в названиях реальных топонимов (деревня Коккенген (Kokkengen) в провинции Утрехт в Голландии, где, по легенде, колонисты пытались создать священное государство, местечко Куканья (Cucagna) на пути из Рима в Лорето, знаменитое своим плодородием и красотой (см.: [31]). 
Тезис о сне и ничего неделании, которые становятся основным условием благополучия, неожиданно возвращает нас к гоголевскому персонажу Хлобуеву, прожигающему жизнь:

...почти всегда приходила к нему откуда-нибудь неожиданная помощь. <...> Благоговейно признавал он тогда необъятное милосердье провиденья, служил благодарственный молебен и вновь начинал беспутную жизнь свою [I4, т. 7, с. 88].

Внутренняя логика этого причудливого персонажа становится, однако, более понятной, если увидеть в ней отсвет той утопической мечты, которая легла в основу легенды о благословенной стране Кокань и которая, по-видимому, эхом отразилась в той Куканьи, что в маршруте «Путешественника» должна была стать этапом на пути обретения Беловодья, оно же - Опоньское царство.

$* * *$

Тема бегунов, бежавших в Сибирь в поисках своего Беловодья, своего рода крестьянского рая на земле, «поддерживает» план духовного просветления и преображения героев в продолжении второго тома «Мертвых душ», известный нам по мемуарной литературе и по высказываниям самого Гоголя. Она же в определенном смысле проливает свет и на те географические границы, которые ему оказываются предопределены, - а именно Сибирь и, возможно, даже более конкретно Алтай (не случайно открывающее второй том описание поместья Тентетникова - «меловые горы, блиставшие белизною даже и в ненастное время, как бы освещало их вечное солнце» [I4, т. 7, с. 8] - почти повторяет изображение Алтайских гор в сделанном Гоголе конспекте из Палласа $[8, \text { c. I85 }]^{9}$ ), так что в определенном смысле можно сказать, что пристальный интерес в конце І840-х гг. к Сибири работающего над продолжением «Мертвых душ» Гоголя шел параллельно все усиливающемуся интересу к теме раскольников. А для изображения дра-

9 Ср.: «Сверху Осиновой горы представляется грозный вид снежных Алтайских <гор>, называемых, по причине вечной белизны, белками. <... Видна оттоле другая гора фигуры конической, коея верх подобен великой каменной пирамиде, превышающей облака» [I4, т. 8, c. 339]. 
мы человеческой души ему понадобился своеобразный маршрут - от безымянного города $\mathrm{N}$ через Тьфуславь и - затем - Алтайские горы, меловая белизна которых отзовется в первой же главе второго тома - в гипотетическое Беловодье, ту самую утопию, которую он сначала хотел претворить в «Выбранных местах из переписки с друзьями», а затем в продолжении своей так и не оконченной, сожженной поэмы и которая оказалась утопией в самом исконном значении этого слова - а именно местом, которого нет. 


\section{Список литературы}

I Аксаков И. О служебной деятельности в России (письмо к чиновнику) // Человек. I993. № I. С. $70-72$.

2 Аксаков И.С. Письма к родным. I849-I856 / Изд. подгот. Т.Ф. Пирожкова. М.: Наука, І994. 653 с.

3 Аксаков С.Т. История моего знакомства с Гоголем / Изд. подгот. Е.П. Населенко и Е.А. Смирнова. М.: Изд-во Академии наук СССР, г96о. 294 с.

4 Балакшина Ю.В. Была ли услышана «чистосердечная повесть» Н.В. Гоголя? История распространения «Авторской исповеди» в списках (К постановке проблемы) // Н.В. Гоголь: Материалы и исследования. М.: ИМЛИ, 2009. Вып. 2. С. $160-\mathrm{I} 72$.

Белинский В.Г. Полн. собр. соч.: в Із т. М.: Изд-во Академии наук СССР, I953-I959.

6 Бочаров С.Г. Генетическая память литературы. М.: РГГУ, 20I2. 34I с.

7 Бухарев А.М. Три письма к Н.В. Гоголю, писанные в I848 году. СПб.: Тип. Морского мин-ва, І86о. 260 с.

8 Видугирите И. Географическое воображение. Гоголь. Вильнюс: Вильнюсский ун-т, 20І5. 294 с.

9 Вишленкова Е. Человеческое разнообразие в локальной перспективе: «большие теории» и эмпирические знания (Казань, первая половина XIX века) // Ab imperio. 2009. № 3. С. 245-345. Выдержки из старых бумаг Остафьевского Архива. Письма к кн. П.А. Вяземскому // Русский архив. І866. № 7. Стб. го8І-Іо82. Гиппиус В. Гоголь; Зеньковский В. Н.В. Гоголь / предисл., сост. Л. Аллена. СПб.: Logos, I994. 343 с.

I2 Гоголь в воспоминаниях современников. М.: ГИХЛ, І952. 7І9 с.

I3 Гоголь в воспоминаниях, дневниках, переписке современников: в 3 т. М: ИМЛИ РАН, 2OII-2OI3.

I4 Гоголь Н.В. Полн. собр. соч: в І4 т. <Б.м.>: Изд-во АН СССР, І937-І952.

I5 [Гоголь Н.В.] Сочинения и письма Н.В. Гоголя: в 4 т. Изд-е П.А. Кулиша. СПб.: В тип. Императорской академии наук, І857.

I6 [Гоголь Н.В.] Сочинения Николая Васильевича Гоголя, найденные после его смерти. Похождения Чичикова, или Мертвые души. Поэма Н.В. Гоголя. Том второй. (5 глав). М.: В Университетской Тип., І855. 304 с.

I7 Дмитриева Е. Продолжение «Мертвых душ»: специфика национальной утопии // Острова любви БорФеда: Сборник к 9о-летию Бориса Федоровича Егорова / ИРЛИ РАН; СПбИИ РАН; Союз писателей Санкт-Петербурга; ред.-сост. А.П. Дмитриев и П.С. Глушаков. СПб.: Росток, 2016. С. 338-345.

I8 Дмитриева E.E. «Мне нужно побольше прочесть о Сибири»: русский Запад versus российский Восток в мифопоэтике Гоголя // Диалог культур: поэтика локального 
текста. Материалы IV Международной научной конференции / под ред. П.В. Алексеева. Горно-Алтайск: Горно-Алтайский ун-т, 20I4. С. I34-I44. Дурылин С.Н. «Дело» об имуществе Гоголя // Н.В. Гоголь. Материалы и исследования: в 2 т. / под ред. В.В. Гиппиуса. М.; Л.: Изд-во АН СССР, І936. Т. І. С. $359-374$. Зеньковский В. Н.В. Гоголь // Гиппиус В. Гоголь; Зеньковский В. Н.В. Гоголь. СПб.: Логос, І994. С. І89-338. Манн Ю. В поисках живой души: «Мертвые души». Писатель-критика-читатель. 2-е изд., испр. и доп. М.: Книга, г987. 350 с. Манн Ю.В. Зачем сожжен второй том «Мертвых душ»... // Известия Российской академии наук. Сер. Лит. и яз. М., 2009. Т. 68, № 2. С. 42-47. Манн Ю.В. Гоголь. Книга третья: Завершение пути. I845-1852. М.: РГГУ, 2013. $496 \mathrm{c.}$

24 Материалы по истории русской литературы и культуры. И.С. Аксаков в Ярославле. По неизданным письмам к нему С.Т. Аксакова и его семьи. Сообщил А.А. Дунин // Русская мысль. І9І5. № 8. С. 89-і3г.

25 Мельников П.И. (Андрей Печерский). В лесах. М.: Эксмо, І998. 942 с.

26 Образиов Ф., протоиерей. О. Матфей Константиновский, протоиерей Ржевского собора (I4 апреля I857 г.) по моим воспоминаниям // Тверские Епархиальные ведомости. І902. № 5, І марта. С. І28-І47.

27 Осповат А.Л. И.С. Аксаков // Русские писатели. I800-I9I7. Биографический словарь. М.: Сов. энциклопедия, І989. Т. г. С. 29-32.

28 Паламарчук П.Г. Список уцелевших от сожжения рукописей Гоголя // Гоголь. История и современность. М.: Советская Россия, І985. С. 484-493.

29 Русский архив. І866. № 4. Стб. 627.

30 Селезнев Н. Старообрядцы XVIII в. и «асирские христиане» Японии // Волшебная Гора: Традиция, религия, культура. М.: Волшебная гора, 2006. Вып. XII. C. I8I-I86.

3I Силантьева О.Ю. Страна Кокань и Шлараффия во французской и немецкой литературах XVIII-XIX вв.: дис. ... канд. филол. наук. М., 2006. 297 с.

32 Смирнова-Россет А.О. Дневник. Воспоминания / Изд. подгот. С.В. Житомирская. М.: Наука, І989. 789 с.

33 Строев А.Ф. Мифы о Сибири в эпоху Просвещения // Сибирско-французский диалог XVII-XX веков и литературное освоение Сибири. Материалы международного научного семинара / под ред. Е.Е. Дмитриевой, О.Б. Лебедевой, А.Ф. Строева. М.: ИМЛИ РАН, 20І6. С. 33-48.

34 Хетсо Г. Что случилось со вторым томом Мертвых душ? // Scando-Slavica. I989. Т. 35. Р. $\mathrm{I}_{37-\mathrm{I} 38 .}$

35 Хетсо Г. Что случилось со вторым томом Мертвых душ? // Вопросы литературы. I990. № 7. С. I28-I39. 
36 Чижевский Д.И. Неизвестный Гоголь // Чижевский Д.И. Избранное: в 3 т. М.: Русское зарубежье, Русский путь, 2007. Т. 3. С. 734-765.

37 Чистов К.В. Русские народные социально-утопические легенды XVII-XIX вв. М.: Наука, I967. 342 с.

38 Benz E. Das Recht auf Faulheit, oder die Friedliche Beendigung des Klassenkampfes // Lafargue-Studien. Stuttgart: Editions Alpha, I974. P. 9I-I08.

39 Burat de Gurgy H. Voyage au pays de Cocagne. Paris: J. Vermot, I863. II6 p.

40 Hervilly E. d'. A Cocagne! Aventures de MM. Gabriel et Fricontin. Paris: A. Lemerre, I898. $358 \mathrm{p}$.

4I Kjetsaa G. Soviet Views on Gogol Today // Literature, culture and society in the modern age: In honor of Joseph Frank. Stanford, I992. Part II. (Stanford Slavic Studies. Vol. 4:2). P. 455-458.

42 Kluge R.-D. Sollte Čiçikov nach Sibirien verbannt warden? Mutmassungen über Fortsetzung und Schluss von N.V. Gogol`s “Toten Seelen” // Tübinger geographische Studien. Festschrift für Adolf Karger. I989. Heft I. S. 447-45I.

43 Le GoffJ. L’utopie médiévale: le pays de cocagne // Revue européene des sciences sociales. T. 27. N 85. Genève, 1989. P. 276-277.

44 Maguire R. A. Exploring Gogol. Stanford: Stanford U.P., I994. 34I p.

45 Müller $M$. Das Schlaraffenland. Der Traum von Faulheit und Müßiggang. Wien: Edition Brandstätter, I984. I86 p.

46 Schreier H. Gogol`s religiöses Weltbild und sein literarisches Werk. Zur Antagonie zwischen Kunst und Tendenz. München: Sagner, I977. I23 p. 


\section{References}

I Aksakov I. O sluzhebnoy deyatel'nosti v Rossii (pis'mo k chinovniku) [On official activity in Russia (letter to the official)]. Chelovek, I993, no I, pp. 70-72. (In Russ.) Aksakov I.S. Pis'ma k rodnym. I849-I856 / Izd. podgot. T.F. Pirozhkova [Letters to relatives. I849-I856 / T. Pirozhkova (ed.)]. Moscow, Nauka Publ., I994. 653 p. (In Russ.)

3 Aksakov S.T. Istoriya moyego znakomstva s Gogolem / Izd. podgot. Ye.P. Naselenko i Ye. A. Smirnova [History of my acquaintance with Gogol / E.P. Naselenko and E. A. Smirnova (ed.)]. Moscow, Izd-vo Akademii nauk SSSR Publ., I960. 294 p. (In Russ.)

Balakshina Yu.V. Byla li uslyshana “chistoserdechnaya povest”" N.V. Gogolya? Istoriya rasprostraneniya "Avtorskoy ispovedi” v spiskakh (K postanovke problemy) [Was the "upright story" of N.V. Gogol heard? The history of the circulation of The Author's Confession in the lists (Stating the problem)]. N.V. Gogol'. Materialy i issledovaniya [N.V. Gogol: Materials and research]. Moscow, IMLI RAN Publ., 2009, issue 2, pp. I60-I72. (In Russ.)

5 Belinskiy V.G. Polnoye sobraniye sochineniy: $v$ I3 $t$. [Complete works: in 13 vols.] Moscow, Izd-vo Akademii nauk SSSR Publ., I953-I959. (In Russ.)

6 Bocharov S.G. Geneticheskaya pamyat' literatury [Genetic memory of literature]. Moscow, RGGU Publ., 20I2. 34I p. (In Russ.)

Bukharev A.M. Tri pis'ma k N.V. Gogolyu, pisannyye v I848 godu [Three letters to N. Gogol, written in I848]. St. Petersburg, Tip. Morskogo ministerstva Publ., I860. 260 p. (In Russ.) Vidugirite I. Geograficheskoye voobrazheniye. Gogol' [Geographic imagination. Gogol]. Vil'nyus, Vil`nyusskij un-t Publ., 20I5. 294 p. (In Russ.)

9 Vishlenkova Ye. Chelovecheskoye raznoobraziye v lokal'noy perspektive: "bol'shiye teorii” i empiricheskiye znaniya (Kazan', pervaya polovina XIX veka) [Human diversity in the local perspective: "big theories" and empirical knowledge (Kazan, first half of the $\mathrm{I}^{\text {th }}$ century)]. Ab imperio, 2009, no 3, pp. 245-345. (In Russ.) Vyderzhki iz starykh bumag Ostaf'yevskogo Arkhiva. Pis'ma k kn. P.A. Vyazemskomu [Excerpts from the old papers of the Ostafyev Archive. Letters to Prince P.A. Viazemsky]. Russkiy arkhiv, I866, no 7, pp. I08I-Io82. (In Russ.) Gippius V. Gogol [Gogol]; Zenkovsky V. N.V. Gogol [Gogol] (preface., comp. L. Allen). St. Petersburg, Logos Publ., I994. 343 p. (In Russ.) Gogol'v vospominaniyakh sovremennikov [Gogol in the memoir of his contemporaries]. Moscow, GIKHL Publ., I952. 7I9 p. (In Russ.)

I3 Gogol'v vospominaniyakh, dnevnikakh, perepiske sovremennikov: $v 3 t$. [Gogol in the memoir, diaries, and correspondence of his contemporaries: in 3 vols.] Moscow, IMLI RAN Publ., 2OII-20I3. (In Russ.) 
I4 Gogol' N.V. Polnoye sobraniye sochineniy: $v$ I4 t. [Complete Works: in I4 vols.]. $<$ B.m.>: Izd-vo AN SSSR Publ., I937-I952. (In Russ.)

I5 [Gogol' N.V.] Sochineniya i pis'ma N.V. Gogolya: $v 4$ t. Izdaniye P.A. Kulisha [Works and letters of N.V. Gogol: in 4 vols. Ed. P. Kulish ]. St. Petersburg, V Tipografii Imperatorskoy akademii nauk Publ., I857. (In Russ.)

I6 [Gogol' N.V.] Sochineniya Nikolaya Vasil'yevicha Gogolya, naydennyye posle yego smerti. Pokhozhdeniya Chichikova, ili Mertvyye dushi. Poema N.V. Gogolya. Tom vtoroy. (5 glav) [Works by Nikolay Vasilyevich Gogol found after his death. Chichikov's Adventures, or Dead Souls. Poem N.V. Gogol. Volume two. (5 chapters)]. Moscow, V Universitetskoy Tipografii Publ., I855. 304 p. (In Russ.)

I7 Dmitriyeva Ye. Prodolzheniye "Mertvykh dush": spetsifika natsional'noy utopii [A Sequel to "Dead Souls": Specificity of the National Utopia]. Ostrova lyubvi BorFeda: Sbornik k 9o-letiyu Borisa Fedorovicha Yegorova [Isles of Love BorFed: In honor of the $90^{\text {th }}$ anniversary of Boris Yegorov], ed. A.P. Dmitriev and P.S Glushakov)].

St. Peterburg, Rostok Publ., 2016, pp. 338-345. (In Russ.)

I8 Dmitriyeva Ye.Ye. "Mne nuzhno pobol'she prochest' o Sibiri”: russkiy Zapad versus rossiyskiy Vostok v mifopoetike Gogolya ["I need to read more about Siberia”: Russian West versus Russian East in Gogol's mythopoetics]. Dialog kul'tur: poetika lokal'nogo teksta. Materialy IV Mezhdunarodnoy nauchnoy konferentsii [Dialogue of cultures: Poetics of the local text. Proceedings of the $4^{\text {th }}$ International scholarly conference], ed P.V. Alekseev. Gorno-Altaysk, Gorno-Altaiskij Universitet, 20I4, pp. I34-I44. (In Russ.)

I9 Durylin S. N. "Delo” ob imushchestve Gogolya [“The Case” of Gogol's Property]. N.V. Gogol'. Materialy i issledovaniya: $v 2 t$. [N.V. Gogol. Materials and research: in 2 vols.], ed. V. V. Gippius. Moscow, Leningrad, Izd. AN SSSR Publ., I936, vol. I, pp. 359-374. (In Russ.)

20 Zen'kovskiy V. N.V. Gogol' [N.V. Gogol]. Gippius V. Gogol'; Zen'kovskiy V. N.V. Gogol' [Gippius V. Gogol; Zenkovsky V. N.V. Gogol]. St. Petersburg, Logos Publ., I994, pp. I89-338. (In Russ.)

2I Mann Yu. V poiskakh zhivoy dushi: "Mertvyye dushi”. Pisatel'-kritika-chitatel' [In search of a living soul: "Dead Souls.” Writer-critic-reader]. 2nd ed. Moscow, Kniga Publ., I987. 350 p. (In Russ.)

22 Mann Yu.V. Pochemu sgorel vtoroy tom "Mertvyye dushi” [Why was the second volume of Dead souls burned]. Vestnik Rossiyskoy akademii nauk, ser. lit. i yaz. Moscow, 2009, vol. 68, no 2, pp. 42-47. (In Russ.)

23 Mann Yu.V. Gogol. Kniga tretja: Zavershenie puti. I845-I852 [Gogol. The third book: The end of the road. I845-I852]. Moscow, RGGU Publ., 20I3. 496 p. (In Russ.)

24 Materialy po istorii russkoy literatury i kul'tury. I.S. Aksakov v Yaroslavle. Po neizdannym pis'mam k nemu S.T. Aksakova i yego sem’i. Soobshchil A.A. Dunin [Materials on the history of Russian literature and culture. I.S. Aksakov in Yaroslavl. 
Unpublished letters to him by S.T. Aksakov and his family. Reported by A.A. Dunin]. Russkaya mysl', I9I5, no 8, pp. 89-I3I. (In Russ.) Melnikov P.I. (Andrey Pechersky). V lesakh [In the woods]. Moscow, Eksmo Publ., I998. 942 p. (In Russ.)

26 Obraztsov F., protoiyerey. O. Matfey Konstantinovskiy, protoiyerey Rzhevskogo sobora (I4 aprelya I857 g.) po moim vospominaniyam [Matthew Konstantinovsky, Archpriest of the Rzhev Cathedral (April I4, I857), according to my memories]. Tverskiye Yeparkhial'nyye vedomosti, I902, no 5, The Ist of March, pp. I28-I47. (In Russ.)

27 Ospovat A.L. I.S. Aksakov [I.S. Aksakov]. Russkiye pisateli. I80o-I9I7. Biograficheskiy slovar' [Russian writers. I800-I9I7. Biographical dictionary]. Moscow, Izd. Sovetskaja encyklopedija Publ., I989, vol. I, pp. 29-32. (In Russ.) Palamarchuk P.G. Spisok utselevshikh ot sozhzheniya rukopisey Gogolya [List of Gogol's manuscripts that survived from burning]. Gogol'. Istoriya i sovremennost' [Gogol. History and modernity]. Moscow, Sovetskaja Rossija Publ., I985, pp. 484-493. (In Russ.) Russkiy arkhiv, I866, no 4, column 627. (In Russ.)

30 Seleznev N. Staroobryadtsy XVIII v. i "asirskiye khristiane" Yaponii [Old Believers of the $18^{\text {th }}$ century and "Asir Christians" of Japan]. Volshebnaya Gora: Traditsiya, religiya, kul'tura [Magic Mountain: Tradition, religion, culture]. Moscow, Volshebnaya gora Publ., 2006, issue I2, pp. I8I-I86. (In Russ.)

3I Silant'yeva O. Strana Kokan' i Shlaraffiya vo frantsuzskoy i nemetskoy literaturakh XVIIIXIX vv.: dissertatsiya ... kandidata filologicheskikh nauk [Country Kokany and Shlarafia in French and German Literatures of the $18^{\text {th }}-19^{\text {th }}$ centuries... PhD thesis]. Moscow, 2006. 297 p. (In Russ.)

32 Smirnova-Rosset A.O. Dnevnik. Vospominaniya / Izd. podgot. S.V. Zhitomirskaya [Journal. Memoir. Ed. S.V. Zhitomirskaya]. Moscow, Nauka Publ., I989. 789 p. (In Russ.)

33 Stroev A.F. Mify o Sibiri v epokhu Prosveshcheniya [Myths about Siberia in the Enlightenment]. Sibirsko-frantsuzskiy dialog XVII-XX vekov i literaturnoye osvoyeniye Sibiri. Materialy mezhdunarodnogo nauchnogo seminara [Siberian-French Dialogue of the $18^{\text {th }}-2 \mathrm{O}^{\text {th }}$ centuries and the literary development of Siberia. Proceedings of the international workshop], eds. E.E. Dmitrieva, O.B. Lebedeva, A.F. Stroev. Moscow, IWL RAS Publ., 20I6, pp. 33-48. (In Russ.)

34 Khetso G. Chto sluchilos' so vtorym tomom Mertvykh dush? [What happened to the second volume of Dead souls?] Scando-Slavica, I989, vol. 35, pp. I37-138. (In Russ.)

35 Khetso G. Chto sluchilos' so vtorym tomom Mertvykh dush? [What happened to the second volume of Dead souls]. Voprosy literatury, I990, no 7, pp. I28-I39. (In Russ.)

36 Chizhevskiy D.I. Neizvestnyi Gogol' [Unknown Gogol]. Chizhevskiy D.I. Izbrannoye: $v 3 t$. [Selected works: in 3 vols.]. Moscow, Russkoye zarubezh'ye, Russkiy put' Publ., 2007, vol. 3, pp. 734-765. (In Russ.) 
37 Chistov K.V. Russkiye narodnyye sotsial'no-utopicheskiye legendy XVII-XIX vv. [Russian folk socio-utopian legends of the $\mathrm{I} 7^{\text {th }}-19^{\text {th }}$ centuries]. Moscow, Nauka Publ., I967. 342 p. (In Russ.)

38 Benz E. Das Recht auf Faulheit, oder die Friedliche Beendigung des Klassenkampfes. Lafargue-Studien. Stuttgart, Editions Alpha, I974, pp. 9I-I08. (In German)

39 Burat de Gurgy H. Voyage au pays de Cocagne. Paris, J. Vermot, I863. II6 p. (In French)

40 Hervilly E. d'. A Cocagne! Aventures de MM. Gabriel et Fricontin. Paris, A. Lemerre, I898. 358 p. (In French)

4I Kjetsaa G. Soviet Views on Gogol Today Literature, culture and society in the modern age: In honor of Joseph Frank. Stanford, I992. Part II (Stanford Slavic Studies. Vol. 4:2), pp. 455-458. (In English)

42 Kluge R.-D. Sollte Čiçikov nach Sibirien verbannt werden? Mutmassungen über Fortsetzung und Schluss von N.V. Gogol`s “Toten Seelen”. Tübinger geographische Studien. Festschrift für Adolf Karger. 1989. Heft I. S. 447-45I. (In German)

43 Le Goff J. L'utopie médiévale: le pays de cocagne. Révue européene des sciences sociales, t. 27, N 85. Genève, 1989, pp. 276-277. (In French)

44 Maguire R.A. Exploring Gogol. Stanford, Stanford U.P., I994. 34I p. (In English)

45 Müller M. Das Schlaraffenland. Der Traum von Faulheit und Müßiggang. Wien, Edition Brandstätter, I984. I86 p. (In German)

46 Schreier H. Gogol`s religiöses Weltbied und sein literarisches Werk. Zur Antagonie zwischen Kunst und Tendenz. München, Sagner, I977. I23 p. (In German) 
УДК 821.I6I.I

ББК $83.3(2 \mathrm{Poc}=\mathrm{Pyc}) 52$

\section{ЧАСОВНЯ В РОМАНЕ}

И.С. ТУРГЕНЕВА «НАКАНУНЕ»:

ИСТОРИЯ, ЛИТЕРАТУРА, МИФ

(К 200-ЛЕТНЕМУ ЮБИЛЕЮ ИВАНА

СЕРГЕЕВИЧА ТУРГЕНЕВА)

\author{
(C) 2018 г. М. С. Акимова \\ Институт мировой литературы \\ им. А. М. Горького \\ Российской академии наук, \\ Москва, Россия \\ Дата поступления статьи: 28 февраля 2018 г. \\ Дата публикации: 25 сентября 2018 г. \\ DOI: I0.22455/2500-4247-20I8-3-3-I44-I6I
}

Аннотация: В статье рассматривается история возникновения мифа о часовне из романа И.С. Тургенева «Накануне». В г903 г. в популярном журнале «Нива» появилась заметка, в которой существовавшую в Кунцеве каменную часовню ошибочно связывали с часовней «встречи и объяснения» главных героев. События романа действительно разворачиваются в Кунцеве, где Тургенев бывал и которое хорошо знал. Отсюда, очевидно, и произошла ошибка, которая была выявлена уже в каталоге к тургеневской выставке г909 г. Однако миф получил продолжение. В І958 г. по следам героев романа отправился юрист, журналист И.Г. Шумский, увлеченный творчеством Тургенева. Он нашел эту часовню, сделал уникальную фотографию и написал две заметки, которые не были опубликованы и хранятся в Рукописном Отделе Пушкинского Дома. Казалось бы, заметки Шумского не имеют большой ценности, поскольку повторяют и развивают недостоверную информацию. Однако на деле это не так. Миф о якобы «тургеневской» часовне послужил сохранению памяти о ней, уже разрушенной. Кроме того, появление и существование этого мифа интересно само по себе. Здесь, на стыке филологии, психологии, культурологии, мы имеем дело с примером психологической потребности человека - и далеко не всегда необоснованной - «привязать» текст к месту, с попыткой - и далеко не всегда неудачной - осмыслить художественный объект как реальный, а литературное произведение - как исторический источник.

Ключевые слова: Тургенев, Шумский, часовня, Кунцево, Давыдково, роман «Накануне», легенда, миф.

Информация об авторе: Мария Сергеевна Акимова - кандидат филологических наук, старший научный сотрудник, Институт мировой литературы им. А.М. Горького Российской академии наук, ул. Поварская, д. 25 а, І2Іо69 г. Москва, Россия.

E-mail: makanja@list.ru

Для цитирования: Акимова М.С. Часовня в романе И.С. Тургенева «Накануне»: история, литература, миф (К 2оо-летнему юбилею Ивана Сергеевича Тургенева) // Studia Litterarum. 20I8. T. 3, № 3. С. I44-I6I.

DOI: I0.22455/2500-4247-20I8-3-3-I44-I6I 


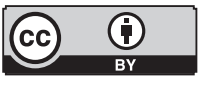

This is an open access article distributed under the Creative Commons Attribution 4.0 International (CC BY 4.0)

\section{THE CHAPEL IN TURGENEV'S NOVEL ON THE EVE: HISTORY, LITERATURE, MYTHOLOGY}

\author{
(C) 20I8. Maria S. Akimova \\ A.M. Gorky Institute of World Literature \\ of the Russian Academy of Sciences, \\ Moscow, Russia \\ Received: February 28, 2018 \\ Date of publication: September 25, 2018
}

\begin{abstract}
The article examines the history of the chapel myth in the novel by Ivan S. Turgenev On the Eve. In 1903, a popular magazine Niva published a note mistakenly claiming that the Kuntsevo stone chapel was the one where Turgenev's main characters "met and explained themselves.” The novel indeed takes place in Kuntsevo: Turgenev visited Kuntsevo and knew it well. This led to a mistake that was corrected in the catalog to Turgenev's exhibition in I909. However, the myth continued to linger on. In I958, lawyer and journalist I.G. Shumsky followed the route of Turgenev's fictional characters fascinated by the works of the former. In Kuntsevo that was still "untouched" by Moscow, he found this chapel, took a unique photo of it, and wrote two notes that were never published yet were archivized in the Manuscript Department of the Russian Literature Institute (the Pushkin House). It might appear that Shumsky's notes have no value as they repeat and develop the fake story. However, this not the case: now, in the $2 \mathrm{I}^{\text {st }}$ century, they are invaluable evidence of the history of Moscow. The myth of Turgenev's chapel served to preserve the memory of the chapel itself that had been destroyed. In addition, the emergence and existence of this myth is interesting in its own terms. Here the interests of philology, psychology, and cultural studies converge. Indeed, we are dealing with a person's psychological need - that is not always unreasonable - to "tie" the text to a specific place; we witness an attempt - not always unsuccessful - to reconsider an art object as "real" and to see a literary work as historical source.
\end{abstract}

Keywords: Turgenev, Shumsky, chapel, Kuntsevo, Davydkovo, novel On the Eve, legend, myth. Information about the author: Maria S. Akimova, PhD in Philology, Senior Researcher, A.M. Gorky Institute of World Literature of Russian Academy of Sciences, Povarskaya 25 a, I21069 Moscow, Russia.

E-mail: makanja@list.ru

For citation: Akimova M.S. The Chapel in Turgenev's Novel On the Eve: History, Literature, Mythology. Studia Litterarum, 2018, vol. 3, no 3, pp. I44-I6I. (In Russ.) DOI: I0.22455/2500-4247-2018-3-3-I44-I6I 


\section{В Рукописном Отделе Пушкинского дома хранятся любопытные архивные} документы, которые до сего момента не привлекали внимания исследователей. Они находятся в архиве Иосифа Григорьевича Шумского (I885I96I) - юриста, журналиста, увлекавшегося творчеством И.С. Тургенева и написавшего о нем ряд небезынтересных, хотя и неоконченных работі.

I Шумский Иосиф Григорьевич (г885-196I), юрист, журналист, автор работ о И.С. Тургеневе. ИРЛИ Ф. 740; 63 ед. хр.; 1953-1964. Статьи «И.С. Тургенев и Полина Виардо», «И.С. Тургенев и музыка», «Музыкальный мир юного Тургенева», «По поводу музыкальной культуры Тургенева», «И.С. Тургенев и В.В. Стасов», «Тургенев и русская народная песня», «О происхождении сюжета комедии И.С. Тургенева “Нахлебник”, «И.С. Тургенев и евреи», «Пушкин» и подготовительные материалы к ним, заметки, рецензии, сценарии, переводы с англ. яз. романа Л. Хьюза «Смех сквозь слезы», стихотворений С.-Т. Колриджа, Т. Гуда, А. Теннисона, Ч. Маккея, Л. Гента, перевод с немецкого яз. книги Г. Брандеса «Воспоминания. Детство и юность», автобиография, списки трудов, письма. Согласно биографической справке ИРЛИ к Ф. 740, № I-63, «И.Г. Шумский родился I8 марта І885 г. в Шумске Волынской губернии в семье служащего. В І893 г. умер его отец, оставив вдову с двумя детьми, из которых Иосиф был младшим. Семья часто меняла места жительства: в І893 г. - Одесса, в I894 г. - Варшава, затем Николаев, Керчь, Батум. В Керчи в I9OI г. Шумский сдал экзамены за 4 класса гимназии, в 1905 г. - экстерном сдал на аттестат зрелости. В 1906 г. он поступил в Одесский университет, а в І9Іг г. окончил его. С осени того же года был зачислен в помощники присяжного поверенного при Одесской Судебной Палате. Имея юридическое образование, Шумский, однако, долго не имел работы по специальности. С г919 по г92І гг. он был зачислен к Коллегию правозаступников в Староконстантиновском уезде Волынской губернии и поселился с женой - Лидией Николаевной (урожд. Ульянова, с І918 - Шумская) в местечке Купели Волынской губернии. В г923 г. Шумские переехали в Одессу, где Иосиф Григорьевич работает в профсоюзных органах Местран и Рабис. С г93І по I938 гг. Шумский живет в Москве, служит в разных учреждениях в качестве юрисконсульта; в I938 г. был принят в Московскую городскую коллегию защитников. С ранней молодости занятиям юриспруденцией сопутствовал постоянный интерес Шумского к литературе и искусству. С 1929 г. он выступает в газетах и журналах, главным образом, как театральный рецензент. Занятия литературой стали постоянными с конца 1950-х гг. Им был собран большой материал к незавершенным им работам об И.С. Тургеневе (главным образом, «И.С. Тургенев и музыка»). 
Среди этих бумаг хранится неоконченная черновая рукопись «Мои поиски часовенки из “Накануне”».

<...> Уже несколько месяцев т.н. в поисках материалов, относящихся к жизни и литературной работе Тургенева, я наткнулся на заметку в одном из № журнала «Нива» за І9о8 г. (г903. - М.А.), в которой рассказывается о том, что на берегу р. Сетунь при впадении ее в р. Москву в 2 верстах от Кунцева (по направлению к г. Москве) стоит часовенка, в которой состоялось свидание героев романа «Накануне»: Елены и Инсарова. Заметка эта иллюстрируется фотоснимком этой часовенки, обнесенной железной решеткой. Автор заметки выражал удивление и сожаление по поводу того, что часовенка эта, всеми забытый литературный памятник, почти разрушена. Автор подчеркивает необходимость позаботиться о сохранении этой литературной реликвии.

Эти строки возбудили во мне желание разыскать эту часовенку, убедиться, «жива» ли она или нет и, если окажется возможность, познакомить советских людей с одним из интереснейших памятников литер. деятельности Тургенева. Хотя о нем порой [довольно часто - зачеркнуто] появляются небольшие заметки в разных литер. органах, он на деле порядочно забыт. И даже 75-летняя дата со дня его смерти, как сообщил мне один режиссер драм. театров, - не будет широко отмечена вниманием.

Можно сказать - обидно, что [вставлено - великий] писатель прошлого века, краса и гордость русской классики, до наших дней не удостоен никакого памятника. А сколько раз в нашей прежней журналистике, начиная с похорон И.С. на Волковом кладбище в Петербурге и позднее - в дни разных юбилейных дат - отмечалось, что недалек тот день, когда не только на родине писателя (в Орле и Орл. области), но и <во> всех городах русского государства будут воздвигнуты монументы в честь автора «Отцов и детей». Тем более обидно, что в свое время даже «Анизы»(?) города Орла (члены Гор. Думы и Двор. общества) считали недостойным для себя чествование памяти великого писателя - автора «памфлета» - «Дым», в котором двор. общество и [нрз] знать выведены с такой уничтожающей сатирической силой.

В печати (журналы «Русская литература» и «В мире книг») были напечатаны несколько заметок и рецензий, связанных с этой темой. Умер в г96г г. Его архив поступил в Пушкинский Дом АН СССР в І97 … г. от вдовы Л. Н. Ш.». 
Вот почему я нашел необходимым проведать, в каком состоянии сейчас этот редкий памятник, прочно живущий в душе тех, кто читал романы Тургенева.

Несколько времени т.н. я отправился отыскивать эту часовенку, не проверив заметки в «Ниве», в гор. Кунцево 2 . Я поехал на теплоходе на р. Москве и, прибыв на пристань, стал расспрашивать людей постарше, не помнят ли они, где была тут часовенка.

Мне удалось тогда набресть на одного старого человека, лет 7о, который объяснил, что вот тут, внизу, на берегу, в небольшом ущелье действительно была часовенка в дни его юности. Тут протекал ключ, у которого останавливались прохожие, чтобы утолить свою жажду чудесной его водой. Много лет спустя, чуть ли не в советское время, часовенка моя пришла в упадок и ее постепенно по камешку разобрали. А до того многие ребята не раз забирали из кружки пожертвования, которые в нее кидали прохожие по призыву какого-то человека, вывесившего плакат.

Человек этот вспоминал о помещике [пропуск]³, который владел в наших лесах имением. Он-де наделял деньгами всех молодых людей, которые уходили на воен. службу, и семью его 4 .

На этом заметка обрывалась. Была ли она не окончена или же часть была утрачена, сказать сложно, но составить полное представление о состоянии часовни на момент посещения ее Шумским не представлялось возможным. Правда, к рукописи были приложены две фотографии:

I. фотография часовни на I908 г. (г903. - M.А.) из статьи «Воспоминание об И.С. Тургеневе (к 2о-летию со дня кончины)»5 [A photo of the chapel (I908) from the essay "Memoir of Ivan S. Turgenev" (On the 20-year anniversary of his death)];

2 Село Кунцево со временем превратилось в дачный поселок, с 1925 по 1960 г. (год вхождения Кунцева в состав Москвы) имел статус города.

3 Очевидно, речь идет о Нарышкиных или Солдатенковых, владевших в разное время усадьбой «Кунцево». Также речь может идти о ком-то из Шереметевых: деревня Давыдково была тесно связана с судьбой и историей соседнего имения Волынское, которым владели в XIX в. Шереметевы [4, с. I60-I6I].

4 ИРЛИ Ф. 740. № 24, Шумский Иосиф Григорьевич. «Мои поиски часовенки из “Накануне” 》. Заметка. Черновая неоконченная рукопись. Приложение: фотографии (2) с изображением часовни в 1908 и 1958 гг. I958, июля г2. 4 Л. Л. І-2,2 об. Внизу на Л. 2 об подпись: «Сергей Егорович Ремезов».

5 Часовня (близ Кунцева, под Москвой), в которой встретилась Елена с Инсаровым - в романе «Накануне». По фот. И. Алексеева авт. «Нивы». Об. Нива, І904. № 34. С. 687. ИРЛИ Ф. 74 О. № 24. Л. 3 . 
2. фотография от І2 июля г958 г., где часовня уже используется под нефтелавку ${ }^{6}$ [A photo of the chapel on July I2, I958. The chapel is aready in use as an oil pump].
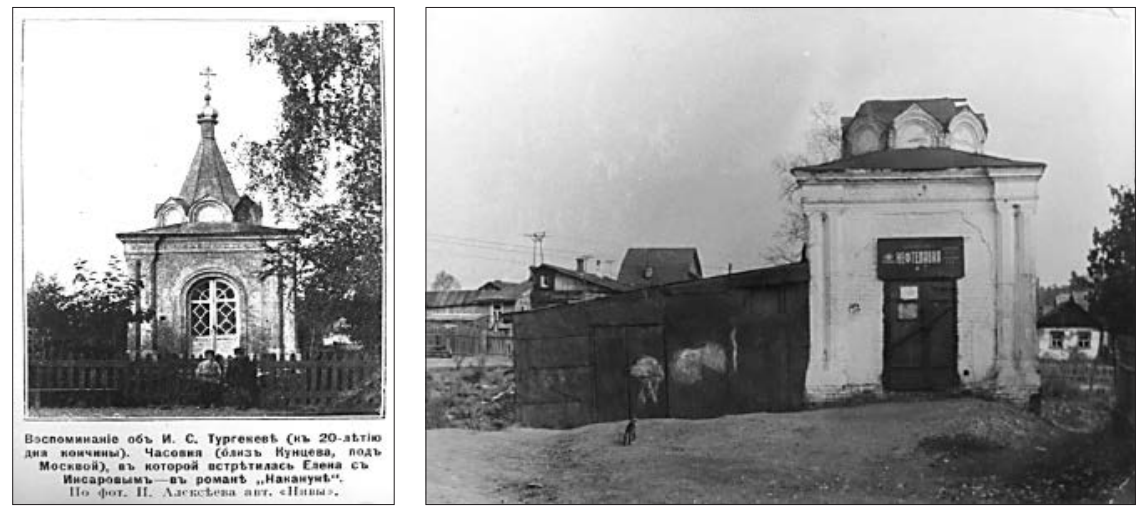

Между тем в архиве И.Г. Шумского нашелся еще один интересный документ - черновая рукопись его отзыва о телепередаче (II марта < $959>$ г.) фрагментов нового фильма по роману И.С. Тургенева «Накануне»7. Рукопись, несмотря на «черновой» внешний вид (написана на оборотах машинописного текста, также связанного с Тургеневым), представляет собой вполне законченный подписанный текст, который дополняет наши знания о кунцевской часовне и, кроме этого, призывает к мемориализации тургеневских мест и восстановлению памяти о Тургеневе в целом.

II марта с.г. зрителям московского телевидения были показаны некоторые эпизоды из готовящейся постановки под руководством режиссера Петрова фильма «Накануне» по роману И.С. Тургенева. Этот фильм явится, несомненно, замечательной данью памяти великого русского писателя, I40-летие (75-летие со дня смерти) со дня рождения которого советская общественность отмечала полгода тому назад. Среди эпизодов, которые должны войти в эту постановку, тов. Петров упомянул в своем пояснительном слове

6 ИРЛИ. Ф. 740. № 24. Л. 4.

7 Шумский И.Г. Отзыв его о телепередаче (г марта < $959>$ г.) фрагментов нового фильма по роману И.С. Тургенева «Накануне» Черновая рукопись // ИРЛИ, Ф. 740. № 26, Архив И.Г. Шумского. 3 л. 
сцену свидания Елены и Инсарова в часовенке близ Кунцева. Автор сценария и режиссер, к сожалению, не указал, будет ли эта сцена снята в специально построенном павильоне или в том месте, где это свидание происходило в действительности, согласно описанию Тургенева. Слушая это сообщение, мы вспомнили о том, что в юбилейные тургеневские дни мы посетили ту местность, где когда-то стояла эта часовенка, чтобы проверить, сохранилась ли она до наших дней или нет. А ведь этот интересный литературный памятник, как видно из опубликованного в г903 г. в журнале «Нива» снимка, еще продолжал существовать, хотя уже со следами заметного разрушения. Автор анонимной заметки высказывал опасение, что эта замечательная культурная реликвия может в скором времени совершенно исчезнуть, если не будут приняты меры к ее сохранности. Естественно, что нам захотелось посещением тех мест, где находилась часовенка, почтить память любимого писателя и проверить к тому же, что сталось с этим литературным памятником.

Поиски часовенки увенчались успехом: мы нашли ее в селе Давыдовка, в нескольких километрах от Кунцева, в сторону Москвы, на высоком берегу р. Сетунь, впадающей в Москву-реку. Своей фасадной стороной часовенка выходит на Театральную улицу, тыл ее упирается в обрыв, ведущий к пологому берегу реки, узенькой ленточкой тянущейся по направлению к столице. Правая сторона расположена возле дачных поселковых строений Давыдково. Но весь внешний вид часовенки производит очень грустное впечатление.

Читатель настоящих строк может убедиться из прилагаемых фотоснимков, какова была эта часовенка через полвека после создания Тургеневым его романа «Накануне» и какою она дошла до наших дней. Если на снимке г903 г. часовенка обрамлена раскидистыми ветвями и прекрасной железной решеткой, то в настоящее время она предстает перед нами «обезглавленной», без всякой ограды и зеленого наряда ${ }^{8}$. Нет более прелестного купола, под которым, вероятно, висел колокол, а ко входным дверям прибита жалкая железная вывеска с надписью «Нефтелавка», за которой скрываются некогда застекленные двери. А рядом с часовней, совершенно вплотную к 8 Очевидно, Шумский предполагал приложить фотографии из неоконченной заметки к этой, более актуальной.

9 Нефтелавка (истор.) - магазин, в котором продавали керосин и другие продукты, производимые из нефти. У М. Булгакова в романе «Мастер и Маргарита» (1929-I940) в нефтелавке «кружками продают керосин и жидкость от паразитов во флаконах». 
ней, примкнул железный сарай, предназначенный, очевидно, для хранения нефтепродуктов.

С помощью старожила, проведшего здесь все свои [дет] годы, нам [вставлено - с трудом] удалось прочесть высеченное на фронтоне торжественное изречение: «Блажен грядый во имя Господне». Эта торжественная надпись свидетельствует о том, что в свое время она приветствовала не мало мимоходящих людей, которые направлялись к реке и оставляли, вероятно, свою посильную лепту.

Теперь, когда наше киноискусство намерено увековечить очарование тех мест, которые описал великий русский писатель в одном из своих замечательных художественных произведений, вновь встает вопрос о принятии срочных мер по восстановлению этого интересного литературного памятника.

Нельзя обойти молчанием тот факт, который отмечен был также выступавшим по телевидению молодым болгарским артистом т. [пропуск] [Любомиром Кабакчиевым. - M.A.], исполняющим роль Инсарова. По словам (артиста), болгарский народ до сих пор очень высоко ценит тот факт, что Тургенев выбрал героем своего романа болгарина (прототипом которого был Катранов), видя в этом произведении доказательство самой тесной духовной связи русского и болгарского народов как в прошлом, так и в настоящем.

Жители деревни Давыдовка, случайно оказавшиеся у часовенки во время нашей фотосъемки, выразили свое горячее желание видеть эту часовенку восстановленной. И.Г. Шумский.

Сцена в часовне, конечно же, в фильме «Накануне» (I959, режиссер В. Петров) есть, как одна из ключевых в романе: в ней происходит объяснение героев. Но снята она в деревянной часовне, и это более соответствует тексту романа: «Елена шла, потупив голову и неподвижно устремив глаза вперед. <...> Крупный дождик закапал, она и его не замечала; но он пошел всё чаще, всё сильнее, сверкнула молния, гром ударил. Елена остановилась, посмотрела вокруг.. К ее счастию, невдалеке от того места, где застала ее гроза, находилась ветхая заброшенная часовенка над развалившимся колодцем. Она добежала до нее и вошла под низенький навес <...>. Она оперлась рукой о ветхое перильце крылечка» [9, с. 233-234].

Легенда же о том, что часовня в Кунцеве и есть та самая часовня встречи и объяснения, родилась (или же, уже родившись, была поддержа- 
на) в очень популярном журнале «Нива». В 34 номере за г903 г. в нем вышла заметка «Воспоминание об И.С. Тургеневе (К 2о-летию со дня его кончины). (С рис. на этой стр.)». В ней с журналистской удалью и однозначностью говорилось:

22-го августа г883 года, ровно 20 лет тому назад, в Буживале, близ Парижа скончался наш знаменитый писатель, Иван Сергеевич Тургенев. Ввиду этой годовщины, мы считаем долгом почтить память незабвенного творца «Дворянского гнезда», «Рудина» и «Записок охотника» и кстати упомянуть об одной очень интересной тургеневской реликвии, находящейся в с. Кунцево, близ Москвы. Всякий, кто читал роман «Накануне», наверное, помнит тот эпизод романа, когда Елена встречается с Инсаровым, после его бегства от нее. Елена идет по дороге близ Кунцева и, застигнутая грозой, укрывается в старой часовне. Спустя некоторое время, она видит проходящего по той же дороге Инсарова, зовет его, - и в часовне происходит их встреча и объяснение.

Вот эта именно часовня, оказывается, существует на самом деле и находится, действительно, близ Кунцева, около деревни Давыдковой, в го-ти верстах от Москвы. Она сохранилась в своем прежнем виде до последнего времени и, по-видимому, не стала даже более ветхой, чем была при Тургеневе... Ветхой она была уже и тогда, и автор «Накануне» описывает ее именно такою: «К ее счастию, невдалеке от того места, где застала ее гроза, находилась ветхая заброшенная часовенка над развалившимся колодцем ${ }^{\text {Iо }}$. Она добежала до нее и вошла под низенький навес».

Часовня построена из кирпича и, вероятно, лишь благодаря этому сохранилась до сих пор. Стены ее, однако, уже во многих местах потрескались. Сквозь стеклянную верхнюю половину ее дверей можно видеть внутренность часовни: несколько икон на стенах, сломанный подсвечник в углу, и ничего больше! Изображения на иконах невозможно разобрать, потому что они представляют собой сплошную черную поверхность. Унынием и даже каким-то мистическим страхом веет от этого покинутого и заброшенного Божьего места...

Ступеньки часовни поросли мхом. Перил, о которых упоминается в романе («Она оперлась рукой о ветхое перильце крылечка»), уже нет и в помине, но зато появилась загородка вокруг часовни.

Iо В Кунцеве по сей день есть несколько источников, но все они расположены довольно далеко от места часовни в Давыдкове. 
Часовня стоит на крутом берегу реки Сетуни, впадающей в Москву-реку. Летом она служит довольно часто местом прогулок и посещений местных дачников, но большинство их, даже и интеллигентные люди, не знают, что эта часовня связана с именем великого писателя. Такова участь всех реликвий подобного рода!

Судя по газетным известиям, в подобном же заброшенном и покинутом виде находится нынче и знаменитая тургеневская усадьба - Спасское-Лутовиново во Мценском уезде: ее продают, и весьма возможно, что она со всеми своими драгоценными воспоминаниями попадет в руки какого-нибудь Колупаева или Разуваева, и тогда всем этим воспоминаниям о Тургеневе конец!

А между тем едва ли какой другой из покойных ныне русских писателей заслужил так много пред русским интеллигентным обществом, как певец и даже создатель общественных настроений в русском обществе, И.С. Тургенев! В его романах ключом бьет современная автору жизнь с ее обстановкой, понятиями, запросами, надеждами и тревогами. Быт крепостных дореформенной России изображен им с необычайной яркостью в «Записках охотника». Не менее ярко схвачены и закреплены навсегда мощною кистью Тургенева те настроения, которые охватывали русское общество в эпоху, предшествующую реформам 6о-х годов, в то время, которое является истинным «Накануне» русской жизни, накануне ее разрыва с прежними формами и понятиями.

Поэтому нам следовало бы хотя теперь, в годовщину кончины И.С. Тургенева, отнестись внимательнее к воспоминаниям о нем! Не мешало бы обратить особое внимание на описываемую заброшенную часовню, реставрировать ее и оградить от возможности разрушения. Пусть эта связанная с романом «Накануне» часовенка, надлежащим образом благоустроенная, отныне явится уже готовым памятником, воздвигнутым нашим вниманием и любовью к памяти И.С. Тургенева, в честь того воспетого им времени, которое подготовило великие реформы шестидесятых годов и, главным образом, освобождение крестьян от крепостного права!

\section{Рядом с заметкой была помещена и фотография часовни ${ }^{\mathrm{II}}$.}

II Часовня (близ Кунцева, под Москвой), в которой встретилась Елена с Инсаровым - в романе «Накануне». По фот. И. Алексеева авт. «Нивы». Нива, I903. № 34, С. 687. URL: http:// www.runivers.ru/bookreader/book48ı1347/\#page/r96/mode/ıup (дата обращения: 27.02.2018). 
В этой заметке многое вызывает сомнения: полная покинутость часовни, достоверность информации о связи с тургеневским романом, время постройки. Так, роман «Накануне» был опубликован в г86о г. Искусствовед И.Е. Печенкин ${ }^{\mathrm{I2}}$ в личной беседе с автором отметил, что «такие формы часовен [с кокошниками и другими элементами в псевдорусском стиле] распространились, конечно, с I870-х». К слову скажем, что с большой долей уверенности можно предположить, что автором проекта часовни был В.О. Грудзин (1824-I894?) - архитектор, инженер, который в конце I860-х - начале г870-х гг. заведовал строительством в большинстве городов Московской губернии, имел обширную частную практику, стал автором нескольких десятков церковных и гражданских построек на территории Москвы и Подмосковья. Так или иначе часовня не то что не могла быть ветхой в конце г850-х гг., но просто-напросто еще не могла появиться. Хотя сама заметка появилась, очевидно, из добрых побуждений - в целях сохранения «места памяти» и памяти о Тургеневе. В истории известны примеры, когда придуманный миф, искусственно созданная легенда места спасали это место от поругания и «мерзости запустения» - скажем, так было с «тютчевским» Мурановом, где Ф.И. Тютчев на самом деле никогда не бывал.

Сомнения в правдивости информации в «Ниве» появились практически сразу после публикации заметки. В І909 г. в Петербурге в Академии наук проходила выставка в память И.С. Тургенева. К ней был издан каталог, в котором данная часовня фигурирует (!): «635. Часовня близ Кунцева, под Москвой, в которой встретились Елена с Инсаровым в романе “Накануне”. По фотографии И. Алексеева, автотипия “Нивы” - “Нива”, г903, № 34 . Из собр. Ф.А. Витберга». Фигурирует часовня, однако, с примечанием: «Сомнительно, чтобы находящаяся в настоящее время в Кунцеве часовня (с которой снята эта фотография) была та самая, о которой говорится в романе Тургенева. - Елена шла по дороге к Берсеневу, а Берсенев жил не в Кунцеве, а возле Кунцева. Часовня стояла невдалеке от той дороги, по которой шла Елена, так что, когда мимо часовни, в которой укрылась Елена, проходил Инсаров, то она могла окликнуть его и остановить. - Изображенная же на C. Іо2 <на > данном рисунке часовня находится в Кунцевском парке, в глу-

I2 Печенкин Илья Евгеньевич - кандидат искусствоведения, доцент, старший научный сотрудник НИИ теории и истории архитектуры и градостроительства (филиал ЦНИИП Минстроя России). 
ши, в стороне от всякой проходной дороги» [5, с. Іог]. Здесь к изложенным выше архитектурным соображениям подключаются и топографические.

Видимо, раз часовня была включена в перечень экспонатов выставки, информация о ней показалась организаторам интересной - или же, в силу популярности легенды о часовне из романа «Накануне», они захотели ее опровергнуть.

Очевидно, что Шумский не был знаком с этим опровержением. Поэтому версия с «тургеневской» часовней в «Ниве» оказалась ему близка. Однако в данном случае интересно, почему сложился этот миф о часовне. Знакомство с историей Кунцева показывает, что образовался он не случайно и имел под собой массу оснований.

Кунцево, живописнейший и до сего дня уголок Москвы, издавна привлекал сюда художников, литераторов, да и рядовых москвичей [6, с. I42-I55]. Усадьба Кунцево на протяжении почти двух веков принадлежала Нарышкиным, затем К.Т. Солдатенкову (первому издателю романа «Отцы и дети»). Здесь бывали (и живали) Екатерина II, прусский король Фридрих Вильгельм III, Александр II с супругой, Н.М. Карамзин, М.Ю. Лермонтов, Л.Н. Толстой $^{\text {I3 }}$ А.И. Герцен, Н.П. Огарев, А.К. Саврасов, И.Н. Крамской, В.Г. Перов, В.В. Пукирев, П.И. Чайковский, М.А. Врубель и многие другие. В г840-е гг. и позже «внешний облик Кунцева быстро менялся. Красота и близость к городу сделали его одним из любимых мест летнего отдыха москвичей. В роще на берегу реки стали появляться дачи, с каждым годом их становилось всё больше. <...> В эти годы в дорогие просторные дачи в кунцевском парке приезжали на лето богатые дворянские семьи, а в окрестных деревнях - Давыдкове, Крылатском и Мазилове - снимали маленькие скромные домики люди среднего достатка ${ }^{\mathrm{I4}}$. Тот, кто не мог или не хотел уезжать далеко от Москвы, охотно проводил лето в Кунцеве» [6, с. I5I-I54], арендуя в кунцевском парке маленькие дачки, окруженные цветниками, окрашенные в яркие веселые цвета.

I3 Л.Н. Толстой поселил в Кунцеве семейство Неклюдовых.

I4 Путеводитель I867 г. сообщал, что в Давыдкове «все крестьянские домики в летнее время заняты москвичами». «Как и Волынское, Давыдково сравнительно рано - уже в середине XIX в., - становится дачным местом. В 40-е гг. XIX в. здесь на даче жил известный историк и общественный деятель Т.Н. Грановский, в I862 г. - поэт А.Н. Плещеев, в I865 г. - писатель А.Ф. Писемский. В І877 г. в окрестностях Давыдкова пишет свои этюды художник И.Н. Крамской. Бывал здесь композитор М.А. Балакирев» [4, с. І6I]; а в советское время там располагалась знаменитая «ближняя» дача И.В. Сталина. 
Сам Тургенев нередко бывал в Кунцеве, хотя сам никогда не жил там подолгу. В.П. Боткин, который проводил там лето I856 г., настойчиво звал его к себе, и Тургенев мечтал о том, чтобы некоторое время перед отъездом за границу пожить в Кунцеве. Но эти планы не осуществились, и в шутливом письме Тургенев писал Боткину, что сможет приехать только на несколько дней:

О, мои Кунцевские друзья,

Вы писали мне виршами, виршами отвечу и я -

Ваше письмо поразило меня в самый центр сердца

И произвело в нем боль язвительнее перца.

Тем она жесточе, что я всё-таки поехать не могу...

Но в Июле я буду непременно - в этом я не солгу.

Это обещание Тургенев сдержал и перед отъездом прожил у Боткина в Кунцеве 2 дня - I3 и I4 июля. <...> В один из своих последних приездов в Москву Тургенев вновь посетил Кунцево, теперь уже в последний раз. Летом I878 г. он был там в гостях у П.М. Третьякова - создателя Третьяковской галереи [6, с. I5I-I54].

В этих местах и разворачиваются события романа «Накануне». Первым же предложением автор поместил и героев, и читателей в атмосферу хорошо знакомого ему места: «В тени высокой липы, на берегу Москвы-реки, недалеко от Кунцева, в один из самых жарких летних дней I853 года лежали на траве два молодых человека» [9, с. I6I] (сегодня в Кунцеве об этом напоминает Тургеневская аллея). В другом месте Тургенев набрасывает картину деревни невдалеке от Кунцева, где снимали дачу Берсенев и Инсаров: «Между деревьями замелькали огни деревеньки <...> она вся состояла из десятка небольших дач. При самом ее начале, направо от дороги, под двумя развесистыми березами, находилась мелочная лавочка; окна в ней были все заперты, но широкая полоса света падала веером из растворенной двери на притоптанную траву и била вверх по деревьям, резко озаряя беловатую изнанку сплошных листьев» [9, с. г8о]. «Небольшой деревянный домик с мезонином, выкрашенный розовой краской, стоял посреди сада и как-то наивно выглядел из-за зелени деревьев» [9, с. І7о], - так описывает Тургенев дом, где жила его героиня, одной фразой передавая характерный облик кунцевских дач. 
Уроженец Орловщины, с 9 лет Тургенев с семьей жил в Москве, хорошо знал ее, ее окрестности и позже описал в своих произведениях. В доме № 37 по Остоженке с I840 по І850 гг. жила В.П. Тургенева, мать писателя, который порой гостил у матушки, и его наблюдения составили канву рассказа «Муму». Дача напротив Нескучного сада, которую родители Ивана сняли на лето г833 г., стала местом действия повести «Первая любовь», а княжна Шаховская, жившая по соседству, - прототипом ее главной героини. Это свойство Тургенева описывать в произведениях знакомые места было известно читающей публике.

В свете этого понятно, откуда могла появиться мифология у кунцевской часовни, а художественный текст - обрасти подробностями реальной географии. Это один из примеров «локального мифа», в одном ряду здесь могут быть поставлены литературно-краеведческие исследования (как специалистов, так и любителей) Москвы Булгакова, Петербурга Достоевского, Парижа Бальзака и Гюго; паломничества к «Лизиному пруду» возле Симонова монастыря в Москве после публикации повести «Бедная Лиза» H.M. Карамзина. Примеры можно продолжать. Данная проблематика активно разрабатывается уже более века: в работах И.М. Гревса и Н.П. Анциферова, их последователей, «литературных краеведов» (см., например, книги Ю.А. Ракова «По следам литературных героев», І974, «Литературные тропы Москвы» Н.М. Молевой, І997). Жанр «литературного путешествия» всегда является востребованным. Н.П. Анциферов говорит даже о «старой психологической потребности» посетить место того или иного знакового события, пусть даже литературного, вымышленного. Он утверждает, что «переживание есть тоже один из путей познания» [I, с. 329], поэтому общение с местом «дает бесконечно много»: оно «облегчает возможность восстановления целостного образа изучаемого явления, конкретизируя его по сохранившимся частям, как бы малы они ни были» [г, с. 329].

В случае с Шумским эта «психологическая потребность» подкреплялась тем, что на І950 г. ландшафты Кунцева находились в хорошей сохранности, о чем свидетельствуют фотографии П.М. Шведова 1947 г. из сборника «Литературное Подмосковье».

Увы, этого нельзя сказать о состоянии на 2018 г. В г96о г. Кунцево входит в состав Москвы, постепенно застраивается (за исключением охранных зон историко-культурного комплекса и памятника садово-паркового 
искусства «Филевский парк», входящего в Природно-исторический парк «Москворецкий»). Главный дом усадьбы Кунцево, в 1976 г. восстановленный в кирпиче после пожара, в 20I4 г. вновь серьезно пострадал в пожаре и ждет серьезного ремонта. Сохранились флигели (с незначительными пристройками), парк, церковь І9І3 г. постройки на месте домового храма Нарышкиных (Суворовский парк, дома 2, 5) [8].

С «тургеневской» часовней все обстоит сложнее. Из записей Шумского мы знаем, что в 1958 г. в здании часовни еще находилась нефтелавка. В І950-І96о-е гг., ввиду активной газификации, нефтелавки были ликвидированы. Соответственно, после І960-х гг. сведения о часовне теряются. Данные Шумского оказались одними из последних. Мы знаем печальную историю второй волны сносов храмов и часовен в хрущевскую «оттепель», а также сносов деревень на месте будущего строительства новых московских районов. «B І96о г. Давыдково входит в черту столицы, а в I966 г. по проекту архитекторов В.Г. Гельфрейха и А.В. Афанасьева оно начинает застраиваться многоэтажными жилыми корпусами. При этом старые деревенские постройки вместе с садами были уничтожены и ушли в прошлое. O прежней деревне напоминает лишь Давыдковская улица» [4, с. I6I]. По информации сайта «Православные храмы микрорайона Давыдкова», где предпринята попытка систематизировать сведения об истории Давыдкова, о находившихся и находящихся здесь храмах и часовнях, «в деревне Давыдково в I884 г. была построена часовня Боголюбской Богоматери. Волынское было знаменито своим чудесным храмом Спаса Нерукотворного, построенным в І703 г. <..> В первые советские десятилетия здесь еще оставалось множество садов. Воздух был чист, природа прекрасная. В прозрачных водах реки Сетунь водилось много рыбы. В те годы эти места были настолько лесисты и живописны, что именно здесь японский кинорежиссер Акиро Куросава снимал свой фильм “Дерсу Узала” (1975). В І920 г. в окрестностях Волынского размещались дачи Высшей партийной школы. В селе насчитывалось 47 жителей, которые в основном занимались обслуживанием дачников. В г930-е гг. в Волынском располагалась дача М.И. Калинина, а напротив, в Давыдкове, находилась дача Сталина. Несколько лет спустя в селе было образовано “хозяйство Волынское-2”, которое специализировалось на обслуживании государственных дач. Советская власть уничтожила все храмы. 
Составитель справочника “Сорок сороков” П.Г. Паламарчук писал, что старожилы показали ему место церкви, которая "ранее стояла на обрыве у Сетуни, где кончается одна из двух оставшихся аллей громадных лип, в кругу березок. Около лежал еще последний камень, оставшийся от уничтоженных надгробий бывшего погоста”. На другой, левой стороне Сетуни стояла деревня Давыдково, располагавшаяся примерно там, где проходит нынешняя Давыдковская улица. В деревне Давыдково было 63 двора и проживало г92 человека, они могли посещать два храма (часовню Боголюбской Богоматери и церковь Спаса Нерукотворного). Рядом с часовней стояла колокольня <...>. Прежние храмы были разрушены, и в I998 г. на добровольные пожертвования тех, кто участвовал в ликвидации последствий бед и катастроф, в честь погибших бойцов МЧС, на территории Центрального регионального центра МЧС был построен храм Святого великомученика Георгия Победоносца» [7]. Также построен временный деревянный храм Смоленской иконы Божией Матери, и в конце 2016 г. дан старт строительству одноименного большого каменного храма.

Итак, казалось бы, заметки Шумского не имеют сколько-нибудь большой ценности, поскольку повторяют и развивают недостоверную информацию. Однако на деле это не так. Его заметки в XXI в. оказываются бесценными данными по истории Москвы, тем более что на очень полных и достоверных сайтах sobory.ru и temples.ru, к которым обращаются все интересующиеся историей и церковным строительством, часовня в Кунцеве никак не представлена. Миф о «тургеневской» часовне послужил сохранению памяти о ней. Кроме того, появление и существование это мифа интересно само по себе. Здесь сходятся интересы филологии, психологии, культурологии. Здесь мы имеем дело с примером психологической потребности человека - и далеко не всегда необоснованной - «привязать» текст к месту, с попыткой - и далеко не всегда неудачной - осмыслить художественный объект как реальный, а литературное произведение - как исторический источник. 


\section{Список литературы}

I Анциферов Н.П. Краеведный путь в исторической науке (Историко-культурные ландшафты) // Краеведение. І928. № 6. С. 32I-338.

2 Данченко M.B. Наследие Кунцева. М.: Фонд «Наследие Кунцева». I86 c. URL: http://munkuncevo.narod.ru/ (дата обращения: 27.02.2018).

3 Жукова А. Прогулки по Москве. Дворцы, усадьбы, парки (Путеводитель для пешеходов). М.: АСТ, 20I7. І28 с.

4 История московских районов / под ред. К.А. Аверьянова. М., АСТ: Астрель, 2010. 479 c.

5 Каталог выставки в память И.С. Тургенева в Имп. Академии наук. Март I9о9. СПб., I909. IV, 202 c. URL: https://dlib.rsl.ru/viewer/oI003756829\#?page=Iо9 (дата обращения: 27.02.2018).

6 Кунцево // Литературное Подмосковье. Архангельское, Черная Грязь, Захарово, Абрамцево, Мелихово, Шахматово, Кунцево. М.: Гос. изд-во культурно-просветительной лит., I950. С. I42-155.

7 Православные храмы микрорайона Давыдково. URL: http://hram-da.moseparh. $\mathrm{ru}$ /istoricheskaya-spravka-o-xramax-postroennyx-na-territorii-davydkova-dooktyabrskoj-revolyucii/ (дата обращения: 27.02.2018).

8 Разумов В. Усадьба Кунцево. Г. Москва. URL: https://deadokey.livejournal. com/I4Io84.html (дата обращения: 27.02.2018).

9 Тургенев И.С. Полн. собр. соч. и писем: в зо т. Изд-е 2, испр. и доп. М.: Наука, І98г. T. 6.497 c. 


\section{References}

I Anciferov N.P. Kraevednyj put'v istoricheskoj nauke. (Istoriko-kul'turnye landshafty) [Local history in historical science (Historical and cultural landscapes)]. Kraevedenie [Local history], I928, no 6, pp. 321-338. (In Russ.)

2 Danchenko M.V. Nasledie Kuntseva [The heritage of Kuntsevo]. Moscow, Fond "Nasledie Kuntseva” Publ. I86 p. Available at: http://munkuncevo.narod.ru/ (Accessed 27 February 20I8). (In Russ.)

3 Zhukova A. Progulki po Moskve. Dvortsy, usad'by, parki (Putevoditel' dlia peshekhodov) [Strolling in Moscow. Palaces, manors, and parks (a guide for pedestrians)]. Moscow, AST Publ., 20I7. I28 p. (In Russ.)

4 Istoriia moskovskikh raionov [The history of the Moscow districts], ed. K.A. Aver'ianova. Moscow, AST, Astrel' Publ., 20Io. 479 p. (In Russ.)

5 Katalog vystavki v pamiat' I.S. Turgeneva v Imp. Akademii nauk. Mart 1909 [Catalogue of the exhibition in the memory of Ivan S. Turgenev at the Imp. Academy of Sciences. March I909]. St. Petersburg, I909. IV, 202 p. Available at: https://dlib.rsl.ru/ viewer/oro03756829\#?page=I09 (Accessed 27 February 2018). (In Russ.)

6 Kuntsevo. Literaturnoe Podmoskov'e. Arkhangel'skoe, Chernaia Griaz', Zakharovo, Abramtsevo, Melikhovo, Shakhmatovo, Kuntsevo [Kuntsevo. Literary Moscow District. Arkhangel'skoe, Chernaia Griaz', Zakharovo, Abramtsevo, Melikhovo, Shakhmatovo, Kuntsevo]. Moscow, Gosudarstvennoe izdatel'stvo kul'turno-prosvetitel'noi literatury Publ., I950, pp. I42-I55. (In Russ.)

7 Pravoslavnye khramy mikroraiona Davydkovo [Orthodox churches of Davydkovo district]. Available at: http://hram-da.moseparh.ru/istoricheskaya-spravka-oxramax-postroennyx-na-territorii-davydkova-do-oktyabrskoj-revolyucii/ (Accessed 27 February 2018). (In Russ.)

8 Razumov V. Usad'ba Kuntsevo. G. Moskva [Kuntsevo manor. Moscow]. Available at: https://deadokey.livejournal.com/I4Io84.html (Accessed 27 February 20I8). (In Russ.)

9 Turgenev I.S. Polnoe sobranie sochinenii i pisem: $v$ zo $t$. [Complete works and letters: in 30 vols.], izdanie 2, ispravlennoe i dopolnennoe. Moscow, Nauka Publ., I98I. Vol. 6. 497 p. (In Russ.) 
УДК 821.I6I.I

ББК $83.3(2 \mathrm{Poc}=\mathrm{Pyc}) 6$

\section{АВТОБИОГРАФИЧЕСКИЙ МИФ В РОМАНЕ Ю.К. ОЛЕШИ «ЗАВИСТЬ»}

(C) 2018 г. М. Комия

Сайтамский университет, Сайтама, Япония

Дата поступления статьи: ог ноября 2017 г. Дата публикации: 25 сентября 2018 г.

DOI: I0.22455/2500-4247-2018-3-3-I62-I75

Статья написана при финансовой поддержке Research Fellowships of Japan Society for the Promotion of Science for Young Scientists

Аннотация: Данная статья посвящена автобиографическому мифу в романе Ю.К. Олеши «Зависть» и составлена на основе анализа черновых автографов романа. До сих пор образ главного героя романа Кавалерова считали автобиографическим. Однако можно утверждать, что история его создания, выявленная в ходе анализа рукописей романа, свидетельствует о том, что он не был создан как автобиографический персонаж, хотя и обладает поэтическим талантом, подобно самому Олеше. В самых первоначальных рукописных вариантах центральным героем «Зависти» был Иван Бабичев. На этой стадии образ Кавалерова - это образ интеллигента, который приспособился к условиям постреволюционного общества и талант и образованность в области литературы которого высоко оценивал фаворит правительства Андрей Бабичев. Однако в процессе написания романа Олеша придавал образу Кавалерова разные отрицательные черты. Такая тенденция к снижению образа приводила к тому, что Кавалеров постепенно переместился в центр социального конфликта и оказался антагонистом Андрея Бабичева, имеющего общественный авторитет. В результате Кавалеров стал главным героем романа. Имея в виду принципиальную перестройку образа в сторону снижения, которая на протяжении всего времени написания романа оказывала на него влияние, в более поздних рукописных вариантах Олеша начал представлять в отрицательном свете даже поэтический талант Кавалерова, который утрачивает силу, так как герой оказывается ленив и зря расточает способности на пустую работу. И так Кавалеров превращается в образ «второразрядного поэта», который радикально отличается от образа автора.

Ключевые слова: Ю.К. Олеша, роман «Зависть», образ Кавалерова, черновые автографы, автобиографизм.

Информация об авторе: Митико Комия - кандидат филологических наук, Research Fellow of Japan Society for the Promotion of Science, Сайтамский университет, Симоокубо 255, p-н Сакура, 3380825 г. Сайтама, Япония.

E-mail: komichi7@hotmail.com

Для цитирования: Комия М. Автобиографический миф в романе Ю.К. Олеши «Зависть» // Studia Litterarum. 2018. T. 3, № 3. С. I62-175. DOI: $10.22455 / 2500-4247-2018-3-3-162-175$ 


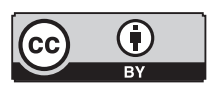

This is an open access article distributed under the Creative Commons Attribution 4.0 International (CC BY 4.0)

\section{THE AUTOBIOGRAPHICAL MYTH IN JU.K. OLESHA'S NOVEL ENVY}

(C) 20I8. M. Komiya

Saitama University,

Saitama, Japan

Received: November oI, 2017

Date of publication: September 25, 2018

Acknowledgements: Financial support for writing this article was provided by Research Fellowships of Japan Society for the Promotion of Science for Young Scientists.

Abstract: This study reinterprets an autobiographical myth in Olesha's novel Envy (I927). The novel's main character Kavalerov has been traditionally interpreted as Olesha's fictional double, Olesha's own remark that Kavalerov's poetic talent matches his own being a strong basis for such reinterpretation. However, upon closely studying the manuscript and exploring Kavelerov's manuscripts, the essay argues that Kavalerov is not an autobiographical character. In writing and rewriting Envy, Olesha repeatedly changed Kavalerov's characteristics, progressively showing him in the bad light. In fact, when Olesha began writing Envy, the main character was Ivan Babichev. At this stage of the novel's composition, Kavalerov, merely a narrator, was described as a poetically talented man, a representative of intelligentsia who managed to survive and adapt himself to the post-revolutionary society. In other words, at the novel's early stages, the character did share certain features with the author. However, Olesha later imbued Kavalerov's character with negative features and made him an antagonist of Andrey Babichev, a favorite of the Soviet government. This rueful change paradoxically reinforced Kavalerov's significance in the novel and he became its main protagonist. In his late manuscripts of the novel, Olesha presented even Kavalerov's poetic talent in the negative light. The novel's final version shows Kavalerov's talent uncultivated because of his idleness: no one recognizes it. Thus, Kavalerov turns into a "second-rate poet" radically breaking with Olesha's self-image.

Keywords: Ju.K. Olesha, Envy, Kavalerov, manuscript, autobiography.

Information about the author: Michiko Komiya, $\mathrm{PhD}$ in Philology, Research Fellow of Japan Society for the Promotion of Science, Saitama University, Shimo-okubo 255, Sakuraku, 3388570, Saitama-shi, Japan.

E-mail: komichi7@hotmail.com

For citation: Komiya M. The Autobiographical Myth in Ju.K. Olesha’s Novel Envy. Studia Litterarum, 2018, vol. 3, no 3, pp. I62-I75. (In Russ.)

DOI: I0.22455/2500-4247-20I8-3-3-I62-I75 
«Зависть» была впервые опубликована в г927 г. в журнале «Красная новь» в номерах 7-8. Этот первый для Ю. Олеши роман открыл ему путь к успеху в качестве писателя. Среди архивных материалов, связанных с романом, хотя некоторые из них уже утеряны, до сих пор осталось более гооо листов рукописей и приблизительно І40 листов машинописи, которые хранятся в Отделе рукописей ИМЛИ РАН (ОР ИМЛИ) и в Российском государственном архиве литературы и искусств (РГАЛИ). В процессе создания романа автор работал по-разному: в течение первых пяти лет, перебирая возможные сюжетные решения, писал от руки черновые наброски, на конечном этапе, в последние полгода, при подготовке романа к публикации, перепечатывал на пишущей машинке последний рукописный вариант, названный им самим «полный черновик». Эта последовательность действий позволяет сделать вывод об изменениях авторского замысла: последний рукописный вариант и машинописные материалы близки к тексту первого издания, тогда как ранние рукописные наброски значительно отличаются от него. Первые наброски характеризуются постоянным изменением фабулы. В работе над ними автор без всякого предварительного плана занимался определенными отдельными сценами, которые приходили ему на ум в разное время [3, с. I54], в результате чего в процессе написания изменились и образы персонажей, и эпизоды, связанные с ними. В связи с тем, что рукописные материалы состоят из отдельных листков, на которых автор редко ставил дату, до недавнего времени, а именно до момента появления в Японии диссертационной работы, написанной автором данной статьи [6], хронологический порядок изменения авторского замысла был неизвестен. В данной статье прослеживается изменение образа глав- 
ного героя Кавалерова на основе анализа рукописей сравнительно раннего этапа.

Роман «Зависть» служил источником автобиографического мифа Олеши. Большинство критиков и исследователей считало образ Кавалерова автобиографическим. Такой взгляд широко распространяется уже сразу после публикации. Как и сам Олеша, Кавалеров - интеллигент. Этот социальный класс стал объектом резкой критики в советском обществе во второй половине г920-х гг. [2, с. I44-I45], и указанное совпадение привлекало внимание, что привело к отождествлению автора с его героем. На Первом съезде советских писателей в 1934 г. сам Олеша отмечал этот факт в своей речи.

Шесть лет назад я написал роман «Зависть». / Центральным персонажем этой повести был Николай Кавалеров. Мне говорили, что в Кавалерове есть много моего, что этот тип автобиографический, что Кавалеров - это я сам. / Да, Кавалеров смотрел на мир моими глазами. Краски, цвета, образы, сравнения, метафоры и умозаключения Кавалерова принадлежат мне. И это были наиболее свежие, наиболее яркие краски, которые я видел. Многие из них пришли из детства, были вынуты из самого заветного уголка, из ящика неповторимых наблюдений [4, с. 57].

После этой речи автобиографический миф об Олеше и его герое Кавалерове основательно утвердился среди критиков и исследователей. Тем не менее некоторые из них относятся к этому мифу достаточно осторожно. Автор книги об Олеше «Сдача и гибель советского интеллигента. Юрий Олеша» А.В. Белинков приводит мнение писателя Л.И. Славина: «...писатель в известной мере должен пережить ощущения своего героя, вызвать в своей душе состояние, чувства своих героев» [I, с. 229]. Ограничивая таким образом автобиографизм в образе Кавалерова, Белинков предупреждает: «...поэтому мы не будем говорить, что Кавалеров - это Олеша. Мы будем говорить, что “...Кавалеров смотрел на мир... глазами...” Олеши» [г, с. 230].

Сам процесс создания образа Кавалерова в черновиках «Зависти» может служить подтверждением правоты Белинкова. Общность Кавалерова с писателем ограничивается лишь поэтическим мироощущением. Опираясь на результаты изучения рукописных вариантов, можно доказать, что Олеша не создавал его как автобиографического героя. 
В первоначальном рукописном варианте «Зависти» главным героем был чудак-изобретатель Иван Бабичев, ни одного из остальных основных персонажей, в том числе и Кавалерова, в нем пока не было. Затем Олеша ввел в роман брата Ивана Бабичева - Андрея, в качестве оппонента Ивана. Уже потом был создан образ Кавалерова, хотя изначально он был не центральным персонажем, а лишь повествователем «истории Ивана Бабичева» . В ходе работы над рукописями автор постоянно вносил изменения в образ Кавалерова, перемещая его в центр конфликта с Андреем Бабичевым. В результате Кавалеров стал центральным персонажем романа.

Как изменялся образ Кавалерова? На первоначальном этапе он был разумным, талантливым интеллигентом. Однако в процессе написания романа автор добавлял ему отрицательные характеристики: переживание героем чувства ущемленного самолюбия вследствие того, что его талант не оценили, негативное отношение к благодетелю Андрею Бабичеву, неопрятная наружность, алкоголизм и т. д. Такая тенденция к снижению образа вряд ли возможна при создании автобиографического героя.

Изменение образа Кавалерова происходило в процессе работы над эпизодом, повествующим о его встрече с Андреем Бабичевым. В данной статье рассматривается ряд вариантов, которые обнаружены в черновых набросках, содержащих этот эпизод.

Вариант г был написан в период, когда Олеша впервые ввел в роман Николая Кавалерова в качестве повествователя «истории Ивана Бабичева». На этом этапе написания Андрей Бабичев был не директором треста пищевой промышленности, как в первом издании в «Красной Нови», а известным инженером, строителем домов-коммун. Кавалеров был его «литературным секретарем».

\section{Вариант I}

Начиная историю Ивана Бабичева, я задержу внимание читателя на личности его брата, известного инженера, строителя домов-коммун, Андрея Петровича Бабичева. / Я работал у него в качестве литературного секретаря (РГАЛИ. Ф. 358. Оп. 2. Ед. хр. 6. Л. 9)².

І РГАЛИ. Ф. 358. Оп. 2. Ед. хр. 6. Л. 9.

2 В варианте г Олеша все еще подчеркивает, что главным героем романа является Иван Бабичев, а Кавалеров - лишь повествователь. К тому же в указанном варианте Кавалеров еще 
Следует обратить внимание на то, что в первом варианте черновиков Кавалеров был человеком, ведущим более здоровый образ жизни, нежели герой из первого издания. В первом издании Кавалеров познакомился с Андреем Бабичевым, когда лежал пьяным у пивной. Андрей Бабичев протянул ему руку помощи, ввел его в свой дом. В первых же черновиках Кавалеров познакомился с Андреем Бабичевым благодаря рекомендации одного своего влиятельного знакомого.

\section{Вариант 2}

Рекомендация [одного ответств] видного работника, знавшего меня по работе в одной из южных республик, дала мне возможность занять должность литературного секретаря у знаменитого инженера [Ивана] Андрея Бабичева. Подчеркиваю это имя: Андрея Петровича Бабичева (РГАЛИ. Ф. 358. Оп. 2. Ед. хр. 8. Л. 66).

В варианте 3, написанном на том же этапе, Кавалеров объясняет суть обязанностей «литературного секретаря».

\section{Вариант 3}

Мои обязанности [состояли в чтении в] [сводились к ежеднев] состояли в следующем: Я должен был следить за книжным рынком, отыскивая новинки, достойные ознакомления, прочитывать их, составлять конспекты и [ознакомлять с ними моего патрона] [Некоторые книги я чит] представлять их моему патрону. Он уделял внимание тому или другому произведению, лично прочитывая книгу (РГАЛИ. Ф. 358. Оп. 2. Ед. хр. 6. Л. го)4.

Очевидно, в рукописных вариантах этого периода Андрей Бабичев нанял Кавалерова на работу, потому что высоко оценивал его талант и образованность в области литературы.

имеет квалифицированную специальность, в отличие от того, что мы видим в опубликованном варианте. В связи с этим можно определить, что вариант г был написан тогда, когда образ Кавалерова был только введен в роман.

3 Вычеркнутые фрагменты текста даются курсивом в квадратных скобках. В варианте 2 должность Кавалерова - литературный секретарь. Исходя из этого, можно утверждать, что вариант 2 был написан примерно в то же время, что и вариант I.

4 В варианте 3 должность Кавалерова та же, что и в вариантах I и 2: «литературный секретарь». Очевидно, варианты I, 2, 3 хронологически отстоят друг от друга недалеко. 
Следует обратить внимание на то, что в этих ранних вариантах образ Кавалерова отличается от его образа из первого издания тем, что Кавалеров из первых черновиков хорошо относится к Андрею Бабичеву. В варианте I Кавалеров хвалит строителя Андрея Бабичева.

\section{Вариант I}

Деятельность Андрея Бабичева известна всей России. Это был [любимец прави] фаворит правительства и кумир рабочих. [Он воздвиг во построил восемь домов-коммун для рабочего населения] Он построил восемь домов-коммун, восемь [грандиозных] гигантских рабочих общежитий. Теперь мы наслаждаемся зрелищем этих зданий, вознесенных на местах пустырей и развалин (РГАЛИ. Ф. 358. Оп. 2. Ед. хр. 6. Л. 9).

Здесь Кавалеров, поддерживая общественное мнение, наслаждается видом домов-коммун, построенных известным архитектором Андреем Бабичевым. Таким образом, на первоначальном этапе написания романа Кавалеров был человеком с более или менее позитивным взглядом на жизнь и одобрительным отношением к Бабичеву. Очевидно, в самом начале Кавалеров был разумным интеллигентом, талант и образованность которого высоко оценивались Андреем Бабичевым.

Тем не менее потом Олеша начал менять образ Кавалерова. Значительные изменения касались его должности и его отношения к Андрею Бабичеву.

\section{Вариант 4}

Мне повезло. Нашелся влиятельный знакомый, знавший меня по работе в одной из южных республик. Он рекомендовал меня строителю домов-коммун. <...> / Я считал свою должность почетной. Кроме того я получил возможность читать, иметь множество книг. Патрон хотел быть в курсе всех литературных течений. [Я читал] Так прожил я у инжера (sic) год. [Сoзнаюсь, что не смотря (sic) на то, что] Я перепечатывал его труды, [отдель] доклады, [листы и формул листы форму формул, я слушал беседы] отдельные заметки. Сознаюсь, [техни] эта отрасль не знаний осталась для меня темной. $<. .>$ Часто он хохотал над деталью какого-нибудь чертежа, как хохочут [над] [после анек] [над выходками циркача и] над [выходками явной] нелепыми вы- 
ходками циркача, [воскли] выкрикивал: - Анекдот! Анекдот! - и [потрясал чертежом.] швырял чертеж в угол. Я [nото] рассматривал чертеж, [и не находил причины] [ломал голову над] и, ломая голову, искал причину [смех] хохота. Это был хохот профессионала, вызывавшийся [страх $u$ ] суеверный страх и зависть (РГАЛИ. Ф. 358. ОП. 2. Ед. хр. 6. Л. 36-37)

К должности «литературного секретаря» прибавляется обязанность, не требующая специальной квалификации, - перепечатывание трудов Андрея Бабичева. В то же время Кавалеров начинает чувствовать «страх и зависть» по отношению к нему.

Получается, что Андрей Бабичев игнорирует талант и образованность Кавалерова, и в Кавалерове просыпается ненависть. Эти два изменения связаны друг с другом. Очевидно, по замыслу Олеши, Кавалеров плохо относится к Андрею Бабичеву потому, что последний оскорбил его гордость.

В более позднем варианте название должности Кавалерова претерпело изменения: из «литературного секретаря» он превращается в просто «секретаря». Автор вводит замену в связи с тем, что теперь Кавалеров не исполняет обязанности литературного информатора.

\section{Вариант 5}

Благодаря случайности, случайной встрече с влиятельным знакомым, знавшим меня по работе в одной из южных республик, я попал в секретари к прославленному инженеру. Он строил аэропланы, совершенствовал двигатели, писал брошюры, - а я делал для него то, что могла бы сделать любая барышня: переписывал на машинке, корректировал оттиски, [выби] подбирал в нумерном порядке [тексты из те] отмеченные им тексты из технических книг. / Я ненавидел моего благодетеля (РГАЛИ. Ф. 358. Оп. 2. Ед. хр. 6. Л. 33 об.) ${ }^{6}$.

5 В варианте 4, в отличие от первоначальных вариантов I, 2, 3, автором понижен уровень квалификации Кавалерова. К тому же герой начинает чувствовать зависть по отношению к Андрею Бабичеву. Очевидно, здесь образ Кавалерова приближается к окончательному, опубликованному, варианту. Ввиду этого можно предположить, что вариант 4 был написан несколько позже, чем три предыдущих.

6 В варианте 5, как и в опубликованных вариантах, Кавалеров перестает быть литературным информатором. Его специальность утрачивает квалифицированный характер. Этот вариант написан позже варианта 4. Здесь также Олеша сделает попытку вывести Андрея Бабичева как строителя аэропланов. Но этот факт встречается в черновиках крайне редко, следовательно, это был пробный, проходной вариант. После писатель меняет Ан- 
Кавалеров считает, что эту работу «секретаря» «могла бы сделать любая барышня». Очевидно, он недоволен тем, что Андрей Бабичев недостаточно оценивает его талант и дает ему неквалифицированную работу. В результате Кавалеров ненавидит Андрея Бабичева.

Становится ясно, что в ходе работы над черновиками Олеша делал образ Кавалерова все более отрицательным. Положительно относящийся к Андрею Бабичеву и ко всему окружающему миру Кавалеров преобразуется в Кавалерова, охваченного завистью и ненавистью.

Что касается других характеристик Кавалерова, то здесь также происходили изменения в сторону снижения образа. Изменив должность героя, автор дополняет его образ отрицательными чертами: наделяет его непривлекательной, неопрятной наружностью и делает его алкоголиком.

В варианте 5 есть следующее продолжение, в котором автор подчеркивает неприглядность Кавалерова.

\section{Вариант 5}

Я ненавидел моего благодетеля. В первый же день, только я пришел к нему, едва увидев меня, он заставил меня помыться. Я [воз] [И я сов] [я худой, как канатный плясун] И боявшийся воды, как кот, я совершал омовение над умывальником похожим на голую женщину, хватаясь за мыло, как за розовый язык (РГАЛИ. Ф. 358. Оп. 2. Ед. хр. 6. Л. 33 об.).

В варианте 5 встреча Кавалерова с Андреем Бабичевым происходит все еще благодаря рекомендации знакомого Кавалерова. Однако в более позднем варианте Кавалеров знакомится с Андреем Бабичевым, когда знаменитый строитель подбирает его пьяным.

\section{Вариант 6}

Днем, от которого нужно [счит] начинать счет [остальным] [всему этому] [в] остальным дням, я считаю тот день, вернее вечер, прекрасный вечер в начале лета, когда меня, пьяного, подобрал [и увез на автомобиле к себе] незнакомый мне, но известный [не только мне, а в] и мне и всей [России] [в] дрею Бабичеву профессию еще раз: вновь делает его строителем коммун. Однако самым удачным автору виделся на раннем этапе работы над романом образ «прославленного инженера». 
[стране] Москве инженер Андрей Петрович Бабичев, строитель домов-коммун (РГАЛИ. Ф. 358. Оп. 2. Ед. хр. 8. Л. 68 об.) ${ }^{7}$.

Здесь деградация Кавалерова связана не только с алкоголизмом. Перед Андреем Бабичевым его гордость унижена с самого начала. Это приводит к тому, что Кавалеров все больше ненавидит своего благодетеля.

Можно утверждать, что добавленные Кавалерову отрицательные характеристики обусловливают более глубокое изображение психики Кавалерова. При этом Кавалеров оказывается участником конфликта с Андреем Бабичевым. В результате образ Кавалерова приобретает все более важную роль в «Зависти», превосходит по значимости и выразительности образ Ивана Бабичева и, наконец, становится центральным персонажем. В создании героя Олеша главным, цементирующим, принципом избирает принцип снижения образа.

Совершенно понятно, что автобиографического героя невозможно создавать настолько отрицательным. Автор не задумывал Кавалерова как автобиографического персонажа. Читатели опубликованного варианта, придавая много значения поэтическому миросозерцанию Кавалерова, считали, что в его образе воплотился сам Олеша. Однако уже из рукописных набросков ясно, что Кавалеров является главным героем не потому, что имеет поэтический талант, а потому, что он, как отрицательный персонаж, находится в центре социального конфликта и является антагонистом Андрея Бабичева, имеющего авторитет в обществе.

До сих пор многие исследователи считают Кавалерова образом «поэта» [I, с. 2І2; 7, с. 28]. Почему Кавалеров «смотрел на мир... глазами...» Олеши? Почему автор дал этому герою свой поэтический талант невзирая на то, что он отрицательный?

Ответ на этот вопрос дает также исследование процесса создания образа Кавалерова. Приписывание поэтического таланта герою и принцип снижения образа появляются на разных этапах написания. У Кавалерова есть талант к литературе уже в первоначальных вариантах. Как было рас-

7 На оборотной стороне варианта 6 Олеша записывает сцену знакомства Кавалерова с Андреем Бабичевым, которая состоялась благодаря рекомендации знакомого. Очевидно, во время написания варианта 6 писателю неожиданно приходят в голову новые обстоятельства знакомства героев. 
смотрено выше, персонаж был задуман интеллигентом, специалистом в области литературы. Когда Олеша впервые ввел его в роман, он работал у Андрея Бабичева как «литературный секретарь». В этом смысле, на первоначальном этапе, образ этого героя был ближе к самому автору, чем на более поздней стадии написания.

Из рукописей видно: с того момента, как Олеша в ходе работы над сценами встречи Кавалерова с Андреем Бабичевым решил изображать этого героя в отрицательном ключе, поэтический талант Кавалерова начал приобретать негативный оттенок. Автор стал подчеркивать его бесплодность. Обнаруживается кардинальное отличие образа Кавалерова от самого автора. Так, в рукописных вариантах более позднего этапа часто содержатся сцены, в которых Кавалеров говорит о мечте стать писателем. И, как правило, для реализации мечты в этом варианте сюжета он не делает ничего. В варианте 7 , в котором повествование ведется от лица соседа Кавалерова, не действующего в опубликованных вариантах, у героя не было написано ни одной страницы, хотя он сообщал, что пишет роман.

\section{Вариант 7}

Иногда он сообщал мне: / - Я пишу роман. / [Я знал, что] [Но ни одной Но ни одной стран] Но он ничего не писал. [Он говорил только, ито все у него готово, наблюдения, материалы] [Его соо] [Такие сообщения его я принимал с интересом] В первую минуту такие сообщения его вызывали у меня радостное оживление. Мне очень хотелось, чтобы, действительно, он начал писать. Это успокоило бы меня. Ведь и я очень часто говорил: / - Кавалеров, я пишу роман. / Ни одной страницы не было написано ни у меня, ни у него (РГАЛИ. Ф. 358. Оп. 2. Ед. хр. 9. Л. 36-36 об.) ${ }^{8}$.

Можно предположить, что автор писал этот вариант, имея в виду отличие самого себя от Кавалерова. В тот период молодой Олеша работал над своим первым романом «Зависть» в надежде достичь славы писателя. Опубликованный после смерти писателя сборник его эссе недаром

8 В варианте 7 Олеша пробует создать принципиально новый сюжет о Кавалерове уже как главном герое. Ввиду этого можно предположить, что вариант 7 более новый по отношению к варианту 6 и что между ними существует большая временная дистанция. 
был назван «Ни дня без строчки». Очевидно, Олеша критически относился к ленивому герою, который не принимается за свой роман.

К тому же изображение поэтического таланта Кавалерова Олеша подчинил принципу снижения положительности героя, делая его бесполезным для общества. И в черновиках, и в первом издании основной доход этого героя - не от исполнения обязанностей секретаря Андрея Бабичева, а от работы для эстрадников. А работу над эстрадой Олеша связывал с «падением» поэта, что видно по более позднему варианту черновиков. В нем Кавалеров говорит:

\section{Вариант 8}

Я понял степень своего падения. [Ведь это случилось!] [Я сошелся со вдовой, со стряпухой] Все шло к [тому] падению. Оно должно было произойти. Слишком легкой, самонадеянной жизнью я жил. Слишком легкий, подозрительно, беспокойно легкий хлеб я добывал! [Hu] Не работал, нигде не служил, писал монологи и [эс] куплеты для эстрадников. Платили за это не мало. <...> Я хотел и мог работать ту работу, о которой только говорил, - и не работал, заносился, хвастал, всех презирал, считал себя лучше других, слишком высокого был о себе мнения (РГАЛИ. Ф. 358. Оп. 2. Ед. хр. І3. Л. ІІ $)^{9}$.

Следует оговориться: когда Олеша писал «Зависть», он тоже зарабатывал с помощью писательства в жанрах массовой литературы. С 1922 до І933 г. он работал в газете железнодорожников «Гудок» под псевдонимом «Зубило» и писал стихотворные фельетоны, которые пользовались большой популярностью в массах. Однако если к работе Кавалерова в эстрадной сфере, связанной со словом «падение», в советском обществе относились пренебрежительно, то работу Олеши в «Гудке», которая вносила вклад в повышение уровня жизни рабочих масс, общество оценивало высоко. Став писателем благодаря успеху романа «Зависть», Олеша с гордостью пишет о работе «Зубила»:

9 Вариант 8 представляет сцену после ночи Кавалерова с Аничкой. На этапе написания варианта 7 эта героиня все еще называлась иначе: Елизавета Кунина. Она была переименована в поздний период работы над романом. 
То, что я нашел свое место среди огромной массы рабочих-железнодорожников хотя бы в качестве их фельетониста, считаю одной из главных удач моей жизни. / Не понимаю различия между высоким и низким жанром литературной работы. С одинаковой ответственностью и серьезностью отношусь к газетной и «толстокнижной» работе. Одинаково важно для меня вызвать удовольствие читателя как стихами «Зубило», так и тем, что подписано - Ю. Олеша [5].

Судя по тому, что в том же году, когда Олеша написал эту статью, он ушел из «Гудка» и сосредоточился на художественной литературе, очевидно, что на самом деле он чувствовал «различие между высоким и низким жанром». Однако следует особенно подчеркнуть тот факт, что в тогдашнем обществе литературная работа для рабочих масс ценилась так высоко, что Олеша, видимо, был вынужден утверждать, что отрицательно относится к вышеназванному различию. Этот писатель, умело справлявшийся с работой для масс, невзирая на свое интеллигентское происхождение, более или менее успешно приспособлялся к условиям нового, советского, общества. А его герой Кавалеров, противник Андрея Бабичева, фаворита правительства, занимающийся работой общественно малозначительной, выбивается из рамок постреволюционной эпохи. Разумеется, что автор создавал образ этого героя с чувством пренебрежения.

Итак, образ Кавалерова, который в первоначальных вариантах рукописей был настоящим «поэтом», в ходе написания романа постепенно подвергался принципу отрицательности и в отношении такого качества, как талант. В результате этого создан образ Кавалерова - «второразрядного поэта». Следуя логике своего положения, он дает своему поэтическому таланту засохнуть и становится неудачником в условиях нового постреволюционного общества. В процессе написания романа расхождение между образом Кавалерова и автопортретом писателя все больше расширялось.

Очевидно, Олеша сделал Кавалерова «второразрядным поэтом» потому, что опасался крушения собственной литературной судьбы. Как интеллигент, писатель стремился приспособиться к постреволюционному обществу, центральным героем которого был пролетариат, старался достичь успеха не только с помощью фельетонов «Зубила», но и работой в области художественной литературы - с помощью романа «Зависть» [6, 


\section{c. 237-243]. Кавалеров же, по замыслу Олеши, был интеллигентом, который перестал прикладывать такие усилия.}

\section{Список литературы}

I Белинков А.В. Сдача и гибель советского интеллигента. Юрий Олеша. М.: Культуpa, 1997. 539 c.

2 Добренко Е.А. Становление института советской литературной критики в эпоху культурной революции: І928-1932 // Добренко Е.А., Тиханов Г.В. (ред.) История русской литературной критики: Советская и постсоветская эпохи. М.: Новое литературное обозрение, 20II. С. І42-206.

3 Олеша Ю.К. Беседа с читателями // Литературный критик. I935. № I2. С. I52-I65.

4 Олеша Ю.К. Зависть; Три Толстяка; Воспоминания; Рассказы. М.: Эксмо, 2013. $704 \mathrm{c.}$

5 Олеша Ю.К. Удача моей жизни // Литературная газета. I933. о5 мая.

6 Komiya M. Olesha «Senbou» soukou kenkyu: jinbutsuzou no seisei wo tyuushin ni: Dis. ... Dr. Philology sciences. The University of Tokyo, 20I7. 26I p.

7 Piper D.G.B. Yuriy Olesha's “Zavist”” // The Slavonic and East European Review. I970. № 48: IIO. P. $27-43$.

\section{References}

I Belinkov A.V. Sdacha i gibel' sovetskogo intelligenta. Jurij Olesha [Surrender and doom of the Soviet intelligentsia. Yuriy Olesha]. Moscow, Kul'tura Publ., I997. 539 p. (In Russ.)

2 Dobrenko E.A. Stanovlenie instituta sovetskoj literaturnoj kritiki v jepohu kul'turnoj revoljucii: I928-I932 [The development Soviet literary criticism as an institute in the period of cultural revolution: I928-I932]. Dobrenko E.A., Tihanov G.V. (eds.) Istorija russkoj literaturnoj kritiki: Sovetskaja i postsovetskaja jepohi [History of Russian literary criticism: Soviet and Post-Soviet era]. Moscow, Novoe literaturnoe obozrenie Publ., 20II, pp. I42-206. (In Russ.)

3 Olesha Ju.K. Beseda s chitateljami [A talk with readers]. Literaturnyj kritik, I935, no I2, pp. I52-I65. (In Russ.)

4 Olesha Ju.K. Zavist'; Tri Tolstjaka; Vospominanija; Rasskazy [Envy; Three fat men; Memoir; Short stories]. Moscow, Jeksmo Publ., 20I3. 704 p. (In Russ.)

5 Olesha Ju.K. Udacha moej zhizni [Success of my life]. Literaturnaja gazeta, I933, May 05. (In Russ.)

6 Komiya M. Olesha "Senbou” soukou kenkyu: jinbutsuzou no seisei wo tyuushin ni: Dis. ... Dr. Philology sciences. The University of Tokyo, 20I7. 26I p. (In Japenese)

7 Piper D.G.B. Yuriy Olesha's “Zavist”". The Slavonic and East European Review, I970, no 48: IIo, pp. 27-43. (In English) 
УДК 82І.І6І.I

ББК

$83 \cdot 3(2 \mathrm{Poc}=\mathrm{Pyc}) 6$

\section{«ЮВЕНИЛЬНОЕ ДЕЛО»: ИСТОРИЯ ОДНОЙ ПОВЕСТИ А. ПЛАТОНОВА}

\author{
(C) 2018 г. Н.И. Дужина \\ Институт мировой литературы \\ им. А.М. Горького Российской академии наук, \\ Москва, Россия \\ Дата поступления статьи: 29 марта 2018 г. \\ Дата публикации: 25 сентября 2018 г.
}

DOI: IO.22455/2500-4247-20I8-3-3-I76-I97

Аннотация: Статья посвящена истории текста повести «Ювенильное море» в творческой биографии писателя. Ситуация с этой повестью во многом типична для произведений А. Платонова: когда написана, точно не известно; ее название под вопросом. Свет на многие исследовательские проблемы проливает реальная история повести, представленная ее автографом и машинописями, а также отзывами современников и другими свидетельствами эпохи. Собранные вместе, эти документы составляют целое «Ювенильное дело» - случайная описка регистратора повести в ОГПУ, где она побывала. Статья построена на архивном материале и включает опирающуюся на документы предысторию написания повести; описание ее автографа, с приведением вычеркнутых фрагментов, что дает представление о работе и позиции автора; анализ двух слоев авторской правки в машинописи; все выявленные отклики на повесть современников писателя иногда не формальные; материалы по попыткам Платонова опубликовать фрагмент повести в виде рассказа «Стройматериалы и оборудование». Цель статьи - представить документальную историю повести: восстановить фрагмент творческой биографии Платонова в контексте литературы времени и отзывов современников; собрать вместе все свидетельства о повести современников писателя. Материал статьи позволяет сделать вывод о том, что повесть «Ювенильное море» была написана весной 1932 г., что ее содержание связано с краеведческой тематикой времени и что Платонову, несмотря на все внешние попытки, не удалось написать социалистическое по духу произведение.

Ключевые слова: Андрей Платонов, «Ювенильное море», история текста, автограф, датировка, публикации, рецензии.

Информация об авторе: Наталья Ильинична Дужина - кандидат филологических наук, старший научный сотрудник, Институт мировой литературы им. А.М. Горького Российской академии наук, ул. Поварская, д. 25 а, І21069 г. Москва, Россия.

E-mail: duzinati@yandex.ru

Для цитирования: Дужина Н.И. «Ювенильное дело»: история одной повести А. Платонова // Studia Litterarum. 2018. T. 3, № 3. С. I76-197. DOI: I0.22455/2500-4247-2018-3-3-I76-I97 


\section{"A JUVENILE CASE" - THE HISTORY OF A STORY BY ANDREY PLATONOV}

This is an open access article distributed under the Creative Commons Attribution 4.0 International (CC BY 4.0)
(C) 20I8. N. I. Duzhina

\author{
A.M. Gorky Institute of World Literature \\ of Russian Academy of Sciences, \\ Moscow, Russia \\ Received: March 29, 2018 \\ Date of publication: September 25, 2018
}

Abstract: The essay discusses Andrey Platonov's story “A Juvenile Sea” and its place in his biography. The article describes external circumstances behind the story's composition, Platonov's unsuccessful attempts to publish the work as a whole, and how he then went on to rework it into a number of shorter stories. Everything concerning the story is very Platonovian. There is no certainty when it was written; its title is in question since Platonov kept changing it; its images, content, and authorial standpoint are bewildering. The story's publication history - i.e. the manuscript, reviews of Platonov's contemporaries and other documentary evidence - cast light on some of these difficulties. Collected together, they constitute an article "A Juvenile Case" - as the story was mistakenly transcribed by the OGPU (security police). The article relies on archival materials. It includes the story's prehistory, a description of the manuscript and of the passages deleted from this manuscript. The latter help establish the nature of Platonov's work and authorial standpoint. The article also includes all known references (both formal and casual) to the story by Platonov's contemporaries and details of Platonov's attempts to publish a short extract from the story under the title "Construction Materials and Equipment." The aim of the article is documentary, i.e. to establish a chapter of Platonov's biography as a writer in the literary context of his time, to collect all factual evidence about the story, and to provide objective information about its real-life context. The article establishes that the story "A Juvenile Sea” was written in the spring of I932, that its subject matter is intimately connected to local historical events, and that Platonov had not succeeded in writing a work that was socialist in spirit.

Keywords: Andrey Platonov, “A Juvenile Sea," history of the text, manusctipt, dating, publication, reviews.

Information about author: Natalya I. Duzhina, $\mathrm{PhD}$ in Philology, Senior Researcher, A.M. Gorky Institute of World Literature Russian Academy of Sciences, Povarskaya 25 a, I21069 Moscow, Russia.

E-mail: duzinati@yandex.ru

For citation: Duzhina N.I. "A Juvenile Case" - The History of a Story by Andrey Platonov. Studia Litterarum, 2018, vol. 3, no 3, pp. 176-I97. (In Russ.)

DOI: I0.22455/2500-4247-20I8-3-3-I76-I97 
История повести «Ювенильное море» во многом типична для творческого наследия Платонова: при жизни писателя не была опубликована, хотя он и делал для этого несколько попыток; ее датировка под вопросом; ее названия менялись; ее содержание вызывает недоумение - то ли типичное произведение советской литературы, то ли пародия на нее. На эти и многие другие вопросы в какой-то степени отвечают дошедшие до нас документы ее творческой истории, в том числе автограф и машинописи, рецензии и воспоминания современников, все зафиксированные попытки опубликовать «Ювенильное море» целиком или частично. Собранные вместе, эти документы рассказывают удивительную историю повести, которая побывала даже в ОГПУ, где едва не получила новый титул: «Ювенильное дело».

Повесть «Ювенильное море» появилась в результате поездок Платонова в конце августа - сентябре г93І г. по животноводческим совхозам Средневолжского и Северокавказского краев. Этой поездке предшествовало драматическое для писателя лето І93І г., когда на него обрушилась критика за повесть «Впрок» (опубликована в журнале «Красная новь», І93г, № 3). У истоков этой критики стояла записка И. Сталина в редколлегию журнала: «Рассказ агента наших врагов, написанный с целью развенчания колхозного движения и опубликованный головотяпами-коммунистами... <...> Надо наказать и автора и головотяпов так, чтобы наказание пошло им “впрок” [8, с. 288]. И Платонова наказали: го июня І93І г. в «Литературной газете» опубликована статья А. Селивановского «В чем “сомневается” Андрей Платонов», І2 июня в газете «За коммунистическое просвещение» - статья Д. Ханина «Пасквиль на колхозную деревню», І8 июня в «Правде» - статья В. Дятлова «Больше внимания тактике классового врага», 3 июля в «Изве- 
стиях» - статья А. Фадеева «Об одной кулацкой хронике». Затравленный этой «критикой», Платонов пишет письма - И. Сталину: «Товарищи из рапповского руководства оценили мою работу как идеологически крайне вредную. <..> Я увидел, что товарищи из РАППа - правы, что я заблудился и погибаю. <..> ...Я оставляю в стороне всякую заботу о своей личности и стараюсь найти способ, каким можно уменьшить вред от опубликования повести “Впрок” [8, с. 284-287], в редакцию «Правды» и «Литературной газеты»: «Моя работа, несмотря на положительные субъективные намерения, объективно приносит вред. <...> Главной же моей заботой является теперь... создание таких произведений, которые бы с избытком перекрыли тот вред, который был принесен автором в прошлом» [8, с. 29I-293, c. 298-299], А.М. Горькому: «...я не классовый враг...» [8, с. 304-306]. Больше всего в эти трудные дни Платонов хочет уехать из Москвы; деньги на командировку он пытается найти через краеведческую секцию ВССП, посылающую большую группу писателей в различные районы СССР, о чем сообщает «Литературная газета» в статье «Перед всероссийской конференцией ВССП»: «Этим летом краеведческая секция отправляет в различные районы СССР І2 писателей (сроком на 2-3 месяца). Писатели обязуются дать определенный листаж литпродукции, показать в художественных

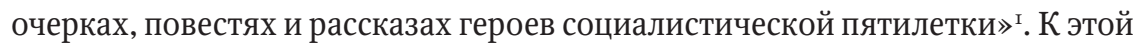
группе писателей Платонов и пытается присоединиться. Іо июня І93І г. пишет жене, отдыхающей с сыном в Сочи: «Уехать я хочу страстно, но нужно достать деньги. С краеведами еще ничего не вышло. Все обещают на днях, а дни идут» [8, с. 296]. Однако деньги удалось найти не сразу. В результате с 3 по г3 августа г93І г., на фоне развернувшейся травли, Платонов пишет пьесу «Объявление о смерти», в какой-то степени автобиографическую [5, c. I87]. И сразу после этого ему удалось договориться с объединением «Скотовод», который считался краеведческой организацией и с которым правление ВССП заключило договор о сотрудничестве, и решить вопрос о своей поездке. В результате I5 августа І93І г. Всесоюзным государственным объединением «Скотовод» писателю выдано командировочное удостоверение, в котором указывалось, что «тов. Платонов, занимающий должность члена о-ва писателей-краеведов, командируется в Средневолжский край по совхо- 
зам»². Согласно этому командировочному удостоверению, Платонов выехал из Москвы во второй половине августа, а вернулся во второй половине сентября. Командировка была долгой, а маршрут писателя - длинным: из писем известно, что во время командировки он посетил города Северного Кавказа и Средней Волги - Орск, Самару и Ставрополь, а также ряд совхозов [8, с. 3І4-3І6]; в относящейся к поездке записной книжке есть, кроме того, записи, сделанные в ЦЧО, Хакассии и Средней Азии и др. [7, с. 8I-92]. Платонов собирает материал для нового произведения, которое могло бы «уменьшить вред от опубликования повести “Впрок”».

Для тех писателей-краеведов, которые уехали раньше Платонова, поездка завершилась в начале сентября, о чем в статье «Писатели-краеведы в районах строительства» и сообщает «Литературная газета»: «Краеведческая секция ВССП послала в районы строительства, колхозы и совхозы около 20 писателей. На днях, на расширенном заседании секции писатели-краеведы тт. П. Сухотин, П. Ширяев (Иссык-кульский конесовхоз), П. Скосырев (проблема Терека), Д. Стонов (Магнитогорск) отчитались в своей работе. $<$...> Планируется выпустить краеведческий альманах по результатам поездок писателей» .

Все писатели, посетившие районы социалистического строительства, должны были отчитаться перед краеведческой секцией ВССП новыми произведениями о «героях социалистической пятилетки» - это было условием командировки. Вероятное всего, таким отчетным произведением и стало «Ювенильное море», что наложило отпечаток не только на образы героев пятилетки в повести, но и на образы ее антигероев, материал для которых Платонов берет, в частности, в «Деле историков и краеведов» I929-I93I гг. [3, с. І20-І24], стараясь придерживаться краеведческой тематики и политической тенденции времени.

Но возникает первый вопрос: а когда же Андрей Платонов отчитался перед краеведческой секцией о своей работе - иными словами, когда он написал «Ювенильное море»? По логике он должен был сделать это осенью I93I г. Однако некоторые особенности автографа, литературный контекст повести, а также имеющиеся данные о попытках ее опубликовать говорят за то, что «Ювенильное море» родилось только весной г932 г. В пользу этой

2 РГАЛИ. Ф. 2г24. ОП. г. Ед. хр. г6. Л. 6.

3 Литературная газета. I93I. го сентября. С. 4. 
версии свидетельствует и стенограмма творческого вечера Андрея Платонова, состоявшегося во Всероссийском Союзе советских писателей г февраля I932 г., - перечисляя написанные им произведения, Платонов ни разу не называет «Ювенильное море», хотя это было бы положительным фактом его отчета [6, с. 294]. Никаких упоминаний о «Ювенильном море» до мая I932 г. в настоящее время не обнаружено.

Создается впечатление, что сразу после поездки у Платонова не было идей по поводу сюжета новой повести. Все, что было, - это записка о жизни в животноводческих совхозах ${ }^{4}$ и записи на ту же тему в записной книжке $[7$, c. 8I-92]; среди этих записей - только одна, напрямую относящаяся к персонажам будущей повести: «Умрищев из невыясн<енных> / Случайно:» [7, c. 82]. В следующий раз Умрищев, а также другие основные герои этой еще не родившейся повести - Вермо, Босталоева и Федератовна - появляются в черновых набросках драматургической формы [2, с. 256-26о], которые, по упомянутым там реалиям, датируются г93г г. Может быть, эти наброски свидетельствуют о неудавшихся попытках Платонова сделать отчетное произведение в виде пьесы? Из этой несостоявшейся пьесы написано несколько разрозненных сцен. От одноименных героев повести персонажи пьесы существенно отличаются: Умрищев здесь - профессор с портфелем; Босталоева уехала из Москвы строить фундамент социализма на окраине страны и живет в крытой арбе (телега на Кавказе и Средней Азии), детально описанной, что может свидетельствовать о стремлении Платонова воспроизвести местный колорит и написать краеведческое по духу произведение; Вермо - московский возлюбленный Босталоевой, о котором сообщается только такая странная портретная деталь, как «кривой зуб». Но ученая старушка Федератовна изменится мало. Речи ее и Умрищева почти полностью перейдут затем в «Ювенильное море».

Что все-таки могло послужить толчком к написанию «Ювенильного моря»? Едва ли уже выношенный замысел всего произведения. Скорее, это была необходимость отчета перед краеведческой секцией ВССП, пославшей Платонова в командировку; первым (судя по некоторым деталям, о которых будет сказано ниже) известным откликом на повесть стала рецензия П. Скосырева, коллеги Платонова по поездке от краеведческой секции: ре- 
цензия отвергала повесть именно как краеведческое произведение, не подходящее для краеведческого альманаха.

Вероятно, «Ювенильное море» было написано в короткий срок. Об этом свидетельствует прежде всего автограф, который ясно показывает, что Платонов пишет быстро, без особого плана и очень небрежно; фразы часто не складываются, что у Платонова бывало крайне редко, он перебирает разные слова, потом зачеркивает весь фрагмент. Много вычеркивает, когда повествование идет «не туда». Зачеркнутое иногда по нескольку раз переписывает, почти не внося изменений; иногда бросает недописанным. Вот, например, некоторые характерные фрагменты, зачеркнутые писателем по ходу работы; в них видны и небрежность письма, и неопределенность замысла, и даже время действия повести.

Так, повествуя о «невыясненных», т. е. о проходящих партийную чистку, которые рассказывают про свою жизнь, Платонов неожиданно «уклоняется» в философию: один из таких «невыясненных», говоривший о своей скрытой болезни, «напоролся на человека, который отверг такой мотив. “Раз ваша болезнь так глубоко скрыта, что вы ее не чувствуете, то это есть “вещь в себе”, а вещь в себе открыл Кант, будучи идеалистом, врагом Маркса и защищая неприкосновенность собственности: стало быть, вещи в себе нету и нет вашей болезни”. - “Тогда я здоров”, - ответил выяснившийся и пропал с тех пор из резерва невыясненных. Сам Умрищев выяснился нечаянно, и то неокончательно. Он напоролся на столь же умного служащего человека, как и сам; человек ему сказал: “если ваша болезнь...»5.

В истории о том, как «сам Умрищев опростался однажды от невыясненности», в окончательном тексте повести рассказывается о помощи случайного начальника случайно встреченного Умрищевым на улице, но сначала она излагалась иначе, слова же при этом не всегда согласовывались: «...он выступал однажды на собрании ячейки РКК, собравшейся в той учрежденской комнате, где он ночевал, с каким-то уклончивым мнением, - и Умрищеву на следующий день дали назначение в мясосовхоз, с тою целью, чтобы до-выяснить его на практической работе. И чем больше объяснял Умрищев свою долю, тем грустнее становилось Вермо...» (л. І6).

5 ИМЛИ. Ф. 629. Оп. г. Ед. хр. 39. Л. 15. Далее ссылки на листы автографа даны в тексте статьи. 
Круг героев повести с самого начала не был строго очерчен: в ходе повествования новые персонажи появлялись легко - и тут же исчезали, например: «Умрищев велел позвать гуртового инженера Ознобкина, Босталоеву, делопроизводителя Мелкова, выходного полевого гуртоправа Цукайло, старушку Федератовну, а заодно и Босталоеву с музыкантом. Умрищев любил...» (л. 47).

В спешке Платонов применяет к Умрищеву, и без того являющемуся сосредоточием почти всех идеологических обвинений начала І930-х гг., дополнительные политические клише: «Но впоследствии Умрищева ожидала печальная скучная доля [механиста - зачеркнуто. - Н.Д.] гнуснейшего тактика оппортунизма, еще ползущего под пузом шевелящегося поверженного кулака безвыходного оппортуниста, и блуждания в дебрях экле...» (л. Іо2).

Многочисленные в повести рассуждения о диалектике Платонов сначала пытался приписать еще и Федератовне: «...старуха практически знала, насколько мучительно-диалектически земное существование, и насколько эта диалектика состоит из точных порций - так что трудно было войти между этими порциями бедной фантазии человека. Маркс, Энгельс, Ленин и теперь Сталин беспрерывно следят за движением в мире диалектических порций и в такт этому движению направляют силы пролетариата, - и лишь тогда пролетариат изменяет жизнь» (л. ІІ9).

В автографе периодически встречаются фрагменты текста, когда Платонов пишет слова, а фраза не складывается, что у него бывало крайне редко: «...чувствуя, что дерущиеся диалектические сущности его сознания лежат свалившись от утомления: - Надежда Михайловна, я изобрел электричество из солнечного света. Нужно сделать оптический трансформатор - он будет превращать пульсацию солнца, луны, звезд, свет человеческих глаз - в электрический ток. Мы живем в [нрзб.] энергии, в любую точку над своей головой в середине водопада энергии в любую точку над в любой точке дня и ночи вы можете поставить оптический кристалл и принимать энергию... До свидания, Надежда Михайловна, - сказал вдруг печально Вермо. - Я ехал с вами утром и увидел на небе электрическую энергию...» (л. 157); «Инженер Вермо, насмехавшийся ранее над дурной унизительной организацией труда в над низкой производительностью труда, сам теперь увидел буржуазность своей насмешки. Он чувствовал стал смотрел по ночам, как спят развернул фронт работ сразу - по всем сопротивлениям...» (л. 260). 
Возможно, испытывая дефицит подходящих тем, Платонов активно использует в повести свои старые темы и образы, в том числе доверяет героям собственное изобретение, «вольтову дугу», которую они предлагают как средство добывать из-под земли во́ды «ювенильного моря» - но вначале предполагалось другое ее применение: «-Зачем же голое мясо то везти, головы? - спросил Кемаль. - Консервы надо делать и колбасу коптить; нужно стремиться к высшему продукту! - А банки где возьмешь? - сомнительно спросил рабочий из этой бригады. - Банки?! - враз задумался Вермо. - Мы будем делать не банки, а горшочки - мы поставим гончарное производство: надо только продумать автоматический формовочный станок и печь из вольтовой дуги!» (л. 238).

Известно, что в окончательном тексте повести Вермо читает сборник статей И. Сталина «Вопросы ленинизма», но сначала он читал не только Сталина, но и Ленина: «По совету Кемаля Вермо ввел добавочную зарплату и люди так умаривались, что не могли смыть водою свой пот и им не хватало сна для забвения усталости. Рассматривая однажды ночью книги Босталоевой, Вермо нашел “Вопросы ленинизма” Сталина и несколько томов Ленина; он начал их перечитывать...» (л. 26I). При этом из параллельного чтения героем двух вождей, Ленина и Сталина, Платонов чуть не сделал вывод в пользу большего ума Ленина: «Под утро Вермо, начитавшись Ленина, затем вновь возвратился к Сталину, и беспокойство его возрастало. В нем происходило знание Он догадался о чем-то хотел догадаться об этой тайне книги Сталина, с целью использования Он находил мысль, но терял ее от радости открытия и снова ощущал в темноте сознания тайну Вышел наружу, залез на башню, снова увидел высоту солнца вышел наружу, лег вниз лицом в степь и подумал: “Я дурак, я что-то недооцениваю - начитавшись, начал думать, что он недостаточно умен, сравнительно...” (л. 265-266).

В какой-то момент в повести проскальзывает даже указание на время действия - очень ценное для ее датировки, - но Платонов вычеркивает фразу: «До самой весны 1932 года Федератовна не получала писем от Босталоевой» (л. 275).

И уже в конце повести писатель вычеркнул такую фразу: «Здесь Федератовна, как была почти голая, так и вскочила со своего ложа и укусила Умрищева за оппортунизм», - написав вместо нее более нейтральный ва- 
риант: «Здесь лежащая Федератовна обернулась к Умрищеву и укусила его за оппортунизм» (л. 277).

Но больше всего в автографе фрагментов, вычеркнутых и снова написанных практически без изменения: Платонова явно не устраивает то, что он пишет.

Автограф зафиксировал два названия повести: первое - «Ювенильное море» - зачеркнуто и вписано новое, «Степное дело». При этом нельзя сказать наверняка, что выбор названия предшествовал работе над текстом; как в первом, так и во втором варианте, оно могло быть придумано уже после ее завершения (так, вероятно, и произошло) и вписано на оставленном для этого месте. Чем была вызвана замена названия? Тем ли, что Платонову вдруг больше понравилось назвать ее «Степным делом», или тем, что название «Степное дело» больше соответствовало требуемому от краеведческого произведения указанию на местность, чем «Ювенильное море»? Если судить по дальнейшей истории текста, то второе предположение кажется все-таки более вероятным. На титульном листе автографа есть указание машинистке: «4 экз.». Дальнейшая история текста повести полностью отражена в этих машинописях и согласуется с известными попытками ее опубликовать.

Об этих попытках свидетельствуют сохранившиеся документы - договор на издание повести и отзывы, которые к тому же фиксируют последующие изменения в ее названии. Во-первых, это уже упомянутый отзыв П. Скосырева на пока еще «Степное дело» для какого-то краеведческого альманаха - вероятно, того, что заявлен в «Литературной газете» и планировался по результатам поездки, но, похоже, так и не был издан. Главная мысль отзыва - повесть лишена элементов, образующих подлинно краеведческое произведение; главный вывод рецензента - печатать повесть в альманахе нельзя: «А. Платонов “Степное дело” (повесть). Очень талантливая вещь. Среди прочих произведений А. Платонова выделяется большей композиционной организованностью. Система образов позволяет говорить о “Степном деле” как о художественной победе Платонова. Но тем не менее печатать ее в альманахе нельзя. Прежде всего, она лишена всех элементов, образующих подлинно краеведческое произведение. Построенная на местном материале (совхозы Киргизии - видимо), она абстрагирует явления; местное перестает играть какую-либо роль... <...> Кроме же того - столь безобразной встает жизнь нашей страны в этой повести, что нет особого 
желания помещать ее на страницах альманаха. Разве отдельные кусочки, маленькие главки - по выбору» ${ }^{6}$.

Возможно, Платонов отдал повесть на отзыв Скосыреву сразу, как только получил машинопись от машинистки, еще даже не успев вычитать текст (ибо, как свидетельствует машинопись, уже при первой серьезной вычитке текста он поменяет название), предположительно в апреле-мае I932 г. Не исключено, что повесть на прочтение Платонов давал не только Скосыреву, один из таких эпизодов, связанный, судя по всему, со «Степным делом», отражен в воспоминаниях К. Зелинского под датой «4 мая I932 г.» и свидетельствует о том, что в начале мая І932 г. Платонов показывал какое-то свое новое произведение, по описанию похожее на «Степное дело», Всеволоду Иванову, в то время редактору «Красной нови»: «Второго мая. Обедаю у Всеволода Иванова. <...> Всеволод входит. - ...Читал вот новую вещь. Платонова. Дал нам. Анархизм опять. Талантливо, но черт те что. Ни партии, ни советской власти, совхоз какой-то...» [4, с. I35].

Отдав новую повесть на прочтение Вс. Иванову и, возможно, П. Скосыреву, в начале мая г932 г. Платонов уезжает в Ленинград и на Свирьстрой - в командировку от газеты «Известия», о чем свидетельствует выданное ему редакцией газеты «Известия» Соглашение о том, что «Тов. Платонов, выезжающий 5 мая с.г. в Ленинград и на Свирьстрой сроком на один месяц, дает редакции четыре очерка...»7. Находясь в Ленинграде, I6 мая I932 г. Платонов подписывает договор с Издательством писателей в Ленинграде на публикацию повести «Степное дело» - с предоставлением издательству права «на издание и переиздание своего труда под названием “Степное дело” размером до 6 печатных листов» и представлением издательству самой повести «в совершенно готовом виде не позже 25 мая I932 г.» ${ }^{8}$ - возможно, текста повести у него при этом не было. Однако в Издательстве писателей в Ленинграде «Степное дело» издано не было. Очень вероятно, что оно туда не было и представлено.

Дальнейшая история повести связана уже с другим ее названием «Ювенильное море»: именно как «Ювенильное море» повесть будет упоминаться в рецензиях и свидетельствах современников, пока Платонов

6 ИМЛИ. Ф. 494. Оп. г. Ед. хр. го. Л. г.

7 РГАЛИ. Ф. 2024. ОП. І. Ед. хр. г5. Л. 3.

8 РГАЛИ. Ф. 2І24. ОП. г. Ед. хр. І5. Л. 7. 
опять ее не переименует. Похоже, что возвращение этого первого названия повести произошло при первой серьезной вычитке текста автором; подобная вычитка обычно имеет место не в очень удаленное от написания время.

Изучение тех экземпляров машинописи, которые сохранились более или менее полно, приводит к следующей реконструкции истории ее текста. Итак, получив от машинистки машинопись под названием «Степное дело» и даже не успев вычитать ее, Платонов, как представляется, отдает ее более или менее одновременно П. Скосыреву для какого-то краеведческого альманаха и Вс. Иванову в «Красную новь», сам же едет в Ленинград. Вероятно, только после возвращения в Москву он серьезно вычитывает машинопись: исправляет опечатки и очень грубые ошибки машинистки, а также вносит кое-какие изменения в текст, при этом правит, как он это часто делает, одновременно два экземпляра; наличие общей в двух экземплярах правки позволяет отделить данный слой исправлений от последующих.

Эта первая серьезная правка I932 г. нейтральна в идеологическом отношении и скорее стилистическая; кроме исправления обычных опечаток, Платонов устраняет допущенные машинисткой несуразности, а их немало. Так, например, во фразе «Умрищев стал как бы неясен, нечеток, персонально чужд...» машинистка сделала ошибку и вместо «персонально» напечатала «нереально»; только теперь Платонов эту ошибку исправляет ${ }^{9}$ Кроме этого, в одном фрагменте машинистка неправильно прочла слово и вместо «постороннего» напечатала «ресторанного», в результате чего получилось следующее: «Священный сел на скамейку в отдышке от собственной тяжести - хотя он не был толст, а лишь громаден в костях и во всех отверстиях и выпуклостях, приноровленных для ощущения всего ресторанного». Платонов исправляет и эту грубую ошибку - зачеркивает «ресторанного» и вписывает «постороннего» (с. 78), как и было в автографе. Одно исправление, которое Платонов сделал в автографе, машинистка не учла, он написал сначала: «Где же тут сидит самая категорическая стерва?», но потом зачеркнул слова «категорическая стерва» и написал «принципиальный стервец» ${ }^{\text {г }}$ машинистка же, не обратив внимание на вычеркивание, напечатала оба вы-

9 ИМЛИ. Ф. 629. Оп. г. Ед. хр. 4І. С. 5 (по исходной нумерации машинописи); ГЛМ. Ф. 335. Оп. г. Ед. хр. 25. С. 5 (по исходной нумерации машинописи). В дальнейшем ссылки на страницы машинописи даны в тексте статьи.

го ИМЛИ. Ф. 629. Оп. г. Ед. хр. 39. Л. 215. 
ражения: «Где же тут сидит самая категорическая стерва? принципиальный стервец?» Платонов вычеркивает «категорическую стерву» в обоих подвергшихся правке экземплярах.

На этом уровне правки он также заменяет некоторые слова и выражения, чем-то не нравящиеся ему стилистически; например, после слов «предал суду десять служащих своего ведомства, дабы они...» вычеркивает часть предложения: «получили примерное наказание и впредь не занимались заготовкой людей впрок» и вписывает: «имели случай опомниться от своих делов»; в предложении «На следующий день доярку Айну хоронили» вычеркивает «хоронили» и вписывает «понесли в гробу два выходных пастуха»; имя Федератовны «Пелагея» заменяет на «Мавра»; в выражении «пространство, напряженное безвыходной и безмолвной электромагнитной энергией солнца» зачеркивает слово «безвыходной» и вписывает «грозной»; в предложении «Проводи классовую политику» заменяет слово «проводи» на «соблюдай» и др.

И что особенно важно для датировки этой правки - одновременно с ней Платонов изменяет название повести и возвращает то самое, которое было вначале. Делает он это следующим образом: срезает у двух машинописей верх страницы с названием «Степное дело» и на свободном месте вписывает от руки: «Ювенильное море (Море юности)», так что никаких следов того, как повесть называлась прежде, на этих машинописях не остается. Таким образом, у Платонова оказывается два более авторитетных, с исправленными опечатками, экземпляра машинописи под названием «Ювенильное море»; и два экземпляра «Степного дела» без правки.

Вычитав текст, внеся в него все необходимые исправления и изменив название, Платонов отдает машинопись в редакцию - теперь уже в московское издательство «Художественная литература» (ГИХЛ), о чем свидетельствует сохранившаяся в его фонде рецензия, написанная Л. Резником: «Андрей Платонов “Ювенильное море”. Эта повесть посвящена одному из важнейших отрицательных явлений нашей жизни - оппортунизму. <...> ...На этой повести со всей яркостью сказалась обычная для творчества А. Платонова (последних лет) ошибка. Отдельные недостатки и язвы нашего аппарата, отрицательные явления жизни столь выпячены, что в общем создают картину сплошной бракованности всей системы. Этот гиперболизм обобщений и нанизываний отрицательного создает в итоге объективно па- 
сквилянтский характер повести. Она выглядит злобной и неверной сатирой на действительность. Ясно, что об издании подобной вещи не может быть и речи» ${ }^{\mathrm{II}}$.

В I933 г. машинопись «Ювенильного моря» (именно «Ювенильного моря», а не «Степного дела») оказалась в ОГПУ (принесена туда кем-то из его агентов, взявших повесть у писателя на прочтение), где с нее была сделана сокращенная копия: частичная перепечатка, вперемешку с пересказом, всего 77 страниц. На первой странице этого «дела» в архиве ФСБ написано «Ювенильное дело»; слово «дело» зачеркнуто, и вместо него вписано «море». В результате этого исправления вся надпись выглядит так: Ювенильное море (Море юности). Роман» - и стоит дата: «Москва І933 г.»; в верхнем левом углу - помета: «Получено через агентуру». На второй странице - запись: «Ювенильное море / Выписки из романа» ${ }^{\mathrm{I2}}$. Сравнение тех фрагментов машинописи ОГпу, которые являются перепечаткой, с оригинальной машинописью повести также помогает в датировке двух слоев ее правки.

Следующее свидетельство о «Ювенильном море» - тоже от ОГПУ: в материалах его слежки за Платоновым есть запись от 20 октября г933 г.: «Рукопись “Ювенильное море” возвращена, даже без отзыва, из альманаха “Год І6-й”» [г, с. 852].

Однако, несмотря на все неудачи с публикациями в I932-I933 гг., Платонов не теряет надежды и в 1934 г. вновь пытается издать повесть, уже серьезно ее переделав. Следы этой попытки тоже сохранила машинопись - одна из тех двух, которые он уже вычитывал и правил. Прежде всего, Платонов снова изменяет название, вернее, избавляется от его необычной первой части «Ювенильное море» и оставляет только вторую - «Море юности». Так как вписывать новое название уже было некуда - из-за отрезанного ранее названия «Степное дело» первая страница машинописи оказалась укороченной, - Платонов отдает эту страницу на перепечатку и затем вписывает от руки сверху: «Море юности (Повесть)». Вместе с первой страницей он одновременно перепечатывает еще и последнюю - вероятно, там были какие-то свидетельства предыдущих попыток публикации; иначе невозможно объяснить перепечатку этой страницы, ибо на ней нет никаких

II РГАЛИ. Ф. 6Іг. ОП. 2. Ед. хр. 246. Л. 228.

I2 ФСБ. Ф. К-4. Оп. г. Порядок 62. Л. 2. 
исправлений. В конце перепечатанной страницы Платонов проставляет от руки дату, позволяющую определить время данной правки: «1934». В сам текст он тоже вносит много исправлений, на этот раз свидетельствующих уже об автоцензуре. Так как эта правка есть только в одном экземпляре машинописи, отделить ее от предыдущей несложно, сравнив две машинописи с авторской правкой.

Внося в текст изменения в ходе этой последней правки, Платонов прежде всего старается убрать то, что может как-то задевать возможных критиков. Так, в выражении «теперь он мчится в действительность из пушки своего класса, заряженный природным талантом и политехническим образованием» вычеркивает слова «из пушки своего класса»³; зачеркивает большой фрагмент про собрание, на котором Умрищев и Божев каются в своих ошибках, а потом Божев видит сон, как «его порет ремнем пролетариат» (c. 23-24). В результате такого сокращения оказывается немотивированной следующая после вычеркивания сцена, Платонов этого не замечает: «Собрание сидело в озадаченном виде. Одна Босталоева улыбнулась и захотела знать, в чем Умрищев и Божев каются...» (с. 25), а эпизода с покаянием уже не было. Кроме фрагментов, уязвимых в политическом плане, Платонов смягчает или даже совсем убирает излишне натуралистические сцены: вычеркивает абзац, где Босталоева пытается давать грудь брату повесившейся Айны (не очень маленькому мальчику), чтобы утешить его после смерти сестры (с. 30); редактирует эпизод, в котором Божев насилует Айну, сглаживая натурализм описания (с. 36). Кроме этого, сокращает действительно длинный диалог Федератовны с Умрищевым (с. 22) и делает несколько нейтральных замен например, в выражении «два благожелательных голубых глаза» зачеркивает «голубых» и вписывает «степного светлого цвета» (с. I6).

Мало вероятно, что Платонов стал бы исправлять текст просто так, чтобы улучшить его или на случай, если возможность опубликовать повесть когда-нибудь представится. Вероятно, предварительная договоренность о ее публикации была, в фонде Гослитиздата сохранилась рецензия на повесть А. Платонова «Море юности». Рецензия написана Н.Г. Плиско, даты на ней нет. Рецензия отрицательная; ее главная идея - произведение пасквильное и враждебное, печатать его нельзя: «А. Платонов “Море юно-

I3 ИМЛИ. Ф. 629. Оп. г. Ед. хр. 4г. С. 3. В дальнейшем ссылки на страницы машинописи даны в тексте статьи. 
сти” (5 листов). Повесть сатирическая. Написана талантливо. Автор поставил задачей разоблачить, высмеять, поиздеваться над оппортунизмом и оппортунистами. Тема хорошая, интересная, нужная. Но А. Платонов свою сатирическую издевку, во-первых, распространил на все стороны нашей действительности, в результате чего ведущие люди нашей эпохи (Бостолоева) (sic!) и близкие к ним (Вермо) выглядят карикатурно, политически неверно, а во-вторых, оппортунизм и оппортунист представляют собой нечто обывательски-мещанское, а не враждебную, сознательную силу, теоретически осмыслившую свои цели. Повесть дает издевательский акцент и над политикой индустриализации. Произведение пасквильное, и хотел того или нет автор, объективный смысл повести явно враждебный. О печатании ее, разумеется, говорить не приходится» ${ }^{\mathrm{I4}}$.

Что касается других известных официальных документов, то «Ювенильное море» названо «Морем юности» лишь однажды - в ответах Платонова на анкету Группкома Московского Товарищества Писателей, которые датируются 3 января I934 г.: «За последние три года мною написано следующее: “Шарманка” - пьеса, “Высокое напряжение” - пьеса, “Море юности” - повесть...» [6, с. 3I8]. Упоминание повести под таким названием в анкете г934 г. может косвенно свидетельствовать и о времени последней правки, ориентированной на публикацию г934 г.

Потерпев ряд неудач с публикацией повести, Платонов решает переделать ее в рассказы, два из которых получили завершенную форму. В фонде писателя в ИМЛИ сохранился рассказ «Человек нашего времени» [2, с. 262-268] с использованием страниц машинописи «Степного дела»; под текстом рассказа стоит неполная дата, без указания года: Ленинград, 24/V. Скорее всего, «Человек нашего времени» был выделен из повести в I934 г. - после того, как Платонов потерпел очередную неудачу с публикацией ее полного текста. И еще один большой фрагмент повести (рассказ о поездке Босталоевой в крайцентр за стройматериалами) Платонов переделал в рассказ «Стройматериалы и оборудование» - когда, неизвестно: в дате на первой машинописи рассказа тоже не указан год: «24/VI» (см. об этом ниже); вероятнее все-таки, что это был тот же г934 г. - в пользу этой даты говорят все датированные попытки напечатать рассказ. 
В настоящее время ничего не известно о стремлении Платонова опубликовать очерк «Человек нашего времени»; однако история «Стройматериалов и оборудования» насчитывает по крайней мере четыре таких попытки.

Первая публикация рассказа предполагалась в каком-то журнале - возможно, «зо дней», если судить по рецензентам, А. Митрофанову и П. Павленко ${ }^{15}$. Эта попытка публикации зафиксировала самое начало истории отдельного текста «Стройматериалов и оборудования», который будет переделываться потом неоднократно: фрагмент машинописи «Ювенильного моря» перепечатан без всяких изменений; полученный таким образом текст не имеет названия, которое вписано Платоновым от руки: «Стройматериалы и оборудование (рассказ)»; страницы машинописи пронумерованы тоже от руки. Этот машинописный текст Платонов правит - исправляет опечатки, убирает скрепы с «Ювенильным морем», а также «вызывающие» детали сюжета (например, факт аборта Босталоевой); что-то вписывает, что-то вычеркивает. Вот некоторые образцы его исправлений: после слов «по учреждению ходили крысы» (л. 2) вписано: «ликвидируя исторические документы.»; «коровье кало» исправлено на «коровьи лепешки» (л. 2); после слов «мне пришлось за это сделать аборт» (л. 4) вписано: «- Босталоева отвернулась, чтобы скрыть улыбку: она лгала - без страсти и влечения она не могла бы сделать даже рукопожатия, и сердце ее не имело хозрасчета». Сделав необходимые исправления, писатель отдает машинопись на перепечатку (л. Іо-2г).

На оценку рецензентам Платонов дает, однако, ту машинопись, в которую он вносил правку: их отзывы написаны прямо на ней. Отзывов два, один принадлежит А. Митрофанову, другой - П. Павленко. На полях первой страницы машинописи вписано: «Рассказ написан мастерски, всем Габриловичам дает фору, но... печатать можно, кое-какие строки выбросив вовсе, кое-какие радикально переделать. Обязательно! А. Митрофанов. 24/VI». На обороте последней станицы - карандашная запись: «Рассказ полон графомании, написан - с начала до конца - с издевкой. Можно напечатать в Известиях Психоневрологического института... и нигде больше. Я против категорически. П. Павленко» (л. 9). Той же рукой (т. е. рукой П. Павленко) 
и тем же простым карандашом напротив абзаца: «Из камеры суда Босталоева ушла, как актриса...» - сделана запись: «Не глупо ли?» (л. 6).

С такими отзывами рассказ, естественно, не был напечатан. И спустя некоторое время Платонов делает попытку включить его в какой-то сборник своих произведений: эту попытку зафиксировали две машинописи, хранящиеся в архиве ИМЛИ: одна машинопись является перепечаткой с той, о которой речь шла выше и которая была сделана, условно говоря, для «зо дней»; она содержит авторскую правку и редакторские пометы ${ }^{16}$; вторая машинопись - перепечатка с этой после внесения в нее правки, без нумерации страниц (что может быть только при подготовке сборника, когда не до конца ясен его состав, чтобы в итоге ввести единую нумерацию); страницы пронумерованы вручную от 50 до 6I ${ }^{\text {I7 }}$. В настоящее время точно известно о подготовке на рубеже I934 и г935 гг. сборника девяти рассказов Платонова под общим названием «Такыр»: о данном сборнике свидетельствует письмо Платонова к Корнелию Зелинскому, члену редсовета «Федерации», от I января г935 г. [8, с. 367-369]. Судя по письму, оно написано при пересылке Зелинскому текстов предполагаемого сборника.

Готовя «Стройматериалы и оборудование» для этого сборника, Платонов продолжает править текст: так, он заменяет «различных партийцев» на «загорелых коммунистов»; добавляет прилагательное «удаленного» в выражение «глядели в широту пространства» (получилось: «глядели в широту удаленного пространства»); вычеркивает слова «ликвидируя исторические документы», добавленные в предыдущей машинописи «Стройматериалов...» после слов «по учреждению ходили крысы» (см. выше); убирает из текста упоминание о Федератовне. Некоторые выражения и даже абзацы вычеркивает редактор - их Платонов восстанавливает, написав рядом с такими исправлениями: «Все нужно печатать», например: л. 5 (от слов «Разве поцеловать мне вас за гвозди...» и до слов «...вечером я сам сяду за автомат, вы подождете десять минут и получите свои гвозди... Везите катанку сюда»); л. 6 («Директор опустил голову к текущим делам. Босталоева сама подошла и поцеловала его - таким способом, что впоследствии, когда Босталоева уже ушла, директор ходил в уборную глядеться в зеркало, - не осталось ли чего на его лице от этой женщины, потому что он все время чувствовал

I6 ИМЛИ. Ф. 629. Оп. г. Ед. хр. 43. Л. І-І3. Ссылки на листы документа даны в тексте статьи.

І7 ИМЛИ. Ф. 629. Оп. г. Ед. хр. 44. Л. І-І2. 
какой-то лишний предмет на своих губах»); л. II («она не гнилая либералка»); л. І2 («Зачем ты шатаешься по всему нашему бюрократизму, кустарная дурочка! Ты бы зашла ко мне сразу»). Некоторые вычеркивания редактора Платонов принимает, например: л. I («...и нужно ждать еще пять или десять лет, чтобы наступил коммунизм, когда механизмы вступят в труд и освободят людей для взаимного увлечения»), л. 5 (после слов «И теперь стояла перед ним эта женщина, требовательная, как республика» редактор вычеркнул «...и так же лишенная пока богатых фондов и особой прелести»; вместо вычеркнутых слов Платонов вписал: «накапливая себе богатые фонды и храня прелесть лица в запас»). Как известно, данный сборник платоновских рассказов издан не был.

Об очередной попытке Платонова опубликовать «Стройматериалы...» в І935 г., теперь уже в журнале «Наши достижения», свидетельствует запись в документах ОГПУ от 8 октября г935 г.: «Редакцией журнала “Наши достижения” был заказан А. Платонову очерк для специального номера, посвященного совершеннолетию ровесников Октября - молодежи, которой минет в этом году восемнадцать. А. Платонов сдал рукопись, называющуюся “Стройматериалы и оборудование”. Эта вещь представляет собой злой пасквиль на советскую действительность. Рассказывается в рукописи об одной молодой коммунистке, ездивший в краевой центр добывать гвозди для своего совхоза. Рукопись была заказана и авансирована Бобрышевым (аванс 500 рублей)» [I, с. 858]. Об этой попытке публикации свидетельствует машинопись «Стройматериалов и оборудования», хранящаяся в РГАЛИ и имеющая редакционную запись в углу на первом листе машинописи: «№ 209 / I9/IX-35 г. / 2 эКз.».

Машинопись для «Наших достижений» Платонов создает на базе той машинописи, которая предполагалась для сборника (экземпляр, хранящийся в ИМЛИ, - см. выше). Номер «Наших достижений», для которого Платонову был заказан очерк, посвящался молодежи - ровесникам Октябрьской революции. Такой ровесницей Октября Платонов делает Босталоеву, подтягивая к этому юному возрасту и остальных героев рассказа; параллельно он убирает из текста те реалии, которые в конце г935 г. уже не существуют. В результате таких исправлений, Босталоева больше не директор мясосовхоза, а помощница директора; ее возрастное определение «женщина» исправлено на «девушка», характеристика «счастливая» - на «крот- 
кая»; после слов «...в скучной пустоте канцелярий.» вписано: «Ей было пока еще девятнадцать лет, и всякое чувство или настроение ее превращалось в мысль счастливой, томящей силой юности»; «РКИ» заменено на «Совконтрестом», так как наркомат Рабоче-крестьянской инспекции был ликвидирован в 1934 г.; выражение «требовательная, как республика, накапливая себе богатые фонды и храня прелесть лица в запасе» (слова, вписанные на предыдущем этапе исправления, - экземпляр ИМЛИ) исправлено на «требовательная, как республика, и милая, как рядовой товарищ»; вычеркнуто все про ювенильное море («Нам хочется достать ювенильное море, а то нам не хватает воды для водопоя...») как реакция на помету редактора на полях: «Зачем это? Непонятно»; в рассказе о встрече Босталоевой с секретарем ячейки чертежно-конструкторского института, у которого она просит динамо-машину, а он в ответ предлагает ей «выйти за него замуж через полгода», - после этих слов добавлено «когда он окончит институт». Как свидетельствует запись в документах ОГПУ, журналу «Наши достижения» рассказ тоже не подошел.

Последняя из известных попыток Платонова опубликовать «Стройматериалы...» относится к г940 г., когда в издательстве «Советский писатель» готовился сборник его рассказов «Течение времени», куда должны были войти и «Стройматериалы...». Сборник так и не увидел света, но сохранилось несколько рецензий на него, в которых есть оценка и этого текста. Один из рецензентов сборника, Ф. Левин, пишет о рассказе очень кратко: «Хороший рассказ “Стройматериалы и оборудование” ${ }^{18}$. Другой рецензент, Л. Разин, придерживается иной точки зрения: «Рассказ “Стройматериалы и оборудование” я воспринял как пасквиль на нашу жизнь. Сердечное отношение Босталоевой к машине, прессующей брикеты из коровьих лепешек, не вызывает никакого сочувствия и волнения. Противопоставление искренней и человеческой заботы Босталоевой сплошному бюрократическому чаду и бумажной суете совслужащих явно фальшиво. Вывод получается неверный, ложный - именно что советская система, сухая, бумажная, чадная суета, а человеческого понимания, сердечных отношений почти нет. Конец рассказа, когда Крайком, воодушевленный энтузиазмом Босталоевой, создает чтото вроде областного комбината по изготовлению брикетов из отбросов жи- 
вотного организма, выглядит совсем издевательски. Л. Разин. I8/IX-40 г.» Третий рецензент, В. Шкловский, в своей манере почти назывных предложений дает скорее положительную оценку рассказа: «"Стройматериалы и оборудование”. Надежда Михайловна Босталоева ищет оборудование для колхоза. Рассказ напоминает один рассказ Габриловича, где показан упорный шахтер, ищущий провод для шахты. Босталоева сделана аскетичной, настойчивой. Рассказ почти хороший, но пересказ событий, детскость его нехороша». Машинопись «Стройматериалов...», предложенная для данного сборника, в настоящее время не обнаружена, однако из рецензии Л. Разина видно, что Платонов продолжал вносить в текст изменения; в этой поздней версии «Стройматериалов..» появляется такая новая сюжетная деталь, как создание крайкомом «областного комбината по изготовлению брикетов из отбросов животного организма».

К такой истории привели искренние попытки Андрея Платонова исправиться и создавать произведения, «которые бы с избытком перекрыли тот вред, который был принесен автором в прошлом...». Как он ни старался писать в соответствии с требованиями литературного заказа, у него все равно получалась «картина бракованности всей системы», «произведение пасквильное и враждебное». Повесть «Ювенильное море» была впервые опубликована в г986 г. с правкой 1934 г.

\section{Список литературы}

I Гончаров B., Нехотин В. Андрей Платонов в документах ОГПУ: Публикация // «Страна философов» Андрея Платонова: Проблемы творчества. М.: ИМЛИ РАН, 2000. Вып. 4. С. $848-885$. Дужина Н. Новые материалы к истории текста произведений Платонова г9зоI93І гг.: «Котлован», «Шарманка», «Ювенильное море». Статья и публикация // Архив А.П. Платонова. М.: ИМЛИ РАН, 2009. Книга І. С. 237-269.

3 Дужина Н. «Дело историков и краеведов» на страницах повести «Ювенильное море» // «Страна философов» Андрея Платонова: Проблемы творчества. М.: ИМЛИ РАН, 2ОІ7. ВЫП. 8. С. І2О-І24. Зелинский К.Л. Три встречи: Воспоминания // Между молотом и наковальней: Союз советских писателей СССР. Документы и комментарии. М.: РОССПЭН. 20II. C. I32-I38. 
Московская Д.С. Первая редакция пьесы «Высокое напряжение»: «Объявление о смерти». Статья и публикация // Архив А.П. Платонова. М.: ИМЛИ РАН, 2009. Книга г. С. 178-236.

6 Платонов Андрей: воспоминания современников. Материалы к биографии. М.: Современный писатель, І994. 486 с.

7 Платонов А. Записные книжки. М.: ИМЛИ РАН, 200о. 4 I9 с.

8 Платонов А. «...Я прожил жизнь»: Письма. М.: Астрель. 20I3. 685 с.

\section{References}

I Goncharov V., Nekhotin V. Andrei Platonov v dokumentakh OGPU: : Publikatsiia [Andrey Platonov in OGPU's documents: Publications]. "Strana filosofov" Andreia Platonova: Problemy tvorchestva [Andrey Platonov's Country of Philosophers: Problems of Creative Art]. Moscow, IWL RAS Publ., 2000, issue 4, pp. 848-884. (In Russ.)

2 Duzhina N. Novye materialy k istorii teksta proizvedenii Platonova I930-I93I gg.: "Kotlovan", “Sharmanka”, "Iuvenil'noe more”: Stat'ia i publikatsiia [New materials in the history of Platonov's works, I930-I932]. Arkhiv A.P. Platonova [Platonov's archive]. Moscow, IWL RAS Publ., 2009, book I, pp. 237-269. (In Russ.)

3 Duzhina N. "Delo istorikov i kraevedov" na stranitsakh povesti "Iuvenil'noe more" ["The Campaign against Historians and Local Historians" in the pages of the story "A Juvenile Sea” by Andrey Platonov]. "Strana filosofov" Andreia Platonova: Problemy tvorchestva [Andrey Platonov's Country of Philosophers: Problems of Creative Art]. Moscow, IWL RAS Publ., 20I7, issue 8, pp. I20-I24. (In Russ.)

$4 \quad$ Zelinskii K.L. Tri vstrechi: Vospominaniia. Mezhdu molotom i nakoval'nei: Soiuz sovetskikh pisatelei SSSR. Dokumenty i kommentarii [Three meetings: Recollections. Between a hammer and an anvil]. Moscow, ROSSPEN Publ., 20II, pp. I32-I38. (In Russ.)

5 Moskovskaia D.S. Pervaia redaktsiia p’esy “Vysokoe napriazhenie”: “Ob”iavlenie o smerti”: Stat'ia i publikatsiia [The first version of a play High Voltage]. Arkhiv A.P. Platonova [Platonov's archive]. Moscow, IWL RAS Publ., 2009, book I, pp. I78-236. (In Russ.)

6 Platonov Andrei: vospominaniia sovremennikov. Materialy k biografii [Andrey Platonov: Contemporary Recollections. Materials on his biography]. Moscow, Sovremennyj pisatel' Publ., I994. 486 p. (In Russ.)

7 Platonov A. Zapisnye knizhki [Notebooks]. Moscow, IMLI RAN Publ., 2000. 4I9 p. (In Russ.)

8 Platonov A. “...Ia prozhil zhizn’”: Pis'ma [...I have lived my life: Letters]. Moscow, Astrel' Publ., 20I3. 685 p. (In Russ.) 
УДК 82I.I6I.I

ББК $83.3(2 \mathrm{Poc}=\mathrm{Pyc})+$

$85.15(2)$

\section{«Я - СЛОН»: РАЗВЕРНУТАЯ МЕТАФОРА В СОВРЕМЕННОМ РОССИЙСКОМ KOMИКСЕ}

\author{
(C) 2018 г. Р.Т. Садуов \\ Башкирский государственный университет \\ Уфа, Россия \\ Дата поступления статьи: о5 января 2018 г. \\ Дата публикации: 25 сентября 2018 г.
}

DOI: I0.22455/2500-4247-20I8-3-3-I98-207

Исследование выполнено при финансовой поддержке РФФИ, проект «Лингвокультурная и иенностная идентичность в современном российском комиксе» № I7-04-00о6I

Аннотация: Настоящая статья посвящена исследованию современного российского комикса как набирающего популярность молодежного жанра литературы. Несмотря на непростую историю развития, жанр становится важной частью российской культуры. В связи с этим актуальность работы обусловлена недостаточной изученностью отечественных произведений в данном жанре. Материалом статьи является комикс «Я - слон», который повествует о молодом человеке, прикованном к инвалидному креслу. В основе сюжета лежит метафорическое уподобление alter ego персонажа слону. При этом метафора растягивается на длину всего текста, полностью погружая читателя в мир рассказчика. Не в состоянии принять новую реальность, разум главного героя отделяется от тела, и на протяжении всего повествования читатель наблюдает за тем, как сознание Антона, которое теперь ассоциирует себя со слоном, пытается примириться со своим телом, представленным в виде безвольной куклы. Представляется, что удачная метафора позволила глубже заглянуть во внутренний мир человека с ограниченными возможностями. Цель статьи состоит в исследовании роли метафоры в раскрытии образа главного героя комикса «Я слон». Комикс также можно считать социально ориентированным, поскольку он поднимает вопросы взаимоотношения между людьми с ограниченными возможностями здоровья и обществом.

Ключевые слова: комикс, Я - слон, развернутая метафора, инвалидность, диссоциация.

Информация об авторе: Руслан Талгатович Садуов - кандидат филологических наук, доцент, ФГБОУ ВО Башкирский государственный университет, ул. Заки Валиди, д. 32, 450076 г. Уфа, Россия.

E-mail: ruslan.saduov@gmail.com

Для цитирования: Садуов Р.Т. «Я - слон»: развернутая метафора в современном российском комиксе // Studia Litterarum. 2018. Т. 3, № 3. С. 198-207. DOI: I0.22455/2500-4247-2018-3-3-I98-207 


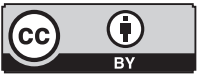

This is an open access article distributed under the Creative Commons Attribution 4.0 International (CC BY 4.0)

\section{"I AM AN ELEPHANT": THE USE OF METAPHOR IN CONTEMPORARY RUSSIAN COMICS}

\author{
(C) 20I8. R.T. Saduov \\ Bashkir State University, \\ Ufa, Russia \\ Received: January 05, 2018 \\ Date of publication: September 25, 2018
}

Acknowledgements: The research has been supported by the Russian Fundamental Research Fund, project "Linguistic, Cultural, and Axiological Identity in Contemporary Russian Comics," \#I7-04-0006I.

Abstract: This article is a study of contemporary Russian comics as an increasingly popular juvenile genre. The genre is becoming integral part of our literary culture despite certain difficulties it faced at the beginning of its history in Russia. The relevance of this essay is due to the lack of sufficient research of Russian comics. It discusses the comics entitled I am an Elephant that tells the story of a young man in a wheelchair. The metaphor of the elephant forms the basis of the plot and mediates between the character and the reader engaging the latter in the character's world. The character's mind unable to adapt himself to the new reality, detaches itself from the body. Throughout the narrative, the reader observes how Anton who is now associating himself with the elephant is trying to reconcile himself with his own body represented as a motionless doll. Yet pain and eventual acceptance of his fate bring the character back to reality. The effective metaphor helps better understand the inner world of the disabled person. The main objective of the essay is to trace the role of the metaphor as the means of representing the character. The comics may be considered socially oriented in that it addresses the problem of relationship between persons with disabilities and society including police and state authorities. In this respect, this comics is socially relevant.

Keywords: comics, I am an Elephant, extended metaphor, disability, dissociation.

Information about the author: Ruslan T. Saduov, PhD in Philology, Associate Professor, Bashkir State University, Zaki Validi 32, 450074 Ufa, Republic of Bashkortostan.

E-mail: Ruslan.Saduov@gmail.com

For citation: Saduov R.T. "I am an Elephant": The Use of Metaphor in Contemporary Russian Comics. Studia Litterarum, 2018, vol. 3, no 3, pp. I98-207. (In Russ.)

DOI: I0.22455/2500-4247-2018-3-3-198-207 


\section{Введение}

Современный российский комикс становится все более актуальным жанром отечественной литературы ввиду повышенного интереса со стороны читателей. В свою очередь, это приводит к появлению новых и более разнообразных комиксов. Безусловно, ввиду своего исторического развития, а также антипропаганды жанра в СССР комикс в представлении большинства читателей остается развлекательной литературой для детей. Данное утверждение верно лишь отчасти. Так, аудитория компании «Bubble», флагмана комикс-индустрии в России, составляет г6-35 лет [3], что делает данный жанр молодежным, но не детским. Помимо этого, далеко не все комиксы носят развлекательный характер. Обратившись к европейской традиции, читатель обнаружит огромное количество автобиографических и вовсе не смешных комиксов. В России складывается аналогичная ситуация. Вместо супергероев персонажами отечественных комиксов часто выступают обычные люди в повседневных ситуациях, раскрываются сложные и многогранные темы, поднимаются вопросы взросления и личностного роста.

Материалом настоящего исследования является комикс «Я слон» (Владимир Рудак, Лена Ужинова), где поднимается болезненная, острая и актуальная тема внутренних переживаний людей, прикованных к инвалидному креслу. Авторы используют иронию и юмор, чтобы передать глубину отчаяния главного персонажа комикса - молодого человека, по имени Антон, с травмой позвоночника, которая оставила его инвалидом. В комиксе демонстрируются некоторые нелицеприятные детали жизни инвалидов, равнодушие общества к людям с ограни- 
ченными возможностями, отчаяние родных, но в то же время желание тех, кого называют «неполноценными», жить обычной жизнью. Самый крупный конфликт в комиксе происходит внутри Антона. Отказываясь принять свое обездвиженное тело, герой диссоциируется от него в образе слона, и большую часть времени повествование ведется от лица животного. Только в самом конце появляется настоящий Антон, очевидно принявший свою судьбу.

Представляется, что произведение целиком является развернутой метафорой, которая играет ключевую роль в развитии сюжета. Цель данной статьи состоит в исследовании роли метафоры в раскрытии образа главного героя произведения.

Природа метафоры сложна и неоднозначна, а теория метафоры представляет собой обширную область языкознания и составляет предмет многочисленных исследований. Как считает Н.Д. Арутюнова, «рост теоретического интереса к метафоре был стимулирован увеличением ее присутствия в различных видах текстов, начиная с поэтической речи и публицистики и кончая языками разных отраслей научного знания» [г, с. 6]. Более того, представляется, что потенциал метафоры еще далеко не раскрыт, равно как и грани ее применения. Тем не менее для нас важно то, что «метафора отвечает способности человека улавливать и создавать сходство между очень разными индивидами и классами объектов» [I, с. I5]. Она «заставляет нас обратить внимание на некоторое сходство - часто новое и неожиданное - между двумя и более предметами» [2, с. I75]. Причем «чем дальше отстоят друг от друга противополагаемые разряды объектов, тем ярче “метафорический сюрприз” от их контакта» [I, с. 20].

Метафора как «вездесущий принцип языка» [4, с. 45] очень близка художественному тексту: «Она с необходимостью предполагает ту или иную степень артистизма» [2, с. I73]. Как инструмент «соположения далекого» [I, с. 2о], она помогает созданию нужного образа, что в свою очередь «венчает творческий процесс» [г, с. I6]. Метафора соответствует художественному тексту своей сутью и статью [I, с. 20]. По необходимости она может быть более или же менее образной, а также простой или сложной, иначе - развернутой, которая понимается как «последовательно осуществляемая на протяжении большого фрагмента сообщения или всего 
сообщения в целом» [6]. Иногда раскрытие образной метафоры происходит в рамках всего текста целиком и требует значительных когнитивных усилий. Ниже рассмотрен пример художественного текста, который представляет собой одну развернутую метафору и реализуется на протяжении текста произведения.

\section{Метафора длиною в текст}

Комикс «Я - слон» представляет собой развернутую метафору от начала до конца. Как упоминалось выше, главный герой комикса - молодой человек Антон, который потерял способность ходить из-за перелома позвоночника. Будучи не способен принять новую реальность, Антон придумывает себе, что его сознание - это слон: «Как вас зовут? Алевтина. А меня Слон. То есть Антон» [5, с. 9]. Более того, поскольку его мать собирается отвезти его в Бурятию в отчаянной надежде, что магия тех мест поставит ее сына на ноги, Антон даже продумывает себе совершенно невообразимое имя «на бурятский манер»: «Тантай Танилсахыемни Зубшеегыт - разрешите познакомиться с Вами» [5, с. 2о]. При этом сознание Антона отделено от тела, которое представлено в виде безвольной тряпичной куклы в инвалидном кресле: «Хчу вас познакомить. Это я. Вернее, мое тело» [5, с. 26]. Диссоциация между сознанием и телом Антона настолько велика, что Слон считает себя первичным по отношению к кукле, которая является всего лишь производной от сознания - его клоном: «Так вот, Антон-клон, перед тобой самое настоящее море» [5, с. 31]. Таким образом, сюжет комикса основан на уподоблении личности главного героя слону, а его тела - кукле.

Разумеется, Антон понимает, что рано или поздно ему придется принять суровую реальность, но для этого потребуется много времени и душевных сил: «Пройдет много времени, прежде чем мы опять станем единым целым, а пока я не могу принять это обездвиженное существо в свою семью» $[5$, с. 26].

Причина, по которой Антон отдаляется от своего тела, понятна: ему тяжело принять, что теперь он беспомощен, однако выбор слона в качестве воплощения сознания не случаен. В разговоре со своей знакомой он объясняет выбор тем, что слон добр: «Я читал, что люди выбирают себе животное, с которым себя ассоциируют. Я буду слоном. Он добрый и боль- 
шой» [5, с. 58]. Позже оказывается, что причина совсем не в этом: ассоциация с животным помогает главному герою защититься от внешнего мира.

Антон указывает на то, что люди, в сущности, редко задумываются над страданиями людей с ограниченными возможностями. Текст изобилует ситуациями вопиюще отрицательного и даже потребительского отношения к инвалидам. Так, Антон приводит в пример свою знакомую Фаину, которая обретает уверенность в себе за счет беспомощности других, делая из Антона своеобразного энергетического донора: «Когда ей кажется, что жизнь не удалась, она тут же вспоминает меня - и ей становится легче» [5, с. 49]. В гротескной форме Антон выражает неспособность государства увидеть реальные нужды инвалидов: «На одном подобном мероприятии незрячему молодому человеку подарили набор классической литературы и видеоплеер, который, как выяснилось позже, не работает» [5, с. II3]. Гротеск также усиливается визуальной формой произведения: молодой человек и его «даритель» не могут пожать друг другу руки - слепой потому, что не может увидеть руку зрячего, а зрячий, видимо, даже не пытался увидеть руку слепого. Общество не может понять инвалида и его страдания: «Допустим, человек на коляске. Его ноги должны быть прикрыты клетчатым пледом. Все же думают, что у парализованного человека мерзнут ноги. А не душа. Или сердце» [5, с. 33]. Увидев же человека в инвалидном кресле, многие отворачиваются: «Вдруг наши глаза встретятся, и мое заболевание перекинется на них» [5, с. Іо9]. В случае если столкновение с таким человеком неизбежно, то обращение с ним далеко не всегда отвечает критериям терпимости: «Милиция и выпивохи считают, что к человеку в инвалидной коляске можно обращаться на “ты”, без особых реверансов... Пьяницы свято верят в то, что ты герой войны, а милиционеры - в то, что ты жалкий попрошайка» [5, с. II5].

Сложности жизни человека в инвалидном кресле приводят к необходимости искать укрытие, отгораживаться от внешнего мира, быть толстокожим, чтобы защититься от общества: «Слон толстокожий. Это символично. Увечному человеку необходимо иметь толстую ментальную кожу» [5, с. 93]. Таким образом, к концу комикса становится понятно, на чем основана метафора произведения: на уподоблении сознания Антона слону в силу того, что и тот, и другой имеют толстую кожу или по крайней мере пытаются ее «отрастить». 
Еще одна метафора приводится в самом конце произведения, где главный герой сравнивает осознание своей судьбы с ощущениями замерзающего человека перед смертью: «Говорят, что замерзающему человеку в какой-то момент становится тепло и уютно. Он готов полностью войти в царство сна, откуда уже нет возврата. Честно сказать, я постепенно начал привыкать к себе другому. Вхожу в сказочное царство, где всегда светит солнце, плывут перистые облака. И нет больных» [5, с. 99]. Это очень непростая и, если вдуматься, грустная метафора. Новая реальность Антона напоминает ему сон, что должно быть хорошо, однако «заснуть» можно только один раз - «возврата уже нет». И сон этот, скорее, переходное состояние от жизни к смерти. Тем не менее Антону удается принять себя таким, какой он есть. Понимание своего состояния - это и есть выздоровление дня него: «Я понял, что здоров, ведь мне больше не снится, что я хожу...» [5, с. І29].

\section{Выводы}

Если в России есть недооцененный и непо́нятый жанр, то это комикс. Пропаганда советских лет, где комикс был «пустым» буржуазным искусством, и отсутствие качественных комиксов в новое время предопределили понимание комикса как детского несерьезного жанра. Представление о нем строится на основании известных всем североамериканских супергероев или, в лучшем случае, японской манги. В этом многообразии совершенно теряется европейский комикс - серьезный, часто автобиографический, совсем не детский. Он довольно многочислен своими представителями, но, к сожалению, малоизвестен в России, что приводит к одностороннему и предвзятому отношению к комиксу со стороны российского читателя.

Серьезный комикс есть и в России, и «Я - слон» о молодом человеке в инвалидном кресле является ярким примером данной разновидности жанра. История представляет собой развернутую метафору, где сознание главного героя уподобляется слону, а тело - безвольной тряпичной кукле. Благодаря метафоре длиной в текст полнее раскрывается образ главного героя Антона. Через реплики слона автор показывает взаимоотношение персонажа с самим собой и окружающим миром. Читатель узнает, почему быть инвалидом так тяжело в моральном плане. В то же время причина, 
по которой Антон выбирает именно слона для своего alter ego, сжимается сердце: «...увечному человеку необходимо иметь толстую ментальную кожу» [5, с. 93] - словно толстокожему слону.

В перспективе представляется важным обратить внимание на роль метафоры в других российских комиксах, а также на взаимодействие вербального и невербального компонентов комикса для более полного раскрытия метафоры. 


\section{Список литературы}

I Арутюнова Н.Д. Метафора и дискурс // Теория метафоры: Сборник: пер. с англ., фр., нем., исп., польск. яз. / вступ. ст. и сост. Н.Д. Арутюновой; общ. ред. Н.Д. Арутюновой и М.А. Журинской. М.: Прогресс, І99о. С. 5-32. Дэвидсон Д. Что означают метафоры // Теория метафоры: Сборник: пер. с англ., фр., нем., исп., польск. яз. / вступ. ст. и сост. Н.Д. Арутюновой; общ. ред. Н.Д. Арутюновой и М.А. Журинской. М.: Прогресс, г99о. С. I73-193. Иванов М. Как делают и продают комиксы в России: интервью с Артемом Габреляновым // Канобу, 20I4. URL: https://kanobu.ru/articles/kak-delayut-i-prodayutkomiksyi-v-rossii-intervyu-s-artemom-gabrelyanovyim-368212/ (дата обращения: 25.I2.20I7)

4 Ричардс А. Философия риторики // Теория метафоры: Сборник: пер. с англ., фр., нем., исп., польск. яз. / вступ. ст. и сост. Н.Д. Арутюновой; общ. ред. Н.Д. Арутюновой и М.А. Журинской. М.: Прогресс, г99о. С. 44-67.

5 Рудак В., Ужинова Л. Я - слон [графический роман]. СПб.: Бумкнига, 20I7. I36 с. 6 Ястребов-Пестрицкий М.С. Наиболее распространенные типы классификаций образных средств языка (на материале поэтического очерка И.Л. Сельвинского «Путешествие по Камчатке») // Вестник Удмуртского университета. 20I5. Т. 25, Вып. 5. C. I76-I8I URL: http://ru.history.vestnik.udsu.ru/files/originsl_articles/ vuu_15_055_28.pdf (дата обращения: 25.12.2017). 


\section{References}

I Arutiunova N.D. Metafora i diskurs [Metaphor and discourse]. Teoriia metafory: Sbornik [The theory of metaphor], trans. from English, French, German, Spanish and Polish. Ed., intr. N.D. Arutiunova; eds. N.D. Arutiunova and M.A. Zhurinskaya. Moscow, Progress Publ., I990, pp. 5-32. (In Russ.)

2 Ivanov M. Kak delaiut i prodaiut komiksy v Rossii: interv'iu s Artemom Gabrelianovym [How they make and sell comics in Russia: interview with Artyom Gabrelyanov]. Kanobu, 20I4. Available at: https://kanobu.ru/articles/kak-delayut-i-prodayutkomiksyi-v-rossii-intervyu-s-artemom-gabrelyanovyim-368212/ (Accessed 25 December 20I7). (In Russ.)

3 Devidson D. Chto oznachaiut metafory [What Metaphors mean]. Teoriia metafory: Sbornik [The theory of metaphor]: trans. from English, French, German, Spanish and Polish. Ed., intr. N.D. Arutiunova; eds. N.D. Arutiunova and M.A. Zhurinskaya. Moscow, Progress Publ., I990, pp. I73-I93. (In Russ.)

4 Richards A. Filosofiia ritoriki [The Philosophy of Rhetoric]. Teoriia metafory: Sbornik [The theory of metaphor]: trans. from English, French, German, Spanish and Polish. Ed., intro. N.D. Arutiunova; eds. N.D. Arutiunova and M.A. Zhurinskaya. Moscow, Progress Publ., I990, pp. 44-67. (In Russ.)

5 Rudak V., Uzhinova L. Ia - slon [I am an Elephant]. St. Petersburg, Bumkniga Publ., 20I7. I36 p. (In Russ.)

6 Iastrebov-Pestritskii M.S. Naibolee rasprostranennye tipy klassifikatsii obraznykh sredstv iazyka (na materiale poeticheskogo ocherka I.L. Sel'vinskogo "Puteshestvie po Kamchatke") [The most widespread types of classification of figurative language instruments (on the essay "A journey across Kamchatka” By I.L. Selvinsky)]. Vestnik Udmurtskogo universiteta, 20I5, vol. 25, issue 5, pp. I76-I8I Available at: http:// ru.history.vestnik.udsu.ru/files/originsl_articles/vuu_I5_055_28.pdf (Accessed 25 December 20I7). (In Russ.) 
УДК 82I.І3І.I.0

ББК $83.3(2=753$. I $) 6$

\section{МИФОПОЭТИКА ПРОСТРАНСТВА В РОМАНАХ ЮРИЯ РЫТХЭУ}

\author{
(C) 2018 г. А.С. Жулева \\ Институт мировой литературы \\ им. А.М. Горького Российской академии наук, \\ Москва, Россия \\ Дата поступления статьи: 27 июня 2018 г. \\ Дата публикации: 25 сентября 2018 г.
}

DOI: $10.22455 / 2500-4247-2018-3-3-208-231$

Аннотация: В статье рассматривается мифопоэтическая основа художественного пространства романов чукотского писателя Юрия Рытхэу. Раскрывается специфика мировидения автора и героев, эволюция творческого сознания писателя. Выявлено, что мифологическое восприятие пространства в романах Рытхэу проявляется в соответствии с теми принципами, согласно которым человеческая мысль рождала миф: антропоморфизм, «закон партиципации» (сопричастия), позднее - анимизм (Л. Леви-Брюль). Подтверждено воздействие жизнедеятельной силы мифов как генетической основы формирования человеческого духа и национальной культуры. Традиционные чукотские мифологические пространственные формы и образы автор проецировал в поэтику текста с поддержкой мифологем, архетипических оппозиций (верх-низ, свой-чужой, близко-далеко, ширинаузость, жизнь-смерть). В процессе анализа двух романов, написанных с разрывом в 4 о лет - «Айвангу» и «В зеркале забвения», - выявлены различные подходы к пространственным субстратам. В первом романе (1964) превалирует реальное место-действие, завуалированный мифологизм в создании образов. В романе «В зеркале забвения», написанном в годы временной эмиграции Рытхэу в Европу (Дания, Германия) в 9о-е гг. ХХ в., интуитивная, содержательная глубина с помощью пространственных структур достигнута не только под воздействием мифологизма, но и не без влияния неомифологизма, постмодернизма. В романе таинственное, многоликое пространство стало многозначимым объектом изображения, представленным в разнообразных ракурсах.

Ключевые слова: чукотская литература, Юрий Рытхэу, романы, мировосприятие, автобиографизм, пространство, мифопоэтика, мифологемы, архетипические оппозиции, сюжет, образ.

Информация об авторе: Альбина Сергеевна Жулева - кандидат педагогических наук, старший научный сотрудник, Институт мировой литературы им. А.М. Горького Российской академии наук, ул. Поварская, д. 25 а, І2Іо69 г. Москва, Россия.

E-mail: aszhuleva@mail.ru

Для цитирования: Жулева А.С. Мифопоэтика пространства в романах Юрия Рытхэу // Studia Litterarum. 2018. T. 3, № 3. C. 208-23I. DOI: $10.22455 / 2500-4247-2018-3-3-208-23 I$ 


\section{MYTHOPOETICS OF SPACE IN THE NOVELS BY YURI RYTKHEU}

This is an open access article distributed under the Creative Commons Attribution 4.0 International (CC BY 4.0)
(C) 20I8. A.S. Zhuleva

\author{
A.M. Gorky Institute of World Literature \\ of the Russian Academy of Sciences, Moscow, Russia \\ Received: June 27, 2018 \\ Date of publication: September 25, 2018
}

Abstract: The article examines mythopoetic basis of the spatial imagery in the novels by a Chukchi writer Yuri Rytkheu. It reveals the specificity of the worldview of the author and his characters as well as the evolution of the writer's creativity. The author argues that mythological representation of space in Rytkheu's novels follows such general principles of the genesis of myths as anthropomorphism, "the law of participation" (communion), and late animism (Lévy-Bruhl). Rytkheu projected traditional mythological spatial forms and images onto the poetics of the text with the help of mythologemes and archetypal binaries (top-bottom, friend-stranger, close-distant, lifedeath). The analysis of his two novels written with a gap of forty years - Aivangu and In the Mirror of Oblivion - reveals two different approaches to spatial substrates. In the first novel (I964), there prevails "real" space as the novel's setting and mythologism of images veiled. The second novel written in the I990s, the years of Rytkheu's temporary emigration in Europe (Denmark, Germany), undergoes influence of postmodernism and neomythologism. In this novel, mysterious, multi-faceted space becomes a meaningful object of representation shown from a variety of perspectives.

Keywords: Chukchi literature, Yuri Rytkheu, novels, perception, autobiography, space, mythological poetics, architypes, opposition, story, national image.

Information about the author: Albina S. Zhuleva, $\mathrm{PhD}$ in Pedagogical Sciences, Senior Researcher, A.M. Gorky Institute of World Literature of the Russian Academy of Sciences, Povarskaya 25 a, I2IO69 Moscow, Russia.

E-mail: aszhuleva@mail.ru

For citation: Zhuleva A.S. Mythopoetics of Space in the Novels by Yuri Rytkheu. Studia Litterarum, 2018, vol. 3, no 3, pp. 208-231. (In Russ.) DOI: I0.22455/2500-4247-20I8-3-3-208-23I 


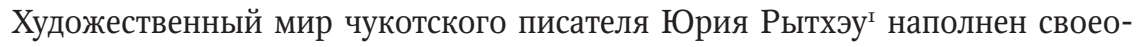
бычными мировоззренченскими представлениями, формами и образами, отражающими модель мира своего народа. Для постижения специфики национального самосознания, выявления изменений мировидения в разные жизненные периоды автора и героев актуально обращение к языку пространственных представлений в его произведениях, поскольку философско-эстетическая категория «пространство» - важнейшая составляющая художественного мира писателя и его произведений. Метафорически пространство нередко берет на себя выражение совсем не пространственных отношений в моделирующей структуре мира. При этом многоликое про-

I Автор романов, повестей, рассказов, написанных на чукотском и русском языках, Юрий Сергеевич Рытхэу (г930-2008) родился в Уэлене Дальневосточного края (ныне Чукотский автономный округ) в семье охотника-зверобоя. Учился в Анадырском педагогическом училище. Начиная с 1947 г. публиковал свои первые очерки и стихи в анадырской окружной газете. C I949 по I954 г. учился на литературном факультете Ленинградского государственного университета - ЛГу. Печатал рассказы в альманахе «Молодой Ленинград», в журналах «Огонек», «Молодой мир», «Дальний Восток», в молодежной газете «Смена». Первый сборник рассказов на русском языке «Люди нашего берега» (пер. с чукотского А. Смоляна) вышел в I953 г. в издательстве «Молодая гвардия». В годы учебы Юрий Рытхэу участвовал в создании учебных книг на чукотском языке, переводил для них сказки А. Пушкина, рассказы Л. Толстого, М. Горького. В г954 г. Рытхэу стал членом Союза писателей. После окончания ЛГу Рытхэу несколько лет работал корреспондентом газеты «Магаданская правда». В г956 г. в Магадане вышел сборник рассказов «Чукотская сага», который принес писателю широкое признание читателей. С 1956 г. жил и создавал свои произведения в Ленинграде. После распада СССР в новых постсоветских странах Юрия Рытхэу перестали печатать. Благодаря Чингизу Айтматову он познакомился с немецким книгоиздателем, который заключил с писателем контракт на издание его произведений на немецком языке и стал его литературным агентом. В течение более десяти лет Рытхэу жил в основном в Дании и Германии. Его произведения стали выходить во многих странах мира: Франции, Финляндии, Нидерландах, Италии, Германии, Испании, Японии и других. С начала третьего тысячелетия Рытхэу постоянно жил в Санкт-Петербурге. 
странство - видимое и недоступное визуальному восприятию, физическое и трансцендентное, концептуальное и ассоциативное - является частью реального пространства и организовано как некоторое единство именно в нем.

Романы «Айвангу» (I964) и «В зеркале забвения» (издан на русском языке в 20ог г.) написаны Рытхэу с разрывом почти в сорок лет и отражают эволюцию развития творческого сознания писателя, свидетельствуют и об изменениях в отражении концепта «пространство». Сравнительный анализ этих произведений - возможность ответить на ряд вопросов, связанных как с мировоззрением автора и его героев, так и с определением специфики, роли и значимости пространственных представлений в отражении действительности в ее реальном существовании и художественном воображении. Среди актуальных вопросов - как писатель в романах проецирует внутренние, рожденные в глубине сознания и души традиционные мифологические пространственные формы и образы в поэтику текста, помогая читателю проникнуть на уровень подсознательного, в психологию персонажей. Поиски ответа предполагали также возможность реконструировать этнографические субстраты, с одной стороны, а с другой - приблизиться к раскрытию онтологических и феноменологических основ, связей, реминисценций культуры чукчей, к процессу развития их художественного сознания.

Определяя первую расширенную концепцию художественного пространства (позднее она разрабатывалась в трудах многих философов и литературоведов, в частности в трудах М. Хайдеггера, М. Мерло-Понти), О. Шпенглер в книге «Закат Европы. Очерки морфологии мировой истории»² особо выделил значимость пространства не только для индивидуального восприятия, но и для культуры в целом, важность для всех видов искусства, существующих в рамках той или иной культуры. Он определил пространство, или способ протяженности, как «прасимвол» культуры. Шпенглер связывал проблему пространства и художественного простран-

2 «Жизнь, ведомая судьбой, ощущается, пока мы бодрствуем, как прочувствованная глубина. Все растягивается, но это еще не “пространство”, не что-то в себе упроченное, а некое постоянное саморастягивание от подвижной точки “здесь” до подвижной точки “там”... Только глубина есть действительное измерение... Переживание мира связано исключительно с феноменом глубины - дали или отдаленности... Наверняка “длина и ширина” дают в переживании не сумму, а единство и оказываются, осторожно говоря, просто формой ощущения. Они представляют чисто чувственное впечатление. Глубина представляет выражение, природу, с нее и начинается мир» [26, с. 327]. 
ства со смыслом жизни и смертью, а глубину пространства - со временем и судьбой. Основная характеристика жизненного пространства - глубина.

В процессе анализа мифопоэтики пространства в романах Рытхэу особое внимание было уделено уточнению, как пространственный «прасимвол» чукотской культуры, существовавший в древности, в эпоху сотворения мифов, а также во времена создания на их основе сказок, легенд, героического эпоса, трансформировался в литературе, отражая тесную связь природы и человека. Как проявляется его роль в структурно-содержательной организации романов Рытхэу - является ли он средством композиционного построения и приемом организации действий и поступков героев, способствует ли пониманию художественного представления о реальной действительности, раскрытию специфики чукотского мировидения.

Изначально было отмечено неослабевающее, широкое и острое внимание автора романов к пространству, в котором происходит действие, к пространственным субстратам, связанным с характеристикой героев, с восприятием своего и чужого мира. Создавая художественный образ пространства, писатель изображал не только реальное географическое пространство, но и вымышленные пространственные координаты. Мифология как генетическая основа чукотской культуры стала частью выстраиваемой в произведениях художественной модели национального образа пространства. Мифологическое восприятие пространства в романах Рытхэу проявляется в соответствии с теми принципами, согласно которым человеческая мысль рождала миф: антропоморфизм, «закон партиципации» (сопричастия), позднее - анимизм³.

3 Антропоморфизм («человекоподобие») - уподобление человеку, наделение человеческими свойствами окружающей природы, животных, предметов, явлений природы. Располагая небольшим количеством знаний, человек стремился строить представления об окружающем исходя из знаний о себе. Ощущая в себе, внутри тела, некую жизненную силу, человек представлял себе дух в виде какого-то существа (чаще всего человекоподобного), то ли в виде неопределенной формы облака. Но как бы то ни было, дух также наделялся жизнью и всем, что ей присуще (в том числе и какой-то телесностью). А.С. Кармин, опираясь на исследования Л. Леви-Брюля о первобытном мышлении, отрицает влияние анимизма как религии, возникшей позднее, на появление мифических образов богов, животных, предметов, которые наделены жизнью, одушевлены. Цитируем сноску из книги Кармина: «Поэтому нельзя согласиться с идущим от крупного этнографа ХIX в. Э. Тайлора взглядом, что первобытному человеку изначально был свойственен религиозный анимизм (от лат. anima - душа), предполагающий веру в существование бестелесной и бессмертной индивидуальной души человека. Первобытный человек не был тайлоровским “философом-дикарем”, 
В романах Рытхэу традиционная для чукотского глаза и слуха поэтика насыщена мифологической знаковой образностью. Это чаще всего не «описание» природы и не ее «переживание», не фрагментарная «картина» мира, а его онтологическое присутствие. Данность мира, осмысленная как целостное существование и даже как целостность его существования. Пространство в романах Рытхэу наполнено реальным жизненным смыслом и тесно связано с героями и их судьбой.

Так, в романе «Айвангу» автор представил аллегорический образ таинственной скалы Сэнлун, которая стала для главного героя судьбоносной. Встречаясь с ней в самые драматические моменты жизни, герой неожиданно для себя получал не просто поддержку и помощь, а спасение от нависшей реальной угрозы гибели. Когда Айвангу, отморозив во время охоты на морзверя ступни ног, полз среди ледяных торосов, превозмогая боль, наступил момент потери воли и желания бороться за свою жизнь. Герой выбился из сил, поддался страху, его глаза засыпала мелкая изморозь. Внезапно появившийся в лунном свете черный лик скалы Сэнлун стал узнаваемым ориентиром и возвратил надежду на спасение, придал силы двигаться дальше. Именно этот момент впоследствии сам для себя герой оценил как отправную точку обретения тайной веры в самого себя и возможности человека. Не менее драматическая для героя ситуация развернулась уже в другое время года на самой скале. Оказавшись в восемнадцать лет после операции ног без ступней и передвигаясь на коленях, Айвангу превратился в изгоя для семьи его невесты, его выгнали из яранги, где он жил, отрабатывая выкуп за невесту. Вернувшись в ярангу отца, он стремится сохранить силу духа, постоянно пытается доказать себе и окружающим свою полноценность и значимость. Убедив отца взять его на охоту, он приплывает вместе с бригадой охотников на вельботе к скале Сэнлун, вершина которой должна стать наблюдательным пунктом за перемещением моржей. Поднимаясь по крутой и скользкой скале вслед за отцом и другими односельчанами на вершину, предварительно из гордости отказавшись от помощи, Айвангу в какой-то момент ощущает, что руки ослабли, «сила ушла из них», пальцы разжались, и он стал падать. Но неожиданно колени

ясно различающим “две принадлежащие ему вещи: свою жизнь и свой призрак (душу)”. Анимизм - а следовательно, и религия - появляется лишь на поздних стадиях развития архаических культур» [8, с. 325]. 
нашли опору, и он уцепился за камень, дополз до вершины. Потрясенные увиденным, охотники, когда обнаружили стадо моржей, оставили Айвангу ждать их возвращения на скале. Когда же нагруженный добычей вельбот возвращался, начался шторм, «у скалы вода кипела, как в котле», и подойти близко не удавалось. Друг Айвангу два раза бросал длинный кожаный ремень с грузом, но юноше не удалось его поймать. И только на третий раз, когда он уже отчаялся, ремень пролетел близко, и, зацепившись, герой оказался в море. «У подножья Сэнлуна волна подхватила Айвангу, подняла и... не успела ударить о скалу» [І6, с. 68]. Таинственная скала помогла спастись от неминуемой гибели и на этот раз.

Жизнеутверждающий, эстетически насыщенный образ одушевленной скалы, наполненной силой морского великана, воплотил в себе как антропоморфные представления чукчей, так и воздействие сопричастия и анимизма. Скала Сэнлун - образец локализованного места, наделенного таинственными возможностями. В мировоззрении чукчей, судя не только по записям этнологов и фольклору, но и по художественной литературе, сохранялись еще и в начале XX в. представления об «иерархизированных», выделенных местах. Таинственные, сакральные места, по мнению М. Фуко, соотносятся с другими особым образом, а именно «приостанавливают, нейтрализуют или переворачивают всю совокупность отношений, которые тем самым ими обозначаются, отражаются или рефлектируются» [24, с. I85].

Следует заметить, что растворение этих представлений у разных народов исследователь связывал с открытиями Галилея о бесконечности и открытости пространства.

Наделенная волшебными способностями скала - пространство-место, которое является средоточием недостижимой для героя тайны, воплощением древней мифологии чукчей. Исследователи других литератур и культур обозначают порой подобные священные места не просто таинственными и сакральными, а «счастливым локусом, где обретаются высшие цели и смыслы» [Іо, с. 54], связывая с сакральным центром, с идентичностью.

Образ одинокой священной скалы Сэнлун возник у автора из древних легенд, волшебно-мифических сказок, и не случайно сравнение ее с огромным каменным пальцем великана, лежащего на дне моря.

Пространственная мифологема «море» в романе «Айвангу» воплощает представления как о духовной, так и материальной культуре чукот- 
ских жителей прибрежных селений. Главный герой постоянно пребывает в диалоге с морем, с Северным Ледовитым океаном. Со своей стороны море и океан, являясь в романе реальным и метафизическим пространством, становятся действующими героями, мистически участвующими в диалоге с человеком. Так, когда Айвангу сумел справиться с переводами на чукотский язык статей для первой тэпкинской газеты, своим ощущением победы он пришел поделиться прежде всего с морем, «улыбался ему», и «ему казалось, что и море улыбается, раскрывая свои могучие объятия». Спасаясь от человеческого непонимания, Айвангу всякий раз бессознательно сворачивал с намеченного пути и шел к морю. Автор объясняет эту близость человека и моря тем, что жители побережья уверены: все большие дороги начинаются у моря, которому они издревле поклонялись, как живому существу, приносили жертвы, уважали зверей, обитающих в его глубинах, воздавали им почести.

Море как сакральный топос часто становится для героя местом его откровений, сомнений, навязчивых и даже малодушных и опасных мыслей. Так, устав от обид и непонимания окружающими его устремлений, Айвангу во время весенней охоты на морского зверя возвращается к размышлениям об эвтаназии, традиционном у чукчей добровольном уходе из жизни, если человек стал неспособным быть добытчиком, обузой для близких, превратился в объект насмешек. Герой пытается убедить себя, что обычаи и правила, которые созданы опытом жизни всего народа, возможно, справедливы, обоснованы необходимостью быть сильным, чтобы покорять суровое пространство. Он вспоминает драматическую ситуацию, возникшую сразу после обморожения ног. Сэйвытэгин, отец Айвангу, повез его на собачьей упряжке на культбазу, где должны сделать операцию, после которой юноша останется без обмороженных ступней и ему будет трудно выживать самостоятельно, он не сможет вернуть невесту. На случай просьбы сына об эвтаназии отец взял с собой винчестер и осторожно пытался выяснить мнение больного о старинных обычаях. Согласно чукотским установкам, если человек, лишившийся возможности добывать пищу, попросит кого-либо из родственников об эвтаназии - лишении жизни с помощью веревки или ружья, - то тот должен выполнить просьбу. Айвангу был в смятении, его мучили сомнения, однако, уезжая на операцию, он мысленно попрощался с родным селением. С тоской смотрел на вытянувшиеся на косе с запада 
на восток яранги, на столбы дыма, которые упирались «в низкое холодное небо». Яранги Тэпкэна издалека казались ему похожими на кучу черных углей на снегу. Все в окружении было в тот трудный для героя момент мрачным, недобрым, даже нарта издавала неприятные звуки - скрипела полозьями по твердому насту, поскольку снег был сухой и ломкий. Почувствовав под шкурой на нарте винчестер и, следовательно, готовность отца смириться с решением сына, если он захочет «не быть в тягость живым и здоровым», Айвангу прежде всего мысленно попрощался с окружающей природой, столь близкой, понятной и любимой: «Прощайте, горы, покрытые снегом! Много вы живете на свете, в ваших морщинах-ущельях не тает снег и каждую весну вырастает трава и ласкает седые скалы. Прощай, вечное небо! Прощайте, звери и птицы, и дальние земли, которые не видели глаза Айвангу» [І6, с. І9]. Услышав решение сына, просьбу помочь уйти из жизни, отец взял в руки винчестер, но выронил его, поскольку был не в силах справиться с сомнениями.

Полные драматизма эпизоды происходят в романе не просто на фоне природы, окружающее пространство как бы соучаствует в событиях. Пространство не раз становится своеобразной мистической поддержкой Айвангу в его борьбе за победу над увечьем. Укрепляются надежды на достижение мечты, и герой встречает утро вместе с радующейся этому просыпающейся природой, демонстрирующей свою активность и красоту. «Исчезли ночные шорохи и шумы, в воздухе будто натянулась невидимая струна в ожидании солнца. Вот прорвалась алая полоска зари, грянул солнечный луч, тронул струну, и запел, заиграл новый день!» [І6, с. 249]. Пространство, космос не всегда благожелательны к герою. Останавливаясь передохнуть, покалеченный Айвангу ощущал порой не просто отсутствие поддержки с неба, а желание противодействовать: «...звезды кинулись ему в глаза, укололи множеством холодных игл» [І6, с. 7].

Создавая образ чукотского охотника, автор постоянно опирался на мифопоэтику фольклора, героического эпоса народа, в котором природа, постоянно испытывающая человека, направляет его поступки, оказывает влияние на судьбу, закаляет характер 4 .

4 О сопричастии и влиянии его на человека и судьбу Леви-Брюль писал в книге «Сверхъестественное в первобытном мышлении». Пространство в пралогическом мышлении, по его мнению, не было тождественным самому себе, а также единообразным и однородным, без- 
Общение с природой, космосом для жителей Севера - постоянное противостояние, требующее крепости и силы духа, практических знаний и умений для взаимодействия. Ледовитый океан кажется герою больше далекого неба, с ним он, как охотник на морзверя, связан тесно, его он одухотворяет, поскольку океан может не только принести удачу на охоте, но и отнять у него все - и байдару, и добычу, и даже саму жизнь. Покорить океан, в его представлении, могут лишь капитаны кораблей, и обращение к далекой детской мечте стать капитаном помогает юноше отогнать нестерпимую боль.

Воплотить детскую мечту в жизнь позднее укрепило желание доказать, что и у чукчей могут быть свои капитаны, которое появилось в ответ на саркастический смех капитана американской шхуны, его наполненные высокомерием и желчью слова: «Скорее растают все льды в Ледовитом океане, все моржи обратятся в акул, нежели капитаном станет туземец!» [І6, с. 8].

Близость и понимание природы, реакция на изменения в ней формировались у чукчей, как и многих других народов Севера, с детства всем телом, и человек становился сопричастным с ее жизнью. Этот жизненный опыт был освоен и автором романов. О том, как постепенно развивалось отношение Юрия Рытхэу к окружающей природе, постигались конкретные точные знания о ней, свидетельствует писатель Тихон Семушкин в книге «Чукотка». В статье «От автора» он вспоминает самую первую встречу с будущим писателем, за судьбой которого позднее пристально следил:

Давно еще, в одну из первых моих поездок на Чукотку, я как-то проходил в полярную лунную ночь по чукотскому поселку. Луна светила ярко, стоял полный штиль. Я шел и прислушивался к отдаленному дыханию моря. Здесь же, поблизости, все было сковано льдом. Мое внимание вдруг привлек мальчик, бегавший вокруг яранги. Он был совершенно голый и поэтому бегал довольно быстро. Мальчик сделал несколько кругов и юркнул в ярангу.

различным в отношении того, что его наполняет. Больше того, между землей и общественной группой существуют «отношения сопричастности, равнозначные своего рода мистической собственности, которая не может быть ни переделана, ни отнята, ни завоевана». Ученый подчеркивал, что на каждом определенном участке территории каждая местность, со свойственной ей обликом и формой, определенными скалами, деревьями, родниками, песчаными дюнами и т. д. мистически связана с видимыми и невидимыми существами, которые якобы пребывают или обнаруживаются людям, с личными духами, которые там ждут своего перевоплощения. «Между этими местностью и существами есть взаимная сопричастность: Ни местность без них, ни существа без местности не были бы тем, чем они являются» [II, с. IOо-IOI]. 
Меня это заинтересовало, и я пошел вслед за ним. Он сидел на оленьих шкурах и весело растирал свои ноги.

Я спросил, что бы это могло значить?

- Видишь ли, - сказал отец-охотник, - я проснулся и не знал: придется мне идти на охоту или нет. Если идти, то надо закусывать поплотней. А какая на улице погода, я не знаю. Вот он и бегал разглядывать обстановку. А то, что он голый, не страшно - пусть привыкает к холоду.

Молодой «метеоролог» интенсивно продолжал себя растирать и посмеивался, прислушиваясь к нашему разговору [І8, с. 6].

Поэтическое восприятие природы были усилены в детстве Рытхэу сказками и легендами его бабушки, о чем он сообщает читателю в размышлениях писателя Гэмо, главного героя романа «В зеркале забвения», прототипом которого был он сам. Из этих воспоминаний мы узнаем, что у бабушки было «примечательное повествование» о каждой скале, ложбине, застывшем и сверкающем льдом водопаде. Так, за Сэнлуном на ровном плато высоко в море отдельно стояла скала с названием «Вечно Скорбящая Женщина». О ней бабушка поведала предание - жена охотника, так и не вернувшегося в родную ярангу с покрытого льдом моря, превратилась в камень.

Не без влияния чукотских сказок и легенд, а позднее книг у будущего писателя Гэмо, главного героя романа «В зеркале забвения», возник интерес к играм, в которых подросток в одиночестве заполнял воображаемое пространство, выстраивая целые стойбища из глины, щепочек и звериных костей на берегу лагуны, подальше от яранг, заселял их людьми. Позднее научился мастерить игрушечные лодки и путешествовал в дальние страны. Так чукотский писатель, описывая детство героя, приоткрыл истоки мировоззренческих установок, творческих исканий, которые оказали существенное влияние на художественные образы его произведений, позволившие читателю услышать голоса как далекого прошлого чукотского народа, так и не слишком отдаленного.

В обоих романах Рытхэу активизированы чукотские пространственные мифологемы, связанные с магией притяжения мест, где происходила максимальная локализация прошлого как автора, так и героев. В этом неодолимом порой притяжении проявляется воздействие жизнедеятельной силы мифов как генетической основы формирования человеческого духа. 
Для прибрежного жителя Айвангу притягательным топосом было море. Длительное расставание с ним во время учебы на капитанских курсах вызывает у героя с трудом переживаемую тоску. Вернувшись, герой испытывает радость и уверен: встрече после долгой разлуки радуется и море, поскольку оно «взволнованно и глубоко дышит». Автор объясняет близость и даже «родственность» человека и моря тем, что оно кормило Айвангу и его предков. Было летом ласковым, наполненным морскими зверями. Осенью, «ощерившись волнами», оно порой набрасывалось на берега, «откусывая куски твердых скал», было ненасытным и злым. Это поведение моря автор объясняет предчувствием моря скорой зимней несвободы, когда льды сковывают его поверхность, уравнивая вольный море-океан с берегами, с мысами, проливами и заливами.

Ощущение сопричастности человека с морем помогало ему ориентироваться в бескрайних морских просторах. Когда Айвангу, собрав последние силы, «переполз лунную тень Сэнлуна», он ощутил, кроме боли, и радость: селение близко, поскольку расстояние уже было определено им во время охоты еще до увечья, оно измерялось наблюдениями за собственными ощущениями: «Пешком идешь - не успеешь вспотеть, а на собачьей упряжке едва успеешь выкурить трубку..» [16, с. Іо]. Необычны способности чукотских морских охотников ориентироваться и измерять расстояние не только по ощущениям тела, но и по звукам в бескрайнем и почти безмолвном пространстве океана. Айвангу полз далеко от берега, но неожиданно он «кашлянул, и гулкое эхо разнеслось по замерзшему морю, отскакивая от ледяных скал». И тогда он, по каким-то известным лишь охотнику на морзверя признакам понял, что берег близко. Это обрадовало героя, прогнало боль и безысходную тоску, вдохнуло в него силы, чтобы ползти дальше, покоряя безбрежность моря, его простор. Необычную топографическую память, до мельчайших подробностей воспроизводящую чувственные впечатления, Леви-Брюль называл «чутьем места»: «Это не какое-то социальное чувство, а чувство места, достигшее высокой степени совершенства (т. е. ставшее такой формой памяти). Тот, кто приобрел это чутье, никогда не заблудится» [II, с. 93-94].

Простор как жизнеутверждающий, формирующий личность концепт активно участвует в создании художественных образов романов. Простор моря и тундры несет с собой ощущение свободы и открытости для чело- 
веческого поселения и обитания, но вместе с ними и проблемы, связанные с обживанием, укоренением, покорением стихий, с поиском ключей для раскрытия тайн окружающей природы. Мифологема тайны органически присуща художественному образу моря и тундры. Ощущение скрытого в ней таинства порождает в первую очередь беспредельность пространства. Простор моря и тундры создает ощущение своеобразной широты в душе (имеется в виду пространственное противопоставление «ширина-узость»), отражается на настроении и самочувствии, самоощущении героев.

Присутствующая в романах другая архетипическая оппозиция «свое-чужое» в отношении пространства выполняет как семантическую, так и поэтологическую функцию. Оппозиция часто предстает как духовная, психологическая несовместимость. «Свое», северное, а точнее - пространство Чукотского полуострова, а еще точнее, «пространство места» (термин Хайдеггера) проживания морских охотников в Уэлене, который назван автором Тэпкеном, становится причиной тоски Айвангу, когда он временно уезжает из родных мест. Айвангу постоянно сравнивает с Тэпкеном селения, в которых ему приходится бывать, периодически его охватывает отчаянная тоска по родным местам. Вернувшись после первой разлуки с ними, он сдержанно радуется всему, что видит, волнуясь, гладит руками закопченные деревянные стойки яранги, ходит на берег моря и подолгу смотрит на вельботы, маячащие в морской дали. Проявление таких чувств говорит о национальном характере - чукотские мужчины сдержанны и закрыты. Они стремятся оберегать свое пространство от «иного», зачастую негативного, с их точки зрения, воздействия на него. Беспокоит, например, Айвангу, сохранившего мифическое сакральное отношение к слову, изменение названий географических мест Чукотки - пролива, островов, озер, рек. Он предлагает, не отвергая присвоенных имен известных путешественников, дописать на картах и исконные чукотские названия.

Тревогу, чувство неуверенности вызывает у чукотских студентов, героев романа «В зеркале забвения», городское пространство Ленинграда (ныне Санкт-Петербурга). Для них в первое время чужим было все: каменные здания, их архитектура, быт и окружающие люди. Юноши постоянно сравнивали все с привычной и родной Чукоткой. Особенно активен в неприятии «чужого» Коравье, который сравнивал с чукотским даже ленинградский воздух. Известно, что, будучи веществом, воздух является в то же 
время пространством и, обозначая явление материального мира, он часто развивает значения, относящиеся к миру духовному. Для Коравье чужой воздух стал губительным как нравственно, так и физически. Юноша обладал очень тонким чутьем. Выйдя впервые на Невский проспект, за несколько кварталов до Невы, «потянул носом» и сказал: «Чую большую воду». И только Нева понравилась ему, поскольку оказалась величественной и многоводной и «могла сравниться с великой чукотской рекой Анадырь». Окружающий воздух города был для чукотских юношей «иным» - «весь пронизан, пропитан влагой, сочащейся отовсюду», им казался необычным даже мелкий дождь, в котором они не увидели привычных, обыкновенных капель. Лишь в утренний час за городом прохладный воздух отдаленно напомнил Гэмо летний воздух Уэлена, «когда солнце стоит над Дежневским массивом и тень от маяка ложится на нетающий снег на склоне холма». Ленинград (Санкт-Петербург) с его окрестностями и Уэлен с мысом Дежнева - словно соперничающие друг с другом герои романа. Коравье, друг главного героя Гэмо, всегда выискивал в чукотской жизни такое, что было лучше, чем в Ленинграде. Оказавшись впервые в ванне ленинградской квартиры, он восхитился возможностью согреться и расслабиться, использовав сравнение с чукотским пространством: «Как в тундре!» Объяснил свой восторг тем, что летом в тундре бывают такие дни, когда стоит жара и маленькие озерца нагреваются почти до самого дна, тогда можно полежать в теплой воде, хотя и недолго, поскольку лед все-таки внизу остается. Он громко ругал постоянно удивлявший его каменный город, утверждая, что, возможно, и души его обитателей «окаменели». Тоскуя по Чукотке, он страдал оттого, что учеба будет длиться слишком долго. Но не дождался ее окончания: не выдержав напряженной душевной борьбы «своего «и «чужого», закончил жизнь суицидом. Столкновение пространств - «своего» и «чужого» - оказалось разрушительным для психики героя, привело к трагедии.

«Манящий зов» пространства в романе «В зеркале забвения» оборачивается для главных героев-двойников почти приказом, колдовским воздействием, и они не способны ему противиться.

Магией притяжения обладает в романе место рождения и детства и автора, и героя - Уэлен. Периодически возвращался к нему в воспоминаниях писатель и главный герой Юрий Гэмо, мечтает побывать там и его 
двойник Георгий Незнамов. Когда же мечта двойника не исполнилась, он просит сына развеять свой прах над просторами Ледовитого океана вблизи маяка. Выполняя просьбу отца, Станислав, сын Незнамова, не знающий ничего о двойничестве, пытается понять причину столь необычной привязанности отца, жителя городка Колосово под Ленинградом, к Крайнему Северу. Первое впечатление не позволяет раскрыть тайну притяжения: вокруг было запустение времен перестройки 90-х гг. XX в., маяк - домик с башенкой - стоял разрушенным и разоренным. И только через открытые проемы выбитых окон и дверей маяка «вольно просматривалась морская даль, прямиком уходящая к Северному полюсу». Неожиданно со скалы ему открылся «немыслимо широкий простор, пронизанный студеным ветром арктических широт, чистым сиянием солнечных лучей». Когда герой прикрыл глаза, ему «пригрезилось, как под его ногами вращается огромный земной шар, а он стоит на стыке двух великих материков - Азии и Америки, на самом кончике края полушария» [I7, с. 395]. Вдали, на длинной галечной косе, вытянувшись на запад, между двумя водами - Ледовитым океаном и лагуной, Станислав увидел дома чукотского селения Уэлен. Ощутив величие открывшегося пространства, он стал немного ближе к пониманию «щемящей тайны». Это огромное пространство породило «чувство потерянности, неожиданного одиночества и ноющей боли в груди», а также сожаление о том, что, заботясь о материальной поддержке отца, не уделял внимания его душевному настрою, его душевным проблемам. Так автор с помощью внутреннего монолога одного из героев активизировал в романе и нравственную функцию пространственности, и историко-социальную.

Истоки пространственных ассоциаций эстетических и этических ценностных оценок магически притягивающего к себе Уэлена, вероятно, находятся в тех подсознательных процессах, которые происходили в детском возрасте. Гэмо, двойником которого был Незнамов, как и автор, родился и жил в этом селении до юношеского возраста.

Высокий скалистый обрыв сразу за маяком был в детстве для героя и, судя по другим автобиографическим произведениям, для писателя Юрия Рытхэу лучшим местом для чтения, «читальным залом всемирной литературы», поскольку здесь он был вне опасности быть застигнутым отчимом, который, «несмотря на свою относительную образованность», терпеть не мог читающего пасынка. 
Герой-подросток постоянно прислушивается к тому, как внизу под обрывом Ледовитый океан отбивает ритм в свой бубен: шумят волны, кричат птицы, свившие гнезда на отвесной скале, издают звуки моржи, и порой долетает до Гэмо свистящий вздох китового фонтана. Этот ритм настраивал на фантазии, и подросток, глядя на водную поверхность, «видел перед собой как бы оживший, ставший действительностью глобус, ту его часть, которая примыкала к штырю земной оси и синевой растекалась вокруг закрашенных белой краской льдов Северного полюса». Став писателем, Юрий Гэмо, как и автор, постоянно описывал родной Уэлен, лишь иногда меняя название, используя слово Улак, которое употребляли соседи-эскимосы, или Тэпкен. Погружаясь в собственные тексты, в картины, создаваемые воображением, они (автор и герой-писатель) значительную часть времени как бы проводили на родине. В их описаниях-воспоминаниях можно всегда узнать скалистый обрыв сразу за маяком, откуда открывается вид на «захватывающий дух простор, уходящий далеко за горизонт, до самого Северного полюса». Герои их произведений пребывают здесь часами, наблюдая за бесконечными птичьими стаями над водной поверхностью, за китовыми фонтанами, моржовыми стадами, движущимися от Берингова пролива на запад. Они вслушиваются в природные вечные звуки - «плеск воды о галечный берег, свистящий взрыв китового фонтана, утробное хрюканье моржей да несмолкаемый птичий гомон. Появляются размышления о вечности и бренности жизни. «В этой вековой музыке и чистом воздухе тело становилось бесплотным, как бы растворенным в окружающем сверкающем пространстве, оно становилось частью этой вечности, и сердце повторяло удары волн о берег», - вспоминает Юрий Гэмо.

Рытхэу, сакрализуя пространство родного ему Уэлена, поэтизируя его в процессе создания образов, реализует автобиографизм, который не является скрытым в романах, особенно «В зеркале забвения». Писатель постоянно со-бытийствует с окружающим миром, вступает с ним в диалог, выражает ощущение своей неповторимости как человека-творца в художественном тексте, в нем материализуется и закрепляется мироощущение его «я». Обратившись к социально-историческим вехам биографии писателя, к личным контактам с современниками, участию в литературных и издательских объединениях, можно увидеть тесную связь биографии героя писателя Юрия Гэмо и самого автора романа. 
Роман «В зеркале забвения» в принципе построен на передвижении по пространству - Незнамов, двойник Юрия Гэмо, находится в поиске людей, которые могут знать и помнить чукотского писателя; с другой стороны, сам писатель постоянно возвращается мысленно к своей прошлой жизни, пытаясь осознать значимость пройденного и сделанного. Появляются пространственные категории разных видов, тесно связанные с временными.

Смена представлений об историческом времени, обращение к биографиям героев, размышления автора о соотнесенности прошлого, настоящего и будущего сопровождаются в романе разноплановыми пространственными картинами: перед читателем предстают образы пространства замкнутого и открытого, земного и космического, реально видимого и воображаемого. Оно глубоко символично, обусловлено в первую очередь концептами мифопоэтического сознания и традиционных верований. Так, представления о верхе и низе как универсальных началах миропорядка присутствуют в чукотской мифологии и использованы Рытхэу в названных романах для выражения «непространственных понятий» - устремленности героев к труднодоступным целям, символизируют их сознательные и бессознательные желания преодолеть себя, достичь своей мечты, что могло бы поднять их над собой и сделать «иными», отличающимися от обычных, укоренившихся взглядов, позволило выявить скрытые возможности и способности человека. И Айвангу, и Юрий Гэмо на чукотских скалах ощущают прилив энергии и сил.

Являясь одной из основных форм познания мира и развития сознания, мифопоэтическое художественное пространство в романах Рытхэу не отражает, как свидетельствует дискурс, обычное место действия, а метафорически принимает на себя выражение совсем не пространственных отношений, моделируя структуру мира автора, оказывая влияние на мировоззрение героев, их восприятие окружающего и поведение, на этическую и эстетическую оценку. Пространство любви и зла, гармонии и дисгармонии, стабильности и нестабильности формируется и поддерживается как автором, так и героями.

Сопричастие с Уэленом и его окрестностями в романе «В зеркале забвения» стало своеобразным лейтмотивом, здесь выразительно представлено самодовлеющее пространство в духе неомифологизма. На Рытхэу оказали влияние художественные тексты нового времени, в которых 
возрождается мифопоэтическое и зачастую самодовлеющее пространство, выступающее как противовес его технизированным образам. Это усвоение и одухотворение пространства совершается разными способами. Среди них - создание новых мифологем о нем, которые используются не только на уровне образов и идей, но порой становятся лейтмотивом целых текстов.

В связи с тем, что специалисты выделяют в развитии мифического сознания две основные стадии: для первой характерно полное тождество духовного и природного, а для второй - разрушение этого тождества, связанного с выделением человеческого из природного окружения, можно отметить, что для сознания главных героев романов Рытхэу характерна как первая (особенно в романе «Айвангу»), так и вторая стадия развития, при этом для Юрия Гэмо, главного героя романа «В зеркале забвения», в его годы зрелости свойственно сознание некоей третьей степени - философское осмысление связи духовного и природного, аксиологический и творческий подход автора к мифологизму.

В романе «Айвангу» автор опирался больше на реальные пространственные субстраты, выразительное представление окружающего мира без ярко выраженного акцента на традиции народа. Сопричастность героя к близкому для него окружающему пространству представлена в соответствии с установками социалистического реализма и нацеливает читателя на формирование характера главного героя. Произведение отличает линейная композиция сюжета, где главное событие - битва героя за самовыживание, за признание его луораветланом , способным добыть морзверя, прокормить семью, добиться исполнения мечты стать капитаном и покорить океан.

В произведении нашли отражение заданные утопические идеи светлого будущего чукчей в ином культурном ареале, с другими жизненными установками, представлена борьба со старыми традициями и верованиями. Рытхэу делает акцент на внедрении нового, порой сознательно избегает описания продолжавшей существовать и в те годы у чукчей тесной связи с природой. «Встречи со скалой» он сопровождает размышлениями героя о желании воплотить свои мечты. И только в конце романа, когда, несмотря ни на какие преграды, герой становится капитаном и проплывает на сейне-

5 Луораветлан - чукотское самоназвание народа, в переводе - «настоящий человек». 
ре мимо Сэнлун, автор концентрирует внимание Айвангу на воспоминаниях, связанных с ней. Герой задумывается о ее таинственной роли в его жизни. В романе «Айвангу» действуют герои 30-6о-х гг. ХХ в., мифологическое мироощущение окружающего пространства проявляется у них чаще всего бессознательно.

В романе «В зеркале забвения», написанном в годы временной эмиграции Рытхэу в Европу (Дания, Германия) в 9о-е гг. XX в., интуитивная, содержательная глубина с помощью пространственных структур достигнута не без влияния неомифологизма, постмодернизма. Сюжет романа трудноуловим, основан на «чистом воображении». Сложные сюжетные сцепления позволяют автору творчески осмыслить свой жизненный путь, становление и развитие себя как писателя. В романе таинственное, многоликое пространство стало многозначимым объектом изображения, представленным в разнообразных ракурсах. Рытхэу привлекает в романе для размышлений и объяснения метафизических и мистических явлений в жизни и теорию вероятности, и учения индийских и китайских философов, и мнения европейских ученых. «В зеркале забвения», кроме видимого и воображаемого, а также духовного, присутствует пространство сновидений и зазеркалья. Ощущается воплощенное желание автора возродить мифопоэтику. Автор включил в текст и свое откровенное признание неправоты, и сожаление о том, что в прошлом ратовал за искоренение многих проверенных жизненным опытом чукотского народа ритуалов и традиций.

Писатель под влиянием бессознательного и сознательного обращения к мифологическому восприятию жизни и смерти, мысленного обращения к логике памяти и забвения, существования параллельных миров и переселения душ переживал в сознании и творчестве некий дуализм. Действие в романе развивается как в мире внешнем, «дневном», так и в загадочном ночном мире, сновидениях, пугающих своей повторяемостью и ясностью, влекущих к непонятным действиям.

Для коммуникации с двойником активно использует Рытхэу состояние сна и «послесонного» дремотного состояния. Обострение превращения своего «Я» в другого часто связано с переменами в природе и происходит с двойниками обычно весной и осенью.

Экзистенциальный подход, рассматривающий противоположности человеческого существования, не схватываемые мышлением, позволил пи- 
сателю подчеркнуть противоречия, парадоксы человеческого бытия, промежуточный характер человеческой реальности. Он постоянно с помощью двойников противопоставляет неподлинное (предметное бытие) и подлинное существование (экзистенция). Трансценденция становится иным, новым измерением постижения сути человеческой жизни, судьбы, бытования. Данный подход свидетельствует об увлечении Рытхэу современной антропологией, основными направлениями неклассической философии, пристальном изучении различных феноменов существования человека, решении задач выявления основ человеческого бытия и прояснения его структуры. Не без влияния исследователей психоаналитической антропологии 3. Фрейда, К.Г. Юнга, Э. Фромма, с работами которых он был хорошо знаком, обращается писатель к скрытым, глубинным пластам человеческой психики, которыми и определяется природа человека. Путем обращения героев-двойников к внутреннему самоанализу Рытхэу стремится обнаружить внутренние структуры человеческого бытия, увидеть процессы, происходящие в подсознании, а порой - расшифровать символический язык бессознательного.

Архетипические оппозиции верх-низ, свой-чужой, близкий-далекий, широта-узость, мифологемы, «прасимволы», традиции, верования, трансформированные пространственные концепты, являясь составляющей картины мира чукотского народа, его культуры, легли в основу литературных образов в романах Рытхэу. Мифопоэтика пространства приблизила к пониманию глубинных процессов бытия, духовной составляющей культуры одного из самобытных народов Севера.

Сквозь призму мифологических представлений о пространстве Рытхэу стремился осмыслить различные феномены человеческого бытия, в первую очередь жизни чукотского народа, его социально-биологические и духовные основы, обращая усиленное внимание читателя на конкретные проблемы онтологии, метафизики. С помощью сюжетно-композиционного построения романов, описания взаимодействия человека и природы, человека и общества, формирования личности, а также внутренних монологов героев, их размышлений о жизни создавал он художественный образ пространства и конструировал образы. Писатель стремился, в том числе с помощью мифологических пространственных субстрат, воссоздать и раскрыть в романах тайны национальной сущности героев. 


\section{Список литературы}

Барт Р. Избранные работы: Семиотика. Поэтика / пер. с фр. М.: Прогресс, I994. $6 \mathrm{I} 6 \mathrm{c.}$

Бахтин М.М. Тетралогия. М.: Лабиринт, І998. 607 с. Бахтин М.М. Эпос и роман. СПб.: Азбука, 200о. 300 с.

Богораз В.Г. Чукчи. Религия / авторизованный пер. с англ. Л.: Изд-во Главсевморпути, І939. 216 с.

Гачев Г.Д. Национальные образы мира. Космо-Психо-Логос. М.: Изд-во Академ. проект, I995. $480 \mathrm{c.}$

Гей Н.К. Категория художественности и метахудожественности в литературе // Литературоведение как проблема. Труды научного совета «Наука о литературе в контексте наук о культуре». Памяти Александра Викторовича Михайлова посвящается. М.: Наследие, 200I. С. 280-30I.

Европейские судьбы концепта культуры (Россия, Германия, Франция. Англоязычный мир). М.: ИМЛИ РАН, 20II. 374 с.

Кармин А.С. Культорология. СПб.: Питер, 200I. 926 с. Кессиди Ф.Х. От мифа к логосу. М.: Мысль, І972. 3 І2 с.

Кофман А.Ф. Латиноамериканский художественный образ мира. М.: Наследие, I997. $320 \mathrm{c}$.

Леви-Брюль Л. Сверхъестественное в первобытном мышлении. М.: Педагогика-Пресс, г999. 608 с.

Лосев А.Ф. История античной эстетики. Аристотель и поздняя классика. М.: Искусство, І975. 776 с.

Лотман Ю.М. О русской литературе. СПб.: Искусство, І997. 848 с.

Мерло-Понти М. Феноменология восприятия / пер. с фр. СПб.: Ювента, Наука, I999. $602 \mathrm{c.}$

5 Пошатаева А.В. Литература народов Севера (Истоки. Становление. Развитие). М.: Наука, І988. І68 с.

Рытхэу Ю. Айвангу. Роман // Рытхэу Ю.С. Голубые песцы. Роман и повесть. М.: Сов. Россия, 1976. С. 3-263.

Рытхэу Ю.С. В зеркале забвения. Роман. СПб.: Изд-во журнала «Звезда», 200 . $400 \mathrm{c}$.

Семушкин Т. Чукотка. Повесть. М.: Худож. лит., І967. 39I с.

Тайлор Э.Б. Первобытная культура / пер. с англ. М.: Политиздат, І989. 573 с. Топоров В.Н. Пространство и текст // Топоров В.Н. Семантика и структура. М.: Худож. лит., І983. С. 227-284.

Флоренский П.А. Соч: в 4 т. М.: Мысль, І999. Т. 3 (2). С. 3-г7о. Фрэзер Дж. Золотая ветвь. М.: Политиздат, г980. 832 с.

Фуко М. Порядок дискурса // Воля к истине: по ту сторону знания, власти и сексуальности. Работы разных лет. М.: Касталь, І996. 448 с. 
24 Фуко М. Другие пространства // Интеллектуалы и власть: избранные политические статьи, выступления и интервью. М.: Праксис, 2006. Ч. 3. С. I9I-204.

25 Хайдеггер М. Бытие и время / пер. с нем. Харьков: Фолио, 2003. 503 с.

26 Шпенглер О. Закат Европы. Очерки морфологии мировой истории. М.: Мысль, І999. 620 с.

27 Юнг К.Г. Психологические типы / пер. с нем. Минск: ООО «Попурри», I998. $656 \mathrm{c}$. 


\section{References}

Bart R. Izbrannye raboty: Semiotika. Poetika [Selected works: Semiotics. Poetics], trans. from French, Moscow, Progress Publ., I994. 616 p. (In Russ.) Bahtin M.M. Tetralogiya [Tetralogy]. Moscow, Labirint Publ., I998. 607 p. (In Russ.)

3 Bahtin M.M. Epos i roman [Epic and novel]. St. Petersburg, Azbuka Publ., 2000. 300 p. (In Russ.)

4 Bogoraz V.G. Chukchi. Religiya [Chukchi. Religion], authorized trans. from English. Leningrad, Izd-vo Glavsevmorputi Publ., I939. 216 p. (In Russ.)

5 Gachev G.D. Nacional'nye obrazy mira [National images of the world]. Kosmo-PsihoLogos. Moscow, Izd-vo Akadem. Proekt Publ., I995. 480 p. (In Russ.)

6 Gej N.K. Kategoriya hudozhestvennosti i metahudozhestvennosti v literature [Categories of fictionality and metafictionality in literature]. Literaturovedenie kak problema. Trudy nauchnogo soveta Nauka o literature $v$ kontekste nauk o kul'ture Literary studies as a problem [Literary Studies as a Problem. Proceedings of the scientific Council on literary research in the context of cultural studies]. Pamyati Aleksadra Viktorovicha Mihajlova posvyashchaetsya. Moscow, Nasledie Publ., 200I, pp. 280-30I. (In Russ.) Evropejskie sud'by koncepta kul'tury (Rossiya, Germaniya, Franciya. Aagloyazychnyj mir [European destinies of the concept of culture (Russia, Germany, France, Anglophonic world)]. Moscow, IMLI RAN Publ., 20II. 374 p. (In Russ.)

8 Karmin A.S. Kul'torologiya [Cultural studies]. St. Petersburg, Piter Publ., 200I. 926 p. (In Russ.)

9 Kessidi F.H. Ot mifa k logosu [From myth to logos]. Moscow, Mysl' Publ., I972. 3I2 p. (In Russ.)

Io Kofman A.F. Latinoamerikanskij hudozhestvennyj obraz mira [South American artistic worldview]. Moscow, Nasledie Publ., I997. 320 p. (In Russ.)

II Levi-Bryul' L. Sverhestestvennoe v pervobytnom myshlenii [The supernatural in primitive thinking]. Moscow, Pedagogika-Press Publ., I999. 608 p. (In Russ.)

I2 Losev A.F. Istoriya antichnoj estetiki. Aristotel' i pozdnyaya klassika [History of ancient aesthetics. Aristotle and the late classics]. Moscow, Iskusstvo Publ., I975. 776 p. (In Russ.)

I3 Lotman Yu.M. Hudozhestvennoe prostranstvo v proze Gogolya [Fictional space in Gogol's prose]. Lotman Yu.M. O russkoj literature [On Russian literature]. St. Petersburg, Iskusstvo Publ., I997. 848 p. (In Russ.)

I4 Merlo-Ponti M. Fenomenologiya vospriyatiya [Phenomenology of perception], trans. from French. St. Petersburg, Yuventa, Nauka Publ., I999. 602 p. (In Russ.) Poshataeva A.V. Literatura narodov Severa (Istoki. Stanovlenie. Razvitie) [Literature of the peoples of the North (Sources. Formation. Development)]. Moscow, Nauka Publ., I988. I68 p. (In Russ.) 
Rytheu Yu. Ajvangu. Roman [Ajvangu. Novel]. Rytheu Yu. S. Golubye pescy. Roman i povest' [Blue Arctic foxes. The novel and the novella]. Moscow, Sov. Rossiya Publ., I976, pp. 3-263. (In Russ.)

I7 Rytheu Yu.S. V zerkale zabveniya. Roman [In the mirror of oblivion. Novel]. St. Petersburg, Izd-vo zhurnala "Zvezda” Publ., 200I. 400 p. (In Russ.)

I8 Semushkin T. Chukotka. Povest' [Chukotka. Story]. Moscow, Hudozhestvennaya literature Publ., I967.39I p. (In Russ.)

I9 Tajlor E.B. Pervobytnaya kul'tura [Primitive culture], trans. from English. Moscow, Politizdat Publ., I989. 573 p. (In Russ.)

20 Toporov V.N. Prostranstvo i tekst [Space and text]. Toporov V.N. Semantika i struktura [Semantics and structure] Moscow, Hudozhestvennaya literature Publ., I983, pp. 227-284. (In Russ.)

2I Florenskij P.A. Sochineniya: $v 4$ t. [Works: in 4 vols.]. Moscow, Mysl' Publ., I999, vol. 3 (2), pp. 3-I7o. (In Russ.)

22 Frezer Dzh. Zolotaya vetv' [Golden bough]. Moscow, Politizdat Publ., I980. 832 p. (In Russ.)

23 Fuko M. Poryadok diskursa [The order of discourse]. Volya k istine: po tu storonu znaniya, vlasti i seksual'nosti. Raboty raznyh let [The will for truth: beyond knowledge, power and sexuality. Works of different years]. Moscow, Kastal' Publ., I996. 448 p. (In Russ.)

24 Fuko M. Drugie prostranstva [Other spaces]. Intellektualy i vlast': izbrannye politicheskie stat'i, vystupleniya i interv'yu [Intellectuals and power: selected political articles, speeches and interviews]. Moscow, Praksis Publ., 2006. Ch. 3, pp. I9I-204. (In Russ.)

25 Hajdegger M. Bytie i vremya [Being and time], trans. from German. Har'kov, Folio Publ., 2003. 503 p. (In Russ.)

26 Shpengler O. Zakat Evropy. Ocherki morfologii mirovoj istorii [The Decline Of Europe. Essays on the morphology of world history]. Moscow, Mysl' Publ., I999. 620 p. (In Russ.)

27 Yung K.G. Psihologicheskie tipy [Psychological type], trans. from German. Minsk, OOO “Popurri” Publ., I998. 656 p. (In Russ.) 
УДК $392+82$

ББК $70(4$ Гем $=253) 5 \mathrm{I}^{+}$

$8 \mathrm{o}(4$ Гем $=253) 5 \mathrm{I}$

\section{ГЕРМАНИЯ ЭПОХИ ПРОСВЕЩЕНИЯ И ИЗУЧЕНИЕ СИБИРИ}

(c) 2018 г. Мишель Эспань

Национальный центр научных исследований

Франции, Эколь нормаль сюперьер,

Лабекс «ТрансферS»

Париж, Франция

Дата поступления статьи: 28 ноября 2017 г.

Дата публикации: 25 сентября 2018 г.

DOI: IO.22455/2500-4247-2018-3-3-232-253

Аннотация: В эпоху Просвещения целый ряд немецких ученых, находившихся в то время на службе Российской империи, начинает научное исследование Сибири в составе «Великой Северной экспедиции» (I733-I743), дело которой было продолжено впоследствии другими исследователями. Иоганн Георг Гмелин, Карл Генрих Мерк, Георг Вильгельм Штеллер, Герхард Фридрих Мюллер, Петер Симон Паллас сосредоточили свое внимание на религиозных практиках, языках и повседневной жизни различных этнических групп Сибири, которые они встречали на своем пути. Их описания, остававшиеся долгое время неизданными, поскольку формально считались собственностью Российской академии наук, были не только ценнейшим вкладом в создание русской идентичности, осмысленной как часть евразийского пространства, но легли также в основу новых наук, таких как антропология и лингвистика. Эти науки в свою очередь можно рассматривать как продукт синтеза традиций немецкой университетской науки и не исследованного до той поры сибирского пространства, которое еще только предстояло в полной мере осмыслить.

Ключевые слова: Сибирь, Алтай, антропология, шаманизм, лингвистика, история гуманитарных наук, русские немцы.

Информация об авторе: Мишель Эспань, профессор, директор Лабекс «ТрансферS» (Национальный центр научных исследований Франции - Эколь нормаль сюперьер) и лаборатории «Немецкоязычные страны - Культурный трансфер» (УМР 8547), 45 рю д’Ульм, 75005 г. Париж, Франция.

E-mail: michel.espagne@ens.fr

Для цитирования: Эспань М. Германия эпохи Просвещения и изучение Сибири // Studia Litterarum. 2018. T. 3, № 3. C. 232-253.

DOI: $10.22455 / 2500-4247-2018-3-3-232-253$ 


\section{ENLIGHTENMENT GERMANY AND THE INVENTION OF SIBERIA}

This is an open access article distributed under the Creative Commons Attribution 4.0 International (CC BY 4.0)
(C) 20I8. Michel Espagne

ENS - CNRS,

Labex Transfers

Paris, France

Received: November 28, 2017

Date of publication: September 25, 2018

Abstract: During the period of German Enlightenment, German scholars at service in the Russian state began scientific exploration of Siberia and organized the "Great northern expedition" (I733-I743) which was later completed by other researchers. Johann Georg Gmelin, Carl Heinrich Merck, Georg Wilhelm Steller, Gerhard Friedrich Müller, and Peter Simon Pallas among others focused on the religious life, languages and everyday life of the Siberian ethnic groups they encountered. Their accounts remained for a long time unpublished as they were a "formal" property of the Russian Academy of Sciences. Not only are they a valuable contribution to the invention of Russian identity conceived as part of the Eurasian space, they also form the basis of new sciences such anthropology and linguistics resulting from the contact between German universities and the widely unexplored Siberian world.

Keywords: Siberia, Altai, anthropology, shamanism, linguistics, history of the humanities, Russian Germans.

Information about the author: Michel Espagne, Professor, Director of the Labex Transfer $\underline{S}$ (ENS-CNRS) and of the UMR "Pays germaniques-Transferts culturels/Archives Husserl” (UMR 8547), 45 rue d'Ulm, 75005 Paris, France.

E-mail: michel.espagne@ens.fr

For citation: Espagne M. L'Allemagne des Lumières et la science de la Sibérie (Enlightenment Germany and the Invention of Siberia). Studia Litterarum, 20I8, vol. 3, no 3, pp. 232-253. (In Russ.) DOI: IO.22455/2500-4247-2018-3-3-232-253 
B XIX в. в составе Российской академии наук мы находим немалое количество ученых, получивших образование в немецких университетах. Начиная с Даниэля Готлиба Мессершмидта (г685-I735), немецкого медика и ботаника на русской службе, и вплоть до Вильгельма Радлова (1837-1918), изучавшего эпос тюркских народов, Сибирь открывали и описывали нередко ученые немецкого происхождения. Порой их исследования составляли часть великих географических экспедиций. Такой была, в частности, экспедиция I733-I743 гг., в которой участвовали одновременно Герхард Фридрих Миллер (Мюллер) (I705-1783), Иоганн Георг Гмелин (I709-I755) и Георг Вильгельм Стеллер (Штеллер) (I709-I746), позже результаты ее дополнил Карл Генрих Мерк (I76I-I799). Интересно отметить, что одну из величайших экспедиций в Сибирь уже XX в., так называемую Jesup North Pacific Expedition (Северо-Тихоокеанскую экспедицию Джесупа, І897-I902), возглавил немецко-американский антрополог, наследник братьев Гримм и Вильгельма Гумбольдта, Франц Боас. B XVIII в. немецкие ученые могли также участвовать, как это было в случае с Симоном Палласом (I74I-I8II), в обширных исследованиях, предпринятых по инициативе Екатерины II для обследования мало известных регионов Российской империи (см.: [2]). Наконец, можно также указать на то, что многие профессора Дерптского (Тартуского) университета были авторами работ о флоре и фауне Сибири. Создается впечатление, что начиная с XVIII в. в России развивается отрасль немецкой науки, объектом которой становится Сибирь, но которая использует интеллектуальный инструментарий, унаследованный ею от немецких университетов, ориентированный притом в основном на изучение народов нерусского проис- 
хождения, населявших сибирское пространство. Так появляется немецкий взгляд на Сибирь и попытка ее «немецкого» описания.

В отличие от истории европейских народов, история народов, населяющих Сибирь, долгое время не имела временного измерения и избегала вопросов, касающихся поиска культурной идентичности той или иной этнической группы. В Сибири речь более шла об истории циркуляций, заимствований, вкраплений и метисаций. Ученые отмечали, например, что у ханты-мансийцев, народа финно-угорской группы, можно легко обнаружить лексику для обозначения текстиля, идентичную татарской [3, p. I3]. Киргизы говорят на тюркском языке, но язык этот принадлежал, скорее всего, древней элите населения, состоявшего в большинстве своем из племен кетов и самоедов [3, p. 23]. Русская колонизация заставила население эвенков и тунгусов покинуть берега Ангары и Лены и переместиться на север, в то время как эвенки, кеты и самоеды, жившие на территории, простиравшейся от Иркутска до Красноярска, переместились на юг, чтобы ассимилироваться на пространстве Алтая с населением тюркского происхождения [3, p. I75]. В лесотундре, в субарктическом поясе, смогла возникнуть в результате смешанных браков между эвенками и якутами новая популяция, говорившая по большей мере на якутском языке с некоторыми словарными заимствованиями из эвенкского языка. Их манера одеваться отвечала в равной степени якутской и эвенкской традиции. Коми, уральский народ, постепенно завоевывал территорию ненцев, некоторые из которых усвоили язык коми как родной. К этим примерам миграции населения следовало бы добавить историю двух миллионов русских (славян), которые в период между I896 и I9I2 гг. переместились с запада на Восточный Урал. Именно русские, хотя и довольно поздно, проявили интерес к сибирским народам. Владимир Богораз был одним из первых членов советского «Комитета содействия народам северных окраин» («Комитета Севера»), созданного в г924 г. при Президиуме ВЦИК, в задачи которого входило среди прочего создание письменных языков. А уже в г930 г. в Якутии выходило двенадцать якутских газет, печатавшихся с использованием алфавита, незадолго до того унифицированного на основе тюркского. Более гоо ооо евреев переселились в Биробиджан в г930-е гг., их официальным языком стал идиш [3, р. 326].

В этом регионе Восточной Сибири этнические наслоения были особенно сложными, поскольку тунгусы, эвенки и родственные им маньчжуры 
представляют собой многочисленную группу, конкурирующую с гораздо менее многочисленным народом нивхи (устар.: гиляки), которые, со своей стороны, родственны курильским и японским айну (айны). Существуют также и другие региональные этносы, как, например, ительмены (или камчадалы), коренное население Камчатки. Перемещение народов имеет следствием циркуляцию языков, но также и религиозных практик. Так, буряты, северный монгольский народ, исповедующий буддизм, будучи самой многочисленной из сибирских нерусских народностей (и второй после русского населения Сибири), представляют собой, конечно же, ламаистскую разновидность буддизма, однако свойственные им шаманские практики, восходящие к более древнему пласту верований, свидетельствуют о еще более сложной истории их происхождения.

Уже в XVIII в. историк Герхард Фридрих Миллер в своих трудах о Сибири обращал особое внимание на происходившие там процессы ассимиляции между различными сибирскими этносами [6, S. 253]. Иоганн Георг Гмелин все в том же XVIII в. с особым вниманием исследует этнические скрещения на сибирской почве. Остиаки и татары встречаются в районе реки Енисей [4, S. I44]. Гмелина интересует то, как тунгусы адаптируются в якутской среде [4, S. I9I-I93], как монголы естественно превращаются в верноподданных русского царя [4, S. I79] и как выстраиваются отношения между китайцами и русскими в приграничных территориях [4, S. I72-I73].

Этнические имбрикации особенно были сильны в районе Алтая и Тувы. Кеты и самоеды в результате ассимиляции с тюркскими племенами составили субэтнос алтае-саян. На протяжении многих веков они несли в себе след монгольского вторжения Чингиз хана в XIII в. Монгольское влияние нашло отражение в физическом облике населения, и если тюркские языки в районах Алтая и Тувы получили наибольшее распространение, то вместе с тем пласт монгольской лексики оставался в них весьма значительным [3, p. 24]. В монгольском ханате Дзунгари, контролировавшем Алтайский край в XVII-XVIII вв., для обозначения местных самоедов и тюркских народов использовали слово «ураанхай». Ханат находился в состоянии постоянной конфронтации как с китайской династией маньчжуров, так и с Тибетом. В конце концов Дзунгари вошел в состав Китая, который Алтайский регион вообще воспринимал как периферийную часть собственной территории. 
Русское население Алтая вплоть до І86о-х гг. было представлено в основном старообрядцами. Затем этот край стал местом, куда стекались миссионеры, открывавшие здесь школы, в то время как параллельно, вокруг бурханизма - «белой веры», стремившейся искоренять шаманизм, - зарождались секты. Тува, бывшая соседней с Алтаем территорией с ее тюркофонным населением кетов и самоедов, оставалась под властью монгольского ханата, прежде чем стать частью маньчжурского Китая и вернуться наконец в состав России во всей сложности своих языковых и религиозных наслоений [3, p. 224]. Буддизм, религия, появившаяся в этом крае в более поздний период, не смогла полностью вытеснить шаманскую практику. Так же как и Монголия, регион Тувы снова, в течение короткого периода времени, оказался под китайской юрисдикцией после г9I8 г. [3, p. 228]. Советские власти стремились вытеснить монгольский язык, заменив его тувинским языком тюркского происхождения, использовавшим латинский алфавит [3, p. 28I]. Монгольское присутствие в бывшем Дзунгари наблюдается вплоть до середины XX в.: в середине I920-х гг. на территории Бурятии насчитывалось 47 монастырей и около I5 ооо лам [3, p. 330]. Будучи местом встречи Монгольской, Маньчжурской и Российской империй и вместе с тем результатом встречи алтайской и тюркской культур, Алтайский регион в особенности демонстрирует необходимость рассматривать Сибирь, и прежде всего ее южную часть, как место культурного трансфера между этническими, языковыми и религиозными группами.

К особенностям, характеризующим межэтнические связи и перемещения в Сибирском регионе, следовало бы добавить еще и примечательную его связь с Германией. По правде говоря, эта особая связь наблюдается до наших дней. Одним из писателей, пользующихся особым успехом в современной Германии, является выходец из Монголии Галсан Чинаг. В г960-е гг. он учился в Лейпцигском университете, где защитил диплом, посвященный творчеству Эрвина Штриттматтера. Сейчас он живет в Улан-Баторе, практикует шаманизм, принадлежа к тюркоязычному меньшинству тувинцев Алтай-Саянского региона. Действие романов Галсана Чинага, которые он пишет на немецком языке, происходит в Алтай-Саянах, т. е. на территории, находящейся на границе Монголии, России и Китая. Этому совмещению трех культурных пространств, определяющих тувинскую идентичность, посвящена его книга «Мой Алтайский край» [II], заставившая мечтать об 
Алтае немало немецких читателей. Впрочем, Алтай в ней предстает как скорее культурный регион, вряд ли имеющий четко очерченные географические границы. Множество немецких литературных премий и орден Федеративной Республики Германии увенчали эту литературную работу, местом приложения которой стало сибирско-китайско-монгольское пространство Тувы.

Вообще же немецкое увлечение многочисленными народностями Сибири, встретившимися на ее территории, имеет гораздо более давнее происхождение. Его истоки относятся к XVIII в. - времени, когда Российская академия наук становится, как уже упоминалось выше, прибежищем для многих немецких ученых и когда императрица Екатерина II (будучи сама немецкого происхождения) поручает в основном немецким ученым дело обследования своей империи, описания ее ресурсов, этнических групп и языков

Если второй этап изучения Сибири был связан с именем Симона Палласа, то начало немецкого обследования сибирской территории было положено Герхардом Фридрихом Миллером, деятельность которого можно рассматривать как образцовую в истории немецкого изучения России. Петр Симон Паллас отправился в путешествие по Сибири и, в частности, по Алтаю в августе I77I г., остановившись в районе Змеиногорска [9, S. 6I2]. Особое его внимание привлекла геология региона, расположенного между Змеиногорском (Шлангенбергом) и Барнаулом, хотя он изучает в этом регионе также и историю горного дела и посещает развалины буддистского храма Аблайкит в окрестностях Усть-Каменогорска [9, S. 547].

Что касается Миллера, то он был сыном директора гимназии и, следовательно, принадлежал к культурной элите Германии своего времени. Он учился в Лейпцигском университете, одном из крупнейших той эпохи, и среди его профессоров был Отто Менке, издатель известнейшего научного журнала эпохи «Akta Eruditorum».

Миллер, как и его коллега, востоковед и историк Готлиб Зигфрид Байер (1694-I738), прибыл в Санкт-Петербург в I725 г. Став секретарем Российской академии наук, Миллер начинает издавать материалы

I Здесь необходимо напомнить, что первые карты Сибири, начиная с карт Себастьяна Мюнстера, Сигизмунда фон Герберштейна и вплоть до карт Иоганна Филиппа Табберта фон Штраленберга были делом рук немецких географов и картографов [2, с. I05]. 
Академии под названием «Novi commentarii», перенеся в русский контекст опыт, приобретенный им при работе над «Acta Eruditorum». Он издает также сборники статей, посвященных истории России («Sammlung Russischer Geschichte», I732-I765), - первый немецкоязычный труд, знакомивший иностранцев с русской историей. Для Миллера, как и для Байера, история России была немыслима без знания географических и этнических особенностей российского пространства. В определенном смысле можно сказать, что история Российской империи дала импульс зарождению немецкой антропологии. Миллер стал частью этого процесса. Его самого рекомендовал историк и философ И.Б. Менке. По его рекомендации, а также рекомендации Антона Фридриха Бюшинга (I724-I793), одного из основателей географической науки в Германии, в Санкт-Петербург приедет Август Людвиг Шлецер (I735-1809), будущий издатель и переводчик на немецкий язык «Нестора» (русских летописей «на древнеславянском языке»»), первый немецкий историк России Средних веков. В этом проекте конструирования идентичности Российской империи, в основу которого кладутся исторические расследования, восточная окраина России и в особенности Сибирь приобретает все большее значение, тем более что это отвечает экономическим потребностям империи, а также необходимости геополитического ее самостоянья.

Во многом благодаря интересу, проявленному немецкими учеными к Сибири, русская история постепенно становится историей, теснейшим образом связанной с Востоком. Изучение Сибири, которое начнется в 1733 г. и продолжится вплоть до I743 г., станет важной эпохой в истории открытия восточных регионов России. Члены экспедиции, в числе которых мы находим Иоганна Георга Гмелина и Георга Вильгельма Стеллера, имели уже заранее составленные вопросники, предвосхищавшие во многом их дальнейшее восприятие и оценку сибирских этносов, чьи нравы, искусства, религию, языки они собирались изучать [І2]. В частности, Миллер в определении этнических групп и распознавании их имбрикаций опирался на лексику: язык становится у него основным отправным пунктом описания и каталогизации встреченных им народностей. Кроме того, ученые имели в своем распоряжении несколько сотен книг, составлявших обширную библиотеку, которую им пришлось восполнить, как только злосчастный пожар уничтожил часть их документации. Миллер взял на себя миссию собирания 
артефактов и занялся выявлением и каталогизацией архивов, оказавшихся ему доступными в Сибири. Иоганн Георг Гмелин, родом из Тюбингена, прежде чем отправиться в Россию, был профессором Геттингенского университета. Георг Вильгельм Стеллер, бывший студент из Виттенберга, а впоследствии ботаник и зоолог, ученик и последователь уроженца города Галле Даниэля Готлиба Мессершмидта, известного ботаника, специализировавшегося на флоре Сибири, был все же прежде всего этнологом, первооткрывателем ительменов Камчатки. Бывший студент медицинского факультета Гиссенского университета Карл Генрих Мерк, который в начале I790-х гг. станет исследовать Чукотку, также вписался в эту группу немецких ученых, отправившихся открывать Сибирь.

Немецким ученым было запрещено публиковать результаты своих исследований, полученных ими во время путешествия по Сибири, - все они считались собственностью Российской академии наук (Гмелин, последовавший совету Альбрехта фон Галлера, был одним из немногих, кто нарушил данный запрет [2, S. I34]). Вот почему величайшие памятники проделанной учеными антропологической работы становились известны гораздо позднее, и явление немецкой антропологии на сибирском материале, основным заказчиком которой выступала Россия, не было оценено в полном объеме.

Работа Георга Вильгельма Стеллера «Beschreibung von dem Lande Kamchatka» («Описание камчатской земли»), опубликованная после его смерти в I774 г., во многих отношениях позволяет нам судить о том интересе, который ученые немцы проявляли к Сибири, и о направленности их исследований․․ Конечно, задачей Стеллера, участника экспедиции Витуса Беринга, было прежде всего изучение региона, расположенного между Камчаткой и Америкой, а опубликованные им впоследствии труды относятся скорее к жанру путевого очерка. И все же во многих отношениях он выходит далеко за пределы этого жанра. Территория Камчатки сначала им рассматривается с узко географической точки зрения: реки, источники, горы, климат, растительность постепенно провоцируют его на более широкие обобщения, от которых он переходит к вопросам социального характера, затронув также проблему русских «острогов», а уже от них перейдя к

2 Вспомним, что сам Лейбниц призывал к изучению Камчатки, предвосхищая тем самым исследования Стеллера и Мерка, проведенные по заданию Российской академии наук (см.: [2, S. II2]). 
описанию ительменов. Стеллер задается вопросом о неясном происхождении населения, его религии, психологии, физической конституции, одежде, способах производства. Его интересует еда, праздники, семейная жизнь, воспитание детей, политическая организация общества, медицина, способы передвижения, торговля. Стеллер создает свой лексикон корякского устного языка, на котором говорят на севере Камчатки. Он с особым вниманием следит за перемещением населения. Он не только интересуется происхождением ительменов, отвергая тезис о возможности существования коренных народов как таковых, но и интересуется одновременно населением Америки. Он стремится показать, что американцы и есть кориаки (коряки): и те и другие используют один и тот же тип судов, имеют сходный тип внешности, пользуются сходными инструментами, носят похожую одежду, сходным образом разрисовывают себе лица, сходным образом делают подарки иностранцам, свидетельствующие об их мирных намерениях. В рассказах чукчей повествуется о том, что в Америке корякские пастухи пасут стада оленей и что расстояние от Камчатки до Америки или до Чукотского полуострова с американской стороны настолько мало, что благодаря другим островам, расположенным между ними, например, Алеутским, сообщение не представляет никакой сложности (см.: [13, S. 25I-252]). Так что можно сказать, что теория Берингова пролива, сыгравшего решающую роль в истории заселения Америки, равно как и теория языковой и мифологической близости Сибири и Аляски, в зародыше уже присутствует у Стеллера.

Особое научное любопытство у немецких исследователей Сибири, которые были, как правило, лютеранского вероисповедания, вызывал религиозный вопрос, который они решали, однако, из европоцентристской перспективы. Так, Стеллер пытался всеми силами найти в космологии ительменов те элементы, которые можно было бы сопоставить с христианством. Вместе с тем Стеллер оставался внимательным и к самобытному характеру религии, исповедуемой ительменами, их представлениям о боге Кутхе и его власти. Ительмены не верят в предопределение, но только в человека и его удачу, полагая, что мир вечен и тела возродятся и воссоединятся с душами (см.: [13, S. 268]). В общении с ними Стеллер, со своей стороны, развивает мысль о том, что бедные станут в другом мире богатыми. Потусторонний мир представляется им, кроме того, неким подобием рая, в котором каждый найдет себе жену. Они верят также во всемирный потоп. 
Некоторое сходство с христианской верой, которое Стеллеру позволили выявить беседы с местным населением, не исключало и противоположной интерпретации. Например, ительмены не хотят креститься, потому что в этом случае они, согласно христианским верованиям, попадут на небо, в то время как сами они предпочитают свой подземный рай. Для ительменов существует понятие греха. Но грех этот связан в основном с нарушением ритуальных запретов. Соскабливание снега с обуви за пределами дома при помощи ножа может вызвать бурю. Запрещено также варить в одном и том же сосуде мясо и рыбу (см.: [гз, S. 274]).

Ительмены охотно толкуют сны. В давние-предавние времена, до того, как они были крещены, они были свободны, а после принятия христианства стали рабами у казаков. Стеллер полагает религию одним из важнейших факторов этнической самобытности.

Религиозная практика, которая более всего привлекает внимание немецких ученых в Сибири, - это шаманизм. Как люди эпохи Просвещения, они видят в шаманизме суеверие, способ обманывать людей, обладающих некрепкой психикой. Вместе с тем они охотно сравнивают шаманов с актерами, играющими одновременно различные роли в постановке, которую можно было бы сравнить с театром саами на севере Европы или индейцев Америки. Миллер, например, провел немало времени в беседах с шаманами. Важными элементами их верований, на которые он обращает особое внимание, является представление о духе места и обожествление природы, искусу которого поддались даже самые простые сибирские жители (см.: [6, S. 259]).

Гмелин описывает свою встречу с тунгусским шаманом, который ведет его ночью на лоно природы, раздевается, затем надевает на себя костюм шамана, к которому подвешены разнообразные металлические предметы. Он начинает свой бег по кругу, изображая тем самым, будто становится рупором некоего духа. Войдя в транс, он отвечает на вопросы, которые задаются при его посредничестве духу. Однако Гмелина весь этот спектакль не слишком убеждает: «В конце концов, мы снова утвердились во мнении, что все это было обманом, и нам бы хотелось отправить его и его нечестивых собратьев в Аргунские серебряные рудники, где они были бы осуждены на вечные работы» [3, p. І70].

К югу от озера Байкал Гмелин столкнулся со смешанным населением монголов и тунгусов, у которых шаманизм естественно сочетается с ламаи- 
змом: «В самых важных и сложных ситуациях они прибегают к шаманам. Когда они больны, то обращаются скорее к монгольским ламам, которые в этих случаях обращают в свою веру немало неофитов» [3, p. I78].

Гмелин особо отмечает монгольский ламаизм бурят, которые, говоря на одном из монгольских языков, оказываются особенно восприимчивыми к монгольскому буддизму. Гмелин долго беседовал с одним ламаистским монахом, который объяснил ему, что у тибетцев шаманы тоже есть, но у них они занимают более низкое положение, чем монахи, буряты же остаются язычниками, лишь частично обращенными в монотеистическую религию [3, p. I74-I75].

Чуть позже Карл Генрих Мерк станет описывать трансы чукотских шаманов, бьющих в барабаны, впадающих в состояние экстаза, наносящих себе травмы, утверждающих, что они обладают силой, способной излечить болезни и предсказать будущее, но при этом без тени сомнения организуют ритуал так, чтобы обратившийся к ним человек пожертвовал лучшего оленя из своего стада (см.: [7, S. 233]). Чукотские шаманы не носят особого костюма, но разрисовывают себе лицо. Их камлание призвано предсказать исход охоты, а когда великий шаман умирает, в местности появляется огненный столп [7, S. 247].

C религиозными практиками якутов Гмелин знакомится, рассматривая внушительные деревянные куклы - якутских идолов, напоминающих ему немецкие скульптуры, что позволяет ему сделать вывод о внутренней связи этих двух традиций [7, S. 224-225]. Позже Мерк увидит этих деревянных идолов у чукотских пастухов, которые возят их с собой на кочевье. Он уточняет, что они сделаны из ветвей, имеющих форму ног, и приводит слова на чукотском языке, обозначающие различных идолов. На берегах реки Китой близ Иркутска Миллер и Гмелин совместно присутствовали при экстатическом ритуале местных жриц, бивших деревянными палочками в барабаны, издававших странные звуки, размахивавших металлическими предметами, украшавшими их кожаные платья, причудливо жестикулировавших, беря в руки горящие угли. В глазах немецких наблюдателей это была своего рода комедия, в отношении которой они проявили немалый скептицизм, но детали которой показались им все же занимательными [7, S. 256-257]. Также в окрестностях Иркутска Гмелин наблюдает за тем, как бурятские языческие жрецы заклинают восход солнца березовой ветвью, а 
затем, в соответствии с четко предписанным ритуалом, приносят в жертву овцу, которую после полагается съесть [7, S. 248-249]. У якутов овцу заменяет жертвоприношение теленка, которое также наблюдает Гмелин: «Он (жрец) собрал немного крови и нарисовал три бесформанных лица на стволе сосны - так, как обыкновенно рисуют лица дети: удлиненный овал, два круга, служащих для изображения глаз, длинная черта посередине, изображающая нос, и горизонтальная черта для рта. Затем либо шаман, либо сами якуты снимают с теленка кожу. Закончив это действо, они растягивают тушу на раме, помещенной на четыре опоры и отстоящей от поверхности земли на высоте одной руки. Тут же мясо измельчается, кости дробятся; кто-то сжимает желудок и внутренности заколотого теленка, чтобы извлечь из них немного сока» [7, S. 227].

Других шаманов Гмелин обнаруживает между Абаканом и Красноярском. Но и здесь он выказывает самый большой скептицизм. Власть шаманов кажется ему вполне объяснимой. И тем не менее интерес к деталям одежды, перегруженной металлическими украшениями, украшенной конской гривой и красными шерстяными пластинами, внимание к вопросу о том, как шаман передает свой дар и свою власть наследнику, интерес к характеру движений и прыжков, совершаемых в трансе, к испускаемым шаманами крикам и шумам, к степени участия в действе зрителей, - все это показывает, что Гмелин, даже если он не понимал и ставил под сомнение целесообразность подобных религиозных практик, все же признавал их важность для живущих в этих краях людей [7, S. 292-293]. Во всяком случае, как только он прибывал в какое-то место в Сибири, например в Красноярск, разговор с местными шаманами был для него приоритетным [7, S. 299].

Религия интересовала немецких исследователей потому, что она отвечала самому принципу организации человеческой жизни, даже если в ее основе не лежала метафизика и даже если она не имела свое Священное писание. Переход от теологии к религиозной антропологии характерен для того типа анализа, который осуждает суеверия, но выявляет одновременно новые возможные формы социальной организации.

Пространство природное и пространство иных религиозных практик, Сибирь для немецких путешественников и странствующих академиков являла собой особого рода лингвистическое пространство. Вопрос о языках не связывался в их сознании с потребностью евангелизации, как это было, 
например, в городе Галле (Халле), ставшем одним из древнейших европейских центров по изучению восточных языков. Но даже если этот фон и присутствовал, то все они были убеждены, что следует сначала изучить мир во всей его неоднозначности. Лингвистические же исследования просвещенных ученых, выходцев из немецких университетов, свидетельствуют скорее о попытках заново написать всемирную историю.

Каталогом языков поначалу считался «Митридат» Иоганна Кристофа Аделунга, первый языковой справочник, учитывавший максимальное количество языков. Однако со временем стало высказываться и недоверие к возможности использования в качестве объекта сравнения переводов на все возможные языки «Отче наш», и начался поиск словаря, который наряду с Богом включал бы в себя также и дьявола, и небо, и ад. Первым языком, с которым сталкивались немцы на русской службе, был русский язык. Для переговоров с различными представителями российской администрации в Сибири Миллер и Гмелин првоначально прибегают к переводчику. Илья Яхонтов, который поначалу помогал Миллеру в публикации его научных работ в Санкт-Петербургской Академии и даже сопровождал его в Сибирь [6, S. 299], проявлял особый интерес к лексическим соответствиям между русским и немецким языками. Когда в І739 г. Яхонтов умирает, Гмелин сочиняет род надгробной речи: «Мы полностью могли полагаться на этого человека во всех наших переводах... Покойного высоко ценили как его соотечественники, так и немцы. Все хорошо ладили с ним, и потому он прекрасно знал о деятельности каждого» [4, S. 274]. Гмелину и Миллеру предложили другого переводчика на замену, однако после смерти Яхонтова они начали уже сами изъясняться на русском языке, а Миллер к тому же начал работать в сибирских архивах.

Многочисленны были языки, которые немецкие ученые открывали для себя в Сибири, упоминания о них в самых разных контекстах пронизывают их путевые заметки. Гмелин, например, приводит слова, обозначающие растения, которые охотно употребляют в еду якуты. Мерк составляет список из 250 слов языка юкагиров или, скорее, одной из разновидностей этого языка, который исчезнет в конце XVIII в., так что словарь, составленный немецким путешественником, станет последним ему памятником [7, S. 98].

Элементы этого языка, заимствованные из списка, составленного Мерком, включены были в «Митридат» Аделунга. Внимание Мерка к язы- 
кам определялось вовсе не желанием установить их самобытность, подчеркнув существующие между ними различия. Напротив, его волновала возможность сближения языков, которое он рассматривал как свидетельство той общей истории, которую имели, казалось бы, совершенно различные между собой этнические группы; он стремился вскрыть их изначальное родство и также те заимствования, которые между ними имели место. Он интересовался различием, но также и сходством, открывавшимся между языком чукчей и языком кориаков, что влекло за собой внимательное изучение им этнических групп - дело, которое он начал одним из первых [7, S. 23].

Для проведения подобного рода лингвистических исследований все же требовалась помощь переводчика, способного установить связи между сибирскими и русским языками. Собирание лексем представляется делом все более амбициозным. В Красноярске Гмелин встретился с бурятами; он стремился понять не только их язык, но и их литературу (фольклор). «Поскольку у меня был рядом переводчик, знающий языки здешних народов, а также и бурятский язык, мне пришла в голову мысль попытаться узнать, как возникала также и музыка, и поэзия у этих народов, и насколько, своими пристрастиями, они отличаются от народов, нам более известныХ» [4, S. 304]. От теории Гмелин переходит к практике, воспроизводя, с подстрочным переводом, текст песен на одном из бурятских диалектов и на тюркском языке, на котором говорили в районе Абакана.

В данном случае мы имеем дело с первыми записями текстов на рассматриваемых языках. Сбор языковых данных идет параллельно с этномузыкологическим описанием, так как Гмелин записывает также и мелодии песен. Так первые путешественники уже предвосхищают то, что будет делать впоследствии первый профессиональный тюрколог Радлов, еще один российский немец, оказавшийся в России столетие спустя [4, S. 305-306]. Недавно опубликованный способом facsimile глоссарий Мерка, сохраненный Петром Симоном Палласом, а затем оказавшийся в документах Аделунга в Санкт-Петербурге, является важным вкладом в изучение семантики северо-восточных сибирских языков и, в частности, языков юкагиров, чукчей и кориаков. Каждый раз в синоптических таблицах представленными оказываются сразу несколько диалектов. Жена Мерка, которая сама была родом из Якутска, говорила на юкагирском языке, и потому своим знанием восточносибирских языков Мерк был обязан также и этим обсто- 
ятельствам сугубо биографического свойства [7, S. 38]. Взаимодействие Гмелина, Мерка, Палласа и Миллера в области лингвистических описаний, их способ работы, в основе которой лежала сходная методология, создает впечатление, что мы имеем дело с подлинной немецкой лабораторией по изучению Сибири.

Среди немецких исследований XVIII в., посвященных сибирским языкам, следует еще раз упомянуть о работе Стеллера, посвященной камчатским ительменам. И он также воспроизводит, вместе с нотной записью мелодии, которую исполняли на флейте, две песни, посвященные мифическому животному, утке Аангич. Благодаря этому мы имеем два текста на языке ительменов из двух разных регионов. Но Стеллер на этом не останавливается, ему еще важно указать тот контекст, в котором надо рассматривать его записи. Он наблюдал, например, за ритуальными обменами оскорблениями. Собака, лиса, лесной дьявол, падаль также фигурируют среди слов ительменского языка. Он пытается объяснить этимологию названия месяцев: «Январь они называют “сюсакоач”; “сюсак” значит “не тронь меня”, noli me tangere. Считается большим грехом пить в этот месяц воду из ключей или ручьев непосредственно ртом или при помощи полых стеблей растений, почему необходимо для этого держать при себе большие деревянные ложки или чашки. Настоящая причина тут, конечно, в том, что ительмены тогда отмораживают себе на сильном холоде губы. <..> Для марта у них есть название “адукоач” от слова “ада”, которым обозначается дымовое отверстие на верху юрты: в марте обычно снег около этого дымохода начинает оттаивать и показывается земля» [13, S. 360].

Изучение языковых особенностей уже предвещает антропологический подход. Стеллер составил словарь, включающий в себя нескольких сотен слов на корякском языке, на котором говорило население в регионе, расположенном между двумя селениями - Туманой и Акланом («Wörterbuch der üblichen Sprache der Korjaken, von Tumana bis Aklan»). Выбирая из различных не нормативных диалектов слова, Стеллер действовал как лингвист, работающий на малоисследованной территории, искусственно создавая при этом элементы нормативного, «классического» языка.

И здесь также отбор слов позволяет понять социальную структуру общества, не случайно для обозначения отца жены и отца мужа (на немецком языке - Schwiegervater) имеются различные обозначения. Человеческое 
тело, животные, растения, быт, время и его течение - все это имеет свое обозначение в словаре ительменов, Стеллер приводит также некоторые глагольные формы, в том числе и примеры спряжения глаголов. Лингвистика здесь явно оказывается на службе у антропологии. Уместно вспомнить, что Стеллер был современником Гердера, который в своем собрании народных песен рассматривал переводы иностранных песен как зеркало, в котором отражается дух народов, а в статье о происхождении языка демонстрировал сам процесс зарождения и формирования мысли.

Транскрибирование слов сибирских языков латинскими буквами, предшествовавшее их транскрипции кириллицей, когда в отношении монгольских языков игнорировался традиционный монгольский алфавит, уже само по себе является феноменом культурного переноса (трансфера), подготовленного лингвистическими изысканиями немецких путешественников эпохи Просвещения.

Религиозные практики не ограничиваются ритуалами, она включают в себя также легендарные рассказы, которые во многих отношениях также могут отражать социальную жизнь соответствующих групп. Стеллер, пожалуй, наиболее подробно исследовал космогоническую мифологию ительменов. Их главный Бог - создатель неба и земли, зовется Кутх. Но они считают его большим глупцом и «именно потому недостойным поклонения» [I3, S. 253]. Если бы он был умен, он не создал бы такого сложного рельефа Камчатки. Однако Кутх взял себе в жены женщину большого ума, которая исправляла совершаемые им ошибки. У них были дети, которые и стали дальними предками ительменов.

В космогонической вселенной ительменов все зависит от людей. Мир вечен, и люди оживут в плоти своей. Вместо откровения священных писаний у ительменов мы имеем свидетельство самого первого ительмена, вернувшегося из подземного мира: «Есть в подземном мире, куда мы все переносимся с нашими душой и телом после смерти, великий и могущественный ительмен по имени Хаэч; это один из первых детей Кутха и первый человек, умерший на Камчатке»; «Он долго проживал в полном одиночестве в подземном мире, пока не умерли также обе оставшиеся после него дочери и не ожили снова у него. Тогда Хаэч решил вернуться в верхний, надземный мир и подробно сообщить своим братьям о том, что происходит в преисподней с человеком после его смерти» [I3, S. 27I]. «Величайшим и лучшим счасть- 
ем, какое только может выпасть на долю человека после его смерти, это, по мнению ительменов, когда его пожирают прекрасные собаки, ибо это гарантирует ему владение ими в подземном мире». «Не желающие принять крещение старики-ительмены возражают против него указанием на то, что в таком случае им придется, наверное, попасть на небо, что звучит, конечно, очень самонадеянно и весьма высокомерно. Они говорят, что охотнее удалятся под поверхность земли» и предпочитают отправиться к своим предкам [I3, S. 27I].

Стеллер пытается реконструировать весь комплекс мифов, объясняющих миросозерцание народа, определяющих особенности их повседневной жизни. В методологическом отношении он относится к тем исследователям, которые наиболее корректно и научно анализируют мифологические верования встреченных им популяций. Но он был не единственным. Гмелин также описывал мифы, связывая их с народной жизнью. В Сибири находят кости уже вымерших на земле животных, сохранившиеся в виде окаменелостей. В частности, речь идет о роге нарвала, которому Гмелин сразу же дает мифологическое объяснение: «Возможно, это был рог единорога, о котором неоднократно говорило и Священное Писание, приписывая ему удивительную силу, недаром Моисей говорит о Боге, силы которого равны силе единорога» [4, S. 267]. Объясняя кочевье якутов, Гмелин ссылается на древнюю якутскую легенду, согласно которой их предки пришли с верховьев Лены, откуда их выгнали буряты, после чего они со своим скотом привязали себя к плотам и плыли таким образом по воде, потом же поселились около Якутска. Так мифы и рассказы служат объяснением происхождения и судьбы народов.

Путешественники и исследователи XVIII в. не слишком интересовались наиболее характерной формой легендарных историй, связанных со знаменитыми эпопеями тюркских народов. Но и их открытие впоследствии было обязано немецкому присутствию в Сибири, поскольку именно немец Радлов собрал и издал сибирский эпос, став, как уже упоминалось выше, одним из основателей тюркологии. Радлов, который учился в Йене, применил методы немецкой филологии и гердеровский опыт издания народных песен к сибирскому материалу. Его труд, посвященный якутскому языку, демонстрирует тесную связь между лингвистикой и антропологией, существующую в немецком подходе к изучению жизни сибирских народов. При 
этом подход самого Радлова оказывается шире и радикальнее, чем у немцев, исследовавших Сибирь в XVIII в. ${ }^{3}$

Продолжая тему, вспомним в этой связи о германисте Викторе Жирмунском, бывшем к тому же еще и биографом Гердера. Прекрасный знаток средневекового германского эпоса, Жирмунский, возможно, был особенно предрасположен к изучению эпоса Центральной Азии и Сибири в период своего вынужденного пребывания в Ташкенте во время Второй мировой войны, связав эту устную поэзию с гомеровской традицией. В особенности его интересовал киргизский след, обнаруживаемый в тюркском эпосе. И все же можно усмотреть преемственность, существующую между немецкими исследованиями Сибири в XVIII в. и антропологическим компаративизмом и сравнительным литературоведением, представителем которых был Жирмунский. Об этой преемственности уже писал, в частности, Марк Азадовский в свой истории русской фольклористики [I].

М.К. Азадовский сам был родом из Иркутска, работал там в 1923I930 гг., заведуя кафедрой русской литературы, издавал этнографический журнал «Сибирская живая старина» и занимался в особенности изучением сибирской библиографии, придерживаясь мнения о том, что изучение русского фольклора есть дело одновременно литературоведа и этнографа. Для Азадовского, который охотно ссылался в этом смысле на опыт декабристов, фольклорные исследования не должны были ограничиваться чистым собирательством, которое практиковалось в немецкой традиции, но проливать свет на те формы жизни, которые отражает фольклор в его постоянной эволюции. Эту идею исторического процесса в действии Азадовский находит уже у Гердера, но в особенности она оказывается дорога русским авторам, связанным с декабристским движением.

И все же интеллектуальный инструментарий, который позволяет Азадовскому динамически осмыслить само понятие «народности», оказывается родственен тому, что утверждалось в немецкой гуманитарной науке XIX в. начиная с Гердера, Бенфея и затем у Штейнталя и Лазаруса. Способность фольклора свидетельствовать о движении истории оказывается центральной в его исследованиях. Поэтическое сознание, показывает он,

3 В своем журнале, который он вел в Сибири [го], Радлов детально описывает, как происходило изучение Телецкого озера и его окрестностей. До него балтийский немец, геолог Грегор фон Хельмерсен, уже описал этот регион [5]. 
развивается параллельно эволюции общественного сознания, которое оно и выражает. Благодаря Азадовскому, к которому апеллирует Жирмунский, сам будучи наследником исторической поэтики Веселовского, сибирский фольклор оказался осмыслен как важный составляющий элемент культурной и литературной идентичности России.

Антропологические исследования немецких ученых, сосредоточенные на религиозных и языковых аспектах жизни сибирских народов, затрагивали вместе с тем различные аспекты также и материальной и социальной жизни. Сближаясь нередко с жанром путевых заметок, они воссоздавали сложную картину жизни народностей и сообществ в их взаимодействии с соседними сообществами. Для нас же важен даже не столько детальный анализ социальных практик, различных у разных этнических групп, сколько трезвый подход немецких ученых, изучающих встречающиеся им этносы как естественно связанные между собой и в которых не следует видеть нечто по определению низшее по сравнению с высоким миром немецкой университетской профессуры. Открытие Сибири приводило тем самым к новому пониманию мира.

Антропология как наука утверждается в эпоху Просвещения усилиями немецких ученых, отправлявшихся в странствия по Сибири. Последнее заставляет нас задуматься об интеллектуальных предпосылках этого явления, о системе преподавания в немецких университетах эпохи Просвещения, об интеллектуальном климате, на который существенное влияние оказал, среди прочего, Гердер, т. е. на все то, что определяло деятельность участников сибирских экспедиций. Некоторые университеты, такие как Гёттинген, где развивалась идея всемирной истории, объединяющей многообразие народов мира, оказались в особенности вписанными в «приключение» русского Востока. Немцы, описывавшие Сибирь, состояли не только на службе у Российского государства, которое вынуждало их хранить в тайне добытые в ходе экспедиций результаты, но, метафорически выражаясь, также и на службе историографии, подпитывавшей их проект. Речь шла об открытии исторического фундамента Империи, об этногенезе, способном интегрировать необъятное и мало дотоле известное пространство Сибири. В то время как в России, по меньшей степени с Петровских времен, доминировало западничество, немецкое открытие сибирских корней России оказалось вписанным в иную перспективу - русской культуры, сохраняющей древние отношения с восточными культурами. 
Вспомним в этой связи труды историка Льва Гумилева, посвященные степным народам, вспомним в более общем плане и о традициях русского евразийства. И в этом контексте можно утверждать, что вопросы о заселении Америки пришедшими из Сибири народностями, об особом видении мира, сформированном под влиянием шаманизма, о взаимоотношениях России с Китаем и Монголией занимали немецких ученых уже в XVIII в. И наследие это ощутимо еще и в веке двадцатом.

Перевод Екатерины Дмитриевой

\section{Список литературы}

I Азадовский М.К. История русской фольклористики: в 2 т. М.: РГГУ, 2013. 978 с.

2 Dahlmann D. Sibirien vom I6. Jahrhundert bis zur Gegenwart. Paderborn: Schöningh, 2009. $435 \mathrm{~S}$.

3 Forsyth J. A history of the peoples of Siberia. Russia'sNorth Asian Colony, Cambridge: Cambridge University Press, I992. 455 p.

4 Gmelin J.G. Expedition ins unbekannte Sibirien. Sigmaringen: Thorbecke, I999. 454 S.

5 Helmersen G. von. Reise nach dem Altai. Sankt Petersburg: Akademie der Wissenschaften, I848. 287 S.

6 Hoffmann P. Gerhard Friedrich Müller (I705-I783). Frankfurt am Main: Peter Lang, 2005. $393 \mathrm{~S}$.

7 Merck C.H. Das sibirisch-amerikanische Tagebuch aus den Jahren I788-I79I. Göttingen: Wallstein, 2009. 4I3 S.

8 Merck C.H. «Beschreibung der Tschuktschi, von ihren Gebräuchen und Lebensart» sowie weitere Berichte und Materialien. Göttingen: Wallstein, 20I4. $552 \mathrm{~S}$.

9 Pallas P.S. Reise durch verschiedene Provinzen des russischen Reiches. Zweyter Theil. Sankt Petersburg: Kayserliche Akademie der Wissenschaften, I773. 744 S.

Io Radloff W. Aus Sibirien-Lose Blätter aus meinem Tagebuche. Leipzig: Weigel Nachfolger, I893. $536 \mathrm{~S}$.

II Tchinag G. Mein Altai. München: Al Verlag, 2006.

I2 Vermeulen H. Before Boas: The Genesis of Ethnography and Ethnology in the German Enlightenment. Lincoln: University of Nebraska Press, 2015. 7I8 p.

I3 Steller G.W. Beschreibung von dem Lande Kamtschatka. Frankfurt; Leipzig: Johann Georg Fleischer, I774. 384 S. 


\section{References}

I Azadovskij M.K. Istorija russkojfolkloristiki: $v 2 t$. [The History of Russian Folklore Studies: in 2 vols.]. Moscow, RGGU Publ., 2013. 978 p. (In Russ.)

2 Dahlmann D. Sibirien vom I6. Jahrhundert bis zur Gegenwart. Paderborn, Schöningh, 2009. 435 S. (In German)

3 Forsyth J. A history of the peoples of Siberia. Russia's North Asian Colony. Cambridge, Cambridge University Press, I992. 455 p. (In English)

4 Gmelin J.G. Expedition ins unbekannte Sibirien. Sigmaringen, Thorbecke, 1999. 454 S. (In German)

5 Helmersen G. von. Reise nach dem Altai. St. Petersburg, Akademie der Wissenschaften, I848. 287 S. (In German)

6 Hoffmann P. Gerhard Friedrich Müller (I705-I783). Frankfurt am Main, Peter Lang, 2005. 393 S. (In German)

7 Merck C.H. Das sibirisch-amerikanische Tagebuch aus den Jahren I788-I79I. Göttingen, Wallstein, 2009. 4I3 S. (In German)

8 Merck C.H. "Beschreibung der Tschuktschi, von ihren Gebräuchen und Lebensart" sowie weitere Berichte und Materialien. Göttingen, Wallstein, 20I4. 552 S. (In German)

$9 \quad$ Pallas P.S. Reise durch verschiedene Provinzen des russischen Reiches. Zweyter Theil. St. Petersburg, Kayserliche Akademie der Wissenschaften, I773. 744 S. (In German) Radloff W. Aus Sibirien-Lose Blätter aus meinem Tagebuche. Leipzig, Weigel Nachfolger, I893. 536 S. (In German)

II Tchinag G. Mein Altai. München, Al Verlag, 2006. (In German)

I2 Vermeulen H. Before Boas: The Genesis of Ethnography and Ethnology in the German Enlightenment. Lincoln, University of Nebraska Press, 20I5. 7I8 S. (In German)

I3 Steller G.W. Beschreibung von dem Lande Kamtschatka. Frankfurt; Leipzig, Johann Georg Fleischer, I774. 384 S. (In German) 
УДК 82-9I

ББК

$82.3(2 \mathrm{Poc}=\mathrm{Pyc})+$

$83.3(2 \mathrm{Poc}=\mathrm{Pyc})$
ПЕТРУШКА В ДЕТСКОМ ТЕАТРЕ ПЕРВОГО ПОСЛЕРЕВОЛЮЦИОННОГО ДЕСЯТИЛЕТИЯ (ДВЕ ПЬЕСЫ С.Я. МАРШАКА)

\author{
(C) 2018 г. С.П. Сорокина \\ Институт мировой литературы \\ им. А.М. Горького Российской академии наук, \\ Москва, Россия \\ Дата поступления статьи: І5 января 2018 г. \\ Дата публикации: 25 сентября 2018 г.
}

DOI: IO.22455/2500-4247-20I8-3-3-254-277

Аннотация: В июле 1920 г. в Екатеринодаре (Краснодаре) по предложению Маршака и при его участии был открыт профессиональный театр для детей. При выработке своих драматургических принципов Маршак ориентировался на детские игры с их импровизационностью, условностью, коллективностью творчества. На этих же принципах основан театр Петрушки, вследствие чего обращение Маршака к нему вполне закономерно. Своего «Петрушку» (I92I) Маршак создал после общения с петрушечником И.А. Зайцевым. Сочиняя пьесу, Маршак стремился заложить в нее характерные для фольклорного театра импровизационное начало, принцип преодоления барьера между сценой и зрительным залом. Маршаку удалось органично соединить формулы и сюжетные ходы фольклорного театра с личным творчеством. Следующая пьеса - «Петрушка-иностранец» (1927) - по построению и сюжету дальше отстоит от фольклорной. Маршак теперь строит сюжет по типу цепевидной сказки, заменяет традиционные персонажи отражающими современные реалии действующими лицами. Петрушка, хотя и сохраняет сходство с фольклорным праобразом, в то же время сильно изменяется, превращаясь из условного персонажа неопределенного возраста, социального положения в мальчишку-озорника. Вербальная структура пьесы меньше опирается на собственно фольклорные речевые приемы. Два «Петрушки» Маршака отразили наиболее характерные тенденции обращения к этому фольклорному явлению в детском искусстве в их развитии от первых послереволюционных лет и до конца г920-х гг.

Ключевые слова: фольклорный театр, Петрушка, детский театр, Маршак, детская литература.

Информация об авторе: Светлана Павловна Сорокина - кандидат филологических наук, старший научный сотрудник, Институт мировой литературы им. А.М. Горького Российской академии наук, ул. Поварская, д. 25 а, І2Іо69 г. Москва, Россия.

E-mail: sorokinasp@mail.ru

Для цитирования: Сорокина С.П. Петрушка в детском театре первого послереволюционного десятилетия (две пьесы С.Я. Маршака) // Studia Litterarum. 20I8. T. 3, № 3. C. 254-277. DOI: I0.22455/2500-4247-2018-3-3-254-277 


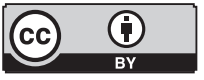

This is an open access article distributed under the Creative Commons Attribution 4.0 International (CC BY 4.0)
PETRUSHKA IN THE THEATRE FOR CHILDREN IN THE FIRST TEN YEARS AFTER THE OCTOBER REVOLUTION (TWO PLAYS BY S.I. MARSHAK)

(C) 20I8. S.P. Sorokina

A.M. Gorky Institute of World Literature of the Russian Academy of Sciences, Moscow, Russia Received: January I5, 2018

Date of publication: September 25, 2018

Abstract: Samuil Marshak came to Ekaterinodar in I9I8 and became the leader of the Department for children's orphanages and colonies in I920. In July I920, he assisted and promoted the foundation of the professional theatre for children. He favored children's improvisation, use of theatrical conventionality, and group work. The same principles were at the basis of the Petrushka theatre; therefore, Marshak's turn to folklore theatre was a natural outcome of his previous work. Marshak wrote his first play Petrushka in I92I upon meeting a popular folklore artist I. Zaitsev. In his play, Marshak attempted to make an emphasis on improvisation that was typical for folklore theatre, for example, encouraging performers to cross a boundary between the stage and the audience. These principles persevered in the staging of the play. Marshak thus naturally combined formulas and plot elements of folklore theatre with those of his own art. He was among those writers who tried to adapt Petrushka theatre for children. The plot and structure of the next play - Petrushka the Foreigner (1927) - were not as dependent on the folklore play as the previous one. Marshak builds the plot as a chain of events, gets rid of traditional folklore characters (except Petrushka), and substitutes the latter with contemporary characters that reflected new social reality. Petrushka as a character also undergoes changes. He is no longer a conventional character without social background and age but a mischievous little boy and urchin. Verbal structure of this play no longer bears on the verbal structure of the folklore play as before. Thus, the essay concludes that Marshak "Petrushka" plays illustrated the main trends of the folklore adaptation for children during the first ten years after the October revolution.

Keywords: folklore theatre, Petrushka, theatre for children, Marshak, children's literature.

Information about the author: Svetlana P. Sorokina, PhD in Philology, Senior Researcher, A.M. Gorky Institute of World Literature of the Russian Academy of Sciences, Povarskaya 25 a, I21069 Moscow, Russia.

E-mail: sorokinasp@mail.ru

For citation: Sorokina S.P. Petrushka in the Theatre for Children in the First Ten Years After the October Revolution (Two Plays by S.I. Marshak). Studia Litterarum, 20I8, vol. 3, no 3, pp. 254-277. (In Russ.) DOI: IO.22455/2500-4247-20I8-3-3-254-277 
25 октября І92I г. на сцене тетра для детей в Краснодаре ${ }^{\mathrm{I}}$ состоялась премьера спектакля по пьесе С.Я. Маршака «Петрушка». Эта пьеса в ряду других, написанных Маршаком для Краснодарского театра, имела немаловажное значение как в личной творческой биографии Самуила Яковлевича, так и в «биографии» советского детского театра. С другой стороны, она - знаменательный факт в «биографии» народного театра Петрушки раннего советского периода.

Что касается творческой судьбы Самуила Яковлевича, то детский писатель Маршак родился именно в Краснодарском театре для детей. К г920 г., когда начинается «детская» история Маршака, он был уже довольно известным литератором, переводчиком произведений английских поэтов, прежде всего Вильяма Блейка. В некоторой степени обращение Маршака к работе для детей было случайностью, обусловленной теми жизненными обстоятельствами, в которые он был поставлен в бурные революционные годы, перевернувшие многие жизни. Летом I9I7 г. семья Маршака переехала из Петрограда в Екатеринодар (после установления советской власти - Краснодар), где отец писателя Яков Миронович получил работу на заводе [8, c. 446]. Как уточняет биограф Маршака М.М. Гейзер, «в Петрограде было голодно, а Кубань давала какие-то надежды, хотя бы на хлеб насущный» [6, с. І28]. Сам Самуил Яковлевич присоединился к семье несколько позже - в I9I8 г. [6, с. І36]. Власть на юге охваченной Гражданской войной страны была в этот период в руках белогвардейцев. Маршак, зарабатывавший на жизнь литературным трудом, становится сотрудником «белой»

I $\quad$ О предыстории этого театра и его возникновении см.: [I7, c. 33-34]. 
газеты «Утро Юга», где пишет стихотворные фельетоны под псевдонимом, который использовал, публикуясь ранее в санкт-петербургских периодических изданиях, - д-р Фрикен [І2; 6, с. І37; 5]. По поводу политических взглядов Маршака в разное время высказывались разные соображения. В советский период о сотрудничестве классика советской детской литературы в белогвардейской прессе в основном умалчивалось. В последние годы палитра рассуждений об этой мало документированной странице жизни писателя стала более пестрой: высказываются мнения как о вынужденной работе Маршака в «Утре Юга» [6, с. І37; 7, с. III], так и о его симпатиях к Белой гвардии и Деникину [5]. Скорее всего, политические взгляды Маршака были не очень определенными. Он явно не был большим приверженцем старой власти, монархистом. Слишком болезненным для мальчика, а затем юноши и молодого человека из еврейской семьи был опыт жизни в царской России (см. письма Маршака к разным лицам этого периода [9, т. 8]). Кроме того, круг представителей интеллигенции, поддержавших начинающего литератора в пору его творческого становления, был демократический: В.В. Стасов, А.М. Горький и др. По-видимому, в первые послереволюционные годы для Маршака, как и для многих других россиян, вопрос о том, как выжить, стоял острее, чем задача политического самоопределения. Естественно, не потерял этот вопрос своей остроты и в марте г920 г., когда Екатеринодар был занят частями Красной Армии: нужно было чем-то заниматься и, возможно, желательно для Маршака было отойти от «взрослой» журналистской работы. Сын писателя следующим образом излагает историю приобщения Самуила Яковлевича к работе с детьми: «Оказалось, что за него (Маршака. - С.С.) поручилась та самая молодая подпольщица-большевичка Дора, которую отец укрывал при белых, когда она заболела тифом. И не только поручилась, но, насколько я могу судить по смутным воспоминаниям о рассказах отца, она именно познакомила его с бывшим начальником политотдела освободившей Краснодар Девятой армии <..> Михаилом Александровичем Алексинским, который вскоре возглавил Кубано-Черноморский отдел народного образования. И отец сразу начал работать в этом отделе. Он собирал бездомных и голодных ребят на улицах города, участвовал в создании первых детских домов и колоний, организации первой продовольственной помощи детям. А следом за тем встала задача их воспитания и образования» [8, с. 453]. Итак, 2 апреля I920 г. Маршак 
был назначен заведующим секцией детских приютов и колоний Областного отдела народного образования [8, с. 453].

Еще в I9I8 г. в Екатеринодаре Маршак познакомился и подружился с Елизаветой Ивановной Дмитриевой [6, с. І39], входившей в петербургский период своей жизни в круг символистов и печатавшей стихи под псевдонимом Черубина де Габриак [8, с. 454-456]. Вместе с ней Маршак организовал драматическую студию в клубе Красной Армии, и к I мая І920 г. в ней был поставлен спектакль для детей по сказке О. Уайльда «Молодой король», инсценированной Дмитриевой [8, с. 453; 6, с. І40] (пьесы для детей она стала писать под псевдонимом Е. Васильева). Эта постановка оказалась не одноразовой затеей. I7 июня І920 г. Маршак выступил на заседании коллегии Областного отдела народного образования с предложением создать профессиональный театр для детей (к этому моменту уже шли репетиции нового спектакля - «Летающий сундук» по сказке Г.-Х. Андерсена в инсценировке Е. Васильевой и С. Маршака), и I8 июля I920 г. премьерой этого спектакля детский театр начал свое существование 2 [8, с. 46I-462]. Так, почти случайно, Маршак стал создателем одного из первых в России детских театров.

Однако эта «случайность» в значительной степени была подготовлена некоторыми предшествующими событиями жизни Маршака. По словам Самуила Яковлевича, впервые с «детским театром» он столкнулся еще в пору своего пребывания в Англии (1912-I9I4), куда отправился учиться. Там ему в руки попала брошюра, рассказывающая о «Школе простой жизни», организованной Филиппом Ойлером. Идеи, лежащие в основе этого учебно-воспитательного заведения, привлекли молодого человека: «Читателю ее (брошюры. - С.С.) рисовалась идеальная семья воспитателей и воспитанников, объединенных идиллической любовью и бескорыстной дружбой, добывающих все необходимое для жизни трудами собственных рук и отделенных от всего остального мира непроходимыми лесными чащами. <...> Упрощение жизненной обстановки, один из главных принципов школы, распространяется не только на подробности домашнего быта, но и на учебные предметы, и на программу детского чтения. С течением времени перед детьми должна раскрыться самая захватывающая из книг: книга

2 Л. Шпет называет первым спектаклем «Кошкин дом» по пьесе С.Я. Маршака, не указывая источника этой информации [17, с. 33]. 
природы. Главной целью подобного “опрощения” было: укрепление духа и тела, приспособление к самым трудным обстоятельствам жизни, а также экономия времени и сил - тех сил, которые обыкновенно тратятся нами на удовлетворение наших - далеко не насущных - потребностей, а могли бы быть потрачены на служение и помощь ближнему» [9, т. 6, с. 464]3.

Маршак неоднократно посещал школу, и она не обманула его ожидания. В ней ему и «случилось наблюдать свободную детскую игру, представляющую собою уже не зачатки драматического искусства, а вполне развитое сценическое действие» $[9 \text {, т. 6, с. I84 }]^{4}$. Среди книг, которые наставники читали своим воспитанникам, особенно полюбились ребятам рассказывающие о рыцарях Круглого стола. Они распределили между собой «имена важнейших рыцарей» и стали играть в них. В статье, написанной на второй год существования Краснодарского театра для детей, Маршак довольно подробно описывает эту игру как важный опыт, давший толчок его собственным размышлениям о роли театра в жизни малышей и подростков и о том, каким должен быть театр для них: «Распределение ролей было как нельзя более удачно. Роль сэра Ланселота, великодушного, безупречного и скромного рыцаря, была дана мальчику, превосходившему всех других товарищей прямотой, честностью и выдержкой характера. Другому мальчику, пылкому и отважному, было присвоено имя рыцаря Тристана и т. д. Как в мистериях, происходящих в Обераммергау, роли эти были постоянными и могли передаваться другим мальчикам только в случае недостойного поведения носителя славного имени. Я наблюдал эту игру в течение целого лета. Она неизменно происходила на лесной поляне. Вначале игра была совершенно произвольной и несогласованной. По мере ее развития вырабатывались постоянные формы, устанавливались характеры, вводились костюмы (панцири, шлемы и т. п.), случайные слова заменялись постоянными репликами, определялся общий режиссерский план - игра естественно и незаметно переходила в театральное представление» [9, т. 6, с. I84].

В той же статье Маршак рассказывает еще об одном подобном опыте, свидетелем которого он стал в 1918 г. в детской колонии на берегу Онеж-

3 Маршак С.Я. Школа простой жизни. Полный текст статьи см.: [9, т. 6, с. 464-467], впервые опубликовано под псевдонимом «д-р Фрикен»: Биржевые ведомости. 1913. 2 авг.

4 Маршак С.Я. Театр для детей. Полный текст статьи см.: [9, т. 6, с. 183-188], впервые опубликовано: Просвещение. Краснодар, г922. № 3-4 (7-8), январь-март. 
ского озера5: «Среди воспитанников колонии был юноша пятнадцати лет, испытавший, несмотря на свой возраст, много превратностей судьбы. Чуть ли не с двенадцати лет он работал на дальнем Севере при постройке дороги, заболел цингой, попал в колонию <...> Рассказами о своей жизни <...> он до того увлек детей, что они решили изобразить “Жизнь Никифора” (так называлась импровизированная пьеса) в лицах. На небольшой площадке во дворе колонии были условно обозначены деревня, где родился Никифор, рядом с ней железная дорога, тут же завод и т. д. Никифор играл роль своего отца, а роль Никифора играл другой мальчик. Деревенские сцены были изображены с большим реализмом: полати, на которых спали отец с матерью (роль матери играл мальчик), полевые работы, брань между родителями Никифора, избиение сына, его бегство и т. д. Так же реалистично были изображены и железная дорога и фабрика» [9, т. 6, с. г85].

Разные «зрители» этих самостийных детских опытов драматического творчества сделали бы разные заключения о том, в чем их суть и каким должен быть театр для детей. Вполне вероятно, что для кого-то они стали бы свидетельством в пользу реалистического и даже натуралистического сценического искусства. Маршака они привели к совсем другим выводам, сформулированным в той же статье. Во-первых, с его точки зрения, театр для детей должен оставлять место импровизации: «Детям доступно высшее искусство - импровизация 6 . Не заменяйте ее там, где не надо, нарочитостью и скучной подготовкой» [9, т. 6, с. I84]. Во-вторых, это должен быть театр, оставляющий простор фантазии: «Характер постановок в театре для детей должен определяться одним принципом: поменьше связывать фантазию зрителя реалистическими подробностями. Ребенок больше любит палку, изображающую лошадь, чем искусно сделанную игрушечную лошадь; смутное подобие паровоза, состоящее из куска дерева и гвоздя в виде трубы, он часто предпочитает модели паровоза. Он ищет работы для своей фантазии и отказывается от тщательно разжеванной умственной пищи» [9, т. 6, с. I87]. Еще один принцип излагает Маршак (совместно с Е. Васильевой) в статье, помещенной в сборнике их пьес, написанных для Краснодарского театра

5 Летом I9I8 г. С.Я. Маршак приехал к своему старшему брату в Петрозаводск и стал работать инструктором дошкольного воспитания в Олонецком губернском отделе народного образования [8, с. 447].

6 Курсив Маршака. 
для детей [4]. По мнению авторов, задача детского театра - устранить непроницаемый барьер между сценой и зрителем, побудить юную публику к сотворчеству, преодолеть зрительскую пассивность: «Спектакль обычно является для ребенка только зрелищем; к творчеству же, как таковому, зритель не приобщен. Даже в том случае, когда действие находит отклик в его душе, - все же самый творческий процесс как бы остается за кулисами. Ребенок не знает того живого актера, который силой своего таланта преображается на сцене в то или иное действующее лицо. Декорации, грим - все это дается в готовом виде. Между тем, во всяком искусстве важнее всего именно творческий процесс» [9, т. 6, с. I7].

Очевидно, что выдвинутые Маршаком театральные принципы органичнее всего могли быть воплощены на сказочном материалер. Сказка и заняла основное место в репертуаре Краснодарского театра. Но уже существовал феномен, эмпирически основывавшийся на этих принципах, - народный театр и, в частности, хорошо знакомая жителям России XIX - начала XX вв. его разновидность - театр Петрушки. Он не мог не привлечь внимание Маршака ${ }^{8}$, работавшего над созданием детского театра.

Маршак был одним из первых, кто попытался перенести петрушечное представление на сцену профессионального театра для детей. Из известных, ярких и интересных попыток, осуществленных ранее Маршака, следует назвать опыт Н.Я. Симанович-Ефимовой и И.С. Ефимова дожники по образованию, они еще в I9I6 г. увлеклись театром Петрушки, начали устраивать кукольные представления, а в декабре I9I8 г. при поддержке Театрального отдела и Детской комиссии театрально-музыкальной секции Отдела просвещения Московского совета рабочих и крестьянских депутатов открыли театр кукол в Мамоновском переулке в Москве [ıг, с. 6]. В отличие от театра, созданного Маршаком, театр Ефимовых был только кукольным и, по преимуществу, в соответствии с народной традицией, пе-

7 См. помещенные в сборнике «Театр для детей» статьи сотрудников Краснодарского театра для детей и, в частности, статью С. Маршака и Е. Васильевой о театральных прологах [4, c. I7-I8]. Отметим также, что взгляды Маршака на театр для детей были в значительной степени типичны для первой половины І920-х гг. См.: [I7, с. 4-I09, II7-I20].

8 Хорошо известно, насколько глубоко Маршак знал фольклор разных стран и народов, чувствовал специфику речи его комических жанров. Таким образом, обращение писателя к театру Петрушки представляется более чем закономерным.

9 В этот же ряд следует включить опыты петроградцев Л.В. Шапориной-Яковлевой, Е.С. Деммени и др. Однако обзор данных опытов не входит в задачу настоящей статьи. 
редвижным [13, с. 64-78]. «Преемственность кукольного дела» [І3, с. І83] как явления фольклорного чрезвычайно важна. Симанович-Ефимова в своей книге подробно рассказывает о личном знакомстве с народными кукольниками начала XX в. [I3, с. I8I-I92]. Особое место отводит она петрушечнику И.А. Зайцеву [Із, с. I83-І88]. Любопытно, что и Маршак создал своего Петрушку под влиянием Зайцева. Об этом рассказала в воспоминаниях о писателе актриса и режиссер Краснодарского театра для детей А.В. Богданова: «В один, как говорится, из “счастливых дней” заведующий Детским Городком ${ }^{\text {Iо } Л . Р . ~ С в и р с к и и ̆ ~ п р и в е л ~ з н а к о м и т ь с я ~ с ~ С а м у и л о м ~ Я к о в л е в и ч е м ~}$ известного кукольника Ивана Афиногеновича Зайцева, который был проездом в Краснодаре. Этот фанатик народного кукольного театра с радостью открывал тайны своего любимого действа. Маршак, автор будущей пьесы для детей, и Орлов, будущий Петрушка, даже заперлись с Зайцевым, чтобы им никто не мешал познавать все тонкости этого искусства» [3, с. I36].

К моменту обращения Маршака к «Петрушке» в Краснодарском театре уже были поставлены пьесы «Сказка про козла», «Город Злосчастья», «Кошкин дом», «Волшебная палочка», «Финист - ясный сокол» [6, с. I42]. Часть этих пьес была создана им в соавторстве с Васильевой. «Петрушку» же (а также «Сказку про козла» и «Кошкин дом»), как позже в письмах к Л.А. Кононенко и С.Б. Рассадину указал Маршак, написал он сам [9, т. 2, c. 584]. Роль Петрушки в спектакле исполнял Дмитрий Николаевич Орлов. Актеры Д.Н. Орлов и его жена А.В. Богданова приехали в Краснодар в І920 г. из Харькова, где играли в труппе Синельникова, и поступили в Краснодарский театр им. А.В. Луначарского. Но вскоре стали сотрудничать также с детским театром, созданным Маршаком ${ }^{\text {II }}$, а через некоторое время покинули взрослую сцену. Орлов стал ведущим актером в театре для детей. Вспоминая о нем, Маршак писал: «В его игре не было и тени упрощения, небрежности или снисходительности, которыми так часто грешат “взрослые” актеры, участвующие в детских утренниках. В сущности, нашему театру для детей повезло. Ему нужен был именно такой исполнитель сказочных ролей, как Орлов, - то есть комедийный, подлинно народный актер, не отгоро-

Iо С.Я. Маршак не остановился на создании детского театра и организовал «вокруг него» детский городок - нечто вроде современных культурных центров для детей, где ребята могли заниматься в различных кружках по интересам.

II В 1922 г. Д.Н. Орлов и А.В. Богданова переехали из Краснодара в Москву, где играли в театре В.Э. Мейерхольда. 
женный рампой от зрителей, для которых игра - родная стихия, а фантазия - реальность» $[9, \text { т. } 7 \text {, с. 268 }]^{\mathrm{I2}}$.

О характере исполнения Орловым роли Петрушки и о самом «облике» спектакля сведений сохранилось не очень много. Известно, что музыку к пьесе, имитирующую звуки шарманки, написал В.А. Золотарев: «Хрипит-сипит простуженная под дождями и ветрами шарманка. Что-то в ней заедает - повторяется один и тот же звук. А потом, пересилив хрипоту, она начинает играть грустную песню. За сценой дирижирует оркестром автор - композитор В.А. Золотарев. Музыка похожа до мелочей на старую шарманку» [3, с. I37]. Декорации создали С.В. Воинов и Я.Г. Гарбуз [4, с. І2]. Сын Маршака вспоминает свои детские впечатления от спектакля: «Помню Дмитрия Николаевича Орлова - Петрушку, перекинувшего ногу через поставленную посреди сцены пестро раскрашенную ширму и весело заливающегося высоким, гортанным раешником» [8, с. 45I]. Он же в воспоминаниях об отце цитирует письмо, написанное в г96о г. Самуилу Яковлевичу Богдановой, которая говорит о Петрушке-Орлове: «А кто помогал убедить Д.Н. Орлова, что он “Петрушка”, с необычным голосом, носом, вылезающий из-за ширмы?» [8, с. 480]. Именно Богданова в уже упоминавшихся воспоминаниях наиболее подробно рассказала о замысле спектакля и его реализации. После знакомства с Зайцевым Маршак загорелся идеей создания своего «Петрушки»: «Дело закипело. На вечерних встречах Маршак писал, переделывал куски “Петрушки”. Тут же они на пробу исполнялись актером, и тут же находились решения этой постановки» [3, с. г36]. Как видим, сам подход к сочинению пьесы в данном случае был сродни импровизационной стихии народного театра, для которого текст ничего не значит в отрыве от сценического действия, от самого процесса исполнения спектакля. Маршак так же старается согласовать текст с непосредственным произнесением актером, не относясь к литературной основе как к неизменной данности.

Идея импровизационности, преодоления барьера между сценой и зрительным залом была положена и в основу постановки пьесы. Организацию действия достаточно полно охарактеризовала Богданова: «Издалека доносятся крики: “Петрушка, Петрушка!” Самуил Яковлевич, сидящий среди детей, встает и приглашает детей пойти посмотреть, что там такое. Навстречу 
в зал входят шарманщик, человек с ширмой и несколько ребят. И среди них рыжий мальчишка с улицы - это была моя роль. Мне надо было играть в дальнейшем как бы “вожака” зрителей. К моему удовольствию, дети, конечно, узнают знакомую им актрису и вступают с ней в дружбу. Шарманщик обращается к Самуилу Яковлевичу и просит разрешить ему показать Петрушку на сцене нашего театра. Самуил Яковлевич поручает рыжему мальчишке проводить шарманщика на сцену. Я это делаю, захватив с собой несколько ребят, и при этом шепчу им: давайте попросим рабочего - пусть он позволит нам устанавливать с ним декорации. Ребята оживляются и уже чувствуют себя как бы включенными в игру - ждут, чтобы “дяденька” разрешил. Разрешение, конечно, дается сейчас же, и мы - несколько человек (по моему приглашению) устанавливаем, верней, помогаем рабочему по его указанию устанавливать декорации. Все идет так, как хотелось: легко, естественно. Окончив работу, мы сбегаем со сцены и садимся среди зрителей. <...> Раздвигается занавес. В публике движение. На ширме появляется Петрушка Орлов. <...> На приветствие детям: “Здравствуйте, здравствуйте!” - ребята отвечают радостно: “Здравствуй!” - и аплодируют. Мы готовы к тому, что Петрушка потянет детей поближе - к ширме. Самуил Яковлевич - главный “ответственный” за этот момент - чувствует, что минута настала, что вот-вот дети поднимутся и побегут к ширме и этим сорвут ход действия. И тогда он встает и делает, привлекая к себе внимание, озорной жест - дескать, пойдем поближе, но тихо и молча. В других рядах повторяют это педагоги. Самуил Яковлевич идет на цыпочках, за ним тихо - ребята, предупрежденные С.Я., чтобы они слушали, что говорит Петрушка. Дети, затаив дыхание двигаются, не спуская глаз с Петрушки, слушают... И вот уже перед ширмой - как на площади - стоят в куче» [3, с. І36-г38]. Таким образом, писатель побуждал юных зрителей становиться соучастниками представления: отвечать на реплики Петрушки, двигаться по зрительному залу, входить на сцену, группироваться перед ширмой, как это делала публика во время игры народных петрушечников. В то же время ему необходимо было управлять реакцией зала, заставлять ребят более внимательно слушать текст. Принцип «не любо - не слушай, а врать не мешай», вполне пригодный для фольклорного театра, все же не мог быть приемлемым для профессионального театра для детей.

Написанная Маршаком пьеса «Петрушка», насколько можно судить по рассказу Богдановой, им самим в значительной степени в ходе представ- 
ления видоизменялась; текст оказывался лишь канвой для речевых импровизаций автора и Орлова-Петрушки: «Петрушка в восторге от близкого соседства с публикой. Он, что ни фраза, - в публику глаз, ища поддержки у ребят. На каждую фразу - хохот. Петрушка вовлекает ребят в общую игру. Сначала отзываются очень скромно и тихо педагоги, поощряя этим и детей к действию. Слышны ребячьи реплики. Петрушка ликует, отвечает мимикой. Вызывает их на активный разговор. И в зависимости от их реплик меняется и Петрушкина интонация и весь его внешний облик. Кто-то из ребят поддерживает вранье - Петрушка еще больше разгорается, азартнее пересказывая свои небылицы. Несмолкаемый хохот стоит в зале. Когда Петрушке уже нет возможности играть, он начинает вместе со всеми заразительно смеяться. Потом мгновенно, протягивая вперед руку, останавливается. В зале воцаряется тишина. Он принимается с новой силой варьировать свои выдумки. Вот тогда происходит самое захватывающее и для детей и для нас, взрослых. В разговор с Петрушкой вступает Самуил Яковлевич. Трудно сказать, что тут происходит. Дети замерли, не спуская глаз со своих любимцев - автора и актера. И, как теперешние “болельщики” на футболе, ждали, кто кого “переиграет”. Все зрители и актеры сливаются воедино. <...> Самуил Яковлевич уличает Петрушку во вранье, Петрушка отвечает мимикой - яркой и такой понятной, что у всех создается впечатление, будто мы слышим голоса обоих. Это чудесное исполнение ролей автора и актера было виртуозно. Петрушка, пораженный доводами автора, вдруг как бы в раздумье на минуту останавливается и, делая трогательно наивное лицо, говорит: “Простите, наврал!..” На одном из спектаклей произошло очень смешное и неожиданное. Самуил Яковлевич явно подавил своими доводами Петрушку, и Орлову ничего не оставалось, кроме признания, что он - актер - побежден автором. Самуил Яковлевич, уверенный в победе, бросает последнюю фразу: “Вот что, Петрушка, нечем тебе больше оправдаться. Почему же ты врешь?” И вдруг Петрушкин голос зазвенел, и он резко выпалил: “Потому что так написано!..” Я ахнула. Такой убеждающий ответ не входил в нашу игру. Петрушка-актер, заигравшийся как ребенок, весело захохотал и зааплодировал, считая автора окончательно побежденным. Ответ Петрушки на самом деле заканчивал спор. Самуил Яковлевич на минуту остановился. Было заметно, что даже он поражен неожиданностью. И вдруг засмеялся: “Петрушечка, дружок, ведь писал-то пьесу я...” Петрушка удивленно открывает глаза... Автор смотрит, 
покачивает головой, подтверждая: “Да, конечно, это я выдумал и шарманщика, и человека с ширмой, и всех действующих лиц. А они все по моему велению уговаривали тебя не врать. Да ты и ухом не повел, сел верхом на ширму и только и знаешь, что говоришь небылицы! Спроси режиссера, Елизавету Ивановнугі, они тебе то же самое скажут”. Петрушка медленно снимает свой колпак с кисточкой, мнет его и растерянно смотрит на нас с Елизаветой Ивановной умоляющим взглядом... И как же трогателен этот Петрушка-весельчак, и как понятно становится детям, что говорил он небылицы не со зла, а чтобы порадовать их веселой выдумкой автора - Маршака. Петрушка вздыхает, вытирает кисточкой набежавшую слезу и сконфуженно говорит: “Извините... Я немножечко переиграл...” [3, с. 138-189].

Таким образом, как и в представлениях петрушечников, Маршак своим текстом как бы только задавал тему (у Маршака такой темой было вранье), а далее перед зрителем развивалась речевая импровизация, успех которой зависел от таланта и остроумия ее участников. В народном театре партнером Петрушки выступал, как правило, шарманщик. В театре Маршака - автор. Интересно при этом, что в самом тексте пьесы такого персонажа вообще нет. Маршак в данном случае использует прием, сходный с подготовленной импровизацией в фольклоре, которая заключается в том, что однажды придуманный и понравившийся исполнителю ход он затем делает постоянным элементом своего выступления, оставляя возможности для дополнительных вариаций [г, с. 399].

Приведенный фрагмент с описанием постановки указывает на то, что этот спектакль был экспериментальным еще в одном отношении - он не был кукольным: Богданова обращает внимание на невозможные в кукольном исполнении мимику, выражение глаз главного героя, его некукольные движения. Кроме того, наверняка Богданова или И. Маршак оставили бы в своих воспоминаниях хотя бы какую-то информацию о куклах, а ничего подобного в них нет. Данное постановочное решение вполне понятно, Орлов, как и другие актеры Краснодарского театра для детей, не владел техникой кукольного театра, а освоить приемы кукловождения в короткое время совсем не просто. Для изготовления театральных кукол также требуется большое мастерство. 
В истории фольклорного театра известны случаи исполнения вертепной кукольной пьесы живыми актерами. В истории народного театра Петрушки нам такие примеры неизвестны. «Живой» и кукольный театры разные, хотя и связанные друг с другом семиотические системы [2]. Взаимодействие их возможно, и очевидно, что при таком взаимодействии неизбежно что-то теряется, а что-то приобретается. Кукла, слишком точно имитирующая человека, может быть интересна, а может вызывать отторжение. Так же и человек, играющий в спектакле, рассчитанном на куклы, может добиться блестящего эффекта, а может выглядеть в нем просто неуместным [I, с. I28-I37]. По-видимому, талант Орлова позволил ему справиться со сложной задачей, которая перед ним стояла, не случайно Богданова делает акцент в своем описании его игры на мимике актера, его активной и выразительной жестикуляции.

Текст пьесы «Петрушка» демонстрирует, что Маршак глубоко проник в природу петрушечного представления, в специфику его речевой стихии. Ему удается чрезвычайно органично сочетать формулы и сюжетные ходы фольклорного театра с личным творчеством. В основу своего «Петрушки» Маршак положил сцены, чрезвычайно близкие к традиционно исполняемым в представлениях народных кукольников: это комические диалоги Петрушки со своей женой Марфуткой (в народном театре женский персонаж чаще еще только невеста главного героя), немцем, сторожем (в народном театре в этой сцене участвовал обычно городовой), доктором. При этом писатель использует отдельные речевые клише фольклорных пьес, по-своему оформляя диалог в целом. Например, сцена с доктором начинается характерным для этого персонажа выходным монологом, в котором Маршак использует фольклорную формулу: «Я - доктор, лекарь, из-под Каменного моста аптекарь, был я в Париже, был и ближе, был в Италии, был и далее», развивая ее далее по-своему: «...объехал все государства, есть у меня разные лекарства, целебные травки, банки, пьявки, держусь старых правил, много людей на тот свет отправил. Тем и знаменит» [9, т. 2, с. 527]. В этом монологе образ доктора вполне соответствует фольклорному «прототипу» - профессионал наоборот. После самохарактеристики следует диалог доктора и Петрушки, также повторяющий фольклорные клише: «Доктор. Что у тебя болит? - Петрушка. Какой же ты доктор, коли спрашиваешь? Сам должен знать, что болит. - Доктор. Тут? - Петрушка. Повыше! - Доктор. Тут? - 
Петрушка. Пониже!» [9, т. 2, с. 528]. И вновь Маршак по-своему развивает дальнейший ход действия: «Доктор. Понимаю, понимаю! Проглоти одну маленькую пилюлю! (Дает пилюлю величиной с арбуз)» [9, т. 2, с. 528]. После отказа Петрушки проглотить пилюлю, которую доктор обещает протолкнуть ему в горло палкой, последний пытается дать ему столь же впечатляющую дозу капель и в конце лечения заявляет, что больной умер. На возражения Петрушки отвечает: «Не умер? Вот дуралей! От моих порошков все умирают» [9, т. 2, с. 528]. Маршак прекрасно чувствует характер комического фольклорного языка и очень хорошо конструирует в его духе речь персонажей своей пьесы, так что переход от традиционных формул к авторскому творчеству практически не ощущается.

Две сцены в пьесе Маршака не имеют аналогов в театре Петрушки. Это эпизод с кондуктором, в котором Петрушка пытается проехать без билета в трамвае, и заключительная сцена вранья Петрушки. Диалог с кондуктором по понятным причинам содержательно абсолютно независим от фольклорных текстов. В то же время построен он в соответствии с принципами фольклорной комической речи, на игре слов, рифм, смыслов. Например, завершается неудачное путешествие Петрушки следующей репликой: «Выгоняют меня зря, ехал до проспекта Октября, а доехал только до Июля - тут меня и турнули!» [9, т. 2, с. 529].

Заключительная сцена вранья играла в спектакле особенно важную роль, поскольку именно по поводу небылиц Петрушки, как пишет в воспоминаниях Богданова, разгорается не зафиксированный в тексте пьесы спор главного героя и самого Маршака. Начинается сцена не совсем обычным для театра Петрушки образом. Традиционный, построенный на смене кратких реплик диалог главного героя с кем-либо из действующих лиц, в данном случае уступает место двум монологам - лживым воспоминаниям Петрушки. В первом используется типичный для народного театра мотив покупки лошади. В фольклорных пьесах он разворачивается как диалог Петрушки и цыгана. У Маршака Петрушка рассказывает, как он некогда покупал коня, который в конце концов заявляет незадачливому новому хозяину: «Я, говорит, мужик, пешком ходить не привык: подавай мне карету!» [9, т. 2, с. 529]. Здесь, как и в народной сценке, приобретение оказывается комически неудачным, но сам характер неудачи несколько переосмысляется. В фольклорных пьесах лошадь обычно оказывается неспособной выполнять те функции, для кото- 
рых она предназначена, из-за дряхлости, что подчеркивается использованием оксюморона: «Не конь, а диво: бежит - дрожит, а упадет, так и не встанет. <...> На гору побежит - заплачет, а с горы бежит - скачет, а завязнет в грязи, так оттуда уж сам вези - отменная лошадь» [Іо, с. 278]. В истории, придуманной Маршаком, конь спесив и не хочет делать то, что должен, - везти седока, a, напротив, требует, чтобы в карете везли его. Таким образом, сам принцип искажения привычных отношений «вещей», характерный для народной смеховой культуры, Маршаком сохраняется в полной мере.

Во втором монологе Петрушка рассказывает о своем героическом подвиге - победе над медведем, но тут же пугается появившейся на сцене собаки, что позволяет шарманщику уличить его во лжи и трусости. По-видимому, здесь-то во время спектакля и включался в игру автор.

Пьеса Самуила Яковлевича - талантливая попытка перенести представление Петрушки на профессиональную сцену театра для детей. В то же время она знаменательное явление той эпохи революционных перемен, в которую писалась. Хотя и не прямо, но в ней преломились весьма важные тенденции времени. Во-первых, Маршак выступил здесь в ряду тех авторов (писателей и деятелей театра), кто попытался превратить театр Петрушки в театр для детей ${ }^{14}$. Фольклорный Петрушка, безусловно, был любимцем детской публики, но все же театром для детей не был, о чем свидетельствует и набор сценок, входивших в представление, и их вербальный строй. С установлением советской власти выдвинутая на государственном уровне идея создания театров для детей самым тесным образом сопрягалась с мыслью об использовании в этих целях народного кукольного театра Петрушки. Об этом говорят неоднократные выступления в прессе представителей партии и правительства, деятелей культуры, обсуждения этого вопроса на различных совещаниях и съездах [I4, с. 93-г35]. В первые послереволюционные годы театр Петрушки как любимое развлечение в прошлом угнетенных классов, понятный и «свой» для простого человека, вполне закономерно оказался востребован в просветительских целях. Маршак со своим «Петрушкой» в этом смысле отразил витавшее в воздухе веяние и в то же время сам принял участие в формировании новой культурной конструкции.

I4 Можно, конечно, говорить и о созвучности принципов театра Петрушки театральным исканиям начала XX в., имея в виду театр для взрослых. Но в настоящей статье этого вопроса мы касаться не будем. 
Безусловно, важно ответить на вопрос, зачем нужен был советской власти театр для детей, о каком просвещении шла речь и как соотносились с официальными идеями взгляды и творческая практика Маршака? На начальном этапе, по данным Б. Хеллман, примерно до середины І920-х гг., партия и правительство не проводили жесткой идеологической политики в области культуры, в том числе и в сфере искусства для детей [І6, с. 285]. В то же время буквально сразу после революции, в феврале І9І8 г., в газете «Правда» вышла статья Л. Кормчего «Забытое оружие», в которой говорилось о необходимости государства «взять на себя ответственность за создание детской литературы» [I5, с. 2I], способной воспитать поколение новых людей. Однако поначалу цель воспитания такого поколения мыслилась скорее как задача эстетического и общеэтического просвещения. Так, в документах и статьях первой половины I920-х гг., которые цитирует в своей монографии Н.И. Смирнова, делается упор именно на эстетическое развитие детей [14, с. 93-I36]. Пьеса Маршака и его собственные творческие установки вполне согласуются с таким пониманием задач детского искусства. В статье «Театр для детей» 1922 г. он писал: «Ребенок в каждой сказке, в каждом художественном произведении хочет увидеть всю жизнь, он не развлекается, а учится. Поэтому театр для детей должен давать пьесы, заключающие в себе большие идеи, - конечно, не в скучной, не в тенденциозной форме, а в живых образах» [9, т. 6, с. 186]. Его пьеса «Петрушка»- один из наглядных примеров реализации изложенной установки. В «нескучной», яркой и веселой форме ребенку в ней рассказывается о том, что врать нехорошо. В том же ключе с «Петрушкой» работали и другие авторы тех лет. В определенном смысле, таким образом, статус театра Петрушки в послереволюционную эпоху повышался. Если до революции бродячие кукольники разыгрывали свои представления только ради развлечения и смеха публики (и собственного заработка), то теперь «Петрушка» оказался официально признанным средством эстетического и этического воспитания.

Отметим, что в новом «положении» театра Петрушки крылись по крайней мере два противоречия. Во-первых, традиционный фольклорный театр принципиально неназидателен. Он часть народной смеховой культуры, не скованной никакими ограничениями. Делать его ступенью некого воспитательного процесса (а воспитание всегда связано с ограничениями) сложно, так как разрушительно для природы фольклорного театра. Но что 
касается Маршака, то в своем «Петрушке» ему удалось найти баланс, позволяющий сохранить прелесть свободной игры, добавив в нее лишь капельку нравоучительности.

Другое противоречие носит еще более общий характер и связано с проблемой перенесения фольклора на сцену. Такое перемещение всегда искусственно, и нужен огромный талант и такт, чтобы оно оказалось эстетически оправданным. Поскольку постановку Краснодарского театра для детей мы увидеть не в силах, то судить, насколько художественно самостоятельным спектакль получился, мы не можем. Что же касается текста, созданного Маршаком, то, на наш взгляд, он удачен и может составить основу очень хорошего представления. Судя по воспоминаниям, спектакль таковым и был.

Пьеса Маршака «Петрушка», включенная в сборник «Театр для детей», шагнула далеко за пределы Краснодара (отметим, что сборник, по-видимому, пользовался популярностью, так как неоднократно переиздавался), наверняка пережив множество сценических воплощений в самодеятельных театрах ${ }^{15}$. На новой профессиональной сцене «Петрушка» был поставлен уже в 1922 г. в петроградском Театре юного зрителя ${ }^{16}$, куда переехал работать и сам Самуил Яковлевич [8, с. 483].

29 апреля г922 г. нарком просвещения А.В. Луначарский вызвал Маршака в Москву, и после беседы с ним Самуил Яковлевич получил назначение в петроградский ТЮЗ, где вскоре занял должность завлита (занимал эту должность до І925 г., а в І926-І927 гг. выступал в качестве консультанта [8, с. 480-48I, 485]). Очень быстро Маршак стал «центральной фигурой во многих детских культурных проектах» [I6, с. 298]: возглавлял студию детской литературы (вместе с О.Е. Капицей), был редактором издательства «Радуга» и журналов «Новый Робинзон», «Ёж» и «Чиж», с І924 г. стал главой детской литературной секции ленинградского отделения «Госиздата».

Новую версию «Петрушки» Маршак создал в 1927 г. Пьеса получила название «Петрушка-иностранец». По своему построению и сюжету она гораздо дальше отстоит от фольклорной комедии, чем первая. Вместо набора слабо связанных между собой сцен, характерного для народного театра и

I5 Известно, например, что Ленинградский театр Петрушки под руководством Е.С. Деммени вырос из самодеятельного театрального кружка и его «профессионализация» связана как раз с постановкой пьесы С.Я. Маршака «Петрушка» в 1924 г. [14, с. I74].

I6 О создании и начальном этапе работы ТЮЗа см.: [17, с. 76-92]. 
первого опыта Маршака, писатель теперь строит сюжет по типу цепевидной сказки: родители отправляют Петрушку в школу, но он не хочет учиться и надевает свой ранец на свинью. Родители пытаются догнать Петрушку, чтобы отдать ему забытые карандаши, тетрадки и пирожок. Петрушка прячется от них в табачный ларек и устраивает драку с продавцом. Их разливают водой дворники. Петрушка убегает. Теперь его разыскивают родители, продавец табака и дворники, а он прячется в ящик с мороженым, отчего мороженое тает. Петрушка снова убегает, а к группе его преследователей присоединяется еще и мороженщик. На берегу Обводного канала Петрушка видит одежду купающегося иностранца, надевает ее и выдает себя за последнего. Французский инженер, чью одежду украл Петрушка, присоединяется к тем, кто ищет безобразника. Петрушке-иностранцу не удается обмануть своих преследователей во главе с милиционером. Он разоблачен, и только просьбы родителей спасают его от отправки в милицию.

В пьесе сохраняются лишь отдельные намеки на традиционные сюжетные ходы. Например, в начале действия Петрушка, чтобы не идти в школу, прикидывается больным, и родители намереваются позвать доктора. В фольклорной комедии сцена с доктором - одна из наиболее популярных; была она и в первой пьесе Маршака. Теперь он саму сцену в текст не включает, ограничившись коротким описанием возможного лечения и отказом от него Петрушки:

Роди те ли .

Если ты нездоров,

Позовем мы к тебе докторов,

Пропишут они тебе валерьянки,

Поставят банки,

Обложат ватой,

Накормят мятой,

Уложат в постель

На семь недель.

Пе т рушка .

Не хочу я докторов -

Я совсем уже здоров [9, т. 2, с. 240]. 
В качестве отсылки к приемам и технике традиционного театра Петрушки можно рассматривать большое количество потасовок, затеваемых главным героем, периодически используемое в пьесе прямое обращение персонажа к зрителям: «Здравствуйте, юные зрители! / А подраться со мной не хотите ли?» [9, т. 2, с. 24I], «Спасите меня, юные зрители! / Гонятся за мною родители» [9, т. 2, с. 242] и т. п. В конце Маршак актуализирует игровой характер произошедшего на сцене. Его герой заявляет: «Драгоценные родители! / Виноват не я, а зрители, / Я для них-то и припас / Сто проделок и проказ <...>» [9, т. 2, с. 25I].

Не остается в «Петрушке-иностранце» персонажей фольклорной комедии (кроме главного героя). Маршак создает произведение о новой жизни, с отражающими современные реалии действующими лицами (милиционер, французский инженер), вкладывая в нее больше назидательности: надо учиться, нельзя обманывать родителей, нельзя лениться, нельзя хулиганить. Сам Петрушка-иностранец, хотя и сохраняет некоторое сходство в своем характере с фольклорным праобразом, в то же время сильно изменяется. Фольклорный герой - персонаж неопределенного возраста, социального положения, кукла, играющая человека. Новый Петрушка Маршака становится гораздо более реалистичным: это мальчишка лентяй и озорник, не задумывающийся о последствиях своих поступков.

В плане вербальной структуры новая пьеса в гораздо меньшей степени опирается на собственно «петрушечные» речевые приемы, Маршак отказывается от использования в ней традиционных формул, но в языке комедии по-прежнему большое значение имеют словесные игры, характерные, впрочем, не только для народного театра, но и для других комических жанров фольклора как русского, так и западноевропейского, с которым Маршак был хорошо знаком и переводчиком которого являлся.

В 1927 г. пьеса была опубликована в издательстве, где работал Маршак («Петрушка-иностранец». Л.: Радуга, І927). В том же году поставлена кукольной группой ленинградского ТЮЗа под руководством Е.С. Деммени. Сам Маршак в письме к Богдановой и Орлову отмечал, что, по его наблюдениям, «Петрушка-иностранец» больше нравится ребятам, чем его старый «Петрушка» [9, т. 8, с. ІІ2 (Письмо от 6 декабря г928 г.)]. В том же письме писатель рассказывает друзьям и соратникам по Краснодарскому театру для детей, что он часто читает своего «Петрушку-иностранца» на встре- 
чах с детьми и предлагает Орлову выступить с этой пьесой на утреннике в Большом зале консерватории. В годы, когда новую силу набирала развернувшаяся еще до революции полемика о вреде для детей сказки и - шире фантазии, игры, Маршак остался верен своим взглядам. В г927 г. он писал A.M. Горькому: «Очень мешает нам в работе отношение педагогов (а они почти единственные, к сожалению, критики и рецензенты дет<ской> литературы). Почти всегда они оценивают произведение только со стороны темы (“Что автор хотел сказать?”). При этом они дают похвальные отзывы часто явно бездарным произведениям и порицают талантливые книжки, не подходящие под их рубрики. <...> Веселые книжки - особенно те, в которых юмор основан на нелепице, - упрекают в легкомыслии и в том, что они вносят путаницу в детские представления. <...> Требуют, чтобы весь текст, все слова и обороты речи были понятны ребенку, а это чаще всего ведет к зализанности и приглаженности, к вытравлению личности ${ }^{\mathrm{I7}}$ писателя из произведения. <..> Пусть люди с юности приучаются к тому, что художественные образы не летят сами, как гоголевские галушки, в рот, а иногда требуют от читателя сосредоточенного внимания и активности» [9, т. 8, с. 96 (Письмо от 9 марта I927 г.)]. Уже два года спустя и Маршак, и ленинградский ТЮЗ попали под огонь суровых обвинений в «мелкобуржуазности», «бессодержательности» творчества, неспособности создать новое «пролетарское искусство» для подрастающего поколения. Печальный этап развития искусства для детей, начавшийся во второй половине I920-х гг. и прерванный Великой Отечественной войной, в настоящее время довольно хорошо исследован, сведения о нем, в частности, обобщены в книге Б. Хеллмана [І6, с. 327-372]. В борьбу был вовлечен и любимый герой народной кукольной комедии. Этот образ во второй половине г920-х гг. весьма по-разному использовался авторами противоположных творческих взглядов. Петрушке Маршака удалось сохранить ту меру свободной игры, которая позволяет искусству для детей не превратиться в иллюстрацию «циркуляра Наркомпроса» [9, т. 7, с. 309 $]^{\mathrm{I} 8}$.

В заключение отметим, что два «Петрушки» Маршака отразили характерные тенденции обращения к этому фольклорному явлению в детском

I7 Курсив С. Маршака.

I8 Маршак С.Я. О наследстве и наследственности в детской литературе. Полный текст статьи см.: [9, т. 7, с. 279-3Іг], впервые опубликовано под названием «Литература - детям»: Известия. 1933. № 131, 23 мая; № 134, 27 мая. 
искусстве в их развитии от первых послереволюционных лет и до конца I920-Х Гг.

\section{Список литературы}

I Богатырев П.Г. Вопросы теории народного искусства. М.: Искусство, I97I. 5II c.

2 Богатырев П.Г. О взаимосвязи двух близких семиотических систем (Кукольный театр и театр живых актеров) // Труды по знаковым системам. Вып. 6: Сборник научных статей в честь Михаила Михайловича Бахтина: к 75-летию со дня рождения. Тарту: Изд-во Тартуского гос. ун-та, І973. С. 306-329. Богданова А.В. Детский городок // «Я думал, чувствовал, я жил...» Воспоминания о С.Я. Маршаке / сост. Б.Е. Галанов. М.: Сов. писатель, І97І. С. І28-I46. Васильева Е., Маршак С. Театр для детей. Краснодар: Кубано-Черноморск. отд. нар. образ., І922. 234 с. Въюгин В.Ю. Д-р Фрикен в тылу врага...(Маршак и газета: к предыстории советской классики) // «Убить Чарскую...» Парадоксы советской литературы для детей. І920-е - І930-е гг. / сост. и ред. М.Р. Балина и В.Ю. Вьюгин. СПб.: Алетейя, 2013. С. 46-76.

6 Гейзер М.М. Маршак. М.: Молодая гвардия, 2006. 325 с.

7 Куценко И.Я. С.Я. Маршак в Екатеринодаре - Краснодаре, І9г8-І922. Краснодар: Б. и., І 997.877 с.

8 Маршак И.С. От детства к детям. Главы из биографической книги // Жизнь и творчество Маршака / сост. Б.Е. Галанов. М.: Детская литература, I975. С. $349-486$.

9 Маршак С.Я. Собр. соч.: в 8 т. М.: Худож. лит., І968-г972.

Iо Народный театр / вступит. ст и ст. к разделам, подгот. текстов и коммент. А.Ф. Некрыловой и Н.И. Савушкиной. М.: Советская Россия, I99I. 544 с. Некрылова А.Ф. Предисловие // Симанович-Ефимова Н.Я. Записки петрушечника. Л.: Искусство, І980. С. 5-32. Петровский М.С. Доктор Фрикен? Что такое? // Литературная газета. І987. № 46. II ноября.

I3 Симанович-Ефимова Н.Я. Записки петрушечника. Л.: Искусство, І980. 27I с.

I4 Смирнова Н.И. Советский театр кукол. М.: Изд-во АН СССР, І963. 384 с.

I5 Хеллман Б. Детская литература как оружие: творческий путь Л. Кормчего // «Убить Чарскую...» Парадоксы советской литературы для детей. І920-е - І930-е гг. / сост. и ред. М.Р. Балина и В.Ю. Вьюгин. СПб.: Алетейя, 2013. C. $20-45$.

I6 Хеллман Б. Сказка и быль. История русской детской литературы. М.: Новое литературное обозрение, 2016. 560 с.

I7 Шnет Л.Г. Советский театр для детей. М.: Искусство, I97І. 432 с. 


\section{References}

Bogatyrev P.G. Voprosy teorii narodnogo iskusstva [The question of the theory of folklore]. Moscow, Iskusstvo Publ., I97I. 5II p. (In Russ.)

Bogatyrev P.G. O vzaimosviazi dvukh blizkikh semioticheskikh sistem (Kukol'nyi teatr i teatr zhivykh akterov) [On the interaction of two close semiotic systems (The puppet theatre and the theatre of human actors]. Trudy po znakovym sistemam. Vyp. 6: Sbornik nauchnykh statei $v$ chest' Mikhaila Mikhailovicha Bakhtina: $k$ 75-letiiu so dnia rozhdeniia [Studies in semiotic systems. Issue 6. Collection of articles in honor of the 75 year anniversary of Mikhail Mikhailovich Bakhtin]. Tartu, Izd-vo Tartuskogo gos. un-ta Publ., I973, pp. 306-329. (In Russ.)

3 Bogdanova A.V. Detskii gorodok [Child's town]. "Ia dumal, chuvstvoval, ia zhil..." Vospominaniia o S.I. Marshake ["I thought, I felt, I lived...” The Memoir about S.I. Marshak], ed. B.E. Galanov. Moscow, Sovetskii pisatel Publ, I97I, pp. I28-I46. (In Russ.)

4 Vasil'eva E., Marshak S. Teatr dlia detei [Theatre for children]. Krasnodar, KubanoChernomorsk. otd. nar. Obraz. Publ., I922. 234 p. (In Russ.)

5 V'iugin V.Iu. D-r Friken v tylu vraga... (Marshak i gazeta: k predystorii sovetskoi klassiki) [ D-r Friken behind the enemy's lines. Marshak and the newspaper: On the prehistory of the Soviet classic literature]. "Ubit' Charskuiu..." Paradoksy sovetskoi literatury dlia detei. I920-e - I930-e gg. [“To Kill Charskaya...” Paradoxes of the Soviet literature for children, I920s - I930s], eds. M.R. Balina i V.Iu. V’iugin, St. Petersburg, Aleteiia Publ., 2013, pp. 46-76. (In Russ.)

6 Geizer M.M. Marshak [Marshak]. Moscow, Molodaia gvardiia Publ., 2006. 325 p. (In Russ.)

7 Kutsenko I.I. S.I. Marshak v Ekaterinodare - Krasnodare, I9I8-I922 [S.I. Marshak in Ekaterinodar - Krasnodar, I9I8-I922]. Krasnodar, sine nomine, I997. 877 p. (In Russ.)

8 Marshak I.S. Ot detstva k detiam. Glavy iz biograficheskoi knigi [From the childhood to children. Chapters from autobiography]. Zhizn' i tvorchestvo Marshaka [Marshak's life and work], ed. B.E. Galanov. Moscow, Detskaia literatura Publ., I975, pp. 349-486. (In Russ.)

9 Marshak S.I. Sobr. soch.: $v 8 t$. [Collection of Writings]. Moscow, Khudozh. lit. Publ., I968-I972. (In Russ.)

IO Narodnyi teatr [Folklore Theatre], introduction, ed., comments A.F. Nekrylova and N.I. Savushkina. Moscow, Sovetskaia Rossiia Publ., I99I. 544 p. (In Russ.)

II Nekrylova A.F. Predislovie [Preface]. Simanovich-Efimova N.I. Zapiski petrushechnika [The notes of the Petrushechnik]. Leningrad, Iskusstvo Publ., I980, pp. 5-32. (In Russ.) gazeta, I987, no 46, II nov. (In Russ.) 
I3 Simanovich-Efimova N.Ia. Zapiski petrushechnika [The notes of the Petrushechnik]. Leningrad, Iskusstvo Publ., I980. 27I p. (In Russ.)

I4 Smirnova N.I. Sovetskii teatr kukol [The Soviet puppet theatre]. Moscow, Izd-vo AN SSSR Publ., I963. 384 p. (In Russ.)

I5 Khellman B. Detskaia literatura kak oruzhie: tvorcheskii put' L. Kormchego [Literature for children as a weapon: Literary career of L. Kormchy]. "Ubit' Charskuiu...” Paradoksy sovetskoi literatury dlia detei. I920-e - I930-e gg. ["To Kill Charskaya...” Paradoxes of the Soviet literature for children, I920s - I930s], eds. M.R. Balina and V.Iu. V'iugin. St. Petersburg, Aleteiia Publ., 20I3, pp. 20-45. (In Russ.)

I6 Khellman B. Skazka i byl'. Istoriia russkoi detskoi literatury [The tale and the truth. The history of Russian Literature for children]. Moscow, Novoe literaturnoe obozrenie Publ., 2016. 560 p. (In Russ.)

I7 Shpet L.G. Sovetskii teatr dlia detei [The Soviet theatre for children]. Moscow, Iskusstvo Publ., I97I. 432 p. (In Russ.) 
УДК $82+398$. .

ББК 63.52I $(=62)+$

$82.3(=632)$

\section{ОГОНЬ, ПОТОП И ВОЙНА \\ С ВОСТОКА: КУЛЬТУРНЫЙ ТРАНСФЕР \\ В СОВРЕМЕННЫХ ЭСХАТОЛОГИЧЕСКИХ ПРЕДСТАВЛЕНИЯХ НА АЛТАЕ}

(C) 2018 г. Д.Ю. Доронин

Научно-исследовательская лаборатория теоретической фольклористики Школь актуальных гуманитарных исследований Института общественных наук Российской академии народного хозяйства и государственной службы при Президенте Российской Федерации, Москва, Россия Дата поступления статьи: 26 января 2018 г. Дата публикации: 25 сентября 2018 г.

DOI: $10.22455 / 2500-4247-2018-3-3-278-303$

Статья выполнена при поддержке гранта РГНФ, проект № I8-о9-оо744 «Современные сакральные практики освоения социальных ландшафтов на южном Алтае»

Аннотация: Проблематика культурного трансфера раскрывается в статье через описание буддийских центральноазиатских влияний и заимствований в эсхатологии и, шире, мифологии алтайцев. В частности, буддийское учение о кальпах сопоставляется с алтайскими представлениями об эсхатологических стихиях айгулах. Анализируется специфика алтайских эсхатологических представлений об огненной катастрофе и водах потопа, выходящих в конце времен из-под земли. С другой стороны, культурный трансфер исследуется на примере фольклорных текстов, демонстрирующих мифологизацию алтайцами других государств и народов (прежде всего, Китая и России) в фольклорных мотивах эсхатологической войны и иноземного нашествия. Представления о последней войне строятся на мессианских ожиданиях грядущего хана и на основании исторической памяти о потрясениях прошлого.

Ключевые слова: Республика Алтай, Алтай, алтайцы, эсхатология, бурханизм, шаманизм, Белая вера, алтайская эсхатология.

Информация об авторе: Дмитрий Юрьевич Доронин - научный сотрудник, Научно-исследовательская лаборатория теоретической фольклористики Школы актуальных гуманитарных исследований Института общественных наук Российской академии народного хозяйства и государственной службы при Президенте Российской Федерации, пр. Вернадского, 82, корп. 9, II957I г. Москва, Россия.

E-mail: demetra2@mail.ru

Для цитирования: Доронин Д.Ю. Огонь, потоп и война с Востока: культурный трансфер в современных эсхатологических представлениях на Алтае // Studia Litterarum. 20I8. T. 3, № 3. С. 278-303. DOI: I0.22455/2500-4247-2018-3-3-278-303 


\title{
FIRE, FLOOD AND WAR FROM THE EAST: CULTURAL TRANSFER IN ALTAIC MODERN ESCHATOLOGY
}

This is an open access article distributed under the Creative Commons Attribution 4.0 International (CC BY 4.0)

\author{
(C) 20I8. D.Y. Doronin \\ Research Laboratory of theoretical folklore studies, \\ School of advanced studies in humanities, School \\ of Public Policy, The Russian Presidential Academy \\ of National Economy and Public Administration, \\ Moscow, Russia \\ Received: January 26, 2018 \\ Date of publication: September 25, 2018
}

Acknowledgements: The article was supported by the grant of the Russian State Fund for the Humanities, project no I8-09-00744 "Modern Sacred Practices in the Development of the Social Landscapes in the Southern Altai."

Abstract: The article examines modern Altai eschatology from the standpoint of cultural transfer. For this purpose, it gives an overview of sources of Altai eschatology, including the main versions (subtradition) of Altai eschatology as well as its oral and folklore genres. It shows that Altai eschatology, especially its Burkhanism version, has not only circular but also axial, linear, or "historical" sense of time. The problem of cultural transfer is revealed through a description of obvious Buddhist Central Asian influences and borrowings in the eschatology and, more broadly, in the mythology of the Altaians. In particular, the Buddhist doctrine of the kalpas is compared with the Altaic notions of eschatological elements of the aiguls. Borrowings from Mongolian and Buddhist eschatology and mythology receive detailed examination. The essay examines the specificity of Altaic eschatological ideas about the fiery disaster and the flood waters emerging at the end of time from under the earth. Finally, the essay explores folklore texts that demonstrate the mythologization of other states and peoples (primarily China and Russia) by Altaians in the folklore motifs of the eschatological war and foreign invasion. Mythological ideas about the last war between eschatological peoples are built on the messianic expectations of the coming Khan and on the memory of the historical upheavals of the past.

Keywords: Altai Republic, Altai, Altaians, eschatology, Burkhanism, shamanism, White faith, Altai eschatology.

Information about authore: Dmitrii Y. Doronin, Research Fellow, Research Laboratory of Theoretical Folklore Studies, School of Advanced Studies in Humanities, School of Public Policy, The Russian Presidential Academy of National Economy and Public Administration, Vernadsky prospect, 82, building. 9, II957I Moscow, Russia.

E-mail: demetra2@mail.ru

For citation: Doronin D.Y. Fire, Flood and War from the East: Cultural Transfer in Altaic Modern Eschatology. Studia Litterarum, 20I8, vol. 3, no 3, pp. 278-303. (In Russ.) DOI: IO.22455/2500-4247-20I8-3-3-278-303 


\section{Алтайская эсхатология: жанры и субтрадиции}

Слабая изученность алтайской эсхатологии ${ }^{\mathrm{I}}$ побудила автора обратиться к данной теме. В настоящее время известны только две небольшие работы, специально посвященные этой теме [24;37], но и они сосредоточены на весьма частных вопросах (лишь на одном из эсхатологических жанров в одном случае и на бурханистской версии алтайской эсхатологии в другом) и поэтому не могут считаться обобщающими. Еще две недавних публикации посвящены современным эсхатологическим ожиданиям на Алтае [I4; I5]. Такое положение является частью более крупной проблемы - слабой изученности тюркской эсхатологии в целом, например, эсхатологические представления не упомянуты в энциклопедической статье «Тюркоязычных народов мифология» [4].

Не лучше обстоит дело с публикацией текстов: за полтора столетия в научный оборот было введено лишь девять алтайских эсхатологических текстов. [I, с. 342-345; 22, с. I34-I39; 24, с. 44; 28, с. I67-I70]. Как пишет исследователь несказочной прозы алтайцев и автор одной из двух статей по алтайской эсхатологии Н.Р. Ойноткинова, «у алтайцев зафиксировано 9 текстов о предстоящем конце мира. К сожалению, в настоящее время этот жанр угасает...» [24, с. 44]. Данное суждение необходимо пояснить:

\footnotetext{
I Эсхатологических представлений неисламизированных аборигенных тюркских народов Республики Алтай, т. е. в данной статье в первую очередь собственно алтайцев (алтай кижи) и теленгитов и в меньшей степени народов из группы так называемых «северных алтайцев»тубаларов, кумандинцев и челканцев. В некоторых случаях будут использованы материалы из мифологии телеутов, относимых ранее к группе «южных алтайцев» (наряду с теленгитами и алтай кижи).
} 
- во-первых, эсхатологическая традиция на Алтае, на мой взгляд, не угасает, a, наоборот, даже переживает некоторый ренессанс, яркий пример беседы-проповеди представителей каракольской группы $A \kappa J a r$ - 'Белой веры' (aлm.) и визионерские тексты автописьма, называемые алтайцами Алтай Кудайдын бичиктери - 'письма Алтай Кудая' (алт.) эсхатологической тематики, полученные писцами-бичикчилер в состоянии измененного состояния сознания и записанные ими в тетради;

- во-вторых, Н.Р. Ойноткинова имела в виду только опубликованные тексты;

- в-третьих, назвав статью «Эсхатологические мифы алтайцев», она рассмотрела эсхатологические тексты только одного жанра - так называемые тексты-пророчества [25, с. 25], в то время как жанров алтайских текстов, касающихся эсхатологической тематики, больше.

Здесь логично обратиться к рассмотрению других эсхатологических жанров алтайского фольклора и соответствующих им эсхатологических субтрадиций мифоритуальных систем тюрков Алтая. Тексты эсхатологического содержания, по уже устоявшейся научной традиции, алтайские фольклористы относят к крупной жанровой группе несказочного фольклора кеп-куучындар - ‘старинные рассказы’ (алm.) [25, с. г9]. При более пристальном рассмотрении можно убедиться, что тексты с эсхатологическими мотивами представлены в следующих жанрах:

I. Стихотворные силлабические тексты-пророчества, чаще всего приписываемые легендарным / историческим провидцам; по большей части это перечни примет / знаков эсхатологической эпохи.

2. Прозаические эсхатологические рассказы.

3. Мессианско-эсхатологические тексты бурханистской традиции.

4. Тексты визионеров [(бичикчи - 'писцов' (aлm.), камов - 'шаманов’ (aлm.)] с эсхатологическими мотивами. Например, так называемые «диктовки»² ак јану улус - 'сторонников Белой веры’ (aлm.), переведенные в машинописную и печатную форму (послания, листовки, газеты). Сюда же относятся дидактические и эсхатологические тексты современных шаманов и других ритуально-магических специалистов - неме билер улус - 'нечто

2 «Диктовки» - русскоязычное название подобных визионерских текстов, употребляемое самими алтайцами, которые верят, что духи или божество Алтай Кудай диктуют эти тексты писцам-бичикчилер как свои послания людям. 
знающих людей’ (aлm.), публикуемые ими в алтайских СМИ или даже в публикуемых ими книгах.

Среди алтайских речевых эсхатологических жанров можно указать: белге - 'угадывание по приметам и ситуациям' (короткие рассказы-предсказания, сообщаемые по какому-то случаю, например, когда рассказчик замечает растущий на горе молодой березовый лес) и табыш - ‘слух' (aлm.), короткие транслируемые сообщения этого речевого жанра также зачастую эсхатологически окрашены. Следует указать и на более долгие и пространные, иногда ритуализованные «вечерние беседы у огня», как томырыир / momuрuир / moмып (в смысле 'рассуждения, философствования'), в том числе на эсхатологическую тему, в айыле на таежной стоянке или в селе.

Вероятно, было бы большой ошибкой рассматривать современные алтайские эсхатологические представления вне определенного историко-культурного контекста. В настоящее время для Республики Алтай характерна сложная этноконфессиональная ситуация [І3, с. 29], что стало следствием бурного «национально-культурного возрождения» I990-х гг. [35, c. 30-42]. Сейчас одновременно сосуществуют и конкурируют друг с другом несколько «проектов идентичности», представлений об «алтайскости» и будущем алтайского народа:

- различные варианты шаманизма и (нео)шаманизма,

- различные варианты Ак Јан (Белой веры), известной русскоязычным исследователям с г904 г. как алтайский бурханизм,

- буддизм, в основном школы Гелугпа, но есть и проекты «алтайского буддизма»,

- «алтайский протестантизм», в основном церкви евангелического и харизматического толка, для которых (в отличие, например, от адвентистов Республики Алтай) «алтайскость», алтайское этнокультурное наследие (язык, обычаи и даже обряды, мифологические и эсхатологические мотивы) представляют большую ценность. С их точки зрения, Бог говорит алтайцам через алтайское, а сохранение и преумножение «алтайскости», алтайского народа - одно из важнейших последствий Его благословления,

- алтайское православие, в меньшей степени, чем протестантизм, окрашенное в «алтайские тона».

Каждое из этих конфессиональных направлений предлагает свои представления о будущем (в том числе катастрофические, эсхатологические 
и мессианские) и/или толкует по-своему традиционные алтайские эсхатологические мотивы. (Квази)исторические и мессианские представления об Ойроте также переосмысляются по-своему: например, как приход Майтреи, возвращение буддийской веры на Алтай, как приход сильного алтайского правителя, ведущего к возрождению народа или как второе пришествие Иисуса Христа. Таким образом, алтайская эсхатологическая традиция неоднородна, можно выявить несколько субтрадиций:

- бурханистскую (мессиански-эсхатологическую),

- шаманистскую,

- эсхатологические представления алтайских буддистов,

- эсхатологические представления алтайских протестантов-харизматов.

Большинство текстов эсхатологической тематики этих алтайских субтрадиций:

- либо описывают катастрофу прошлого, чаще всего потоп (такие тексты правильнее отнести в особую группу катастрофических),

- либо сообщают о знаках/приметах последнего века,

- либо, пророчествуя, описывают эсхатологические события (войны, катастрофы, порча мира, эпоха сомнительного благоденствия),

- либо сообщают о грядущем обещанном возвращении легендарного правителя и его деяниях, чаще всего возвышающих народ (группа мессианско-эсхатологических текстов).

Несколько слов необходимо сказать об историчности и моделях времени в алтайской эсхатологии. Бурханистская субтрадиция в наибольшей степени связана с легендарной историей и (квази)историей алтайцев. Именно поэтому для этой (мессианской) эсхатологии более всего характерно не кольцевое, а осевое, линейное, «историческое» ощущение времени. Поэтому было бы ошибкой вслед за некоторыми исследователями [I8; 25, c. 25-26] приписывать всей тюркской эсхатологии кольцевую модель времени. Элемент цикличности можно увидеть и в бурханистских текстах (мотив возвращения правителя), однако именно эти тексты конца джунгарского (ойротского) владычества³ над народами Алтая (XVIII в.) исследователи

3 Джунгарское ханство - государство западных монголов (ойратов) в XVI-XVIII вв. на территории, которая сейчас относится к Казахстану, Киргизии, Китаю, России и Монголии. Занимало земли от Тибета и Китая на юге до Сибири на севере, от Урала, Хивинского и Бухарского ханств на западе до Халха-Монголии на востоке. Перестало существовать после третьей ойратско-маньчжурской войны (I755-I759), междоусобицы и геноцида ойратов со 
чаще всего соотносят с реактуализацией в мифологии алтайских тюрков модели линейного, (квази)исторического времени [І8, с. 56]. Другие исследователи, например Л.И. Шерстова, связывают возникновение линейного, исторического времени с еще более поздней эпохой - с бурханистскими массовыми молениями алтайцев в I904 г. в урочище Тӧрӧн ${ }^{4}$. В концепции автора возникновение новой темпоральности связано с формированием нового (алтайского) этноса [37, с. I85]. На мой взгляд, исследователь, опираясь на фольклор бурханистов, конструирует свою собственную «мифологию времени» у алтайцев, причастную рождению их нового этноса.

Общую схему [7, с. I23] алтайской эсхатологии можно представить в виде последовательности тем (обобщающих, группирующих несколько близких мотивов)5: [г. Знамения и вестники эсхатологической эпохи] + [2. Эсхатологическая эпоха: 2.I. чудесный мир «технической эсхатологии» + 2.2. испорченный / перевернутый мир] + [3. Эсхатологическая война] + [4. Эсхатологическая катастрофа: айгуль, потоп, огненная катастрофа] + [5. Возвращающийся / грядущий правитель и новый мир].

Многие мотивы алтайской эсхатологии, по всей видимости, интернациональны: например, последняя война между народами, измельчание людей, утрата ценности золота (голодный человек не может выменять даже самую малость еды за большой самородок золота) или мотивы технической эсхатологии (железные быки и железные птицы, небо в паутине). Когда и откуда эти мотивы были заимствованы в алтайскую традицию или же они настолько давно транслируются на алтайском, что могут уже считаться частью местной эсхатологической традиции, - на все эти вопросы весьма сложно ответить. Но, на мой взгляд, предположение Н.Р. Ойноткиновой о том, что эсхатологические повествования появились в фольклоре алтай-

стороны Китая. Тюркские народы юга Алтая входили в состав ханства и вспоминают эту эпоху как свой «золотой век».

4 Моления сторонников Ак Јан (Белой веры) начала XX в., движения, для которого были характерны религиозно-националистические настроения (например, отказ от русских денег, земельной реформы и власти), мессианские и эсхатологические чаяния, связанные с ожиданием скорого возвращения Ойрот-хана. При этом западномонгольский (джунгарский) правитель XVII-XVIII вв. был мифологизирован в народном сознании как истинный правитель всех алтайцев и как посланник божества ӥч-Курбустана / Ак Бурхана, а о его возвращении возглашалось в особых ритуальных текстах - гимнах-молитвах јарлыкчылар (алт.) - 'пророков'.

5 Ниже различные смысловые блоки в схеме алтайской эсхатологии для наглядности заключены в квадратные скобки. 
цев под влиянием христианской книжной и устной традиции, со ссылкой на русские тексты [24, с. 47], не доказано и сомнительно. По всей видимости, заимствование произошло в гораздо более ранние времена (например, в Средневековье через тибетский буддизм и / или уйгурское манихейство), поскольку типичные эсхатологические тексты-пророчества были опубликованы В.И. Вербицким уже в І850-е гг. [Іо, с. II4] и В.В. Радловым в I860-е гг. [23, с. I67-I70; 28, с. 364-365]. Вероятно, к началу активной деятельности Алтайской духовной миссии (основана в I830 г.) жанр алтайских текстов-пророчеств уже сформировался. По крайней мере протоиерей В.И. Вербицкий не дает каких-то комментариев, из которых бы следовало, что такие тексты появляются у алтайцев под влиянием православия, хотя для него, как для священника и миссионера, подобная рецепция и восприимчивость алтайской культуры была бы, несомненно, важным свидетельством успеха Миссии.

Таким образом, проблематика культурного трансфера в алтайской эсхатологии может рассматриваться в нескольких аспектах:

- во-первых, очевидные буддийские центральноазиатские влияния и заимствования в эсхатологии и, шире, мифологии алтайцев [3о, с. 37];

- во-вторых, мифологизация других государств и народов (прежде всего, Китая и России) в мотивах эсхатологической войны и иноземного нашествия.

\section{Калъпы и айгулы: буддийские центральноазиатские влияния}

Ярким примером центральноазиатского культурного трансфера в алтайской эсхатологии является мифологическое представление о нескольких, сменяющих друг друга мировых катастрофах. Так, в соответствии с буддистским учением о кальпах 6 существует три вида разрушений: огнем, водой и ветром [8, с. 8I-86, 9I-93; 9, с. I80-I85, I95-197; 22, с. I96; 26, с. 3335, 57-65]. На Алтае бытуют похожие на это учение рассказы об айгулах (aлm.) - 'эсхатологических стихиях', наиболее известные в народе по пророчествам Боора, алтайского провидца, жившего в XVIII в. Так, в одной из опубликованных версий пророчества Боора написано:

6 Кальпа - единица измерения времени, глобальные временные периоды в индуизме и буддизме. 
Шесть стихий, шесть айгулов придет в движение в смутный век Боро Тююки: вода, огонь, ветер, мороз, земля и человек. Все стихии придут в неистовство. Так настанет последний срок - Боро Тююки [2, с. Іо9].

Рассказ об айгулах удалось в 2015 г. записать и мне:

(С.К.) - Много было, много пророчеств делали всяких разных, таких вещей очень много было. Очень интересные вещи рассказывала женщина, может, слышал ты, Коныр. Бабушка Коныр, вот она. Коныр, она, вот, говорила как раз вот это - айгул. Айгул, вот стихии, айгулдар. Про стихию, вот, наводнение было. И вот она говорила про четыре айгула. Стихия воды, стихия огня, стихия ветра и стихия холода, по-моему, льда, что ли. Нет, не льда, чтото такое. Надо мне вспомнить, потому что у меня где-то это опубликовано, я делала это. И вот он первый, вот этот первый айгул был, когда было, вот это наводнение было.

(Д.Д.) - Какое? Вот, недавно которое было?

(С.К.) - Ну, нет. Вот этот, про конец света говорим же. Потоп, всемирный потоп. <... Вот эти айгулы, и вот она перечисляла. И перечисляла вот эти признаки, мне его надо найти, я его делала, вот этот материал. И что там, вот, огонь, когда всё сгорает, ветер, когда всё уносит, и четвёртое же там было... Вода, огонь, ветер и что-то вот это прямо тоже вселенское что-то такое, когда всё там. <...> Вот этот разговор я вспомнила, знаешь, вот в связи с чем: когда у нас пожары-то начались, и землетрясение было, мы вспомнили про эти айгулыт

Таким образом, всемирный потоп прошлого был одним из айгулов. Л.И. Шерстовой удалось собрать алтайские эсхатологические представления, согласно которым Земля переживает второй период своего существования. Первая Земля погибла в потопе [36, с. I85; 37, с. 183]. Некоторые мои информанты, как мне удалось выяснить, говорили о нескольких эсхатологических потопах: один, который уже был, и второй - чайык, который

7 Записал Д.Ю. Доронин от С.К. Кыдыевой (1954 г.р., алтайка, сӧӧк Чагандык) в г. ГорноАлтайск 21.IO.20I5 г. Здесь и далее приведены тексты полевых материалов автора, записанные на русском языке, при этом с помощью информантов всякий раз выяснялось правильное написание алтайских имен и понятий. 
будет. Это будет потоп, предваряемый землетрясением, его ядовитые воды выступят из-под земли:

(Д.Д.) - Вот потоп, кстати, странно: ведь это же не предсказание о будущем, а то, что было в прошлом.

(Э.Е.) - Не, будущее, [это то], что чайык чыгар .

(Д.Д.) - То есть все-таки будет еще один потоп?

(Э.Е.) - Да. Чайык, и вот его ждали. Было землетрясение, потом нашли јер-былык9, и вот следующим шагом должно было быть как раз чайык. <..>

Ну, то, что конец света, один из возможных, видимо, вариантов - это то, что всех смоет, всех людей. Произойдет большой потоп, и уцелеют лишь только те люди, которые будут высоко в горах. И обычно подговаривали, что вот как раз вот люди, которые же проживают на Алтае, и уцелеют, так как они якобы очень высоко живут и тем самым будут спасены от потопа. А все низменности, ну, просто затопит, зальет всех людей, животных. <..>

Речь еще к тому же, что чайык - это не означает, что вода не придет откуда-то из ближайшего океана или моря. Она из-под земли выйдет. Это чайык, вот суть его в том, что он снизу выходит. То есть вода выйдет снизу, смоет всех, а люди, которые, вот, в горах, они останутся.

(Д.Д.) - А что это за вода из-под земли?

(Э.Е.) - Ну, из-под земли выйдет вода, никто не знает где, но она откуда-то из расщелины. Выйдет вода, и не просто вода, а вода с ядом ${ }^{\text {то }}$.

Таким образом, в отличие от библейской версии ${ }^{\mathrm{II}}$ потопа, который происходил от идущих ливней, в алтайских эсхатологических текстах со-

8 Чайык чыгар (алт.) - 'выступающий/появляющийся потоп'

9 Jep-былык / Кер балык - огромная и/или чудовищная рыба, согласно современным мифологическим представлениям алтайцев обитающая в подземных водах, появляющаяся в глубоких озерах как вестник войн/катастроф или конца света. Известны тексты, в которых эта рыба описывается как опора земли и/или ассоциируется с китом или даже мамонтом.

го Записал Д.Ю. Доронин от Э.В. Енчинова (1980 г.р., алтаец, сӧӧк Тодош) в г. ГорноАлтайск 06.ІІ.20I6 г.

II Хотя в Торе и, соответственно, в Библии говорится о развергающихся/открывающихся источниках великой бездны. Но удивительно, что комментаторы-библеисты говорят все-таки о ливне как о причине потопа, хотя очевидно, что тут можно увидеть две причины появления воды потопа, и, соответственно, возможно предположить две мифологические модели - потоп, приходящий сверху (воды дождя), и потоп, приходящий снизу (воды, проступающие изпод земли). 
общается не о дожде, а о воде, которая поднимается, все затопляя, из-под земли, как, например, встречаем и в пересказе бурханистской эсхатологии, сделанном в начале XX в. Д.А. Клеменцем:

Скоро с неба станет падать огонь, из земли будут бить ключи, которые затопят долины, а горы будут трястись и рассыпаться [І6, с. I57].

Возможно, что в мифологическом смысле это - древняя вода, относящаяся к зоне подземного, Нижнего мира. Вместе с этой водой на поверхность Среднего мира всплывают Кер-бальк и другие чудища Нижнего мира, которые, таким образом, являются вестниками грядущей катастрофы. В некоторых текстах особенность (нижней, подземной) воды потопа, ее катастрофичность и губительность подчеркиваются указанием на то, что она ядовита для всего живого на земле. Возможно, что «потоп, проступающий снизу», - это более архаичная, в сравнении с христианской, азиатская «модель потопа». Похожие параллели, согласно сообщению С.Ю. Неклюдова, обнаруживаются и у других азиатских народов: так, согласно калмыцкой сказочной традиции, «пуп земли» прикрыт гигантским быком; если его сдвинуть, хлынет вода и зальет землю. О воде, заливающей землю из земного отверстия, участники экспедиции под руководством С.Ю. Неклюдова записывали у дархатов (в частности, ими было зафиксировано мифологическое предание про озеро Хубсугул, которое возникло именно таким катастрофическим образом $\left.{ }^{\text {I2}}\right)$.

Другая распространенная версия эсхатологической катастрофы на Алтае - это гибель Земли в спускающемся с небес огне, в котором будет гореть вся поверхность земли и даже камни. В очистительной катастрофе водой и огнем Л.И. Шерстова обнаруживает несомненные ламаистские параллели, связанные с концуом света: гибель нынешней Вселенной представляется как ужасная катастрофа, когда «бедствия истребят почти всех живущих, после чего Земля очистится огнем и водой» [г7, с. г26; 37, с. г84].

Несомненные буддистские заимствования содержат и мифологические тексты, собранные и опубликованные в XIX в. протоиереем В.И. Вербицким

I2 Бат-Очир Дуужий. О том, как возникло озеро Хубсугул // Мифо-ритуальные традиции Монголии. Тексты интервью // Фольклор и постфольклор: структура, типология, семиотика. URL: http://www.ruthenia.ru/folklore/mongexp.htm\#207 (дата обращения: I2.I2.20I7). 
[Іо]. По моим наблюдениям, эти тексты, будучи переизданными значительным для Республики Алтай тиражом в 1993 г. (500о экз.), на волне алтайского «национально-культурного возрождения» снова были абсорбированы и реинтерпретированы живой, развивающейся мифологической традицией алтайцев. Необходимо добавить: мифологические тексты, собранные В.И. Вербицким в «Алтайских инородцах», вызывали критическое отношение уже в XIX в.: так, епископ Бийский Макарий (Невский) и переводчик при Алтайской духовной миссии, собиратель фольклора Михаил Чевалков полагали, что эти тексты нельзя считать чисто алтайскими, поскольку к алтайским воззрениям, несомненно, примешаны воззрения и имена буддийские и монгольские [ІІ, с. 305]. Вслед за ними такое же критическое отношение к миссионерскому источнику поддерживали Л.П. Потапов и В.А. Муйтуева [І9,

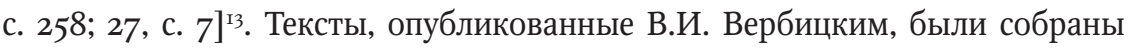
миссионером Стефаном Ландышевым от крещеного инородиа Ефима Корты, долгое время жившего среди теленгитов Чуйской степи (современная территория Кош-Агачского р-на), где, как считается, Ефим попал под влияние монголов-ламаистов $[27$, с. 7$]$. Однако во влиянии буддизма и монгольских мифологических представлений на алтайские нет ничего экстраординарного, такая рецепция в алтайской мифологии происходила неоднократно [5, с. 79; 22, с. 19-20; 30, с. 5; 36, с. I76-178], происходит она и в наше время. Поэтому

I3 Л.П. Потапов в вопросе о буддийском влиянии в текстах, опубликованных В.И. Вербицким, фактически просто повторяет А. Голубева, а В.А. Муйтуева ссылается на Л.П. Потапова. На мой взгляд, поиск «общеалтайской» или «чисто алтайской» мифологической традиции едва ли возможен, поскольку она развивалась и развивается во взаимодействии с другими (буддийскими, манихейскими, христианскими и пр.) традициями [30; 3I, c. 224; 36, с. I6I-I63]. Хотя Л.П. Потапов и В.А. Муйтуева едины в критическом отношении к миссионерскому источнику, они расходятся в оценках других источников. Так, Л.П. Потапов весьма критически относился к мифологическим текстам, записанным Л.Э. Каруновской в I929 г. от Мерея Танаша (крещеного шамана и јарлыкиы Кондратия Танашева) чуть ли не как к фантазиям [33, с. I44], но В.А. Муйтуева считала Мерея компетентным информатором, который просто не мог дать в корне неверные сведения [19, с. 26I]. Л.П. Потапов в несколько идеологическом духе тяготел к исследованию алтайского шаманизма как своего рода национальной религии саяно-алтайских народов $[27$, с. 6], теологию и ритуалы которой он пытался представить в виде стройной системы. Вероятно, по этой причине в меньшей степени его интересовали или даже вызывали критику материалы «гибридного типа», выбивающееся из общей картины «религии» алтайцев. Моя позиция близка к позиции алтайского исследователя и носителя традиции В.А. Муйтуевой, однако я иду чуть дальше, предлагая рассматривать тексты, собранные Ст. Ландышевым и В.И. Вербицким, как часть и репрезентацию локальных вариантов алтайской мифологической системы, в большей степени насыщенных заимствованиями из буддийской традиции. 
я считаю допустимым рассматривать опубликованные В.И. Вербицким тексты (пусть и содержащие очевидные ламаистские заимствования) в качестве репрезентирующих одну из возможных алтайских эсхатологических субтрадиций. Такой авторитетный современный исследователь, как Л.И. Шерстова, полагает, что было бы неверным рассматривать алтайскую мифологию / религию только как шаманистическую, и указывает на бытование алтайских мифологических представлений, в которых ламаистское мировоззрение проявляется детально и выразительно [36, с. г6г].

Буддийские элементы в алтайской эсхатологии - частный случай обширной темы взаимовлияний алтае-тюркского (изначально шаманистского) и буддийского (монгольского и тибетского) миров. Космогонические, этиологические и эсхатологические мифы, имена мифологических персонажей (Бурхан, богатыри Мангдышире и Майдере, девица Эрьке-шудюн), ритуальные предметы и практики (магические книги-судуры, подкуривание можжевельником-арчыном, возлияния молоком и маслом, жертвенники кӥре и тагылы, каменные кучи-обоо, светильники-јула, статуэтки бодхисатв) свидетельствуют о включении в алтайскую мифологию и, в частности, в эсхатологию буддистских элементов. Мангдышире и Майдере (алтайские версии имени бодхисаттвы Манджушри и имени грядущего Будды Майтреи) сражаются в конце времен с хозяином подземного мира Эрликом и его богатырями, в это же время, согласно некоторым современным эсхатологическим представлениям, скрытая магическая книга Судур бичик (алтайская калька слова «сутра») являет себя людям.

Помимо буддистских заимствований в алтайской мифоритуальной системе велико влияние культурного трансфера прежних монгольских империй на самосознание современных алтайцев. Как известно, в прошлом кочевые предки алтайцев входили в состав государств Чингисхана, его потомков, а позже были конфедератами джунгар (ойратов). По прошествии двух с лишним веков после падения Джунгарского ханства монгольская (ойратская) история присваивается исторической памятью алтайцев и воспринимается как «золотой век» их прошлого. Контекст республиканской науки дает обоснование этому присвоению, создавая перформативные описания алтайского этногенеза [32, с. 38]. «Родословие каждой алтайской семьи восходит к Ойротской эпохе», - заключает алтайский востоковед и Эл башчы алтайского народа Бронтой Бедюров [6, с. 22]. 
В контексте «низовой» повседневности алтайцы, конечно же, отделяют себя от монголов посредством таких актуальных культурных практик, как трансграничная торговля и конокрадство, а также из-за наличия «естественного» рубежа госграницы и разницы в языке и религии. Однако на уровне личного присвоения легендарной истории алтайцы связывают себя с монголами: мне неоднократно приходилось слышать о «монгольских родах» среди алтайцев (могол, ойрот, меркит, тербет, майман, тумат, чорос), среди сельского населения популярны рассказы о магической книге Судур Бичик, о горных крепостях Амурсаны и мессианско-эсхатологические представления о грядущем Шӱнй или Ойрот-Каане. По словам одного из моих информантов, «за плечами каждого алтайца стоит Чингисхан», а Телецкое озеро считается местом захоронения конницы, унесшей в глубины тайну погребения хана, который в конце времен вновь вернется к своему народу. Ревизия ойратского наследия в спорах о будущем алтайского народа - популярная тема молодежной блогосферы [34].

\section{Кыдаты как эсхатологический народ}

Эсхатологическая война - одна из самых разработанных тем в алтайской эсхатологии. Существует несколько точек зрения на то, между кем произойдет эта последняя битва. Самая популярная версия связывает ее с кыдатами - китайцами, что, по всей видимости, является исторической памятью о геноциде джунгар и на Алтае, устроенном китайцами в XVIII в. Один из моих информантов в ответ на расспросы о китайцах и последнем веке вспомнил старую алтайскую пословицу:

Эрдине сӧӧги јӱујеринде, эрдин сӧӧги Чан јеринде - ‘кости боевого коня должны лежать на поле битвы, кости хорошего мужчины должны лежать остаться в Чан' (алm). Это Чина, Китай. Значит, вся наша история - это всё было противостояние кочевников с Китаем ${ }^{14}$.

О китайцах как эсхатологическом народе можно прочесть уже в записях мифологических текстов, сделанных в г86о-х гг. миссионером Стефаном Ландышевым и изданных затем протоиереем и этнографом

I4 Записал Д.Ю. Доронин от Б.Т. Самыкова (І947 г.р., алтаец, сӧӧк Кергил, родом из с. Каспа Шебалинского р-на Республики Алтай) в г. Горно-Алтайске 3І.Іо.2ог6 г. 
В.И. Вербицким. В одном из этих текстов ${ }^{15}$ богатырь-небожитель ТюрунМузыкай, воплотившись в человека Тямаа-Тюрун, после победы над демоническим противником странствует по всей земле, пока китайский хан не узнает за его человеческим обличием божество - правителя среднего из 99 миров. В награду перед своим уходом он благословляет хана, оставляя ему эсхатологическое знание-наказ и небесную книгу о происхождении мира: «Но смотри, чтобы с тобой никто не воевал и ты ни с кем не воюй и не имей связи с другими землями. Когда будет война других с царством твоим, тогда близка будет кончина века!» [Iо, с. Іог]. Вся судьба мира - и его начало, и его конец - оказывается (в представлении алтайца-ойрота XIX в.) в руках Китая.

К текстам об эсхатологической войне с китайцами примыкают другие тексты «китайской легенды» ${ }^{16}$ на Алтае, например, завет телеутских военных вождей Абака, Мачика и / или алтайского мудреца и провидца Боора никогда не поселяться рядом с китайцами и не откочевывать в их земли. В противном случае алтайский народ исчезнет, растворившись среди китайцев.

(С.Б.) - Да, есть такое. Там не конец света, там будет война, при которой будет преобладать и, в конце концов, победит кара калык - черный народ, имеется в виду Китай. Кара кыдат, ну, то есть черный Китай победит.

(Д.Д.) - А с кем он будет воевать?

(С.Б.) - Но, наверное, со всем остальным <миром>.

(Д.Д.) - А Вы слышали такое, что будет последняя битва между Катунью и Бией?

(С.Б.) - Именно об этой битве и говорится. Но имеется в виду не в прямом смысле о битве, но еще говорят: «Не меч победит мир, мир победит труд». Имеется в виду китайский труд. Я так думаю ${ }^{17}$.

I5 Уже в г88о-е гг. этнографы комментировали мифологические тексты, собранные Ст. Ландышевым, не как чисто алтайские, поскольку к алтайским воззрениям несомненно примешаны воззрения и имена буддийские и монгольские [Іі, с. 305].

I6 Под «китайской легендой» здесь понимается комплекс мифологических представлений о китайском нашествии, кыдатах (китайцах) и о Китае как об эсхатологическом акторе. См. также о «китайской легенде» на примере русской эсхатологии: [3, с. I36-I43; 7, с. 206-215].

I7 Записал Д.Ю. Доронин от Б.Т. Самыкова (г947 г.р., алтаец, сӧӧк Кергил, родом из с. Каспа Шебалинского р-на Республики Алтай) в г. Горно-Алтайске 31.І0.2016 г. 
А о китайцах вот этот, сын Солтона - Боор, тоже предсказатель Майманов, он говорил. Рерих о нем писал, что он спрашивал: «Кто умный на Алтае?» - это Бооре. Он все время «Бооре» пишет: «Все алтайцы, все тюрки знают его имя». Вот, он что сказал. Даже и не он, а Мочик и Абак, предводители алтайские: вы не старайтесь примкнуться к китайцам, их так много, что вы себя потеряете. В смысле, как народ. Почему вы должны присоединиться к русскому, потому что когда-нибудь я свой народ разыщу по глазам, что это тюрки. А если присоединить к китайцам, вы почти ж-то визуально одинаковые, и вы там растворитесь. <..> То есть этот народ, кыдаты, говорит, китайцы - их так много, что вы среди них растворитесь. И через какое-то время я найду вас по волосам, то есть черные волосы среди чужих, среди славян. <...> Они все время остерегали: только не с китайцами! ${ }^{18}$

В одном из записанных мною в 2003 г. текстов кара-кыдаты сравниваются с пожирающей все на своем пути саранчой ${ }^{19}$; в подобных случаях эсхатологические ожидания «запускаются» геополитическими страхами на Алтае в связи с возможной китайской экспансией. Конкретным событием, актуализировавшим фольклорные представления в качестве объяснительной модели в начале XXI в., было решение о строительстве газопровода и автомагистрали через плато Укок.

В других рассказах китайцы трактовались как кара калык, кара албаты - 'черный народ’, кара-башту албаты - 'народ черноголовых', побеждающий все другие народы в конце времен. При этом некоторые информанты из с. Каспа и с. Ортолык объединили алтайцев и китайцев в этот единый эсхатологический народ-победитель, который станет править всем миром в конце веков. В этом случае последняя битва интерпретировалась как война белой и монголоидной рас.

\section{Две войны}

Весьма распространенные на Алтае предсказания сообщают о двух последних тяжелых войнах - средней войне с Запада, которую можно будет

I8 Записал Д.Ю. Доронин от Н.М. Киндиковой (1953 г.р., алтайка, сӧӧк Кара Майман) в г. Горно-Алтайске 31.10.2016 г.

I9 Представления о саранче в современных алтайских эсхатологических тестах, возможно, заимствованы из библейских мифологических образов (см., например, Исх. Іо: І2-15; Иоил. I: 6; 2: 5; Откр. 9: 3-ІІ). 
пережить, и большой, последней войне с Востока, которая сметет все.

Ну, и там, там говорилось, и вот это часто, постоянно вспоминается об этом, что война, которая придет с Запада, - это будет средняя война. А вот эта последняя война - она придет с Востока, вот примерно так. Јаан, большая война придет с Востока. Вот такие моменты были ${ }^{20}$.

Один из моих информантов, пожилой алтаец, вспоминает пересказ своей бабки того, что пророчествовал о будущих войнах и о последней войне странствующий тибетский лама, заехавший к ним в село:

Вот бабка рассказывала: «Приезжал, - говорит, - до четырнадцатого года, приезжал, - говорит, - алтаец к нам. Лама, он приехал с Тибета. В Апшуяхту приезжал, на белом коне. <... В Вот два дня он рассказывал. У него такой большой книжка, два дня, два ночи говорил он. Вот он, он свой книгу открывает - вот говорит, говорит. Вот рассказывает это вот: «Вот так вот, вот, вот, вот... чё будет». И вот его сказание все сбылось!

Вот эту, Отечественную, войну он сказал вот. Как же он сказал? Скоро, говорит, начнется война, кровь прольется. А эта империалистическая война еще не началась.

Ну, ладно, говорит, это четырнадцатый год. Потом, говорит, снова начнется движение народа, кровь прольется. Потом немного народ нормально поживет. Потом, говорит, вот это - репрессии, все это, кровь прольется, и потом большая война, говорит, начнется.

После нее народ хорошо будет жить. Но немного будет жить хорошо, говорит. А потом, говорит, сказал, черный народ начнется, вот движение, говорит, знаешь, нет? Кара албаты - это вот чеченцы, вот эти, вся вот эта кровь прольется. После этого немного [мира] будет, а потом война, говорит, начнется. Исшо, говорит, война, вот эта, третья мировая. Бабка вот так сказала. Вот эта третья мировая война! ${ }^{21}$

20 Записал Д.Ю. Доронин от С.К. Кыдыевой (1954 г.р., алтайка, сӧӧк Чагандык) в г. ГорноАлтайск 2І.10.2015 г.

2 І Записал Д.Ю. Доронин от С.В. Анакова (I96I г.р., алтаец, сӧӧк Кергил) в с. Каспа Шебалинского р-на Республики Алтай І8.09.201г г. 
В большинстве случаев «войну с Востока» информанты трактовали именно как китайское нашествие. В некоторых версиях напутствия покидающего свой народ Ойрот-Каана тоже присутствует этот мотив: «Уходя, Ойрот-Каан сказал: Если приду со стороны заката солнца - мягко пройду. Если приду со стороны восхода солнца - у мужчин отрезая кончик большого пальиа, пройду, у женщины срезая кончик груди, пройду» [2, с. 63]. «Китайская легенда» при этом интерпретируется через легенды ойротского цикла: грядущий Ойрот отождествляется с катастрофическим нашествием с Востока.

\section{Кровавые реки: традиционные мотивы в современном контексте}

Наиболее яркий мотив в описании эсхатологической битвы - кровавые реки; в зависимости от исторического контекста эсхатологическими противниками могли считаться русские или китайцы. Так, например, в некоторых текстах јарлыкчы первой четверти XX в. сообщалось о грядущей битве Ойрота и его народа с русскими при слиянии Бии и Катуни. Борьба будет столь жестока, что Катунь потечет кровью, а по Иртышу попльвут трупы убитых воинов [І2, с. I4I]. Этот же мотив можно встретить при описании кровавых битв прошлого или в предсказании Боора о последнем веке [2, c. IO9].

Приход русских и приход жыдатов сопоставляются в одном мифологическом рассказе, записанном мною от информанта-тубалара в Артыбаше: при приходе белого леса (берез) и белых людей с Алтая уходят алмысы, а если придут китайцы, то Алтай покинут его духи-ээзи. В этом эсхатологическом рассказе актуализировался мотив «уходящей чуди», мифологизировались современные геополитические страхи и текстуализировались воспоминания о советско-китайском конфликте на острове Даманский.

Подобным же образом «китайская легенда» актуализировалась во время китайско-вьетнамской войны 1979 г.: по словам информанта, на Алтае многие считали, что СССР ввяжется в конфликт на стороне Вьетнама, и Алтая, как приграничную территорию, это коснется в первую очередь. Ожидание войны с китайцами-кыдатами воспринималось алтайцами не только в политическом, но и в эсхатологическом контексте. По воспоминаниям информантов, актуализировалось эсхатологическое белге: например, красный закат интерпретировался как знак приближающейся военной 
катастрофы, бойни на Алтае. Катастрофические настроения и эсхатологические ожидания проявились в детской среде: так, в Усть-Канском районе мальчики смешанными русско-алтайскими дружескими ватагами строили в лесу стены из кольев и землянки для партизанской обороны во время ожидаемого вскоре китайского нашествия.

\section{Заключение}

Алтайская эсхатология, включая большой «мессианский компонент» и пласт воспоминаний о «золотом веке» Джунгарского правления, легендарно-исторична, поскольку связана с постоянными переживаниями, разговорами и дискуссиями алтайцев о своем великом прошлом, о судьбе, направлении и пути развития своего народа. Время алтайской эсхатологии отчасти близко «историческому» времени былины в его описании С.Ю. Неклюдовым: здесь также присутствует «осознание исторического процесса как воспроизведение старого, а не создание нового», и в описании грядущей эсхатологической эпохи «характерно обращение идеала назад, к прошлому» [2I, с. 38-39], «золотому веку» правления Шӱнӥ или Ойрот-Каана. Эсхатологическое знание о грядущем парадоксальным образом определяется легендарно-историческим прошлым конкретных событий XVIII в. (войны, междоусобица, китайское/монгольское нашествие, переселение этнических групп, бегство правителя) и даже «биографическим» временем прошлого [2I, c. 36] реально живших людей (Ойрот-Каан, Шӱнй, Амыр-Санаа, Эдиен-Каан, Боор), с которыми связывается теперь эсхатологическое знание. Как было показано, немалую роль в формировании сюжетно-мотивного фонда алтайской эсхатологии играет культурный трансфер. 


\section{Список литературы}

I Aлтай кеп-куучындар / Алтайские мифы // сост. Е.Е. Ямаева, И.Б. Шинжин. Горно-Алтайск: ИЧП «Ак Чечек», I994. 4I4 с. Алтайские исторические предания Ойротской эпохи: XVII-XIX вв. / пер. с алт. Е.В. Королёвой, гл. ред. и сост. Б.Я. Бедюров. Новосибирск: Гео, 20I4. 203 с. Ахметова М.В. Конец света в отдельно взятой стране: Религиозные сообщества постсоветской России и их эсхатологический миф. М.: ОГИ, 20Іо. 333 с. Басилов В.Н., Потапов Л.П. Тюркоязычных народов мифология // Мифы народов мира: Энциклопедия: в 2 т. М.: Сов. Энциклопедия, І988. Т. 2. С. 536-54I. Батьянова Е.П. Телеутская версия бурханизма // Этнографическое обозрение 2005. № 4. С. 70-85.

6 Бедюров Б.Я. Алтайские исторические предания Ойротской эпохи // Алтайские исторические предания Ойротской эпохи: XVII-XX вв. Новосибирск: Гео, 2014. C. 5-22.

7 Бессонов И.А. Русская народная эсхатология: история и современность. М.: Гнозис, 2014. 333 с.

8 Васубандху. Абхидхармакоша. Гл. III. / близкий к тексту пер. с тибетского Б.В. Семичева, М.Г. Брянского. Улан-Удэ: Бурят. кн. изд-во, І98о. 260 с. Васубандху. Абхидхармакоша (Энциклопедия Абхидхармы). Раздел третий: Учение о мире / пер. с санскрита Е.П. Островской, В.И. Рудого. СПб.: Изд-во «Андреев и сыновья», г994. 335 с. Вербиикий В.И. Алтайские инородцы: Сборник этнографических статей и исследований. М.: Тов-во скоропечатни А.А. Левенсон, I893. XIV, 22I с. Голубев А. Предисловие // Православный собеседник. І886. Ч. І. С. 304-306. Данилин А.Г. Бурханизм. Из истории национально-освободительного движения в Горном Алтае. Горно-Алтайск: Ак Чечек, г993. 204 с. Доронин Д.Ю. Религиозные лидеры и течения «алтайской веры»: герменевтика наследия и вариативность // Философия в современном мире: диалог мировоззрений: Материалы VI Российского философского конгресса (Нижний Новгород, 27-30 июня 2012 г.): в 3 т. Н. Новгород: Изд-во Нижегородского гос. ун-та им. Н.И. Лобачевского, 20I2. Т. І. С. 438.

I4 Доронин Д.Ю., Енчинов Э.В. Сибирское «поле» конца света: социальные ситуации алтайской эсхатологии // XII Конгресс антропологов и этнологов России: сб. материалов. Ижевск, 3-6 июля 2017 г. / отв. ред. А.Е. Загребин, М.Ю. Мартынова. М.; Ижевск: ИЭА РАН, УИИЯЛ УрО РАН, 2ОІ7. С. 383-384.

I5 Енчинов Э.В. Эсхатологические мифы в современной алтайской культуре // I Сибирский форум фольклористов: Тезисы докладов / Сер. «Памятники фольклора народов Сибири и Дальнего Востока». Новосибирск: ООО «Академиздат», 2016. C. $156-158$. 
Клемени Д.А. Из впечатлений во время летней поездки в Алтай в 1904 году // Известия ИРГО / под ред. А.А. Достоевского. І905. Вып. І, кн. 6г. C. I55-I59.

I7 Кочетов А.Н. Ламаизм. М.: Наука, І973. г99 с.

I8 Львова Э.Л., Октябрьская И.В., Сагалаев А.М., Усманова М.С. Традиционное мировоззрение тюрков Южной Сибири. Пространство и время. Вещный мир. Новосибирск: Наука. Сибирское отд., І988. 224 с.

I9 Муйтуева В.А. О сборнике В.И. Вербицкого «Алтайские инородцы» // Алтайские инородцы. Горно-Алтайск: Ак-Чечек, г993. С. 257-269. Неклюдов С.Ю. Кальпа // Мифы народов мира: Энциклопедия: в 2 т. М.: Сов. Энциклопедия, г987. Т. г. С. І96. Неклюдов С.Ю. Поэтика эпического повествования: пространство и время. М.: Форум, 20I5. 215 c. Несказочная проза алтайцев // Памятники фольклора народов Сибири и Дальнего Востока / сост. Н.Р. Ойноткинова, И.Б. Шинжин, К.В. Яданова, Е.Е. Ямаева. Новосибирск: Наука, 20II. Т. 30.565 с.

23 Образцы народной литературы тюркских племен, живущих в Южной Сибири и Дзунгарской степи, собранные В.В. Радловым. СПб.: Тип. Императорской Академии наук, І866. Ч. г: Поднаречия Алтая. С. І13-I59.

24 Ойноткинова Н.Р. Эсхатологические мифы алтайцев: «чудесный мир» перед концом света // Мельниковские чтения: Материалы Седьмой межрегиональной науч.-практ. конф. (Новосибирск, І9 февраля 2015 г.) / науч. ред. Н.В. Леоновой. Новосибирск: НГОНБ, 2ОI5. С. 44-49.

25 Ойноткинова Н.Р., Ямаева Е.Е. Несказочная проза алтайцев / сост. Н.Р. Ойноткинова, И.Б. Шинжин, К.В. Яданова, Е.Е. Ямаева. Новосибирск: Наука, 20II. С. II-46.

26 Островская Е.П., Рудой В.И. Проблемы исследования буддийской космологии // Васубандху. Абхидхармакоша (Энциклопедия Абхидхармы). Раздел третий: Учение о мире. СПб.: Изд-во «Андреев и сыновья», г994. С. 6-66.

27 Потапов Л.П. Алтайский шаманизм. Л.: Наука, І99г. 319 с.

28 Радлов В.В. Из Сибири: Страницы дневника. М.: Наука. Главная редакция восточной литературы, г989. 749 с.

29 Религиозные деноминации в Республике Алтай / отв. ред. Н.О. Тадышева. ГорноАлтайск: ООО «Горно-Алтайская типография», 2015. 479 с.

30 Сагалаев А.М. Мифология и верования алтайцев. Центральноазиатские влияния. Новосибирск: Наука, І984. І2г с.

3I Стеблева И.В. К реконструкции древнетюркской религиозно-мифологической системы // Тюркологический сборник. М.: Наука, І97І. С. 213-226. 
32 Тадина Н.А. «Ойрот» как символ государственности в этническом сознании алтайцев // Единая Калмыкия в единой России: через века в будущее (матер. конф.). Элиста: ЗАО «НПП «Джангар», 2009. Ч. І. С. 424-427.

33 Токарев С.А. Пережитки родового культа у алтайцев // Труды Института этнографии им. Н.Н. Миклухо-Маклая. Новая серия / отв. ред. С.П. Толстов. М.; Л., І947. T. I. C. 139-I58.

34 Торбоков A. Земля ойратов - Алтай // ARD: портал деловой информации. 3.02.2015. URL: http://asiarussia.ru/articles/6008/ (дата обращения: I2.I2.20I7).

35 Тюхтенева С.П. Земля. Вода. Хан Алтай: этническая культура алтайцев в XX в. Элиста: Изд-во КалмГУ, 2009. 167 с.

36 Шерстова Л.И. Бурханизм: истоки этноса и религии. Томск: Томский гос. ун-т, 20IO. 285 c.

37 Шерстова Л.И. Эсхатология раннего бурханизма: из опыта реконструкции традиционного этнического самосознания // Вестник Томского государственного университета. История. 20I3. № 3 (23). С. I8I-I85.

38 Ябыштаев Т.С. От национального движения алтайцев к образованию Республики Алтай // История и современность Республики Алтай (матер. конф.). ГорноАлтайск: Комитет по делам архивов Республики Алтай, 20I2. С. II-I4. 


\section{References}

Altaj kep-kuuchyndar, Altajskie mify [Altay kep-kouchinga, Altai myths], comp.

E.E. Yamaeva, I.B. Shinzhin. Gorno-Altajsk, IChP “Ak Chechek” Publ., I994. 4I4 p. (In Russ.)

Altajskie istoricheskie predaniya Ojrotskoj epohi: XVII-XIX vv. [Altai historical legends Oyrotskih epoch: $18^{\text {th }}-19^{\text {th }}$ centuries], trans. from Altaic by E.V. Korolyovaya, ed. B.Ya Bedyurov. Novosibirsk, Geo Publ., 20I4. 203 p. (In Russ.)

Ahmetova M.V. Konec sveta v otdel'no vzyatoj strane: Religioznye soobshchestva postsovetskoj Rossii i ih eskhatologicheskij mif [The end of the world in a single country: Religious communities of post-Soviet Russia and their eschatological myth]. Moscow, OGI Publ., 20IO. 333 p. (In Russ.)

Basilov V.N., Potapov L.P. Tyurkoyazychnyh narodov mifologiya. Mify narodov mira: Enciklopediya: $\mathbf{2} 2 \mathrm{t}$. [Myths of the peoples of the world: encyclopedia: in 2 vols.] Moscow, Sovetskaya Enciklopediya Publ., 1988, vol. 2, pp. 536-54I. (In Russ.) Bat'yanova E.P. Teleutskaya versiya burhanizma [Teleut version of Burganism]. Etnograficheskoe obozrenie [Ethnographic review], 2005, no 4, pp. 70-85. (In Russ.) Bedyurov B.Ya. Altajskie istoricheskie predaniya Ojrotskoj epohi [Altai historical legends of the Oyrotskaya epoch]. Altajskie istoricheskie predaniya Ojrotskoj epohi: XVII$X X v v$. [Altai historical legends Oyrotskih epoch: $17^{\text {th }}-2 \mathrm{O}^{\text {th }}$ centuries] Novosibirsk, Geo Publ., 20I4, pp. 5-22. (In Russ.)

7 Bessonov I.A. Russkaya narodnaya eskhatologiya: istoriya i sovremennost'. [Russian folk eschatology: history and modernity]. Moscow, Gnozis Publ., 20I4. 333 p. (In Russ.)

8 Vasubandhu. Abhidharmakosha. Gl. III. [Abhidharmakośakārikā. Ch. III], trans. from Tibetan by B.V. Semichev, M.G. Bryansky. Ulan-Ude, Buryat. kn. izd-vo Publ., I980. 260 p. (In Russ.) Vasubandhu. Abhidharmakosha (Enciklopediya Abhidharmy). Razdel tretij: Uchenie o mire [Abhidharmakosha (Encyclopedia of Abhidharma). Section three: the Doctrine of peace], trans. from Sanskrit E.P. Ostrovskay, V.I. Rudov. St. Petersburg, Izd-vo “Andreev i synov'ya” Publ., I994. 335 p. (In Russ.) Verbickij V.I. Altajskie inorodcy: Sbornik etnograficheskih statej i issledovanij [Altai foreigners: Collection of ethnographic articles and studies]. Moscow, Tovarishchestvo skoropechatni A.A. Levenson Publ., I893. XIV, 221 p. (In Russ.) Golubev A. Predislovie [Foreword]. Pravoslavnyj sobesednik [The Orthodox interlocutor], I886, ch. I, pp. 304-306. (In Russ.) Danilin A.G. Burhanizm. Iz istorii nacional'no-osvoboditel'nogo dvizheniya v Gornom Altae [Burkhanism. From the history of the national liberation movement in the Altai Mountains]. Gorno-Altajsk, Ak Chechek Publ., I993. 204 p. (In Russ.)

I3 Doronin D.Yu. Religioznye lidery i techeniya "altajskoj very”: germenevtika naslediya i variativnost' [Religious leaders and the trends of "altaic belief": the hermeneutics of the heritage and variativity]. Filosofiya $v$ sovremennom mire: dialog mirovozzrenij: 
Materialy VI Rossijskogo filosofskogo kongressa (Nizhnij Novgorod, 27-30 iyunya 2012 g.): v 3 t. [Philosophy in the modern world: dialogue of worldviews: Proceedings of the $4^{\text {th }}$ Russian Philosophical Congress (Nizhny Novgorod, June 27-30, 20I2): in 3 vols.] N. Novgorod, Izd-vo Nizhegorodskogo gosuniversiteta im. N.I. Lobachevskogo Publ., 20I2, vol. I, p. 438. (In Russ.) Doronin D.Yu., Enchinov E.V. Sibirskoe “pole” konca sveta: social'nye situacii altajskoj eskhatologii [Siberian apocalyptic "field": social situations of Altai eschatology]. XII Kongress antropologov i etnologov Rossii: sb. materialov. Izhevsk, 3-6 iyulya $2017 \mathrm{~g}$. [The $12^{\text {th }}$ Congress of anthropologists and ethnologists of Russia: proceedings. Izhevsk, 3-6 July 20I7], eds. A.E. Zagrebin, M.Yu. Martynova. Moscow; Izhevsk, IEA RAN, UIIYaL UrO RAN Publ., 20I7, pp. 383-384. (In Russ.)

Enchinov E.V. Eskhatologicheskie mify v sovremennoj altajskoj kul'ture [Eschatological myths in contemporary Altai culture]. I Sibirskij forum fol'kloristov: Tezisy dokladov [I ${ }^{\text {st }}$ Siberian forum of folklorists: Abstracts]. Novosibirsk, OOO “Akademizdat" Publ., 20I6, pp. I56-I58. (In Russ.) Klemenc D.A. Iz vpechatlenij vo vremya letnej poezdki v Altaj v I904 godu [The glimpses of the summer trip to Altai in I904]. Izvestiya IRGO [Proceedings of IRGO], ed. A.A. Dostoevsky. I905, issue I, book 6I, pp. I55-I59. (In Russ.)

I7 Kochetov A.N. Lamaizm [Lamaism]. Moscow, Nauka Publ., I973. I99 p. (In Russ.)

I8 L'vova E.L., Oktyabr'skaya I.V., Sagalaev A.M., Usmanova M.S. Tradicionnoe mirovozzrenie tyurkov Yuzhnoj Sibiri. Prostranstvo i vremya. Veshchnyj mir [Traditional world outlook of the Turki in South Siberia. Space and time. Material world]. Novosibirsk, Nauka. Sib. otd-nie Publ., I988. 224 p. (In Russ.)

I9 Mujtueva V.A. O sbornike V.I. Verbickogo "Altajskie inorodcy” [On V.I. Verbic]. Altajskie inorodcy [Altai aliens]. Gorno-Altajsk, Ak-Chechek Publ., I993, pp. 257-269. (In Russ.)

Neklyudov S.Yu. Kal'pa. Mify narodov mira: Enciklopediya: $v 2 t$. [Myths of the peoples of the world: encyclopedia: in 2 vols.]. Moscow, Sovetskaya Enciklopediya Publ., I987, vol. I, p. I96. (In Russ.)

2I Neklyudov S.Yu. Poetika epicheskogo povestvovaniya: prostranstvo i vremya [Poetics of epic narrative: space and time]. Moscow, Forum Publ., 2015. 215 p. (In Russ.)

22 Neskazochnaya proza altajcev [Non-Fairytalish Fiction of the Altai People]. Pamyatniki fol'klora narodov Sibiri i Dal'nego Vostoka [Folklore monuments of the peoples of Siberia and the Far East], comp. N.R. Ojnotkinova, I.B. Shinzhin, K.V. Yadanova, E.E. Yamaeva. Novosibirsk, Nauka Publ., 20II. Vol. 30. 565 p. (In Russ.)

23 Obrazcy narodnoj literatury tyurkskih plemen, zhivushchih v Yuzhnoj Sibiri i Dzungarskoj stepi, sobrannye V.V. Radlovym [Samples of folk literature of the Turkic tribes living in southern Siberia and Dzungarian steppe collected by V. V. Radlov]. St. Petersburg, Tipografiya Imperatorskoj Akademii nauk Publ., I866. Ch. I: Podnarechiya Altaya, pp. II3-I59. (In Russ.) 
24 Ojnotkinova N.R. Eskhatologicheskie mify altajcev: "chudesnyj mir" pered koncom sveta. Mel'nikovskie chteniya: Materialy Sed'moj mezhregional'noj nauch.-prakt. konf. (Novosibirsk, I9fevralya 20I5 g.) [Melnikovsky reading: proceedings of the Seventh scientific conference (Novosibirsk, I9 February 2015)], ed.

N.V. Leonovoj. Novosibirsk, NGONB Publ., 20I5, pp. 44-49. (In Russ.)

25 Ojnotkinova N.R., Yamaeva E.E. Neskazochnaya proza altajcev [Fairy-tale prose of the Altai people], comp. N.R. Ojnotkinova, I.B. Shinzhin, K.V. Yadanova, E.E. Yamaeva. Novosibirsk, Nauka Publ., 20II, pp. II-46. (In Russ.)

26 Ostrovskaya E.P., Rudoj V.I. Problemy issledovaniya buddijskoj kosmologii [The aspects of the study of the Buddhist cosmology]. Vasubandhu. Abhidharmakosha (Enciklopediya Abhidharmy). Razdel tretij: Uchenie o mire [Vasubandhu. Abhidharmakosha (Encyclopedia of Abhidharma). Section three: the Doctrine of peace]. St. Petersburg, Izd-vo “Andreev i synov'ya” Publ., I994, pp. 6-66. (In Russ.) Potapov L.P. Altajskij shamanism [Altai shamanism]. Leningrad, Nauka Publ., I99I. 3I9 p.

28 Radlov V.V. Iz Sibiri: Stranicy dnevnika [From Siberia: the pages of the diary]. Moscow, Nauka. Glavnaya redakciya vostochnoj literatury Publ., I989. 749 p. (In Russ.)

29 Religioznye denominacii $v$ Respublike Altaj [Religious denominations in the Republic of Altai], ed. N.O. Tadysheva. Gorno-Altajsk, OOO “Gorno-Altajskaya tipografiya” Publ., 20I5. 479 p. (In Russ.)

30 Sagalaev A.M. Mifologiya i verovaniya altajcev. Central'no-aziatskie vliyaniya [Mythology and beliefs of the Altai people. Central Asian influences]. Novosibirsk, Nauka Publ., I984. I2I p. (In Russ.)

3I Stebleva I.V. K rekonstrukcii drevnetyurkskoj religiozno-mifologicheskoj sistemy [On the recontruction of the Old Turkian religious and mythological systems]. Tyurkologicheskij sbornik [Turkological collection]. Moscow, Nauka Publ., I97I, pp. 213-226. (In Russ.)

32 Tadina N.A. "Ojrot" kak simvol gosudarstvennosti v etnicheskom soznanii altajcev ["Ojrot" as a symbol in the national and ethnical consciousness of the Altai people]. Edinaya Kalmykiya v edinoj Rossii: cherez veka v budushchee (mater. konf.) [United Kalmykia in the unified Russia: across ages and towards the future (conference proceedings)]. Elista, ZAO “NPP «Dzhangar” Publ., 2009, ch. I, pp. 424-427. (In Russ.)

33 Tokarev S.A. Perezhitki rodovogo kul'ta u altajcev [The remnants of the ancestral cult of the Altai people]. Trudy Instituta etnografii im. H.H. Mikluho-Maklaya. Novaya seriya [Proceedings of the Institute of Ethnography. H. H. Mikluho-Maclay. New series], ed. S.P. Tolstov. Moscow, Leningrad, I947, vol. I, pp. I39-I58. (In Russ.)

34 Torbokov A. Zemlya ojratov - Altaj [The world of Ojrot - Altai]. ARD: portal delovoj informacii [ARD: business information portal]. 3.02.2015. Available at: http:// asiarussia.ru/articles/6008/ (Accessed I2 December 20I7). (In Russ.) 
35 Tyuhteneva S.P. Zemlya. Voda. Han Altaj: etnicheskaya kul'tura altajcev v XX v. [Land. Water. Khan Altai: ethnic culture of the Altai in the $20^{\text {th }}$ century] Elista, Izd-vo KalmGU Publ., 2009. I67 p. (In Russ.)

36 Sherstova L.I. Burhanizm: istoki etnos a i religii [Burkhanism: the origins of ethnicity and religion]. Tomsk, Tomskij gosudarstvennyj universitet Publ., 20IO. 285 p. (In Russ.)

37 Sherstova L.I. Eskhatologiya rannego burhanizma: iz opyta rekonstrukcii tradicionnogo etnicheskogo samosoznaniya [Eschatology of the early Burhanism: reconstructing traditional etnical self-consciousness]. Vestnik Tomskogo gosudarstvennogo universiteta. Istoriya, 20I3, no 3 (23), pp. I8I-I85. (In Russ.)

38 Yabyshtaev T.S. Ot nacional'nogo dvizheniya altajcev k obrazovaniyu Respubliki Altaj [From the national movement of the Altai people towards Altai republic]. Istoriya i sovremennost' Respubliki Altaj (mater. konf.) [History and modernity of Altai Republic (conference proceedings)]. Gorno-Altajsk, Komitet po delam arhivov Respubliki Altaj Publ., 20I2, pp. II-I4. (In Russ.) 
УДК 82I.III-93

ББК 83.3(4Вел) 5 I

\section{LUMIÈRES АНГЛИЙСКОЙ КРИТИКИ}

(C) 2018 г. Н.И. Рейнгольд

Российский государственный гуманитарный университет,

Москва, Россия

Дата поступления статьи: о5 марта 2018 г. Дата публикации: 25 сентября 2018 г.

DOI: I0.22455/2500-4247-20I8-3-3-304-354

Аннотация: Настоящая публикация включает вступительную статью и перевод источника - «Жизнеописания Свифта» из книги «Жизнеописания наиболее выдающихся английских поэтов» (I78г) Сэмюэла Джонсона (I709-I784), крупнейшего английского критика и биографа XVIII в. Автор статьи указывает на парадоксальный случай, связанный с рецепцией С. Джонсона в России: его главный труд в области литературно-биографической критики так и не был переведен на русский язык. В статье приводятся факты многочисленных некритических заимствований отечественными критиками и литературоведами $\mathrm{XIX-XX} \mathrm{вв.} \mathrm{из} \mathrm{джонсоновских} \mathrm{«Жизнеописаний».} \mathrm{Отмечен} \mathrm{универсализм} \mathrm{личности}$ С. Джонсона - биографа, критика, эссеиста, лексикографа, драматурга, поэта, составителя комментариев, автора памфлетов, мастера эпистолярного жанра, наконец, христианина, оставившего после себя собрание молитв и размышлений. Дается описание источника, его места в наследии С. Джонсона и, шире, в английской культуре. Подчеркивается, что именно С. Джонсон создал литературнобиографическое и критическое эссе в Англии эпохи Просвещения. Говоря о подготовке к изданию в серии «Литературные памятники» первого полнотекстового перевода на русский язык «Жизнеописаний наиболее выдающихся английских поэтов», автор статьи приводит в качестве примера публикуемый ниже перевод «Жизнеописания Свифта», сопровождаемый комментариями.

Ключевые слова: Сэмюэл Джонсон, Джонатан Свифт, английская литература XVIII в., Просвещение, жанр жизнеописания, жанр биографии, литературная критика, исторический контекст, комментирование текста, перевод источников.

Информация об авторе: Наталья Игоревна Рейнгольд - доктор филологических наук, доктор философии по английской литературе (Великобритания), профессор, заслуженный профессор Российского государственного гуманитарного университета, Российский государственный гуманитарный университет, Миусская пл., 6, г25993 г. Москва, Россия.

E-mail: n.reinhold@mail.ru

Для цитирования: Рейнгольд Н.И. Lumières английской критики // Studia Litterarum. 20I8. T. 3, № 3. C. 304-354. DOI: 10.22455/2500-4247-2018-3-3-304-354 


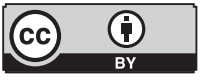

This is an open access article distributed under the Creative Commons Attribution 4.0 International (CC BY 4.0)
LUMIĖRES OF THE ENGLISH CRITICISM (Introductory Article). Samuel Johnson. Swift (From The Lives of the Most Eminent English Poets). Translated into Russian, with Notes

(C) 20I8. N.I. Reinhold Russian State University for the Humanities, Moscow, Russia Received: March 05, 2018

Date of publication: June 25, 2018

Abstract: This publication includes the introductory article and the translation of the source text, namely, "The Life of Swift" from The Lives of the Most Eminent English Poets (I78I) by Samuel Johnson (I709-I784), a great eighteenth-century English literary critic and biographer. The author points at the paradox-like case of Samuel Johnson's reception in Russia, with his magnum opus hasing been left untranslated into Russian. The article draws numerous examples of the unacknowledged borrowings from Johnson's Lives made by the nineteenth-and twentieth-century Russian critics and scholars. The article highlights various aspects of Johnson's versatile activities as a biographer and critic, an essay master and a compiler of the dictionary, a playwright and a poet, an editor and a publisher of commentaries and notes, a writer of pamphlet and letter writing, and last but not least, a good Christian who had left a collection of prayers and meditations. The article provides a detailed description of the source text in question, and defines its status among Johnson's works and in English letters at large. The author of the article claims Johnson to be the true founder of the literary-cum-biographical-cum-critical essay eighteenth-century in England. She mentions the forthcoming publication of the first full-text translation of The Lives of the Most Eminent English Poets into Russian in the book series "Literaturnye pamyatniki," and gives as a sample the translation of "The Life of Swift," accompanied by notes.

Keywords: Samuel Johnson, Jonathan Swift, eighteenth-century English literature, the age of Enlightenment, a life, the genre of a biography, literary criticism, historical context, text commenting, translation.

Information about the author: Natalya I. Reinhold, DSc in Philology, PhD in English (United Kingdom), Professor and Head of the Department for Translation Studies, Interpreting and Translation at the Russian State University for the Humanities, Miusskyi Sq., 6, I25993 Moscow, Russia.

E-mail:n.reinhold@mail.ru

For citation: Reinhold N.I. Lumières of the English criticism. (Introductory Article). Samuel Johnson. Swift (From The Lives of the Most Eminent English Poets). Translated into Russian, with Notes Studia Litterarum, 2018, vol. 3, no 3, pp. 304-354. (In Russ.) DOI: I0.22455/2500-4247-2018-3-3-304-354 
Общее место о пользе знания источников наводит порой на парадоксальные случаи. Например, произведение, значимое в истории одного народа и в мировой культуре, остается непереведенным, не освоенным другим народом, другой культурой. Кто-то сразу возразит: а в чем беда? Разве в мире все переведено? Разве нет текстов, которые, будучи важнейшими для прошлого и настоящего одного народа, совершенно не известны в других странах? Разве не в этом дополнительная ценность перевода как деятельности, которая позволяет, по мысли Вольфганга Изера, снова и снова, независимо от времени, забрасывать «рекурсивную петлю» в «черный ящик» «межкультурного пространства» [5, р. 32, 34]? Разве не в этом прелесть открытия? Свобода перевода и переводчика, наконец? Да, разумеется. Только речь о другом. Об авторитетных произведениях, которые, оставаясь непереведенными на какой-либо иностранный язык, постоянно присутствуют в общих разговорах. И при этом как источники остаются за кадром. Каждый такой casus интересен своей историей. Почему не перевели и не переводят, хотя постоянно используют, цитируют, не называя исходный текст и его автора? Во многом это вопросы историко-социологические, обсуждение их требует фактов, статистики, изучения рецепции и т. д. Об одном из таких casus речь в публикуемом материале.

Описывая Просвещение в Англии, отечественное литературоведение обычно ссылается на Джозефа Аддисона и Ричарда Стила, пионеров жанра английского нравоучительного эссе. Их воспитательные «опыты» (essays) печатались в газетах «The Tatler» (Болтун) и «The Spectator» (Зритель) в I709-I7І4 гг. Литературоведы обычно сопровождают эту ссылку указанием, что предшественниками Аддисона и Стила на почве нравоучительно- 
го эссе были итальянцы Каза и Кастильоне, деятели эпохи Возрождения. Источник этой параллели, как правило, не называют: сама ссылка давно стала общим местом. Имя автора, если и было известно, давно стерлось в памяти.

Другой пример. О знании биографии Джона Милтона русскими читателями XIX в. можно судить по предисловиям к переводам «Потерянного рая». Так, полный прозаический перевод П.А. Каншина знаменитой поэмы, опубликованный в Санкт-Петербурге в г89г г., предваряет обширная вступительная статья «Мильтон. Его жизнь и произведения». Предисловие изобилует подробностями. Например, Милтон - потомок аристократического рода, предки его некогда владели большим поместьем в графстве Оксфорд, во времена войны Алой и Белой Розы их имущество было конфисковано. «Мильтон первый из всех англичан после возрождения наук и искусств довел до совершенства писание латинских стихов, которые у него отличаются большим изяществом» [2, с. 3]. «Он [Милтон. - H.P.] безотлучно пробыл к Кембридже целых семь лет, если не считать короткого промежутка времени, на который он, как говорят, за какую-то мелкую провинность удален был из учебного заведения» [2, с. 5]. «Перед отъездом он [Милтон. - H.P.] получил от знаменитого сэра Генри Уоттона полезный совет "abbere i pensieri soretti ed il viso sciolto", то есть держать свои мысли про себя, сохраняя при этом непринужденный и откровенный вид» [2, с. 7]. И так далее. За сто с лишним лет, прошедших со времени опубликования в I777 г. первого русского перевода «Потерянного рая» Милтона до I890-х гг., в России накоплено немало знаний о жизни создателя поэмы, и в конце XIX в. источники их еще были известны. Сегодня уже нет. Мы не знаем, откуда взяты эти факты.

Другой пример: Джонатан Свифт. У нас «Путешествия Гулливера» давно перешли в разряд детской литературы. Представляя же Свифта советским детям, авторы предисловий к этой книге считали необходимым упомянуть фразу, брошенную смельчаком Свифтом одному важному священнику: «Да стоило мне только палец поднять, и толпа разорвала бы вас на куски!» Понятно, что Свифта чуть ли не с восхищением изображали атеистом, но вопросы: откуда эта фраза? каков источник? что были за обстоятельства? - опять-таки остаются риторическими. Впрочем, в советское время трудно было ожидать более или менее полной биографии Свифта - настоятеля собора Св. Патрика в Дублине. Обратимся в таком случае к 
русским биографиям Свифта конца XIX в. Как тогда представляли Свифта широкой аудитории русских читателей? Например, В.И. Яковенко, автор биографического очерка о Свифте, опубликованного в I89г г. в библиотеке «Жизнь замечательных людей», явно не испытывал пиетета перед Свифтом и не считал нужным удалять из его биографии неудобные места. Так, Яковенко ссылается на скептическое мнение Джона Драйдена о поэтических способностях Свифта: «Драйден, литературный диктатор того времени и родственник Свифта, по поводу их [пиндарических од Свифта. - H.P.] сказал, между прочим: “Кузен Свифт, вы никогда не будете поэтом”. Слова эти сильно задели Свифта и он никогда не забывал жестокой обиды, нанесенной ему Драйденом» [4, с. 2г]. Описывая политическую деятельность Свифта, Яковенко приводит факты и цифры: например, памфлет Свифта «Поведение союзников» «имел необычайный успех. <..> Опубликованный 27 ноября [І7І2 г. - H.P.], он уже в декабре вышел вторым изданием, которое разошлось в четыре часа. В течение каких-нибудь двух месяцев было продано ІІ тысяч экземпляров» [4, с. 70-7I]. Личная жизнь Свифта описана с запоминающимися деталями: на предложение Свифта его возлюбленной Стелле обнародовать их брак, она ответила отказом: «Слишком поздно» [4, c. 48]; а, говоря о предчувствии Свифтом своей смерти, Яковенко приводит красочное сравнение: «Глядя однажды на дерево с усохшей верхушкой, он сказал: “Смерть так же поразит прежде всего мою голову”. Слова эти оказались до некоторой степени пророческими» [4, с. 88]. Список примеров заимствований можно продолжить, но вернемся к нашему вопросу: каков их источник? И, в отличие от предыдущих случаев с Аддисоном, Стилом и Милтоном, Яковенко приводит список источников. В нем, в частности, указаны «Жизнь Джонатана Свифта» Генри Крэйка («The Life of Jonathan Swift» by Henry Craik) и «Свифт» («Swift») Лесли Стивена (Leslie Stephen). Желание В.И. Яковенко опереться на труды современных ему иностранных авторов понятно (мы и сегодня отдаем предпочтение «свежим» источникам при подготовке публикаций). Но здесь у нас, повторяю, особый случай.

Особым его делает общий для всех приведенных выше примеров источник. Это «Жизнеописания выдающихся английских поэтов» Сэмюэла Джонсона.

Перефразируя высказывание Лабрюйера о любви, можно сказать: «Для русских Сэмюэл Джонсон подобен привидению: его упоминают во всех 
разговорах, но никто его не видел». За двести с лишним лет, прошедших со смерти С. Джонсона, на русском языке появилось всего несколько переводов из его трудов. Благодаря им мы знаем лишь Джонсона-лексикографа. Филологи цитируют его высказывания «по Босуэллу». Авторы предисловий к изданиям Шекспира, Свифта, Поупа и других пользуются его суждениями, порой не зная (или не желая знать), что принадлежат они Сэмюэлу Джонсону. Удивительна его судьба «на берегах Волги»! Хотя в докторе Джонсоне англичане в первую очередь видят родоначальника литературной критики, основателя жанра биографии, создателя гуманитарной науки, а уж потом единоличного творца словаря английского языка... в таком качестве он практически не известен русским из-за отсутствия переводов.

Напомню несколько фактов.

Сэмюэл Джонсон (Samuel Johnson, I709-I784) - центральная фигура английского Просвещения, гуманитарной мысли XVIII в. И сегодня Сэмюэл Джонсон - самый цитируемый после Библии и Шекспира английский автор.

Биограф, критик, эссеист, лексикограф, драматург, поэт, редактор, составитель комментариев и примечаний, автор политических памфлетов, мастер эпистолярного жанра, наконец, христианин, оставивший после себя собрание молитв и размышлений, - все это Сэмюэл Джонсон, или доктор Джонсон, как уважительно называют его англичане. Его «Жизнеописания выдающихся английских поэтов», его труд по изданию и комментированию пьес Шекспира, его деятельность эссеиста, составителя словаря английского языка - все это вехи развития английской литературы и культуры в целом. Универсализм и масштаб личности С. Джонсона объясняют его славу. В нем сошлись широта мысли человека Просвещения, английский прагматизм и чувство достоинства, умение здраво судить обо всем - в том числе и о своей стране, ее истории в общем развитии народов, - талант поэта и проницательность критика, безграничная любознательность, позволявшая ему писать на любые темы, - от овощей и китайской архитектуры до тирании и гэльского языка. Как заметил Дж. Бейли, «Сэмюэл Джонсон - это основа нации (“a national institution”)».

Сегодня многие европейцы знают о Сэмюэле Джонсоне благодаря его биографу и другу Джеймсу Босуэллу (James Boswell, I740-I795). Написанная Босуэллом биография «The Life of Samuel Johnson, Comprehending an 
Account of his Studies and Numerous Works, in Chronological Order», впервые увидевшая свет в I79I г., через семь лет после смерти Джонсона, сохранила для потомков многие его высказывания и, возможно, главное: обаяние личности. Кстати, первым познакомил русского читателя с Босуэллом, автором жизнеописания Сэмюэла Джонсона, еще в г850-е гг. А.В. Дружинин [г].

Самое значительное произведение в литературном наследии критика - это «Жизнеописания наиболее выдающихся английских поэтов, с критическими наблюдениями над их трудами» (“The Lives of the Most Eminent English Poets; with Critical Observations of Their Works”, I78I). Место «Жизнеописаний» в английской литературе и критике трудно переоценить. Это основательный труд об английской поэзии XVII-XVIII вв. В нем Джонсону удалось решить одновременно несколько больших задач. Он создал форму критического обсуждения жизни и творчества поэта, установил иерархию для нескольких поколений английских поэтов. Определил магистральные и второстепенные линии развития поэзии. Предложил критерии суждения о поэзии с опорой на греко-римскую традицию и европейскую риторику XVI-XVIII вв. Прочертил историческую линию развития английского языка и в связи с нею - английской поэзии. Чувство и знание истории у Джонсона безупречны. Его оценки отличают ясность, здравость и толерантность. Весы джонсоновских суждений редко склоняются в сторону хвалы, чаще уравновешиваются указанием на промахи и ошибки, случающиеся и у самых крупных поэтов. Взгляд соколиный - видит все: от крупных до малейших деталей. К Джонсону полностью применима та характеристика идеального критика, которую предложил Т.С. Элиот в эссе «Мэтью Арнолд»: «Обозревающий картину критик обязан пристально вглядеться в даль, сквозь мощную призму своей мысли суметь различить на горизонте еле заметные фигурки и затем сравнить с ними и мельчайшие явления вблизи. Он должен верно оценить обстановку и масштабы окружающих нас объектов в едином целом обширной панорамы» [3, с. I73].

Вот уже 250 лет «Жизнеописания» Джонсона для англоязычного мира - основной вклад в критику поэзии.

В книгу входят 52 литературно-биографических и критических очерка об английских поэтах XVII-XVIII вв.; из них русскому читателю - не специалисту, но образованному читателю, филологу, студенту - известны от силы десять-двенадцать фигур. 
Первое десятитомное издание I779 г. называлось «Предисловия, биографические и критические, к произведениям английских поэтов» («Prefaces, Biographical and Critical, to the Works of the English Poets») и входило в 65-томное издание сочинений английских поэтов.

Первое же издание собственно «Жизнеописаний выдающихся английских поэтов» в четырех томах увидело свет в I78г г. [6].

Второе четырехтомное издание I783 г. - новая, уточненная и последняя прижизненная редакция предыдущего издания I78г г. Это издание автор считал окончательным. В дальнейшем этот памятник переиздавали сотни раз полностью и выборочно. Кстати, первое издание с укороченным названием «Жизнеописания английских поэтов» («The Lives of the English Poets») вышло в г8го г.

Обращает на себя внимание содержательный принцип, лежащий в основе композиции издания. Первое жизнеописание в каждом из четырех томов посвящено крупнейшему, самому выдающемуся, по мысли С. Джонсона, поэту данной школы, данного направления в поэзии. Так, первый том открывает жизнеописание Авраама Коули (другое написание - Каули) (Abraham Cowley, I6I8-I667), основателя (согласно авторскому взгляду) метафизической поэзии в английской литературе XVII в. Второй том начинается с жизнеописания Джона Драйдена (John Dryden, I63I-I700), крупнейшего драматурга, поэта, переводчика, «отца английской критики» (the father of English criticism). Третий том открывает жизнеописание Мэтью Прайора (Matthew Prior, I664-I72I), поэта по всем меркам неординарного, сочетавшего в себе государственный ум и изобретательность стихотворца. Четвертый том начинается с жизнеописания Александра Поупа (Alexander Pope, I688-I744), крупнейшего английского классициста, центральной фигуры в английской поэзии эпохи Раннего Просвещения. Таким образом, в распределении литературно-биографического материала по четырем томам виден взгляд C. Джонсона на основные вехи развития английской поэзии XVII-XVIII вв.

В каждом «Жизнеописании» Джонсон добивается, во-первых, биографической полноты. Он собирает из разных источников (письменных и устных) свидетельства жизни своего героя, каждый раз устанавливая их достоверность. Это образец английского подхода к биографии - стремление к полноте сведений, фактов, вплоть до воспроизведения бытовых документов вроде счетов, рецептов и т. д. 
Вторая важная и ценная сторона «Жизнеописаний» - исторический контекст. Обсуждение творчества поэтов XVII в. сопровождается многими интереснейшими подробностями общественной, политической, религиозной жизни Англии эпохи гражданской войны, правления Кромвеля и периода Реставрации. Например, Джонсон цитирует речь Эдмунда Уоллера в Парламенте - этот документ был надолго изъят из официальной истории Парламента; описывает разные лагеря, разные позиции деятелей того времени, взаимоотношения поэта и власти, короля и Парламента. Все это делает его «Жизнеописания» бесценным историческим документом.

В-третьих, в «Жизнеописаниях» содержатся интересные литературные документы, по большей части не известные в переводе на русский язык. Например, те же записки Драйдена, сохраненные актером Гарриком и переданные им Джонсону. Или письмо Драйдена к сыновьям. Или полемика Драйдена и Элкана Сеттла (Elkanah Settle, I648-ı724). И многое другое.

В-четвертых, «Жизнеописания» объединены общим замыслом: установить хронологическую последовательность сочинений поэта, навести порядок в его библиографии, дать критическую оценку его стихов просодии, художественного вкуса мастера, определить его место в английской поэзии. Разумеется, в духе XVIII в.: эссеистично, а не в форме научного трактата.

В-пятых, своими «Жизнеописаниями» Джонсон заложил основы комментирования поэтического текста.

В-шестых, Джонсон очертил взгляды предшественников и современников на перевод поэзии.

Все это делает его «Жизнеописания» одной из главных опор английской литературы и культуры в целом. Это труд выдающегося биографа и критика эпохи Просвещения, изложение литературно-критических и эстетических идей С. Джонсона. Наконец, это шедевр жанра биографии, который вот уже двести пятьдесят лет не увядает в английской литературе, составляет ее славу. Это свод критических суждений классика английской литературы, первое произведение нового для XVIII в. жанра критической биографии. На них опирается английская словесность последующих столетий, многие мысли Джонсона уже не один век служат крылатыми выражениями для англичан. 
В настоящее время готовится к печати в серии «Литературные памятники» полнотекстовый комментированный перевод первого прижизненного издания “The Lives of the Most Eminent English Poets; with Critical Observations of Their Works” («Жизнеописания наиболее выдающихся английских поэтов, с критическим наблюдениями над их трудами») Сэмюэла Джонсона. Из обширного корпуса литературно-критических опытов вниманию читателей предлагается впервые публикуемый полный перевод «Жизнеописания Свифта» (в журнальном варианте).

Не забегая вперед, отметим в джонсоновской биографии Свифта то, что и спустя почти триста лет поражает критической силой, масштабом и остротой.

Джонсону удалось нарисовать в полный рост Свифта-полемиста, ведущего спор по всем фронтам: с королями и вельможами, иерархами церкви и первыми лицами государства, лучшими поэтами и писателями того времени. Свифт у Джонсона - боец в окружении великанов и карликов: из тысяч известных ему подробностей борьбы тори и вигов Джонсон выбирает самое важное, рисуя образ политического гения.

Мы вроде бы всегда знали про Свифта, автора «Писем суконщика», но только Джонсон имел смелость назвать Свифта отцом и легендой Ирландии потому, что именно Свифт научил ирландцев гордиться собой, отстаивать свои экономические интересы и свободу перед англичанами.

Отдельного упоминания заслуживает слово Джонсона о Свифте рачительном священнике, декане главного дублинского собора Святого Патрика, чьими стараниями в Лондоне в первой половине XVIII в. построили 50 новых церквей.

Такая биография Свифта - ключ к его «Гулливеру». Если кто-то думает, что этот роман - талантливая игра воображения, то, прочитав Джонсона, скорей всего пересмотрит свое мнение. В одном из жизнеописаний Джонсон вскользь обронил, что нетрудно придумать повествовательный ход, позволяющий изображать предметы в большем или меньшем масштабе относительно их настоящего размера. Зато (продолжим уже от себя) трудно быть Свифтом, человеком невероятной судьбы, воплощением колеса фортуны, стоиком по духу, бойцом по складу ума, единственным поэтом во всей английской литературе, почти ничего никогда не заимствовавшим у других. 
Таким его изваял Сэмюэл Джонсон. Каждый поворот фразы его повествования о Свифте - это выверенный взмах резца скульптора. Его насыщенная, весомая речь - это плод ума одного из светочей английской культуры, столпа Просвещения.

\section{Сэмюэл Джонсон СВИФТ}

у нас уже есть Жизнеописание ${ }^{\mathrm{I}}$ доктора Свифта, с завидным трудолюбием и вниманием составленное доктором Хоксвортом согласно замыслу, которым я с ним поделился в доверительную пору нашей дружбы. И поскольку все, что я думал о жизни Свифта, я давно уже сообщил этому искусному литератору, умеющему подать рассказ прелестным слогом и с вящим драматизмом, то многого от меня ждать не стоит².

ДЖОНАТАН СВИФТ был сыном присяжного поверенного Джонатана Свифта ${ }^{3}$, согласно записи, собственноручно им составленной, и родился он в Дублине в день Св. Андрея в г667 году; и, согласно его же словам, пересказанным Поупом Спенсу, он родился в Лестере и был сыном священника, служившего в Хирфордширском приходе4. Эта неопределенность места рождения сохранялась в течение всей жизни Свифта. Он не возражал, когда ирландцы называли его уроженцем Ирландии, но сам себя иногда называл

I B переводе сохранены заглавные и прописные буквы подлинника.

2 Хоксворт Джон (John Hawkesworth, I720-I773), литератор, друг Сэмюэла Джонсона; его биографический очерк о Дж. Свифте, опубликованный в I754-I755 гг. послужил основным источником джонсоновского жизнеописания. Хоксворт - издатель собрания сочинений Свифта, куда вошли и упомянутый биографический очерк (The Works of Jonathan Swift. In I2 vols. L.: Printed for Bathurst, I754-1755), и письма Свифта (Letters Written by Jonathan Swift. In 3 vols. $6^{\text {th }}$ ed. L., I767).

3 Свифт Джонатан (Jonathan Swift, I640-I667), отец писателя Дж. Свифта.

4 Хирфордшир (Херефордшир) - графство на западе Англии. Историками установлено, что священником в Хирфордшире был дед Свифта по отцовской линии; рассказ же Поупа в передаче Спенса - явная ошибка. Об этом Джонсон наверняка знал и тем не менее отметил две версии происхождения Свифта. Причина, возможно, подсказана его жизнеописаниями Конгрива и Прайора, где имеется следующая сентенция: если выдающийся человек сеет сомнения относительно своего собственного происхождения, то это может говорить о его неискренности. 
англичанином. Предадим и мы, со спокойной душой, этот вопрос тенетам таинственности, что он так любил напускать.

Каковы бы ни были обстоятельства рождения Свифта, образование у него точно ирландское. В шесть лет его отправили учиться в школу в Килкеннй, а в пятнадцать лет (в I682 году) он был принят в университет Дублина.

Особым прилежанием в учебе он не отличался и учиться не любил. Читателей, конечно, огорчит тот факт, что экзаменаторы, решавшие вопрос о присуждении ему степени Бакалавра Искусств, сочли его недостойным кандидатом на общих основаниях, и степень он в конце концов получил особой милостью 6 - так в университете Дублина именуют полное небрежение обязанностями.

Нетрудно представить меру пережитого им позора и последующее благотворное воздействие стыда. Именно тогда он решил заниматься по восемь часов в день и следующие семь лет твердо следовал этому правилу, добившись всем известных результатов. Об этой стороне его жизни хорошо бы вспоминать почаще: она поучительна и служит побудительным примером для тех, кто, предаваясь до поры до времени страстям или веселью, не развивает своих способностей, а когда часть жизни уже растрачена впустую, впадает в отчаяние от мысли, что наверстать упущенное уже невозможно.

Следующие три года своего пребывания в Дублине Свифт трудился в поте лица своего изо дня в день, и, если память и наблюдательность не подводят его старого однокашника7 , тогда-то и появился на свет первый набросок «Сказки Бочки».

В I688 году Свифту исполнился двадцать один год, умирает его дядя Годвин Свифт ${ }^{8}$, всё это время поддерживавший его материально; он остается без средств к существованию и едет за советом к матери в Лестерэ; та надо-

5 Килкенни - ирландский город в юго-восточной части Ирландии, ведет свою историю с VI в. (Kilkenny, или Cill Chainnigh, букв. church of Cainnech, церковь Каника).

6 По-латыни «speciali gratia». Курсив С. Джонсона.

7 Речь об Уильяме Вэринге (другое написание - Вильям Уоринг) (William Waring), получившем степень бакалавра в I685 г.

8 Свифт Годвин (Godwin Swift, I624-ı695), дядя Дж. Свифта; здесь в повествование Джонсона вкралась неточность: Годвин Свифт умер в I695 г., и Дж. Свифт уехал из Дублина в Лестер в г689 г.

9 Свифт Абигейл Эрике (Эбигел Ирик) (Abigail [Ericke] Swift, I640-I7Io), мать Дж. Свифта; в Лестере (старое написание, встречающееся в русских биографиях Свифта, Лейчестер) она жила с тех пор, как ее сын пошёл в школу в Килкенни. 
умила его обратиться за помощью и покровительством к супругу одной из своих родственниц, сэру Уильяму Темплугі, чей отец сэр Джон Темпл, Глава Кассационного Суда Ирландии, был в свое время очень дружен с Годвином Свифтом, благодетелем Джонатана.

Темпл доброжелательно принял племянника старинного друга своего отца и за беседой проникся к нему таким расположением, что никуда его от себя не отпустил, и Свифт прожил в его доме два года. Однажды ему довелось быть представленным Королю Вильгельму, который иногда наносил визиты Темплу, страдавшему подагрой: Свифт взялся сопровождать короля на прогулке по саду, и его Высочество собственноручно показал ему, как следует на голландский манер срезать спаржу.

Свою благосклонность юноше Король Вильгельм выразил единственным доступным его воображению образом: предложил ему чин ротмистра.

Вместе с семейством Темпла Свифт переехал в Мур-парк; примечательно, что на аудиенцию к Королю Вильгельму Темпл послал именно Свифта после собственных безуспешных попыток убедить графа Портленда в совершенной безопасности для королевской власти нового законопроекта о трехлетнем сроке действия парламента, вызвавшего сильное сопротивление монарха. Свифт поспешил на встречу, распираемый гордостью от такого назначения и преисполненный уверенности в успехе, как то свойственно молодым людям; он наверняка вооружился доводами и до мельчайших деталей продумал защиту, но вся его стройная аргументация оказалась бессильна перед твердой позицией Короля; впоследствии, когда ему доводилось вспоминать о том первом поражении, он всегда ссылался на него как на лучшее средство излечиться от гордыни.

Незадолго до отъезда из Ирландии у него случилось расстройство, которое он связывал с тем, что однажды переел фруктов. Происхождение любой болезни - дело темное. Кажется, какой мальчишка не объедается фруктов при первом удобном случае? - и ничего, никаких последствий. У Свифта же периодически случались приступы головокружения, сопровождаемые потерей слуха; это недомогание, начавшееся у него в раннем возрасте, терзало его всю жизнь и в конце концов свело его в могилу, помрачив его рассудок.

Іо Темпл Уильям (Темпль Вильям) (William Temple, I628-ı699), государственный деятель, дипломат, вельможа, литератор. 
Болезнь отравляла его жизнь в Мур-парке, ему посоветовали пожить в родном климате, и он отправился в Ирландию; но перемена мест облегчения не принесла, и, вернувшись в дом сэра Уильяма, он возобновил свои

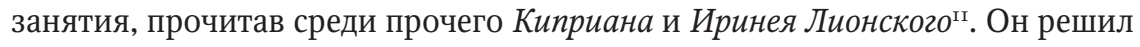
спасаться физическими упражнениями и взял за правило каждые два часа бегать по полмили вверх и вниз по горке.

Надо думать, никакой особой симпатии к Дублинскому университету после истории с присуждением бакалаврской степени он не питал, и его решение поступить в Оксфорд, чтобы там получить степень Магистра Искусств, выглядит понятным. Позорящая его формулировка в предъявленном им документе не фигурировала, и 5 июля 1692 года ему вручили со всем почетом и уважением Магистерскую степень.

В пору своей жизни у Темпла раз в год он навещал мать в Лестере; обычно шел туда пешком, лишь в дождливую погоду подсаживался в крытую повозку, а ночевал в самых затрапезных подворьях, неизменно платя шесть пенсов за чистое постельное белье. Лорд Оррери объясняет такую повадку Свифта его врожденной слабостью к грубости и плебейству; кто-то, возможно, увидит в этом его стремление познать жизнь во всей ее пестроте, а кто-то с той же долей вероятности узреет в этом глубоко затаенную страсть к накопительству.

Прошло еще какое-то время, и Свифт стал тяготиться своим пребыванием в Мур-парке, полагая, что заслуживает большего вознаграждения, чем удовольствие от бесед с Темплом, какими бы благотворными они ни были; и, наконец, его терпению пришел конец, он ушел, хлопнув дверью (случилось это в г694 году).

Рассказывают, что Темпл, понимая, что он дал повод для недовольства Свифта, подыскал ему место Заместителя Главы Кассационного Суда Ирландии, заведомо зная, по словам одного из его родственников, что его протеже не годен для этой должности. И тогда Свифт твердо решил принять священнический сан, поначалу рассчитывая самое большее на должность

II Киприан Карфагенский, или Тасций Цецилий Киприан (ок. 200-258 г. н.э.), епископ Карфагенский, латинский богослов, чьи сочинения посвящены осмыслению вопросов отступничества и раскола; Ириней Лионский (ок. 130-202 г. н.э.) - один из первых отцов церкви, богослов, автор сочинения «Против ересей». Джонсон отмечает факт чтения Свифтом ранних Отцов церкви как свидетельство его работы над «Сказкой бочки». Курсив С. Джонсона. 
капеллана в торговом квартале Лиссабона; однако благодаря рекомендации лорда Кейпла ${ }^{\mathrm{I2}}$ он получил пребенду в Килруте ${ }^{\mathrm{I3}}$ при епископате Коннора с годовым доходом около ста фунтов.

Но тут обнаружилось, что Темплу с его недугами никак не обойтись без такого наперсника, как Свифт, и он стал призывать его вернуться, обещая взамен пребенды в Ирландии добыть ему выгодное место в Англии. Свифт согласился, тем более что и сам, наверное, сожалел о разрыве отношений, и они снова зажили душа в душуㅎ; вполне вероятно, за те четыре года, что пролегли между его возвращением и кончиной Темпла, он и мог написать «Сказку Бочки» и «Битву Книг»15.

Свифт всегда лелеял мысль, что рожден поэтом, и кому только не посвящал свои оды в духе Пиндара: и Темплу, и Королю, и Афинскому Обществу ${ }^{16}$ - этой небольшой кучке малоизвестных литераторов, выпускавших газетный листок с ответами на вопросы, которые корреспонденты задавали в своих письмах. Мне рассказывали, что, познакомившись с виршами Свифта, Драйден сказал ему: «Братец Свифт, поэта из тебя не получится» ${ }^{17}$, и после того вердикта Свифт всегда с неприязнью отзывался о Драйдене ${ }^{\mathrm{I} 8}$.

В 1699 году Темпл умер и в наследство оставил Свифту свои рукописи, не забыв также заручиться обещанием Короля Вильгельма предоставить Свифту первую освободившуюся в Вестминстере или в Кентербери пребенду.

I2 Кейпл Генри (Henry Capel, I638-I696), один из трех лордов-судей в Ирландии.

I3 Это произошло в г695 г. Килрут (Cill Ruaidh, букв. «церковь рыжего») - город в Cеверной Ирландии, по преданию, церковь в Килруте была основана в 4I2 г. Пребенда (лат. Prebenda, иначе Beneficia) - название на Западе тех материальных средств, какие получают духовные лица всех категорий в виде земельных владений, домов для жительства клира, доходов по церкви, денежного жалованья.

I4 Свифт пробыл в Килруте полтора года.

I5 «Битва книг» (The Battle of the Books, I697) была опубликована вместе со «Сказкой бочки» (A Tale of a Tub) в I704 г.

I6 Речь о следующих одах Свифта: «Ода сэру Уильяму Темплу» (Ode to Sir William Temple), «Ода королю. На его ирландский поход» (Ode to the King. On His Irish Expedition) и «Ода Афинскому обществу» (Ode to the Athenian Society).

I7 B I735 г. Свифт отозвался о Драйдене как о близком родственнике: они были троюродными братьями. Эта история существует в нескольких редакциях, на нее ссылаются Дин Свифт, Дж. Уортон, Т. Уортон-старший и Э. Фентон.

I8 Известно, что Свифт скрыто вышучивал Драйдена в «Сказке бочки» и насмешливо отозвался о его переводе Вергилия в своей «Битве книг». 
Свифт, спеша напомнить Королю о себе, посвятил его Высочеству изданные посмертно сочинения Темпла из унаследованных им рукописей ${ }^{19}$, однако ничто - ни посвящение, ни добрые воспоминания о преданном и обласканном им вельможе - не оживило в памяти Короля Вильгельма данное когда-то слово ${ }^{20}$. Пообивал было Свифт высокие пороги, но вскоре оставил эту пустую затею.

Спустя некоторое время граф Беркли предложил Свифту сопровождать его в поездке по Ирландии на правах личного секретаря, тот предложение принял и только в Дублине узнал о том, что его новую должность перехватил некто Буш, убедивший графа в том, что священник на роль секретаря не подходит ${ }^{21}$. В ответ на подобные ложь и непостоянство такой человек, как Свифт, не мог не вскипеть от негодования.

Но самое тяжелое ждало его впереди. Лорд Беркли собирался передать в новые руки церковный приход в Дерри, а Свифт рассчитывал его получить, но из-за того, что новоявленный и, видимо, умасленный взяткой секретарь употребил свое влияние, приход уплыл в другие руки. Свифту же достались пребенды Ларакора и Рэтбеггана в церковном округе Мита ${ }^{22}$, что в совокупности не составляло и половины дохода настоятеля.

В Ларакоре Свифт развернулся: проповеди отныне читались и по средам, и по пятницам; свои обязанности приходского священника он исполнял ревностно, согласно предписаниям, налагаемым саном.

Обосновавшись, он пригласил в Ларакор бедную Стеллу, молодую женщину по фамилии Джонсон²3, дочь стюарда в доме сэра Уильяма Темпла, которой последний, в знак благодарности за преданную службу ее отца, оставил по завещанию тысячу фунтов. Вместе с ней приехала миссис Дингли, чья пожизненная рента составляла сорок семь фунтов в год. В обществе

I9 Помимо свода рукописей, У. Темпл оставил Свифту гоо фунтов; в I700-I703 гг. Свифт издал трехтомное собрание писем У. Темпла с посвящением королю Вильгельму III.

20 Впоследствии Свифт с нескрываемым презрением повторял: «Слово короля! Ну и выражение!»

2I Беркли Чарлз (Берклей Чарльз) (Charles Berkeley, I649-I7I0), государственный деятель, назначен в описываемое время лордом-судьей Ирландии; Буш Артур (Arthur Bushe), служащий на ирландской таможне, получивший место личного секретаря графа Беркли. 22 Дерри, также Лондондерри - город в северо-западной части Ольстера; Ларакор и Рэтбегган - небольшие приходы в графстве Мит (Meath).

23 «Стелла» (букв. звезда) - адресат «Дневника для Стеллы» Свифта, ее подлинное имя: Эстер Джонсон (Эсфирь Джонсон) (Esther, или Hester Johnson, I68I-I728). 
этих дам Свифт коротал досуг, откровенничал, но они никогда не жили одним домом, и ни с одной из женщин Свифт не оставался наедине. Когда он надолго отлучался, дамы переезжали в его Приходской дом, а по возвращении хозяина перебирались на квартиру или гостили у соседа-священника.

Свифт не из тех мыслителей, что повергают в изумление свет своими ранними интеллектуальными достижениями: если не считать нескольких поэтических Опытов, первое свое сочинение «О Раздорах в Афинах и Риме»²4 он опубликовал в тридцать четыре года (в І7ог году). Когда во время визита к одному из епископов Свифт услышал о том, что Бернет написал очередной памфлет, выказав себя в нем знатоком политики, он позволил себе усомниться в авторстве Бернета, а принимавший его епископ ${ }^{25}$ отмел его доводы, сказав, что Свифт «слишком молод», и повторил: «молод и самонадеян».

Через три года (в I704-м) в свет вышла «Сказка Бочки» ${ }^{26}$, книга, по самым скромным оценкам, написанная человеком весьма своеобразным, без злого умысла, но, конечно, являющая собой опасный прецедент. Свое авторство Свифт так и не признал, хотя повсеместно и в общем бездоказательно считается, что автор именно он; единственным основанием в пользу этого суждения служит отсутствие других претендентов, а также тот факт, что Свифт не опротестовал отказ в назначении его епископом, который последовал вскоре после того, как Архиепископ Шарп и Герцогиня Сомерсет показали книгу Королеве 27.

24 Полное название «Слово о раздорах и расколе между знатью и плебсом в Афинах и Риме» (Discourse of the Contests and Dissentions between the Nobles and the Commons in Athens and Rome, I7OI). Сочинение посвящено конституционной борьбе представителей Палаты лордов и Палаты общин по вопросу импичмента четырем пэрам, подписавшим Договор о разделе испанского наследства (Partition Treaty).

25 Речь об Уильяме Шеридане (William Sheridan, I636-I7II), епископе Килмора. Бернет Гилберт (Gilbert Burnet, I643-I7I5) - епископ Солсбери, автор «Истории моего времени» (History of My Own Time, I723-I734).

26 «Сказка бочки» (A Tale of a Tub) была опубликована анонимно в I704 г.

27 Историю о противодействии выдвижению Свифта в епископы рассказывают все биографы писателя: Хоксворт, Делани (другое написание - Дилени) и Оррери. Речь идет об Архиепископе Йоркском Джоне Шарпе (John Sharp, I645-I7I7) и Элизабет Сеймур, герцогине Сомерсет (Elizabeth Seymoor, I667-I722). В «Дневнике для Стеллы» содержатся нелицеприятные отзывы Свифта об этих персонах. Примечательно, что С. Джонсон впервые высказал серьезные сомнения в авторстве Свифта еще в I773 г. По его мнению, «Сказка бочки» сильнее любого другого сочинения Свифта. Джонсон предполагал, что автором «Сказки бочки» был Дж. Арбетнот. Примечательно, что в свой словарь Джонсон не включил ни одной цитаты из «Сказки бочки». 
Позднее, когда вокруг этой невероятной книги поднялся ажиотаж, Сэчеврелл в беседе со Смолриджем намекнул, лести ради, на его предположительное авторство, на что последний возмущенно ответил: «Никакие блага мира, ни Ваши, ни мои, ни вместе взятые, ни нынешние, ни будущие, не подвигли бы меня написать “Сказку Бочки” ${ }^{28}$.

Следует признать, что отступления, касающиеся Уоттона и Бентли ${ }^{29}$, обнаруживают либо недостаток знания, либо небезупречную позицию автора «Бочки»: он или не разобрался в существе двух споров, или намеренно их исказил. Но Ум Правде не соперник - всё равно рано или поздно сдастся. Потомки справедливо расценили, кто достоин лавров победителя в споре за ученость ${ }^{30}$.

Сходство «Битвы Книг» с «Combat de Livres» ${ }^{3 \mathrm{I}}$, во Франции вызванным к жизни тем же вопросом о Древних и Новых, столь велико, что, по-моему, трудно поверить в случайность совпадений; во всяком случае, безапелляционные анонимные опровержения, предпосланные английской книге в доказательство неведения автора о французском сочинении, не кажутся мне убедительными ${ }^{32}$.

После этого Свифт какое-то время не появлялся на публике; возможно, он ушел с головой в свои штудии и копил силы для будущего взлета. Мне неизвестно, бывал ли он в то время в Англии и как заботился о своей пастве. Только четыре года спустя он заявил о себе как о состоявшемся авторе, опубликовав за один І7о8-й год пародию на астрологию «Переживания Прихожанина Англиканской Церкви», выдав себя за некоего Бикерстаффа,

28 Сэчеврелл (Сачеверелль, Сачеверелл) Генри (Henry Sacheverell, I674-I724), священнослужитель англиканской церкви; Смолридж Джордж (George Smalridge, I663-I7I9), настоятель церкви Христа в Оксфорде, епископ Бристоля.

29 Уоттон (Воттон) Уильям (William Wotton, I666-І727) оспорил аргументы У. Темпла в пользу превосходства древних ученых в своем сочинении «Размышление о древней и новой учености» (Reflections upon Ancient and Modern Learning, I694). Бентли Ричард (Richard Bentley, I662-I742) доказал, что «Послания Фалария» (Epistles of Phalaris), принятые Темплом за подлинные, на самом деле таковыми не являются. Свифт в споре «Древних и Новых» поддерживал Темпла.

30 Этой фразой Джонсон указывает на Бентли и Уоттона как на победителей в споре о «Древних и Новых».

3I “Combat de Livres" (I688) - сочинение Франсуа де Кальера (Francois de Callières, I645I7І7), французского дипломата.

32 Джонсон, по-видимому, разделяет взгляд Уоттона на «Битву книг» как на заимствование из труда Франсуа де Кальера. 
а также «Рассуждение о Неудобстве Уничтожения Христианства в Англии» и апологию Причащения.

«Переживания Прихожанина Англиканской Церкви» написаны предельно скупо, сдержанно, просто и ясно, а «Рассуждение о Неудобстве Уничтожения Христианства в Англии» - остроумно и взвешенно-иронично. Стоит даже процитировать один пассаж из последнего сочинения:

«Если бы христианство в один прекрасный день было отменено, то каким образом свободомыслящие серьезные мыслители и мудрые ученые могли бы найти другую тему, столь подходящую со всех точек зрения для упражнения своих способностей? Каких лишились бы мы чудесных и удивительных произведений человеческой мысли, созданных теми гениальными умами, которые, в силу привычки, полностью посвятили себя пасквилям на церковь и насмешкам над религией и поэтому уже никогда не смогут блеснуть или отличиться в какой-либо другой области? Каждый день мы жалуемся на упадок остроумия среди наших писателей, и неужели мы теперь откажемся от величайшей, может быть единственной темы, которая у нас осталась? Да кому бы могло когда-нибудь прийти в голову, что Эсгил 33 - столь остроумный писатель, а Толанд ${ }^{34}$ - философ, если бы у них под рукой не было неистощимой темы христианства, которая обеспечила их материалом? Какая другая тема из области искусства или природы могла бы создать Тиндалю35 славу глубокого мыслителя и привлечь внимание читателей к его сочинениям? Нет, только продуманный выбор темы возвышает и отличает подлинного писателя. Если бы сотня таких писак, как они, выступила на стороне религии, все сто тотчас бы канули в Лету” 36 .

Доказать разумность Причащения нетрудно, сложнее подметить, как пренебрегают его истинным смыслом ${ }^{37}$.

33 Эсгил Джон (John Asgill, I659-I738), полемист-деист.

34 Толанд (Толэнд) Джон (John Toland, I670-I722), деист, участник богословских диспутов.

35 Тиндаль (Тиндал) Мэтью (Matthew Tindal, I657-I733), деист, участник теологических споров.

36 Отрывок из «Рассуждения о неудобстве уничтожения христианства в Англии» цит. в переводе Б. Томашевского по: Свифт Дж. Памфлеты. М.: ГИХЛ, І955. С. 22-36.

37 Свифт выступил против отмены закона о Причащении, согласно которому все, кто поступал на государственную службу, должны были проходить обряд по уставу англиканской 
Стил, задумывая своего «The Tatler», обратил внимание на общий интерес к заметкам, опубликованным под именем Бикерстаффа, и решил воспользоваться этим, уже известным среди читателей прозвищем ${ }^{38}$.

На следующий год Свифт выступил с «Проектом Содействия Преуспеянию Религии» ${ }^{9}$, адресовав его леди Беркли, чье расположение, вполне вероятно, позволило ему крепко встать на ноги. Проект всем хорош: и цель у него благая, и написан он живо и изящным слогом, - единственное возражение, которое он вызывает, как, впрочем, и любой другой проект, состоит в том, что он не то чтобы непрактичен, а совершенно невыполним, в силу того, что требует от человечества столь великого рвения, единодушия и трудолюбия, каких трезвомыслящему человеку трудно ожидать от простых смертных.

В тот год он еще написал «Защиту Бикерстаффа» и пояснение к «Древнему Пророчеству» - ту его часть, что следует за изложением фактов ${ }^{40}$; остальное осталось незаконченным, но и то, что имеется в виде плана, достойно всяческого восхищения.

Вслед за тем в жизни Свифта наступила полоса бурной и значительной деятельности. В г7го году прелат Ирландии ${ }^{41}$ поручил ему добиться согласия Королевы на возвращение ирландскому духовенству Десятин и Первинок ${ }^{42}$. С этой целью Свифт вступил в сношения с мистером Харли ${ }^{43}$, которому был представлен как человек, натерпевшийся бед и унижения при последнем кабинете министров за то, что отказался участвовать в некоторых тёмных делишках. Что это были за дела, не уточнялось, а в слове «унижение», полагаю, скрывался намёк на его отстранение от епископства

церкви. В ноябре І7ІІ г. Свифт в «Дневнике для Стеллы» описал, как несколько молодых повес «получили причастие не за набожность, а за службу, согласно парламентскому закону».

38 Периодическое издание “The Tatler” (Болтун) выходило с I2 апреля I709 г.; издавая собрание опубликованных в нем статей, Ричард Стил в предисловии поблагодарил Свифта за разрешение использовать имя его персонажа Исаака Бикерстаффа.

39 Свифт посвятил свой «Проект содействия преуспеянию религии» (Project for the Advancement of Religion, I709) Элизабет Беркли (Elizabeth Berkeley, I655-I7I9). Проект состоял в придании морали и религии статуса «модных придворных добродетелей».

40 Речь о «Защите Исаака Бикерстаффа» (A Vindication of Isaac Bickerstaff, I709) и «Знаменитом предсказании Мерлина, британского волшебника» (A Famous Prediction of Merlin, the British Wizard, I709), - последнее представляет собой мистификацию, сочиненную в начале XVI в. и, видимо, истолкованную Джонсоном как подлинную.

4I Архиепископ Армы - Нарциссий Марш (Narcissus Marsh, I638-I7І13).

42 Первинки, или Первые Плоды (The First Fruits) - доходы церкви за первый год.

43 Харли Роберт (Robert Harley, I66I-I724), лорд казначей, принял Свифта в октябре I7Іо г. 
стараниями Шарпа, именуемого не иначе как «безобидным орудием в руках ненавистников» и впоследствии осмеянного им как «ищущего спасения в судебных исках» 44 .

Харли считал, что ему повезло с таким даровитым помощником, в ту пору он строил планы и имел виды на будущее, поэтому лед между ними быстро растаял, но сказать, что Свифт стал его доверенным лицом, пожалуй, было бы неправильно, недаром у некоторых есть сомнения на этот счет; хотя, опять же, трудно представить, чтобы Свифт воодушевился, не будучи уверенным, что ему доверяют, и легко поддался бы беспочвенным иллюзиям.

Разумеется, он был вхож во все те кабинеты, где на заседаниях разрабатывался первоначальный план действий, и получил известность как один из шестнадцати министров, или, если угодно, чиновников министерства, которые каждую неделю встречались друг у друга на дому и входили в так называемое общество «Братьев» 45 .

Свифт не вдруг обрел репутацию несгибаемого Тори; поначалу круг его общения включал всех без исключения интеллектуалов, в том числе Стила, чью похвалу он заслужил своей умной беседой и несколькими публикациями в «The Tatler», выходившем с г7го года ${ }^{46}$. Но политическая борьба затягивала Свифта, и он в том же году разразился тридцатью тремя статьями в новоявленном «The Examiner» ${ }^{7}$. В искусстве полемики перевес всегда был за ним, ибо там, где вся система поведения и весь публичный уклад уязвимы для критики, обвинителю, располагающему всеми фактами, сам бог велел нападать и выигрывать; и все же, боюсь, ни один из выпадов Свифта не сравнится по остроумию ни с одним из ответных уколов Аддисона ${ }^{48}$.

44 Джонсон цитирует строки 5I-52 из стихотворения Свифта «Автор о самом себе» (The Author upon Himself, I7I4), где говорится об архиепископе Шарпе. Ср. в оригинале: «Не sues for pardon».

45 В I7ІІ-І7І2 гг. Свифт ссылался на «Общество», или «Братьев»- вечерний клуб тори, созданный Генри Сент-Джоном, в который входили 22 члена.

46 До І705 г. Свифт был вигом в политических вопросах. Среди его знакомых такие видные виги, как Аддисон, Стил, Эмброуз, Филипс, Конгрив. В «The Tatler» Свифт опубликовал два своих стихотворения «Утренняя картина» (A Description of the Morning) и «Описание городского ливня» (A Description of a City Shower).

47 Периодическое издание “The Examiner" (Исследователь), выходившее с г7го г., было органом партии тори.

48 Осенью г7Іо г. Аддисон издал пять выпусков «The Whig Examiner» (Исследователь вигов). 
В начале следующего года в свет вышло его «Предложение об исправлении, улучшении и закреплении Английского Языка в письме графу Оксфорду»49, где Свифт, увы, не выказал себя ни знатоком общих основ языка, ни строгим исследователем истории языков различных. Полагая возможным, вопреки опыту, достижение устойчивости и стабильности, он предлагает в качестве проверенного средства учредить академию, - академию, чьи предписания, буде последняя учреждена, люди наотрез отказались бы выполнять, а сама она, пройдя несколько раз через процедуру выборов, за короткое время изменилась бы до неузнаваемости.

В том же году он написал «Письмо Членам “Клуба Октября” : так называлась группа сельских представителей партии Тори, которых пригласили заседать в Парламенте, а они собрали клуб в составе приблизительно ста человек и устраивали закрытые заседания для поднятия общего настроения и боевого духа ${ }^{50}$. Резонно подметив, что Министры не торопятся использовать имеющиеся возможности, не принимают в расчет воодушевление народа, они призвали к более решительным переменам и энергичным действиям, требуя наказания и отставки тех чиновников, кого они во всеуслышание объявили ворами.

Королева и Харли не одобряли их рвения. Королева, скорее всего, осторожничала, а Харли выгадывал: к Тори он примкнул то ли вынужденно, то ли из корысти, и, получив власть, он толком не знал, на что ее употребить; чувствуя необходимость отблагодарить тори, на чьих плечах он вознесся, он тем не менее не хотел упускать возможность примириться с Вигами, пусть и в отдаленной перспективе, поэтому он тайно переписывался сразу с двумя претендентами на трон, держа вопрос о наследовании в подвешенном состоянии. Он не знал, что делать, и в итоге не делал ничего; из-за своей политики быть слугой двух господ он потерял власть и нажил себе врагов.

Свифт вроде бы разделял позицию членов «Клуба Октября», но подтолкнуть Харли к более решительным действиям при всем желании был не в

49 «редложение» (A Proposal for correcting, improving, and ascertaining the English Tongue) Свифта вышло в мае І7І2 г. Виги подвергли его острой критике, Вольтер же в своих «Письмах об английской нации» (I733) вменил в вину вигам отказ создать после смерти королевы Анны академию английского языка.

50 «Клуб октября» (другой вариант - Октябрьский клуб) состоял из сотни эсквайров (название клуба аналогично празднованию «Oktoberfest» в Германии). Члены клуба призывали к жестким мерам против прежнего кабинета министров, состоявшего из вигов. 
силах: все его попытки оказались тщетными. Зачем человеку торопиться, если он не знает, куда идти? Харли и так по природе своей был медлителен, а нерешительность сделала его вдвойне осторожным, и он втайне хвалил себя за дальновидность, слыша, как окружающие сетуют на неспешный ход событий.

Впрочем, всё решали Тори, поэтому их старались если не задобрить, то расположить к себе, а Министру если не потакали, то, по крайней мере, относились к его поведению снисходительно.

Свифт в ту пору достиг апогея на политическом Олимпе: в I7І2 году, за десять дней до созыва Парламента, он опубликовал «Поведение Союзников»51. Идея состояла в том, чтобы склонить соотечественников к миру ${ }^{52}$, и Свифту это удалось как никакому другому писателю. Народ, который до этого тешил себя фейерверками и победными реляциями, с обожанием взирая на Генерала ${ }^{33}$ и его окружение как на благодетелей, превративших Англию, казалось, в образец для подражания других стран, оторопел от стыда и гнева при новости о том, что «рудники истощены, миллионы убиты»54, и всё это ради обогащения голландцев или прославления императора, без малейшей выгоды для собственной страны. Вскрылись факты подкупа соседей, за чьи интересы мы же и воевали, и наличия немалого числа союзников среди врагов.

Тогда страна впервые узнала то, о чем сегодня известно всем: войну искусственно затягивали, чтобы Мальборо набивал себе карманы, и если бы он и дальше продолжил опустошать казну, конца войне было бы не видать. Но Свифт, сочиняя свой памфлет, думаю, еще не знал о том, что была созвана комиссия по присуждению Мальборо пожизненного звания генерала и только вмешательство лорда Каупера, наотрез отказавшегося утвердить протокол, аннулировало это решение.

«Что бы ни получал человек», сказано в учении, «он все получает по заслугам»55. Воздействие политического трактата в огромной мере зависит от настроения народа, а народ в то время кипел от возмущения, и поэтому

5I В оригинале «The Conduct of the Allies». Это произведение Свифта было опубликовано 2I ноября I7ІІ г. Новый состав Парламента должен был заседать 7 декабря, чтобы по сути ратифицировать мирный договор, обсуждение которого шло полным ходом.

52 Речь идет о мире с Францией.

53 Генерал Мальборо Джон Черчилль (John Churchill Marlborough, I650-I722), военачальник, известный крупными победами в начале XVIII в.

54 Джонсон цитирует стихотворение Томаса Тикла (Томаса Тикля) (Thomas Tickell, I685I740) «Поэма о будущем мире» (Poem on the Prospect of Peace, I7І2).

55 Это парафраз сентенций средневековых схоластов, например, Фомы Аквинского. 
одной искры было достаточно, чтобы разгорелся пожар. Рассказывают, что с ноября по январь было продано одиннадцать тысяч оттисков свифтовского памфлета - число по тем временам невиданное: тогда мы еще не были читающей нацией. Конечно, хватало людей, облеченных властью, влиятельных, которые способствовали распространению книги. Она не сходила с уст собеседников, к ней прибегали как к аргументу в споре, она служила источником для парламентских решений.

И все же, если холодно оценить этот чудодейственный памфлет, то сомнений не останется: его успех - производное разгоряченного воображения читателей, а само сочинение представляет собой изложение вопиющих фактов не самым бойким пером.

В том же І7І2 году Свифт опубликовал свои «Размышления о Буферном Договоре»56, написанные в продолжение его «Поведения Союзников» и со всей очевидностью доказывающие, что переговоры велись с ущемлением интересов Англии - в пользу голландцев, готовых присвоить часть завоеванной страны.

Затем, в ответ на памфлет епископа Бернета, опубликованный в назидание народу против усиления в стране папистских настроений ${ }^{57}$, Свифт разразился «Замечаниями по поводу Вступительной Статьи Епископа Сарума к третьему тому его “Истории Реформации” ${ }^{58}$, где он не упускает случая хлестко отчитать епископа, что наводит на мысль о существовании каких-то иных причин его неприязни к Бернету, нежели политическая брезгливость 59.

Отныне к Свифту, новоявленному фавориту и предположительно доверенному лицу правительства Тори, любой, зависимый от Двора, человек обращался с почтением, какое умеют выказывать только прислужники. Вскоре он на себе ощутил издержки высокого положения: похвалиться знакомством с ним было равносильно повороту фортуны. Со всех сторон

56 Памфлет «Некоторые замечания о буферном договоре между ее Высочеством и генерал-губернаторами» (Some Remarks on the Barrier Treaty) был опубликован в феврале г7ı2 г. 57 Бернет Гилберт (Gilbert Burnet, I643-I715), епископ, опубликовал «Вступление к третьей части “Истории Реформации” в в 7 ІІз г.

58 В своем памфлете Свифт, в частности, писал, что Бернет «за пятьсот миль носом чует Папство». Под именем «епископа Сарума» имеется в виду Г. Бернет.

59 Некоторые факты свидетельствуют о том, что епископ Бернет, вкупе с другими лордами, обещал, в случае обретения ими власти, осыпать Свифта привилегиями. 
к нему взывали с просьбами, инструкциями, жалобами; он был нарасхват, радея то одному, то другому знакомому, для одного добывая место, другому помогая усидеть. Ему самому представлялось, что он преизрядно хлопочет за просителей, но ему этого было мало: он хотел, чтобы и другие разделяли его уверенность в том, что многие достойные виги, включая Аддисона и Стила, сохранили свои должности именно благодаря его поддержке. Но, как бывает с каждым влиятельным лицом, среди нескончаемой вереницы просителей всегда найдется кто-то, чье прошение останется без ответа; обиженных всегда будет больше, чем довольных, ибо оказанное кому-то одному преимущество дает всем остальным повод для жалобы. Как говорил Людовик XIV, «стоит мне сделать назначение, и сто подданных оказываются недовольными, а от одного жди неблагодарности» ${ }^{60}$.

Независимый нрав и чувство равноправия, с которыми Свифт держался в обществе Министров, его нелицеприятная критика и открытая дружба давно вошли в поговорку. Несколько случаев, выбивающихся из этой общей линии поведения, погоды не делают. Однако нет большего сервилизма по отношению к Власть предержащим, чем в их присутствии кичиться своей независимостью. Между сословиями всегда сохраняется дистанция: да, вышестоящее лицо может предложить своему менее именитому собеседнику быть накоротке, и тот, скорее всего, согласится; но на великодушие редко отвечают капризами и наскоками, чаще те проистекают из менее благородного источника: кичливого самодовольства, мстительной посредственности. Тот, кто осознает свою независимость, будет подчеркивать свою значимость до тех пор, пока в нем нуждаются, и, если слуга особо даровит, любая колкость будет сходить ему с рук; однако, колкости он позволяет себе только потому, что он слуга. Свифту же, по всей видимости, удалось сохранить благосклонность вельмож даже тогда, когда нужда в нем отпала; вероятно, более благородные свойства его натуры возобладали над задиристостью, к которой он питал определенную слабость.

Много говорят о его бескорыстии, о некоем рыцарстве, кажущемся в его положении романтичным и неуместным. Как говорится, свято место пусто

60 Джонсон приводит по-английски высказывание Вольтера в «Веке Людовика XIV» (Siècle de Louis XIV), глава XXVI: «Toutes les fois que je donne une place vacante, je fais cent mécontents et un ingrate». Это же высказывание Джонсон перифразирует в своем романе «Расселас», глава XXVII. 
не бывает: если есть церковные вакансии, их нужно раздать, и приближенные к власти люди, имеющие необходимую квалификацию, вправе рассчитывать на эти должности. В І7Із году Свифт получил место Декана Св. Патрикаб ${ }^{6}$, лучшее назначение из всех, что могли добыть его доброжелатели. Тогдашний кабинет Министров имел сильную поддержку со стороны священников, хотя те так до конца и не приняли автора «Сказки Бочки», громко возмущаясь и высказывая недовольство тем, что он становится Деканом Английского Собора.

Да, действительно, Свифт отказался взять пятьдесят фунтов, предложенные ему лордом Оксфордом, зато позднее ничто не помешало ему принять от казначейства чек на тысячу фунтов, а тот после смерти Королевы где-то затерялся, и ему пришлось, как он пишет, «multa gemenus» (с большим прискорбием $)^{62}$ распрощаться с мыслью об этой сумме.

Находясь на гребне власти, в самый разгар политической борьбы он записывал в дневник подробности визитов, прогулок, бесед с Министрами, ссор со своим слугой, делясь ими с миссис Джонсон и миссис Дингли, которым, он наверняка знал, было интересно всё, что с ним происходит, вплоть до каждой мелочи. Едва ли кому-то из недоброжелателей Декана попадались на глаза эти житейские описания. Однако именно они странным образом притягивают внимание читателя: то и дело попадаются имена людей, слывущих знаменитостями, и хочется читать дальше в надежде обнаружить новые подробности; но даже если таковые не отыскиваются, жаловаться грешно, поскольку чтение совсем не утомляет. Как нетрудно заметить, деятельный честолюбивый Свифт тосковал по домашнему очагу.

Он отправился в Ирландию сразу по получении места Декана, однако не пробыл там и полмесяца, как его снова затребовали в Англию, дабы он помирил лорда Оксфорда и лорда Болингброка, чьи отношения дали трещину, с каждым днем их взаимная неприязнь только росла, а Болингброк так и не избыл свою до конца дней ${ }^{63}$.

6I Самый большой англиканский собор из двух соборов Дублина (второй - «Christ Church», или Собор Церкви Христовой); основанный в конце XII в., собор Св. Патрика стал англиканским собором Ирландской церкви в период Реформации; в конце XIX в. собор получил статус Национального собора Ирландии.

62 Примечательно, что Харли, лорд Оксфорд послал Свифту 50 фунтов за его статьи в «The Examiner» (Исследователе), опубликованные в марте I7ІІ г., а чек на гооо фунтов Свифт принял в I7Із г., в надежде пустить эти деньги на ремонт дома настоятеля в Дублине.

63 Джонсон описывает события I7II-I7І2 гг. 
Свифту удалось свести враждующие стороны, но закончилась встреча к взаимному неудовольствию, и тогда Свифт устроил второе рандеву, после которого у него самого не осталось сомнений в неизбежности разрыва, о чем он недвусмысленно предупредил обоих политиков. Оксфорд с ним не согласился, считая, что еще не всё потеряно, а Болингброк шепотом признал его, Свифта, правоту.

В начале I7I4 года, незадолго до этого сокрушительного удара по кабинету Министров, Свифт в ответ на памфлет Стила «О Кризисе», за который последнего прогнали из Палаты Общин, опубликовал свой под названием «Публичный Дух Вигов» 64 . К тому времени Свифт настолько отдалился от Стила, что даже не считал нужным сохранять видимость приличий в их отношениях: это видно по его тону, то небрежному, то полубрезгливому.

В том памфлете Свифта несколько раз упоминались шотландцы ${ }^{65}$, и каждый раз с таким нестерпимым для гордого народа вызовом, что Шотландские Лорды, разом вспомнив, что их «нельзя безнаказанно обидеть» ${ }^{66}$, добились аудиенции Королевы и потребовали репараций. Была изготовлена листовка с предложением заплатить триста фунтов тому, кто раскроет имя пасквилянта. От этой бури, по словам Свифта, ему удалось «спастись только благодаря одной уловке», - что это была за уловка и кто ее придумал, неизвестно, но после того случая его репутация сред шотландцев пошла в гору, и «Шотландия снова предложила ему свою дружбу» ${ }^{67}$.

Виги видели в нем столь серьезную угрозу своему существованию, что в Парламенте открыто возражали против его сношений с Министрами, на чем особенно настаивали Айлаби и Уолпол ${ }^{68}$, которые в скором будущем стали видными деятелями.

64 «Публичный дух вигов» (The Publick Spirit of the Whigs, I7I4) - последняя попытка Свифта защитить кабинет министров во главе с Оксфордом; этот памфлет написан в опровержение статьи Стила «О кризисе» (The Crisis, I714).

65 В мае І707 г. вступила в действие Уния об объединении Англии и Шотландии, подписанная в І706 г.

66 Джонсон перифразирует девиз Шотландии: «Nemo me impune lacessit» (лат.).

67 Здесь, как и в предыдущей цитате, Джонсон следует за стихотворением Свифта «Автор о самом себе» (The Author upon Himself, I7I4).

68 Айлаби Джон (John Aislabie, I670-I742), государственный деятель, политик из партии вигов, ответственный за создание так называемого южноазиатского пузыря; Уолпол Роберт (Robert Walpole, 1676-I745), граф Орфорд, политик из партии вигов. 
Отлученный от своих высокопоставленных друзей, Свифт быстро потерял влияние, истощились его замыслы, и он, видя, что более в его услугах не нуждаются, удалился летом I7I4 года в Беркшир; там, пользуясь гостеприимством своего знакомого ${ }^{69}$, он написал памфлет, который впоследствии был запрещен, а ныне известен под названием «Свободные Мысли о современном Положении Дел» ${ }^{\circ}$.

Пока он выжидал, следя за тем, как разворачиваются события, внезапная смерть Королевы обрушила политическую систему, созданную Тори, похоронив всякие надежды на примирение с воинственно-победным лагерем Вигов, и Свифту оставалось лишь прозябать в безвестности.

О его возвращении в Ирландию Оррери и Делани рассказывают столь по-разному, что если мы хотим поверить им обоим (а у нас нет оснований сомневаться в достоверности их сведений) и сохранить их репутацию незапятнанной, то выход только один: предположить, что они описывают разные периоды в жизни Свифта. Говоря, что Свифту был оказан почтительный прием, Делани имеет в виду первые две недели его пребывания, то есть пору его вступления в законные права Декана; а когда Оррери рассказывает об обструкции, которую ему устраивали жители на улицах, он толкует о более позднем времени, когда Свифт уже окончательно обосновался на новом месте, то есть уже после смерти Королевы ${ }^{\text {т. }}$

Первое время рогатки в юридических вопросах ему пытался ставить архиепископ Дублина, но довольно быстро обнаружилось, что по части ведения дел благородный безупречный Свифт редко ошибается и, если он прав (а прав он почти всегда), то он не уступит ни пяди.

Он еще не остыл от партийных споров и придворных интриг, недавние волнения все еще занимали его мысли, подобно тому, как море волнуется после недавнего шторма. По свежим следам памятных событий он написал записки о «Смене Министров» и о «Поведении Кабинета Министров» $7^{2}$.

69 Речь идет о преподобном Джоне Гири (John Geree), в доме которого в местечке Леткоум Бассет в Вэнтедже Свифт прожил лето І7І4 г.

70 Полное название памфлета - «Некоторые свободные мысли о современном положении дел» (Some Free Thoughts upon the Present State of Affairs, I74I).

7I Королева Анна умерла г августа I7І І4 г.

72 Свои «Воспоминания о случившейся в г7Іо г. перемене» (Memoirs Relating to that Change Which Happened in the Year I7Іо) Свифт написал осенью I7І4 г., а «Расследование поведения последнего при жизни королевы кабинета министров» (Enquiry into the Behaviour of the Queen's Last Ministry) - в 1715-I7І7 гг. Оба сочинения были опубликованы посмертно в 1765 г. 
Говорят, что тогда же он возобновил работу над «Историей последних Четырех Лет Правления Королевы Анны», начатую еще при жизни ее Высочества, и весьма упорно трудился над этим сочинением, но огласке так и не предал. Уже после его смерти рукопись оказалась в руках лорда Оррери и доктора Кинга. Да, книгу с точно таким же заглавием, под именем Свифта выпустил в свет доктор Лукас, но мне нечего сказать по этому поводу, кроме того, что упомянутая публикация никоим образом не совпадает с тем представлением о книге, которое я как слушатель вынес из беседы графа Оррери и Льюиса Старшего 73.

Итак, Свифту пора было привыкать к ненавистной для него мысли, что он ирландец, и пытаться наладить свою жизнь в стране, которая казалась ему местом ссылки. Видимо, тогда-то он и стал истово набожным. В те дни его впервые посетила мысль о смерти и более уже не оставляла, став наваждением всей его жизни.

Дважды в неделю он устраивал в своем доме приемы, не без удивления обнаружив, что они привлекают все больше и больше гостей обоего пола из числа людей образованных, с тонким вкусом. Миссис Джонсон переехала из сельской местности в Дублин и снимала комнаты неподалеку от дома Декана. В дни торжеств она хлопотала по хозяйству, но за столом вела себя на правах гостьи, как одна из приглашенных дам.

По будням он имел обыкновение столоваться за деньги у кафедрального капеллана мистера Уоррэла ${ }^{74}$, у которого был чистый опрятный дом и обходительная супруга. Такой неприхотливый образ жизни сложился у Свифта из желания расплатиться с долгами, которые он успел наделать, а потом, когда необходимость отпала, он продолжал следовать старому распорядку уже из любви к скопидомству. Впрочем, скаредность не мешала ему сохранять лицо: он обедал на серебре и любил говаривать, что среди

73 «Историю последних четырех лет правления королевы Анны» (History of the Last Four Years of the Queen) Свифт написал в I7I2-I7І13 гг. В І737 г. он переслал рукопись через Оррери Уильяму Кингу (William King, I685-1763), бывшему главой колледжа Св. Марии в Оксфорде, якобиту по убеждениям, однако граф Оксфорд и другие публиковать ее отсоветовали. Доктор Чарлз Лукас (Charles Lucas, I7I3-I77I), врач по профессии и радикал по политическим взглядам, был фактическим редактором издания «Истории» Свифта. Излагая свои сомнения в этом вопросе, Джонсон ссылается на Эразма Льюиса (Erasm Lewis, I670-I754), политика, с которым был знаком.

74 Уоррэл Джон (John Worrall, ок. I666-I75I), глава церковного хора в соборах Св. Патрика и Церкви Христовой. 
ирландцев благородного звания он единственный бедняк, который ест на серебре, и единственный богач без собственного выезда.

Многие тщетно ломали голову над тем, как он проводил остальное время, чему посвящал часы своих штудий. Чужая душа - потемки, а Свифт никому никогда не открывался и ни перед кем не отчитывался ни о своих делах, ни о досуге.

В І7І6 году доктор Эш, епископ Клогера, тайно обвенчал сорокадевятилетнего Свифта и миссис Джонсон; как сообщил мне доктор Мэдден, венчание происходило в саду. После женитьбы все осталось, как прежде: молодые не съехались, продолжали жить в разных домах, и супруга Свифта переселялась в настоятельские покои мужа лишь тогда, когда у того обострялись приступы головокружения. Как говорит лорд Оррери, «если бы кто-то захотел доказать, что они встречаются наедине, без третьих лиц, сделать это было бы трудно»75.

До поры до времени жизнь Декана собора Св. Патрика текла мирно, не выходя за рамки узкого круга друзей и посвященных, но в I720 году Свифт напечатал памфлет, в котором посоветовал ирландцам, как лучше им распорядиться своей мануфактурой и, следовательно, как ее усовершенствовать $^{76}$. Кажется, что может быть более естественным для человека, чем право распоряжаться плодами рук своих или привязанность к тому, что он собственноручно произвел на свет божий? Однако так не думали те, чьи интересы были связаны с английской торговлей: самая мысль о таком праве, самое напоминание о подобной привязанности представлялись им настолько преступными, что печатника памфлета взяли под стражу; возмущенная этим беззаконием, как справедливо замечает Хоксворт, публика обратила внимание на предложение памфлетиста, и вскоре имя автора было у всех на устах.

В 1723 году умерла миссис Ваномри - история этой бедной женщины, на свое несчастье боготворившей ум и ославившей себя именем Baнесса, слишком хорошо известна, чтобы повторять ее в подробностях ${ }^{77}$.

75 Неточная цитата из: Boyle John (Orrery). Remarks on the Life and Writings of Dr. Jonathan Swift. L., I752. P. 25.

76 Имеется в виду «Предложение о всеобщем употреблении ирландской мануфактуры» (Proposal for the Universal Use of Irish Manufacture, I720).

77 Ваномри Эстер (Esther or Hester Vanhomrigh, І688-1723) познакомилась со Свифтом в Лондоне около г707-І708 гг. и последовала за ним в Ирландию в I7І 4 г. Здесь и ниже курсив С. Джонсона. 
Молодая женщина увлекалась литературой, а ее наставником и ментором на литературном поприще был Decanus, Декан, или по-другому (если переставить буквы) Cadenus; и в какой-то момент, разгоряченная похвалами учителя, она воспылала к нему нежными чувствами. Свифту тогда было примерно сорок семь - в этом возрасте мужское тщеславие особенно падко на амурную благосклонность барышень. Если кто-то скажет, что Свифту не следовало бы поощрять страсть, раз он не собирался отвечать на нее взаимностью, то хорошо бы вспомнить столь ненавистную Свифту сентенцию: «мужчины есть мужчины». Впрочем, возможно, вначале он просто не придавал этому значения и, как он сам пишет, оставался в неведении. После его женитьбы на Стелле единственным честным оправданием его снисходительного и обнадеживающего отношения к ухаживаниям этой барышни могло быть его подспудное желание отложить объяснение до последнего из боязни причинить ей боль. Она же решила, что ею пренебрегли, и от горя зачахла; но перед смертью она распорядилась об опубликовании стихотворения, в котором Cadenus клялся ей в любви и пел панегирик ее совершенству $^{78}$. О том, какой эффект произвела эта публикация на Декана и Стеллу, можно судить по рассказу Делани:

«С большой долей уверенности полагаю, что они оба (хотя и по-разному) были потрясены и огорчены произошедшим. Декан на два месяца уехал на юг Ирландии, пытаясь развеяться и избежать кривотолков, а Стелла приняла приглашение их общего знакомого, человека общительного и радушного, ею чрезвычайно уважаемого и ценимого, и переехала на какое-то время в его дом. Там-то и встретил ее мой информатор, от которого я знаю наверняка, что во время частых визитов в тот гостеприимный дом он всякий раз старался поддержать и отвлечь ее от горьких мыслей.

Один его рассказ особенно врезался мне в память. Я уже рассказывал о том, что ее знакомый был человеком на редкость гостеприимным, компанейским, с обширными связями, и однажды случилось так, что к обеду пожаловали господа, непосвященные в историю Стеллы; а поскольку тогда все только и обсуждали стихотворение «Каденус и Ванесса», то неудивительно, что в какой-то момент один из гостей заметил: “Необыкновенная особа, эта 78 Речь о стихотворении Свифта «Каденус и Ванесса» (Cadenus and Vanessa), написанном в I7ІІ г. 
Ванесса, раз вдохновила Декана на такие прекрасные стихи!” Миссис Джонсон только улыбнулась в ответ и сказала, что “по ее мнению, это еще нужно доказать, ведь всем известно, что Декан и метлу может воспеть в стихах” 79.

В I724 году репутация Свифта сильно поднялась благодаря «Письмам Суконщика» ${ }^{80}$. Дело было так: некто Вуд из Вулвергемптона, что в Стэффордшире, известный свой предприимчивостью и большими аппетитами, сделал подношение герцогине Мюнстера ${ }^{81}$ и получил за это патент на чеканку ста восьмидесяти тысяч фунтов полупенсовиками и фартингами для королевства Ирландии, где наблюдался крайне опасный и острый дефицит медной монеты, - дефицит этот делал потенциальным должником всякого человека, отпустившего другому товар в кредит: сами посудите, разве может не обслужить кухарка или владелец питейного заведения клиента, у которого в кармане серебро? И разве оставит такой клиент свои деньги, если у хозяина нет сдачи?

Поэтому проект был более чем вероятен. Благодаря агентам, собравшим по всей стране старые полупенсовики и тем самым изъявшим их из обращения, Вуд постарался увеличить и без того огромный дефицит мелких денег, и он уже был в шаге от победы, предвкушая, как прольет над Ирландией свой медный дождь свежеотчеканенной монеты и тот на его глазах обратится в дождь золотой, да не тут-то было. Обнаружив, что металл в значительной степени обесценен, Свифт, скрывшись под именем «М.Б., Суконщик», написал «Письма», где раскрыл возможные гибельные последствия обмена золота и серебра на медь, чья цена не доходила и до трети ее номинальной стоимости.

Страна забурлила, люди повсеместно отказывались принимать новые деньги; однако ирландские власти расценивали подобные демарши против королевского патента как действия преступные, и некто Уитшед ${ }^{82}$, в то время занимавший должность Верховного Судьи, известный тем, что именно он руководил процессом по делу печатника, издавшего предыдущий памфлет, что именно он девять раз распускал Присяжных, пока их не

79 Джонсон цитирует отрывок из эссе П. Делани: Delany Patrick. Observations upon Lord Orrery's Remarks on the Life and Writings of Dr. Jonathan Swift. L., I755. P. 57-58.

80 Речь о «Письмах Суконщика к ирландскому народу» (The Drapier's Letters to the People of Ireland, I724).

8I Герцогиня Мюнстера (I667-I743), любовница короля Георга I.

82 Уитшед Уильям (William Whitshed, ок. I656-I727), лорд-судья, глава королевского суда Ирландии. 
принудили посредством угроз и под страхом скандала огласить особый вердикт, теперь затеял разбирательство по делу вышеозначенного Суконщика, но не смог добиться от Коллегии Присяжных нужной статьи обвинения.

Тогда лорд Картерет ${ }^{83}$, вкупе с Тайным Советом, издал постановление, в котором за раскрытие личности автора «Четвертого Письма» было обещано триста фунтов. В своих сношениях с печатниками Свифт сохранял инкогнито, доверяя только своему дворецкому, которому и продиктовал памфлет. Тот же, сразу по обнародовании постановления, исчез и почти сутки не появлялся дома, заронив у хозяина вполне резонное подозрение в предательстве; поэтому, когда он вернулся, Декан потребовал, чтобы тот сложил с себя полномочия и уходил восвояси, «ибо я прекрасно понимаю», сказал он, «что моя жизнь в твоих руках, и я не намерен из страха терпеть твою наглость или небрежение». Дворецкий покаянно божился, что не виноват, и умолял хозяина не гнать, а запереть его в доме, пока не улягутся страсти и сохраняется хоть малейшая вероятность нежелательного развития событий, но Свифт был неумолим: выгнал слугу и думать о нем забыл; но когда объявленный срок поимки истек, он принял его обратно. Спустя какое-то время он собрал ни о чем не догадывавшуюся прислугу и объявил, что за безупречное поведение он дарует дворецкому Роберту место церковного служки в соборе Св. Патрика с годовым доходом от тридцати до сорока фунтов и просит отныне величать его не иначе как мистером Блэкни; впрочем, тот еще несколько лет продолжал служить у него дворецким.

С тех пор за Свифтом закрепилось имя «Декана». Ирландский народ почитал его за своего героя, благодетеля и защитника, авторитет его был столь высок, что никто из людей равного с ним статуса или богатства о подобном и мечтать не мог.

С того памятного года повелось, что торговцы взирали на него, как на оракула, а для черни он стал кумиром, поэтому все те, кто хотел задобрить торговый люд или добиться благоволения народа, заискивали перед ним и боялись его, как огня. Суконщик стал символом, добрым знаком; куда ни глянь, в какую сторону ни обрати слух, везде были налицо знаки народной благодарности Суконщику.

83 Картерет Джон (John Carteret, I690-I763), английский наместник в Ирландии в I724 г. 
И, скажем прямо, было за что: чего стоило одно спасение Ирландии от кабальнейшего и хищнического вторжения! И так во всем: если дело касалось общественного интереса, он выступал его рьяным поборником, всякий раз упрочивая в глазах народа завоеванный авторитет. Он даже не гнушался некоторым бахвальством: когда Лорд-судья архиепископ Болтер обвинил его в подстрекательстве людей при попытках отрегулировать хождение в стране монет, Свифт бросил: «Да стоило мне только поднять палец, и они разорвали бы вас на куски!»

Однако вскоре упоение славой омрачила личная трагедия: как раз в год торжества Суконщика обнаружились первые признаки нездоровья у миссис Джонсон, его незаменимой собеседницы, его целительницы, и за два года она так исчахла, что никаких надежд на выздоровление не осталось.

Свифт в то время был в Англии, собирался по приглашению лорда Болингброка отправиться на зиму во Францию, но, получив тревожное известие, бросился не мешкая назад, в Ирландию, чем, вероятно, спас несчастную, во всяком случае, помог ей оправиться на какое-то время от болезни.

Видимо, решив, что все обошлось, он вернулся (в I727 году) в Англию; там вместе с Поупом он подготовил к публикации три тома «Пестрой смеси», снабженные жалобно-извинительным Предисловием Поупа ${ }^{84}$.

В том же знаменательном году свет увидели «Путешествия Гулливера», встреченные публикой со смешанным чувством забавы и замешательства: столь новым и необычным казалось это сочинение. Читатели проглотили его с таким жадным любопытством, что цена первого издания подскочила еще до того, как вышло второе; книгу читали богачи и бедняки, ученые и недоросли. Критики набрали в рот воды от изумления, не зная, как судить о книге, написанной с вызывающим неправдоподобием и в нарушение всяческих правил: тут всякое разумение бессильно. Но, когда стали разбираться, выяснилось, что наименьшее удовольствие читателям доставила та часть, где описывается Летающий Остров, а самой омерзительной признали историю Гуигнгнмов.

84 В трехтомное издание «Пестрой смеси в прозе и стихах» (Miscellanies in Prose and Verse, I727-І732) вошло больше сочинений Свифта, чем Поупа. 
Свифт упивался успехом своей новой книги, а тем временем подоспело известие о кончине Короля ${ }^{85}$, и уже через три дня после восшествия на трон новых Короля и Королевы ${ }^{86}$ он целовал им руки.

Свифт был отмечен вниманием Королевы еще в бытность ее Принцессой, и теперь ее Высочество оказала ему достойный прием; но то ли Королева заронила в нем надежды, которым не суждено было исполниться, то ли у него родились ожидания, о которых она не подозревала, в его отношении к ней установилась настороженность, обострившаяся после того, как она, пообещав прислать ему какие-то медали, слово свое не сдержала.

Не знаю, возможно, и у нее были к нему какие-то претензии. Взять ту же историю с письмом, в котором Королеву весьма настойчиво просили оказать покровительство одной даровитой ирландке, миссис Барбер, пытавшейся организовать подписку на издание своих стихов. Автором письма значился Свифт, и по оборотам речи и эмоциональной окраске то был явно его опус; однако чужой почерк и некоторые несообразности вызывали сомнения. Когда вокруг этого письма поднялся шум и Свифта призвали к ответу, он, указав на имевшие место несообразности, заявил о беспочвенности обвинений, однако их не отмел: лавируя между правдой и вымыслом, он красноречиво умалчивал о главном.

По-видимому, он был не прочь возобновить карьеру придворного и потому старался заручиться благорасположением миссис Хоуард ${ }^{87}$, памятуя о том, как поступала в прежние времена миссис Мэшем ${ }^{88}$, только его лесть острослова не возымела никакого толка: либо у дамы было маловато власти, либо поэтическое бессмертие ее не интересовало.

Вскоре у него случился приступ головокружения; из дома пришли тревожные вести о нездоровье миссис Джонсон. Тогда он без всяких объяснений, спешно покинул Поупа, у которого гостил, написав ему с дороги из Честера, что «двум больным друзьям под одной крышей не ужиться» ${ }^{89}$.

85 Король Георг I умер в дороге по пути в Ганновер ІІ июня І727 г.

86 Король Георг II и королева Каролина.

87 Хоуард, Генриетта (Henrietta Howard, ок. I688-I767), любовница Георга II, она же графиня Саффолк.

88 Мэшем (Машам) Эбигейл (Abigail Masham, ок. I670-I734), фрейлина королевы Анны, часто упоминаемая в «Дневнике для Стеллы» Свифта.

89 Джонсон цитирует письмо Свифта Поупу от І2 октября І727 г. 
Дома его ждало горе: бедняжка Стелла стояла одной ногой в могиле, тая на глазах, и через два месяца, 28 января I728 года ее не стало; ей было сорок четыре года. Судя по его записям, ради нее он был готов на все, лишь бы она жила; без сомнений, ему внушала ужас мысль о смерти той, кого он больше всего на свете любил и чей конец он сам невольно ускорил ${ }^{90}$.

Несчастная Стелла пала жертвой двух желаннейших женских достоинств, красоты и обаяния. Как пишет Делани, она на свою беду полюбила человека, обожавшего все неординарное и возжелавшего для себя такого счастья, которое было бы непохоже на обычные ожидания людей и на то, что диктует Провидение. Когда она поселилась в Ирландии, он, видимо, решил, что она навсегда останется в его власти, и потому сделал все, чтобы помешать намечавшемуся вполне выгодному браку, чиня мелочные препятствия и предъявляя заведомо невыполнимые требования9г . Он не был спокоен за свою собственность, пока она была предоставлена сама себе: на их пути могли встать чьи-то неприязнь, честолюбие или чей-то каприз; чтобы «закрепить уверенность»92 и получить Стеллу в полное обладание, и был придуман тайный брак со всеми вытекающими радостями совершенной дружбы, но не отягощенный супружеским долгом. Однако бедную Стеллу такое положение не устраивало: за замужнюю женщину ее никто не признавал, а в глазах света она была кем-то вроде содержанки. Долгое время она слепо надеялась, что он обнародует их брак и объявит ее своей, но это время все не наступало, он переменился, рассудок его померк, и когда, наконец, он предложил признать ее своей законной супругой, она отказалась: «слишком поздно». Еще несколько лет она изводила себя горькими раздумьями, а потом умерла, зачахнув во власти человека, безмерно любившего и почитавшего ее.

Любопытствующих, конечно, интересует, чем она сумела так приворожить Свифта, что он попрал даже основные законы, лишь бы ее удер-

90 Джонсон ссылается на «Молитвы за больную во время ее недомогания» (Prayers for a Sick Person during Her Illness) (г7 октября и 6 ноября г727 г.) и «На смерть миссис Джонсон» (On the Death of Mrs Johnson) (28 января I728 г.).

9I Известно письмо Свифта сватавшемуся к Стелле Уильяму Тисдаллу (Тисдаллю) (William Tisdall, I669-I735) от апреля I704 г., в котором Свифт пишет о невозможности их брака.

92 Джонсон цитирует из «Макбета», действие IV, сцена I. Ср. в оригинале: «assurance double sure» и в переводе Ю. Корнеева: «для уверенности вящей» (цит. по: Шекспир Уильям. Макбет // У. Шекспир. Полное собрание сочинений: в 8 т. М.: Искусство, I96о. Т. VII. С. 67). 
жать? Ответить на этот вопрос непросто. Свифт - влюбленный, и его свидетельства сомнительны. Что принадлежит до Делани и ирландцев, то они на все смотрели глазами Свифта, и поэтому от них тоже мало проку. Судя по восторженной влюбленности Свифта, очень может статься, что она хоть и была редкостной праведницей, красавицей и натурой в высшей степени утонченной, только начитанности ей явно не хватало, раз она на родном языке писала с ошибками; а что касается ее хваленого остроумия, то среди метких фраз, записанных с ее слов самим Свифтом, настоящих перлов нет ${ }^{93}$.

Читатель «Письма к Даме по поводу ее Замужества» вправе усомниться, стоит ли принимать на веру суждение Свифта о женском совершенстве94; ибо если его общие наблюдения о женщинах таковы, как он их излагает, то женщине не надо было быть семи пядей во лбу или образцом добродетели, чтобы привести его в восторг: он легко поддавался очарованию. Так что превосходство Стеллы было, пожалуй, местного свойства: победительницей ее делало мелкое окружение.

В недавно опубликованных заметках о жизни Свифта его женитьба названа маловероятной, чуть ли не небылицей, но, увы, это не так: как рассказал мне доктор Мэдден, эту печальную историю бедняжка Стелла поведала перед смертью соборовавшему ее доктору Шеридану, и у Делани о том сказано сочувственно как о несомненном факте. Свифт не мог вспоминать о Стелле без вздоха.

Остаток дней он провел в Ирландии, с которой так и не примирился, ни под гнетом почти деспотической власти, ни прикормленный пряником почти слепого обожания. Время от времени он изъявлял желание посетить Англию, но всегда откладывал поездку по какой-то причине. На склоне лет он писал Поупу, что надеется увидеться с ним еще раз, «но если не доведется, то расстанемся, как все смертные»95.

После смерти Стеллы он очерствел, сделался нетерпимым; мог выгнать приятеля из-за стола, а потом удивлялся, почему его все покинули. Но интерес к публичным делам не утратил, разражаясь время от времени

93 Вероятно, Джонсон имеет в виду сочинение Свифта «Bon Mots de Stella».

94 Джонсон ссылается на стихотворение Свифта «Письмо к молодой даме по поводу ее замужества» (Letter to a Young Lady on Her Marriage, 1723).

95 Джонсон цитирует письмо Свифта Поупу от І2 октября І727 г. 
директивами, порицаниями, критикой, каковых, по его мнению, требовала острота момента, и перо его скрипело не напрасно.

В коротком стихотворении о Пресвитерианах, которых он на дух не переносил, он нелестно отозвался о законнике Беттсуорте ${ }^{96}$, опорочившем себя наглым отношением к священникам, и тот в одночасье потерял свою немаленькую репутацию, сделавшись объектом всеобщего презрения. Разъяренный, опозоренный Беттсуорт явился к Свифту с требованием сказать, не он ли автор стихотворения.

«Мистер Беттсуорт», ответствовал Свифт, «в молодости я был знаком со светилами закона, и они, зная мою склонность к сатире, дали мне один совет на тот случай, если ко мне явится какой-нибудь негодяй или тупица из тех, кого я продернул, и пристанет с вопросом “Это вы - автор того пасквиля?”: сказать, нет, не я. Так что мой ответ, мистер Беттсуорт, нет, вы ошиблись адресом» 97.

Беттсуорта такой ответ не устроил, он продолжал публично требовать сатисфакции в виде телесного наказания, но на защиту Декана встало все население прихода Св. Патрика. Выступая в Парламенте, Беттсуорт заявил, что Свифт лишил его годового дохода в тысячу двести фунтов.

Потом молва разнесла слух о еще одном благодеянии Свифта. Он отложил несколько сотен фунтов для того, чтобы ссужать беднякам небольшие суммы от пяти шиллингов, по-моему, до пяти фунтов. Ссуда была беспроцентной, единственное условие - при возврате денег добавлять небольшую мзду казначею; и, главное, Свифт требовал возвращения денег точно в обещанный срок. Однако срок часто сдвигался, заем не отдавали: строгий педантизм - плохой советчик при расчетах с беднотой. Все это, казалось, можно было легко предвидеть, но Свифт не шел ни на какие уступки: вместо этого он постановил взыскивать долги через суд. Строгость и без того не красит кредитора, что уж тут говорить о человеке, который под видом благотворителя натравливает судебных приставов? Шум поднялся страшный, возмущение народа не знало предела, и ему пришлось отказаться от своей затеи, признав, что он совершил глупость, ожидая пунктуальности от бедняков.

\footnotetext{
96 Беттсуорт Ричард (Richard Bettesworth, ок. I689-I74I), член ирландского парламента, имевший высший судейский чин. Свифт высмеял Беттсуорта в стихотворении «О словах братья протестанты и братья христиане» (On the Words - Brother Protestants, and Fellow Christians, I733).

97 Точный источник цитаты неизвестен.
} 
Проклятием его жизни стала пустота, на которую он сам себя обрек из-за разъедавшего его недовольства, а оно только обострялось с ненавистным ему одиночеством. Нельзя сказать, что он был всеми брошен: в доме у него бывали и ученые мужи, и светские дамы; он пописывал стихи и прозу, охотно раздавал списки своих виршей и, по-видимому, был совсем не прочь увидеть их в печати. Его излюбленный девиз - «Vive la bagatelle!»98 Он считал безделки неотъемлемой частью жизни, возможно, и неотъемлемой частью самого себя. Праздность была не по нем, а недуги поневоле заставляли его быть праздным, не давая подолгу писать или сидеть за книгами. С возрастом привычка баловать себя усиливается, а у него был свой резон прельщаться мелкими забавами: в любом деле он жаждал аплодисментов, и его ими сторицей награждали искренние поклонники, ибо сомневаться в его превосходстве не приходится. Тот, кому много льстят, и сам быстро учится льстить: нас обычно приучают к порядку, пугая или стыдя, а как можно воздействовать страхом или стыдом на человека, если он не слышит ничего, кроме похвал в свой адрес?

С годами у него участились приступы головокружения и внезапной потери слуха, усилившаяся глухота сказалась на беседе; к тому же приступы становились все тяжелее, пока, наконец, его не прихватило так, что он более и не помышлял ни о каком умственном или физическом напряжении: случилось это с ним в I736 году, во время работы над поэмой «Клуб Легиона»99.

Он всегда считал свои деньги и щедрых застолий не любил, но, экономя на мясе, не мог отказать себе в вине. Когда к нему в гости заходили друзья, рассчитывая у него отобедать, он по своему обыкновению давал каждому из гостей, независимо от пола, по шиллингу, предлагая сделать заказ на свой вкус. В конце концов, жаба задушила в нем чувство гостеприимства: ему стало жалко бутылки вина для гостей, а в Ирландии, как известно, люди в гости не ходят, если в доме нет выпивки.

Оказавшись отлученным от бесед с друзьями, забросив занятия, он остался без дела и без потехи; решив когда-то давно на свою голову (а может быть, поддавшись какой-то безумной затее) ни при каких условиях не

98 «Да здравствуют безделки!» (фр.) Джонсон дал следующее определение французского слова «bagatelle»: пустячок, безделка (a trifle, a thing of no importance). Ср. у Стерна в «Сентиментальном путешествии по Франции и Италии»: «Да здравствуют интрижки!» Цит. в переводе А. Франковского: Стерн Л. Сентиментальное путешествие... СПб., 2006. С. І 46. 99 «The Legion Club» (I736) - сатира Свифта на ирландский парламент. 
носить очков, он на старости лет лишился и чтения; в итоге он закоснел в своих идеях, годами не оттачиваемых в спорах, не освежаемых с книгами, и забил себе голову житейскими заботами, доведя себя до сумасшествия ${ }^{100}$.

Впрочем, одну книгу он все же опубликовал в I738 году: то был его ранний опус «Учтивая Беседа» ${ }^{\text {ог }}$, а затем уже посмертно напечатали его «Наставления Слугам» ${ }^{102}$. Судя по двум этим выступлениям, Свифт по своему обыкновению подмечал все, что наблюдал, ибо собрать такое количество подробностей по памяти ему, конечно, было не под силу.

Он делался все более буйным, слабея рассудком, пока, наконец, в I74I году не было решено установить над ним и его собственностью опеку. Он уже почти никого не узнавал, попеременно впадая то в помешательство, то в слабоумие. Дольше других он привечал миссис Уайтви ${ }^{\mathrm{10}}$, но вскоре и ее черты стерлись у него из памяти. За обедом ему подавали мясо разрезанным на кусочки, но, пока в столовой находилась прислуга, он к нему не притрагивался; только спустя час брал в руки тарелку и съедал мясо, шагая по комнате: такова была сила старой привычки находиться на ногах по десять часов в день.

На следующий год (в І742-м) у него воспалился левый глаз, образовался фурункул размером с яйцо, по телу пошли нарывы; от боли он потерял сон и чудом себя не покалечил: пять человек насилу его удерживали, чтобы он не вырвал себе глаз.

В конце концов опухоль спа́ла, к нему ненадолго вернулся рассудок: он стал узнавать врача, домочадцев, вновь поселив в них надежду на выздоровление; но затем через несколько дней снова впал в заторможенное

Iоо В «Жизнеописании Янга» (традиционное написание - Юнг) есть пророческое воспоминание о Свифте. «Рассказывая о Свифте, Янг пишет: “Помню, прогуливались мы как-то всей компанией в окрестностях Дублина, и вдруг он остановился как вкопанный; все как ни в чем не бывало пошли дальше, но мне стало не по себе, я вернулся и вижу: он стоит как столб, на том же месте и, задрав голову, смотрит не отрываясь на величественный вяз с почерневшей засохшей кроной. Показал рукой и говорит: “Вот так и я - с головы сгнию”». Цит. в переводе по: Johnson Samuel. Young // Samuel Johnson The Lives of the most eminent English Poets; with Critical Observations on their Works. In IV vols. L., MDCCLXXXI. Vol. IV. P. $374-375$.

Iог Свифт писал «Учтивую беседу» (Polite Conversation) в I730-I735 гг., опубликовав ее в I738 г. в Дублине.

Iо2 «Наставления слугам» (Directions to Servants) Свифт начал писать в I704 г., переработал в I730-І738 гг.; опубликованы посмертно в 1745 г.

I03 Уайтви Марта (Martha Whiteway, I690-I768), овдовевшая кузина Свифта. 
состояние, слег, стал ко всему безучастным и как будто лишился дара речи. Только спустя год полной немоты он, по рассказам, в ответ на слова своего управляющего о том, что в доме готовятся отпраздновать его день рождения, устроив 30 ноября фейерверки и иллюминацию, сказал: «Глупости это все, пустое!»

После того случая, если верить воспоминаниям, он еще несколько раз ронял что-то, не лишенное смысла, но потом наступило полное молчание, и продолжалось оно до самой его кончины в октябре I744 года: он тихо отошел на семьдесят восьмом году жизни.

СУдить о Свифте как об авторе будет справедливым лишь тогда, когда его сила будет меряться воздействием, какое она возымела. Во время правления королевы Анны Свифт повернул вспять общественное настроение, бывшее в пользу Вигов, и какое-то время именно его политические мнения задавали в Англии тон: не признавать этого нельзя. При следующем правлении он избавил Ирландию от поборов и угнетения, показав, что ум, вкупе с правдой, обладает мощью, перед которой власти бессильны. Он не преувеличивал, говоря, что Ирландия - «его должница» ${ }^{104}$. Именно с той поры, когда он взял ирландцев под свое крыло, они и ведут отсчет своему богатству и преуспеванию. Он первым научил их во всем иметь свой собственный интерес, знать себе цену и не уступать, и это он вдохнул в них чувство равенства с остальным человечеством, которое с тех пор не дает им покоя, обязывая требовать для себя прав и добиваться справедливости. И их нельзя упрекнуть в неблагодарности своему благодетелю, ибо они всегда почитали его за своего хранителя и внимали ему, как владыке.

Что принадлежит до его сочинений, то они совсем иные по темпераменту и манере выражения. Чужой среди его книг выглядит «Сказка Бочки»: больше он никогда не писал с таким неистовством, с таким неистощимым воображением, с такой быстротой мысли, таким живым языком, как тогда. «Сказка Бочки» столь уникальна и своеобразна, что ее следует рассматривать саму по себе: то, что верно по отношению к ней, не будет таковым по отношению ни к какому другому его произведению.

I04 Джонсон перефразирует строчку из «Стихов на смерть доктора Свифта» (Verses on the Death of Dr. Swift): «Королевство свое он оставил должником» (The Kingdom he hath left his Debtor). 
Остальные его работы написаны ровно, легким слогом, напоминающим больше мелкий ручеек, нежели полноводное течение. Его коньком была простота. Те, кто говорит, что у него в сочинениях нет метафор, ошибаются, они у него есть; но употребляет он их не со вкусом, а по необходимости. Он - пурист, и, хотя у него, возможно, попадаются обороты не совсем точные, все же солецизмами он не грешит, и любой, кто ссылается на его суждение, может в нем не сомневаться. Фразу он строит без «воды», но и не слишком сжато, легко избегая каких-то неловких оборотов в сложных грамматических периодах, не нарушая логических связей и сохраняя плавность переходов.

Стиль его сообразен его мысли, которой всегда были чужды субтильность, украшательство, блеск кончетто, выспренность, риторические фигуры или завихрения учености. К страстям он холоден, удивлять или изумлять публику не привык, главное для него - понимать самого себя и быть понятным читателю: чтение Свифта не требует обширных предварительных знаний, достаточно, если у читателя есть обыкновенный словесный багаж и житейский опыт; ему не придется штурмовать вершины или обследовать глубины, - путь его пролегает по равнине, под ногами у него всегда твердая почва, без обрывов и препятствий.

Свифт всегда добивался того, чтобы мысль передавалась понятным и надежным способом, и то, что ему это удалось, достойно всяческих похвал, хотя, пожалуй, и не самых пышных. Такая манера хороша для дидактических целей, когда требуется объяснить что-то неизвестное, но там, где нужно пробудить угаснувший было интерес к истинам известным, она оказывается бесполезной; она учит, но не убеждает.

Как политик он сформировался в кругу Вигов, но когда те отошли от своих принципов, он от них отмежевался, не впав при этом в противоположную крайность; в течение всей жизни он держался одной линии поведения, которую определял как склад мысли «Прихожанина Англиканской Церкви» ${ }^{\circ 5}$ : в государственной политике быть заодно с Вигами, а в религии - с Тори.

Для священника он был в меру честолюбив: радел за преумножение благ священнослужителей и споспешествовал их почитанию; с раскольни-

I05 Это определение - часть заглавия сочинения Свифта «Переживания прихожанина англиканской церкви» (Sentiments of a Church of England Man, I7II). 
ками старался держаться границ терпимости, но их нападкам всегда давал отпор.

Свои обязанности Декана он исполнял самым ревностным образом. Церковными доходами распоряжался рачительно: по словам Делани, при нем на поновление и ремонт Собора денег ушло больше, чем за все время с момента его возведения ${ }^{\text {106 }}$. Особенно он пестовал церковный хор, и, хотя музыку не любил и не понимал, при нем в хор отбирали только лучших певцов с отменными рекомендациями.

Он возобновил в своем храме практику еженедельных причастий и сам, собственноручно раздавал святые дары, отправляя ритуал торжественным и трепетным образом. Каждое утро он шел в церковь, молился наравне с прихожанами, а вечером посещал литургию, дабы убедиться в подобающем ее исполнении.

Проповеди он читал «звучно, проникновенно, без изысков; голос у него был резкий, высокого тембра, совсем не мелодичный».

Он принял духовный сан в надежде стать выдающимся проповедником, а оказалось, как он позднее сетовал, что, ввязавшись в политические дебаты, «ему не оставалось ничего другого, как проповедовать памфлеты» ${ }^{\text {1о7 }}$ Неоправданно суровая самокритика, не подтверждаемая его опубликованными проповедями!

Подозрения же его в безбожии во многом проистекали из его отвращения к лицемерию: не желая казаться лучше, он делал вид, будто он хуже, чем есть на самом деле. В Лондоне он, избегая посторонних глаз, всегда ходил к заутрене; в доме у себя собирал слуг на утреннюю молитву с такими хитроумными предосторожностями, что гостивший у него доктор Делани узнал об этом только спустя полгода. Мало того что Свифт старался не афишировать свои добрые дела, так он еще был не прочь поддержать молву о дурных поступках, которые не совершал. Он позабыл, что когда-то сам говорил: лицемерие - меньшее зло, чем неприкрытое кощунство. Доктор Делани, при всем его стремлении выставить Свифта в выгодном свете, и то неодобрительно отозвался об этой черте его характера.

Iо6 Готический собор Св. Патрика в Дублине, самый грандиозный храм в Ирландии, строился с II9I по I270 гг.

Iо7 Здесь Джонсон, видимо, цитирует Делани: Delany Patrick. Observations upon Lord Orrery's Remarks on the Life and Writings of Dr. Jonathan Swift. L., I755. P. 42. 
Внешне Свифт не отличался особенной привлекательностью. Его портил землистый цвет лица, от которого он никак не мог избавиться, хотя умывался, как восточный чистюля. Смотрел на все сурово, с кислой усмешкой, и это выражение редко сменялось подобием улыбки: смех был не по нем.

Домочадцам он спуску не давал, и уживаться с таким хозяином было, наверное, крайне трудно: решительный нрав в соединении с мелочной подозрительностью, которая читается в его сочинениях, делали его человеком тяжелым в общении. Положение не спасала и его привычка по большим праздникам дарить прислуге подарки: награда - разовая вещь, а хозяйское глумление величина постоянная. Он и чужих слуг не жаловал. Как-то однажды за обедом у графа Оррери он в присутствии подававшего им слуги сказал: «Этот человек за время обеда успел пятнадцать раз ошибиться». В чем именно ошибся слуга, лорд Оррери, от которого я слышал эту историю, не счел нужным уточнить у своего гостя. Кстати, я мог ошибиться цифрой.

В хозяйстве у него царила своеобразная, ничем не прикрытая и не оправданная, удручающая скаредность. Начав однажды откладывать по необходимости, он так втянулся в это дело, что поначалу казавшаяся забавой привычка постепенно превратилась в неприятнейшую обузу. Впрочем, он никогда не позволял скупости, даже если она напоминала аскезу, взять верх над его добродетелью. Будучи по натуре аскетом, в принципиальных вопросах он поступал щедро; и если вспомнить, для чего предназначались его маленькие сбережения, как он распределял мелкие суммы среди бедняков, то окажется, что он просто предпочитал один способ тратить деньги всем остальным и копил лишь для того, чтобы ему было что раздать. Он не разбогател в ущерб своим преемникам, - наоборот, он преумножил ценность и Ларакора, и настоятельских покоев.

Что бы ни говорили о его скупости или щедрости, следует помнить, что он не был богачом. Его приход приносил ему немногим больше семисот фунтов в год.

Никакой сердечности или светскости в его меценатстве не было в помине: он выручал, помогал без тени сочувствия или доброты, так что облагодетельствованные им едва ли его за это любили.

Он взял за правило давать за один раз не более одной монеты, поэтому карман у него всегда был набит монетами разного достоинства. 
За что бы он ни брался, он все делал по-своему, не принимая в расчет то обстоятельство, что исключительность, уже подразумевающая некоторое презрение к общепринятым конвенциям, суть своего рода вызов, который резонно вызывает у окружающих отпор; вот отчего, собственно, тот, кто ведет себя не так, как другие, оказывается хуже прочих, даже будь он на голову выше остальных.

О его нраве можно судить по рассказу Поупа:

«Незнакомцы принимают странную, резкую манеру доктора Свифта за неприязнь. В действительности это не так, но без примера этого не объяснить. Вот первый, что приходит в голову. Как-то вечером мы с Геем пошли его проведать: вы же знаете, какие мы все закадычные друзья. Только вошли, слышим: “Ба, господа! (это Свифт) Какими судьбами? Как?! Вы оставили компанию лордов, от которых вы без ума, и пришли навестить бедолагу Декана?” - “Да, ваше общество нам приятней любого другого”. - “Так я вам и поверил, даже не рассчитывайте. Но раз вы здесь, полагаю, вам нужно заказать обед”. - “Нет, преподобный, мы уже отобедали”. - “Отобедали?! Как, когда?! Еще восьми нет. Право, все это очень странно; но если все-таки желаете, я вмиг распоряжусь. - Постойте-ка, что же нам заказать? Парочка лобстеров будет очень кстати, это два шиллинга; два пирога с фруктовой начинкой - это еще один шиллинг; ну и, конечно, вы не откажетесь выпить со мной по бокалу вина? пусть даже вы, не желая вводить старого приятеля в расход, и пообедали плотно раньше обычного”. - Но мы не хотим выпивать, мы просто зашли поговорить с вами. - "Нет уж, позвольте! если вы у меня обедаете, значит, и выпиваете. - Итак, бутылка вина, еще два шиллинга, дважды два четыре, плюс один, всего пять: ровно по двадцать шесть на каждого. Вот, Поуп, держите, это Ваши полкроны, а это Ваши, сэр; мне для друзей ничего не жалко, так и знайте”. - Все это он отчеканил, как только он один умеет, не дрогнув ни единым мускулом лица, и по сути заставил нас принять деньги, не дав нам вставить ни слова» ${ }^{\text {108. }}$.

I08 Рассказ Поупа, относящийся к I73о г., заимствован у Спенса: Spence Joseph. Observations, Anecdotes and Characters of Books and Men, ed. James V. Osborn. 2 vols. Oxford, I966. Vol. I. P. 53-54. 
В повседневной жизни он не стеснялся давать волю капризам и отпускать едкие замечания, и его страшно обижало, когда кто-нибудь, не уловив его добродушных шуток или критического апломба, или незлобивых эскапад, встречал их в штыки или, того хуже, пытался оспорить. Он всегда был на две головы выше окружающих, и, если бы рядом случился соперник, по всем статьям его превосходящий, он такого соседства наверняка не потерпел бы. Что бы кто-то осмелился давать ему совет... - как выражается его приятель Делани, «для начала было бы неплохо осмелиться с ним заговорить!» Впрочем, в какой-то момент эта привычка задавать тон оказалась непосильной ношей, и Свифт, который всех и вся видел насквозь, проявил слабость к низкой лести.

О чем бы Свифт ни писал, он всегда берет свой привычный снисходительный тон, скорее поучая, чем воздействуя убеждением, ожидая, что этот безапелляционно-непререкаемый стиль будет воспринят как своего рода шутка. Однако он перестарался: своей наигранной категоричностью, которая только для противников звучала иронично, а для сторонников вполне серьезно, он явно польстил собственному самолюбию.

Рассказчик он был от бога и сам это про себя знал. Его завораживало почтительное молчание, с каким ему внимали слушатели, он по много раз рассказывал одну и ту же историю.

Впрочем, справедливости ради надо сказать, что он не только говорил, но и слушал: он взял за правило, проговорив минуту, делать паузу, предоставляя слово собеседнику. Во всем, что касается времени, он был педантичным компьютером (computer) ${ }^{\text {г9 }}$ и знал, какое количество минут уходит на ту или другую операцию.

Резонно предположить, что в беседе, как и в письмах, он любил показать, что он на короткой ноге с Великими мира сего, что он причастен к тому мимолетному равноправию, которое возникает между людьми в отсутствие церемоний, традиционно отделяющих одно сословие от другого. Такое нарушение приличий среди его единомышленников называлось широтой души. Но мудрый человек не станет принимать подачки, зная, что их в любую минуту может отобрать законный владелец. Тот же, кто вторгается

Iо9 Здесь С. Джонсон использует слово «соmputer» (от лат. (com)putare - считать), которое появилось в английском языке в начале XVII в. и до конца XIX в. означало человека, умеющего превосходно делать расчеты в цифрах, оценивать объем, размер и т. д. 
на чужую территорию, оказывается зависим от чужой воли: его или с позором прогоняют, или терпят из жалости и снисхождения.

Если судить по письмам, полагая их надежным источником, о том, каков был склад мысли Свифта, то он предстает человеком, не вызывающим любви или зависти. Такое впечатление, будто всю жизнь его неудовлетворенная гордыня бунтовала против прозябания и отсроченных надежд. Он то кидается в спор, то деликатничает, то встает в позу, то нападает; о себе он говорит исключительно с возмущением и скорбью, а о других - по-разному: когда весел, то с наглым апломбом, а когда уныл, то зло и ядовито. Из писем, которыми он обменивался с Поупом, можно заключить, что все четверо, включая Арбетнота и Гэя, воплощали собой все разумение и всю добродетель человечества, что их достоинства - это мировой светоч, и другого такого не будет. Век погряз в темноте, они одни противостоят мраку.

Если уныние, охватившее его после изгнания в Ирландию со смертью Королевы, еще можно понять: идеи отвергнуты, надежды растоптаны, веселая жизнь кончилась, важная должность и блестящие связи остались в прошлом; то все последующие сетования его на судьбу, поначалу вполне естественные, оправдать нельзя: они смехотворны, поскольку бесполезны; время и разум - лучшие доктора. Но было уже поздно: брюзжание вошло в привычку, чувства притупились. Слушая его постоянное нытье, Болингброк, как ему казалось, угадал настоящую причину и предложил Свифту бросить свой приход и получить новый в Англии, но получил отказ, зато у Свифта осталась возможность и дальше жаловаться на судьбу.

Самое трудное в анализе характера Свифта - это разобраться, из-за какого интеллектуального изъяна ему так нравилось копаться в идеях, противных уму любого другого человека. Одно дело - мысли об удовольствии, пусть даже запретном: они подстегивают воображение; а чем могут быть привлекательны для ума болезнь, увечье или грязь? Делани хочется думать, что изначально мысль Свифта была свободна от всей этой проказы и что виной всему его долгий визит к Поупу. Он не замечает, что таким предположением принижает своего героя, выставляя почти шестидесятилетнего мужа испорченным мальчиком, легко поддающимся дурному влиянию взрослого. Но дело-то в том, что Гулливер много раньше описал своих йэху и что придумавшего эти образы ничему дурному не учили. 
Таково мое представление о характере Свифта, а теперь предоставим слово человеку, знавшему его лучше многих. Вот как о нем рассказывает лорду Оррери доктор Делани, вспоминая многолетнее знакомство:

«Сударь, если принять во внимание исключительный, своеобычный и всеяднейший склад Свифтова ума, чьи намерения всегда благородны, пусть они и не всегда столь же хороши в исполнении, ума проникновенного и благодатного даже в минуту брани; если принять во внимание суровое правдолюбие Свифта, твердость, с какой он противостоял угнетению и произволу властей; его верность узам дружбы, искреннюю любовь и безотказное служение религии, его принципиальность в принятии правильных решений и неукоснительное им следование; его радение о своей церкви, церковном хоре, приходском хозяйстве, о доходе; его желание указать на ошибки в чтении и стиле изложения каждому, читавшему проповедь с амвона его храма; как и его заботу о благосостоянии преемников, которое он старался преумножить, делая отчисления от собственных доходов в приходскую казну; если учесть несокрушимый патриотизм, с которым он относился к нелюбимой стране; его разнообразнейшие, разумные, взвешенные и многократные благодеяния в течение всей жизни, а также его последнюю волю передать все свое состояние (не говоря о состоянии его супруги) на христианские нужды - все эти пожертвования, чью сладость он никак не мог вкусить при жизни. Если принять во внимание его предложения, порой скептические, порой шутливые, порой серьезные, по укреплению истинной веры и добродетели; его успехи на поприще возвращения десятин и первинок в ведение ирландской церкви к превеликому ее благу; а также то обстоятельство, что это с его легкой руки (без преувеличения) в Лондоне построили пятьдесят новых церквей ${ }^{\text {го }}$.

Если обобщить все перечисленное, то Свифт по своему характеру кажется очень похожим на свои сочинения: их обоих надо внимательнейшим образом перечитывать и пересматривать, и всякое новое изучение обнаруживает новые красоты и достоинства.

IIо Своим сочинением «Проект содействия преуспеянию религии» (Project for the Advancement of Religion, I709) Свифт внес свою лепту в решение Парламента построить в Лондоне 50 новых церквей, которое было принято в I7ІІ г. 
Исследовать их все равно что вглядываться в солнце, на котором хоть и есть пятна, но их не видно из-за яркого света; и чьи бы надменное невежество, гордыня, злоба, враждебность или зависть ни тщились затмить или очернить светило, я берусь утверждать, что затмение будет коротким.

Заключаю: никакой другой человек не послужил своему отечеству так, как это сделал Свифт. Он был ему верным, старательным, несгибаемым другом; мудрым, проницательным и преданным советчиком, многое в жизни претерпевшим: и суровые испытания, и подлые преследования, и угрозы его свободе и благополучию.

Он прожил благочестивую жизнь, умер благодетелем, и имя его в Ирландии будут чтить в веках» ${ }^{\Perp 1}$.

В ПОЭТИЧЕСКИХ СОЧИНЕНИЯХ доктора Свифта критику негде особо развернуться. Среди них много шутливых, почти всегда забавных стихотворений, как водится, легких и живых. По большей части они таковы, какими их задумал автор: благозвучные, точные по рифме, без единого сбоя в размере. Редко когда попадется вымученное выражение или пустой эпитет: все его стихи воплощают его собственное определение хорошего стиля - «подобающие слова в подобающих им местах».

Подразделять это собрание на классы по признаку серьезности или пустяковости предмета значит повторять и так известное читателю и выискивать изъяны, о которых автор, часто писавший не всерьез, а шутки ради, и сам прекрасно знал.

В предисловии к одному из ирландских изданий говорится как об установленном факте, что Свифт не позаимствовал ни одной идеи ни у древних, ни у новых писателей. Это не совсем так; но что действительно верно, так это то, что другого такого же скупого на заимствования сочинителя надо поискать и что, при всех способностях и недостатках Свифта, едва ли найдется кто-либо, столь же достойный именоваться истинным оригиналом.

III Джонсон, ценивший в биографии личные знания биографа, завершает «Жизнеописание Свифта» цитатой из заключительной части книги П. Делани: Delany Patrick. Observations upon Lord Orrery's Remarks on the Life and Writings of Dr. Jonathan Swift. L., I755. P. 46-47. 


\section{Список литературы}

I Дружинин А.В. Джонсон и Босвелль. Картина британских литературных нравов во второй половине XVIII столетия // Собрание сочинений А.В. Дружинина: в 8 т. (ред. изд. Н.В. Гербеля). СПб.: Тип. Имп. Акад. наук, I865-I867. T. IV. С. 7-245.

2 [Милтон Дж.] Потерянный и возвращенный рай. Поэма Джона Мильтона. Со статьею о жизни и произведениях автора. Полный перевод с английского П.А. Каншина. С рисунками. СПб.: Изд-е книгопродавца В.И. Губинского, І891. 605 с.

3 Элиот T.С. О классике: из литературно-критического наследия / вступ. ст. А. Зверева; публ., пер. и коммент. Н. Бушмановой // Вопросы литературы. І988. № 8. С. $160-208$.

4 Яковенко В.И. Д. Свифт. Его жизнь и литературная деятельность. Биографический очерк. СПб.: Тип. Тов-ва «Общественная польза», г89г. ІІ2 с.

5 Iser Wolfgang. On Translatability: Variables of Interpretation // European Messenger. I995. IV/I. P. 30-38.

6 Johnson Samuel. The Lives of the Most Eminent English Poets; with Critical Observations on their Works. By Samuel Johnson. In Four Volumes. L., MDCCLXXXI. 


\section{References}

I Druzhinin A.V. Johnson i Boswell. Kartina britanskikh literaturnikh nravov vo vtoroi polovine I8 stoletiya [Johnson and Boswell. The overview of the literary landscape of the second half of the $\mathrm{I}^{\mathrm{th}}$ century]. Sobranie sochineniy A.V. Druzhinina: $v 8 t$.

[Collected works of A.V. Druzhinin: in 8 vols.]. St. Petersburg, Tipografia imperatorskoi akademii nauk Publ., I865-I867, vol. IV, p. 7-245. (In Russ.)

2 [Milton John.] Poteriannyi i vozvraschchonnyi rai. Poema Dzhona Miltona. So statiei o zhizni i proizvedeniakh avtora [Paradise Lost and Paradise Regained. The Poems by John Milton]. Introduced and translated from the English by P.A. Kanshin. With drawings. St. Petersburg, Izdanie knigoprodavtsa V.I. Gubinskogo Publ., I89I. 605 p. (In Russ.)

3 Eliot T.S. O Klassike: iz literaturno-kriticheskogo naslediia, vstupitel'naya statia A. Zvereva; publikatsiia, perevod i kommentarii N. Bushmanovoi [About the classic: from the literary-critical heritage. Introduction by A. Zverev, translated from the English, with notes by N. Bushmanova]. Voprosy literatury, I988, issue 8, p. I60-208. (In Russ.) Yakovenko V.I. D.Swift. Ego zhizn' i literaturnaia deiatel'nost'. Biografichskii ocherk [Swift. His life and literary activities. A biographical essay]. St. Petersburg, Tipografiia tovarisch. “Obshchestvennaya pol'za”, ı891. II2 p. (In Russ.)

5 Iser Wolfgang. On Translatability: Variables of Interpretation. European Messenger, I995, IV/I, pp. 30-38. (In English)

6 Johnson Samuel. The Lives of the Most Eminent English Poets; with Critical Observations on their Works. By Samuel Johnson. In Four Volumes. L., MDCCLXXXI. (In English) 


\section{ПРАВИЛА}

\section{ОФОРМЛЕНИЯ СТАТЕЙ}


I K рассмотрению и опубликованию принимаются статьи, оформленные в соответствии с правилами, принятыми в журнале. Объем статьи вместе с примечаниями не более г п.л. - 40 ооо знаков вместе с пробелами (для аспирантов - не более о,5 п.л. - 20 ооо знаков вместе с пробелами), включая примечания.

2 Автор представляет все материалы (текст статьи, дополнительные шрифты, если таковые использовались в тексте, договор ${ }^{\mathrm{I}}$ ) по электронной почте: stud-lit@mail.ru или отправляет статью через услугу на сайте журнала www.studlit.ru

3 Текст должен быть напечатан в текстовом редакторе Microsoft Word, формат A4, поля - 2 см со всех сторон, шрифт - Times New Roman, кегль I4, межстрочный интервал - I,5, абзацный отступ (красная строка) - I,25, ориентация - книжная, без переносов.

4 Первая страница должна содержать следующую информацию:

- название рубрики, кегль - г4;

- УдК (см., например, teacode.com/online/udc или udk-codes.net), кегль - І4;

- ББК (см., например, http://roslavl.library67.ru/files/382/bbk.pdf), кегль - I4.

I B соответствии с частью четвертой Гражданского кодекса Российской Федерации (раздел VII «Права на результаты интеллектуальной деятельности и средства индивидуализации») представляемые в журнал статьи должны сопровождаться лицензионным договором о передаче Учредителю журнала неисключительных авторских прав. 
- Название статьи - по центру, без отступа, полужирным шрифтом, прописными буквами, кегль - I4.

- Под названием статьи по центру указывается знак авторского права, год, инициалы и фамилия автора/ов, кегль - I2.

- Далее по центру указывается полное название организации, город, страна, кегль - I2.

- По правому краю размещается информация о дате отправки статьи.

- Далее приводятся сведения о финансовой поддержке работы (грант и др.), кегль - I2, выравнивание по ширине.

- Размещаются аннотация (200-250 слов; она должна представлять собой реферат-резюме статьи с соблюдением последовательности изложения) и ключевые слова на русском языке, кегль - І2, выравнивание по ширине.

- Информация об авторе: имя, отчество, фамилия, ученая степень (если есть), звание (если есть), должность, полное название организации, адрес организации вместе с индексом, город, страна, E-mail, кегль - I2.

- После этого размещается та же самая информация на английском языке:

- Название статьи на английском языке - по центру, без отступа, полужирным шрифтом, прописными буквами, кегль - I4.

- Под названием статьи по центру указываются фамилия, имя, отчество автора/ов, кегль - I2.

- Далее по центру указывается полное название организации, город, страна, кегль - І2.

- По правому краю размещается информация о дате отправки статьи.

- Далее приводятся сведения о финансовой поддержке работы (грант и др.) (Acknowledgements), аннотация и ключевые слова (Abstract, Keywords), информация об авторе (Information about the author), кегль - I2, выравнивание по ширине.

- Далее - текст статьи - выравнивание по ширине, без переносов.

5 В конце статьи приводится СПИСОК ЛИТЕРАТУРЫ в алфавитном порядке (сначала русские источники, затем иностранные) в соответствии с ГОСТом 7.0.5.-2008 в виде нумерованного списка. Фамилия и инициалы авторов пишутся раздельно. В тексте статьи ссылки оформляются следующим образом: [1], [2, с. 5], [3, с. 34; 5, с. 2], [7, стб. 23], [го, л. 6]. 
6 Примечания оформляются в виде постраничных автоматических сносок. Цифра сноски в конце предложения ставится перед точкой. Шрифт сносок: Times New Roman, кегль I2.

7 Ссылки на архивные материалы даются в виде постраничных автоматических сносок.

8 После Списка литературы приводится REFERENCES:

- Транслитерируются только источники, написанные кириллицей; французские, немецкие, итальянские, польские и пр. источники не транслитерируются и не переводятся.

- Для выполнения транслитерации необходимо использовать специальную программу.

- Войти в программy http://translit.net/ и выбрать вариант системы Библиотеки Конгресса (LC).

- Вставить в специальное поле весь текст библиографии на русском языке и нажать кнопку «в транслит».

- Затем копировать транслитерированный текст в готовящийся список References.

- Далее необходимо отредактировать полученное и добавить переводы на английский язык:

- перевести на английский язык название книги, источника и др. и вставить его в квадратных скобках [ ] после соответствующих названий;

- заменить // на точку;

- заменить / на запятую;

- перевести на английский язык место издания (например, было М. - после редактирования: Moscow);

- заменить двоеточие после названия места издания на запятую;

- после транслитерации издательства добавить Publ.;

- исправить обозначение страниц: вместо 235 s. - 235 р., вместо S. 45-47 - pp. 45-47;

- курсивом выделить название источника;

- в конце библиографической ссылки необходимо добавить указание на оригинальный язык статьи (In Russ.).

9 Сокращения. При первом упоминании лица обязательно указываются И.О., И.О. отделяются пробелом от фамилии. Годы при указании опре- 
деленного периода указываются только в цифрах: 30-е гг., а не тридцатые годы. Конкретная дата дается с сокращением г. или гг.: І920 г., I920-I922 гг. Не век или века, а в. или вв. (римскими цифрами): IX в. Писать только полностью: так как, так называемые. Из сокращений допускаются: т. д., т. п., др., т. е., cм.

Iо Кавычки - только «», если закавыченное слово начинает цитату или примыкает к концу цитаты, употребляются кавычки в кавычках: «“раз”, два, три, “четыре”».

II Архивные материалы должны сопровождаться вступительной статьей, оформленной в соответствии с вышеизложенными правилами. 


\section{ПОРЯДОК РЕЦЕНЗИРОВАНИЯ}

I Рукописи, поступившие в редколлегию журнала «Studia Litterarum», проходят обязательное рецензирование с целью их экспертной оценки.

2 На первом этапе редакцией проводится экспертиза рукописей на предмет их соответствия формальным требованиям.

3 Рукописи, не соответствующие требованиям к оформлению и не отвечающие содержательно-тематическому профилю журнала, не рассматриваются и не рецензируются. Решение об отклонении статьи от рассмотрения и публикации в этом случае принимается редколлегией. 4 Рукописи, соответствующие содержательно-тематическому профилю журнала и удовлетворяющие формальным требованиям, передаются на рецензирование двум независимым экспертам, имеющим наиболее близкую к теме статьи специализацию.

5 Экспертная оценка рукописи проводится по принципу внешнего двойного «слепого» рецензирования, когда ни рецензент не знает имени автора, ни автор не знает имени рецензента.

6 Для проведения экспертной оценки рукописи могут привлекаться как члены редколлегии, так и высококвалифицированные специалисты из ИМЛИ РАН и других организаций. Рецензенты обязаны следовать принятой в журнале Публикационной этике.

7 Рецензии пишутся в свободной форме или по разработанной редколлегией схеме. 
8 Текст рецензии предоставляется автору по его запросу без указания Ф.И.О., должности и места работы рецензента. В случае наличия в рецензии рекомендации доработать и/или переработать текст статьи автору направляется сокращенный текст рецензии с конструктивными замечаниями без указания Ф.И.О., должности и места работы рецензента. В случае отклонения статьи от публикации автору направляется мотивированный отказ.

9 Статья, направленная автору на доработку, должна быть возращена в сроки, указанные в письме.

Iо Статья, не рекомендованная рецензентами к публикации, к повторному рассмотрению не принимается и не рассматривается на заседании редколлегии.

II Сроки рецензирования в каждом отдельном случае определяются с учетом возможности максимально оперативной публикации статьи. Максимальный срок рецензирования статьи - 3 месяца.

I2 Статьи, успешно прошедшие процедуру рецензирования, рассматриваются на заседании редколлегии. После принятия редколлегией решения о допуске статьи автор получает письмо с краткой информацией о результатах рецензирования и примерных сроках публикации рукописи. I3 Оригиналы рецензий хранятся в архиве журнала «Studia Litterarum» в течение 5 лет.

I4 Статьи членов редакции, редколлегии и международного редакционного совета, имеющих право на приоритетную публикацию в журнале I (одной) статьи в год, подвергаются рецензированию и обсуждаются на заседании редколлегии в общем порядке. 


\section{PEER-REVIEW PROCESS}

I It is mandatory that all manuscripts submitted to the journal Studia Litterarum are peer reviewed by experts in the field.

$2 \quad$ At the first stage of the reviewing process, the Editorial Department reviews manuscripts on the subject of their compliance with the journal's formal requirements.

3 Manuscripts that do not meet the formal requirements or the subject scope of the journal will not be considered or peer reviewed. The Editorial Board decides whether the essay shall not be considered or accepted for publication.

4 Manuscripts that meet the formal requirements or the subject scope of the journal are sent to two independent reviewers in the specific field of the submitted manuscript.

5 The essay undergoes a double "blind" review process, e.g. when any of the reviewers knows the author's name nor the author knows the names of the reviewers.

6 The invited reviewers may be members of the Editorial Board or any other highly qualified experts from IWL RAS and other institutions. Reviewers must follow the principles of Publishing Ethics accepted by the journal.

$7 \quad$ Reviews are written in a free form or according to the scheme developed by the Editorial Board.

8 The review is sent to the author on his or her request without indicating the reviewer's name, job title, and place of work. If the reviewer recommends that the author revises/makes minor revisions and resubmits the manuscript, he or she will be sent a partial text of the review with suggestions without indicating the 
reviewer's name, job title, and place of work. In case of rejection, the author will receive a motivated refusal.

$9 \quad$ The essay sent to the author for revision shall be returned by the time specified in the letter.

IO The essay rejected by reviewers shall not be resubmitted or considered at the Editorial Board meeting.

II The time period of the review is determined in each particular case considering the most rapid possible publication of the essay. It takes the maximum of three months to have the manuscript reviewed.

I2 The manuscripts that have successfully undergone the peer review process will be considered at the Editorial Board meeting. After making a decision about the essay's acceptance, the author will receive a letter briefly informing him or her about the results of the review and the possible date of publication.

I3 The original copies of reviews are kept in the archive of the journal Studia Litterarum for 5 years.

I4 Members of the Editorial Board, international Editorial Board, and the Editorial Department have the right for the priority publication of one (I) article per year; these articles are reviewed and accepted for publication on a common basis. 


\section{ПОДПИСКА}

Уважаемые коллеги!

Оформить подписку на журнал «Studia Litterarum» можно во всех отделениях Почты России по каталогу ОАО Агентства «Роспечать» «Газеты. Журналы».

Подписной индекс - 80538 .

Рассылка экземпляров журналов производится только по подписке.

По поводу приобретения отдельных номеров журнала необходимо обращаться в редколлегию: І2Іо69 г. Москва, ул. Поварская, д. 25 а. 
Для заметок 
Для заметок 


\section{STUDIA LITTERARUM}

Литературные исследования

Literary Studies

Научный журнал

Academic journal

Том 3, № 3

Vol. 3, no 3

Дизайн обложки и макет журнала В.А. Музыченко

Верстка А.З. Бернштейн

Корректор Е.Н. Сченснович

I6+

Подписано в печать 24.08.2018

Формат 60×901/16

Усл.-печ. л. 23,0

Тираж 500 экз. Заказ №

Отпечатано в ППП «Типография “Наука”

І2Іо99, Москва, Шубинский пер., д. 6

Институт мировой литературы им. А. М. Горького

Российской академии наук

І2Іо69, Москва, ул. Поварская, д. 25 а

тел. (495) 69I-23-0I, 690-05-6I 